\title{
Intellectual Property in the Global Arena
}

\author{
Edited by \\ JÜRGEN BASEDOW, \\ TOSHIYUKI KONO \\ and AXEL METZGER
}

\author{
Max-Planck-Institut \\ für ausländisches und internationales \\ Privatrecht
}

Materialien zum ausländischen

und internationalen Privatrecht

49

Mohr Siebeck 
Materialien zum ausländischen und internationalen Privatrecht

Herausgegeben vom

Max-Planck-Institut für ausländisches und internationales Privatrecht

Direktoren:

Jürgen Basedow, Holger Fleischer und Reinhard Zimmermann

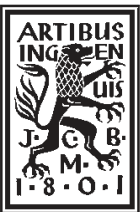





\title{
Intellectual Property in the Global Arena
}

Jurisdiction, Applicable Law, and the Recognition of Judgments in Europe, Japan and the US

\author{
Edited by \\ Jürgen Basedow, Toshiyuki Kono \\ and Axel Metzger
}

Mohr Siebeck 
Jürgen Basedow, born 1949; Director, Max-Planck Institute for Comparative and International Private Law and Professor of Law, University of Hamburg; Titular Member and Secretary General, International Academy of Comparative Law.

Toshiyuki Kono, born 1958; 1981 LL.B.; 1983 LL.M. (Kyoto); Distinguished Professor of Law at Kyushu University.

Axel Metzger, born 1971; Studies in law in Hamburg and Paris; 2001 Dr. iur.; 2006 LL.M. (Harvard); 2008 Habilitation; Professor of Civil Law, Intellectual Property, Information Technology and Private International Law at the Leibniz Universität Hannover, Germany.

e-ISBN PDF 978-3-16-151296-4

ISBN 978-3-16-150444-0

ISSN 0543-0194 (Materialien zum ausländischen und internationalen Privatrecht)

Die Deutsche Nationalbibliothek lists this publication in the Deutsche Nationalbibliographie; detailed bibliographic data are available on the Internet at http://dnb.d-nb.de.

(C) 2010 by Mohr Siebeck Tübingen.

This work is since 01/2020 licensed under the license "Attribution-NonCommercialNoDerivatives 4.0 International" (CC BY-NC-ND 4.0). A complete version of the license text can be found at: https://creativecommons.org/licenses/by-nc-nd/4.0/. An electronic version of this book is freely available, thanks to the support of libraries working with Knowledge Unlatched. KU is a collaborative initiative designed to make high quality books Open Access for the public good. More information about the initiative can be found at www.knowledgeunlatched.org.

The book was printed by Gulde-Druck in Tübingen on non-aging paper and bound by Großbuchbinderei Spinner in Ottersweier.

Printed in Germany. 


\section{Preface}

The private international law of intellectual property is currently much debated worldwide. Art. 8 of the European "Rome II" Regulation of 2007, which codifies a territorial approach for the infringement of intellectual property, has provoked an intensive discussion in Europe whether the lex loci protectionis is still appropriate for intellectual property litigation in the age of worldwide networks. A condensed outcome of this debate is summarized in the "Principles for Conflict of Laws in Intellectual Property" (CLIP Principles) drafted by the European Max Planck Group on Conflict of Laws in Intellectual Property (CLIP). The First Preliminary Draft of the CLIP Principles has been published on April 8, 2009, the Second Preliminary Draft on June 6, 2009. The CLIP Principles are scheduled to be finalized in 2011 .

In the United States, the American Law Institute's "Intellectual Property: Principles Governing Jurisdiction, Choice of Law, and Judgments in Transnational Disputes" of 2007 (ALI Principles) are the focal point of the debate. Both the CLIP and the ALI Principles are designed for the interpretation and gap-filling of international and domestic law and as models for national and international legislators.

The Japanese Transparency Proposal, a product of the Transparency Project which provides information on Japanese law related to international business in English, has been finalized in 2009. Inspired by the ALI and the CLIP Principles, the Japanese Transparency Proposal aims to facilitate legal development of Japanese domestic private international law. Namely, the Transparency Proposal echoes to the 2006 Japanese private international law statute which did not establish any specific conflicts rules for intellectual property matters. Further, the Transparency Proposal aims to guide the ongoing modernization of domestic international jurisdiction legislation by highlighting intellectual property-related problems and putting forward possible solutions.

The volume provides a comparative analysis of the ALI Principles, the CLIP Principles and the Transparency Proposal. It compiles papers presented at an international conference held in Tokyo on May 8 and 9, 2009. The Annex of the volume collects the black letter version of the ALI Principles of 2007, the Second Preliminary Draft of the CLIP Principles, 
which has been taken into account although published shortly after the conference, and the Transparency Proposal. The "Principles on Private International Law on Intellectual Property (Japanese Proposal)" prepared by the WASEDA University Global-COE Project ${ }^{1}$ have only been published after the submission of the papers and could therefore not be taken systematically into consideration.

The editors would like to thank the American Law Institute, especially Ms. Nina Amster and the reporters of the project, Prof. François Dessemontet, Prof. Rochelle Dreyfus and Prof. Jane Ginsburg, for the permission of reprint. Likewise, we are grateful to the members of the CLIP group for their permission to publish the Second Preliminary Draft of the CLIP Principles. The editors would also like to thank Ms. Ingeborg Stahl for the editing of the book, Dr. Jan Asmus Bischoff, LL.M. (NYU) for the preparation of the register, Mr. Paul Jurčys, LL.M. (Kyushu) and Mr. Simon Vande Walle, LL.M. (Kyushu and Georgetown) for summarizing the discussions and useful comments, and our publisher Mohr Siebeck for the production of the book. The organization of the conference and the contributions of the Japanese authors became possible due to the support by KAKENHI (Grant in-Aid for Scientific Research on Priority Areas) of the Ministry of Education, Culture, Sports, Science and Technology, Japan.

Hamburg, Fukuoka and Hannover, May 2010

Jürgen Basedow

Toshiyuki Kono

Axel Metzger

${ }^{1}$ Kigyô to hôsôzô [Quarterly Review of Corporation Law and Society] Vol.15 (2009), p. 250, English translation available at <www.globalcoe-waseda-law-commerce.org/ activity/pdf/19/21.pdf>. 


\section{Table of Contents}

Contributors ..................................................................................

Part 1: Foundations ............................................................................... 1

Jürgen Basedow

Foundations of Private International Law in Intellectual Property.............. 3

François Dessemontet

The ALI Principles: Intellectual Property in Transborder

Litigation

Paulius Jurčys/Simon Vande Walle

Summary of Discussion on Foundations ................................................ 49

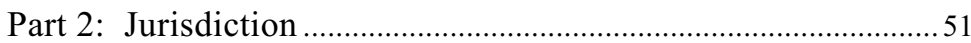

Christian Heinze

A Framework for International Enforcement of Territorial Rights:

The CLIP Principles on Jurisdiction

Shigeki Chaen/Toshiyuki Kono/Dai Yokomizo

Jurisdiction in Intellectual Property Cases: The Transparency

Proposal

Paulius Jurčys/Yuko Nishitani/Simon Vande Walle

Summary of Comments and Discussion on International

Jurisdiction

Part 3: Applicable Law ...................................................................... 155

Axel Metzger

Applicable Law under the CLIP Principles:

A Pragmatic Revaluation of Territoriality. 
Ryu Kojima/Ryo Shimanami/Mari Nagata

Applicable Law to Exploitation of Intellectual Property Rights in the Transparency Proposal

Paulius Jurčys/Simon Vande Walle

Summary of Comments and Discussion on Applicable Law

Part 4: Recognition and Enforcement

Pedro A. de Miguel Asensio

Recognition and Enforcement of Judgments in Intellectual

Property Litigation: The CLIP Principles

Toshiyuki Kono/Nozomi Tada/Miho Shin

Recognition and Enforcement of Foreign Judgments Relating to IP

Rights and Unfair Competition

Paulius Jurčys/Simon Vande Walle

Summary of Comments and Discussion on Recognition and Enforcement.

Annex

Annex I: Intellectual Property: Principles Governing Jurisdiction, Choice of Law, and Judgments in Transnational Disputes

Annex II: Principles for Conflict of Laws in Intellectual Property

Annex III: Transparency Proposal on Jurisdiction, Choice of Law, Recognition and Enforcement of Foreign Judgments in Intellectual Property.

Table of Principles 403 


\section{Contributors}

Jürgen Basedow, Dr. iur. (Hamburg), Dr. iur. habil. (Hamburg), Dr. h.c. (Stockholm), LL.M. (Harvard), Director, Max Planck Institute for Comparative and International Private Law, Hamburg, Germany and Professor of Law, University of Hamburg, Germany

François Dessemontet, Docteur en droit (Lausanne), Professor Emeritus at the University of Lausanne, Switzerland

Shigeki Chaen, LL.B. (Osaka), LL.M. (Osaka), Professor at Osaka University, Japan

Christian Heinze, Dr. iur. (Hamburg), LL.M. (Cambridge), Senior Research Fellow, Max Planck Institute for Comparative and International Private Law, Hamburg, Germany

Paulius Jurčys, LL.M. (Kyushu and Vilnius), LL.D. Candidate at Kyushu University, Japan

Ryu Kojima, LL.B. (Tokyo), LL.M. (Harvard), Associate Professor at Kyushu University, Japan

Toshiyuki Kono, LL.B. (Kyoto), LL.M. (Kyoto), Distinguished Professor of Kyushu University, Japan

Axel Metzger, Dr. iur. (Munich and Paris), Dr. iur. habil. (Hamburg), LL.M. (Harvard), Professor at the Leibniz University of Hannover, Germany

Pedro A. de Miguel Asensio, Dr. iur. (Madrid), LL.M. (Amsterdam), Professor at the Complutense University of Madrid, Spain

Mari Nagata, LL.B. (Osaka), LL.M. (Osaka), Ph.D. (Osaka), Associate Professor at Osaka University, Japan

Yuko Nishitani, LL.B. (Kyoto), LL.M. (Kyoto), Dr. iur. (Heidelberg), Visiting Professor at Hosei University, Japan 
Ryo Shimanami, LL.B. (Tokyo), LL.M. (Tokyo), Professor at Kobe University, Japan

Miho Shin, LL.B. (Kyoto), LL.M. (Kyoto), Ph.D. (Kyoto), Adjunct Professor at Aoyama Gakuin University and Hakuoh University, Japan

Nozomi Tada, LL.B. (Osaka), LL.M. (Osaka), Ph.D. (Osaka), Professor at Kumamoto University, Japan

Simon Vande Walle, Lic. Jur. (Leuven), LL.M. (Kyushu and Georgetown), LL.D. Candidate at Kyushu University, Japan

Dai Yokomizo, LL.B. (Tokyo), LL.M. (Tokyo), Professor at Nagoya University, Japan 
Part 1: Foundations 



\title{
Foundations of Private International Law in Intellectual Property
}

\author{
JÜRGEN BASEDOW
}

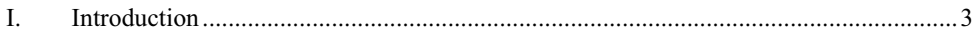

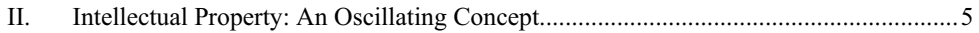

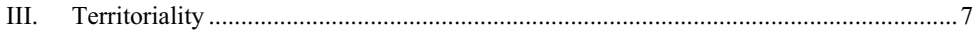

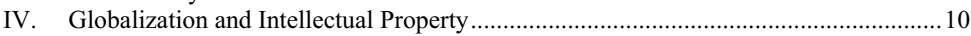

V. Intellectual Property and Neighboring Categories of Law ...................................... 11

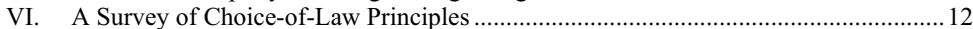

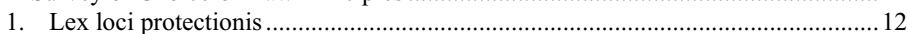

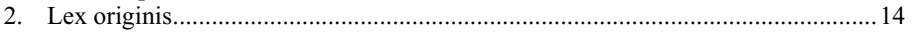

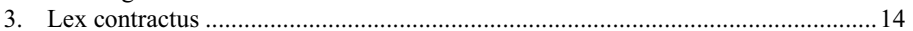

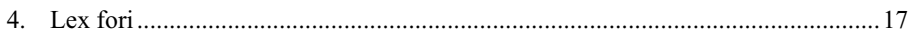

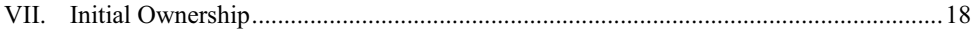

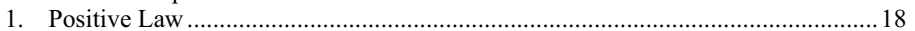

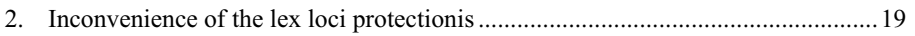

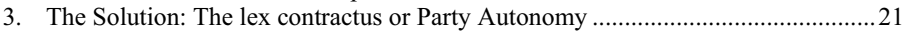

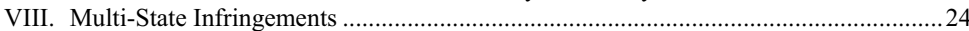

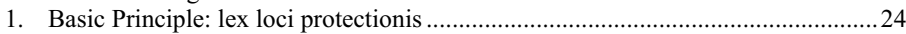

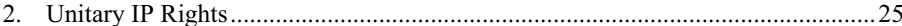

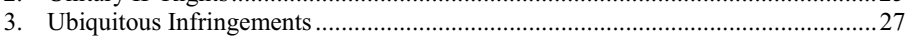

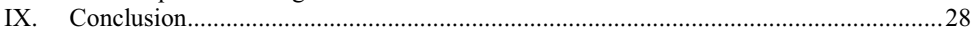

\section{Introduction}

Intellectual property and the conflict of laws have developed as two separate bodies of law. Their mutual relation has been the object of occasional - though increasingly frequent - academic contributions, ${ }^{1}$ but not very

${ }^{1}$ See Alois Troller, Das internationale Privat- und Zivilprozessrecht im gewerblichen Rechtsschutz und Urheberrecht, 1952; Eugen Ulmer, Die Immaterialgüterrechte im internationalen Privatrecht, 1975; Ulrich Drobnig, Bernd von Hoffmann, Dieter Martiny and Paul Heinrich Neuhaus, Die Immaterialgüterrechte im künftigen internationalen Privat- 
often of statutory regulation. Only in recent times have conflict legislators given an eye to intellectual property: the Austrian Act on Private International Law of 1978 contains special provisions on rights in intangibles, ${ }^{2}$ and so do inter alia the Swiss Act of $1987,{ }^{3}$ the Italian Act of $1995,{ }^{4}$ the Korean Act of 2001, ${ }^{5}$ and the Belgian Act of 2004. ${ }^{6}$ In 2007, the European

recht der Europäischen Gemeinschaften, RabelsZ 40 (1976) 189-230; Haimo Schack, Zur Anknüpfung des Urheberrechts im IPR, 1979; Jacques Raynard, Droit d'auteur et conflits de lois, 1990; Kamen Troller, Industrial and Intellectual Property, in: International Encylopedia of Comparative Law vol. 3 ch. 22 (1994); Jane Ginsburg, The Private International Law of Copyright in an Era of Technological Change, Recueil des cours 273 (1998) 239 seq.; James Fawcett, Paul Torremans, Intellectual Property and the Conflict of Laws, 1998; Marta Pertegás Sender, Cross-Border Enforcement of Patent Rights, 2002; François Dessemontet, International Private Law of Intellectual Property, YB PIL 6 (2004) 70-84; Jürgen Basedow/Josef Drexl/Annette Kur/Axel Metzger (eds.), Intellectual Property in the Conflict of Laws, 2005; Dário Moura Vicente, A tutela internacional da propriedade intelectual, 2008.

${ }^{2}$ See sect. 34 of the Federal Law of 15 June 1978 (Austrian Bundesgesetzblatt 304) on Private International Law (IPR-Gesetz): “(1) Das Entstehen, der Inhalt und das Erlöschen von Immaterialgüterrechten sind nach dem Recht des Staates zu beurteilen, in dem eine Benützungs- oder Verletzungshandlung gesetzt wird. (2) Für Immaterialgüterrechte, die mit der Tätigkeit eines Arbeitnehmers im Rahmen seines Arbeitsverhältnisses zusammenhängen, ist für das Verhältnis zwischen dem Arbeitgeber und dem Arbeitnehmer die für das Arbeitsverhältnis geltende Verweisungsnorm ( $\$ 44)$ maßgebend”.

${ }^{3}$ See Art. 110 of the Federal Law on Private International Law of 18 December 1987, Bundesblatt 1988 I, 5, English translation in Am.J.Comp.L. 37 (1989) 193: “(1) Intellectual property rights shall be governed by the law of the State in which protection of the intellectual property is sought. (2) In the case of claims arising out of infringement of intellectual property rights, the parties may agree, after the act causing damage has occurred, that the law of the forum shall be applicable. (3) Contracts concerning intellectual property rights shall be governed by the provisions of this Code concerning the law applicable to contracts (Art. 122)." For rights in intangibles flowing from employment relations, Art. 122 (3) refers to the law applicable to the employment contract.

${ }^{4}$ See Art. 54 of the Law of 31 May 1995, no. 218 - Reform of the Italian System of Private International Law (Gazzetta Ufficiale Supplemento Ordinario al no. 128 of 3 June 1995, p. 5-18): "I diritti su beni immateriali sono regolati dalla legge dello Stato di utilizzazione".

${ }^{5}$ See $\S 24$ of the Act no. 6465 of 7 April 2001, German translation in RabelsZ 70 (2006) 342, 346; English translation in YB PIL 5 (2003) 315, 321: "The protection of intellectual property rights shall be subject to the law where the right was infringed".

${ }^{6}$ See Arts. 93 seq. of the Law of 16 July 2004 holding the Code of Private International Law, Moniteur Belge of 27 July 2004, English translation in RabelsZ 70 (2006) 358, 384. - Art. 93: “(1) Intellectual property rights are governed by the law of the State for the territory of which the protection of the intellectual property is sought. (2) Nevertheless, the determination of the original owner of the industrial property right is governed by the law of the state with which the intellectual activity has the closest connections. If the activity takes place within a framework of contractual relations, that State is presumed to be the State of which the law applies to these contractual relations, until proof to the contrary is brought." - Art. $94 \S 1$ : "The law applicable by virtue of this 
Union dealt with the infringement of intellectual property rights (IP rights) in Article 8 of its Rome II Regulation on the law applicable to non-contractual obligations. ${ }^{7}$

Rule-making activities have also occurred outside state legislatures: in 2007, the American Law Institute adopted principles in this field (ALI Principles), ${ }^{8}$ and in Europe, a group of scholars from several countries is still discussing a similar set of principles on conflict of laws in intellectual property (CLIP Principles). ${ }^{9}$ The ongoing work of two Japanese groups gives evidence of the worldwide interest in, and the momentum of, the subject. ${ }^{10}$

The following remarks are meant to shed some light on the basic considerations underlying the development of conflict rules in the field of IP rights. They will focus on choice-of-law issues, leaving jurisdiction and the recognition of judgments to other contributions.

\section{Intellectual Property: An Oscillating Concept}

The notion of intellectual property rights commonly used at present suggests two things: first, the existence of an overall concept that is, second,

section determines notably: 1 . Whether an asset is movable or immovable; 2 . the existence, nature, content and scope of the rights in rem that can affect an asset, as well as of intellectual property rights; 3 . the holders of such rights; 4 . the possibility to dispose of such rights; 5 . the manner of constitution, modification, transfer and extinction of those rights; 6 . the effects of the rights in property vis-à-vis third parties. $\S 2$....”.

7 See Art. 8 of Regulation (EC) No 864/2007 of the European Parliament and of the Council of 11 July 2007 on the law applicable to non-contractual obligations (Rome II), OJ 2007 L 199/40: “(1) The law applicable to a non-contractual obligation arising from an infringement of an intellectual property right shall be the law of the country for which protection is claimed. (2) In the case of a non-contractual obligation arising from an infringement of a unitary Community intellectual property right, the law applicable shall, for any question that is not governed by the relevant Community instrument, be the law of the country in which the act of infringement was committed. (3) The law applicable under this Article may not be derogated from by an agreement pursuant to Article 14".

${ }^{8}$ The American Law Institute, Intellectual Property: Principles Governing Jurisdiction, Choice of Law, and Judgments in Transnational Disputes, 2007 (see Annex I infra) (hereinafter cited as ALI Principles).

${ }^{9}$ See the reproduction of the Secondary Preliminary Draft of the CLIP Principles in this book in Annex II infra.

${ }^{10}$ After this paper had been finalised the Japanese Transparency Group adopted its Proposal which is reproduced below in Annex III to this book. Even more recently, the Waseda Research Group published its Principles on Private International Law on Intellectual Property - Waseda University Global-COE Project 2008.12.15, see the English translation in Global Center of Excellence, Waseda University for Corporation Law and Society, The Quarterly Review of Corporation Law and Society 2009, 250-257. 
close or similar to that of property in tangibles. Both assumptions are wrong, or at least misleading. While there is a general belief that the product of the human mind - i.e., an individual's ideas - deserves protection, this is not more than the philosophical basis for intellectual property rights. There is not a single jurisdiction that defines intellectual property as a general concept.

Instead, the law grants protection only to specific results spawned by human creativity, such as technical innovations, works of music or literature, or certain designs. ${ }^{11}$ Accordingly, the Stockholm Convention establishing WIPO defines intellectual property by an enumerative list that "includes rights relating to literary, artistic, and scientific works; performances of performing artists, phonograms and broadcasts; inventions in all fields of human endeavour; scientific discoveries; industrial designs; trademarks, service marks, and commercial names and designations; protection against unfair competition; and all other rights resulting from intellectual activity in the industrial, scientific, literary and artistic fields." ${ }^{2}$

Nor is the comparison of intellectual property with property in tangibles appropriate. Both differ in a basic quality: While the use and consumption of corporeal goods is characterized by rivalry and exclusion, it is not in regard to intangibles. The latter can be used by an unlimited number of persons at the same time; this may reduce their commercial value, but it will in no way affect their substance and qualities. Thus, intellectual property receives its exclusive character by the sole operation of law, while the use and consumption of tangible property is exclusive by its very nature. As a consequence, property rights in tangibles must be protected to avoid conflicts and even social unrest, whereas the protection of intellectual property rights is rather a matter of maximizing social welfare.

These differences in nature explain why authors in some countries have preferred other concepts like the "law of intangibles" (Immaterialgüter-

${ }^{11}$ Cf. Alexander Peukert, Geistiges Eigentum (allgemein), in: Jürgen Basedow/Klaus Hopt/Reinhard Zimmermann (eds.), Handwörterbuch des Europäischen Privatrechts, vol. I, II, 2009, p. 648 seq.

${ }^{12}$ See Art. 2 (viii) of the Convention Establishing the World Intellectual Property Organization, done at Stockholm on 14 July 1967, 828 UNTS 3; a similar enumerative definition of intellectual property is laid down in Art. 1 para. 2 of the Agreement on Trade-Related Aspects of Intellectual Property (TRIPS) which is Annex 1C of the Agreement Establishing the World Trade Organization, signed at Marrakesh on 15 April 1994, 1867 UNTS 154, OJ 1994 L 336/214: "For the purposes of this Agreement, the term 'intellectual property' refers to all categories of intellectual property that are the subject of Sections 1 through 7 of Part II". 
recht) to that of intellectual property. ${ }^{13}$ Dubious as it may appear at the level of substantive law, however, the latter concept is more suited for the needs of private international law.

The peculiar technique employed by this discipline is to bundle up a large number of legal issues relating to one and the same area of the law, in one category, e.g., non-contractual liability, marriage, unfair competition, succession, securities in movables - or intellectual property. As a consequence, the single issues arising in the legal analysis of a conflict will then have to be classified, i.e., attributed to one of the more comprehensive categories (or statuta). This characteristic method of private international law allows the conception of categories or statuta that encompass rather heterogeneous legal institutions, such as, e.g., companies that are basically subject to the same conflict rule irrespective of whether they are partnerships, private limited companies, or large corporations whose shares are traded at the stock exchange. The same approach is appropriate in regard to intellectual property, although the various rights differ considerably regarding their coming into existence, extent, protection, and extinction. The unitary or holistic approach does not exclude, and even necessitates, a more differentiated analysis when it comes to the single conflict rules that may relate to the specific types of intellectual property rights.

\section{Territoriality}

The differences between property in tangibles and in intangibles are reflected by differences in legal history. While we do not know of any legal system in ancient times that did not in one way or the other deal with the attribution of property rights in corporeal objects, intellectual property rights have been acknowledged only fairly recently. Initially they were granted by seigneurs and princes on an individual basis for the promotion of their own wealth; they would accord the exclusive right to print a book or to produce items based on a given technology in order to participate in the profit made, by the extraction of royalties. For similar utility considerations it could also occur that such rights were withdrawn at a later stage. Under the philosophical influence of the Enlightenment, the claim for more stability and for independence from individual concessions was made. But the first statutes ensuring legal security in this respect were only

13 See Peukert (supra note 11); Louis Pahlow, Geistiges Eigentum, in: Albrecht Cordes/Heiner Lück/Dieter Werkmüller (eds.), Handwörterbuch zur deutschen Rechtsgeschichte, vol. I, $2^{\text {nd }}$ ed. 2008 , col. 2010 seq. 
enacted after the French Revolution. ${ }^{14}$ They replaced the prince's discretion in according the right by a list of statutory prerequisites for the recognition of such rights; their administration was left to special authorities under the control of the court system.

The evolution from the system of seigneurial privileges to the statutory system in the course of the nineteenth century did not lead to a thorough reconsideration of the nature of intellectual property rights. Apart from moral rights in copyrighted works, they were still considered as flowing from the powers of the respective sovereign who had simply ceded and bound the exercise of its discretion by the enactment of statutes on patents, copyright, etc. At the end of this process, intellectual property rights are still artifacts of positive law or, as the European Court of Justice once put it in regard to companies, "creatures of national law. They exist only by virtue of the varying national legislation which determines their ... functioning." $"$ In this view, the private law remedies provided in the case of infringements are nothing more than annexes to the public law relation between the right holder and the respective state.

As a consequence, intellectual property rights have always been considered as being confined to the territory ruled by the respective sovereign. In the words of the ALI Principles: "It has simply been assumed that each State's rules apply to anything transpiring within its borders, and no further." 16 Since legislation on IP rights, just like the previous system of privileges, pursued mercantilistic objectives, national governments were preoccupied by two concerns: the risk that foreign states might grant protection to inventions and copyrighted works only at a very low level or not at all, and the risk that they would discriminate against foreign inventors and authors.

\footnotetext{
14 See Helmut Coing, Europäisches Privatrecht 1800-1914, vol. II, 1989, p. 152 seq. referring to French decrees of 1791 and 1793 as the first legislative acts espousing the principle of intellectual property; for industrial property, see Ulrich Loewenheim, Gewerblicher Rechtsschutz, in: Adalbert Erler, Ekkehard Kaufmann, eds., Handwörterbuch zur Deutschen Rechtsgeschichte, vol. I, 1971, col. 1652, 1653; for copyright statutes enacted in the numerous German states throughout the $19^{\text {th }}$ century, see Vogel, in: Schricker (ed.), Urheberrecht.Kommentar, $3^{\text {rd }}$ ed. 2006, Einleitung, nos. 67 seq. Sometimes, the English Statute of Anne, 8 Ann. ch. 21, also referred to as the Copyright Act, 1710 , is considered to be the first copyright act; see William Cornish/David Llewelyn, Intellectual Property: Patents, Copyright, Trademark and Allied Rights, $5^{\text {th }}$ ed. 2003 , nos. 1-14 and 9-02 seq. But protection under that act was still dependent on a registration of the right by the guild of stationers, Eugen Ulmer, Urheber- und Verlagsrecht, $3^{\text {rd }}$ ed 1980 , p. 55.

15 ECJ 27 September 1988, case 81/87 (ex parte Daily Mail plc), [1988] E.C.R. 5483 para. 19.

${ }^{16}$ See ALI Principles (supra note 8), p. 193.
} 
It is due to these apprehensions that international conventions on these matters were agreed at an early stage in the development of uniform law: In fact, the Paris Convention for the Protection of Industrial Property of $1883^{17}$ and the Berne Convention for the Protection of Literary and Artistic Works of $1886^{18}$ were the first uniform law conventions agreed on the eastern side of the Atlantic. Both conventions implicitly acknowledge that each contracting state has its own legislation on intellectual property rights. On this basis, they endorse two principles: (1) the adoption of certain minimum standards of substantive law to be implemented by each contracting state; and (2) national treatment for foreign inventors and creators, i.e., the prohibition of any discrimination of foreign originators.

The rules setting forth these principles are not drafted very clearly. From a present-day reading, in particular Article 5(2) of the Berne Convention may be interpreted as containing a choice-of-law rule, too. After stating that the enjoyment of the creator's rights "shall be independent of the existence of protection in the country of origin of the work," this provision prescribes that "the extent of protection, as well as the means of redress afforded to the author to protect his rights, shall be governed exclusively by the laws of the country where protection is claimed."

In light of the historical public law background of IP rights outlined above, it is not very likely that this provision was meant to designate the law applicable to the protection of copyright by contract or tort. ${ }^{19}$ But there is little doubt that the commitment to national treatment contained in that provision limits the discretion of the national legislature when it comes to

${ }^{17}$ Paris Convention for the Protection of Industrial Property, done on 20 March 1883, 828 UNTS 305.

18 The Berne Convention for the Protection of Literary and Artistic Works, done on 9 September 1886, 1161 UNTS 3.

${ }_{19}$ For the debate on the interpretation of Art. 5 para. 2 of the Berne Convention as a choice-of-law rule, see Bernd von Hoffmann in Staudinger, Kommentar zum Bürgerlichen Gesetzbuch mit Einführungsgesetz und Nebengesetzen. Einführungsgesetz zum Bürgerlichen Gesetzbuch/IPR Art. 38-42, Neubearbeitung 2001, Art. 40 EGBGB no. 375. See also S.J. Schaafsma, Rome II: intellectuele eigendom en oneerlijke concurrentie, Weekblad voor Privaatrecht, Notariaat en Registratie (WPNR) 2008, 998,999 who advocates the interpretation of that provision as both a prohibition of discrimination and a choice-of-law rule. As a consequence, he claims Art. 5 para. 2 of the Berne Convention to prevail over Art. 8 Rome II in accordance with Art. 28 para. 1 of the Regulation; see p. 1000 . For an opposite view on Art. 5 para. 2 Berne Convention, see Nerina Boschiero, Infringement of Intellectual Property Rights - A Commentary on Article 8 of the Rome II Regulation, YB PIL 9 (2007) 87, 97 seq.; Haimo Schack, Das auf (formlose) Immaterialgüterrechte anwendbare Recht nach Rom II, in: Dietmar Baetge/Jan von Hein/Michael von Hinden (eds.), Die richtige Ordnung - Festschrift für Kropholler, 2008, p. 651, 661. In light of this debate, the unequivocal reference of Art. 8 Rome II to the lex loci protectionis cannot be regarded as redundant. 
the adoption of choice-of-law rules for infringement proceedings. National conflict rules that subject the damages claims of foreign authors to rules that differ from those governing the damages claims of domestic authors would hardly be in line with Article 5(2), since they do not ensure national treatment to foreign authors. A different result could only be inferred in regard to the parties' agreement on the choice of a foreign law, since in that case the difference in treatment between domestic and foreign authors would not follow from state action but from private agreement not addressed by the national treatment provisions of the Paris and Berne conventions. Apart from party autonomy, the territoriality principle, meaning the application of the law of the state for which protection is sought, would however indirectly follow from the commitment to national treatment under international law.

\section{Globalization and Intellectual Property}

New developments relating to the production, exploitation, and infringement of intellectual property rights have brought about far-reaching changes and exposed the territorial principle to increasing doubts.

In present times, the acquisition of intellectual property rights - instead of being merely the consequence of human creativity that occurs naturally is the direct objective of strategically planned business activities. Research and development are key factors for the productivity of enterprises; the IP rights often are their major assets. The respective activities form the object of strategic planning, e.g., of cooperation agreements, mergers, and outsourcing. The division of labor at the national and/or international level has become a common occurrence in the field of research, too.

The resulting difficulties for the IP system may be illustrated by the following example. Where the laboratories of a major drug maker have developed a new pharmaceutical agent, long series of experiments will be needed before new drugs containing that agent can be put on the market. Often, the drug maker will not carry out these experiments in-house but will commission another - domestic or foreign - company to do that. When checking the reactions and compatibility of the patented agent with other substances, new compounds may be discovered that are also eligible for patents. As to the owner of such patents, the national laws of the companies involved may provide different answers.

Similar divergences may arise in the context of international cooperation arrangements concerning the development of software, the production of movies, or the creation of advertising strategies. In all these cooperative endeavors, the international division of labor is favored by the progressive 
opening of national markets for services as laid out in the General Agreement on Trade and Services (GATS) ${ }^{20}$ and by the revolution in communication technology. If applied to such international cooperation relations, the territorial principle might lead to the recognition of different persons as originators and right holders in different countries with regard to one and the same object of intellectual property.

The fundamental changes in communication technology, in particular the digitalization and satellite transmission of information, also affect the exploitation and the infringement of IP rights. Thus, software licenses, music, or trademarks are spread worldwide within seconds; users resident anywhere in the world may gain unauthorized access to copyrighted materials or may upload data that infringe trademarks protected in many countries. Multi-state distribution of intellectual property and multi-state infringements are corollaries of the worldwide web. It goes without saying that the territorial principle makes the protection of intellectual property rights increasingly difficult where infringements, due to the communication techniques used, are inherently ubiquitous.

\section{Intellectual Property and Neighboring Categories of Law}

As pointed out above (supra II.), the mechanism of private international law includes the classification of legal issues as being part of a category of law - in this case, of IP law. Classification may raise problems where neighboring categories of law governed by different choice-of-law rules suggest themselves as alternatives to intellectual property.

As far as the rights covered by the concept of intellectual property are concerned, recital 26 of the Rome II Regulation points out that "for instance, copyright, related rights, the sui generis right for the protection of data bases and industrial property rights" are meant and subject to the principle of the lex loci protectionis. ${ }^{21}$ The list is not conclusive; in accordance with the ALI Principles, moral rights might be added. ${ }^{22}$

It is doubtful, however, whether also the right of publicity, i.e., the right to one's image or voice, can be classified as an IP right. The ALI Principles consider infringements of this right as a matter of unfair competition pinpointing the economic exploitation of, instead of the intrusion into, other people's private life. ${ }^{23}$ In Germany, invasions of the right of publicity

${ }^{20}$ General Agreement on Trade in Services, done at Marrakesh on 15 April 1994, OJ 1994 L 336.

21 See supra note 7.

22 ALI Principles (supra note 8), § 301 Comment f., p. 203

23 ALI Principles (supra note 8), § 301 Comment e., p. 203. 
have traditionally been characterized as infringements of a general right of personality subject to the general choice-of-law rule on torts. ${ }^{24} \mathrm{~A}$ significant practical difference concerns agreements on the applicable law: While Rome II excludes the free choice of law by the parties for infringements of IP rights and generally also for unfair competition, such choice is permitted in relation to the general conflicts rule. ${ }^{25}$

This takes us to another overlap of categories of the law: the infringement of IP rights and unfair competition. The unauthorized use of IP rights, in particular trademarks, will often be sanctioned under both IP law and the law of unfair competition. The respective claims may therefore be classified under both headings. In cross-border cases this will not often give rise to inconveniences, since the law applicable to unfair competition is the law of the country whose market is affected; it is in this country where the respective IP rights will generally be infringed. Exceptionally, however, the general choice-of-law rule on torts will apply under Rome II where an act of unfair competition affects exclusively the interests of a specific competitor; in that case, the common origin of the companies involved may prevail over the law of the market affected, and the parties may also be allowed to choose the applicable law. ${ }^{26}$

Apart from the situations outlined above, the law applicable to IP rights may get into conflict with the law chosen by the parties in the field of transfer and license agreements. Like all other contracts, such agreements are primarily subject to the law chosen by the parties (see infra VI.), and that may be a law that differs from the lex loci protectionis. It is up to a fine-tuning of the relevant choice-of-law rules to find out which aspects of a contract are subject to the law chosen by the parties and which not.

\section{A Survey of Choice-of-Law Principles}

In intellectual property, three choice-of-law principles claim application to different aspects of a litigation: the lex loci protectionis, the lex contractus, and the lex fori.

\section{Lex loci protectionis}

The lex loci protectionis is the law of the country for which protection is sought, not the law of the country where protection is sought. The two ex-

\footnotetext{
24 von Hoffmann (supra note 19), Art. 40 EGBGB, no. 53 seq.

${ }_{25}$ See Articles 4, 6 para. 4, 8 para. 3 and 14 Rome II, supra note 7.

26 Compare Article 6 para. 2 with Articles 4 and 14 Rome II, supra note 7.
} 
pressions are sometimes confounded, but must be clearly distinguished. ${ }^{27}$ The latter could be interpreted as referring to the country of the court where a claim for protection is pending; in this case it would simply be synonymous to the lex fori and would indirectly refer to the rules on jurisdiction. Where legal action is taken in the courts of the country of protection, lex fori and lex loci protectionis would be identical. But there may also be a competent court outside that country, and such court should not apply its own law, but the law of the country for which protection is sought, which would be a foreign law in that case.

Except for the Belgian Code on Private International Law, the statutory materials listed in the introduction (supra I.) do not contain much information on the substantive scope of the lex loci protectionis. Following the Belgian law, ${ }^{28}$ both the ALI Principles ${ }^{29}$ and the CLIP Principles ${ }^{30}$ are more detailed in this respect. Under these instruments there is unanimity that the existence of IP rights, including the formal and substantive requirements for their constitution, are subject to the lex loci protectionis, which also governs their validity, their scope and possible limitations or exceptions, their duration including the extinction, their transferability and the manner and formal requirements of transfer, licenses and security interests in IP rights, co-ownership and the transferability of shares, as well as the infringement of IP rights.

At first sight, the ALI Principles appear to take a different approach, allowing the parties to agree at any time on the designation of a law that will govern their dispute. ${ }^{31}$ However, the seemingly wide party autonomy is narrowed by a large number of exceptions that reflect the IP aspects listed above. ${ }^{32}$ The comments and illustrations for party autonomy provided by the ALI appear to be limited to purely obligatory - i.e., inter partes - effects, in particular to infringement, and explicitly state that an "agreement cannot create intellectual property protection in jurisdictions where none exists." ${ }^{, 3}$ While the differences between the national laws and principles are not as significant as it might appear at first sight, marked differences can be ascertained regarding the law applicable to infringe-

27 See Boschiero, above at fn. 18, YB PIL 9 (2007) 98 seq.; see also Jürgen Basedow, Axel Metzger, Lex loci protectionis europea, in: Alexander Trunk (ed.) Russland im Kontext der internationalen Entwicklung: Internationales Privatrecht, Kulturgüterschutz, Geistiges Eigentum, Rechtsvereinheitlichung - Festschrift für Boguslavskij, 2004, p. 153,159 seq.

${ }^{28}$ See Article $94 \S 1$ of the Belgian Act (supra note 6).

29 See ALI Principles (supra note 8), § 301.

${ }^{30}$ See various provisions of the CLIP Principles (supra note 9), part 3.

31 ALI Principles (supra note 8), § 302.

32 ALI Principles (supra note 8), § 302 (2).

33 See ALI Principles (supra note 8), § 302, Comment a., Illustration, p. 213. 
ments (see below 8) and to initial ownership (see below 7); in both areas the ALI Principles give room to party autonomy.

\section{Lex originis}

Before turning to IP contracts, it should be mentioned that non-registered IP rights, in particular copyrights, are subject in some countries not to the lex loci protectionis, but to the law of origin, which is sometimes defined as being the law of first publication of a copyrighted work or, before publication, the law governing the author's personal status. ${ }^{34}$ Both connecting factors appear to promise a universal recognition of the author's copyright in accordance with the same law. ${ }^{35}$

However, as pointed out above, the obligation enshrined in Article 5 para. 2 of the Berne Convention to grant national treatment to foreign authors does not permit contracting states to enact state legislation that subjects their copyright to a law that differs from the one governing the copyright of domestic authors. ${ }^{36}$ As a consequence, Portugal, where private international law refers to the lex originis as the law governing copyright, has to accommodate inland treatment by a reservation for "special legislation" covering also cases governed by the Berne Convention; therefore, the reference to the lex originis is without significance in practice. ${ }^{37}$

\section{Lex contractus}

A second set of issues related to the transfer and licensing of IP rights is subject to the lex contractus, i.e., general choice-of-law rules for contracts. Except for the Swiss Act, ${ }^{38}$ this rule is not made explicit in any of the national statutes on private international law listed in the introduction (supra I.). But it is nevertheless recognized everywhere as a matter of clas-

\footnotetext{
${ }^{34}$ See, e.g., Art. 48 para. 1 of the Portuguese Civil Code: "(1) Without prejudice to what is laid down in special legislation, the rights of authors are regulated by the law of the place of first publication and, in the absence of publication, by the author's personal law" (my translation, J.B.). A similar rule relating to the existence, content, and extinction of copyright can be found in Art. 60 of Law no. 105 on the regulation of legal relations of private international law of Romania of 22 September 1992, original text and German translation in Wolfgang Riering, ed., IPR-Gesetze in Europa, 1997, p. 132, 154 seq.

35 See Schack (supra note 1), p. 42 seq. and 53 seq.; id. (supra note 19), p. 663 seq.; James Fawcett/Paul Torremans, Intellectual Property and Private International Law, 1998, p. 512.

${ }^{36}$ See the text supra at note 19.

37 See Moura Vicente (supra note 19), p. 230, who cites other literature claiming that because of the need of inland treatment Art. 48 para. 1 of the Civil code is without practical application.

38 See Article 110 (3) of the Act (supra note 3).
} 
sification. The report Giuliano/Lagarde on the 1980 Rome Convention on the law applicable to contractual obligations ${ }^{39}$ is based on the assumption that the Convention applies to contracts relating to intellectual property to the extent that contractual issues are at stake. ${ }^{40}$ The distinction of contractual and non-contractual issues may sometimes be difficult to carry out, ${ }^{41}$ but is inevitable. The European Commission's proposal for the Rome I Regulation contained an explicit choice-of-law rule for license agreements ${ }^{42}$ which was criticized for its excessive simplicity ${ }^{43}$ and therefore deleted from the final text of the Regulation. ${ }^{44}$ But this does not mean that license agreements are excluded from the Regulation; rather, its general choice-of-law rules apply and have to be interpreted in a way that is appropriate to the type of agreement in question.

The classification of issues as contractual or non-contractual is alleviated by provisions such as Article $94 \S 1$ of the Belgian $\mathrm{Act}^{45}$ which point out that the possibility to dispose of IP rights, i.e., their transferability and the manner of transfer, are subject to the lex loci protectionis; similar provisions are contained in the ALI Principles ${ }^{46}$ and the CLIP Principles. ${ }^{47}$

${ }^{39}$ Rome Convention of 19 June 1980 on the Law Applicable to Contractual Relations, consolidated version in OJ 2005 C 334.

${ }^{40}$ See Mario Giuliano, Paul Lagarde, Report on the Convention on the Law Applicable to Contractual Obligations, OJ 1980 C 282/1, 10 at para. 2 excluding in rem rights and rights in intangibles from the scope of the convention, while Article 4 (3) of the Rome Convention explicitly refers to contracts dealing with in rem rights in real property, thereby making clear that the exclusion referred to in para. 2 of the report does not relate to the contractual issues.

${ }^{41}$ See the examples given by Paul Torremans, Licences and assignments of intellectual property rights under the Rome I Regulation, Journal of Private International Law (JPIL) 2008, 397, 398-399.

${ }^{42}$ See Article 4 (1) (f) of the Commission Proposal for a regulation of the European Parliament and the Council on the law applicable to contractual obligations (Rome I), $\operatorname{COM}(2005) 650$ of 15 December 2005; the rules of the proposal are also published in Max Planck Institute for Comparative and International Private Law, Comments on the European Commission's Proposal for a Regulation of the European Parliament and the Council on the law applicable to contractual obligations (Rome I), RabelsZ 71 (2007) $225,254$.

${ }^{43}$ See the CLIP Comments on the European Commission's Proposal for a Regulation on the Law Applicable to Contractual Obligations (Rome I) of 15 December 2005 and the European Parliament Committee on Legal Affairs' Draft Report on the Proposal of 22 August 2005, 4 January 2007, see <www.cl-ip.eu/>, last accessed on 18 March 2009; see also the Max Planck Institute, previous note, RabelsZ 71 (2007) 263-265; Torremans (supra note 41), JPIL 2008, 403 seq.

${ }^{44}$ See Article 4 of Regulation (EC) no 593/2008 of the European Parliament and of the Council of 17 June 2008 on the law applicable to contractual obligations (Rome I), OJ 2008 L 177/6.

45 See supra note 6.

46 ALI Principles (supra note 8), § 302 (2) (b) and (c). 
They enunciate the general principle that all properties of an IP right which may become relevant for contracts but which attach to the right as such are non-contractual in nature. By contrast, all obligations arising between the parties to an IP-related contract to make use of the right in a certain way or to abstain from certain ways of using it, are contractual in nature and subject to the lex contractus.

In the first place, the characterization as contractual opens the gate for party autonomy. The parties may choose the applicable law ${ }^{48}$ subject to internationally mandatory provisions, like for example $\S 32 \mathrm{~b}$ of the German Copyright Law, which safeguards the author's right to a reasonable remuneration even for contracts subject to a foreign law if certain minimum contacts with Germany can be established. ${ }^{49}$ The effects of choice-oflaw agreements may further be confined by consumer protection legislation of the consumer's country of residence under conflict rules such as Article 6 of the Rome I Regulation; ${ }^{50}$ as an example, the widespread provisions against unfair terms in consumer contracts may be cited.

Where the applicable law has not been chosen by the parties, the owner of the IP right will generally be considered as the person effecting the characteristic performance of a transfer or license agreement; consequently, the law of the country where the owner or licensor is habitually resident would apply under Article 4 para. 2 Rome I Regulation. ${ }^{51}$ But the obligations incumbent on the transferee or licensee may be of an equal or even greater weight.

${ }^{47}$ CLIP Principles (supra note 9), § 3:301.

48 See Article 3 of the Rome I Regulation (supra note 44); ALI Principles (supra note 8), § 315; CLIP Principles (supra note 9), § 3:501.

$49 \S 32$ of the German Copyright Act of 1965 as amended by a law of 10 September 2003, Bundesgesetzblatt I, p. 1774, provides: “(1) For the grant of exploitation rights and the permission of the use of the work, the author is entitled to claim the remuneration agreed. Where the amount of the remuneration has not been decided a reasonable remuneration is deemed to have been agreed. To the extent that the remuneration agreed is not reasonable the author is entitled to the other party's approval of an amendment of the contract that grants a reasonable remuneration to the author. (2)....(3) The other party may not invoke a contract term which deviates from paras. 1 and 2 to the author's detriment. The provisions mentioned in the $1^{\text {st }}$ sentence also apply where they are circumvented by other arrangements...(4)... ." And $\S 32$ b provides: " $\S 32$ and 32 a are of mandatory application, 1 . where the exploitation contract would be subject to German law in the absence of a choice of law or 2. where significant acts of exploitation to be committed within the geographical scope of this law are the object of the contract" (my translation, J.B.).

${ }^{50}$ See supra note 44.

${ }^{51}$ See supra note 44; see also ALI Principles (supra note 8), § 315 (2). 
Suppose that the license forms part of a franchise contract that would be subject to the law of the franchisee under Article 4 para. 1 e) Rome I. ${ }^{52}$ The granting of the license on the one hand and the franchisee's distribution duties appear to outweigh each other to the effect that no characteristic performance can be ascertained and the law of the closest connection would be applicable under Article 4 para. 4 Rome I. But even where the licensor's performance can be considered to be characteristic, the licensee may have undertaken other commitments, e.g., the printing of a certain number of copies or the issue of a soft cover edition, etc., that may create a closer connection with a country different from that of the licensor.

In order to cope with these and other complex contractual arrangements, the European CLIP group proposes to balance, in determining the applicable law, a number of factors that may have greater or lesser significance from case to case. ${ }^{53}$ This balancing test may lead to the determination of a performance different from that of the licensor as being characteristic, to the negation of a characteristic performance (Article 4 para. 4 Rome I), or to the operation of the escape clause (Article 4 para. 3 Rome I) ${ }^{54}$ As a consequence, the CLIP Principles have abandoned the concept of characteristic performance and instead instruct the court to look for the closest connection of the contract with any one state. Contrary to some critics, ${ }^{55}$ Article 4 Rome I appears to be sufficiently flexible to allow for appropriate solutions and to accommodate the balancing test proposed by the CLIP group.

\section{Lex fori}

A third choice-of-law principle that has to be taken into account in IP law, as in other areas, is the lex fori for procedural issues. This principle is generally acknowledged; however, the classification of single issues as being substantive or procedural in nature varies. ${ }^{56}$ While the ALI Principles have

52 See supra note 44.

53 See the CLIP Comments (supra note 43); CLIP Principles (supra note 9), § 3:502; Torremans (supra note 41), JPIL 2008, 403 seq.; see also Pedro de Miguel Asensio, Applicable Law in the Absence of Choice to Contracts Relating to Intellectual or Industrial Property Rights, YB PIL 10 (2008) 199, 207 seq.

54 Cf. Dieter Martiny, in Münchener Kommentar zum Bürgerlichen Gesetzbuch, vol. $10,3^{\text {rd }}$ ed. 1998, Art. 28 EGBGB nos. 262 seq.

55 See the criticism by Nerina Boschiero, Spunti critici sulla nuova disciplina comunitaria della legge applicabile ai contratti relative alla proprietà intellettuale in mancanza di scelta ad opera delle parti, in: Gabriella Venturini/Stefania Bariatti (eds.), Nuovi strumenti del diritto internazionale privato - Liber Fausto Pocar, 2009, p. 141, 152 seq.

56 This is particularly noteworthy between common law and civil law jurisdictions; see Martin Illmer, Neutrality Matters - Some Thoughts about the Rome Regulations and 
not tackled this problem, the European CLIP Principles closely follow the Rome I and Rome II Regulations.

Unlike the common law, both EU instruments classify prescription as substantive, not as procedural. ${ }^{57}$ Likewise and contrary to common law perceptions, the assessment of damages is governed, under the Rome Regulations, by the lex contractus or lex delicti, and not by the lex fori. ${ }^{58}$ By the same token, the burden of proof cannot be considered as being procedural ${ }^{59}$ instead, the pertinent provisions contain substantive rules on the outcome in the case of uncertainty about the relevant facts. The applicable law would therefore be the lex loci protectionis, in particular in cases of infringement, or the lex contractus where facts relevant for contractual issues have to be ascertained.

\section{Initial Ownership}

\section{Positive Law}

As pointed out before, the division of labor in the production of IP rights makes it sometimes difficult to determine the initial owner of such a right. The Rome II Regulation has been criticized for not having tackled this problem. ${ }^{60}$ But this issue is simply outside the scope of an instrument on non-contractual liability; in the terms of the general part of private international law, it is a preliminary question to the issue of infringement. ${ }^{61}$ The existence and ownership of IP rights are a matter for the general - national and international - choice-of-law rules on intellectual property which have not been harmonized by EC law so far and actually contain some pertinent provisions.

Where the inventor is an employee, the European Patent Convention of 1973 deals with this problem and refers to the law of the country in which the employee is mainly employed. When that country cannot be determined, the law of the country where the employer has his place of business

the so-called Dichotomy of Substance and Procedure in European Private International Law, Civil Justice Quarterly (C.J.Q.) 28 (2009), 237, 241 seq.

${ }^{57}$ See Article 12 (1) (d) Rome I (supra note 44), and Article 15 (h) Rome II (supra note 7); CLIP Principles (supra note 9), $\S 3: 506$ (1) (d) in regard to contractual claims; a corresponding provision on non-contractual claims is $\S 3: 604(4)$.

58 See Art. 12 (1) (c) Rome I (supra note 44), making however a reservation for limits imposed by the law of procedure, and Art. 15 (c) Rome II (supra note 7); cf. Illmer, above at fn. 53, C.J.Q. 28 (2009) 242.

${ }^{59}$ See Article 18 (1) Rome I (supra note 44), and Article 22 (1) Rome II (supra note 7); the CLIP Principles contain a corresponding general rule in Article 3:806.

${ }^{60}$ See Boschiero (supra note 19), YB PIL 9 (2007) 102.

${ }^{61}$ See Schack (supra note 19), p. $652-653$. 
to which the employee is attached shall apply. ${ }^{62}$ In general, therefore, the lex loci protectionis is excluded in these cases to the extent that the right to a patent before registration is at issue; it regains its unfettered significance after registration. Some of the conflict statutes listed in the introduction (supra I.) contain similar rules. They allow for choice-of-law agreements either directly or indirectly by the contractual determination of the main working place.

The Belgian Act of 2004 extends this rule to other cases where industrial (sic!) property results from contractual relations, and establishes a rebuttable presumption that the lex contractus, as the law of the closest connection, governs initial ownership. ${ }^{63}$ Analogous rules can be found in the ALI Principles for registered rights, ${ }^{64}$ for non-registered trademarks, ${ }^{65}$ and - in a rather complex rule - also for other rights that do not arise out of registration, in particular copyrights. ${ }^{66}$

\section{Inconvenience of the lex loci protectionis}

An assessment of these rules must take into account that the universal and unambiguous identification of the initial owner of an IP right is of the utmost significance for the operation of the whole system. In fact, the application of the lex loci protectionis to issues such as transferability and formal validity of transfer is hinged upon a clear and uniform identification of the initial owner. Where national rules differ in regard to the initial acquisition of IP rights resulting from cooperative research or production, the economic surplus flowing from the exploitation of such rights will by necessity be suboptimal because owner A in country X and owner B in country $\mathrm{Y}$ will get into permanent conflicts, not only in their respective countries of origin, but also on third markets where either A or B will prevail, depending on who is considered as being the initial owner by the national IP law.

${ }^{62}$ See Article 60 (1) of the Convention on the Grant of European Patents of 5 October 1973, 1065 UNTS 199: “(1) The right to a European patent shall belong to the inventor or his successor in title. If the inventor is an employee the right to the European patent shall be determined in accordance with the law of the State in which the employee is mainly employed; if the State in which the employee is mainly employed cannot be determined the law to be applied shall be that of the State in which the employer has his place of business to which the employee is attached. (2)....".

${ }^{63}$ See Article 93 (2) of the Belgian Act (supra note 6); for a commentary, see Marta Pertegás, in: J. Erauw et al., eds., Het Wetboek Internationaal Privaatrecht Becommentarieerd - Le Code de droit international privé commenté, 2006, p. 477.

${ }^{64}$ ALI Principles (supra note 8), § 311.

${ }^{65}$ ALI Principles (supra note 8), § 312.

${ }^{66}$ ALI Principles (supra note 8), § 313. 
The resulting situation will be one of split ownership, similar to the one resulting from expropriations that occurred, e.g., after World War II in East Germany and that led to a rather troublesome coexistence of two corresponding trademarks in East and West where the expropriation, because of its territorial confinement, was not recognized. ${ }^{67} \mathrm{~A}$ conflict rule that would leave the determination of the initial owner to the lex loci protectionis would likely generate similar problems in many cases of a cooperative production of IP rights involving originators from different countries. In the light of the increasing frequency of such arrangements, such a choice-of-law approach would be archaic and would impair the productivity gains to be expected from those forms of cross-border cooperation.

The CLIP Principles take account of these considerations by allowing choice of law regarding the right to claim a registered right. ${ }^{68}$ But they stick to the lex loci protectionis as far as copyright and the entitlement to IP rights arising out of registration is concerned. ${ }^{69}$ This conflict rule is, however, toned down by the right granted to the judge to give effect to work-made-for-hire provisions ${ }^{70}$ of the law of another state that has a close connection with the situation. ${ }^{71}$ When that requirement is met, the judge may construe the parties' relationship under the law applicable, i.e., the lex loci protectionis, as involving a transfer or exclusive license of all economic rights in the work.

With regard to non-registered IP rights, the CLIP proposal is insufficient and inconsistent in several respects. First, it leaves the matter to the discretion of the judge instead of providing for a clear-cut and binding conflict rule; there are no criteria for the exercise of that discretion. Moreover, experience shows that judges who have to apply their own law under the relevant conflict rule are reluctant to make use of such discretion in favor of a foreign law. ${ }^{72}$ Second, the CLIP proposal emerges from the basic

${ }^{67}$ Bundesgerichtshof (BGH, German Federal Court) 15. January 1957, Gewerblicher Rechtsschutz und Urheberrecht (GRUR) 59 (1957), 352 = IPRspr. 1956-57, Nr. 165 (Pertussin); BGH 24 July 1957, GRUR 1958, 189, 194 (Zeiss) with a note by Hefermehl = IPRspr. 1956-57 Nr. 170.

${ }^{68}$ See CLIP Principles (supra note 9), § 3:201(3).

69 See CLIP Principles (supra note 9), § 3:201 (1).

${ }^{70}$ See, for example, for the United States 17 U.S.C. $\S 201$ (b): "In the case of a work made for hire, the employer or other person for whom the work was prepared is considered the author for purposes of this title, and, unless the parties have expressly agreed otherwise in a written instrument signed by them, owns all of the rights comprised in the copyright." The concept of "work made for hire" is the object of a lengthy definition in 17 U.S.C. $\$ 101$

${ }^{71}$ See CLIP Principles (supra note 9), § 3:201 (2).

72 A solution similar to the CLIP proposal is contained, in favor of overriding mandatory provisions of a foreign law, in Article 7 (1) of the Rome Convention (supra note 39). The reported decisions do not indicate that judges tend to disregard their own 
notion of an inalienable core of moral rights that would be exposed to the risk of derogation if deviations from the lex loci protectionis were allowed; but why should the courts of a country whose substantive law subjects initial ownership of an IP right arising from cooperation to the agreement of the parties accept a conflict rule which basically excludes party autonomy and freedom of contract? The pertinent CLIP Principle cannot claim to result from a universal perspective. Third, while the CLIP proposal is driven by considerations of mandatory protection of the author, it allows a derogation in favor of foreign dispositive rules on work made for hire, which is contradictory. Fourth, it interferes with the operation of the substantive law of the lex causae instead of qualifying the basic conflict rule at the level of private international law. But if the rules of substantive law on the construction of contracts are deemed to be accessible to the interference by the CLIP group, why is the existence of an inalienable core of moral rights being treated as an unshakeable creed that determines the basic approach in private international law and does not admit any restrictions? All in all, the acceptance of this proposal in international judicial practice appears rather unlikely.

\section{The Solution: The lex contractus or Party Autonomy}

This unsatisfactory situation could be avoided by the unification of substantive law on this matter, in particular a rule that would leave it to the parties' agreement to decide on the initial owner. The worldwide acceptance of such a rule does not appear very likely, however, and it would have to be supplemented anyway by a default rule applying in the absence of such agreement. Given the great variety of possible forms of cooperation with different contributions made by the partners, such a default rule could hardly cover all cases in a satisfactory way. A choice-of-law rule, therefore, appears to be inevitable for the time being, and an international agreement on a choice-of-law rule is perhaps easier to achieve than a unification of substantive law. Again the great diversity of forms of international cooperation in the field of research, development, and production

\footnotetext{
law applicable under the relevant conflict rule in favor of a foreign law; for Belgium, see Tribunal de commerce de Mons 2 November 2000, Revue de droit commercial belge 2001, 617, 619 seq.; see also the survey of the judicial practice by Dieter Martiny, Europäisches Internationales Vertragsrecht vor der Reform, Zeitschrift für Europäisches Privatrecht (ZEuP) 2003, 590, 616, stating that the effect of foreign overriding mandatory provisions is hardly ever a matter of judicial disputes; in a similar vein $i d$., Neue Impulse im Europäischen Internationalen Vertragsrecht, ZEuP 2006, 60, 91 seq. If the courts do not set aside their own law in favor of foreign mandatory provisions, it is difficult to see why they should give a greater weight to foreign default rules like the work-made-for-hire provisions.
} 
of IP rights would favor party autonomy, since the parties have a better knowledge of their own cooperation scheme and also of the relative advantages of the national legal systems involved.

On the other hand, the admission of party autonomy in this field would certainly accentuate or even strengthen pre-existing asymmetries between the parties. In a short-term view, the large producers of IP rights established in the United States, the European Union, and Japan would impose the choice of their own laws on their respective contracting partners. But in the long run, other countries may engage in a regulatory competition for IP laws that are attractive for IP producers and trigger a shift of choice-of-law clauses to the new statutes. One could object that the choice-of-law mechanism would expose the smaller parties to international cooperation agreements to foreign laws, depriving them of the benefits that would flow from their activities under their own laws. One might even argue that free choice of law, where applied to initial ownership, would broaden the brain drain from developing and threshold countries to the industrialized world.

But this outcome is not very likely. First, the information produced by Third World originators will improve their own situation and that of their respective national economies, even if some of the work product will be owned by their partners from industrialized countries under the respective cooperation agreements. Second, the legal security afforded by the recognition of party autonomy in this field will encourage investment in the respective areas in Third World countries. And third, where a national government of a developing or threshold state, in weighing the pros and cons, feels a need to protect domestic originators, it may enact internationally mandatory rules to that effect which will prevail over the parties' choice-of-law agreement.

It is submitted, therefore, that the law governing the contract underlying the cooperative production of IP rights should determine the identity of the initial owner in cases of cross-border cooperation arrangements. Opponents to this proposition argue that it cannot be applied to copyright because a person who would acquire, under the lex loci protectionis, a copyright including certain inalienable moral rights, might be deprived of these entitlements by virtue of a contractual choice of law; this is said to conflict with the mandatory character of their inalienability, which some believe to be rooted in constitutional guarantees of fundamental rights.

It is doubtful whether the assumptions underlying this argument in substantive law are correct; comparative investigations point instead to a farreaching although not complete freedom of contract in regard to moral rights. ${ }^{73}$ Moreover, it is questionable whether the whole system of private

${ }^{73}$ See Axel Metzger, Rechtsgeschäfte über das Droit moral im deutschen und französischen Urheberrecht, 2002, suggesting throughout the book that the dogma of inalien- 
international law relating to copyright, which is essentially an economic right, should be determined by the existence of some marginal entitlements of a moral and mandatory character; they could be coped with by escape clauses for mandatory provisions where the decision of a case actually turns on them. It should finally be recalled that our proposition advocates not abandoning the lex loci protectionis as such, but restricting it with regard to cases where intellectual property rights result from cross-border cooperation; in such cases it will sometimes be unclear who is the holder of the right under the lex loci protectionis, and the laws of the countries may also differ in identifying that right holder. Application of the various leges locorum protectionis may therefore be of little avail, and the certainty about the identity of the initial owner gained by the parties' choice of the applicable law will outweigh the remaining inconveniences.

Some support for the view explained above is given by the judgment of the European Court of Justice in Duijnstee v. Goderbauer, ${ }^{74}$ which dealt with the exclusive competence for proceedings under what is now Art. 22 no. 4 of the Brussels I Regulation ${ }^{75}$ in patent cases. Referring to the travaux préparatoires, the Court confirmed the "restrictive nature of the provision" which should apply only to disputes about the existence, validity, and lapse of a patent, but not to a litigation about the entitlement to a patent which has to be decided on the basis of the legal relation between the parties. ${ }^{76}$ Since jurisdiction for such disputes has to be decided in accordance with the general rules of the Brussels I Regulation, it follows that choice-of-forum agreements are possible under Art. 23. This would appear to apply to copyright, too, which is not even mentioned in Art. 22 no. 4. If agreements can determine the competent courts for proceedings about initial ownership, it is difficult to see why they should be completely excluded with regard to the applicable law.

As pointed out before, the preceding proposition concerns only the identification of the initial owner in cases of contractual arrangements of a cross-border cooperation that lead to the production of IP rights. After the determination of the initial owner has been made, the lex loci protectionis will come into play again and apply to issues relating to the further development of the IP right in question.

ability is subject to a large number of exceptions and restrictions in both German and French law.

${ }^{74}$ ECJ 15 November 1983, case 288/82 (Duijnstee v. Goderbauer), [1983] E.C.R. 3663 .

${ }^{75}$ Council Regulation (EC) no. 44/2001 of 22 December 2000 on jurisdiction, and the recognition and enforcement of judgments in civil and commercial matters, OJ $2001 \mathrm{~L}$ $12 / 1$.

${ }^{76}$ ECJ (supra note 74), paras. 23-26. 


\section{Multi-State Infringements}

\section{Basic Principle: lex loci protectionis}

As a matter of principle, the infringement of IP rights must be governed by the lex loci protectionis. It would be contradictory to subject the existence and content of these rights to the law of the country for which protection is sought and to apply a different law when the owner actually seeks protection. Since IP rights are nothing but creatures of positive law, their existence and scope is tantamount to the description of what constitutes an infringement and of the remedies available. Applying a different law to infringement would inevitably change the content of the IP right as laid out in the lex loci protectionis. This inherent link has explicitly been acknowledged by the more recent national statutes listed in the introduction (supra I.), in particular the laws of Belgium, Korea, and Switzerland. Without dealing with the basic issues of IP rights like existence, ownership, or validity, Article 8 of the Rome II Regulation equally refers to the lex loci protectionis for all issues relating to the infringement of such rights.

These considerations also conflict with the authorization of the parties to agree on the law applicable to infringements. Nevertheless, the free choice of law is permitted by $\S 302$ of the ALI Principles, whereas the statutory provisions cited in the introduction (supra I.) are silent in this respect and thereby exclude the parties' choice of the applicable law. The only exception is Article 110 para. 2 of the Swiss Act, which allows the parties to agree, after the occurrence of the infringement, on the lex fori as the applicable law. ${ }^{77}$ While the free choice of law is also permitted, as a general rule, by Article 14 of the Rome II Regulation, Article 8 para. 3 explicitly excludes such agreements in regard to the infringement of IP rights. $^{78}$

Choice-of-law agreements may bring about strange situations indeed. Suppose, for example, an IP right granted by a country where infringers get very low compensation or no compensation at all under the national law of torts. If license agreements concerning such IP rights are subject, by standardized choice-of-law clauses, to the law of contracts and torts of the U.S., the infringing licensee might be confronted with very high damages claims, including even punitive damages. It goes without saying that the very character of the IP right in question changes if such an exorbitant protection is granted as a matter of general practice. This assessment might differ for individual choice-of-law agreements made after the occurrence of the infringement, which explains the Swiss rule mentioned above.

\footnotetext{
77 See supra note 3.

78 See supra note 7 .
} 
The application of the lex loci contractus to infringement cases is however hinged upon two assumptions: First, it presupposes that the reference to the locus protectionis is unequivocal in the sense that there is only one legal system dealing with the consequences of infringements for the whole territory where the IP right is in force. Second, the operation of any choice-of-law rule must lead to a selection of one or more applicable laws out of the very large number of legal systems in the world. These prerequisites may be absent in some cases.

\section{Unitary IP Rights}

As to the first condition, difficulties may arise in federal entities if the IP right covers several jurisdictions without being supplemented by sanctions applicable in the case of infringement. This does not concern the U.S. since the various federal acts establishing IP rights contain provisions dealing with the compensation of losses resulting from the breach of those IP rights. While American law in general does not recognize a federal common law, leaving the law of torts in particular to the single states, ${ }^{79}$ the situation differs regarding the infringement of IP rights because of federal statutory provisions. ${ }^{80}$

Different consequences must be drawn, however, in regard to the European Union. Here, two types of IP rights exist: The single member states grant and administer national IP rights which, although harmonized in substance to a large extent by EC Directives adopted under Article 95 EC, have a purely territorial scope limited to the respective member state. Next to these national IP rights the Community has created Community IP rights by regulations issued under what is now Article 308 EC. They owe their existence not to national sovereignty, but to the sovereignty of the European Community; they have been created by regulations which are directly applicable under Article 249 EC and will therefore prevail over any national enactment that might be adopted for their amendment. Their geographical scope is not the sum of the 27 national territories of the member states, but ipso iure extends to the whole of the Community. According to its wording, the legislative basis of the underlying regulations, i.e., Article 308 EC, is subsidiary to other provisions of the Treaty that provide the necessary powers; therefore, given the Community powers under Article

79 Erie R.R.Co. v. Tompkins, 304 U.S. 64, 78 (1938); for choice-of-law, see Klaxon Co. v. Stentor Electric Manufacturing Co., 313 U.S. 487, 496 (1941).

${ }^{80}$ For copyright infringements, see 17 U.S.C. $\S 501$ seq.; for patent infringements, see 35 U.S.C. $\S 271$ seq., 281 seq.; for trademark infringements, see 15 U.S.C. $\S 1114$ seq. 
$95 \mathrm{EC}$, no approximation or unification of national laws is possible on the basis of Article $308 .^{81}$

As compared with the national IP rights, the Community IP rights are therefore sui generis as it is clearly spelled out in recitals 2 and 3 of the Community Trademark Regulation: ${ }^{82}$

Whereas the principle of unitary character of the Community trademark...will apply unless otherwise provided for in this Regulation; whereas the barrier of territoriality of the rights conferred on proprietors of trademarks by the laws of the Member States cannot be removed by approximation of laws; whereas in order to open up unrestricted economic activity in the whole of the Common Market for the benefit of undertakings, trademarks need to be created which are governed by a uniform Community law directly applicable in all Member States.

Contrary to what has been argued by a commentator of the Rome II Regulation, ${ }^{83}$ the locus protectionis of a unitary Community IP right is therefore always the whole of the Community. ${ }^{84}$ As a consequence, the reference to the lex loci protectionis is made to Community law as such, i.e., to said regulations. To the extent that they do not contain rules on the liability for infringements, an additional conflict rule would be needed to designate the law of the country which applies to that liability (sub-designation, Unteranknüpfung). This is the background of Article 8 para. 2 Rome II which refers to the law of the country where the act of infringement was committed. Because of the universal application of the Rome II Regulation, the applicable law under Article 8 para. 2 could be the law of a third country for example, Japanese law - if a content provider has uploaded, in Japan, information that infringes a Community trademark. ${ }^{85}$

${ }^{81}$ See Ivo Schwartz, in Hans von der Groeben, Jürgen Schwarze, eds., Kommentar zum Vertrag über die Europäische Union und zur Gründung der Europäischen Gemeinschaft, vol. $4,6^{\text {th }}$ ed. 2004 , Artikel 308 EG no. 65 with many references.

${ }^{82}$ Council Regulation (EC) no. 40/94 of 20 December 1993 on the Community trade mark, OJ 1994 L 11/1, now consolidated in Council Regulation (EC) no. 207/2009 of 26 February 2009, OJ 2009 L 78/1.

${ }^{83}$ See Schaafsma (supra note 19), WPNR 2008, 1000 seq. who considers the Community regulations on unitary IP rights as unifying national law.

${ }^{84}$ See Hamburg Group for Private International Law, Comments on the European Commission's Draft Proposal for a Council Regulation on the Law Applicable to NonContractual Obligations, RabelsZ 67 (2003) 1, 23; Schack (supra note 19), p. 657.

${ }^{85}$ This possibility is rejected by Schack (supra note 19), p. 659, who alleges that a right not recognized in a third state cannot be infringed in that country. But the act committed in the third country leads to an infringement in the EU; while the infringement occurs in the EU, the act may be committed in a third state. The "act of infringement" addressed by Article 8 para. 2 Rome II is the physical act that results in an infringement of the unitary IP right; that infringement is located in the European Union indeed. 


\section{Ubiquitous Infringements}

The second assumption underlying the lex loci protectionis (or the approval of any other choice-of-law rule) is the possibility to identify, by its application, one or several, but in any case a limited number of, applicable laws. This assumption is no longer justified where the infringing acts are committed by means of modern communication techniques such as satellite communication or the Internet. In theory, an infringement committed through the Internet affects corresponding IP rights existing under all national laws worldwide. The conduct of proceedings in such multi-state infringement cases becomes impracticable for the right holder, which in turn would reduce the protection of his rights considerably or even to naught.

So far, none of the statutory texts listed in the introduction (supra I.) has dealt with choice-of-law problems arising from ubiquitous or multistate infringements. The solutions proposed in academic writings have not indicated viable alternatives to the lex loci protectionis. ${ }^{86}$ Both the ALI Principles and the CLIP Principles, however, provide for a kind of escape clause that allows the application of the law of the closest connection to such infringements $;{ }^{87}$ the ALI Principles go a step further and declare that law applicable also to the issues of existence, validity, duration, and attributes of intellectual property rights. ${ }^{88}$ Both instruments indicate some relevant factors for the determination of the closest connection, in particular the residence and center of main interest of the parties, the place of performance of the activities giving rise to the infringement, and the principal markets toward which the parties direct their activities.

This escape clause will most likely have a greater significance in American courts than in European courts. Article 8 Rome II does not provide for any exception from the lex loci protectionis, while the lack of statutory choice-of-law rules in the U.S. gives some latitude to the courts in choosing the applicable law. Which will be the effect of the escape clause under such conditions? Where an action for a multi-state infringement of IP rights is taken to a U.S. court, the court will have, at a first stage, the possibility of declining its own jurisdiction under the forum non conveniens doctrine. This procedural device and the escape clause in choice of law will enable the courts to either accept the case and decide it under American law or to decline jurisdiction. On the contrary, the probability of a court accepting jurisdiction and deciding the case under foreign

\footnotetext{
${ }^{86}$ For a concise discussion, see Josef Drexl, in Münchener Kommentar zum Bürgerlichen Gesetzbuch, vol. 11, $4^{\text {th }}$ ed. 2006, IntImmGR nos. $206-211$, p. $890-893$.

${ }^{87}$ See ALI Principles (supra note 8), §321; CLIP Principles (supra note 9), Art. 3:603.

${ }^{88}$ See the previous note.
} 
law would appear rather low. In this perspective, the escape clause which appears to be a kind of security valve at first sight, may turn out to be rather a welcome device for courts that want to avoid the application of foreign law.

In the European Union, the procedural situation differs. According to the European Court of Justice, most rules on jurisdiction of the Brussels I Regulation apply only if the defendant is domiciled in the Union and the plaintiff in a third state. ${ }^{89}$ Moreover, the Brussels I Regulation excludes the forum non conveniens doctrine and thereby the judicial discretion in jurisdictional matters. ${ }^{90}$ For instance, if a Japanese owner of corresponding IP rights protected in member states and third states sues a European infringer in a court of an EU member state for a multi-state infringement occurring inside and outside the European Union, the court will apply the lex loci protectionis of every country affected, whether a member state or a third state, in accordance with Articles 3 and 8 Rome II. There is no loophole for the escape clause designed by the CLIP Principles. In order to avoid chaos in such a multi-state infringement litigation, however, the court, under its national rules of civil procedure, may split the whole litigation into as many separate procedures as there are states involved.

\section{Conclusion}

(1) As an overarching concept, intellectual property is appropriate for private international law, allowing for, but not imposing, general conflict rules for all IP rights.

(2) The grant of IP rights pursues objectives of public (economic) policy. Their structure is shaped by public law; therefore, the point of departure for choice of law is the principle of territoriality. They generate a kind of path dependency for the present and future development of international IP law, although the territorial principle gets into increasing tensions with globalization, in particular the global dissemination of data through the worldwide web and with the production of IP rights in international cooperation schemes.

(3) The demarcation of IP rights from neighboring areas of the law is less difficult than it might appear. The article advocates the classification of moral rights, but not of personality rights, as IP rights.

${ }^{89}$ ECJ 13 July 2000, case C-412/98 (Group Josi Reinsurance Co. ./. Universal General Insurance Co.), [2000] E.C.R. I-5925, paras. 58-60 with further references.

90 ECJ 1 March 2005, case C-281/02 (Owusu ./. Jackson), [2005] E.C.R. I-1383 paras. 37 seq., 45 . 
(4) The territorial principle has to be spelled out as referring to the law of the country for which protection is sought. This lex loci protectionis has a very wide scope. It covers all properties that attach to the IP right as such, including infringement. The separation of the law governing infringement from the law relating to the existence, etc., of the IP right - for example, by allowing choice of law for infringement - may lead to a fundamental change of the substance of the IP right and is rejected as a matter of principle.

(5) Choice-of-law principles governing contracts, in particular party autonomy, are acknowledged for the contractual transfer and license of IP rights, too.

(6) As in other fields, the application of choice-of-law rules pursues, idealistic as that might appear sometimes, the objective of an international harmony of decisions. In the field of IP rights this objective is hinged upon an unequivocal determination of the initial owner of corresponding IP rights. Where only one originator is in question, the matter can be left to the lex loci protectionis. Where, however, IP rights result from a cooperation between two or more partners, the laws of the single countries may arrive at different conclusions as to the identity of the initial owner. The choice of the applicable law by the parties can forego such inconveniences.

(7) Infringement is and should basically be subject to the lex loci protectionis. Where infringement is ubiquitous because of the communication techniques used, an escape clause is advocated by the ALI Principles and by the CLIP Principles. However, the results will be very different in the United States and in Europe. 



\title{
The ALI Principles: Intellectual Property in Transborder Litigation
}

\author{
FRANÇOIS DESSEMONTET
}

$\begin{array}{ll}\text { I. Introduction } & \text { History and ambitions } \\ \text { II. } & \text { JII. } \\ \text { III. } & \text { Personal jurisdiction } \\ \text { 1. } & \text { Subject matter jurisdiction } \\ \text { IV. } & \text { Applicable Law }\end{array}$

\section{Introduction}

The ALI Principles Governing Jurisdiction, Choice of Law, and Judgments in Intellectual Property in Transnational Disputes have been published in August 2008. They are a breakthrough in the area of disputes involving two or several countries. To present then, we shall focus after a short introduction on the three main Chapters Jurisdiction, Choice of Law and Recognition of Foreign Judgments.

Each of the 36 Sections is deserving of attention. However, in as many minutes to introduce them, reason dictates to make choices and to talk only on highlights, on the most basic or the most innovative solutions. It will be impossible to comment on each and every provision. We will attempt to expose the ways in which the ALI Principles propose to remedy the fragmentation of legal systems and to simplify multicountry litigation. 


\section{History and ambitions}

From the inception of intellectual property, that is at the end of the XVth century for patents, XVIth century for copyright privileges and somewhat earlier for trademarks, each Sovereign has granted rights according to the best interests of his State. The aim was to promote industry and commerce within these national borders and these antique legislations were effective only within the domestic, often narrow borders. The paradigm changed in the mid XIXth century. Then great trading States such as England and France obtained through bilateral negotiations with less powerful partners like Russia, Belgium or Switzerland an extensive protection for their authors or inventors, sometimes even trademark owners. ${ }^{1}$

The system of these conventions created universal protection (in the main civilized States of the time) for English and French authors. This protection was premised on the country of origin principle: if someone is entitled to copyrights in England or France, his entitlement will be recognized and enforced in Russia or Switzerland (sometimes only for the books written in a foreign language and not for the translation).

However, the system of bilateral protection also led to an unbalance between French or English authors for example, and domestic authors in other countries. These domestic authors were not or were little protected by national legislation, in Russia or Switzerland for example, while foreign authors enjoyed in the same country the much wider protection which had been conceded to their mighty country by the tsarist or Swiss government. In itself, this discrimination in favor of the foreigners was conducive of much reform in the legislation for the countries which had not felt the need to protect intellectual property before the conclusion of a bilateral agreement. However, arm-wringing negotiating tactics bring about a bitter taste, as we can still witness nowadays in the bilateral negotiations between the US and other countries regarding the alleged inadequacies of the latter's intellectual property legislation or practice. This could engulf intellectual property in any popular rebellion against foreigner friendly government politics, as is obvious in our days for transgenic seeds in India, for example.

Therefore, at the end of the XIXth century, enlightened spirits desired to change the bilateral approach in favor of a multilateral approach. Costa Rican authors for example would enjoy in every country signatory of the multinational Convention of Union of Berne of 1886 the benefit of the legal protection as instituted by the local legislation of that country. The

${ }^{1}$ See e.g. the conventions between Switzerland and France of 1864, between Switzerland and some German States of 1869 and 1881, as well as the German-Swiss Convention of 1892, still effective as of today in the area of trademark use. 
multilateral approach could work in favor of the authors and inventors or the more developed countries only if a minimum level of protection was compulsory for each State signatory of the multilateral convention. The intellectual property became territorial in all respects. It was said that a Japanese author acquires rights in his work which are distinct in every of the more than 200 countries of the world: same film, or same mark, or same invention, yet a bundle of rights all subject to different rules and regulations. This system prevails today, even under the TRIPs Agreement of 1994. However, recent case law or legislation abandon in some countries such as Japan and Switzerland one of the main areas in which the territorial reasoning was put to practical use, i.e. the national exhaustion (or first sale) doctrine.

The system is fragmented as to the rights and entitlements which are given to the authors, designers, performers, inventors and trademark owners, but the confusion is aggravated by the further fragmentation of the judiciary. Two hundred countries may be competent for a worldwide infringement case, such as occurs on Internet for example. There is no international jurisdiction to harmonize the case law and the practice. Until the institution by the GATT of the Dispute Resolution Board of the World Trade Organization, there was no recourse for a country observing that the minimal protection is not granted to its citizens in a another country (with the exception of bilateral negotiations, which tend to favor only the mighty and the powerful nations and their authors). Therefore there were innumerable conflicts of law and parallel jurisdiction. In a given patent case the courts of 19 countries could come to adjudicate the essentially identical issues.

This of course inspired the legal commentators. A Basle $\mathrm{PhD}$ thesis proposed a unification of intellectual property at the beginning of the XVIIIth century. ${ }^{2}$ Then some French commentators of international private law such as Battifol and Niboyet proposed a universalist approach. The German speaking literature was enriched by the treatise of professor Aloïs Troller in $1952^{3}$, then by the research and proposals presented in 1975 at the Nymphenburg Colloquium by professor Eugen Ulmer at the request of the Commission of the European Union. ${ }^{4} \mathrm{I}$ also gave a legal opinion in

2 J.R. Thurneysen, Juristische Inaugural-Dissertation De Recusione Librorum Furtiva, zu Teutsch: Vom unerlaubten Bücher-Nachdruck ("On Unauthorized Printing of Book"), Basle 1725 translated by H. Thieme in: Die Berner Übereinkunft und die Schweiz ("The Berne Convention and Switzerland"), Bern 1986, 13-46.

${ }^{3}$ Das internationale Privat- und Zivilprozessrecht im gewerblichen Rechtsschutz und Urheberecht, Basle 1952.

${ }^{4}$ E. Ulmer, Die Immaterialgüterrechte im internationalen Privatrecht ("Intellectual Property in Conflicts of Laws"), Köln, Berlin etc. 1975, translated as Intellectual 
1976 to the Hague Conference of International Private Law on choice of law for licensing of intellectual property assets, following which the choice of law of transfer of technology agreements remained on the agenda there for 15 years, without notable progress. In 1996, professor Jane Ginsburg of Columbia University and I presented a common proposal for conflicts of law in Internet related intellectual property cases. ${ }^{5}$ Professor Rochelle Dreyfuss of New York University published in 2000 a seminal article on jurisdictional issues taking into account the likely failure of the Hague Convention to reach a consensus on the recognition of foreign judgment generally. In 2001 the American Law Institute appointed 3 reporters (Prof. Dreyfuss, Ginsburg and myself) and a panel of 26 advisors (13 from the US, 13 from the rest of the world, among which one of the most distinguished scholars was professor Toshiyuki Kono of Japan). After the usual preparation of drafts, discussion among the panel members, examination by the Executive Committee and the floor, the American Law Institute approved the Principles on 14 May 2007 and published them in September 2008. This has made our draft one of the quickest ever to reach completion, and yet we fulfilled our ambitions.

We ambitioned to set up a set of Principles which would be non binding and helpful for the courts, the practitioners and the scholars. We ambitioned to facilitate the international trade and the cultural life while respecting the needs of the economy worldwide. We hoped to harmonize the particular regime of choice of law and choice of jurisdiction for intellectual property rights with the general rules applicable to conflicts. We wanted the Principles to be compatible with all major legal traditions. And finally, we hoped to coordinate the rules applicable to each different set of IP rights, such as copyrights, patents, designs, trademarks and unfair competition with each other.

Did we succeed? Other, more qualified scholars will pass judgment on that. We have been told that already a dozen $\mathrm{PhD}$ dissertations are being prepared on these Principles. Hopefully these younger learned minds will viciously attack some of the solutions and gallantly defend most of the Principles (or the other way round...). I should like to stress that each of you may examine the solutions I will sketch today under the four viewpoints of practicality, respect of other rules on conflicts, compatibility with major legal traditions and consistency within all areas of intellectual property.

Property Rights and the Conflict of Laws (1978). See also my treatise Le Droit d'auteur ("Copyright Law"), Lausanne 1999, 639 seq.

${ }^{5}$ See Propositions conjointes, following my article Internet, le droit d'auteur et le droit international privé, in Revue suisse de jurisprudence 1996, 288 seq. 


\section{Jurisdiction}

The ALI Principles concerning jurisdiction are premised on the necessary respect of the requirements of personal jurisdiction over the respondent and of subject matter jurisdiction over the litigation. They take into account the party autonomy to a very large extent, as well as The Hague Convention of Choice of Court Agreements of 30 June 2005. ${ }^{6}$

There are four tests to determine the State the courts of which are competent to hear a dispute relating to intellectual property rights

1. General forum: habitual residence of respondent

2. Subject matter forum: country of infringement with limitation to that country's damages

3. Party autonomy with some limitations for standard form agreements

4. Contractual license for the country of the forum with limitation to the IP rights in the contract.

\section{Personal jurisdiction}

The general forum warrants what could be called the "natural judge" for the respondent: is the judge of his or her country of habitual residence. As the notion of domicile is much narrower under the English and some other laws the ALI Principles follow the more modern continental European codifications of the law of conflict and some international conventions and they are based only on the notion of habitual residence. ${ }^{7}$ For legal entities, statutory seat, place of the incorporation, place of the central administration or principal place of business indicate the natural forum.

There are derogations to the principle of the "natural judge" being the judge sitting at the habitual residence of the respondent. When the respondent is extending its activities to an important degree outside its country of residence, as it is organizing itself to take hold on those other markets, it is only natural that it could be attracted to the courts of those other countries. Hence the well known test of "doing business" in US practice. However, within the States of the Union, this test is not uniformly applied. Further, the test of "doing business" is tricky to apply in an Internet based econ-

${ }^{6}$ This Convention does not apply to the disputes concerning the validity of industrial property rights or to disputes involving consumers or employment contracts. Intellectual property contracts are subject to the convention (see art. 2 (n)(o)). Issues of intellectual property may be examined by the chosen court on a preliminary basis (art. 3).

According to Comment $b$ ad Sec. 313, p. 140, a natural person may not have more than one habitual residence. It is known that in texts such as the Restatement of the Law and the Principles, "comments" express the official views of the ALI, while "Reporters' Notes" air the opinions of the reporters. 
omy, in which it may be said that any person offering goods or services through Internet is "doing business" in all countries from which the offer can be viewed, or at least from which the offer can be followed by an acceptable order. "To be viewed" may sometimes already qualify as "doing business" if the service is offering something interesting to watch.

Nevertheless, generally speaking, to do business will imply more. For example, it may imply accepting credit cards issues by the financial institution of that country, or shipping goods to that country. Sometimes it may even imply attempting to abide by the laws and regulations of the buyer's country of residence or of the country of delivery of the goods if different. Linguistic filters or other filters may also exclude business coming from a given country or group of countries. Therefore, the ALI Principles do not accept the test of "doing business" to determine jurisdiction, but they do accept the dual test of "substantially acting" in a State or "directing activities to that State" [Sec. 204 (1) \& (2)]. Only in the particular case when the respondent is not amenable before a "natural judge", i.e. the court of its habitual residence, or place of incorporation etc. in a World Trade Organization country, the ALI Principles allow for some use of the test of "doing business" in order to accept the jurisdiction of the courts of the country in which the respondent "solicits or maintains contacts, business, or an audience... on a regular basis" [Sec. 204 (3)(b)].

As a consequence, respondents that are located in the 50 or so less developed countries which are not yet part of the WTO and therefore not bound by the minimal standards of protection of IP rights embedded in the TRIPs Agreement of 1994 may not argue of their natural judge being outside the WTO zone in order to escape from the jurisdiction of the courts of WTO countries when they are doing business in one or more of these WTO countries. The ALI Principles are premised on the idea that non WTO countries may be "information havens". This quasi general WTO related jurisdiction extends to "claims respecting injuries arising out of conduct outside the State that relates to the alleged infringement in the State, wherever the injuries occur". In my view, the damages can be claimed in that forum for all injuries "wherever they occur". This formulation would be clearer, but the actual text of the ALI Principles has been inspired by the Max Planck Institute project. ${ }^{8}$ The concern was that the intent to benefit from an information haven should be clearly shown for this quasi general jurisdiction to apply. Nevertheless, the Max Planck Institute's observations are not based on practical experience of the judiciary. Before any court of law, the most difficult proof is the proof of intention. God only knows about intentions, the judge has evidence of acts or abstentions. Therefore, a progressive interpretation

${ }^{8}$ See MPI Proposal in: Drexl/Kur (eds.), Intellectual Property and Private International Law (2005), pp. 309-334. 
of Sec. 204 (3) ALI Principles should conduct courts aware of the difficulty of evidence relating to intent to accept quasi general jurisdiction on the basis of "regularly doing business" when the respondent resides in a non WTO country and to the extent that the harm, wherever it occurs, is related to the infringing acts giving rise to the jurisdiction.

In case of multiple respondents, consolidation before the natural judge of one of them is possible if there is a risk of inconsistent judgment and if the forum is closely related to the entire dispute so that there is no other forum which would appear to be more closely related to the litigation.

Sec. 207 recites the insufficient grounds for jurisdiction in a very classical approach:

- Presence of tangible property belonging to the respondent in the alleged forum

- Existence of an IP right belonging to the respondent which is not involved in the litigation

- Nationality of plaintiff or respondent

- Presence of plaintiff in the forum

- Conduct of commercial or other activities by respondent unless the dispute arises out of these activities

- Service of a writ upon the respondent

- Completion of the formalities necessary to execute the agreement involved in the dispute.

The consequence of not abiding by these Principles is that the ensuing judgment should not be recognized abroad. It will be noted that the Principles do not mention the forum non conveniens test among the reasons to reject a jurisdiction.

\section{Subject matter jurisdiction}

The rules over subject matter jurisdiction determine the ambit of the decision of the forum which is acceptable under the rules on personal jurisdiction which we just mentioned. These rules supplement national rules on subject matter jurisdiction but of course do not purport to replace them.

The first and foremost Principle is that a court will not be deemed not to be competent simply because it should apply foreign law. This stands to reason, yet for English jurisdiction in particular, it has long been thought that they were not competent to apply foreign law and should therefore decline their jurisdiction whenever foreign law is involved. ${ }^{9}$

9 See e.g. Fairchild Semiconductor Corporation vs. 3D Semiconductor, Inc. (D Me 2008) 2008 WL 5179743 at 5 seq. (discussing concerns arising from the application of foreign intellectual property legislation). 
When the invalidity of a foreign registered intellectual property right is declared, the judgment will not be opposable to third parties. The idea is that only the courts of the country of registration of that right can decide upon the extent of the public domain in that country. ${ }^{10}$ Otherwise, the foreign court will be competent for all claims and defenses among the parties, regardless of the territorial source of these claims or defenses, of the "country of origin" of the right.

The authors of the ALI Principles have given a special attention to the declaratory actions. These actions are extremely important in the area of intellectual property, because it may be said that many disputes revolve about the validity or invalidity of a patent, design or trade mark. Often as well, the respondent to a possible action for infringement will file somewhere an action claiming that it does not infringe upon an IP right. Further, license agreements oftentimes bind rather large companies that are ready to respect their duties when the court has first decided on the exact extent of these duties. A typical case might be the following: a chemical company has received a site license for the production according to a certain patented process. Due to environmental concerns its factory has to be relocated. Will the license allow for the new factory somewhere else to apply the patented process? Declaratory actions also take up negative contractual issues, for example does a new development fall under the existing license or not?

The merit of these declaratory actions may differ in fact, but in international litigations, they have in common to allow for delay. If a declaratory action is introduced in a country the courts of which are known for taking years and years, if not decades, to definitely decide an issue, the other actions may be practically crippled, or there is the risk of inconsistent judgments. This has been known as the "Italian torpedo": the respondent to an infringement under a European IP right files a declaratory action and can expect that the litigation will last ten years at least. For a right limited in time, this is too long. Some commentators maintain that the system has changed in Italy for the admissibility of these actions, but this obviously is a larger problem not limited to the country of Giulietta and Romeo. The solution of the Principles is to allow declaratory actions claiming that an IP right is invalid only in the country of registration. Of course it does not help in Europe since European patents do give rise to national registrations for all countries where protection is claimed at the European Office for Patents in Munich. Nevertheless, it may give some relief against declaratory actions that would be filed in other countries in which there would be no registration. All other declaratory actions, for example the actions con-

${ }^{10}$ See along the same pattern but with more detailed regulation Art. 2(3) and 10 of The Hague Convention on choice of court agreements of 30 June 2005. 
cerning licensing agreements, will follow the general rules. So do also the jurisdiction for provisional measures. The presence of tangible property related to the IP rights in dispute is sufficient to admit jurisdiction, but if the goods are only in transit, the ambit of the provisional measures is restricted to temporary detention while the true owner of the good is identified and joined to the proceedings. The ALI Principles so take into account the TRIPs and European Union rules applicable to the detention of infringing goods at the borders.

\section{Consolidation and coordination}

In an ideal world, there would be only one court adjudicating the same claims based on the same facts between the same parties. However, the territoriality of intellectual property entails that this might often not be the case. The authors of the ALI Principles are courageously attempting to propose rules for the coordination in the larger meaning of the word of the multiple litigations which bear on identical or similar allegations in numerous countries before several courts.

The authority of the court first seized to examine coordination and consolidation of the claims will be noticed, as well as the general favor towards consolidation rather than coordination in the stricter meaning of the word, i.e. the cooperation between courts that independently proceed towards the resolution of parallel cases in different countries. Coordination is an awkward undertaking, since each and every step, be it an order or perhaps even a letter by one court to the other etc. could become the subject matter of an appeal, thus effectively impeding the efficient unfurling of the proceedings. If consolidation can take place, it is wished that it will happen before a court which has expertise in the IP area. It is also desirable that this court decides to apply one law to all aspects of the dispute, with the exception that if a party can prove that in a given country, the consequences of the application of that country's law are different, the party may request the consolidating court to take these differences into account.

If consolidation takes place and if the court applies one law to the entire litigation, the IP rights holders will find it much easier to pursue piracy. Conversely, the respondents may find it difficult because the whole world market may be closed to their products. The proper answer to the risks inhering in such consolidated proceedings is a very decided respect of the "ordre public" (="public policy") provisions of each and every country. However, it is a decisive advantage of the ALI Principles that they squarely favor the energetic pursuit of IP rights compliance throughout the world. In a global village, the financial crisis of 2008-2009 has shown, it is not less or more regulations that matter much, but the more effective enforcement of norms that already exist. 


\section{Applicable Law}

\section{Territoriality}

The court which is competent will in most cases apply its own laws, because the judges and counsel know them best. However, the experience in small countries such as Switzerland whose courts are often chosen by commercial parties shows that national courts are able and willing to apply foreign law if so directed by their rules on conflicts of laws.

The ALI Principles are premised on party autonomy in jurisdictional matters. Therefore, it may be hoped that parties often designate as exclusively competent one court which will know of their dispute wherever the infringement or violation of the license agreement takes place. Further, the consolidation of parallel proceeding also leads the consolidating court to examine all facts of the case independently of the country where these facts are alleged to happen, and to embrace all legal questions between parties independently of the legal order which applies to the solution of the dispute. As a result, courts may have to apply foreign law and, more particularly, foreign legislation on intellectual property.

Nevertheless, the question of applicable law should not be understood too broadly. A good many issues are governed by laws that are not amenable to the choice of the parties, such as public law restrictions concerning currency control, taxation, governmental approval, registration and procedures before the Registrar, as well as procedures before customs authorities, certification of the origin of goods, etc.. When the ALI Principles refer to the applicable law, it is not to these public laws, but to the private law aspects of the case, and the main requirements of the legislation on the validity of IP rights as well as their transferability. In the same fashion, party autonomy regarding licensing transactions exists but with more or less narrow boundaries. Further, as is obvious, there is a need for the court to choose a specific law only when the parties did not agree, expressly or impliedly (for example by both pleading the same law), that a given law should apply. The ALI Principles recognize that some issues escape party autonomy, because of the national public interest (for example in defining public domain and cultural policies). So there is no party autonomy for the validity and maintenance of IP rights, the existence and the extent of the protection, as well as the transferability and duration of rights or the remedies afforded to aggrieved IP rights owners. In the same manner, there is no party autonomy for the formal recordation of transfers and licenses. Finally, party autonomy in standard form agreements is limited to a reasonable choice in view of the nexus between the parties, the subject matter of the agreement and the State the law of which is chosen. It is in my view reasonable to opt for the law of the State the 
courts of which are chosen for the adjudication of any dispute between the parties, even if this choice of court is the only reason to apply that law. The court having to decide on the reasonableness of the parties' choice will take into account the residence of the parties and their resources, as well as the sophistication of the non drafting party. Of course, the capacity of the parties cannot be governed by the law which they chose. It will be governed by the law of the habitual residence of the party whose capacity is at issue.

Most IP legislations are territorial in nature. Territoriality means that registered rights are submitted to the law of the State of the registration of the IP right. For unregistered rights territoriality means the application of the law of the State for which protection is sought, as Art. 5 (2) of the Berne Convention already stated in 1886 . For unfair competition claims, territoriality means the application of the law of the State in which the damage arises. Once again, the territorial law will apply to determine the existence, validity, duration, attributes and infringement of intellectual property rights and the remedies for their infringement (Sec. 301 (1)). The same rule applies to the right of publicity, which is no longer deemed to be a right of privacy [i.e. "the right to be left alone"], but a commercial right [i.e. "the right to sell or license one's own image"].

Territoriality also means that the legislations on intellectual property usually apply and are intended to apply only within the confines of a given country. Nevertheless, some legislations and mainly recent cases provide for an extraterritorial reach of important provisions. Internet has greatly accelerated the understanding that the very purpose of national copyright and trademark law could be defeated if the effect of IP legislation would stop at the border.

Moreover, there are three areas where the territoriality principle seems practically inadequate in a world of 200 countries: Who is entitled to a given IP asset? On which basis should damages be awarded: only domestic damage or also harm occurring in foreign countries? Should licensing agreements providing for worldwide licenses or licenses granted for several countries be subject to a different law in each and every country where they apply? In these three areas, it does not seem reasonable to have two hundred possible solutions to one and the same legal issue. For example, was it really reasonable that the trademark Hag would belong to one company in Belgium (by reason of post world war II confiscation) and to another company in the rest of Europe? Entitlement to any given IP asset should be uniform throughout the world, as is for example the title to movable property (the owner of a car in Japan will have his property recognized by Korean courts on the basis of his property rights under Japanese law if he takes his car by ferry to Korea). Besides, in the correct view 
entitlement to IP rights is based on the human dignity (and not only on the ancillary doctrines of reward or contract between the inventor and Society). This allows for example women as well as men to be characterized as authors even if some countries might decide otherwise under their positive law. It is the effect of the overriding value of human rights as embedded in the Universal Declaration of Human Rights of 1948 [a non binding text], the European Convention on Human Rights of 1949, the United Nations Pact on the Economic, Social and Cultural Rights of 1966, that all enumerate intellectual property as being guaranteed to all human beings. No positive anchoring of the intellectual property in domestic statutes could suffice to explain the real extent of the entitlement to copyright or protection for inventions.

Therefore, the ALI Principles, while recognizing the territoriality of intellectual property legislation, take into account the necessity of uniform solutions in the three areas of entitlement, monetary remedies and licensing agreements. In a case of multiterritorial infringement, for example, the adjudicating court may select one law to apply to the entire case. Nonetheless, a party always enjoys the right to prove that for one of the States involved in the dispute, its law is different, and to request that this be taken into account for the scope of liability and the remedies.

\section{Title to IP rights}

Prof. Jane Ginsburg ${ }^{11}$ and Prof. G. Koumantos ${ }^{12}$ as well as a host of other distinguished commentators ${ }^{13}$ have maintained that one law and one law only should apply to the title to IP right, at least in the area of copyright. The ALI Principles follow the views of these distinguished scholars and operate a distinction between registered rights and unregistered rights.

\footnotetext{
${ }^{11}$ Conflits de loi et titularité initiale du droit d'auteur ("Conflicts of laws and initial entitlement to copyright”), Cahiers droit d'auteur Nr 18 (July-August 1989) 1 seq. Mrs Ginsburg later changed her opinion, for example see Jurisclasseur périodique [JCP] 1992 II 21780 at 4 seq. and JCP 1994, I, 3774; International Law of Copyright in an Era of Technological Changes, Rec. Cours of The Hague Academy of International Private Law, t. 273, 239 seq.; and now Chapter 20 of J.Ginsburg \& S. Ricketson, International Copyright and Neighbouring Rights: The Berne Convention and Beyond, 2 vols., Oxford 2006.

12 Le droit international privé et la Convention de Berne ("Law of Conflicts and Berne Convention"). Droit d'auteur 1988, at 439 seq.

${ }^{13}$ See Prof. Desbois, Niboyet, Battifol and Bartin cited by M. Josselin-Gall, Les contrats d'exploitation du droit de propriété littéraire et artistique ("Contracts to Use Copyright”), Paris 1995, at 254 fn 92 and 284 fn 171. See also D. Moura Vicente, La propriété intellectuelle en droit international privé, Rec. Cours La Haye t. 335 (2008), at 261 and fn 428.
} 
The initial title to registered rights is governed by the law of each State of registration, unless there has been a preexisting relationship between or among the parties. In that case, the initial title is governed by the law of the preexisting relationship [Sec. 311].

The initial title to unregistered rights in the nature of common law trademarks, trade dress, and commercial names is governed by the law of the State in which the trademark or trade dress or commercial name identifies the source of the goods or services.

The initial title to copyright is governed by the law of the creator's State of residence at the time of the creation of the subject matter of the copyright. Only one law will govern throughout the world. There will be no discrepancy between the status of author throughout the world. It gives a needed safety to the parties contracting with the author, for example the publishers, the broadcast organizations and other distributors of the work, wherever they are active. This solution favors exploitation of the copyrighted work across the globe.

If there are several authors to the same work, for example a movie, they can select the law governing the title. When they did not opt for a specific law, the governing law will be the law of the State of residence of the majority of the authors. No distinction should be drawn here between "main authors" and "ancillary authors" (such as are the designers of the set, the costume designer, the cutter in the creation of a movie).

If these tests do not lead to determination of the applicable law, the ALI Principles declare applicable the law of the State in which the work was exploited for the first time ${ }^{14}$ or the law governing the employment of the authors.

\section{Transfers and licenses}

The ALI Principles declare applicable for the issue of transferability the law of each State for which the rights are transferred, as well as the recordation rules relating to the transfer. The wisdom of subjecting the validity of transfer to more than 200 laws for worldwide licenses and transfer may be doubted. However, the question is rather: which other law could apply? In my own view, the possibility to transfer an IP right should be made dependant on the country of origin of the IP right, such as has been decided in the ALI Principles for the sole category of unregistered rights. At least

\footnotetext{
${ }^{14}$ See Art. 5(4) of the Berne Convention. The place of first publication of a work is the "country of origin" for the purpose of determining applicability of the Berne Convention. The "first publication" under the Berne Convention may be very limited as can be the "first exploitation" under the ALI Principles, so that these two notions should be regarded as equivalent. See ALI Principles Sec. 313, Reporters' Note 4 at 145 (Annex I infra).
} 
the same solution should have prevailed for unregistered rights. For the registered rights, nevertheless, the common dogma is that they separately arise from registration in each and ever country which registers them. Therefore, there might be some apparent justification in the view that the possibility of transferring a right is just another of the "attributes" of that right.

The transferability is not subject to party autonomy. The parties cannot change the rules on transferability. The idea is that each State has mandatory provisions on transferability, for example as regards the moral rights of the authors, or the protection of employed authors or inventors. This should be examined more closely, as some countries, for example Switzerland, have few if any rules on transferability. Other countries are much more concerned with limiting transferability, for example France or Germany for authors. The result of the application of the ALI Principles will be a piecemeal validity of the transfer which parties have endeavored but may not have been able to attain under all legal orders at stake. Nothing is worse than before adoption of the Ali Principles, but nothing is better either. It shows that further efforts should be launched to reach more practical solutions, for example within the framework of the Max Planck Institute ongoing project on Intellectual Property and Conflicts of law.

As to the transfer and license under the rights that are transferable or licensable, the ALI Principles are premised on the widest recognition of the party autonomy. It is said that approximately $80 \%$ of all international commercial contracts have a choice of law clause. It is only justice to recognize the agreement of the parties in this regard once they have reached it. Of course, as for the applicable law generally, the contractual choice of law is determinative only for areas and issues which are left to the parties' common will and intent, and it does not extend to public law matters such as currency exchange, taxation, governmental approval of all kinds etc. It is worth noticing that no nexus must exist between the law chosen by the parties and the subject matter of the contract. It is therefore open to the parties to opt for a neutral law, as they do all the time in international arbitration cases.

In this regard, it will be noted that the ALI Principles do not deal at all with arbitration, as the world of arbitration requires case to case tailored solutions rather than general rules applicable independently of the common intention of the parties. Further, the chapters on Jurisdiction and recognition of foreign judgments are obviously devoid of application in arbitral matters, for which the New York Convention of 1958 on the Recognition and Enforcement of Foreign Arbitral Awards provides a sufficient basis. Only the chapter on the applicable law may inspire counsel and arbitrators if they have to resolve a similar difficulty in an arbitral case. 
The only limitations that the ALI Principles propose to party autonomy are designed to protect the weaker party against the choice of law which a standard form agreement would impose.

If no provision of the agreement selects the law applicable to disputes arising under that agreement, the usual test of the closest connection shall apply: the contract is presumed to be most closely connected to the State in which the assignor or the licensor resided at the time of the execution of the contract, and the law of that State will apply.

The doctrine of the so called characteristic performance has been generalized and refined by A.F. Schnitzer, a German scholar who as a refugee in Switzerland was able to publish in my country and thus to influence Swiss case law. The Swiss Federal Tribunal adopted it in the 50's, and our draft Bill on private Law of 1979 was based on it, while the rest of Europe followed the same principle as enshrined in the Rome Convention on the Law applicable to contractual obligations of 1980.

Some years ago a frequent misconception was to believe that the place of performance of the characteristic obligation would provide the closest connection allowing to determine the law applicable to the contract. Therefore, many authors maintained that the license agreement should be governed by the law of the country in which the IP right was due to be exploited, which in practice is often the law of the licensee. At least they proposed the law of the exclusive licensee to apply, since they considered the exclusive licensee to be more interested in the fate of the IP asset than the licensor. However, both Art. 122 of the Swiss law on international private law of 1987 and the ALI Principles Sec. 315 (2)(2d phrase) correctly make the law of the assignor or of the licensor applicable to the contract. These provisions so attain a consistency between the law of the license and the law governing in the country for which the technology or the work has been designed, where the IP assets were first marketed and to which environment the whole organization of the debtor of the characteristic has been geared. The rules on contracts will be governed by the same law as the liability deriving from contract, the enforcement of judgments and possible arrest and forced sale of property in order to recover monetary awards.

Further, there should be little doubt that from a natural justice point of view, the IP assets are more closely connected to the place in which they have been created than to the place or places in which the license agreement will allow the licensee or one of the licensees to work them. Who made the "characteristic performance" in the first place? The author, the inventor or the company which invested in R \& D operations.

Furthermore, a policy consideration should not be overlooked. Technology transfer is so common that we tend to ignore the difficulties which 
parties coming from different regions of the world face when their personnel has to cooperate towards the successful introduction of a new technology. Yet license agreements very often lead to costly and protracted litigations. For example, licensing is the third most often arbitrated issue under the rules of arbitration of the International Chamber of Commerce in Paris, after sale and contract for work. In my view, making the licensor's law applicable is a very promising tool to instill confidence to small and medium enterprises that might otherwise reject any idea of sharing their IP assets with companies of different continents.

It is worth mentioning the existence of other rules on the law applicable to security interests for example to guarantee a loan, and involuntary transfers, such as those following a bankruptcy. The law of the State of registration will apply, or if the IP right is not registered, the law of the country where protection is sought will be applicable. It is not the law governing the loan or the bankruptcy.

Finally, the consolidation before a single court may lead this court to apply a single law, for example its own law. However, the ALI Principles reserve the right of a party to request application of a different law for the infringement or other issues arising in a different country, to the extent that this party may prove the contents of that other law, for example through legal opinions or the filing of judgments.

In all cases, public policy of the forum and mandatory rules of third countries (so called lois de police or lois d'application immédiate) must be respected by the adjudicating court. As most recent conventions and domestic laws, the ALI Principles do not accept the renvoi. ${ }^{15}$ This means that when the ALI Principles declare the law of a given State to be applicable, the rules on conflicts of that law will not be applied with the result that the law of a third State should apply.

\section{Recognition and enforcement of foreign judgments}

As most other recent codifications of international private law, starting with the Swiss Act on international private law of 1987, the ALI Principles devote a chapter to the recognition and enforcement of foreign judgments. In fact, this chapter has been at the core of the early efforts to restate the principles applicable to IP rights, because the oncoming and already predictable failure of nations to agree on the draft The Hague Convention on

${ }^{15}$ With the exception of Sec. 202 (3)(a) declaring that "a choice-of-court agreement is valid as to form and substance if it valid under the entire law of the designated forum State, including its conflicts rules" (emphasis is ours). 
Enforcement of Judgments had left IP rights holders very exposed to the fragmentation of their rights and difficulties in enforcing foreign decisions.

The chapter on enforcement also provides an indirect incentive to apply the rules on jurisdiction and applicable law, since the respect of those rules should facilitate the recognition of foreign awards.

The ALI Principles make themselves applicable only if the rendering court has applied the ALI Principles regarding jurisdiction or applicable law. Of course no one can prohibit the following scenario: the rendering court did not apply the ALI Principles, yet the enforcing court will look at the ALI Principles to decide whether the foreign judgment should be recognized. However, some grounds for not enforcing the judgment will then be irrelevant, most notably the grounds taken from a mistaken application of the ALI principles on jurisdiction and from an erroneous choice of law under the ALI Principles.

It will be noted that generally, the enforcing court will not look at the correct application of the law of the State of the rendering court regarding personal jurisdiction, contrary to the domestic tradition of some countries, e.g. France. Nevertheless, if the respondent did not appear in court, then there is a heightened danger of insufficient application of that law, and the rendering court will have to reexamine application of the law of the rendering State on personal jurisdiction in this particular case of default.

The Ali Principles have a limitative listing of grounds not to enforce foreign judgments:

\section{Mandatory grounds to refuse recognition and enforcement}

- Lack of procedural fairness, lack of integrity, missing timely notice

- Fraud on the rendering court

- Contrariety with public policy of the enforcement State

- Lack of jurisdiction of the rendering court under ALI Principles on court selection and insufficient ground to affirm jurisdiction, or under its own rules.

\section{Optional grounds to refuse recognition and enforcement}

- Inconsistency with other jurisdictional rules of the ALI Principles

- Erroneous choice of law

- Lis pendens between the parties

- Inconsistency with the Rules on consolidation or coordination

The enforcing court will make its own determinations of fact ands law whenever, lack of procedural fairness, doubts at to the integrity of the rendering court's judges, or fraud is at stake. Otherwise it will defer to the 
facts as established by the rendering court, unless the judgment has been rendered in default of appearance.

For remedies, the ALI Principles endeavor a nuanced solution, in view of the generally unfavorable view that foreign jurisdiction entertain on the US judgments awarding punitive damages and the converse enmity of some Anglo-American jurisdiction to specific performance:

- For compensatory damages and attorney's fees and costs, their award should be fully enforceable

- Punitive damages will be enforced only inasmuch as could have been awarded by the courts of the enforcement State

- Injunctions will be enforced only if they could have been ordered by the courts of the enforcement State

- As to declaratory judgments, they will be fully enforceable between the Parties, but not against third parties.

\section{Conclusion}

The ALI Principles have one merit: they exist, they have been approved after a wide ranging review by judges, practicing lawyers and academics within the American Law Institute and a thorough examination by advisors from the five continents.

From a methodological point of view, the ALI Principles combine the European approach to conflicts - i.e. giving solutions as to the applicable law by general rules defining whole categories of cases and assuring predictability - and the practical American approach to jurisdiction, however without the full extraterritorial "long arm" statutory basis of "doing business" and all the ensuing uncertainties. They foster an innovative coordination between parallel courts and favor the consolidation of international cases of intellectual property before the most competent judges.

They encompass the whole area of intellectual property, including less traveled fields of intellectual property such as trade secrets or right of publicity, and unfair competition generally.

The ALI Principles are the first set of transnational soft law rules to take into account the importance of Internet and the need to sustain the growth of the world economy by forging avenues to facilitating the administration of worldwide IP rights portfolios. Cultural life will also be favored to the extent authors and producers, as well as publishers, are now in a position better to contract over their rights knowing which law is applicable and where a litigation could be bought to bar if a dispute should arise. 


\section{Summary of Discussion on Foundations}

\section{by Paulius Jurčys and Simon Vande Walle}

Prof. Metzger commented on the present-day justification for the principle of territoriality of intellectual property rights. He mentioned that the historical background given in Prof. Basedow's paper explains the principle's development, but does not justify it. He suggested that the principle of territoriality could be considered as a corollary of each State's right to conduct its own trade policy, i.e. the State's right to set the market rules for its own national economy. This is probably the most suitable presentday justification. As long as the justification for the principle of territoriality is not clarified, it is difficult to determine in which areas of the law territoriality should prevail.

Prof. Basedow responded that, if the intellectual property framework could be designed from scratch, the principle of territoriality would probably not be the starting point. However, the current situation should be understood in terms of path-dependency: a number of international intellectual property treaties have been adopted and ratified by the vast majority of independent States. Instead of sacrificing the existing international treaties and rejecting the principle of territoriality, the existing intellectual property system should be adjusted to the needs of a globalized world and to new methods of communication.

Prof. Dessemontet expressed doubts that the principle of territoriality could be replaced by a framework based on the principle of universality. He stressed the fact that intellectual property cases with an international element, although increasingly frequent, still constitute only a very small fraction of all cases. In the large majority of cases that do not raise private international law issues, the territoriality principle still works very well. Moreover, it is doubtful that universality would work in cross-border situations because of the diversity of courts. On the other hand, universality may be achieved gradually through party autonomy in those areas where it is possible. Indeed, under the ALI Principles, CLIP Principles and the proposal drafted by the "Transparency of Japanese Law Project" (hereinafter the "Japanese Proposal"), there is party autonomy with respect to jurisdiction and applicable law. In addition, there are rules which allow for the consolidation of multi-state infringement cases and rules that allow the court to apply a single law to certain multi-state infringements ( $\$ 321$ ALI Principles; Art. 302 Japanese Proposal; Art. 3:603 CLIP Principles). The combination of these rules results in quite a universal approach. These provisions illustrate the point made by Prof. Basedow: the principle of territoriality is a given but we can adjust and modify it where necessary. 
This way, universality can be achieved step-by-step, under close scrutiny and only in the areas that really warrant a universal approach.

Prof. Basedow addressed the choice-of-law rules in the recently adopted Rome I and Rome II Regulations. He expressed the view that Rome I provides for sufficiently flexible choice-of-law rules for licensing and transfer agreements. As for the applicable law to non-contractual obligations, Prof. Basedow recalled that the preliminary draft proposal of the Rome II Regulation ${ }^{1}$ contained no specific choice-of-law rule for intellectual property infringements. As a result, the general choice-of-law rule referring to the law of place where the loss was sustained would have been applicable (Art. 3(1) of the Proposal). However, if the plaintiff and the defendant are from the same country, the law of that country would be the applicable law even in case of an infringement of intellectual property rights. In its comments to this Preliminary Draft, the Hamburg Max Planck Institute pointed out that there should be a specific rule for intellectual property rights which takes into account the principle of territoriality. ${ }^{2}$ The final text of the Rome II Regulation addresses this concern and contains a specific conflict rule for intellectual property rights (Art. 8 Rome II Regulation).

A member of the audience presented the facts of the Card Reader case ${ }^{3}$ decided by the Japanese Supreme Court. The case concerned a Japanese plaintiff who held a patent registered in the U.S. The plaintiff brought an infringement suit before the Japanese courts against a defendant located in Japan. One of the questions in the Card Reader case was whether the Japanese court could apply U.S. law to the case. The Supreme Court ruled that the application of U.S. patent law would be contrary to the public policy of Japan. The audience member asked whether this solution reached by the Supreme Court would be in line with the ALI Principles and CLIP Principles.

Prof. Basedow replied that, in his opinion, the principle of territoriality refers to the territorial scope of the intellectual property rights. The principle of territoriality does not mean that only U.S. courts can apply U.S. patent law. Prof. Basedow indicated that, based on the facts presented to him, both ALI Principles and CLIP Principles would lead to the application of the lex loci protectionis (i.e. U.S. law).

\footnotetext{
${ }^{1}$ Preliminary Draft Proposal for a Council Regulation on the Law Applicable to NonContractual Obligations (3 May 2002), available at <http://ec.europa.eu/justice_home/ news/consulting_public/rome_ii/news hearing_rome2_en.htm $>$.

${ }^{2}$ Hamburg Group for Private International Law, Comments on the European Commission's Draft Proposal for a Council Regulation on the Law Applicable to Noncontractual Obligations, at 22 , available at $<$ www.mpipriv.de/de/data/pdf/comments hamburggroup.pdf $>$.

${ }^{3}$ Supreme Court, 26 September 2002, 56 Minshu 1551, English translation available at $<$ www.courts.go.jp/english/judgments/text/2002.9.26-2000.-Ju-.No..580.html $>$.
} 
Part 2: Jurisdiction 



\title{
A Framework for International Enforcement of Territorial Rights: The CLIP Principles on Jurisdiction
}

\author{
CHRistian HEINZE
}

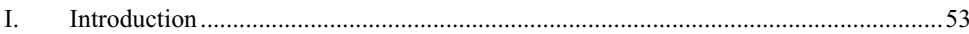

II. The past: Strict territoriality of intellectual property litigation...................................54

III. The present: Rise and fall of cross-border enforcement under the Brussels regime......54

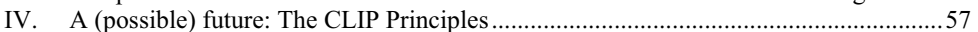

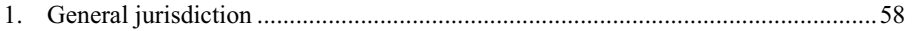

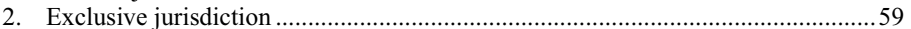

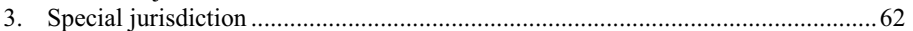

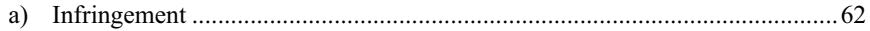

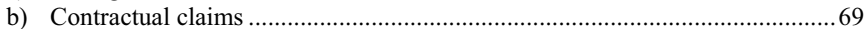

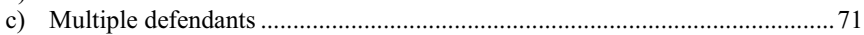

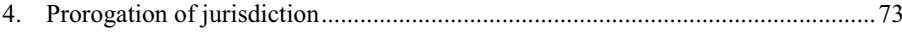

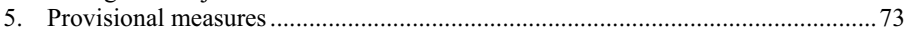

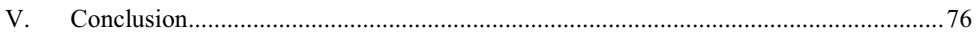

\section{Introduction}

Jurisdiction for intellectual property disputes is a subject that has been extensively discussed in the recent past. Still, it remains highly topical: In April 2009, the European Commission adopted a green paper on the review of Council Regulation (EC) No 44/2001 on jurisdiction and the recognition and enforcement of judgments in civil and commercial matters ${ }^{1}$ which explicitly asked for appropriate solutions to enhance the enforcement of industrial property rights. ${ }^{2}$ The following text will try to contribute to this

${ }^{1}$ COM (2009) 175 final; see also the corresponding Report from the Commission to the European Parliament, the Council and the European Economic and Social Committee on the application of Council Regulation (EC) No 44/2001 on jurisdiction and the recognition and enforcement of judgments in civil and commercial matters COM (2009) 174 final.

${ }^{2}$ COM (2009) 175 final, question 4. 
debate by giving a first insight into the work of the European Max Planck Group for Conflict of Laws in Intellectual Property (hereafter abbreviated as "CLIP") 3 in the field of jurisdiction ${ }^{4}$. Before that, a few introductory remarks on the development in Europe shall illustrate the context of our work.

\section{The past: Strict territoriality of intellectual property litigation}

Turning to the past, we have seen that a public-law-inspired territoriality approach has traditionally governed intellectual property law. ${ }^{5}$ For jurisdiction, the consequence of this strict territoriality concept has been that intellectual property, the most flexible and incorporeal form of property, has been treated essentially in the same manner as land, the most inflexible and corporeal form of property. ${ }^{6}$ In essence, each state claimed exclusive jurisdiction for disputes concerning its own intellectual property rights and declined any jurisdiction over foreign intellectual property rights. ${ }^{7}$

\section{The present: Rise and fall of cross-border enforcement under the Brussels regime}

This strict territorial approach to jurisdiction was gradually abandoned in Europe $^{8}$ after World War II and finally came to an end with the Brussels

\footnotetext{
${ }^{3}$ CLIP is a group of European scholars in the fields of intellectual property and private international law that is funded by the Max Planck Society. It was established in 2004 and meets regularly to discuss issues of intellectual property, private international law and jurisdiction. The group's goal is to draft a collection of principles for conflict of laws in intellectual property and to provide independent advice to legislators. A preliminary draft of the CLIP Principles is available under <www.cl-ip.eu $>$.

${ }^{4}$ As the work of CLIP is not finished, some of the solutions presented here may be subject to change in later debates.

${ }_{5}^{5}$ Cf. the contribution of Jürgen Basedow in this volume p. 3 seq.

${ }^{6}$ This is most apparent in English case law where the Moçambique-rule developed in British South Africa Co. v Companhia de Moçambique [1893] A.C. 602, 621 for actions in trespass over foreign land was extended to foreign intellectual property; cf. Pearce $v$ Ove Arup Partnership Ltd (Jurisdiction) [2000] Ch. 403, 433 seq.; Lucasfilm v Ainsworth [2009] EWCA Civ 1328 paras. 174 seq.; TS Production LLC v Drew Pictures Pty Ltd [2008] FCAFC 194 paras. 14 seq. (Australia).

${ }^{7}$ For Germany Reichsgericht 18 June 1890, JW 1890, 280, 281 - Lampen; for France CA Douai 20 March 1967, Rev. crit DIP 57 (1968) 691, 692; TGI Paris 4 May 1971, Rev. crit. DIP 63 (1974) 110, 111; for the Netherlands Rechtbank Amsterdam 25 January 1926, reported in GRUR 1928, 25, 26.

${ }^{8}$ For Germany starting as early as the 1930 s and 1950 s, Reichsgericht 8 July 1930 , RGZ 129, 385, 388 - Vacuum Oil; Bundesgerichtshof 2 October 1956, BGHZ 22, 1, 13 -
} 
Convention in 1973. Under the Brussels Convention ${ }^{9}$ and its successor, the Brussels Regulation (hereafter abbreviated as "BR"), ${ }^{10}$ exclusive jurisdiction for intellectual property disputes is limited to "proceedings concerned with the registration or validity of patents, trade marks, designs, or other similar rights required to be deposited or registered" (Article 22 No. 4 $\mathrm{BR})$. For all other disputes, in particular infringement disputes, the general rules of the Brussels Regulation apply, ${ }^{11}$ which may establish jurisdiction in the courts of a state different from the country of protection. ${ }^{12}$ As a result, a practice of cross-border enforcement of intellectual property rights has begun to emerge since the 1990s, in particular in Dutch and German courts. ${ }^{13}$

However, even if the Brussels regime in theory allows for cross-border enforcement of intellectual property rights, it has its drawbacks. On the one hand, the rules of the Brussels Regulation are not tailored to the specific needs of intellectual property disputes, which may lead to uncertainties in their interpretation and application in such disputes. An example is the jurisdiction "in matters relating to tort, delict or quasi-delict" which Article 5 No. 3 BR establishes "in the courts for the place where the harmful event occurred or may occur." While it is settled case law that the expression "place where the harmful event occurred" must be understood

Flava Erdgolt; Bundesgerichtshof 30 January 1969, GRUR 1969, 373, 375 - Multoplane; OLG Düsseldorf 25 March 1966, GRUR Int. 1968, 100, 101 - Kunststofflacke; LG Düsseldorf 18 March 1958, GRUR Ausl. 1958, 430, 430 seq. - Hohlkörper; LG Düsseldorf 27 October 1966, GRUR Int. 1968, 101, 102 - Frauenthermometer. In the United States, the courts seem to be more reluctant to pursue adjudication of foreign infringement actions; cf. Voda v Cordis, 476 F.3d 887 (Fed. Cir. 2007). For a comparison between U.S. and European law, Schauwecker GRUR Int. 2008, 96.

${ }^{9}$ Brussels Convention on jurisdiction and the enforcement of judgments in civil and commercial matters, OJ L 299, 31 December 1972, p. 32, consolidated version in OJ C 27, 26 January 1998, p. 1.

${ }^{10}$ Council Regulation (EC) No 44/2001 of 22 December 2000 on jurisdiction and the recognition and enforcement of judgments in civil and commercial matters, OJ L 12 , 16 January 2001, p. 1.

${ }^{11}$ With a caveat for the special rules for unitary Community rights in Article 94 seq. Council Regulation (EC) No 207/2009 of 26 February 2009 on the Community trade mark (codified version), OJ L 78, 24 March 2009, p. 1, Article 79 seq. Council Regulation (EC) No 6/2002 of 12 December 2001 on Community designs, OJ L 3, 5 January 2002, p. 1 and Article 101 Council Regulation (EC) No 2100/94 of 27 July 1994 on Community plant variety rights, OJ L 227, 1 September 1994, p. 1.

12 Jenard Report OJ C 59, 5 March 1979, p. 36.

13 For references, see CLIP, Exclusive Jurisdiction and Cross-Border IP (Patent) Infringement - Suggestions for Amendment of the Brussels I Regulation, <www.ip.mpg. de/shared/data/pdf/clip_brussels_i_dec_06_final.pdf $>$ p. 3; for the English position under the Brussels Convention, see Pearce v Ove Arup Partnership Ltd (Jurisdiction) [2000] Ch. $403,445$. 
as being intended to cover both the place where the damage occurred and the place of the event giving rise to it, ${ }^{14}$ it is unclear how this distinction may be applied to intellectual property infringements. ${ }^{15}$

On the other hand, and much more problematic, the European Court of Justice (ECJ) has severely limited the possibilities of cross-border enforcement of intellectual property rights in two famous decisions of 13 July 2006, GAT/LuK and Roche Nederland. In these decisions, the ECJ gave a broad interpretation to the exclusive jurisdiction provision of Article 22 No. 4 BR (GAT/LuK) and (almost) ruled out the possibility of a consolidation of claims against multiple defendants if parallel rights in different jurisdictions are infringed (Roche Nederland). In effect, the European Court of Justice advocated a renaissance of the territorial, country-bycountry enforcement of (registered) intellectual property rights that seemed to be overcome by the Brussels Convention and is in no way mandated by the letter, the spirit, or the history of the Brussels regime.

Both decisions have led to widespread criticism by academics and practicing lawyers in the field. ${ }^{16}$ Aside from doctrinal objections, the reterritorialization of intellectual property litigation is questionable because it disregards both the reality and the necessity of international enforcement of intellectual property rights. Right holders typically hold parallel rights in different countries concerning the same invention, trademark, or literary work. A consolidation of enforcement actions for several countries allows a cost-efficient concentration of disputes and reduces the risk of diverging judgments; unsurprisingly, it lies in the interest of stakeholders in the field. ${ }^{17}$ Furthermore, already today more than $90 \%$ of patent litigation in Europe (probably less so in trademarks and copyright) takes place in just four member states of the European Union, namely Germany, France, the United Kingdom, and the Netherlands. ${ }^{18}$ As this number does not corres-

14 See infra note 49.

15 See infra text at note 53.

${ }^{16}$ See inter alia Heinze/Roffael, GRUR Int. 2006, 787, 790 seq.; Kur, IIC 2006, 844, 847 seq.; Luginbühl/Stauder, sic! 2006, 876, 878 seq.; Wittwer, European Law Reporter 2006, 391, 393; Adolphsen, IPRax 2007, 15, 17 seq.; Bukow, Festschrift Schilling, 2007, 59, 64-68; Gottschalk, JZ 2007, 300, 302 seq.; Kubis, Mitt. 2007, 220, 223 seq.; CLIP, Exclusive Jurisdiction and cross border IP (patent) infringement - suggestions for amendment of the Brussels I Regulation, <www.ip.mpg.de/shared/data/pdf/clip_brussels i_dec_06_final.pdf $>$.

17 Recommendation from the Commission to the Council to authorise the Commission to open negotiations for the adoption of an Agreement creating a Unified Patent Litigation System, SEC (2009) 330 final, p. 3: "Stakeholders have repeatedly reported that (...) [multi-forum litigation] involves considerable cost, complexity and legal insecurity resulting from the risk of contradicting court decisions".

${ }^{18}$ Communication from the Commission to the European Parliament and the Council - Enhancing the patent system in Europe, COM (2007) 165 final, p. 7. 
pond with the overall distribution of patents in Europe, ${ }^{19}$ it seems to suggest that some jurisdictions are preferred over others as venues for patent infringement disputes. An explanation for this observation could be that these "model" or "test" jurisdictions guide the parties' decision about settlement of their international patent disputes. Finally, and this is an aspect which is sometimes overlooked, ${ }^{20}$ cross-border enforcement and the possibility of consolidation of actions creates competition between national courts to provide the best service at the best price. A few numbers from a European Commission paper may illustrate this aspect: While an average patent dispute in Germany normally costs around $€ 140,000$ for two instances, the price tag is $€ 100,000$ to $€ 350,000$ in the Netherlands, $€ 90,000$ to $€ 350,000$ in France, and $€ 300,000$ to $€ 2,500,000$ in the United Kingdom. ${ }^{21}$ Against these considerations, it is no surprise that the European Commission expressed discomfort with the present state of affairs in its recent proposal to reform the Brussels Regulation: "Pending the creation of the unified patent litigation system, certain shortcomings of the current system may be identified and addressed in the context of Regulation (EC) No $44 / 2001 ., 22$

\section{A (possible) future: The CLIP Principles}

As a proposal for future reform, the CLIP Principles ${ }^{23}$ try to promote cross-border litigation by limiting exclusive jurisdiction to those situations in which truly the public law nature of the intellectual property right and the regulatory interests of the country of protection are concerned. For all other situations, the CLIP Principles aim at an intellectual property-spe-

19 There are countries for which patents are requested in a significant number of EPO applications (Spain, Italy) which seem to attract less patent infringement litigation than their share in applications would suggest, <http://documents.epo.org/projects/babylon/ eponet.nsf/0/95912970A38DFA51C12575A00056E74A/\$File/patents_granted_by_country 2008.pdf $>$.

${ }^{20}$ For a detailed analysis, de Miguel Asensio, Annali italiani del diritto d'autore, della cultura e dello spettacolo (AIDA) 2007, 3 .

${ }^{21}$ Communication from the Commission to the European Parliament and the Council - Enhancing the patent system in Europe, COM (2007) 165 final, p. 8.

${ }^{22}$ Green paper on the review of Council Regulation (EC) No 44/2001 on jurisdiction and the recognition and enforcement of judgments in civil and commercial matters, COM (2009) 175 final, question 4, p. 7.

${ }^{23}$ The CLIP Principles are not meant as a proposal for reform of the Brussels Regulation in general, but rather were drafted as a specific instrument for intellectual property disputes, including questions of choice of law. The second preliminary draft can be found in the Annex II to this volume. 
cific evolution of the Brussels system of procedural fairness ${ }^{24}$ in order to avoid uncertainties in its interpretation and better address questions specific to intellectual property litigation. This dual purpose can best be illustrated by a comparison between some of the rules of the Brussels Regulation and the CLIP Principles, with some side notes on the corresponding proposals of the American Law Institute (ALI Principles). ${ }^{25}$

\section{General jurisdiction}

The starting point for any jurisdiction system is the rule of general jurisdiction. The Brussels Regulation attributes general jurisdiction to the courts of domicile: According to Article 2 BR, "persons domiciled in a Member State shall, whatever their nationality, be sued in the courts of that Member State." For the definition of domicile, the Regulation distinguishes between legal and natural persons: Whereas for companies and other associations the place of domicile is defined either as its statutory seat, its central administration, or its principal place of business (Article 60 $\mathrm{BR}$ ), the domicile of natural persons is determined by the forum's internal law (Article $59 \mathrm{BR}$ ). Subject to the rules on exclusive jurisdiction, the courts of the defendant's domicile have jurisdiction for all claims against the defendant. ${ }^{26}$

In general, the CLIP Principles follow the model of Brussels I (Article 2:102(1) CLIP). They do, however, propose a change in terminology, using the term "habitual residence" instead of "domicile." 27 This proposal is in line with younger European regulations in civil procedure ${ }^{28}$ and avoids misunderstandings about the meaning of "domicile," in particular in common law countries where the notion of domicile under the Brussels Regu-

${ }^{24}$ Cf. ECJ 10 June 2004, Case C-168/02, Rudolf Kronhofer v Marianne Maier and Others [2004] ECR I-6009 paras. 15, 18.

25 American Law Institute, Intellectual Property - Principles governing jurisdiction, choice of law and judgments in transnational disputes, 2008. The text of the ALI Principles can be found in the Annex I to this volume. For a comparison Kur/Ubertazzi, The ALI Principles and the CLIP Project: A Comparison, in: Stefania Barriatti (ed.), Litigation Intellectual Property Rights Disputes Cross-Border: EU Regulations, ALI Principles, CLIP Project, Milan 2010, p. 89.

26 ECJ 7 March 1995, Case C-68/93, Fiona Shevill, Ixora Trading Inc., Chequepoint SARL and Chequepoint International Ltd v Presse Alliance SA [1995] I-415 para. 32.

${ }^{27}$ For the distinction between residence and domicile, see Kono 30 [2005] Brooklyn Journal of International Law 865, 870 .

28 E.g., Article 3(1) Council Regulation (EC) No 2201/2003 of 27 November 2003 concerning jurisdiction and the recognition and enforcement of judgments in matrimonial matters and the matters of parental responsibility, repealing Regulation (EC) No 1347/ 2000, OJ L 338, 23 December 2003, p. 1. 
lation is different from the domestic concept. ${ }^{29} \mathrm{~A}$ similar solution is found in $\S 201$ ALI Principles, which also prefer the concept of residence ${ }^{30}$ (with some minor differences, e.g., an additional residence of companies in the country of incorporation or formation, $\$ 201(3)$ (b) ALI Principles) to the concept of domicile. For the definition of habitual residence of legal persons, the CLIP Principles follow (with slight modifications) the model of Article 60 BR (Article 2:102(3) CLIP). In addition, Article 2:102(2) CLIP defines the principal place of business as the habitual residence of natural persons acting in the course of a business activity, thus following the model of Rome I and Rome $\mathrm{II}^{31}$ and streamlining (to a certain extent) the habitual residence for legal and natural persons ${ }^{32}$. A more general definition of habitual residence for all natural persons (including those not acting in the course of a business activity) was considered to be difficult to define in the abstract. As it would probably not add much in content to the natural understanding of the term, ${ }^{33}$ the CLIP group decided to leave this to the judge. However, a need was felt to clarify that the term "principal place of business" in Article 2:102 CLIP is not to be understood as a "doing business" rule, but rather follows the model of Article $60 \mathrm{BR}$. This clarification is found in Article 2:102(4) CLIP.

\section{Exclusive jurisdiction}

Under the Brussels Regulation, questions of exclusive jurisdiction are relevant in intellectual property disputes only in proceedings concerned with the registration or validity of registered intellectual property rights, in

${ }^{29}$ Cf. the special definition of domicile in ss. 41 seq. Civil Jurisdiction and Judgments Act 1982, ch. 27.

30 With the word "residence" the ALI Principles incorporate the same notion as "habitual residence;" American Law Institute, Intellectual Property - Principles governing jurisdiction, choice of law and judgments in transnational disputes, 2008, comment a. to $\S 201$ ALI Principles.

31 Article 19(1) Regulation (EC) No 593/2008 of the European Parliament and of the Council of 17 June 2008 on the law applicable to contractual obligations (Rome I), OJ L 177, 4 July 2008, p. 6; Article 23(2) Regulation (EC) No 864/2007 of the European Parliament and of the Council of 11 July 2007 on the law applicable to non-contractual obligations (Rome II), OJ L 199, 31 July 2007, p. 40.

${ }^{32}$ In the further discussions of the CLIP group, it will be considered whether a natural person acting in the course of a business activity should be subject to general jurisdiction both in the courts of the principal place of business and (private) habitual residence, thereby mirroring the distinction made for legal persons in Article 2:102(3) lit a and lit. c CLIP. This could be implemented by amending Article 2:102(2) CLIP.

${ }^{33}$ For such a definition, see $\S 201(2)$ ALI Principles. 
particular patents and registered trademarks. ${ }^{34}$ Until the GAT/LuK decision of the European Court of Justice, the different national courts in Europe disputed whether the exclusive jurisdiction under Article 22 No. 4 BR applies also if invalidity of the intellectual property right is raised merely as a defense in an infringement action. ${ }^{35}$ In GAT/LuK, an action between two German companies over the infringement of a French patent, the European Court of Justice favored a broad interpretation, holding that "exclusive jurisdiction provided for by Article 22 No. 4 BR should apply whatever the form of proceedings in which the issue of a patent's validity is raised, be it by way of an action or a plea in objection, at the time the case is brought or at a later stage in the proceeding." ${ }^{36}$ As a result, any infringement proceedings in which the defendant contests the validity of the registered right falls under the exclusive jurisdiction of the country of registration, thus making it highly unattractive to litigate registered rights outside the country of protection because any infringement action runs the risk of being thwarted by a plea of invalidity (even if unfounded or abusive). ${ }^{37}$

The decision GAT/LuK is unsatisfactory in many ways and should therefore not serve as a model for rules on exclusive jurisdiction. ${ }^{38}$ First, it is unsatisfactory from a doctrinal point of view because it makes the jurisdiction of the infringement court dependent on the later plea of invalidity on the part of the defendant, a concept alien to settled notions of procedural law and incompatible with other jurisprudence of the European Court of Justice. ${ }^{39}$ Further, it is unsatisfactory from a practical point of view because it makes it much harder to litigate parallel patents in a single

${ }^{34}$ Exclusive jurisdiction may also result from a jurisdiction agreement (Article 23(5) $\mathrm{BR}$ ), but this form of exclusive jurisdiction is different from exclusive jurisdiction established by law because it is subject to the parties' agreement.

${ }^{35}$ For references, see CLIP, Exclusive Jurisdiction and Cross-Border IP (Patent) Infringement - Suggestions for Amendment of the Brussels I Regulation, <www.ip.mpg. $\mathrm{de} / \mathrm{shared} / \mathrm{data} / \mathrm{pdf} / \mathrm{clip}$ brussels_i_dec_06_final.pdf $>$ p. 3 .

${ }^{36}$ ECJ 13 July 2006, Case C-4/03, Gesellschaft für Antriebstechnik mbH \& Co. KGv Lamellen und Kupplungsbau Beteiligungs $K G$ [2006] ECR I-6509 para. 25.

${ }^{37}$ There is some debate on the consequences (stay or dismissal of the infringement action) and the limits of the GAT/LuK decision, in particular in case of abuse; see Opinion of Mr Advocate General Geelhoed delivered on 16 September 2004, Gesellschaft für Antriebstechnik mbH \& Co. KG v Lamellen und Kupplungsbau Beteiligungs $K G$ [2006] ECR I-6509 para. 46.

${ }^{38}$ Moura Vicente, La propriété intellectuelle en droit international privé, 2009, p. 400. See also §211(1) ALI Principles, which permits adjudication of claims and defenses arising under foreign IP rights and contracts which are related to these rights.

39 ECJ 8 May 2003, Case C-111/01, Gantner Electronic GmbH v Basch Exploitatie Maatschappij BV [2003] I-4207 para. 26, 31 seq.; ECJ 14 October 2004, Case C-39/02, Marsk Olie \& Gas A/S v Firma M. de Haan en W. de Boer [2004] I-9657 para. 36. 
forum, even in the courts of the country where both claimant and defendant are established. Finally, it is unsatisfactory from a policy point of view because its justification - the necessary involvement of the national administrative authorities to issue the registered right ${ }^{40}$ - holds true only for disputes which concern the grant or withdrawal of the registered right, not its enforcement between two private parties in an action for infringement where the question of validity is raised only incidentally without becoming part of the res judicata of the final judgment.

For these reasons, the CLIP Principles propose a more balanced approach. The exclusive jurisdiction of the state granting the registered right $^{41}$ is respected (Article 2:401(1) CLIP), but it is limited: It does not apply to disputes where validity or registration arises in a context other than by principal claim or counterclaim (Article 2:401(2) CLIP). On the other hand, the decisions resulting from disputes where validity or registration arises in a context other than by principal claim or counterclaim do not affect the validity or registration of those rights as against third parties (Article 2:401(2) CLIP) ${ }^{42}$. A similar solution is proposed in $\$ 211 \mathrm{ALI}$ Principles: § 211(1) ALI Principles permits an adjudication of claims and defenses arising under foreign intellectual property laws, but grants effectiveness to the adjudication of the validity of registered rights only to resolve the dispute among the parties to the action $(\$ 211(2)$ ALI Principles). ${ }^{43}$ Finally, for those ownership disputes which do not fall under Ar-

40 ECJ 13 July 2006, Case C-4/03, Gesellschaft für Antriebstechnik mbH \& Co. KGv Lamellen und Kupplungsbau Beteiligungs KG [2006] ECR I-6509 para. 23.

${ }^{41}$ From a policy point of view, it could be asked whether the restriction of exclusive jurisdiction to registered rights is not based on an antiquated "act of state" understanding of exclusive jurisdiction for validity disputes which does not fully reflect the more modern justification for exclusive jurisdiction, namely the respect for the economic policy decisions of the state granting the monopoly (IP) right. Based on an "economic policy justification", it could be asked whether exclusive jurisdiction for erga omnes validity decisions should be extended to unregistered rights (e.g. the unregistered Community design, Article 24(3) Community Design Regulation 6/2002). For the time being, the CLIP group has decided against an extension of exclusive jurisdiction to unregistered rights because of considerations of judicial efficiency and tradition under the Brussels regime, but it recognises the policy objections against the distinction between registered and unregistered rights.

${ }^{42}$ For unitary IP rights such as the Community Trademark or a possible future Community Patent, it might be considered to go beyond Article 2:401 CLIP and allow an erga omnes invalidation of the right in any state which is member of the supranational organisation granting the unitary right (Article 100 Community Trademark Regulation 207/ 2009, Article 86 Community Design Regulation 6/2002). However, in view of the judicial reluctance towards any form of validity decision outside the country of registration, such an approach seems too bold for the time being.

43 See also $\S 213(2)$ and (3) ALI Principles for proceedings to obtain a declaration of invalidity. 
ticle 2:401 CLIP ${ }^{44}$ Article 2:205 CLIP establishes a special (optional) jurisdiction in the country where the right exists ${ }^{45}$ or for which an application is pending.

\section{Special jurisdiction}

The rules of special jurisdiction offer an alternative to the rule of general jurisdiction, leaving the plaintiff the choice where to sue. The following presentation will focus on jurisdiction for infringement actions, contractual disputes, and multiple defendants, leaving aside the less intellectual property-specific jurisdiction for civil claims arising out of criminal proceedings (Article 5 No. 4 BR, Article 2:204 CLIP), for disputes arising out of the operations of a branch (Article 5 No. 5 BR, Article 2:207 CLIP), for indemnification (Article 6 No. 2 BR, Article 2:208 CLIP), and for counterclaims (Article 6 No. 3 BR, Article 2:209 CLIP). It may just briefly be mentioned that Article 2:210 CLIP clarifies ${ }^{46}$ that an action for a declaratory judgment may be based on the same ground of jurisdiction as a corresponding action seeking substantive relief. ${ }^{47}$

\section{a) Infringement}

Probably the most important special jurisdiction for intellectual property disputes is the jurisdiction for infringement actions. Under the Brussels regime, infringement actions fall under the jurisdiction rule for "matters relating to a tort, delict or quasi-delict" in Article 5 No. 3 BR. ${ }^{48}$ Such actions may be brought "in the courts for the place where the harmful event occurred or may occur." The "place where the harmful event occurred or

\footnotetext{
44 An example would be ECJ 15 November 1983, Case 288/82, Ferdinand M.J.J. Duijnstee v Lodewijk Goderbauer [1983] ECR 3663 paras. 25-26.

45 The word "exists" shall not deny the existence of foreign IP rights outside their relevant country of protection.

${ }^{46}$ For the debate, Gardella, Torpedoes and Actions for Negative Declarations in International IP Law Litigation, in: Nuyts (ed.), International Litigation in Intellectual Property and Information Technology, 2008, 181, 197 seq.

47 This seems to be the position of Japanese law as well as a result of the Coral Powder Case, Kono 30 [2005] Brooklyn Journal of International Law 865, 870. It is also the position of the ALI Principles, § 213(1) ALI Principles.

48 The concept of "matters relating to tort, delict and quasi-delict" in Article 5 No. 3 BR covers all actions which seek to establish the liability of a defendant and which are not related to a "contract" within the meaning of Article 5 No. 1 BR, ECJ 27 September 1988, Case 189/87, Athanasios Kalfelis v Bankhaus Schröder, Münchmeyer, Hengst and Co. and others [1988] ECR 5565 para. 17. A contract in the meaning of Article 5 No. 1 BR is an "obligation freely assumed by one party towards another", ECJ 17 June 1992, Case C-26/91, Jakob Handte \& Co. GmbH v Traitements Mécanochimiques des Surfaces SA [1992] ECR I-3967 para. 15.
} 
may occur" has been understood by the European Court of Justice to comprise both the place where the damage occurred and the place of the event giving rise to it. ${ }^{49}$ At the heart of this interpretation lies the understanding that liability in tort can arise only if a causal connection can be established between the damage and the event in which that damage originates. ${ }^{50}$ However, it seems doubtful whether this distinction between the place of damage and the place of the event giving rise to the damage can be applied to the infringement of intellectual property rights. Whereas the traditional tort distinguishes between act, causation, and damage, the infringement of an intellectual property right requires only that the defendant committed an act which falls in the scope of the absolute right of the right holder. ${ }^{51}$ For example, it is sufficient to find for trademark infringement if the defendant used a trademark in the course of trade without the right holder's consent in a manner which the law attributes to the exclusive domain of the trademark owner. ${ }^{52}$ Unlike the traditional triad of act, causation, and damage, intellectual property delicts focus on the act of infringement which is be prohibited per se. The (pecuniary) damage caused by the infringement may be relevant for the award, but it is not necessary to find for damage to establish infringement. In addition, there is another important difference between intellectual property infringements and other torts: Whereas in the law of delict it normally does not matter where the act giving rise to the damage was committed, this is not true for intellectual property infringements. Due to their territorial nature, intellectual property rights of state A can only penalize conduct engaged in within the territory of $\mathrm{A} .^{53}$ Acts committed outside the national territory of A in country B will

49 ECJ 30 November 1976, Case 21/76, Handelskwekerij G. J. Bier BV v Mines de potasse d'Alsace SA [1976] ECR 1735 para. 19; ECJ 1 October 2002, Case C-167/00, Verein für Konsumenteninformation v Karl Heinz Henkel [2002] ECR I-8111 para. 44; ECJ 5 February 2004, Case C-18/02, Danmarks Rederiforening, acting on behalf of DFDS Torline A/S v LO Landsorganisationen i Sverige, acting on behalf of SEKO Sjöfolk Facket för Service och Kommunikation [2004] ECR I-1417 para. 40; ECJ 10 June 2004, Case C-168/02, Rudolf Kronhofer $v$ Marianne Maier and Others [2004] ECR I-6009 para. 16; ECJ 16 July 2009, Case C-189/08, Zuid-Chemie BV v Philippo's Mineralenfabriek $N V / S A$ para. 23 (not yet reported)

${ }^{50}$ ECJ 30 November 1976, Case 21/76, Handelskwekerij G. J. Bier BV v Mines de potasse d'Alsace $S A$ [1976] ECR 1735 para. 16.

${ }_{51}$ Metzger, Jurisdiction in Cases Concerning Intellectual Property Infringements on the Internet, Brussels I Regulation, ALI Principles and Max Planck Proposals, in: Leible/ Ohly, Intellectual Property and Private International Law, 2009, 251, 258.

52 Article 5(1) Directive 2008/95/EC of the European Parliament and of the Council of 22 October 2008 to approximate the laws of the Member States relating to trade marks (Codified version), OJ L 12, 16 January 2001, p. 1.

${ }^{53}$ ECJ 22 June 1994, Case C-9/93, IHT Internationale Heiztechnik GmbH and Uwe Danzinger v Ideal-Standard GmbH and Wabco Standard GmbH [1994] ECR I-2789 para. 
not constitute an infringement of A's intellectual property rights and are legal if no comparable protection exists at the place of action in B. ${ }^{54}$ This holds particularly true in the case of registered rights: If patent protection exists only in country A and the act of infringement, e.g., downloading patented software, occurs in country B, the courts of B cannot base jurisdiction on infringement because the patent is not even protected there. ${ }^{55}$

Territoriality and the act-based conception of intellectual property infringements are the traditional points which distinguish intellectual property infringements from other wrongs. In the world of ubiquitous communication, they need to be complemented by concerns for two other intellectual property-specific problems of the forum delicti: First, a focus only on the action of the alleged infringer would be an invitation for him to hide in jurisdictions inaccessible for efficient enforcement and distribute infringing material via the Internet. We must therefore accept that the place of direction or effect of his conduct may also be sufficient to establish jurisdiction based on infringement. ${ }^{56}$ Here again it is necessary to strike a balance between the interests of plaintiff and defendant: not any form of accessibility of an Internet website in any country should suffice to establish jurisdiction, ${ }^{57}$ but only qualified conduct. Finally, an intellectual property-specific rule for jurisdiction in tort must take into consideration the possibility of widespread or even ubiquitous infringement via electronic media such as the Internet. It must therefore provide for restrictions to prevent a worldwide ground for special jurisdiction based on the mere accessibility of a website which would in effect lead to a plaintiff's forum. ${ }^{58}$

22; ECJ 14 July 2005, Case C-192/04, Lagardère Active Broadcast v Société pour la perception de la rémunération équitable (SPRE) and Gesellschaft zur Verwertung von Leistungsschutzrechten mbH (GVL) [2005] ECR I-7199 para. 46.

54 If the intellectual property law of A exceptionally provides for its extraterritorial application, this might lead to infringement of the intellectual property law of A, but this infringement occurs in state A, not at the place of action in B.

55 Metzger (supra note 51), 258.

56 See also Kono 30 [2005] Brooklyn Journal of International Law 865 (871 seq.) who points out that the emphasize on "acts" instead of "effects" in the ALI Principles might be regarded as too narrow from a Japanese point of view.

57 This seems, however, to be the position of the French courts, Cass. civ. 9 December2003, Castellblanch ./. Roederer, Rev. crit. DIP 2004, 632, 633 f.; for a possible limitation Cass. com. 20 March2007, F P+B, Société HSM Schuhmarketing GmbH ./. Société Gep Industries, La Semaine Juridique - Edition générale n 20-21, II 10088, 29: "la cour d'appel a exactement retenu sa compétence dès lors que les faits allégués de commercialisation de ces produits sur le territoire national seraient susceptibles de causer un prejudice;" Diederichsen, RIW 2008, 52, 56.

${ }^{58}$ For skepticism concerning worldwide grounds for special jurisdiction (in the context of contractual jurisdiction) ECJ 19 February 2002, Case C-256/00, Besix $S A v$ Wasserreinigungsbau Alfred Kretzschmar GmbH \& Co. KG (WABAG) and Planungs- 
Such a restriction of the forum delicti appears compatible with the Brussels Regulation as it is one of their objectives "that the jurisdictional rules [be] interpreted in such a way as to enable a normally well-informed defendant reasonably to predict before which courts, other than those of the State in which he is domiciled, he may be sued." ${ }^{, 59}$

In light of these considerations, the CLIP Principles design the rule for jurisdiction in tort around an intellectual property-specific concept of tort, the infringement (Article 2:202(1) CLIP). As a result of the concept of territoriality, infringement can - as in substantive law - occur only in a state where the IP right exists (Article 2:202(2) CLIP). ${ }^{60}$ Actions occurring in places where no intellectual property right exists might constitute an infringement in foreign countries as a result of extraterritorial application of their intellectual property laws, but do not constitute an infringement in the place of action and therefore cannot open jurisdiction based on infringement in the state of action. ${ }^{61}$ In this regard, the proposal of CLIP differs from the ALI Principles which allow a person to be sued "in any State in which that person has substantially acted, or taken substantial preparatory acts, to initiate or to further an alleged infringement," extending this court's jurisdiction "to claims respecting all injuries arising out of the conduct within the State that initiates or furthers the alleged infringement, wherever the injuries occur" (§ 204(1) ALI Principles). The more restrictive approach of CLIP is founded not only on the concept of territoriality, but also on procedural considerations: The forum delicti

und Forschungsgesellschaft Dipl. Ing. W. Kretzschmar GmbH \& KG (Plafog) [2002] ECR I-1699 para. 49 seq.; see also ECJ 10 June 2004, Case C-168/02, Rudolf Kronhofer $v$ Marianne Maier and Others [2004] ECR I-6009 para. 20.

59 ECJ 17 June 1992, Case C-26/91, Jakob Handte \& Co. GmbH v Traitements Mécano-chimiques des Surfaces SA [1992] ECR I-3967 para. 18. See also pending Case C-509/09, referring decision BGH 10 November 2009, GRUR 2010, 261.

${ }^{60}$ ECJ 22 June 1994, Case C-9/93, IHT Internationale Heiztechnik GmbH and Uwe Danzinger v Ideal-Standard GmbH and Wabco Standard GmbH [1994] ECR I-2789 para. 22; ECJ 14 July 2005, Case C-192/04, Lagardère Active Broadcast v Société pour la perception de la rémunération équitable (SPRE) and Gesellschaft zur Verwertung von Leistungsschutzrechten $m b H(G V L)$ [2005] ECR I-7199 para. 46: "Those rights [copyright] are therefore of a territorial nature and, moreover, domestic law can only penalise conduct engaged in within national territory".

${ }^{61}$ The question whether the forum delicti may be outside the country of protection is subject to debate in the interpretation of Article 5 No. 3 BR; for a detailed and recent analysis including case law in the member states, Schauwecker, Extraterritoriale Patentverletzungsjurisdiktion, 2009, p. 100 seq.; see also Nuyts, Suing at the Place of Infringement: The Application of Article 5(3) of Regulation 44/2001 to IP Matters and Internet Disputes, in: Nuyts (ed.), International Litigation in Intellectual Property and Information Technology, 2008, 105, 116 seq. (arguing against a limitation of the forum delicti to the country of protection). 
is based on the existence of a particularly close connecting factor between the dispute and the courts of the place where the harmful event occurred, which justifies the attribution of jurisdiction to those courts for reasons relating to the sound administration of justice and the efficacious conduct of proceedings. The courts for the place where the harmful event occurred are usually the most appropriate for deciding the case, in particular on the grounds of proximity and ease of taking evidence. ${ }^{62}$

If we apply this rationale to intellectual property infringements, it becomes clear that actions taken outside the country of protection should normally ${ }^{63}$ be irrelevant for a finding of infringement because they are not prohibited by the territorial right. If actions outside the country of protection are irrelevant to establish infringement, it is difficult to see what relevant evidence for the proof of infringement could be found outside the country of protection. Rather, actions outside the country of protection should be regarded as being outside the elements which give rise to liability and thus cannot justify conferring jurisdiction to the courts at the place of action. ${ }^{64}$ Furthermore, it should not be forgotten that a universal jurisdiction at the place of action for all infringements arising from this action irrespective of the country of protection would be open not only to the right holder, but also to the infringer to seek a negative declaration denying infringement for all countries where the injury may occur (Article 2:210 CLIP). The understandable desire to seek immediate redress at the place of action can be dealt with adequately in interim proceedings (Article 2:501 CLIP), leaving the decision in substance to the courts of the defendant's domicile or to the courts of the country of protection where the injury (infringement) occurs.

In addition to the general requirement that the intellectual property right exists, the definition of infringement in Article 2:202 CLIP (in the June 2009 version) requires one of two other possible elements: On the one

62 ECJ 16 July 2009, Case C-189/08, Zuid-Chemie BV v Philippo's Mineralenfabriek $N V / S A$ para. 24 (not yet reported).

${ }^{63}$ An exception might be considered if a process is the subject matter of the patent. As such, a patent extends to products obtained directly by the patented process (Article 28(1) lit. b TRIPS) irrespective of the place of production; relevant evidence might be found outside the country of protection to ascertain whether the products were obtained directly by the patented process. However, this exception seems to be too limited to justify a general forum delicti outside the country of protection, Grabinski, GRUR Int. 2001, 199, 204 N. 64.

${ }^{64}$ The reasoning of ECJ 10 June 2004, Case C-168/02, Rudolf Kronhofer v Marianne Maier and Others [2004] ECR I-6009 para 18 could be applied by analogy: "There is nothing (...) to justify conferring jurisdiction to the courts of a Contracting State other than that on whose territory the event which resulted in the damage occurred and the damage was sustained, that is to say all of the elements which give rise to liability. To confer jurisdiction in that way would not meet any objective need as regards evidence or the conduct of the proceedings" (emphasis added). 
hand, infringement occurs on the basis of the traditional "act-based" concept of infringement in a state where the defendant has acted to initiate or further the infringement (Article 2:202(2)(a) CLIP 2009). ${ }^{65}$ On the other hand, and this is the result of the more "effects-oriented" approach, infringement occurs also in those countries to which the activity is directed ${ }^{66}$ or in which the activity has substantial effect (Article 2:202(2)(b) CLIP 2009). ${ }^{67}$ With these criteria (action, direction, substantial effect), the CLIP Principles define the "qualified conduct" necessary to open jurisdiction at the place of infringement. In choosing these criteria, the CLIP Principles try to implement both the "directed to" test which has been advocated by courts in trademark law ${ }^{68}$ and the requirement of "commercial effect" which has been proposed by the WIPO Joint Recommendation Concerning Provisions on the Protection of Marks, and Other Industrial Property Rights in Signs, on the Internet. ${ }^{69}$ The requirement of substantiality was included to serve as a filter to sort out minor infractions of intellectual property rights which should be concentrated in the defendant's forum.

Against the approach of Article 2:202(2) CLIP 2009, it has been objected that the right holder might in many cases only find a single infringing article in the jurisdiction. In such a situation, the right holder will want to obtain information about the extent of the infringement by applying for a search and/or information order at the place of infringement, possibly combined with an (interlocutory) injunction stopping further infringement ${ }^{70}$. If infringement jurisdiction can only be established by proving substantial activities or substantial harm within the jurisdiction, this could be too burdensome for an effective enforcement of intellectual property rights. In view of these arguments, the group has reconsidered

${ }^{65}$ A similar provision is found in $\S 204(1)$ ALI Principles, however (apparently) without the restriction to those countries in which the IP right exists and with a more extensive scope of jurisdiction which extends to "claims respecting all injuries arising out of the conduct within the State that initiates or furthers the alleged infringement, wherever the injuries occur" ( $§ 204$ (1) $2^{\text {nd }}$ sentence ALI Principles), while Article 2:202 (1) CLIP limits infringement jurisdiction outside ubiquitous media to infringements that occur or may occur within the territory of the State in which that court is situated.

${ }^{66}$ This element could also be regarded as an extension of the "act-based" concept of infringement.

${ }^{67}$ Infringement jurisdiction in the country of "direction" (limited to injuries occurring in that state) is also established by $\S 204$ (2) ALI Principles: "A person may be sued in any State in which its activities give rise to an infringement claim, if it reasonably can be seen as having directed those activities to that state".

${ }_{68}$ BGH 13 October 2004, NJW 2005, 1435, 1436 - hotel-maritime.dk.

69 Available under <www.wipo.int/about-ip/en/development_iplaw/pub845.htm>. For an explanation, Kur, IIC 2002, 41; Kur, in: Basedow/Drex1/Metzger/Kur (ed.), Intellectual Property in the Conflict of Laws, 2005, 175, 177 seq.

${ }^{70} \mathrm{Cf}$. Articles 7, 8, 9(1)(a) Directive 2004/48/EC; Article 47, 50(1)(a) and (b) TRIPS. 
Article 2:202 CLIP in its most recent draft (February 2010) to find a better criterion to balance the legitimate interests of right holders to effectively enforce their (information) rights with the interests of third parties not to be exposed to a world-wide forum delicti which is based on the mere accessibility of a website or other minor and unintended spill-over effects. In order to strike such a balance, the CLIP group will probably preserve the general concept of infringement jurisdiction based on "qualified conduct" of the alleged infringer in Article 2:202 CLIP, ${ }^{71}$ but drop the requirement of substantiality on the jurisdiction level ${ }^{72}$ and shift the burden of proof to challenge infringement jurisdiction to the alleged infringer.

A presentation of the forum delicti would not be complete without some words on the extent of jurisdiction. Under the Brussels Regulation, most commentators agree that jurisdiction based on infringement is limited to those infringements that occurred in the forum state ("mosaic approach"). ${ }^{73}$ Some $^{74}$ justify this by an application of the Shevill decision of the European Court of Justice ${ }^{75}$ on intellectual property law; others come (more convincingly) to the same conclusion by pointing to the fact that infringement occurs in the forum state only with regard to domestic intellectual property rights, which necessarily leads to jurisdiction being restricted to the infringement of domestic rights. ${ }^{76}$ Irrespective of its doctrinal justification, the "mosaic approach" places a substantial burden on the plaintiff to litigate worldwide infringements. In most cases this can be justified by the possibility to sue either for all infringements in the place of the defendant's residence ${ }^{77}$ or to sue only in those places of infringement where the lion's share of the sales are found, expecting that losing these markets will make it unattractive for the infringer to continue his conduct. For these

71 Article 2:202 CLIP in its most recent wording reads: "In disputes concerned with infringement of an intellectual property right, a person may be sued in the courts of the State where the alleged infringement occurs or may occur, unless the alleged infringer has not acted in that State to initiate or further the infringement and his/her activity cannot reasonably be seen as having been directed to that State".

${ }^{72}$ For applicable law see Article 3:602 CLIP.

${ }^{73}$ Metzger (supra note 51), 260.

${ }^{74}$ Cass. Civ. 16 July 1997, RIDA 176 (1998), 403, 405 - Wegmann.

75 ECJ 7 March 1995, Case C-68/93, Fiona Shevill, Ixora Trading Inc., Chequepoint SARL and Chequepoint International Ltd $v$ Presse Alliance SA [1995] ECR I-415 paras. $25,30,32$ seq.

${ }^{76}$ OLG Düsseldorf, IPRax 2001, 336, 336 seq. - Schussfadengreifer; (Swiss) Bundesgericht 23 October2006, GRUR Int. 2007, 534, 536 - Internationale Zuständigkeit in Patentsachen I; Grabinski, GRUR Int. 2001, 199, 204 seq.; Heinze, Einstweiliger Rechtsschutz im europäischen Immaterialgüterrecht, 2007, 231, 234.

77 This is possible under the CLIP Principles due to limited exclusive jurisdiction but more problematic under the Brussels Regulation as far as registered rights are concerned due to the extensive interpretation of Article 22 No. 4 BR; see above IV 4. 
reasons, Article 2:203(1) of the CLIP Principles adheres in principle to a strict "territorialization" of infringement jurisdiction: the provision limits the scope of jurisdiction to infringements that occur or may occur within the territory of the state in which that court is situated. However, the territorial fragmentation of infringement jurisdiction appears unsatisfactory if the infringement is carried out through ubiquitous media such as the Internet, and a concentration of all claims in the state of the infringer's residence seems inappropriate because this state has, for lack of substantial effect, no interest in litigating the worldwide infringement. ${ }^{78}$ In such a situation in which the infringer directs almost all his activities to states other than his home state (which might be a copyright haven), Article 2:203(2) CLIP makes a worldwide concentration of all infringement actions in one forum (other than the infringer's residence) possible, provided that substantial activities in furtherance of the infringement in its entirety have been carried out within the territory of the state in which the court is situated, or ${ }^{79}$ the harm caused by the infringement in the state where the court is situated is substantial in relation to the infringement in its entirety. ${ }^{80}$

\section{b) Contractual claims}

Less intellectual property-specific but still relevant for intellectual property disputes is the jurisdiction at the place of performance of a contract (Article 5 No. 1 BR). The Brussels Regulation establishes jurisdiction at the place of performance and offers two different solutions to define this place: If the contract concerns the sale of goods or the provision of services, Article 5 No. 1 lit. $\mathrm{b}$ defines a uniform place of performance for all obligations flowing from the contract: The uniform place of performance where all actions relating to this contract may be brought is the place where the goods were delivered or the services were provided. For all other contracts, the jurisdiction for contractual claims is determined by the

\footnotetext{
${ }^{78}$ Or if the home state of the defendant has a low level of IP protection ("information haven"), Metzger (supra note 51), 260 seq.

${ }^{79}$ See also Metzger (supra note 51), 264 who argues in favor of an extension of an earlier, more restrictive version of Article 2:203(2) CLIP.

${ }^{80}$ The ALI Principles, by contrast, provide a different (probably more generous) rule for unrestricted infringement jurisdiction in $\S 204(3)$ : “A person who cannot be sued in a WTO-member State through the application of $\S \S 201-204(1)$ may be sued in any State in which its activities give rise to an infringement claim if: (a) it reasonably can be seen as having directed those activities to that State, and (b) it solicits or maintains contacts, business, or an audience in that State on a regular basis, whether or not such activity initiates or furthers the infringing activity. The court's jurisdiction extends to claims respecting injuries arising out of conduct outside the State that relates to the alleged infringement in the State, wherever the injuries occur".
} 
obligation which arises under the contract and the non-performance of which is relied upon in support of the action (the so-called "obligation in question"). The place of performance of this obligation is determined by the law applicable to the contract by virtue of the private international law of the forum (Article 5 No. 1 lit. a, c BR).$^{81}$ As a license contract does not qualify as a contract for the provision of services within the meaning of Article 5 No. 1 lit. b BR, ${ }^{82}$ the place of performance of such a contract has to be determined for any single obligation in question separately by application of the lex contractus. Thus, there is no uniform (let alone single) place of performance for license contracts, but rather the place of performance and the jurisdiction for matters relating to license contracts depends on the law applicable to the contract.

The CLIP Principles try to remedy this lack of uniformity for the important field of license (and transfer) contracts ${ }^{83}$. To this end, the CLIP Principles adhere to the general concept of jurisdiction at the place of performance of the obligation in question (Article 2:201(1) CLIP), but provide for an autonomous and uniform definition for all contractual obligations arising from contracts having as their main object the transfer or license of an intellectual property right. For such contracts, the state where the obligation in question is to be performed is defined as the state for which the license is granted or the right is transferred (Article 2:201(2) CLIP). To avoid a concentration of all contractual claims in one forum (which should - in the case of license or assignment contracts - only be possible in the defendant's habitual residence or in a court agreed by juris-

${ }^{81}$ See, respectively, with regard to the concept of "obligation" referred to in Article 5 No. 1 of the Brussels Convention, ECJ 6 October 1976, Case 14/76, A. De Bloos, SPRL v Société en commandite par actions Bouyer [1976] ECR 1497 para. 13; ECJ 15 January 1987, Case 266/85, Hassan Shenavai v Klaus Kreischer [1987] ECR 239 para. 9; ECJ 29 June 1994, Case C-288/92, Custom Made Commercial Ltd v Stawa Metallbau GmbH [1994] ECR I-2913 para. 23; ECJ 5 October 1999, Case C-420/97, Leathertex Divisione Sintetici SpA v Bodetex BVBA [1999] ECR I-6747 para. 31; ECJ 19 February 2002, Case C-256/00, Besix SA v Wasserreinigungsbau Alfred Kretzschmar GmbH \& Co. KG (WABAG) and Planungs- und Forschungsgesellschaft Dipl. Ing. W. Kretzschmar GmbH \& $K G$ (Plafog) [2002] ECR I-1699 para. 44, and with regard to the place of performance of that obligation within the meaning of Article 5 No. 1 of the Brussels Convention ECJ 6 October 1976, Case 12/76, Industrie Tessili Italiana Como v Dunlop AG [1976] ECR 1473 para. 13; Custom Made Commercial (above) para. 26; ECJ 28 September 1999, Case C-440/97, GIE Groupe Concorde and Others $v$ The Master of the vessel "Suhadiwarno Panjan" and Others [1999] ECR I-6307 para. 32; Leathertex (above) para. 33, Besix (above) paras. 33, 36.

${ }^{82}$ ECJ 23 April 2009, Case C-533/07, Falco Privatstiftung and Rabitsch $v$ Gisela Weller-Lindhorst (not yet reported) para. 44.

${ }^{83}$ See also Brinkmann, IPRax 2009, 487, 492 who argues in favor of a legislative amendment of Article 5 No. 1 Brussels Regulation. 
diction agreement), Article 2:201(2) CLIP clarifies that jurisdiction under Article 2:201(2) is limited to activities relating to the license or transfer of the intellectual property right for that particular state. Finally, Article 2:201(3) CLIP deviates from the case law of the European Court of Justice under the Brussels Regulation ${ }^{84}$ in permitting a concentration of contractual and delictual claims in the same court ${ }^{85}$. The corresponding provision in $\S 205$ ALI Principles ${ }^{86}$ will probably lead to similar results as Article 2:201 CLIP in most cases, but has no answer for intellectual property contracts other than license and assignment and is less adapted to the traditional European "place of performance" concept of contractual jurisdiction.

\section{c) Multiple defendants}

The last rule of special jurisdiction which shall be presented in this paper is jurisdiction for multiple defendants. According to Article 6 No. 1 BR, a person domiciled in a member state which is one of a number of defendants may also be sued in the courts for the place where any one of the defendants is domiciled, provided that the claims are so closely connected that it is expedient to hear and determine them together to avoid the risk of irreconcilable judgments resulting from separate proceedings. The implications of this rule for intellectual property disputes can only be fully understood with the case law of the European Court of Justice in mind, in particular the decision in Roche Nederland ${ }^{87}$ In this case, two American patent holders sued Roche Nederland and a number of its subsidiaries for violation of parallel European patents in several countries. The European Court of Justice rejected the possibility of consolidation in the Netherlands where the parent company was resident, stressing that no connection "could ... be established between actions for infringement of the same European patent where each action was brought against a company established in a different Contracting State in respect of acts which it had com-

${ }^{84}$ ECJ 27 September 1988, Case 189/87, Athanasios Kalfelis v Bankhaus Schröder, Münchmeyer, Hengst and Co. and Others [1988] ECR 5565 para. 19 (decided in the context of an action based on Article 5 No. 3, not Article 5 No. 1 BR).

${ }^{85}$ For license and assignment contracts, Article 2:201(2) CLIP and Article 2:202(1) CLIP should almost always point to the same forum anyway. The concentration may be relevant for actions under Article 2:201(1) CLIP.

86 "A person may be sued in a State with respect to any claim alleging the breach of an agreement transferring or licensing intellectual property rights for exploitation in that State. When this section offers the sole basis of jurisdiction, the defendant may be sued only with respect to those intellectual property rights provided by that State and related to the agreement".

${ }^{87}$ ECJ 13 July 2006, Case C-539/03, Roche Nederland BV and Others v Frederick Primus and Milton Goldenberg [2006] ECR I-6535. 
mitted in that State." ${ }^{88}$ As a result, actions based on different national intellectual property rights can (almost) never be consolidated on the basis of Article 6 No. 1 BR, even if the defendants are closely related (parent and subsidiaries) and the intellectual property rights are subject to European or international harmonization.

Here again, the European Court advocates a "re-territorialization" of intellectual property litigation even if the right claimed to be infringed is subject to (partial) harmonization such as the European patent by the European Patent Convention (EPC). While it is accepted that the European Patent Convention only provides for partial harmonization, it should not be neglected that the enforcement directive 2004/48/EC and Article 41 seq. TRIPS have also led to a certain minimum harmonization in the field of sanctions, at least within the European Union. In light of these supranational instruments, it seems inappropriate and even counter-productive to substantive law harmonization efforts to treat harmonized or even uniform $^{89}$ intellectual property rights as completely national entities which exist fully independent in each country of protection. ${ }^{90}$ Therefore, the CLIP Principles try to moderate the restrictive interpretation of Article 6 No. 1 BR by letting it suffice for a risk of irreconcilable judgments that the disputes against several defendants involve "essentially" the same legal and factual situation. This more moderate wording shall make it possible to consolidate different infringement actions based on intellectual property rights which are subject to international harmonization in their requirements and scope (such as the European patent or national trademarks in the different member states of the European Union) in a single forum. Instead of excluding a consolidation of such claims from the outset, the CLIP Principles propose a further requirement for consolidation of infringement actions against several defendants in a single forum, namely that the defendant habitually resident in the state where the claims are brought has coordinated the activities leading to the infringements or is otherwise most

${ }^{88}$ ECJ 13 July 2006, Case C-539/03, Roche Nederland BV and Others $v$ Frederick Primus and Milton Goldenberg [2006] ECR I-6535 para. 33.

${ }^{89}$ Such as the European Community Trade Mark, see Article 1(2) of Council Regulation (EC) No 40/94 of 20 December 1993 on the Community trade mark, OJ L 11, 14 January 1994, p. 1; the Community Design, see Article 1(3) of Council Regulation (EC) No 6/2002 of 12 December 2001 on Community designs, OJ L 3, 5 January 2002, p. 1; or the Community plant variety right, see Article 2 of the Council Regulation (EC) No $2100 / 94$ of 27 July 1994 on Community plant variety rights, OJ L 227, 1 September 1994, p. 1. The effect of the Roche Nederland decision on unitary rights is unclear.

${ }^{90}$ Kur, IIC 2006, 844, 850; Gonzalez Beifuss, Jurisdiction over Co-Defendants after Roche Nederland, in: Nuyts (ed.), International Litigation in Intellectual Property and Information Technology, 2008, 79, 84 seq. 
closely connected with the dispute in its entirety (Article 2:206(2) CLIP). These criteria try to identify the center of parallel infringement activities at the residence of the coordinator of the activities (e.g., the parent company of several subsidiaries) where a consolidation of all actions seems appropriate. $^{91}$ In its future work, the CLIP group will try to elaborate these concepts further, possibly by providing definitions for "the same legal and factual situation" (Article 2:206(1) CLIP) and for the "center of activities" where a consolidation appears appropriate (Article 2:206(2) CLIP).

\section{Prorogation of jurisdiction}

As most other international instruments, ${ }^{92}$ the CLIP Principles accept the parties' autonomy to choose a forum for their dispute before or after the dispute arises. The court chosen by the parties will normally have jurisdiction to decide on all disputes between the parties irrespective of the place of infringement, ${ }^{93}$ subject only to the rules on exclusive jurisdiction and specific rules of the forum protecting consumers and employees (Article 23(5) BR, Article 2:101 CLIP). Given the general acceptance of jurisdiction clauses, the CLIP Principles follow existing provisions, in particular Article 23 Brussels Regulation, but propose certain clarifications regarding the scope of jurisdiction agreements (Article 2:301(1) CLIP: jurisdiction is deemed to be exclusive and to comprise all contractual and non-contractual obligations and all other claims arising from that legal relationship), the rules determining the validity of such agreements (Article 2:301(2), (3) CLIP), the exception for exclusive jurisdiction (Article 2:301(4) CLIP), and the doctrine of severability of jurisdiction agreements (Article 2:301(5) CLIP).

\section{Provisional measures}

Another - often neglected - field of particular practical importance in intellectual property litigation is provisional measures. The Brussels Regulation does not provide a positive rule for these measures but rather an "opening clause" in Article 31 BR which opens the mandatory and con-

91 A broader provision on multiple defendants is found in $\S 206$ ALI Principles. Article 2:206 CLIP is modeled more closely on Article 6 No. 1 BR, but leaves certain leeway by relying on the "most closely connected" criterion in Article 2:206(2) CLIP (which is also found in $\S 206(1)$ (b) ALI Principles). It might be subject to further debate in the CLIP group whether the "most closely connected" criterion could be further elaborated to enhance legal certainty.

92 See also $\S \S 202,203$ ALI Principles.

93 See also $\S \S 202,211$ ALI Principles; Peukert, Contractual Jurisdiction Clauses and Intellectual Property, in: Drexl/Kur (eds.), Intellectual Property and Private International Law, 2005, 55, 57 seq. 
clusive system of jurisdiction rules for the different national rules on provisional measures. As a result, the Brussels Regulation establishes a twotier system: Jurisdiction for provisional measures can either be based on the jurisdiction rules of the Brussels Regulation itself (a court having jurisdiction as to the substance of a case in accordance with Articles 2 and 5 to 24 of the Regulation also has jurisdiction to order any provisional or protective measures which may prove necessary ${ }^{94}$ ) or it can be based on Article 31 Brussels Regulation in connection with the different national rules on jurisdiction for provisional measures. This system, in particular the jurisdiction based on Article $31 \mathrm{BR}$ and the national rules, is dangerous for the uniformity of the European law because national courts might grant very far-reaching "provisional" measures ${ }^{95}$ which effectively pre-empt the decision on the substance of the case and make it possible to circumvent the mandatory and conclusive rules of jurisdiction laid down in Article 224 BR. Therefore, the European Court of Justice has subjected provisional measures based on Article $31 \mathrm{BR}$ in connection with national rules of jurisdiction to additional requirements, namely (a) the existence of a real connecting link between the subject matter of the measures sought and the territorial jurisdiction of the member state of the court before which those measures are sought ${ }^{96}$ and (b) an autonomous Regulation definition of provisional measures which includes interim payment orders only if, first, repayment to the defendant of the sum awarded is guaranteed in case the plaintiff is unsuccessful regarding the substance of his claim and, second, the measure sought relates only to specific assets of the defendant located or to be located within the confines of the territorial jurisdiction of the court to which application is made. ${ }^{97}$ In light of these developments, the text of Article $31 \mathrm{BR}$ is incomplete and cannot serve as a model for international rule-making.

The CLIP Principles take the two-tier system of the Brussels Regulation as a starting point to propose a number of amendments and clarifications. First, it is expressly clarified by Article 2:501(1) CLIP that a court having jurisdiction as to the substance of a case in accordance with Articles 2:102 to Article 2:401 also has jurisdiction to order any provisional or protective

94 ECJ 17 November 1998, Case C-391/95, Van Uden Maritime BV, trading as Van Uden Africa Line v Kommanditgesellschaft in Firma Deco-Line and Another [1998] ECR I-7091 para. 19.

95 Such as the Dutch kort geding or the French référé-provision.

96 ECJ 17 November 1998, Case C-391/95, Van Uden Maritime BV, trading as Van Uden Africa Line v Kommanditgesellschaft in Firma Deco-Line and Another [1998] ECR I-7091 para. 40.

97 ECJ 17 November 1998, Case C-391/95, Van Uden Maritime BV, trading as Van Uden Africa Line v Kommanditgesellschaft in Firma Deco-Line and Another [1998] ECR I-7091 para. 47. 
measures which may prove necessary ${ }^{98}$ without that jurisdiction being subject to any further conditions. ${ }^{99}$ This clarification mirrors the case law of the European Court of Justice and might prove useful for a better understanding of the provision. Further, Article 2:501(2) CLIP opens a second avenue for provisional relief in either the state where the measure is to be enforced (Article 2:501(2) lit. a CLIP) or the state for which protection is sought (Article 2:501(2) lit. b CLIP). ${ }^{100}$ The additional jurisdiction at the place of enforcement (Article 2:501(2) lit. a) is justified by the particular need for a quick enforcement of provisional measures. This need can be best met if the court where the measure can be enforced has jurisdiction to grant immediate relief, thus avoiding lengthy proceedings to enforce foreign judgments. The justification for Article 2:501(2) lit. b CLIP, the additional jurisdiction in the country of protection, is less obvious, in particular as Article 2:202 CLIP will normally provide for jurisdiction at the place of infringement anyhow. However, in limited circumstances (e.g., as a result of a jurisdiction or arbitration agreement), jurisdiction under Article 2:202 CLIP might be excluded. For such a situation, Article 2:501(2) lit. b CLIP clarifies that provisional measures shall be available in the country of protection even if there is no jurisdiction for the substance of the case. While Article 2:501(2) CLIP expands jurisdiction for provisional measures to the benefit of the plaintiff, Article 4:301(1) CLIP tries to balance this advantage on the recognition and enforcement level by excluding measures based solely on Article 2:501(2) from the liberal recognition and enforcement regime of Part 3 of the CLIP Principles, thereby limiting the effect of measures based on Article 2:501(2) CLIP to the country in which they were granted. A further safeguard for the rights of the defense is Article 4:301(2) CLIP, which excludes provisional measures adopted without prior hearing of the adverse party and enforceable without

98 ECJ 17 November 1998, Case C-391/95, Van Uden Maritime BV, trading as Van Uden Africa Line v Kommanditgesellschaft in Firma Deco-Line and Another [1998] ECR I-7091 para. 19.

99 ECJ 17 November 1998, Case C-391/95, Van Uden Maritime BV, trading as Van Uden Africa Line v Kommanditgesellschaft in Firma Deco-Line and Another [1998] ECR I-7091 para. 22. A similar provision is found in § 214(1) ALI Principles.

$100 \S 214(2)$ ALI Principles opens additional jurisdiction for provisional measures for the "courts of any States in which the intellectual property is registered or in which the tangible property is located," if the measure is limited to the territory of that state. This provision will probably come to similar results as Article 2:501 CLIP, but (apparently) restricts "enforcement jurisdiction" (Article 2:501(2)(a) CLIP) to tangible property and "country of protection" jurisdiction (Article 2:501(2)(b) CLIP) to registered rights. $\S 214(3)$ ALI Principles clarifies that a non-infringer may be subject to an action for temporary detention of the goods. This provision seems to deal more with a specific remedy than with jurisdiction stricto sensu and was therefore left out of the jurisdiction section of the CLIP Principles. 
prior service to that party from recognition and enforcement. ${ }^{101}$ The accumulation of possible venues under the first two paragraphs of Article 2:501 CLIP may lead to coordination problems which Article 2:501(3) CLIP $^{102}$ tries to solve by according a "coordination competence" to the court deciding on the substance of the case. Finally, Article 2:501(4) CLIP provides an intellectual property-specific definition of provisional measures which is inspired by Article 50(1) TRIPS. Given the different national notions of provisional measure, a specific definition is needed to clarify the scope of Article 2:501 CLIP and avoid a possible circumvention of the jurisdiction rules for the substance of the case by resorting to interim payment orders which are available in certain jurisdictions.

\section{Conclusion}

All in all, the CLIP Principles are evolutionary rather than revolutionary in nature: They aim not at fundamental reconstruction of the rules of international jurisdiction, but rather at their evolutionary adaption to the specific needs of intellectual property litigation. To this end, they take more than 30 years of experience under the Brussels rules of jurisdiction as a starting point and adjust its provisions to correct the overly territorial and traditional understanding of intellectual property litigation expressed in the GAT/LuK and Roche Nederland judgments of the European Court of Justice. The cautious approach of the CLIP Principles might be criticized. However, also on the jurisdiction level it should not be forgotten that the attribution of adjudicatory competence is not only a matter of procedural fairness and efficacy, but also a powerful tool to safeguard legitimate national conceptions of economic and cultural policy which lie at the heart of the differences in substantive intellectual property law and the principle of territoriality itself.

\footnotetext{
101 This provision is inspired by ECJ 21 May 1980, Case 125/79, Bernard Denilauler $v$ SNC Couchet Frères [1980] 1553 para. 18. Article 4:301(2) CLIP does not affect more liberal regional enforcement rules (Article 4:103 CLIP) such as currently debated in Europe, COM (2009) 175 final, question 4; Heinze, 120 [2007] ZZP 303, 312.

${ }^{102}$ The provision might be relocated to the section on coordination of proceedings (Article 2:705(3) CLIP) and amended to reflect that only the court first seized, in accordance with the CLIP Principles, with the substance of the matter, shall enjoy coordination authority. In addition, it may be clarified that the "coordinating court" cannot directly modify foreign provisional measures, but rather has to ask the foreign court to do so.
} 


\section{Jurisdiction in Intellectual Property Cases: The Transparency Proposal}

\section{SHIGEKi CHAEN/TOSHIYUKI Kono/DAi YOKOMIZO}

I. Introduction

II. International Jurisdiction Concerning Existence, Registration, Validity, and

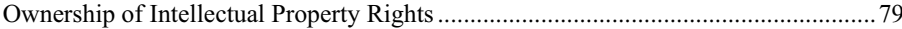

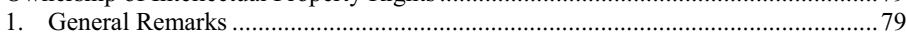

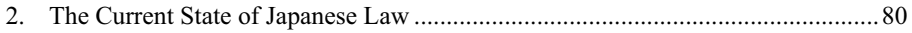

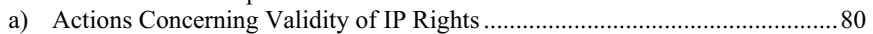

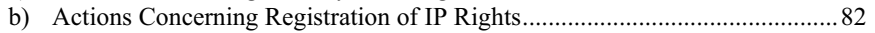

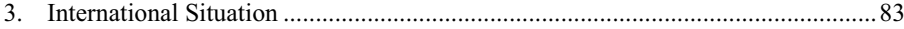

4. International Jurisdiction over Actions Concerning the Validity or

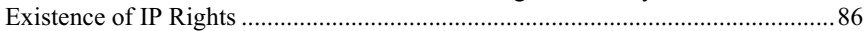

a) Actions Concerning the Validity of IP Rights ........................................... 86

b) Actions Concerning the Existence of IP Rights ............................................... 88

5. International Jurisdiction over Actions Concerning the Registration or

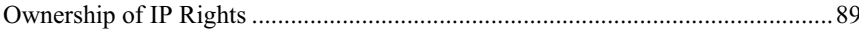

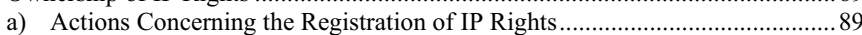

b) Actions Concerning the Ownership of IP Rights ........................................ 90

III. International Jurisdiction over Actions Concerning Intellectual Property

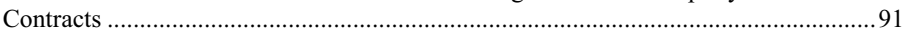

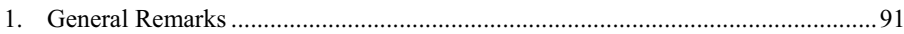

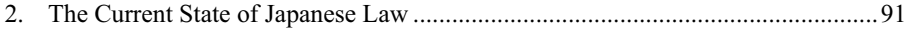

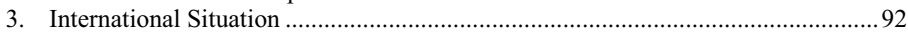

4. International Jurisdiction over Actions Concerning Contracts Relating to

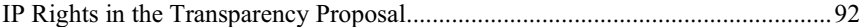

IV. International Jurisdiction and IP Infringement Claims ............................................ 94

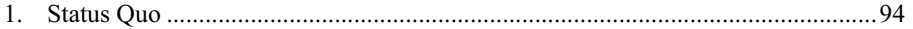

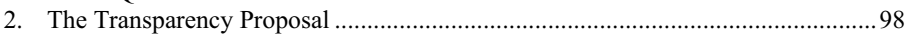

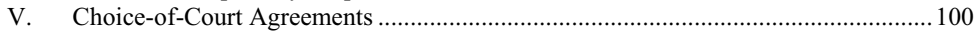

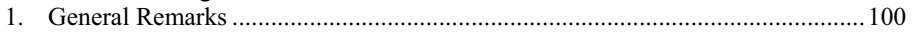

2. Choice-of-Court Agreements in Japan ............................................................. 100

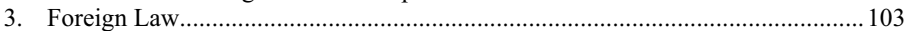

a) The 2005 Hague Choice of Court Convention............................................... 103

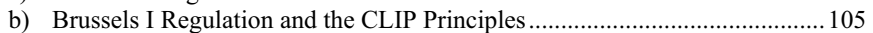

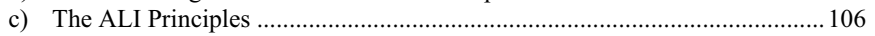

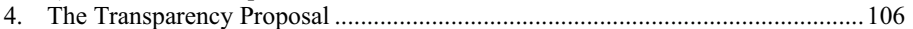

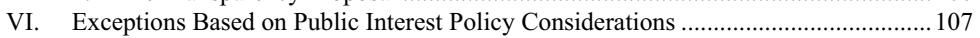

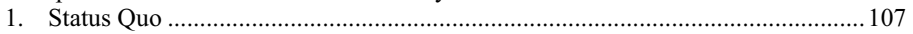




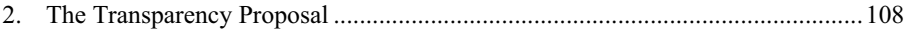

VII. Joinder of Claims in Intellectual Property Cases....................................................... 109

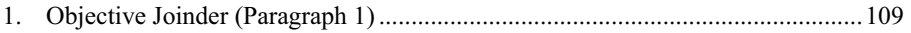

a) Circumstances Where Objective Joinder Becomes an Issue in

b) Objective Joinder under the Current Law ...................................................110

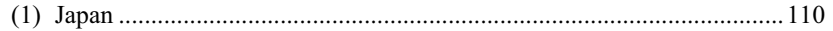

(2) Other Countries ............................................................................. 111

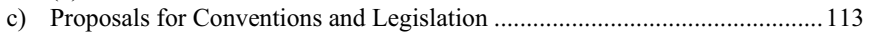

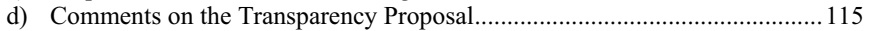

2. Subjective Joinder (Paragraph 2) and the "Spider in the Web" (Paragraph 3) .....118

a) Circumstances Where a Subjective Joinder Becomes an Issue in

International Disputes on Intellectual Property .............................................118

b) Subjective Joinder under the Current Law..................................................... 119

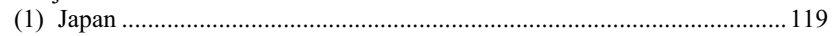

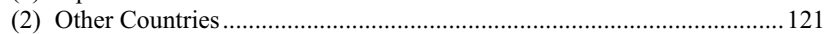

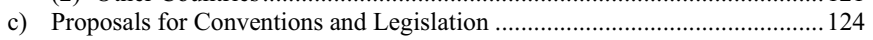

d) Comments on the Transparency Proposal................................................... 126

(1) Subjective Joinder (Paragraph 2) ......................................................... 126

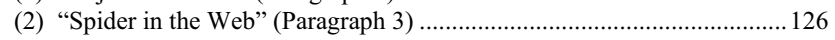

VIII. International Jurisdiction and Provisional Measures ............................................... 128

1. Circumstances where Provisional Measures Become an Issue in International Disputes over Intellectual Property ............................................ 128

2. Jurisdiction to Order Provisional Measures under the Current Law ...................... 128

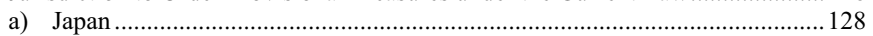

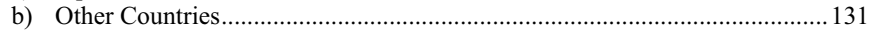

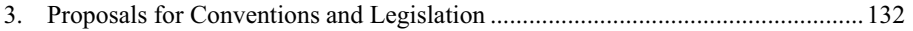

4. Comments on the Transparency Proposal ...................................................... 134

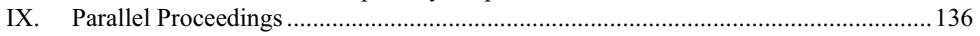

1. Circumstances Where International Parallel Litigation Becomes an Issue

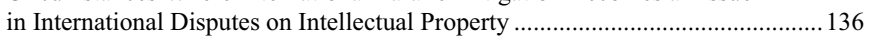

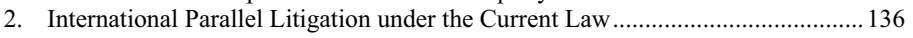

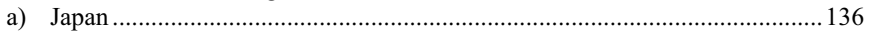

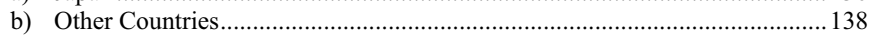

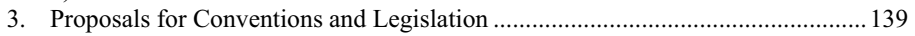

4. Comments on the Transparency Proposal ...................................................... 142

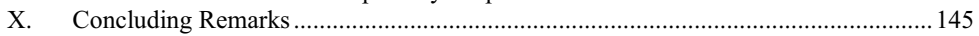

\section{Introduction}

The exercise of international jurisdiction by domestic courts is one of the cornerstone issues in cross-border intellectual property litigation. Jurisdictional issues are even more complicated given the fact that certain aspects such as registration and validity of intellectual property rights might be subject to exclusive jurisdiction of the courts of a granting country. The Legislative Proposal of the Transparency Project (hereinafter 
referred to as "the Transparency Proposal") tries to strike the balance between the sovereignty considerations and efficient IP dispute resolution. This article provides for a closer analysis of issues that are peculiar to adjudication of cross-border intellectual property disputes. In particular, legal issues pertaining to international jurisdiction concerning existence, registration, validity, ownership, IP contracts, infringements of intellectual property rights, joinder of claims, and parallel proceedings are elaborated in the following sections.

\section{International Jurisdiction Concerning Existence, Registration, Validity, and Ownership of Intellectual Property Rights}

\section{General Remarks}

Article 103 provides for international jurisdiction over actions concerning the existence, registration, validity, or ownership of IP rights. ${ }^{1}$ This article is divided into cases where an IP right is granted under Japanese law and cases where it is granted under foreign law. In the former case, the international jurisdiction of Japanese courts is affirmed without another basis for international jurisdiction (Paragraph 1). In the latter case, the international jurisdiction of Japanese courts is affirmed where there is a basis for international jurisdiction in Japanese courts, such as a defendant's domicile in Japan (Paragraph 2).

As explained below, it is generally thought, in Japan as well as in foreign countries, that the courts of the country of registration have exclusive jurisdiction over actions concerning the registration or validity of IP rights that arise from registration, such as patent rights. However, the Transparency Proposal does not adopt this thinking, and recognizes that there are cases in which the jurisdiction of Japanese courts should be affirmed even where the IP right was granted under foreign law. However, a judgment invalidating an IP right granted under foreign law should not be effective against third parties, but only effective between the parties to the action (Paragraph 3).

Intellectual property rights granted under Japanese law that arise from registration, such as patent rights, cannot be invalidated in a civil action. In order to invalidate a Japanese patent right, it is necessary to request an administrative adjudication of invalidity in the Patent Office (Art. 123 of the Japanese Patent Act).

\footnotetext{
${ }^{1}$ See Article 103 of the Transparency Proposal, Annex III infra.
} 


\section{The Current State of Japanese Law}

\section{a) Actions Concerning Validity of IP Rights}

There are no cases in Japan in which the validity of an IP right granted under the laws of a foreign country has been directly contested. However, in Sango Suna ${ }^{2}$ case, in which the plaintiff seeked a declaration of the nonexistence of a right to bring a claim for an injunction against the infringement of a U.S. patent right, Tokyo District Court stated in obiter dicta that "it is generally understood that the country of registration of a patent right has exclusive jurisdiction over actions seeking a judgment negating the establishment of a patent right or invalidating a patent right." The prevailing academic opinion is that the courts of the country of registration have exclusive jurisdiction over actions concerning the validity of IP rights arising from registration. On the other hand, for actions concerning copyrights that do not require registration to be established, academic opinion is virtually unanimous that there is no country with exclusive jurisdiction. ${ }^{3}$

Also in its report ${ }^{4}$ the International Jurisdiction Study Group, which was commissioned by the Ministry of Justice to study international jurisdiction, made the following statement about actions concerning the validity of IP rights:

Where a foreign country is the place of registration, the international jurisdiction of Japanese courts is not given for actions concerning the validity of IP rights that arise by registration of their establishment, even where there is a basis for international jurisdiction in Japanese courts.

\section{The reason given was this:}

Concerning actions related to validity of foreign patents, patents and similar rights are granted by administrative dispositions of each country, and the nature of such rights is such that their validity can best be judged by the registering country. Moreover, if a country other than the registering country issues a declaration of the invalidity of a patent, it will only be effective as between the parties, and it is highly unlikely that the registering country will recognize the judgment and that registration will be invalidated. Considering the above points, it could be proper for the courts of the registering country

\footnotetext{
2 Tokyo District Court, 16 October 2003, Hanrei Jiho No.1874, p. 23.

3 Makiko Takabe, Shôgaiteki chosakuken soshô no ronten [Issues in International Copyright Cases], in: Saito Hiroshi Sensei gotaishoku kinen, gendai shakai to chosakukenhô [In Honor of Professor Hiroshi Saito's Retirement: The Modern Society and Copyright Law] (Kôbundo, 2008), p. 125, 126-127; Yasuto Komada, Chosakuken wo meguru kokusai saiban kankatsu oyobi junkyohô ni tsuite [International Jurisdiction and Applicable Law Concerning Copyright], Kokusai shihô nenpô [Japanese Yearbook of Private International Law], No.6, p. 63, 64-66 (2004).

${ }^{4}$ This report is reprinted in NBL No. 883 to No. 888 (2008).
} 
to have exclusive jurisdiction, even where the international jurisdiction of Japanese courts is affirmed under general forum provisions. ${ }^{5}$

On the other hand, where the issue of the validity of the IP right granted under foreign law may be presented as an incidental issue, such as where the issue is raised as a defense in an infringement action (it is generally thought that an infringement action involving foreign IP rights is not subject to the exclusive jurisdiction of the country of registration), academic opinion is not unanimous over how Japanese courts can deal with the issue. Some say that courts of Japan can decide the issue. ${ }^{6}$ Others say that it is improper for a court to decide the validity of an administrative disposition in another country, and that when there is a litigation in the country of registration to invalidate a right, a Japanese court can stay the proceedings pursuant to Article 168(2) of the Patent Act. ${ }^{7}$ In the above Sango Suna case, the Tokyo District Court adopted the first view, stating that even if the defense of patent invalidity may be presented in a claim for injunction,

the decision of invalidity of the patent has only effect as a decision within the reasoning of a judgment in the action seeking injunction, and does not invalidate the patent right as against third parties. Therefore, allowing to present this defense should not be a reason to

${ }^{5}$ The Interim Draft prepared by the International Jurisdiction Legislative Committee of Japan's Legislative Council (herein after referred to as "the Interim Draft") (published in July 2009) also provides that "Actions related with validity and effects of intellectual property rights which are subject to registration (as they are defined in Art. 2(2) of the Basic Intellectual Property Law) can be brought only before Japanese courts if the place of registration is in Japan". This Interim Draft was further elaborated as a part of the Minji Sosho Ho oyobi Minji Hozen Ho no Ichibu wo Kaisei suru Horitsu (the Draft for Amendment of a Part of the Code of Civil Procedure and Civil Provisional Remedies Act) and, on March 2, 2010, was submitted to the Diet. The text of this final Draft is available at <www.moj.go.jp/HOUAN/SAIBANKAN9/refer02.html> (last visited on 28 March 2010).

${ }^{6}$ For example, Shigeki Chaen, Gaikoku tokkyo shingai jiken no kokusai saiban kankatsu [International Jurisdiction over Foreign Patent Infringement Case], Nihon kôgyô shoyûkenhô gakkai nenpô [Annual of Japanese Industrial Property Law Association], No. 21 (1997), p. 59, 75.

${ }^{7}$ For example, Makiko Takabe, Tokkyoken shingai soshô to kokusai saiban kankatsu [Patent Infringement Action and International Jurisdiction], in: Nobuhiro Nakayama (ed.), Chiteki zaisan hô to gendai shakai - Makino Toshiaki hanji taikan kinen [Intellectual Property and Modern Society: In Honor of the Retirement of Judge Toshiaki Makino] (Shinzansha, 1999), p. 125, 135. Miho Shin, Chiteki zaisanken shingai soshô ni kansuru kokusai saiban kankatsu ni tsuite (2) [International Jurisdiction over Intellectual Property Infringement Actions (2)], Hôgakuronso Vol. 155, No. 5, p. 55, 71 (2004) says that courts can exceptionally decide the invalidity that is effective between the parties to the action only where the existence of a basis for invalidity is clear. See also Masaki Sugiura, Shôgai mondai [International Problems], in: Toshiaki Iimura/Ryuichi Sagara (eds.), Chiteki zaisan kankei soshô [Intellectual-Property-Related Litigation] (Seirin Shoin, 2008), p. 273, 283-284. 
reject the international jurisdiction of a country other than the country of registration, and even if the defending party in an action seeking injunction raises the defense of patent invalidity, that should not be a barrier to hearing the action in a court of a country other than the country of registration. ${ }^{8}$

\section{b) Actions Concerning Registration of IP Rights}

The report of the International Jurisdiction Study Group makes the following statement about actions concerning the registration of IP rights: ${ }^{9}$ "Where Japan is the place of registration, courts of Japan shall have exclusive jurisdiction over actions concerning the registration of IP rights that arise by registration of establishment." The reason for this is given as follows:

In actions concerning registration of patents and similar rights, even if international jurisdiction could be exercised in a country other than the country of registration of the IP right, in order to make registration and other things in accordance with this judgment, procedures will have to be taken in the country of registration anyway. Therefore, it is proper for the courts of the registering country to have exclusive jurisdiction. ${ }^{10}$

${ }^{8}$ In the Interim Draft, no special jurisdiction rules for claims related to intellectual property rights' infringement are provided. Regarding the treatment of invalidity defense, it is explained as follows: The question whether an invalidity defense is possible in cases related to infringements of foreign patent rights is not an issue to be dealt at the time when international jurisdiction issue is decided, but is a problem of substantive law. The question of validity should be decided under the applicable patent law of the registering country. Therefore, for example, if an action is brought with regard to infringement of an American patent, the question is whether an invalidity defense shall be decided under the American law or not. Nevertheless, some more investigation is necessary regarding pending infringement and validity proceedings, namely whether infringement proceedings should be ceased until another court of a foreign country has decided the validity issue (see Art. 168(2) of the Japanese Patent Act).

9 An example given is the case where the actual inventor files a claim for the transfer of the name in which a patent is registered against a usurping applicant who was granted registration claiming to be the actual inventor. However, actions related to the ownership of intellectual property rights are not subject to exclusive jurisdiction rules. This issue is clearly illustrated in the Interim Draft where it is stated that actions related with initial title to intellectual property rights are related to the substance of these rights, and only very seldom require special or technical skills.

${ }_{10}$ The Interim Draft provides that "actions concerning a registry or registration shall be brought only to Japanese courts when the registry or a place where registration should occur is in Japan." In the Interim Draft, claims related to registration of intellectual property rights fall under the notion of "actions related to registry or registration." Furthermore, this provision comprises not only registered intellectual property rights, but also copyright-related issues that are subject to registration. 
Looking at the precedents, the court in the Inositol Manufacturing Method case $^{11}$ viewed the plaintiff's claim for the return of a patent right as a claim for transfer of registration, and stated that

Patent \#3 in this case is a United States patent, so an action involving registration of a United States patent is entirely a problem of the ownership of a patent right in that country, and there is no room for exercising the international jurisdiction of Japanese courts.

On the other hand, a different view was possibly adopted in the Card Reader case $^{12}$, which involved a United States patent for an invention that $\mathrm{Y}$, a former employee of A company, made as an employee. $\mathrm{X}$ filed a claim against $\mathrm{Y}$, based on the argument that A company had assigned the patent right to $\mathrm{X}$, that $\mathrm{Y}$ should register the assignment of it to $\mathrm{X}$ with the United States Patent Office. Tokyo District Court admitted X's claim without questioning an issue of international jurisdiction, stating: "It can be inferred that $\mathrm{Y}$ understood that after he applied for the patent in his own name, obtained the patent right, and registered it, $\mathrm{Y}$ would as a matter of course assign the patent right to A company." The appeals court decision ${ }^{13}$ dismissed X's claim with prejudice for the reason that it could not find an implied agreement for $\mathrm{Y}$ to assign the patent right to A company, but here, too, international jurisdiction was not questioned. In the Fujika Trademark case $^{14}$, the plaintiff demanded that the defendant should bring procedures to cancel the registration of the transfer of a Jordanian trademark in the defendant's name because the plaintiff had cancelled a contract for transfer of the trademark from plaintiff to defendant, and here again Tokyo District Court issued its judgment without questioning its international jurisdiction. The appeals court decision ${ }^{15}$ was the same.

\section{International Situation}

In other countries, it is also generally thought that courts of the country of registration have exclusive jurisdiction over actions concerning the registration or validity of IP rights that arise from registration. Article 22(4) of the Brussels I Regulation ${ }^{16}$ provides that

in proceedings concerned with the registration or validity of patents, trade marks, designs, or other similar rights required to be deposited or registered, the courts of the Member States in which the deposit or registration has been applied for, has taken place

11 Tokyo District Court, 26 September 2003, Case No. 14128 (wa) of 2003.

12 Tokyo District Court, 22 October 1993, Chizaishu Vol. 26 No. 2, p.729.

13 Tokyo High Court, 20 July 1994, Chizaishu Vol. 26 No. 2, p.717.

14 Tokyo District Court, 4 March 2004, Case No. 4044 (wa) of 2001.

15 Tokyo High Court, 9 August 2004, Case No. 1627 (ne) of 2004.

${ }^{16}$ Council Regulation (EC) No.44/2001 of 22 December 2000 on jurisdiction and the recognition and enforcement of judgments in civil and commercial matters, OJ L12, 16.1.2001, p.1 
or is under the terms of a Community instrument or an international convention deemed to have taken place

have exclusive jurisdiction. As a basis, with regard to Article 16(4) of the Brussels Convention ${ }^{17}$, similar to Article 22(4) of the Brussels I Regulation, the official report of this Convention noted that "[b]ecause the grant of the domestic patent is exercise of national sovereignty, Article 16(4) provides the exclusive jurisdiction in proceedings concerned with the validity of the patent." ${ }^{\prime 18}$ The European Court of Justice also held, with regard to Article 16(4) of the Convention, that

the exclusive jurisdiction in proceedings concerned with the registration or validity of patents conferred upon the courts of the Contracting State in which the deposit or registration has been applied for is justified by the fact that those courts are best placed to adjudicate upon cases in which the dispute itself concerns with the validity of patents or the existence of the deposit or the registration. ${ }^{19}$

In the process of making the Convention on Jurisdiction and Foreign Judgments in Civil and Commercial Matters at the Hague Conference on Private International Law, the Special Commission on the Jurisdiction and Foreign Judgments in Civil and Commercial Matters adopted a Draft Convention in 1999 (hereinafter referred to as "the Hague Draft Convention on Jurisdiction and Foreign Judgments"). Article 12(4) of the Draft Convention also provided that

[i]n proceedings which have as their object the registration, validity [or] nullity [, or revocation or infringement,] of patents, trade marks, designs or other similar rights required to be deposited or registered, the Contracting State in which the deposit of registration has been applied for, has taken place or, under the terms of an international convention, is deemed to have taken place, have exclusive jurisdiction. This shall not apply to copyright or any neighbouring rights, even though registration or deposit of such right is possible.

In the drafting process of the above Convention, there were divisions of opinion on whether the infringement action should be subject to the exclusive jurisdiction of the country of registration, or whether courts of a country other than the country of registration can decide the validity of the IP right raised as a defense.

Under the Brussels I Regulation or the Brussels Convention, an infringement action of patents or other rights is thought to be subject not to the exclusive jurisdiction, but to the general jurisdiction rule. And con-

\footnotetext{
${ }^{17}$ Convention on Jurisdiction and the Enforcement of Judgments in Civil and Commercial Matters (signed at Brussels, 27 September 1968).

${ }_{18}$ Paul Jenard, Report on the Convention on the Jurisdiction and the Enforcement of Judgments in Civil and Commercial Matters (signed at Brussels, 27 September 1968), OJ C59, 5 March 1979, p. 35.

${ }^{19}$ Case 288/82, Duijnstee v. Goderbauer [1983] ECR 3663, para. 22.
} 
cerning a defense of invalidity, the European Court of Justice held, in GAT $v$. $L u K,{ }^{20}$ that even though the issue of validity of a patent was not raised by way of an action but as a defense, the rule of the exclusive jurisdiction provided in Article 16(4) of the Brussels Convention applies. ${ }^{21}$ In opposition to this decision, Article 2:401 of the Second Preliminary Draft of Principles for Conflict of Laws in Intellectual Property, ${ }^{22}$ prepared by CLIP (European Max Planck Group on Conflict of Laws in Intellectual Property) (hereinafter referred to as "the CLIP Principles") in 2009, provides, while recognizing the exclusive jurisdiction of courts of the country of registration over disputes having as their object a judgment on the registration or validity of a patent or any other IP right protected on the basis of registration in Paragraph 1, that "Paragraph 1 does not apply where validity or registration arises in a context other than by principal claim or counterclaim. The decisions resulting from such disputes do not affect the validity or registration of those rights as against third parties."

On the other hand, American Law Institute's Intellectual Property: Principles Governing Jurisdiction, Choice of Law, and Judgments in Transnational Disputes (hereinafter referred to as "the ALI Principles") in 2008, eases the exclusive jurisdiction over actions concerned with the validity of rights. $\S 213(2)$ and (3), while making it a rule that an action to obtain a declaration of the invalidity of a registered right may be brought only in the state of registration, make an exception for an action to declare the invalidity of the rights registered in two or more states, and provides as follows:

(2) Except as provided in subsection (3), an action to obtain a declaration of the invalidity of a registered right may be brought only in the State of registration. (3) An action to declare the invalidity of the right in two or more States may be brought in the State or States in which the

${ }^{20}$ Case C-4/03, GAT v. LuK [2006] ECR I-6509.

${ }^{21}$ Under the influence of this case, Article 22(4) of the Lugano Convention, which had been the same as Article 16(4) of the Brussels Convention, was amended as follows:

The following courts shall have exclusive jurisdiction, regardless of domicile:

(.)

4 in proceedings concerned with the registration or validity of patents, trade marks, designs, or other similar rights required to be deposited or registered, irrespective of whether the issue is raised by way of an action or as a defence, the court of the State bound by this Convention in which the deposit or registration has been applied for, has taken place or is, under the terms of a Community instrument or an international convention, deemed to have taken place.

Without prejudice to the jurisdiction of the European Patent Office under the Convention on the grant of European patents, signed at Munich on 5 October 1973, the courts of each State bound by this Convention shall have exclusive jurisdiction, regardless of domicile, in proceedings concerned with the registration or validity of any European patent granted for that State irrespective of whether the issue is raised by way of an action or as a defence.

$22<$ www.cl-ip.eu $>$. 
defendant is resident, but the judgment will be effective only to resolve the dispute between or among the parties to the action.

This rule is explained as a compromise between the reluctance to examine the acts of foreign public authorities and efficiency gains. ${ }^{23}$

\section{International Jurisdiction over Actions Concerning the Validity or Existence of IP Rights}

\section{a) Actions Concerning the Validity of IP Rights}

As shown above, both in Japan and internationally there is a strong school of thought that the courts of the country of registration have exclusive jurisdiction over actions concerning the validity of IP rights that arise by registration. As a result, even if a Japanese court were to reject this thinking and render a judgment concerning the validity of an IP right registered in a foreign country, there is little possibility that this judgment would be recognized in other countries. Nevertheless, our study group is of the opinion that there are cases in which Japanese courts should have international jurisdiction over actions concerning the validity of foreign IP rights for two reasons discussed below. I mention here that the Transparency Proposal does not provide for exclusive jurisdiction in the country of registration for IP right infringement lawsuits, and recognizes that the validity of a foreign IP right can be decided where it is raised as an incidental issue in an action pertaining to a foreign IP right.

The first reason is that rejecting the exclusive jurisdiction of the country of registration would contribute to adequate dispute resolution. When the only substantive issue in a dispute involving an IP right is its validity, a ruling on validity will be the best solution to the dispute. The rule of exclusive jurisdiction thus impedes definite resolution of the dispute between the parties, because a defendant in an infringement action brought in a country other than the country of registration is not able to counterclaim concerning validity, and jurisdiction by a choice-of-court agreement would also not be permitted under the rule of exclusive jurisdiction. Further, the rule likely also precludes the parties to the dispute from referring the validity of the right to arbitration. Even if a judgment by a court of a country other than the country of registration is not recognized in other countries, it is possible that the parties will voluntarily comply with the judgment, particularly in the case of jurisdiction by a choice-of-court agreement or agreed arbitration. Accordingly, actions concerning the validity of an IP

23 The American Law Institute, Intellectual Property: Principles Governing Jurisdiction, Choice of Law, and Judgments in Transnational Disputes (2008), §213, comment $\mathrm{c}$. 
right registered in a foreign country should be allowed to be brought in Japanese courts in some cases.

The following problem might be raised in response. Adopting a rule negating exclusive jurisdiction in the country of registration will result in cases in which foreign courts have jurisdiction over actions concerning the validity of Japanese IP rights. This will result in the possibility that persons faced with allegations that they are violating a Japanese IP right will adopt a strategy of delaying dispute settlement by bringing actions concerning the validity of this right in foreign courts where legal proceedings are slow. If this strategy were to succeed, it would impair the effectiveness of Japanese IP right protection.

However, the success of such a strategy would hinge on the effect that an action in a foreign court would have upon the right holder bringing an infringement action in a Japanese court. The Transparency Proposal addresses this problem of concurrent international litigations in Article 201 as follows:

In cases where a suit is pending in a court in a foreign country and is based on the same cause of action as or the cause of action related to that in a lawsuit in front of the Japanese court, when the primary obligation should be or should have been performed in that foreign country, or the primary facts occurred or should occur in that foreign country, in the absence of special circumstances, the claim shall be dismissed.

In the above case, the "primary facts" occurred or should occur in Japan. Thus the right holder would not be foreclosed from filing an infringement action in Japanese court. The suspected infringer's strategy would not succeed.

There could be cases where a foreign court has international jurisdiction over actions concerning the validity of Japanese IP rights and invalidates those rights. But the Transparency Proposal provides, as a requirement of the recognition and enforcement of a foreign judgment, that " $[t]$ he content of the judgment and the court proceedings are not contrary to the public policy in Japan" in Article 402(3), and it is understood that non-application of absolutely mandatory statutes, the inconsistency of the rights situation with the country of registration, or the non-guaranteeing of an opportunity to pursue a claim about the validity and scope of rights may be contrary to public policy.

The second reason is that the bases for recognizing the exclusive jurisdiction of the country of registration over actions concerning the validity of a right are not necessarily firm. One of the bases given is that the country of registration can best judge the validity of a right. Although correct in itself, this alone cannot justify exclusive jurisdiction that would, for example, preclude the international jurisdiction of the court of the country where the defendant is domiciled. This would also prevent the validity of a 
right from being raised as an incidental issue, including as a defense to an infringement suit.

Another basis given for exclusive jurisdiction is that an IP right arises from registration, which is an administrative disposition, giving it an aspect of the act of state. In other words, it would be improper for the court of one country to judge the validity of a state action of another country. Certainly, a judgment invalidating an foreign IP right that is effective against third parties would likely be considered interference with the national sovereignty of this foreign country. However, where such a judgment is only effective between and among the parties to the action, the problem of interference with national sovereignty does not arise. As seen in the above-described Sango Suna decision ${ }^{24}$, the understanding that the validity of a foreign IP right may be judged when asserted as a defense in an infringement suit is based on this very fact that the decision is only effective between the parties to the lawsuit. If the defense of invalidity is allowed in this way in an action for infringement of a foreign IP right, then in the same way, a judgment invalidating a foreign IP right that is effective only between the parties to the lawsuit should also be allowed.

As stated above, §213(2) and (3) of the ALI Principles provide that where a right has been registered in multiple countries, an action seeking a declaration of invalidity of a registered right may be brought in the country where the defendant resides. The ALI Principles and the Transparency Proposal are in agreement on this point of departure from the rule of exclusive jurisdiction of the country of registration. However, the prerequisites set by the ALI Principles - multiplicity of rights and suit in defendant's country of residence - are not relevant to the question of whether such an action may be filed in a country other than the country of registration. Therefore, this Transparency Proposal does not provide such prerequisites.

\section{b) Actions Concerning the Existence of IP Rights}

An action concerning the "existence" of an IP right, as set forth in Article 103(1) and (2), refers to an action for a declaration of the existence of a copyright or other IP right that does not require registration to be established. An action pertaining to such an IP right does not require that any country have exclusive jurisdiction. The inclusion in Paragraph 1 of the term "existence" is instead to allow a lawsuit for a declaration of the existence of a copyright or other such right to be filed in the courts of the country that granted the right. The courts of the country that granted the copyright or other such right can best decide whether such a right exists. It

\footnotetext{
24 Supra note 2.
} 
follows that the international jurisdiction of Japanese courts should be recognized for actions disputing the existence of a copyright or other such rights that were granted under Japanese law, even where there is no other basis for the international jurisdiction of the Japanese courts. ${ }^{25}$

In the Tsuburaya Production case $^{26}$, a claim for a declaration that the appellee on final appeal did not hold a copyright over the work in question, the Supreme Court affirmed the international jurisdiction of Japanese courts, stating "the property that is the purpose of the claim exists in Japan, and therefore it is clear that the venue of the place of the assets, as provided for in Japan's Code of Civil Procedure (Art. 5(4); ${ }^{27}$ former Code of Civil Procedure, Art. 8), is in Japan." The issue argued in this case was not whether a copyright over the work in question exited in Japan, but whether the appellee on final appeal owned an existent copyright. That is, in this case, the issue was not the existence of a copyright, but the ownership of a copyright. However, Article 103 treats actions concerning the existence of IP rights and actions concerning the ownership equally, so Japanese courts have international jurisdiction over actions seeking to hold that the opposite party doesn't own a copyright in Japan, according to Paragraph 1.

\section{International Jurisdiction over Actions Concerning the Registration or Ownership of IP Rights}

\section{a) Actions Concerning the Registration of IP Rights}

The Transparency Proposal also rejects exclusive jurisdiction in the country of registration for actions concerning the registration of IP rights. With the exception of registration that establishes a right, as in the case of IP rights that are created by registration, the registration of IP rights is generally conducted for the purpose of publication, and is only conducted based on the substantive rights, and therefore has only a weak relationship

${ }^{25}$ The existence of Japanese copyright and other such rights is often disputed in cases where a dispute has arisen between the parties concerning matters such as infringement and there is jurisdiction in Japan on a basis such as that of the place where the tort was committed. In such a case, the joinder jurisdiction of Japan is recognized for an action seeking a declaration of the existence of the copyright or other right. Therefore, as a practical matter, there would probably not be much of a difference if "existence" were not included in Article 103 (1) of the Transparency Proposal.

${ }_{26}$ Supreme Court, 8 June 2001, Minshû Vol. 55 No. 4, p. 727.

27 Article 5(4) of the Code of Civil Procedure provides as follows: "An action on a property right against a person who has no domicile (in the case of a juridical person, business office or other office; hereinafter the same shall apply in this item) in Japan or whose domicile is unknown" can be filed in the court with jurisdiction over "[t]he location of the subject matter of the claim or security thereof or of any seizable property of the defendant." 
with the state. For that reason, a court of a country other than the country of registration would not likely be considered to have interfered with the national sovereignty of the country of registration by rendering a judgment in an action concerning the registration. Even if it would be difficult to say that there is no intervention in national sovereignty, it is clear that it would be to a much lower degree than in the case of an action concerning the validity of a right. As introduced above, the Card Reader case ${ }^{28}$ decided on the merits a claim for the registration of an assignment of a United States patent, and the Fujika Trademark case ${ }^{29}$ decided, on the merits, a demand for procedures to register the cancellation of a previously registered transfer of a Jordanian trademark. It is likely that international jurisdiction was not questioned in these decisions because the courts considered the above points.

Therefore, even if registration in accordance with a judgment requires some procedure in the country of registration, there should be no need for exclusive jurisdiction in the country of registration. In response, an opposing view could be that there should be exclusive registration in the country of registration because even if international jurisdiction over actions concerning the registration of IP rights were affirmed, some procedure would have been taken in the country of registration to recognize the judgment or other measures in order to conduct a registration in accordance with the judgment, and this would be a roundabout way of doing things. ${ }^{30}$ However, if one considers the nature of the registration of IP rights as described above, it is reasonable to expect the registration agency in the country of registration to conduct a registration based on the judgment of the Japanese court, without requiring the country to recognize the judgment or take some other such procedure.

\section{b) Actions Concerning the Ownership of IP Rights}

The Japanese Patent Act provides that a transfer of a patent right shall not be effective unless it is registered (Patent Act Art. 98(1)(i)). In this way, there are cases in which ownership of an IP right is linked to registration. In other cases, there is no reason to require that the country of registration that grants the right have exclusive jurisdiction over actions concerning the ownership of an IP right. On the other hand, the question of who owns an Japanese IP right has great effect on the exploitation in Japan of an IP

\footnotetext{
28 Supra note 12.
}

29 Supra note 14.

30 This thinking is given as a reason for the following statement in the report of the International Jurisdiction Study Group: "[T]he exclusive jurisdiction of Japanese courts shall be recognized in actions concerning a registry or registration, when the registry or a place where registration should occur is in Japan". 
right, so an action concerning this issue should be allowed to be brought in Japan. For the above reason, the Transparency Proposal affirms the international jurisdiction of the Japanese courts over actions concerning the ownership of Japanese IP rights, even where there is no other basis for international jurisdiction of Japanese courts.

\section{International Jurisdiction over Actions Concerning Intellectual Property Contracts}

\section{General Remarks}

Article 104 provides for international jurisdiction over actions concerning contracts related to IP rights. ${ }^{31}$ Where the object of the contract is an IP right granted under Japanese law, the jurisdiction of Japanese courts should be affirmed. Contracts related to IP rights include contracts on the transfer of rights, license contracts, and so on. The main focus of this Article is the license contract. Meanwhile, Article 103 of the Transparency Proposal confers international jurisdiction upon Japanese courts in disputes which have as their object registration or ownership of Japanese IP rights.

\section{The Current State of Japanese Law}

There are no cases in Japan in which international jurisdiction for actions concerning IP right contracts has been disputed, and there has been almost no debate on this issue.

Article 5(1) of the Code of Civil Procedure provides that actions on property rights are to be brought in the court having jurisdiction over the place of performance of the obligation. There is an influential view among commentators concerning international jurisdiction that jurisdiction based on the place of performance of the obligation is recognized only for contract actions. ${ }^{32}$

The report of the International Jurisdiction Study Group states as follows about jurisdiction based on place of performance of the obligation:

1. Japanese courts shall have international jurisdiction over actions involving claims related to contracts:

i. When the contract unambiguously provides for the place of performance, and that place of performance is in Japan; or

${ }^{31}$ See Article 104 of the Transparency Proposal, Annex II infra.

32 See Satoshi Watanabe/Mari Nagata, Gimu rikôchi no kankatsuken [Jurisdiction Based on Place of Performance of the Obligation], in: Akira Takakuwa/Masato Dogauchi (eds.), Kokusai minji soshôhô (Zaisanhô kankei) [International Civil Procedure Law (Related to Property Law)] (Seirin Shoin, 2002), p. 74. 
ii. When the place of performance is in Japan according to the governing law unambiguously chosen in the contract.

2. Where international jurisdiction is recognized, under the rule in 1 above, for an action involving the primary obligation in a contract, the international jurisdiction of Japanese courts shall also be recognized for actions involving claims for damages for failure to perform that obligation. ${ }^{33}$

\section{International Situation}

In many foreign countries, international jurisdiction over actions concerning contracts is affirmed in courts in the place of performance of the obligation. Article 5(1)(a) of the Brussels I Regulation also provides that "[a] person domiciled in a Member State may, in another Member State, be sued ... in matters relating to a contract, in the courts for the place of performance of the obligation in question."

Article 2:201 of the CLIP Principles has the same provision. And, concerning contracts having as their main object the transfer or license of an IP right, the state where the obligation in question is to be performed is provided to be in principle the state for which the license is granted or the right is transferred. Also, § 205 of the ALI Principles provides that a person may be sued in a State with respect to any claim alleging the breach of an agreement transferring or licensing IP rights for exploitation in that State.

\section{International Jurisdiction over Actions Concerning Contracts Relating to IP Rights in the Transparency Proposal}

The general trend in Japan and foreign countries for actions concerning contracts is to affirm international jurisdiction in the courts of the place of performance of the obligation. However, it is unclear how the place of performance of the obligation is to be determined for jurisdictional purposes. On this point, the above report of the International Jurisdiction Study Group has attempted to protect foreseeability for the parties by limiting

\footnotetext{
33 The Interim Draft provides:

1) Actions related with performance of contractual obligations can be brought before Japanese courts if:

a) the place of performance of the obligation is in Japan; or

b) the applicable law which was chosen by the parties provides that the place of performance of obligation shall be in Japan.

2) Actions related with negotiorum gestio, unjust enrichment or damages which arise because of non-performance of contractual obligations or other action related with claims which are concerned with contractual obligations (except actions covered by paragraph 1 above), can be brought before Japanese courts if actions related with performance of such obligations can be brought before Japanese courts according to the rules a) and b) of the preceding paragraph.
} 
this to situations where the contract unambiguously provides for the place of performance of the obligation, or where the place of performance is determined in accordance with the applicable law that is unambiguously chosen in the contract.

Our study group also thought that the place of performance of the obligation must be clearly determined in order to ensure foreseeability for the parties. We decided that the place of performance of the obligation should be the country of registration or the country that grants the right, for the following reason. License contracts for IP rights include an obligation of the licensor to not seek an injunction or damages for the exploitation of the IP right by the licensee, so it is clear that the place of performance of this main obligation is the country of registration or the country that grants the right. Concerning contracts on transfer, this point is clearer. For that reason, an action concerning contracts for Japanese IP rights in Japanese courts would not conflict with the need for foreseeability for the parties. In addition, a contract for Japanese IP rights concerns the exploitation of the IP rights in Japan, so it is appropriate for an action concerning such a contract to be brought in a Japanese court.

Where the place of performance of the obligation is unambiguously provided (for example, in a license contract, the place to pay royalties is unambiguously provided), it could be said that affirming international jurisdiction in a court in that place doesn't injure the foreseeability for the parties. It could therefore be thought that international jurisdiction is affirmed also in courts in the place unambiguously provided for. However, our study group rejected this thought because the country of registration or the country that grants the right is clearly the place of performance of the main obligation, and if suing in a court of another country is desired, a choice-of-court agreement can be made between parties.

Where a contract covers the IP rights of multiple countries including Japan, actions that could be brought in Japanese court under this Article are limited to a portion of the contract related to Japanese IP rights. Article 2:201(2) of the CLIP Principles and $\S 205$ of ALI Principles are the same on this point. However, if in such a contract the portion related to Japanese IP rights are the main part, because "the primary obligation was to be performed in Japan"(Art. 110(1) of the Transparency Proposal), the international jurisdiction of Japanese courts is affirmed over claims involving the portion related to IP rights of another country, through "objective joinder" jurisdiction. 


\section{International Jurisdiction and IP Infringement Claims}

\section{Status Quo}

In order to establish the rules of the international jurisdiction over the claims on the infringement of intellectual property rights, two questions should be answered. The one is if the infringement of intellectual property rights granted by a foreign country should exclusively fall under the jurisdiction of that country, or if such exclusive nature of the jurisdiction should be rejected. The other is if special rules of international jurisdiction for the infringement of intellectual property rights should be established, or if general jurisdictional rules on tort should be applied to the infringement of intellectual property rights.

The English court has been negatively answering the first question ${ }^{34}$ and refused to exercise its jurisdiction over foreign intellectual property rights, without differentiating such intellectual property rights that can be established without registration ${ }^{35}$ and those that need registration. ${ }^{36}$ However, the English court has recently relaxed its negative stance as far as the infringement of copyright is concerned, due to the lack of registration to establish copyrights, and affirmed its jurisdiction over a claim on the infringement of a U.S. copyright. ${ }^{37}$

In the context of U.S. law, claims on patents and copyrights are exclusively subject to the subject matter jurisdiction of the federal courts (Judiciary and Judicial Procedure, 28 USC $\left.\S 1338(a)^{38}\right)$. However, since this provision applies only to U.S. patents and copyrights, other provisions must be examined for the infringement of foreign intellectual property rights to be subject to the jurisdiction of the U.S. federal courts. ${ }^{39}$ American courts have refused to extend the scope of Judiciary and Judicial Pro-

\footnotetext{
34 Potter v. Broken Hill Pty. Co Ltd., [1906] 3CLR 479. See also Plastus Kreativ AB v. Minnesota Mining and Manufacturing Co., [1995] RPC 438.

${ }_{35}$ Tyburn Production Ltd. v. Conan Doyle, [1991] Ch 75.

36 Coin Controls Ltd. v. Suzo International (UK) Ltd., [1999] Ch 33.

37 Lucasfilm Ltd. v. Andrew Ainsworth, [2008] EWHC 1878 (Ch). Also, see Pearce v. Ove Arup Partnership Ltd., [2000] Ch 403; R Griggs Group Limited v. Evans, [2004] EWHC 1088 (Ch); Satyam Computer Services Ltd. v. Upaid Systems Ltd., [2008] EWHC 31 (Com).

${ }^{38} \S 1338$ Patents, plant variety protection, copyrights, mask works, designs, trademarks, and unfair competition (a) The district courts shall have original jurisdiction of any civil action arising under any Act of Congress relating to patents, plant variety protection, copyrights and trademarks. Such jurisdiction shall be exclusive of the courts of the states in patent, plant variety protection, and copyright cases.

39 This has been declared in Armstrong v. Virgin Records, Ltd., 91 F. Supp. $2^{\text {nd }} 628$ (2000).
} 
cedure, 28 USC $\S 1338(b),{ }^{40,41}$ while $\S 1332(a)^{42}$ may be a basis for the federal courts' jurisdiction. ${ }^{43} \S 1367(\mathrm{a})^{44}$ has been denied as a basis to exercise the jurisdiction of the federal courts over foreign patents. ${ }^{45}$

On the other hand, the Japanese Supreme Court has never raised the issue of the exclusiveness of the jurisdiction in the cases on the infringement of foreign intellectual property rights. ${ }^{46,47}$ Some lower courts did not question it either. ${ }^{48,49}$

$40 \S 1338$, (b) The district courts shall have original jurisdiction of any civil action asserting a claim of unfair competition when joined with a substantial and related claim under the copyright, patent, plant variety protection, or trademark laws.

${ }^{41}$ Mars Inc. v. Kabushiki-Kaisha Nippon Conlux, 24 F.3d 1368 (Fed. Cir. 1994). Also see SRAM Corp. v. SunRace Roots Enter. Co., 390 F. Supp.2d 781 (2005).

${ }^{42} \S 1332$ Diversity of citizenship; amount in controversy; costs

(a) The district courts shall have original jurisdiction of all civil actions where the matter in controversy exceeds the sum or value of $\$ 75,000$, exclusive of interest and costs, and is between-

(1) Citizens of different states;

(2) citizens of a state and citizens or subjects of a foreign state;

(3) citizens of different states and in which citizens or subjects of a foreign state are additional parties; and

(4) a foreign state, defined in section 1603(a) of this title, as plaintiff and citizens of a state or of different states.

For the purposes of this section, section 1335, and section 1441, an alien admitted to the United States for permanent residence shall be deemed a citizen of the state in which such alien is domiciled.

${ }^{43}$ Baker-Bauman v. Walk, 2007 U.S. Dist. LEXIS 23080; London Film Prods. Ltd. v. Intercontinental Communications, Inc., 580 F.Supp. 47 (S.D.N.Y. 1984). Cf. Quantitative Fin. Software v. Infinity Fin. Tech., 47 U.S.P.Q.2d 1764 (S.D.N.Y. 1998).

$44 \$ 1367$ Supplemental jurisdiction.

(a) Except as provided in subsections (b) and (c) or as expressly provided otherwise by federal statute, in any civil action of which the district courts have original jurisdiction, the district courts shall have supplemental jurisdiction over all other claims that are so related to claims in the action within such original jurisdiction that they form part of the same case or controversy under Article III of the United States Constitution. Such supplemental jurisdiction shall include claims that involve the joinder or intervention of additional parties.

${ }^{45}$ Mars Inc. v. Kabushiki-Kaisha Nippon Conlux, 24 F.3d 1368 (Fed. Cir. 1994); Ideal Instruments, Inc. v. Rivard Instruments, Inc., 434 F. Supp.2d 640 (2006); Voda v. Cordis Corp., 476 F.3rd 887 (2007).

${ }^{46}$ The Card Reader case, where the U.S. patent was at stake (Supreme Court

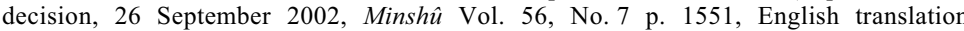
available at <www.courts.go.jp/english/judgments/text/2002.9.26-2000.-Ju-.No..580.html> (last visited at 4 October 2009)).

${ }^{47}$ The Tsuburaya Production case, where a declaratory judgment on the ownership of Thai copyrights was sought together with other claims. A joinder was admitted by the Supreme Court (judgment of 8 June 2001, Minshû Vol. 55, No. 4, p. 727, English translation available at <www.courts.go.jp/english/judgments/text/2001.6.8-2000-O-

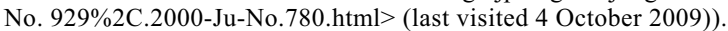


The Interim Draft for the Legislation on International Jurisdiction of the International Jurisdiction Legislative Committee of Japan's Legislative Council $^{50}$ (hereinafter referred to as "the Interim Draft"), which was published in July 2009, takes the same stance, with the following two arguments. First, when a dispute on the infringement of foreign patents has arisen, if the parties want to proceed in front of a Japanese court, Japanese court would be a convenient forum for the parties. Second, if the parties agreed to choose a foreign court as a forum for disputes on Japanese patents, there is no reason to invalidate such agreement. ${ }^{51}$

The situation in Germany seems similar to Japan. ${ }^{52,53}$ The Brussels I Regulations Article 22, paragraph $4,{ }^{54}$ which stems from Article 16, paragraph $4,{ }^{55}$ of the Brussels Convention, makes registration and validity of patents, marks, design, or other similar rights that need submission or registration exclusively subject to the jurisdiction of the country of registration. This provision also is understood as not applicable to infringe-

${ }^{48}$ In the Tetsujin 28 Gou (Ironman No. 28) case on the infringement of a U.S. copyright, where Tokyo District Court denied the jurisdiction of a Japanese court without raising the issue of the exclusiveness of the jurisdiction over a U.S. copyright case.

49 In the Sango Suna (Coral Powder) case, where a negative declaratory judgment for non-existence of injunction claim based on the U.S. Patent Act was sought, Tokyo District Court affirmed the jurisdiction of Japanese courts (judgment of Tokyo District Court, 18 November 2002, Hanrei Taimuzu No. 1115, p. 277).

50 Available at <www.moj.go.jp/SHINGI/090710-1-2.pdf $>$ (last visited 31 August 2009). Also see supra note 5.

51 The Supplementary Explanation to The Interim Draft for the Legislation on International Jurisdiction of the International Jurisdiction Legislative Committee of the Legislative Council in Japan ("the Supplementary Explanation"), p. 37, available a $<$ http://search.e-gov.go.jp/servlet/Public?CLASSNAME=Pcm1030\&btnDownload=yes\& hdnSeqno $=0000055115>$ (last visited 30 July 2009).

52 Jens Adolphsen, Europäisches und internationales Zivilverfahrensrecht in Patentsachen, $\left(2^{\text {nd }}\right.$ ed., Carl Heymanns, 2009), p. 214 et seq.

${ }_{53}$ German Courts exercised the jurisdiction over foreign marks. E.g., RGZ, 129, 385; BGH 22, 1 .

54 Article 22

The following courts shall have exclusive jurisdiction, regardless of domicile:

[...] 4. in proceedings concerned with the registration or validity of patents, trade marks, designs, or other similar rights required to be deposited or registered, the courts of the Member State in which the deposit or registration has been applied for, has taken place or is under the terms of a Community instrument or an international convention deemed to have taken place.

55 Article 16

The following courts shall have exclusive jurisdiction, regardless of domicile:

[...] (4) in proceedings concerned with the registration or validity of patents, trade marks, designs, or other similar rights required to be deposited or registered, the courts of the Contracting State in which the deposit or registration has been applied for, has taken place or is under the terms of an international convention deemed to have taken place. 
ment claims. ${ }^{56}$ Thus, the jurisdiction over the infringement of foreign intellectual property rights usually is not exclusive.

As for the second question, in most countries general rules of tort jurisdiction are applicable. ${ }^{57}$ The Interim Draft notes that it will not introduce a specific provision applicable to the infringement of intellectual property rights. ${ }^{58}$

The ALI Principles, ${ }^{59}$ which were published in 2008, contain a special provision for the infringement of intellectual property rights, § 204. This provision primarily focuses on acts of the defendant (paragraph 1). The jurisdiction of a country may reach the damages occurred in that country, if defendant's activities were addressed to that country (paragraph 2). This provision is explained as the adaptation of the traditional jurisdictional rule on tort and the jurisdiction of the place of tortuous results, in accordance with changes and developments of Internet environment. ${ }^{60}$

The CLIP Principles, ${ }^{61}$ published in June 2009, contains two provisions on the infringement of intellectual property rights, i.e., Articles 2:202 ${ }^{62}$ and $2: 203 .{ }^{63}$ In the process of drafting these provisions, the following was taken into consideration. First, while in regular tort cases each factor of a tort, i.e., act, causation, and damage, should be examined equally, in cases of intellectual property rights the infringing act should be focused upon, since other factors have significance only in calculating the amount of monetary compensation. Second, in cases of the infringement of intellectual property rights due to their territoriality, in contrast to regular tort cases, it is decisively important where the infringing act was committed. Hence, jurisdictional rules, which focus on the factor of act, are appropriate. On the other hand, the infringement of intellectual property rights can more easily occur in the Internet environment than regular tortuous acts. Therefore, although the place of tortuous results or the place to which tortuous activities are addressed is legitimate as a jurisdictional ground, the expansion of the jurisdiction must be controlled. ${ }^{64}$

\footnotetext{
${ }^{56}$ Ulrich Magnus/Peter Mankowski, Brussels I Regulation (Sellier, 2007), p. 362 at para. 65 .

57 In the USA, see Almon A. Heath v. A. B. Dick Company, 253 F.2d 30 (1958), at p. 34; Ortman v. Stanray, 371 F.2d 154 (1971), at p. 159. For German law, see, for example, Haimo Schack, Internationales Zivilverfahrensrecht $\left(4^{\text {th }}\right.$ ed., C.H. Beck, 2006), para. 306a.

${ }_{58}$ Also see the Supplementary Explanation (supra note 51) at p. 37.

59 The American Law Institute, supra note 23.

${ }^{60}$ The ALI Principles, § 204 Comment (a) (supra note 23) p. 48.

${ }^{61} \mathrm{See}<$ www.cl-ip.eu/> (last visited at 31 August 2009).

${ }^{62}$ See Annex I infra.

${ }^{63}$ See Annex I infra.

${ }^{64}$ See Christian Heinze's contribution in this volume, supra p. 53 seq.
} 
The Waseda Project Proposal ${ }^{65}$ proposed jurisdiction in the place where an intellectual property right is registered or deemed to be registered (intellectual property rights which can be established with registration) or the place where the intellectual property is protected (intellectual property rights which do not need registration to be established) (Art. 8). According to this project, as for ubiquitous infringements, when an intellectual property right is the primary object of the infringement, all claims may be joined to the claim in the country which granted the intellectual property as the primary object of the infringement (Art. 11).

\section{The Transparency Proposal ${ }^{66}$}

As mentioned above, the Interim Draft takes the position that the jurisdiction rule on tort should apply to claims on the infringement of intellectual property. Article 2-6 of the Interim Draft provides that claims on tort may be brought in the place where the tort occurred, unless Japan is the only place of the occurrence of results and the occurrence was usually unforeseen. A note is added to this provision that "the place where the tort occurred" includes both the place of tortuous acts and the place of results of infringing acts.

This is the stance to be welcomed, since it widens the scope of the jurisdictional rule, but it is not yet satisfactory because the current provision of the Interim Draft would not allow courts to take preventive actions against soon-occurring infringing acts. If no preventive measure could be taken - for example, in cases where infringing actions via Internet or the flow of pirate products from an off-shore production site are surely foreseen - damages could be huge. This is a specificity of the infringement of intellectual property rights. We are of the opinion that in such cases preventive measures should be taken. The Transparency Proposal therefore includes "the place where results of an intellectual property infringement are to occur" and "an infringing act is to take place."

The infringement of intellectual property rights as the ubiquitous infringement requires further considerations. "Ubiquitous infringement" means concurrent multi-territorial infringements evoked by a single act of operation. In the era of cloud computing, a server as the central point of infringement is no longer identifiable. It means that identifying an infringing "act" does not make much sense, and the factor of an "act" is losing its significance as jurisdictional ground in the context of the Internet. Thus, in contrast to the CLIP Principles, the Transparency Proposal focuses on the

$65<$ www.globalcoe-waseda-law-commerce.org/activity/pdf/19/21.pdf> (last visited, 28 March 2010).

${ }^{66}$ See Article 105 of the Transparency Proposal, Annex II infra. 
factor of results. On the other hand, since the place of the occurrence of results can be largely expanded to many countries through the Internet, the jurisdiction must be concentrated in a limited number of countries. Therefore, the Transparency Proposal focuses on the country where results are or to be maximized. Such a country is usually foreseeable to persons who allegedly infringe or have infringed the intellectual property in question. Therefore, different from the Interim Draft, this provision of the Transparency Proposal does not contain any exception just to cope with the foreseeability of concerned parties.

Focusing on results needs further attention in cases of the ubiquitous infringement of copyrights, since the length of the protection period of copyright differs from country to country. Suppose that "The Little Prince," which is still under the protection of copyright in France, is uploaded on a website run by a Japanese in Japan. If this website in written only in Japanese and a Japanese translation of the work is uploaded, the website targets only Japan and hence Japan would be the place "where the results are or to be maximized" according to the Transparency Proposal. But since the copyright protection of the work has expired, ${ }^{67}$ to proof the violation of right would be impossible. Thus the jurisdiction in Japan should be denied. If, on the other hand, the website is written in French, could the copyright holder of the work bring a suit for injunction in front of a Japanese court? The answer is no, since in this case the website targets France and/or francophone countries and the place "where the results are or to be maximized" should be France and/or francophone countries. In order for the copyright holder to bring a suit in Japan, he/she should apply the general jurisdictions based on the residence or the principal place of business of the website creator.

The jurisdiction over infringement claims provided for in the Transparency Proposal covers only the intellectual property rights granted by the forum state. Intellectual property rights granted by other countries do not fall under the jurisdiction. However, Article 110 of the Transparency Proposal allows Japanese courts to consolidate claims by a joinder, if the primary obligations should be or should have been performed in Japan, or the primary facts occurred or should occur in Japan. ${ }^{68}$ If the joinder of claims would be allowed, even though these conditions are not satisfied, the exercise of such a joinder would be taken as exorbitant by courts in other countries and the judgment rendered based on the joinder could not be recognized in these countries. Similarly, jurisdiction over infringement

${ }^{67}$ In Japan, copyright is in principle protected 50 years after the death of the author (Article 51(2), of the Japanese Copyright Act).

${ }^{68}$ See Article 110 of the Transparency Proposal and analysis in part VII of this article. 
claims pursuant to Article 105 should be limited only to the damage sustained in the forum country. This Transparency Proposal takes the view that the plaintiff could also bring a suit for the compensation of damages sustained in several countries as a result of multi-state infringement. However, under this Transparency Proposal only courts of the defendant's domicile (Art. 101 and 102) are competent to decide such claims.

\section{Choice-of-Court Agreements}

\section{General Remarks}

Choice-of-court agreements are becoming increasingly used in international commercial transactions. Together with choice-of-law clauses, choice-ofcourt agreements are often included in international contracts related to transfer of rights to use intellectual property assets. Choice-of-court clauses are also often included in online contracts. However, there is much legal uncertainty related to the validity and enforceability of choice-of-forum clauses as well as the scope of what legal disputes can be submitted by the parties to a specific court. The Transparency Proposal takes a businessoriented approach which aims to facilitate the enforceability of choice-ofcourt clauses related to cross-border intellectual property disputes.

\section{Choice-of-Court Agreements in Japan}

Article 11 of the Code of Civil Procedure deals with domestic choice-ofcourt agreements. In Japan, choice-of-court agreements are usually considered to be a method for settlement of contractual disputes arising from preexisting legal relationships. Choice-of-court agreements can be made in the proceedings at the court of first instance (Art. 11(1) Code of Civil Procedure), which in practice means that Japanese courts would enforce choice-of-court agreements made before the date of the oral arguments. The parties' choice-of-court agreement, however, cannot override exclusive jurisdiction provisions.

In order to assure the protection of the interests of the parties and legal certainty, choice-of-court agreements must be made in writing (Art. 11(2) Code of Civil Procedure). The written form requirement is also satisfied if the choice-of-court agreement is concluded by electronic means (Art. 11(3) Code of Civil Procedure). If a choice-of-court clause is a part of a larger contract, the nullity of a contract does not render the choice-of-court clause invalid ("separability doctrine"). ${ }^{69}$ According to the established case law,

${ }^{69}$ Cf. T. Mitani, Minji soshô hô kôgi [Lectures on Civil Procedure Law] (Seibundô, 2005), p. 42. 
choice-of-court agreements do not necessarily have to be in one document (e.g., offer and acceptance) ${ }^{70}$ nor do the documents have to be signed by the parties, especially if this is an established commercial practice in a certain trade area. In addition to this, the written form requirement has been interpreted as obliging the parties to clearly specify the substance of the disputes which should fall under the ambit of the choice-of-court agreement and indicate the court which should decide the dispute. ${ }^{71}$ However, parties can only choose courts which are functionally competent to hear the dispute referred. Japanese law also allows prorogation and derogation, which means that parties can either designate a specific court or exclude some courts from hearing the dispute. ${ }^{72}$ If the parties have designated a court for the settlement of the dispute but did not specify whether such designated court has exclusive jurisdiction, the prevailing opinion is that such agreements are deemed to confer exclusive jurisdiction upon the designated court. ${ }^{73}$

Under Japanese law, choice-of-court agreements which are included in B2C contracts have been interpreted for the benefit of weaker parties who cannot be deprived of the home court advantage. ${ }^{74}$ Hence, choice-of-court agreements that are obviously detrimental to the interests of the defendant (the weaker party) may not be enforceable. ${ }^{75}$ Similarly, choice-of-court agreements which prevent the parties from raising any claims with regard to particular issues might not be enforceable. ${ }^{76}$ More generally, any choiceof-court agreement must not be contrary to public policy.

Although the Japanese Code of Civil Procedure does not contain any rules concerning international choice-of-court agreements, such agreements have usually been enforced by Japanese courts. ${ }^{77}$ In 1975 the

\footnotetext{
${ }^{70}$ See also Kôji Shindô, Shin-minji soshō hō [New Civil Procedure Law] (Kōbundō, 2008), p. 111.

${ }^{71}$ Shindô (supra note 70) p. 111. Seiichi Tanaka, Kokusai gôi kankatsu jyôkô ni kan suru oboegaki [Notes Concerning International Choice-of-Court Clauses], in Gendai keiyaku hō no tenkai [Development of Current Contract Law] (2000), p. 465.

72 Shindô (supra note 70) p. 110-111.

73 Mitani (supra note 69) p. 40.

${ }^{74}$ See, e.g., Shindô (supra note 70) p. 110-111.

75 Tanaka (supra note 71) p. 464.

${ }^{76}$ Ibid. p. 464.

77 See, e.g., Osaka District Court, judgment, 23 March 1986, Hanrei Jihô No. 1200 p. 97, abbreviated English translation available at $<$ http://tomeika.jp/search/content. php?did=1521>; Tokyo District Court, judgment, 28 February 1994, Hanrei Taimuzu No. 876, p. 268, abbreviated English translation available at $<$ http://tomeika.jp/search/ content.php?did=1096> (declining jurisdiction on the grounds that parties have concluded choice-of-court agreement designating courts of California as exclusively competent); Kobe District Court, judgment, 10 November 1997, Hanrei Taimuzu No. 981, p. 191, abbreviated English translation available at <http://tomeika.jp/search/ content.php?did=1537>; Tokyo High Court, judgment, 28 November 2000, Hanrei Jiho
} 
Supreme Court of Japan handed down the landmark judgment in the Chisadane case and upheld the validity of an exclusive choice-of-court agreement. ${ }^{78}$ In this case, a dispute arose regarding damage to crude sugar which occurred during its transport from Brazil to Osaka. The question was whether a choice-of-forum clause included in a bill of lading was enforceable or not. By and large, the Supreme Court followed the established practice under Article 11 of the Code of Civil Procedure and held that it is sufficient if the parties specify a country where the dispute is to be resolved. The choice-of-court agreement must be in writing, although the parties are not obliged to sign the agreement as long as its content is drafted sufficiently clearly. International choice-of-forum agreements are valid if they are not contrary to public policy, do not fall under the exclusive jurisdiction of Japan and the designated forum accepts jurisdiction over the case. In cases where parties refer to a particular court but do not specify whether the designated court has exclusive jurisdiction, such a choice-of-court clause is deemed to confer exclusive jurisdiction upon the chosen court. The Court also stated that the reciprocity requirement which is one of the conditions for recognizing foreign judgments is not a necessary condition in determining the validity of a choice-of-court agreement.

The decision of the Supreme Court inspired many discussions in academia, especially with regard to the law applicable to the validity and effects of choice-of-court agreements. While some authors argue that the validity of a choice-of-court agreement should be determined under the law applicable to the whole contract, it seems that the prevailing opinion now is to apply the law of the forum (lex fori). ${ }^{79}$

\footnotetext{
No. 1743, p. 137, abbreviated English translation available at $<$ www.tomeika.jur.kyushuu.ac.jp/procedure/E-label/LA1-H12.11.28.pdf> (where the exclusive choice-of-court clause in employment contract was upheld); Tokyo District Court, judgment, 26 September 2003, Hanrei Taimuzu No. 1153, p. 268, abbreviated English translation available at <www.tomeika.jur.kyushu-u.ac.jp/procedure/E-label/LA1-H15.09.26HT.pdf> (where the Tokyo district court enforced parties' exclusive choice of a Hawaiian court agreement). Although legal scholars were not unanimous as to whether the legal requirements applied to domestic choice-of-court agreements could be transposed to international choice-of-court agreements, see, e.g., Eiji Adachi, Gôi, ôso, hanso oyobi heigô ni yoru kokusai saiban kankatsukan [International Jurisdiction Pertaining to Choice of Courts, Appearance, Counterclaims and Joinder or Claims], in: Kokusai shihô nenpô [Japanese Annual of Private International Law] (2008), p. 79.

78 Supreme Court, judgment, 28 November 1975, Minsh $\hat{u}$ Vol. 29, No. 10, p. 1554, abbreviated English translation available at <www.tomeika.jur.kyushu-u.ac.jp/procedure/ E-label/LA1-S50.11.28.pdf>.

${ }^{79}$ See, e.g., Adachi (supra note 77) pp. 79-80.
} 
The Interim Draft in principle follows the existing domestic law regarding choice-of-court agreements. ${ }^{80}$ The parties are not allowed to contract out of exclusive jurisdiction (Art. 13 of the Code of Civil Procedure). The choice-of-court agreement shall be deemed invalid when a designated foreign court cannot exercise jurisdiction over the case. Choiceof-court agreements are null and void if they are obviously contrary to public policy. Finally, parties cannot make choice-of-court agreements concerning matters related to registration or entries in public registries According to Article 2-8 of the Interim Draft, claims related to registration and entries in public registries also cover matters related to the registration of intellectual property rights. Claims related to existence and validity of registered intellectual property rights fall under the exclusive jurisdiction of Japanese courts when the intellectual property rights concerned are registered in Japan (Art. 4-2 of the Interim Draft).

In cases where the validity or effects of a registered intellectual property right arises as a preliminary question raised as a counter-defense by the defendant, the Explanatory Report indicates that the possibility of an invalidity defense depends on the applicable law (e.g., the question of whether the invalidity of an American patent can be challenged in the proceedings concerning the infringement of the American patent shall be decided pursuant to the applicable American patent law) ${ }^{81}$ This issue is treated as a problem of parallel proceedings, which means that a court may decide whether there is a need to suspend the proceedings until the question of registration or the validity of the intellectual property right concerned is resolved. The same reasoning should also apply with regard to disputes pending at courts chosen by the parties.

\section{Foreign Law}

\section{a) The 2005 Hague Choice of Court Convention}

After prolonged negotiations to adopt a global judgments convention, the Convention on Choice of Court Agreements (hereinafter referred to as "the

\footnotetext{
${ }^{80}$ Article 3-1 of the Interim Draft provides:

1. In the course of first instance proceedings, the parties may agree that claims shall be made before a court of Japan or another country. However, this rule shall not apply when a foreign court designated in an exclusive choice of court agreement declines jurisdiction over the case.

2. Agreements referred to in paragraph 1 above (hereinafter "choice of court agreements") shall be based on fixed legal relationships and are invalid unless concluded in writing.

3. Choice of court agreements saved in electromagnetic records (concluded by means of electronic computing engines which serve for the processing of data) are deemed to be made in writing.

${ }^{81}$ Supplementary Explanation (supra note 51) p. 38.
} 
Hague Choice of Court Convention") was signed on 30 June 2005. Similarly to the 1958 New York Convention on Recognition and Enforcement of Foreign Arbitral Awards, the Hague Choice of Court Convention aims to create a comprehensive legal framework that ensures the effectiveness of exclusive choice-of-court agreements. Pursuant to Article 3 of the Convention, "exclusive choice-of-court agreements" are agreements concluded in writing or any other alternative means which designate one or more courts of a contracting state to decide disputes that have arisen or may arise in connection with a particular legal relationship. Choice-ofcourt agreements are deemed to be exclusive unless the parties have expressly agreed otherwise. Pursuant to Article 5, the court designated in a choice-of-court agreement shall have jurisdiction over the dispute and shall not decline jurisdiction on the sole ground that a court of another contracting state is competent to decide the dispute. A judgment given by a chosen court shall be recognized by the courts of other contracting states unless certain conditions set out in Article 9 exist.

Cross-border intellectual property matters were one of the major sources of opposition during the whole Hague negotiation process. The final text of the Hague Choice of Court Convention excludes a number of matters from its scope. The Convention shall not be applied inter alia to choice-of-court agreements pertaining to the validity of intellectual property rights other than copyrights and related rights (Art. 2(2)(n)) and the infringement of intellectual property rights other than copyright and related rights, except where infringement proceedings are brought, or could have been brought (Art. 2(2)(o)), or for breach of a contract between the parties relating to such rights. Hence, two issues should be analyzed.

First, the Convention distinguishes between copyrights and related rights and other (registered) intellectual property rights. Such a distinction is made mainly on the ground that the existence of copyrights and related rights does not depend on the registration of such rights; conversely, patents, designs, and trademarks are created by registering them at the competent national authorities. Acts of registration are usually considered to be closely related to the sovereignty of a granting state and depend on the fulfillment of certain requirements posited in the domestic laws. The granting of registration, the declaration of the invalidity of a registered right, and corrections in the registries require the involvement of national authorities and are made according to prescribed procedural rules. The Convention exempts choice-of-court agreements pertaining to the registration and validity of (registered) intellectual property rights in many jurisdictions fall under the exclusive jurisdiction of the granting country. The Convention applies to choice-of-court agreements concerning disputes where the validity of a registered intellectual property right is challenged 
as a defense (e.g., in a dispute for the payment of royalties, where the licensee raises a claim that the licensed intellectual property right is inva$\operatorname{lid}^{82}$ ). In such cases, the court can decide upon the validity of the intellectual property right as a preliminary matter, but such a decision would not be subject to recognition under the Convention.

Second, the Convention does not apply to choice-of-court agreements which designate a competent court to hear intellectual property infringement disputes unless such a dispute arises from a pre-existing relationship. An example of such a pre-existing legal relationship could be a licensing contract and infringement proceedings related to it. According to the Official Commentary, intellectual property "infringement actions are covered, even if brought in tort, provided they could have been brought in contract. $"{ }^{\prime 3}$ On the other hand, copyright-related disputes are fully covered by the Convention (including infringement disputes and disputes where the court should decide upon validity, Art. 2(2)(o)).

\section{b) Brussels I Regulation and the CLIP Principles}

Article 23(1) of the Brussels I Regulation provides that

if the parties, one or more of whom is domiciled in a Member State, have agreed that a court or the courts of a Member State are to have jurisdiction to settle any disputes which have arisen or which may arise in connection with particular legal relationship, that court or those courts shall have jurisdiction. Such jurisdiction shall be exclusive unless the parties have agreed otherwise

This provision applies when at least one of the parties is resident in the member state; the national law provisions of the forum country are applied only when neither of the parties have their residence in any of the member states. The Brussels I Regulation will not apply for purely domestic matters (e.g., when choice-of-court agreements are made between the parties who are resident in the same member state and make a choice-of-court agreement with regard to the court of that member state). The Regulation would apply, though, when residents of the same member state designate a court of another member state.

By making choice-of-court agreements, parties can escape from the application of general and special grounds of jurisdiction, but they cannot contract out of exclusive jurisdiction (Art. 22(4) of the Regulation). It means that parties can also agree upon the jurisdiction regarding disputes related to domestic or foreign intellectual property rights. Nevertheless, in light of the recent decision of the European Court of Justice (ECJ) in GAT

\footnotetext{
82 Para. 37, ibid.

83 Para. 39, ibid.
} 
v. $L u K,{ }^{84}$ the court designated in a choice-of-court agreement which hears a dispute related to foreign patent rights shall decline jurisdiction if the validity or existence of a given foreign patent right is challenged. However, if the court designated in the choice-of-court agreement has exclusive jurisdiction over the dispute, such a choice-of-forum clause shall be enforceable.

The CLIP Principles also uphold broad party autonomy and provide for some clarifications. Namely, parties are allowed to make a choice-of-court agreement for their dispute except in matters that fall under exclusive jurisdiction rules (Art. 2:301(4)). In cases where the invalidity of a registered intellectual property right has to be decided as a preliminary matter, the CLIP Principles provide that a court decision upon the validity shall have only inter partes effects (Art. 2:401(2)).

\section{c) The ALI Principles}

$\S 202$ of the ALI Principles provides for a detailed set of rules concerning choice-of-court agreements pertaining to intellectual property. Most of those provisions are drafted according to the outcomes reached in the negotiations in the Hague. Parties are also allowed to make a choice-ofcourt agreement regarding all disputes; however, the chosen court can hear the case if it has subject matter jurisdiction over the dispute. Cases whose object is a declaration that certain registered intellectual property rights are invalid shall be brought before a court of a registering country. The novelty of the ALI Principles is that the validity of choice-of-court agreements that are included in standard form agreements is made subject to the reasonableness criterion ( $\$ 202(4)$ of the ALI Principles).

\section{The Transparency Proposal}

Article 107 of the Transparency Proposal ${ }^{85}$ takes this a step further than the 2005 Hague Choice of Court Convention and follows the approach adopted in the ALI and CLIP Proposals in that it allows the parties to make choiceof-court agreements with regard to contractual and non-contractual disputes over intellectual property. At the same time, the drafters of the Proposal acknowledge that the possibility of a choice-of-court agreement in an IP infringement case is less likely. Although Article 107 of the Transparency Proposal literally resembles the proposed rule on choice-of-court agreements in the Interim Draft, some further clarifications are necessary.

Under the Transparency Proposal, a designated court can hear all disputes referred to by the parties in a choice-of-court agreement, unless the

${ }^{84}$ Case C-4/03, GAT v. LuK, [2006] ECR I-6509, para. 24.

${ }^{85}$ See Article 107 of the Transparency Proposal, Annex II infra. 
object of the dispute falls under the exclusive jurisdiction (Art. 103 of the Transparency Proposal). In cases where a court designated in a choice-ofcourt agreement has to decide upon the existence, registration, validity, or ownership of a foreign intellectual property right as a preliminary matter, such a decision shall have only inter partes effects. The drafters were also aware of possible situations where one of the parties to a choice-of-court agreement might institute proceedings (e.g., for a negative declaratory judgment) before a court other than the one designated in the choice-ofcourt agreement with the aim of hampering the bringing of a suit against it (so-called "torpedo" claims). In fact, the actual plaintiff would be preempted from filing a suit until the court seized had previously declined jurisdiction over previously instituted proceedings. Pursuant to Article 201 of the Transparency Proposal, the court second seized, which is also the designated court, can stay the proceedings until the court first seized decides on its jurisdiction. At the same time, the court designated in the choice-of-court agreement may directly contact the court first seized in order to facilitate the proceedings.

\section{Exceptions Based on Public Interest Policy Considerations}

\section{Status Quo}

In the U.K. and the U.S., the forum non conveniens test has been applied to intellectual property rights cases in order to refrain from exercising the jurisdiction, even if the jurisdiction could be affirmed based on the rules of specific jurisdictions. ${ }^{86}$ On the other hand, the forum non conveniens is not accepted in Germany, since it would lead to legal uncertainty. ${ }^{87}$ The Brussels I Regulation does not have general exception clause. Under the scheme of the Brussels I Regulation, cumulative jurisdictions should be adjusted in the scheme of lis pendens in Section 9 of the Regulation.

In Japan, the case law has developed the so-called "special circumstances" test. After the Supreme Court also accepted it, ${ }^{88}$ this test has become an integral part of Japanese case law. This influences the ongoing

${ }^{86}$ For example, Automated Marine Propulsion Systems v. Aalborg Ciserv International, 859 F. Supp. 263 (1994); Boosey \& Hawkes Music Publishers., Ltd. v. Walt Disney Co., 934 F. Supp. 119, at 124; Boosey \& Hawkes Music Publishers., Ltd. v. Walt Disney Co., 145 F.3d 481 (1998); Creative Technology v. Aztech Sys. PTE, 61 F.3d 696 (1995); Murray v. BBC, 81 F.3d 287 (1996); Skelton Fibres v. Canas, 96 Civ. 6031 (DLC), 1997 WL 97835, at*4 (S.D.N.Y. Mar. 6, 1997).

${ }^{87}$ For example, Schack (supra note 57 ) at p. 179.

88 Judgment of the Supreme Court, 11 November 1997, Minshû Vol. 51, No. 10, p. 4055, English translation available at <www.courts.go.jp/english/judgments/text/ 1997.11.11-1993-O-No.1660.html $>$ (last visited 4 October 2009). 
legislative work. ${ }^{89}$ Hence the Interim Draft adopted the position that the whole or a part of the claim may be dismissed, taking various factors of the case into consideration. ${ }^{90}$

Neither the ALI nor the CLIP Principles contain any general exception clause that could reverse the results of the application of individual jurisdiction rules. However, both principles have provisions as a tool to coordinate several courts, taking various factors into consideration. ${ }^{91}$ Since the Interim Draft is a domestic legislative work, not a set of rules to be applied worldwide, it does not have to take the jurisdiction of a foreign court as an independent requirement into consideration. ${ }^{92}$

\section{The Transparency Proposal}

We propose to create a complete set of rules applicable to IP-related cases. ${ }^{93}$ One of the reasons why we do so is to avoid being subject to otherwise applicable rules that are not completely unproblematic. A good example is the above-mentioned "special circumstances" test developed by Japanese courts. During the last 20 years, Japanese courts have brought various factors into this framework, including procedural elements as well as the burden to apply foreign law. ${ }^{94,95}$ Hence this "special circumstances" test lost its nature as an exception; instead, it has become a general clause on international jurisdiction. If this test were applicable and could reverse

${ }^{89}$ Supplementary Explanation (supra note 51) p. 53.

90 Article 6 (General Rule on International Jurisdiction)

"Even if a suit may be brought in front of a Japanese court in accordance with the provisions in Chapters 1 through 5, the court may dismiss the whole or a part of claim, if the court confirms special circumstances which would hamper the fairness between the parties of the case and adequate and quick proceedings, taking into consideration the nature of the case, residences of the parties and witnesses to be examined, the location of the things to be verified and other factors".

${ }_{91} \S 222$ of the ALI Principles; Art. 2:701 etc. of the CLIP Principles.

92 Supplementary Explanation, supra note 39, p. 54.

93 See Article 109 of the Transparency Proposal, Annex II infra.

94 Toshiyuki Kono/Yoshihisa Hayakawa/Hirofumi Takahata, Kokusai saiban kankatsu ni kansuru hanrei no kinôteki bunseki [Functional Analysis of Judgments on International Jurisdiction], NBL No. 890 (2008), at p. 72 et seq.

95 The forum non conveniens test should be so conducted in the following manner: first, there must be another court with jurisdiction; second, a good balance of private and public interests should be struck. This is the framework set up by the Gulf Oil Corp. v. Gilbert, Doing Business as Gilbert Storage \& Transfer Co., 330 U.S. 501; 67 S.Ct. 839; 91 L.Ed.1055 (1947)

Private interests include accessibility to evidence, costs, enforceability, and comparative advantage for a fair trial, while public interests include the burden of a jury and appropriateness to apply the law of the forum state. However, the court should not dismiss claims just in order to avoid the application of foreign laws. Boosey \& Hawkes Music Publishers, Ltd. v. Walt Disney Co., 145 F.3d 481 (1998), at p. 492. 
the results of the application of jurisdictional rules, the significance to elaborate individual rules would be lost. Our Proposal therefore intends not to adopt such a "special circumstances" test.

On the other hand, a set of jurisdictional rules without general exception may bring about certain difficulties. For example, a claim for injunction in another country is filed in Japan, but it is manifest that this country will not recognize Japanese judgments due to its very special public health care policy, or because the country very generously protects the freedom of expression as its policy. Taking these potential cases into consideration, our Proposal suggests that Japanese courts should decline jurisdiction if claims are closely related to public interest policy of specific countries. It should be also emphasized that "public interest policy" in this provision means "policy adopted to serve and improve public interest," and is a much narrower notion than "public policy" or "ordre public" in the conventional sense.

Other factors often referred to in regular cases to possibly reverse results - such as the difference of financial situations between parties or the concentration of evidence in one country - are not unusual in IP cases. These factors could be dealt with by interpreting specific rules. In IP cases, the objective is intangible and the types of infringing acts could be more difficult to expect due to the rapid development of digitization. Applying a general exception would raise more uncertainty in IP-related cases.

\section{Joinder of Claims in Intellectual Property Cases}

\section{Objective Joinder (Paragraph 1$)^{96}$ \\ a) Circumstances Where Objective Joinder Becomes an Issue in International Disputes on Intellectual Property}

For example, in cases where the infringement of intellectual property rights in multiple countries occurs pursuant to the same contract or act such as a license contract with regard to patent rights in multiple countries $^{97}$ or the unauthorized posting of photos on Internet websites ${ }^{98}-$ and the plaintiff files claims based on the infringements of intellectual property rights in foreign countries, in addition to a claim based on the infringement of intellectual property rights in Japan in the courts of Japan, an issue arises as to whether Japanese courts shall have international jurisdiction over such claims, even though they do not ordinarily have international

\footnotetext{
${ }^{96}$ See Article 110(1) of the Transparency Proposal, Annex II infra.

97 Ortman v. Stanray, 371 F.2d154 ( $7^{\text {th }}$ Cir. 1967).

98 Cf. Kelly v. Arriva Soft Corp., 336 F.3d 811 ( $9^{\text {th }}$ Cir. 2003).
} 
jurisdiction over claims based on the infringement of intellectual property rights in foreign countries. ${ }^{99}$

\section{b) Objective Joinder under the Current Law}

\section{(1) Japan}

With respect to the objective joinder of international jurisdiction, although there is a view that no particular restrictions should be imposed, ${ }^{100}$ it can be said that a majority of authors currently take the view that a connection between the claims is required. ${ }^{101}$ Factors such as the need to consider the difficulty of collecting evidence or the burden on the defendant in defending an action in Japan are pointed out in the context of international jurisdiction where, unlike in the case of domestic jurisdiction, there are no means of transferring a matter. ${ }^{102}$ In a Supreme Court decision of 8 June 2001 (Tsuburaya Production case), ${ }^{103}$ in which a Japanese company claimed for damages against a Thai person over issues including permission to exploit copyrights and the ownership of copyrights in Japan and Thailand, the court ruled that a close connection between the claims should be found with respect to an objective joinder. It reasoned from the perspective of the rational allocation of judicial functions in international society and the requirement of avoiding complication and prolongation of the trial, giving Supreme Court confirmation to the existing majority view for the first time. Additionally, in its specific decision the Supreme Court gave

${ }^{99}$ For example, in cases where the defendant has no domicile in Japan.

100 Tokyo District Court, interlocutory judgment, 23 October 1987, Hanrei Jihô No. 1261, p. 48, abbreviated English translation available at $<$ http://tomeika.jp/search/ content.php?did=1523>; Tokyo District Court, interlocutory judgment, 30 May 1989, Hanrei Jihô No. 1348, p. 91, abbreviated English translation available at $<$ http:// tomeika.jp/search/content.php?did=128>; Tokyo District Court, interlocutory judgment, 19 June 1989, Hanrei Taimuzu No. 703, p. 246; Sueo Ikehara, Kokusai saiban kankatsu ken [International Judicial Jurisdiction], in: Chûichi Suzuki/Akira Mikazuki (ed.), Shin jitsumu minji soshô kôza 7 kokusai minji soshô/Kaisha soshô [New Practical Lecture on Civil Procedure 7 International Civil Litigation/Litigation with regard to Company] (1982), p. 35.

${ }^{101}$ As for the discussions, see Satoshi Watanabe, Kyakkan teki heigô ni yoru kokusai saiban kankatsu [International Judicial Jurisdiction on the Grounds of Objective Joinder], in Ishikawa Akira sensei koki shukuga, gendai shakai ni okeru minji tetsuzuki hô no tenkai [jô] [In Honor of Professor Akira Ishikawa's 70 ${ }^{\text {th }}$ Anniversary: Development of Civil Procedure Law in Modern Society (1)] (2002), p. 367; Yasushi Nakanishi, Case Note, Shiho Rimâkusu [Remarks on Civil Law], 2002(2), p. 150.

${ }_{102}$ Tokyo District Court, judgment, 27 November 1998, Hanrei Taimuzu No. 1037, p. 235; abbreviated English translation available at $<\mathrm{http}: / /$ tomeika.jp/search/content. php?did=1575>.

${ }^{103}$ Minshû Vol. 55(4), p. 727, English translation available at <www.courts.go.jp/ english/judgments/text/2001.6.8-2000-O-No.929\%2C.2000-Ju-No.780.html> (last visited at 4 October 2009)). 
examples to illustrate that whether or not the disputes are substantively the same should be one of the benchmarks for determining the existence of a close connection. ${ }^{104}$ Furthermore, with respect to a counterclaim, a lower court ruled in a case related to familial status that in the absence of special circumstances, international jurisdiction should be affirmed, so long as the counterclaim is closely related to the primary action. ${ }^{105}$

\section{(2) Other countries}

In Europe, only a few countries have a rule with respect to objective joinder. ${ }^{106}$ Moreover, some countries such as the U.K. do not permit a claim for joinder in itself with regard to the infringement of foreign patents, considering Article 22(4) of the Brussels I Regulation, which concerns exclusive jurisdiction and covers infringement litigation. ${ }^{107}$ One of the countries which has a rule on objective joinder, Belgium, permits objective joinder for claims that are so closely connected there is an interest to try and decide them at the same time in order to avoid incompatible solutions which might result if they were tried separately (Private International Law, Art. 9). ${ }^{108}$ In the Brussels I Regulation, there is only a provision on counterclaims, which allows the court in which the original claim is pending to have jurisdiction over "a counter-claim arising from the same contract or facts on which the original claim was based" (Art. 6 (3)). ${ }^{109}$

In the United States, supplemental jurisdiction is permitted over claims that are so related to claims in the action within original jurisdiction that they form part of the same case or controversy. ${ }^{110}$ The criteria are, accord-

${ }^{104}$ Dai Yokomizo, Case Note, Hôgaku Kyokai Zasshi [Journal of the Jurisprudence Association], Vol. 119(10), (2002), p. 2095, 2105. As a lower tribunal judgment which followed this Supreme Court decision, Tokyo District Court, 4 April 2006, Hanrei Jihô No. 1940, p. 130; abbreviated English translation available at $<$ http://tomeika.jp/search/ content.php?did=985>.

${ }_{105}$ Tokyo High Court, 13 April 2006, Hanrei Jihô No. 1934, p. 130.

106 According to Schack (supra note 57) at p. 124, Greece, Italy, and Belgium have such rules.

107 E.g., Coin Controls Limited v. Suzo International (UK) Limited and Others, [1997] FSR 660, 672.

108 "Lorsque les juridictions belges sont compétentes pour connaître d'une demande, elles le sont également pour connaître d'une demande qui y est liée par un rapport si étroit qu'il y a intérêt à instruire et à juger celles-ci en même temps afin d'éviter des solutions qui pourraient être inconciliables si les causes étaient jugées séparément".

${ }^{109}$ However, as mentioned later, this does not mean that the objective joinder is denied under Brussels I Regulation. Moreover, a counterclaim with regard to the validity of foreign patents is not covered by Article 6 (3) because of Article 22 (4). Marta Pertegás Sender, Cross-border Enforcement of Patent Rights, (Oxford, 2002), at p. 167.

11028 U.S.C. $\$ 1367$ (Supplemental jurisdiction).

“(a) Except as provided in subsections (b) and (c) or as expressly provided otherwise by Federal statute, in any civil action of which the district courts have original juris- 
ing to case law, whether the claims arise from "the common nucleus of operative fact," and it is ordinarily expected that they are judged in the same procedure. ${ }^{111}$ Additionally, courts have discretion on whether they exercise this supplemental jurisdiction. ${ }^{112}$ However, it seems that the U.S. courts are hesitant in exercising this jurisdiction in order to join claims with regard to the foreign patent infringement and the U.S. patent infringement. It is true that, on the one hand, in a case that concerned the non-payment of the license fee under a patent transfer contract which covered domestic and foreign patents on the same product and the wrongful termination of the said contract, a claim for the joinder was allowed from the fact that the grounds of the claims are the result of the similar acts the defendant did within and outside of the United States and that the interpretation would be important in the foreign patent infringements. ${ }^{113}$ On the other hand, in a patent infringement case where a U.S. company sued a Japanese company, a claim for the joinder of the third claim on the grounds of the infringement of a Japanese patent to the claims on the U.S. patent infringement was dismissed, on the grounds that a) the third claim was an apparatus claim whereas the main claim concerned the method patent, b) the scopes of devices were different, c) the alleged infringement acts were different (the one was a direct infringement whereas the other was an indirect infringement), and d) the laws applicable to the claims are different. ${ }^{114}$ In particular, in a recent case in which an Oklahoma resident sued a Florida company on the grounds of infringement of not only a U.S.

diction, the district courts shall have supplemental jurisdiction over all other claims that are so related to claims in the action within such original jurisdiction that they form part of the same case or controversy under Article III of the United States Constitution. Such supplemental jurisdiction shall include claims that involve the joinder or intervention of additional parties.

(b)...

(c) The district courts may decline to exercise supplemental jurisdiction over a claim under subsection (a) if-

(1) the claim raises a novel or complex issue of State law,

(2) the claim substantially predominates over the claim or claims over which the district court has original jurisdiction,

(3) the district court has dismissed all claims over which it has original jurisdiction, or

(4) in exceptional circumstances, there are other compelling reasons for declining jurisdiction.

(d)...

(e)..."

This provision entered into force on 1 December 1990.

111 United Mine Workers of Am. v. Gibbs, 383 U.S. 715 (1966); Sinclair v. Soniform, 935 F.2d 599, 603 ( $3^{\text {rd }}$ Cir. 1991).

11228 U.S.C. $\S 1367(\mathrm{c})$.

113 Ortman v. Stanray, 371 F.2d 154 ( $7^{\text {th }}$ Cir. 1967).

114 Mars Inc. v. Kabushiki-Kaisha Nippon Conlux, 24 F.3d 1368 (Fed. Cir. 1994). 
patent but also European, U.K., French, German, and Canadian patents, the plaintiff obtained joinder with the application based on the Patent Cooperation Treaty. The U.S. Federal Circuit Court held the court should not exercise its discretion for the supplemental jurisdiction and did not allow the claims for the joinder, on the grounds of the principle of independence of patent in the Paris Convention, comity, judicial cost, Act of State Doctrine, etc. ${ }^{115}$ Thus, it seems the recent practical tendency in the United States is that supplemental jurisdiction is not allowed even if underlying patents correspond with each other and the alleged infringement acts are similar. ${ }^{116}$

\section{c) Proposals for Conventions and Legislation}

Many proposals for conventions and legislation that have been published so far require the existence of certain relationships between the claims. For example, Japan's International Jurisdiction Study Group report published in April 2008, which encompasses not only intellectual property disputes but also general international civil disputes, and the Interim Draft for the legislation on international jurisdiction of the International Jurisdiction Legislative Committee of Japan's Legislative Council, allow objective joinder in cases where a "close connection" is found between multiple claims between the same parties, and with respect to a counterclaim, in cases where "the claim as the object of the counterclaim is closely connected with the claim as the object or the defense in the primary action."117

115 Voda v. Cordis, 476 F.3d 887 (Fed. Cir. 2007). It is to be noted that there was a dissenting opinion by Judge Newman. As for this case, Marta Pertegás Sender, The Appropriate Venue for Cross-Border Patent Disputes: Heading (Far) West?, in: Arnaud Nuyts (ed.), International Litigation in Intellectual Property and Information Technology (Kluwer, 2008), p. 89; Marko Schauwecker, Zur internationalen Zuständigkeit bei Patentverletzungsklagen - Der Fall Voda v. Cordis im Lichte europäischer und internationaler Entwicklungen, GRUR Int. (2008), p. 96.

116 See generally, Harold C. Wegner, Voda v. Cordis in Trans-Border Patent Enforcement, available at <www.foley.com/files/tbl_s31Publications/FileUpload137/2989/Voda Texas Paper.pdf $>$ (last visited 30 March 2009).

117 International Jurisdiction Study Group Report (6), NBL No. 888 (2008), p. 72 et seq.

"Article 6(1). Objectively Similar Claims

1. Japanese courts shall have international jurisdiction regarding several closely related claims among the same parties if Japanese courts can exercise international jurisdiction concerning one of those claims.

2. If Japanese courts have international jurisdiction regarding the main claim, they shall also have international jurisdiction regarding the counterclaim which is based on the same contract of factual circumstances.

3. Rules in subparagraphs 1 and 2 shall not be applied if foreign courts have specific jurisdiction concerning other claims or counterclaims." 
Furthermore, in the ALI Principles, ${ }^{118}$ subject matter jurisdiction is recognized with respect to "all claims and defenses among the parties arising out of the transactions, occurrence, or series of transactions or occurrences on which the original claim is based" $(\S 212) .{ }^{119}$ In special provisions regarding international jurisdiction in the area of intellectual property published by the Max Planck Institute in 2003, however, the courts in the place of the defendant's habitual residence are said to have jurisdiction over all infringement claims against the defendant, regardless of the place of infringement (Art. 12a(3)(ii) and (4)(i)). ${ }^{120}$

Additionally, examples of the imposition of certain additional restrictions on objective joinder are seen in legislative proposals regarding intellectual property, in relation to the handling of cases where infringements

It is said that paragraph 1 adopted the criteria of the above-mentioned Tsuburaya Production Case, whereas paragraph 2 took the provision under Brussels I Regulation into consideration. As for the Interim Draft with regard to legislation on international jurisdiction of the International Jurisdiction Legislative Committee of Japan's Legislative Council, see $<$ http://search.e-gov.go.jp/servlet/Public?Doing $>$.

"Article 5. Jurisdiction with respect to Claims for Joinder

1. In cases where several claims are asserted in one action, if Japanese courts have international jurisdiction over one of those claims and have no international jurisdiction over the others, the action can be taken in Japanese courts as long as that claim is closely connected with the others.

2. If Japanese courts have international jurisdiction over the claim as the object of the main action and no international jurisdiction over the claim as the object of the counterclaim, the defendant can take the counterclaim in Japanese courts where the main action is pending, as long as the claim as the object of the counterclaim is closely connected with the claim as the object of the main action or the defense".

118 The American Law Institute, supra note 23.

119 The Korean proposal given at "The $8^{\text {th }}$ Symposium on Intellectual Property Law and Private International Law" (20-21 December, 2008 at Waseda University) sponsored by the Waseda Institute for Corporations Law and Society, as part of the Global Centers of Excellence program, recognizes the fact that the burden on the defendant is relatively smaller in an objective joinder, compared to a subjective joinder, and also the fact that there is a particular need to flexibly allow objective joinder in order to effectively resolve international disputes on intellectual property rights over the Internet and, referring to the ALI Principles, allow objective joinder with respect to related claims arising out of the same or a series of transactions or acts of infringement as the original claim, as follows: Article 208 (Objective joinder)

"(1) The court that has jurisdiction over one claim shall have jurisdiction over related claims between the same parties arising out of the same or a series of transactions or acts of infringement as the original claim, regardless of the place of the transaction or infringement; provided, however, with respect to cases where jurisdiction is acquired by the provisions of Article 204(2), that this shall be limited to claims related to transactions or acts of infringement that occurred in that country".

${ }^{120}$ As for the MPI proposal in 2003, see Josef Drexl/Annette Kur (ed.), Intellectual Property and Private International Law, (Hart Publishing, 2005), at pp. 309-334. See also Marcus Norrgård, Provisional Measures and Multiple Defendants in the MPI Proposal, in: Drexl/Kur, id., p. 35, p. 51. 
arise in multiple countries, such as when "ubiquitous infringement" is involved. To illustrate, the ALI Principles restrict the possibility of a joinder to situations where the defendant resides in the forum, and where jurisdiction by agreement or jurisdiction by appearance is affirmed in the forum, by requiring the court to also have personal jurisdiction over individual claims in the first place. ${ }^{121}$ Moreover, other proposals suggest, in cases where international jurisdiction is affirmed on the grounds of the place where the loss arose, restricting jurisdiction to claims related to transactions or acts of infringement that occurred in that country. ${ }^{122}$ Furthermore, there are proposals that suggest that a joinder of actions regarding the infringement of intellectual property rights in other countries should be allowed only in the country to which the intellectual property rights that were the primary subject of the infringement belong. ${ }^{123}$

\section{d) Comments on the Transparency Proposal}

In cases where the infringement of intellectual property rights in multiple countries becomes an issue pursuant to the same contract or act, it is considered convenient for both parties, in terms of costs and other factors, to resolve the disputes between the parties in one action in a single court, and to grant reciprocal international recognition to the validity of the decision. ${ }^{124}$ Accordingly, there is ample reason from a practical business perspective for allowing claims based on the infringement of intellectual property rights in multiple countries to be tried in one action. Moreover, allowing the objective joinder of claims against infringement of intellectual property rights in multiple countries would mean, in particular, that jurisdiction over the merits, which is the basis of extraterritorial provisional measures against infringement of intellectual property rights in foreign countries, is given to the court in the forum, providing an important means of protection to holders of intellectual property rights by facilitating speedy injunctions. ${ }^{125}$

$121 \S 212(1)$.

122 Article 208(1) of the Korean proposal described in supra note 102.

123 Article 11 of the Waseda Project Proposal in supra note 102. See $<$ www. globalcoe-waseda-law-commerce.org/activity/pdf/19/21.pdf > (last visited, $28 \mathrm{March}$ 2010).

124 Pedro Alberto De Miguel Asensio, Cross-Border Adjudication of Intellectual Property Rights and Competition between Jurisdictions, 16 Annali italiani del diritto d'autore, della cultura e dello spettacolo (AIDA), 105 (2007), e-print available at: $<$ http://eprints.ucm.es/7828/> (last visited, 26 June 2009). See also Pearce v. Ove Arup Limited and Others, [1997] WLR 779.

${ }_{125}$ Arnaud Nuyts/Katarzyna Szchowska/Nikitas Hatzimihail, Cross-Border Litigation in IP/IT Matters in the European Union: The Transformation of the Jurisdictional Landscape, in: Nuyts (supra note 115) pp. 9-13. It will be described later in the 
Certainly, the differences in the scope of protection and its interpretation in the legal systems of different countries are not insignificant, particularly in the case of patent rights. It follows that the disadvantages in cases where objective joinder is allowed would include the difficulties that accompany decisions on infringement under foreign patent law when the court of the forum applies foreign patent law, and prolonged trials due to the application of the laws of multiple countries. ${ }^{126}$ Additionally, there may also be problems with effectiveness for the courts of Japan, which do not share common systematic preconditions for the recognition and enforcement of foreign judgments such as the Brussels I Regulation in the European Union, in relation to trying actions regarding the infringement of foreign intellectual property rights and issuing broad extraterritorial injunction orders. Even considering these points, however, it is still the view that the practical benefits outweigh the disadvantages if the disputes between the parties are resolved by one trial in a single court.

It is therefore considered desirable to uphold objective joinder, not only in cases where the ownership of copyrights in multiple countries with respect to the same work is based on the interpretation of the same license agreement, ${ }^{127}$ or where intellectual property rights in multiple countries were infringed by one and the same act on the Internet, ${ }^{128}$ but even in cases where acts that are of the same kind, but cannot be described as the same act, are at issue, such as where the defendant sells the same type of products in multiple countries. Accordingly, in this Proposal, an objective joinder is granted in cases where a close connection is found among the claims, without being limited to cases where the foundation of each claim is "based on the same contract or facts." Under this Proposal, an objective joinder would even be granted for a claim of infringement of a foreign patent right and a claim of unfair competition as a responding counterclaim, ${ }^{129}$ on the basis that one and the same act is at issue, and there is a strong need

\footnotetext{
legislative proposals concerning international parallel litigation that this Proposal acknowledges countermeasures, such as suits for declarations of non-existence of the obligation, in order to also consider the other party while attempting to coordinate between each suit.

${ }^{126}$ Cf. Voda v. Cordis Corp., 476 F.3rd 887 (2007), pp. 903-904.

127 Cf. Supreme Court, judgment, 8 June 2001, supra note 47.

128 For example, where it is considered that the infringement of multiple copyrights took place through one and the same act, such as the posting of photos on a website as described above.

${ }^{129}$ Cf. Tokyo District Court, 16 October 2003, Hanrei Jihô No. 1874, p. 23, Hanrei Taimuzu No. 1151, p. 109 [Coral Sand case], abbreviated English translation available at $<$ http://tomeika.jp/search/content.php?did=1591>.
} 
to attempt to achieve a coordinated solution, despite the possibility that the governing laws would be different. ${ }^{130}$

However, if a close connection between the claims as described above were the only requirement, there would be a possibility that an objective joinder would be granted in cases where the close connection between the dispute as a whole and Japan is not particularly strong, and that foreseeability for the defendant would be compromised, as in cases where Japan's international jurisdiction is recognized as the place of the results of the act in tort jurisdiction, ${ }^{131}$ or where Japan's international jurisdiction is affirmed as jurisdiction of the place of performance of the obligation with respect to an incidental obligation, where the contract at issue incorporates multiple obligations. For example, if an action regarding the ownership of a copyright in a foreign country were pending in a court in Japan, encouraging the plaintiff to add a claim for a declaration of ownership of a Japanese copyright with respect to the same work, and to have an objective joinder granted with respect to the claim concerning the ownership of a foreign copyright based on international jurisdiction over the relevant claim, ${ }^{132}$ would be a problem from the viewpoint of the protection of the defendant's right of defense, so long as the relevant dispute is not centered in Japan. Therefore, in this Proposal, if the general jurisdiction over the defendant is not affirmed in Japan, the circumstances under which an objective joinder is granted are limited to cases where Japan is the place of performance of the primary obligation, or the place of the primary results of the act. ${ }^{133}$ The issue of whether or not Japan is the place of performance of the primary obligation, or the place of the primary results of the act, is to be decided in accordance with individual circumstances of the case, and in this regard, some foreseeability for the parties is lost. Considering the diversity of international infringements of intellectual property rights, however, it is no doubt inevitable that this degree of flexibility be adopted. ${ }^{134,135}$

${ }^{130}$ In reality, in the above-mentioned Coral Sand Case, the law applicable to the issue regarding the inexistence of claim for injunctive relief and the law applicable to the issue whether the act in question would be the defamation act or not were different.

${ }^{131}$ Cf. Supreme Court, judgment, 8 June 2001, supra note 47.

132 Cf. Ibid.

133 MPI Proposal in 2003 requires that the principal part of the activities which caused the alleged infringement act occurred in the forum. See Annette Kur, Jurisdiction and Enforcement of Foreign Judgments: The General Structure of the MPI Proposal, in: Drexl/Kur (supra note 120) p. 27.

${ }^{134}$ Cf. Kur, id., p. 27, note 16.

135 It should be noted that this provision on objective joinder could be used by the infringer's part. It is the case where an infringer takes an action for the confirmation of non-obligation in the place where he or she resides and seeks the objective joinder for other claims with regard to intellectual properties in different countries. Under this 
Furthermore, while claims regarding matters of exclusive jurisdiction are excluded from objective joinder as a matter of course under general doctrine, this article does not make particular provision in regard to exclusive jurisdiction, conforming to the position taken by the Proposal, which does not recognize exclusive jurisdiction over international civil disputes regarding intellectual property. If a provision to the effect of "[w]ith respect to the regulations in paragraph 1 , this shall not apply to the other claims or counterclaims in cases when under Japanese law there is a basis for jurisdiction in a foreign country such as would give the courts of Japan exclusive international jurisdiction," were added to the Proposal, this paragraph would be of benefit not only in disputes concerning intellectual property, but also as a provision for cases related to property in general. ${ }^{136}$

\section{Subjective Joinder (Paragraph 2) and the "Spider in the Web" $(\text { Paragraph } 3)^{137}$ \\ a) Circumstances Where a Subjective Joinder Becomes an Issue in International Disputes on Intellectual Property}

For example, in cases where an intellectual property right in Japan is infringed by a subsidiary or agency in Japan, an issue arises as to whether Japanese courts should have international jurisdiction that they do not ordinarily have, not only with respect to the other party that carries out an act of infringement in Japan directly, but even in relation to claims against a parent company in a foreign country, which carries out related acts of

\footnotetext{
Proposal, if the victim takes an action in another country's court in such a case, the case will be dealt with under Article 201 on international parallel litigation.

${ }^{136}$ How about the case where a foreign court has the exclusive jurisdiction on one of the claims or counterclaims to be consolidated, on the grounds of the parties' exclusive jurisdiction agreement? From the viewpoint of the necessity that a dispute between parties be resolved in one action at the same court, it may be a solution to leave all claims to the said foreign court, respecting the party's agreement. However, it does not seem reasonable to extend the effect of the parties' agreement on the exclusive jurisdiction to the related claims which has not been covered by the parties' agreement, considering the forum designated by the parties is not necessarily the most closely connected with the dispute as a whole. Rather, it seems more appropriate, from the viewpoint that the dispute as a whole should be resolved in an appropriate forum, to take advantage of the objective joinder in spite of the existence of the exclusive jurisdiction agreement, considering that the cases where the objective joinder will be allowed under this Proposal are limited to the cases where the dispute as a whole and Japan are quite closely connected, such as the cases where the defendant's domicile, the place of the performance of the primary obligation, or the place of the occurrence of the primary facts is located in Japan.

${ }^{137}$ See Article 110 of the Transparency Proposal, Annex II infra.
} 
inducement and assistance. ${ }^{138}$ Moreover, taking the matter even further, in cases where subsidiaries or agencies that belong to the same corporate group infringe corresponding intellectual property rights in multiple countries, an issue arises as to whether or not a joinder of claims against these parties should be allowed. ${ }^{139}$

\section{b) Subjective Joinder under the Current Law}

\section{(1) Japan}

Some judicial precedents have affirmed international jurisdiction in the absence of special circumstances in cases of a subjective joinder of the grounds of joint tort in Japan. ${ }^{140}$ However, in many cases a subjective joinder is allowed only where there are special circumstances such that conducting a trial in the courts of Japan, in light of specific facts, conforms to the principles of fairness as between the parties and the expectation of a proper and speedy trial, as a result of considering the extent of the disadvantage to a defendant who would be forced to respond to an action in a foreign country. ${ }^{141}$ In contrast, the Supreme Court decision of 28 April

${ }^{138}$ Cf. Tokyo District Court, 14 May 2001, Hanrei Jihô No. 1754, p. 148, abbreviated English translation available at $<$ http://tomeika.jp/search/content.php?did=1583>; Tokyo District Court, 28 November 2007 (yet unpublished).

139 Cf. Case C-539/03, Roche Nederland et. al. v. Primus [2006] ECR I-6335.

140 Tokyo District Court, judgment, 20 June 1986, Hanrei Jihô No. 1196, p. 87, Hanrei Taimuzu No. 604, p. 138; Tokyo District Court, interlocutory judgment, 1 June 1987, Hanrei Taimuzu No. 641, p. 269 (jurisdiction affirmed); Tokyo District Court, judgment, 1 June 1987, Kin'yu shôji kanrei [The Financial and Business Law Precedents], No. 790, p. 32 (however, jurisdiction denied from the fact that special circumstances exist since there was no connection between the defendant and Japan); Tokyo District Court, judgment, 28 June 1989, Hanrei Taimuzu No. 723, p. 228 (jurisdiction affirmed), abbreviated English translation available at $<\mathrm{http}$ ://tomeika.jp/search/content. php?did=1090>; Tokyo District Court, judgment, 14 January 1994, Hanrei Taimuzu No. 864, p. 267 (indirect jurisdiction affirmed), abbreviated English translation available at $<$ http://tomeika.jp/search/content.php?did=1587>.

${ }_{141}$ Tokyo District Court, interlocutory judgment, 8 May 1987, Hanrei Jihô No. 1232, p. 40, Hanrei Taimuzu No.637, p. 87; Tokyo District Court, judgment, 28 July 1987, Hanrei Jihô No. 1275, p. 77, Hanrei Taimuzu No. 669, p. 219; Tokyo District Court, judgment, 23 October 1990, Hanrei Jihô No. 1398, p. 87, abbreviated English translation available at $<$ http://tomeika.jp/search/content.php?did=1527>; Tokyo District Court, judgment, 29 January 1991, Hanrei Taimuzu No. 764, p. 256; Tokyo District Court, judgment, 25 April 1995, Hanrei Taimuzu No. 898, p. 245, abbreviated English translation available at $<$ http://tomeika.jp/search/content.php?did=1535>; Tokyo High Court, judgment, 25 December 1996, Kô Minshû Vol. 49, No. 3, p. 109, abbreviated English translation available at $<$ http://tomeika.jp/search/content.php?did=126>; Tokyo District Court, judgment, 5 February 1997, Hanrei Taimuzu No. 936, p. 242, abbreviated English translation available at $<$ http://tomeika.jp/search/content.php?did=1100>. 
1998 (the Sadhwani Case) ${ }^{142}$ affirmed a subjective joinder, in a case of the recognition and execution of a foreign judgment, on the grounds that "there is a strong need to conduct a unified trial, on the basis that the actions are based on the same cause at substantive law and are closely related to each other." This decision is regarded in a doctrinal sense as an adoption of the standard of "a close connection between the claims" as the standard for international jurisdiction, not only for objective joinder but also for subjective joinder. ${ }^{143}$ Although there are lower court cases that have followed the framework of this decision and appear to have considered the close connection between the claims on one hand, ${ }^{144}$ there are on the other hand still many examples of court decisions that depend on the formula used in lower court case precedents to date. ${ }^{145}$

As examples of intellectual-property-related cases, there are two cases involving infringement of domestic patent rights in which suits were filed on the grounds of joint tort against the foreign parent company in addition to the Japanese company that manufactured and sold the products in Japan. In one of the cases, subjective joinder was not raised as an issue at all, ${ }^{146}$ and in the other case, the court followed the decision of the main lower court precedents to date, ruling that subjective joinder was allowed only

where there are special circumstances that recognizing international jurisdiction in the courts of Japan particularly conforms to the principles of fairness as between the parties and the expectation of a proper and speedy trial, such as where joint actions are inherently necessary, or a strong relationship of a similar degree is found between the claim against the co-defendant and the claim against the defendant. ${ }^{147}$

${ }^{142}$ Minshû, Vol. 52, No. 3, p. 853, English translation available at <www.courts go.jp/english/judgments/text/1998.04.28-1994-O-No.1838.html>.

${ }_{143}$ Eiji Adachi, Case Note, Bessatsu Jurisuto [Jurist, Special Issue], No. 185 (2007), p. 174,175

${ }^{144}$ Tokyo District Court, judgment, 25 October 2004, Hanrei Taimuzu No. 1185, p. 310, abbreviated English translation available at $<$ http://tomeika.jp/search/content. php?did=1607>

145 Nagoya District Court, judgment, 26 December 2003, Hanrei Jihô No. 1854, p. 63, abbreviated English translation available at $<\mathrm{http}: / /$ tomeika.jp/search/content php?did=1601>; Tokyo District Court, Judgment, 14 March 2005 (yet unpublished); Tokyo District Court, judgment, 28 August 2006 (yet unpublished); Tokyo District Court, Judgment, 11 April 2008, Hanrei Taimuzu No. 1276, p. 332.

${ }^{146}$ Tokyo District Court, judgment, 14 May 2001, Hanrei Jihô No. 1754, p. 148 , abbreviated English translation available at $<$ http://tomeika.jp/search/content.php?did= $1583>$. Cf. Satoshi Watanabe, Takokuseki kigyô grûpu niyoru nihon tokkyoken shingai to waga kuni no kokusai saiban kankatsu [Infringement of Japanese Patent by the Group of Multinational Enterprises and International Jurisdiction], $L \& T$, No. 18 (2003), p. 20; Shôichi Kidana, Kokusai chiteki zaisankenhô [International Intellectual Property Law] (Nihon hyôronsha, 2009), p. 225.

147 Tokyo District Court, judgment, 28 November 2007 (yet unpublished). 
As can be seen, it can be said that the treatment of subjective joinder in Japan is highly restrictive at present.

\section{(2) Other Countries}

In Europe, subjective joinder was allowed in a court where one of the codefendants is domiciled under the Brussels Convention (Art. 6(1)). Then, after an ECJ Judgment, ${ }^{148}$ the following text was added: "provided the claims are so closely connected that it is expedient to hear and determine them together to avoid the risk of irreconcilable judgments resulting from separate proceedings." ${ }^{149}$ Thus, the issue arises as to what constitutes cases where "the claims are so closely connected."

First, courts in member states acknowledged the connection between claims in the cases where the single intellectual property right is allegedly infringed by several persons. ${ }^{150}$ Moreover, also in the cases where a group of intellectual property rights established in different countries are allegedly infringed, the judgments that affirmed the close connection prevail mainly in the Netherlands, in particular in the cases that concerned the corresponding patents in several countries arising out of the same European patent. ${ }^{151}$ Whereas some authors support this view, ${ }^{152}$ it was criticized from the viewpoint of the independence of the rights, that is to say, that a European patent consists of different countries' patents which are governed by different local laws. ${ }^{153}$ In addition, the extensive use of this joint jurisdiction became problematic, as can be seen from an example that allowed the international jurisdiction against a parent U.K. company and a Netherlands' subsidiary in the Hague court on the grounds of this provi-

148 ECJ Judgment of 27 September 1988, case 189/87, Kalfelis [1988] ECR 5565.

49 "A person domiciled in a Member State may also be sued:

1. where he is one of a number of defendants, in the courts for the place where any one of them is domiciled, provided the claims are so closely connected that it is expedient to hear and determine them together to avoid the risk of irreconcilable judgments resulting from separate proceedings".

${ }_{150}$ Pearce v. Ove Arup Partnership Ltd and others, [1999] 1 All ER 769; Coin Controls Ltd. v. Suzo International (UK) limited and Others, [1997] FSR 660, 672. Furthermore, Abkco Music \& Records Inc. v Music Collection International Ltd. et al., [1995] EMLR 449. James J. Fawcett/Paul Torremans, Intellectual Property and Private International Law (Oxford University Press, 1998), p. 172; Sender (supra note 109) p. 91; Nuyts/Szchowska/Hatzimihail (supra note 125) p. 14.

151 Sender (supra note 109) at p. 91. However, contra, see Ford Dodge Animal Health Ltd. and others $v$. Akzo Nobel NV (patent) licensed to Intervet International BV, [1998] FSR 222. Cf. Expandable Grafts, Ethicon \& Cordis Europe v. Boston Scientific [1999] FSR, 352, pp. 358-359.

${ }_{152}$ Sender (supra note 109) at p. 93.

153 G. O'Sullivan, Cross-border jurisdiction in patent infringement proceedings, [1996] EIPR, 654, p. 657. 
sion, although $96 \%$ of the alleged infringement acts occurred in the U.K. ${ }^{154}$ As the result of this, the "spider in the web" doctrine was developed by a court in the Netherlands. ${ }^{155}$ According to this doctrine, which emphasizes the defendant's foreseeability, ${ }^{156}$ in the cases where the rights are allegedly infringed by several companies belonging to the same group, international jurisdiction would be allowed under Article 6(1) only when the defendant domiciled in the Netherlands is the management epicenter of this group. ${ }^{157}$ This doctrine was accepted by other countries such as Belgium, and also accepted favorably in academic opinions, which considered it reasonable that the situation where the infringers belong to the same group and the infringement is controlled by the single company sufficiently justifies the jurisdiction over the multiple defendants in the court that has jurisdiction against the company ordering the said policy, whereas it does not justify the jurisdiction of the court that has jurisdiction over the companies which are ordered. ${ }^{158}$ Having said that, the problem was mentioned that even under this doctrine it is possible that a conflict of jurisdictions might arise among courts in EU member states, from the fact that the interpretation of the "spider" would be different according to the interpretations of each state's conflict of laws. ${ }^{159}$

Under these circumstances, the ECJ has recently held, in a case where American patent-holders sued nine companies of Roche group in the Hague District Court, that the infringements of patents arising out of the same European patent do not constitute a situation where "the claims are so closely connected." ${ }^{160}$ The court ruled that, whereas it is necessary for the application of Article 6(1) that claims occur under the same legal and factual situation, there is no same factual situation since the defendants are different and the alleged infringement acts are perpetuated in different countries. Further, there is no same legal situation since the infringement of different countries' patents arising out of a European patent is still to be determined by the different countries' laws. Moreover, the court explicitly denied the "spider in the web" doctrine as follows: Even in cases where the

\footnotetext{
154 Nuyts/Szchowska/Hatzimihail (supra note 125), at p. 18.

155 The Hague Court of Appeal, 23 April 1998, Expandable Grafts, Ethicon \& Cordis Europe v. Boston Scientific (supra note 151) 352.

${ }^{156}$ Expandable Grafts, Ethicon \& Cordis Europe v. Boston Scientific (supra note 151) p. 359.

${ }^{157}$ However, the member states' conflict of laws determines where the management epicenter is, that is, the seat. Expandable Grafts, Ethicon \& Cordis Europe v. Boston Scientific (supra note 151) p. 360.

158 Nuyts/Szchowska/Hatzimihail (supra note 125) at p. 19; Cristina Gonzalez Beilfuss, Is There Any Web for the Spider? Jurisdiction over Co-defendants after Roche Nederland," in: Nuyts (supra note 115) p. 85.

159 Sender (supra note 109) pp. 100-101.

160 Case C-539/03, Roche Nederland et. al. v. Primus [2006] ECR I-6335.
} 
defendant companies belonging to the same group act in the same way, it cannot be said that there is the same legal situation. Rather, if joinder were allowed in such a case, many problems would arise for the fair administration of justice: a decrease in the defendants' foreseeability, an increase of forum shopping, the necessity of substantive review before the trial on the merits, the impossibility of the joinder for the trial on the validity of the patents because of exclusive jurisdiction, etc. These problems may become factors for increasing the risks rather than the advantages.

This judgment is fiercely criticized by academic opinions which consider that this ruling may seriously restrict the possibility of cross-border intellectual property disputes under the Brussels system. ${ }^{161}$ Also, in response to this judgment, the CLIP group published a reform proposal that would introduce the "spider in the web" doctrine to Article 6(1) of Brussels I Regulation. ${ }^{162}$

161 Nuyts/Szchowska/Hatzimihail (supra note 125) p. 31; Beilfuss (supra note 158) pp. 84-88; Michael Wilderspin, "La compétence juridictionnelle en matière de litiges concernant la violation des droits de propriété intellectuelle - Les arrêts de la Cour de justice dans les affaires C-4/03, GAT c. LUK et C-539/03, Roche Nederland c. Primus et Goldberg," Rev. crit. 2006. 777, p. 794.

162 European Max Plank Group for Conflict of Laws in Intellectual Property (CLIP), "Exclusive Jurisdiction and Cross Border IP (Patent) Infringement: Suggestions for Amendment of the Brussels I Regulation" (20 December 2006), available at <www.ivir. $\mathrm{nl} /$ publications/eechoud/CLIP Brussels_\%20I.pdf> (last visited 9 March 2009).

The addition of the following provisions to Article 6 (1) is proposed.

"For the purposes of this provision, a risk of irreconcilable judgments exists in disputes involving essentially the same legal and factual situation.

(i) A finding that disputes involve the same legal situation shall not be excluded by the mere fact that different national laws are applicable to the separate proceedings, provided that the applicable provisions of the relevant national laws are harmonised to a considerable degree by Community legislation or an international convention applicable in each of the proceedings.

(ii) Where the risk of irreconcilable judgments arises out of the fact that the defendants engage in coordinated activities, the defendants may only be sued in the courts for the place where the defendant coordinating the activities is domiciled. Where the activities are coordinated by several defendants, all defendants can be sued in the courts for the place where any one of the defendants coordinating the activities is domiciled."

Furthermore, the CLIP Principles, in which European Max Planck Group on Conflict of Laws in Intellectual Property on 6 June 2009 (available Annex II infra) follows this proposal, is the following: "a risk of irreconcilable judgments exists in disputes involving essentially the same legal and factual situation" (Article 2:206 (1)). Also, under this draft, jurisdiction is allowed not only in the cases where there is a close connection between claims, but also in "the court in the State of the habitual residence of the defendant who coordinated the activities leading to the infringements or is otherwise most closely connected with the dispute in its entirety" (Article 2: 206 (2)). 


\section{c) Proposals for Conventions and Legislation}

Many proposals for conventions and legislation that have been published so far allow subjective joinder in cases where a close connection exists between claims. For example, in the report by Japan's International Jurisdiction Study Group mentioned above, which targets general international jurisdiction, the Interim Draft allows subjective joinder with respect to actions where "the rights or obligations, which are the purpose of the actions, are common among several people, or are based on the same factual and legal causes." 163 Moreover, in the ALI Principles, personal jurisdiction over multiple defendants is affirmed where the claim against the defendant who resides in the forum and the claims against the other defendants who do not reside in the forum are "so closely connected that they should be adjudicated together to avoid a risk of inconsistent judgments," so long as other requirements are met. Furthermore, a close connection between the claims is also listed as one of the necessary conditions in the Max Planck Institute Proposal of 2003 (Art. 14(1)(a)). ${ }^{164}$

Among legislative proposals regarding intellectual property, however, there are some that impose requirements in addition to a close connection between the claims. For example, the ALI Principles require that there be a foreseeable connection between the forum's intellectual property rights at

163 Supra note 119 , p. 72 et seq.

“Article 6(2) Subjective Joinder

1. If Japanese courts have international jurisdiction regarding one of the claims raised by multiple plaintiffs or against different defendants, or one of several claims which are made on the same legal or factual basis; Japanese courts should also have international jurisdiction regarding other claims.

2. The rule provided in subparagraph 1 shall not be applied if a foreign court has exclusive jurisdiction regarding one of the claims."

It is explained that this provision was drafted on the reflection that introduction of subjective joinder in international jurisdiction should be limited since it may gravely compromise the defendant's interest.

Article 5(3) of the Interim Draft by the Legislative Committee of Japan's Legislative Council is as follows:

"(3) In cases where several claims are asserted in an action from or against several persons, if Japanese courts have international jurisdiction over one of those claims and have no international jurisdiction over the others, the action can be taken in Japanese courts as long as the rights or obligations, which are the purpose of the actions, are common among several people, or are based on the same factual and legal causes".

164 However, considering that since on a strict interpretation, intellectual property rights, which are independent rights in each country, cannot be said to create a risk of inconsistent judgments, if intellectual property rights in different countries are being addressed, more liberal methods should be adopted. The Max Planck Institute Proposal does not consider the "risk of inconsistent judgments" as do the ALI Principles. Norrgård (supra note 120) pp. 51-52. The close connection between the claims is also required in the second preliminary draft of the CLIP Principle (Article 2:206 (1)). See also Article 14 of the Hague Draft Convention on Jurisdiction and Foreign Judgments. 
issue and each nonresident defendant, ${ }^{165}$ and that there be no forum that is more closely related to the entire dispute. ${ }^{166}$ The Max Planck Institute Proposal of 2003, which basically relied upon Article 14 of the Hague Draft Convention on Jurisdiction and Foreign Judgments, also requires a substantial connection between the forum and the dispute for defendants who do not habitually reside in the forum. ${ }^{167}$ Furthermore, the CLIP Principles requires that the defendant who coordinated the activities leading to the infringements have habitual residence in the forum, or that the forum is most closely connected with the dispute in its entirety. ${ }^{168}$

Moreover, there are differences in the treatment of intellectual property rights that are established in each country with respect to the same subject. Namely, the ALI Principles, which contemplate cases of multiple defendants agreeing to carry out an act that has the effect of global infringement, ${ }^{169}$ allow a joinder so long as the connection between the other defendants and the forum are proven, along with coordinated action among the defendants, even when different intellectual property rights in each country are at issue. ${ }^{170}$ Further, the Max Planck Institute Proposal of 2003 allows a joinder on the condition that the defendant who habitually resides in the forum is the person who primarily carried out infringement, in addition to the requirements described above. ${ }^{171}$ On the other hand, under some other proposals, infringement of the same intellectual property right is the only matter taken into consideration for a subjective joinder. ${ }^{172}$

$165 \S 206(1)(a)$. Moreover, AIPPI, Question Q174: Jurisdiction and applicable law in the case of cross-border infringement (infringing acts) of intellectual property rights, Resolution, (2003; available at <https://www.aippi.org/download/comitees/174/SR174 English.pdf $>$ ). Article $1(\S 3)$ requires a sufficient objective relationship with a forum court with respect to international jurisdiction concerning infringement of intellectual property rights in a foreign country.

$166 \S 206(1)(\mathrm{b})$.

167 Article 14(1)(b). Norrgård (supra note 120) p. 51.

168 Article 2:206(2).

169 Examples listed here include file-sharing services, search engines, and the offers of various Internet services (auctions, streaming television, and radio).

${ }_{170}$ ALI (supra note 23) pp. 61-62, Illustration 165 (an example of a joinder regarding improper use of medical documents around the world through a medical consortium); Reporters' Notes 1 (the fact that the example of the "spider in the web" is taken into consideration is clearly expressed).

${ }^{171}$ Article 14(1)(c). Norrgård (supra note 120) at p. 51. It is evident that the CLIP Principles contemplate the case that concerns the intellectual properties in different countries, from the text that "a risk of irreconcilable judgments exists in disputes involving essentially the same legal and factual situation".

172 Article 10 of the Waseda Project Proposal at the symposium described in supra note 119 , See <www.globalcoe-waseda-law-commerce.org/activity/pdf/19/21.pdf $>$ (last visited, March 28, 2010).

"In cases where multiple people are defendants and they are involved in the infringement of the same intellectual property rights, a suit may be filed jointly at the 


\section{d) Comments on the Transparency Proposal}

\section{(1) Subjective Joinder (Paragraph 2)}

In infringement of intellectual property rights, there are many cases where a subsidiary or agent directly carries out acts of infringement, and a parent company in a foreign country induces and assists. In these cases, there would no doubt be ample reason, from a practical business perspective, in allowing closely related claims against (or by) related parties regarding infringement of the same intellectual property rights to be tried in the same action, in order to attempt to resolve the cases uniformly and avoid conflicting decisions between the parties. Japan's precedents so far have been very suppressive on this point. In Europe, however, subjective joinder is regarded as a matter of course, and Japan needs a change of attitude through legislation to allow subjective joinder more proactively. However, a subjective joinder involves a significant burden on a co-defendant, who is forced to mount a defense in a foreign country. In particular, the joinder of a claim against a co-defendant who has no direct connection with Japan at all will sometimes be extremely prejudicial to foreseeability for the codefendant, and may even substantively deprive the defendant of the right of defense. Accordingly, in this Proposal, a subjective joinder is allowed, where viewed objectively, solely when the co-defendant was able to foresee an action in Japan, such as in cases where the party that directly carries out the acts of infringement is a wholly owned subsidiary or agent of a foreign company and the acts are carried out in accordance with the instructions of the foreign parent company (the proviso to Paragraph 2). ${ }^{173}$

Additionally, the same matters described for objective joinder also apply with respect to the exclusion of matters regarding exclusive jurisdiction. ${ }^{174}$

\section{(2) "Spider in the Web" (Paragraph 3)}

The situation where multiple defendants residing in different countries jointly infringe respective intellectual property rights in multiple countries is also covered by combining Paragraph 1 regarding objective joinder and Paragraph 2 regarding subjective joinder. This means that if the general jurisdiction over one defendant is in Japan or Japan is the place of the primary act of infringement, and the foreseeability of an action in Japan is

courts of the country that protects the intellectual property rights that are the subject of the infringement, in the country of the domicile of the defendant who directly carried out the acts of infringement, or in the country of domicile of the person who was the primary infringer".

${ }^{173}$ These are the same requirements as the purport of ALI Principle § 206(1)(a).

174 As for the exclusive jurisdiction agreement, cf. supra note 139. 
affirmed for the other co-defendants, Japan's international jurisdiction over the co-defendants with respect to infringements of intellectual property rights in multiple countries would be affirmed.

In international disputes concerning intellectual property, however, we need to go further, also responding to situations where intellectual property rights in multiple countries are separately infringed by companies belonging to the same corporate group that sell the same product in different countries, under a uniform command from the corporate headquarters. ${ }^{175}$ In these cases, defendants with independent juridical personalities carry out infringements with respect to independent intellectual property rights in each country, and these situations do not fall within cases where subjective joinder normally assumes. In reality, however, corresponding intellectual property rights in multiple countries are infringed by the same corporate group, and it can be stated that a situation arises where it is desirable to resolve the disputes among the parties in one trial, as in the case of an objective joinder.

Certainly, there are no precedents regarding such disputes in Japan. Considering the generally suppressive attitude toward joinder of jurisdiction seen in precedents in Japan, it might be considered exorbitant jurisdiction. In Europe, however, these types of disputes are at issue at courts in each country from time to time, and it is predicted that they will be an issue in Japan in the near future as well. Additionally, given the fact that the ALI Principles, the 2003 Max Planck Institute Proposal, and the CLIP Principles also argue for the introduction of provisions that deal with such disputes, it can be said that these types of provisions are necessary, and are accepted as reasonable jurisdiction based on international standards. ${ }^{176}$

Accordingly, in this Proposal we decided to introduce the "spider in the web" theory in a straightforward manner. ${ }^{177}$ Given the fact that the theory is an extension of the combination of objective and subjective joinder, first

175 Norrgård (supra note 120$)$ p. 50, 52.

176 Such a rule was favorably appreciated by Eiji Katayama, Yôroppa ni okeru kurosubôdâ injankushon [Cross-border Injunction in Europe], in: Nobuhiro Nakayama (ed.), Chiteki zaisan hô to gendai shakai - Makino Toshiaki hanji taikan kinen [Intellectual Property and Modern Society: In Honor of the Retirement of Judge Toshiaki Makino] (Shinzansha, 1999), p. 265, 279.

177 As an alternative way to realize the same result without introducing this doctrine, it can be considered to rely on the objective joinder, in denying the independent legal personalities between co-defendants on the grounds of the "piercing the corporate veil" doctrine and acknowledging the unity of co-defendants. However, under the current situation where, in the context of international jurisdiction, the "piercing the corporate veil" doctrine is used in an extremely limited way (e.g., Yokohama District Court, Judgment, 16 June 2006, Hanrei Jihô No. 1941, p. 124, abbreviated English translation available at $<$ http://tomeika.jp/search/content.php?did=987>), the adoption of such an approach seems highly unrealistic. 
of all, the individual restrictive requirements for objective joinder and subjective joinder must be satisfied. Namely, either jurisdiction over the defendant must be in Japan or the infringement must be or must have been primarily carried out in Japan, and foreseeability must be affirmed with respect to the other co-defendants. In addition to the above, there must be a substantive relationship between the intellectual property rights of each country that has been infringed. The words "substantively related" are used in a narrower meaning than in regard to the close relationship required in Paragraph 1 for objective joinder. That is to say, it is insufficient that the acts of infringement, such as the manufacture and sale of the same product, are merely of the same type, and a substantive relationship between each of the intellectual property rights will only be found where the scope of application and details of the corresponding intellectual property rights that are infringed in each country are similar beyond a certain degree. ${ }^{178}$ Cases that satisfy these restrictive requirements are limited to exceptional cases such as those of European patents at present, but they will gradually increase as the unification of the intellectual property laws of each country progresses in the future. ${ }^{179}$

\section{International Jurisdiction and Provisional Measures}

\section{Circumstances Where Provisional Measures Become an Issue in International Disputes over Intellectual Property}

The issue here is whether, in international disputes over intellectual property, Japan's international jurisdiction should be affirmed not only with respect to provisional measures in Japan, but also with respect to applications for provisional measures against acts of infringement in foreign countries.

\section{Jurisdiction to Order Provisional Measures under the Current Law \\ a) Japan}

Under the framework of the Supreme Court judgment of 11 November 1997, known as the ruling on referring to "the provisions of domestic territorial jurisdiction under the Code of Civil Procedure plus exceptional

\footnotetext{
178 Cf. CLIP, supra note 162.

179 As for the Plurilateral Patent Prosecution Highway (PPH) which Japan has been discussing, see press statement, available at <www.jpo.go.jp/torikumi/kokusai/ kokusai2/pdf/takokukanhighway-kekka/01.pdf > (last visited on 19 August 2009); John S. Tessensohn, Whither the Global Patent Prosecution Highway? (2008) 30 European Intellectual Property Review, pp. 261-268.
} 
circumstances, ${ }^{180}$ the courts will refer to Article 12 of the Civil Provisional Remedies $\mathrm{Act}^{181}$ with respect to provisional measures in the context of Japan's international jurisdiction, and in the absence of exceptional circumstances, in cases where Japanese courts have jurisdiction over the case on the merits, or where rights that should be preserved or the subject of the dispute is located in Japan, will affirm international jurisdiction. ${ }^{182}$ With respect to jurisdiction other than the jurisdiction on the merits, however, views include those rejecting international jurisdiction ${ }^{183}$ and those that consider the possibility of the execution of a foreign judgment on the merits in Japan. ${ }^{184,185}$

Incidentally, there is a question as to whether a provisional measure ordering inaction in regard to acts in a foreign country is accepted under the current law. Authors have been centered on a provisional measure against an act in Japan so far, ${ }^{186}$ and few articles discuss this point. There is a noteworthy theoretical view in favor of acceptance, on the basis that it is possible to indirectly achieve the purpose of the preservation for execution and secure the effectiveness of such a provisional disposition by including an order to pay a certain amount of money in the text of an order

${ }^{180}$ Minshû, Vol. 51, No. 10, p. 4055, abbreviated English translation available at $<$ www.courts.go.jp/english/judgments/text/1997.11.11-1993-O-No.1660.html>.

181 “i) Provisional measures cases are under the jurisdiction of the court that has jurisdiction on the merits or the district court that has jurisdiction over the place of the location of the object that is to be provisionally seized or the subject of the dispute."

182 Asahikawa District Court, Ruling, 9 February 1996, Hanrei Jihô No. 1610, p. 106, Hanrei Taimuzu No.927, p. 254, abbreviated English translation available at <http:// tomeika.jp/search/content.php?did=120>; Tokyo District Court, Ruling, 28 August 2007, Hanrei Jihô No. 1991, p. 89, Hanrei Taimuzu No. 1272, p. 282, abbreviated English translation available at $<\mathrm{http}$ ://tomeika.jp/search/content.php?did=999>. Masato Dogauchi, Hozen soshô no kokusai saiban kankatsu [International Jurisdiction with regard to Litigation on Provisional Measures], in: Akira Takakuwa/Masato Dogauchi (eds.), Shin saiban jitsumu taikei 3 kokusai minji soshô hô (zaisan hô kankei) [New System on Judicial Practice 3 International Civil Procedure Law (Patrimonial Cases)] (Seirin Shoin, 2002), p. 399; Hideyuki Kobayashi, Kokusai minji hozen hô josetsu kokusai minji hozen hô no riron teki kôchiku ni mukete [Introduction to International Civil Provisional Remedies Law: For the Establishment of International Civil Provisional Remedies Law], Jôchi Hôgaku Ronshû [Sophia Law Review], Vol. 38, No. 1 (1994), p. 33.

183 Junpeki Rin, Case Note, Juristo [Jurist], No. 460, p. 136.

184 Asahikawa District Court, Ruling, 9 February 1996, supra note 182.

185 As for the discussion, see Dogauchi, supra note 182

186 E.g., Yasushi Nakamura, Husakui wo meizuru karishobun meirei to kokusai saiban kankatsu [Provisional Measure to Order the Inaction and International Jurisdiction], Hanrei Taimuzu No. 798 (1993), p. 43. 
for a provisional measure where the obligor breaches the order for the provisional measure. ${ }^{187}$

There is no precedent deciding the issue of whether a provisional measure ordering inaction with regard to acts in a foreign country is possible; however, there is an Osaka District Court Ruling of 6 November $2000,{ }^{188}$ that is not related to provisional measures, in which a court in Japan ordered inaction against acts in a foreign country. In this case, after a reorganization creditor filed an action to collect a claim in a United States District Court in New York during the corporate reorganization procedures of a Japanese company, the reorganization administrator filed a petition for an injunction with a court in Japan against the United States action as an order for the implementation of the reorganization plan. The court ruled that "reorganization creditors may not receive payment for a claim from the reorganization company, or file a suit or perform other actions in order to receive payment for a claim, either within or outside Japan, independently of the reorganization plan that this court has approved." ${ }^{189}$ In addition, in a decision dated 3 September 1998 applying Japan's Antimonopoly Act with respect to an act of private monopolization by a foreign business entity, the Japan Fair Trade Commission ordered the defendant Canadian company to give notice to a Belgian company which did not conduct business activities in Japan. ${ }^{190}$ Therefore, generally speaking, under Japan's procedural law, there have been orders handed down granting injunctions against acts in a foreign country, and there seems no reason that such orders would not be accepted in the context of provisional measures.

With respect to intellectual property, however, a separate issue arises regarding the relationship with the principle of territoriality. In a Supreme

187 Yukiko Hasebe, Hozen no hitsuyô to hi Hozen kenri no sonzai [Necessity of Provisional Remedies and Existence of Right to be Provisionally Remedied], in Takakuwa/ Dogaichi, Kokusai minji soshôhô (Zaisanken kankei) [International Civil Procedure Law (Related to Property)] (Seirin Shoin, 2002), p. 406, 411.

${ }^{188}$ Yamamoto/Yamamoto/Sakai (ed.), Kokusai tôsan hôsei no shin tenkai - riron to jitsumu [New Developments of International Insolvency Law: Theory and Practice], Kin'yu Shôji Hanrei, No. 1112 (2001), p. 53 et seq.

${ }_{189}$ For a favorable view on this ruling, see Satoshi Watanabe, Gaikoku soshô sashitome meirei - Nihon no saibansho wa meirei dekiru ka [Anti-suit Injunction against a Foreign Court: Can a Japanese Court Order it?], in: Matsui/Kidana/Yakushiji/Yamagata (ed.), Gurôbaruka suru sekai to hô no kadai [Globalizing World and Challenges of Law] (Tôshindo, 2006), p. 229, 244.

${ }_{190}$ Not published. In this case, Dai Yokomizo, Case note, Juristo, No. 1177 (2000), p. 208. 
Court decision of 26 September 2002 (the Card Reader case), ${ }^{191}$ in which the demand for injunction and disposal of an act in Japan pursuant to the Patent Act in the United States was at issue, the claim for injunction and disposal was not allowed pursuant to the territoriality principle. ${ }^{192} \mathrm{In}$ accordance with this decision, which was based on the territoriality principle, it would be impossible to demand an injunction against the other party's acts outside Japan, at least when intellectual property rights in Japan are the rights being preserved. On the other hand, however, when intellectual property rights in a foreign country are the rights being preserved, it is interpreted that injunction against the other party's acts in such a foreign country is allowed in accordance with this decision. ${ }^{193}$

\section{b) Other Countries}

Under the Brussels I Regulation, other than to the court having jurisdiction on the merits, application may be made to the courts in any member state as long as it may be available under the law of that state (Art. $31{ }^{194}$ ). ${ }^{195}$ It is

191 Minsh $\hat{u}$, Vol. 56, No. 7, p. 1551; translated in Japanese Annual of International Law, Vol.46 (2003), p. 168, English translation also available at <www.courts.go.jp/ english/judgments/text/2002.9.26-2000.-Ju-.No..580.html>.

192 "However, Japan has adopted the principle of territoriality with regard to patents as mentioned above. Hence to recognize injunctions and so on against conduct in Japan based on the relevant United States patent despite the patent of each country only having effect in the territory of that country would produce substantially the same result as extending the effect of the relevant U.S. patent to Japan, which is outside the territory of the United States, and violates the principle of territoriality adopted by Japan. Further, since there is no treaty between Japan and the United States providing that the effect of patents of the other country are to be recognized mutually in each country, to order an injunction against conduct within Japan or the destruction of objects in Japan as a result of the application of United States patent law to the engaging, within Japan, in conduct actively encouraging infringement of the relevant United Sates patent is contrary to fundamental ideology of the patent law order of Japan".

193 Cf. Tokyo District Court, 16 October 2003, Hanrei Jihô No. 1874, p. 23, Hanrei Taimuzu No. 1151, p. 109 [Coral Sand case], abbreviated English translation available at $<$ http://tomeika.jp/search/content.php?did=1591>, where the court determined the case for the confirmation of the non-existence of injunction claim in applying the U.S. patent law. Contra, Makiko Takabe, Tokkyo ken shingai soshô to kokusai saiban kankatsu [Patent Infringement Litigation and International Jurisdiction], in Nobuhiro Nakayama (ed.), Chiteki zaisan hô to gendai shakai - Makino Toshiaki hanji taikan kinen [Intellectual Property and Modern Society: In Honor of the Retirement of Judge Toshiaki Makino] (Shinzansha, 1999), p. 125, 136 (based on the idea that the judicial power is spatially limited to the territory of its country)

194 "Application may be made to the courts of a Member State for such provisional, including protective, measures as may be available under the law of that State, even if, under this Regulation, the courts of another Member State have jurisdiction as to the substance of the matter". 
under discussion and seems still unsolved whether or not extraterritorial provisional measures may be available under Article 31. ${ }^{196}$ Even so, in EU countries, after extraterritorial provisional injunctions have been ordered in the pre-trial procedure by the courts in the Netherlands in the $1990 \mathrm{~s},{ }^{197}$ they have been ordered in Germany and Belgium. ${ }^{198}$

Additionally, after the GAT v. $L u K$ judgment ${ }^{199}$ recently decided by the ECJ with regard to the defense of the invalidity of a patent, it is considered that the defense of invalidity has no influence on provisional measures. ${ }^{200}$ On the contrary, the above-mentioned Roche judgment is said to influence provisional measures in that it restricts the scope of jurisdiction on the merits. $^{201}$

\section{Proposals for Conventions and Legislation}

Among the proposals for conventions and legislation that have been published to date, an example that prescribes jurisdiction to order provisional measures is Article 13 of the Hague Draft Convention on Jurisdiction and Foreign Judgments. ${ }^{202}$ This Draft Convention concerns international jurisdiction in general, and it accepts jurisdiction to order provisional measures over property in the courts of the country where the property is located, as well as the jurisdiction to order provisional measures of the court with jurisdiction over the merits. Furthermore, even with respect to other courts, provisional measures are accepted, limited within the territory of those

195 See Asako Matoba, Ôshû shihô saibansho niyoru hozen meirei kanren handanBurasseru jôyaku 24 jô (Kisoku 31 jô) no kaishaku [Ruling of European Court of Justice with regard to Provisional Measures: Interpretation of Article 24 of Brussels Convention (Article 31 of Brussels I Regulation)], Kôbe Hôgaku Zasshi [Kôbe Law Journal], Vol. 58, No. 2 (2008), p. 99.

196 Katarzyna Szychowska, Jurisdiction to Grant Provisional and Protective Measures in Intellectual Property Matters, in: Nuyts (supra note 115) p. 207, 227.

${ }_{197}$ Cf. Heleen Bertrams, Das grenzüberschreitende Verletzungsverbot im niederländischen Patentrecht, GRUR Int. 1995, p. 193.

198 Nuyts/Szchowska/Hatzimihail, in: Nuyts (supra note 125) pp. 9-13.

199 Case C-4/03, GAT v. LuK [2006] ECR I-6523.

200 Szychowska (supra note 196) p. 217.

201 Id., p. 220.

202 [Article 13 Provisional and protective measures]

"1. A court having jurisdiction under Articles 3 to 12 to determine the merits of the case has jurisdiction to order any provisional or protective measures.

2. The courts of a State in which property is located have jurisdiction to order any provisional or protective measures in respect of that country.

3. A court of a Contracting State not having jurisdiction under paragraphs 1 or 2 may order provisional or protective measures, provided that

a) their enforcement is limited to the territory of that State, and

b) their purpose is to protect on an interim basis a claim on the merits which is pending or to be brought by the requesting party." 
courts, so long as the purpose is to temporarily preserve the claim on the merits. Additionally, Article 13(1) is interpreted as making it possible to carry out provisional measures that are effective outside the territory of those courts. ${ }^{203}$ In the Interim Draft in Japan, application may be allowed in cases where the court having jurisdiction on the merits is in Japan, or the object that is to be provisionally seized or the subject of the dispute is located in Japan. ${ }^{204}$

With respect to intellectual property disputes, the ALI Principles confer jurisdiction to order provisional and protective measures to the courts that have jurisdiction on the merits, the courts of the country where the intellectual property rights are registered, or the courts where the tangible property is located. However, the effectiveness of preservative measures ordered by the courts of the country where the intellectual property rights are registered or where the tangible property is located is limited to the area within the forum territory. ${ }^{205}$ Additionally, the 2003 Max Planck Institute Proposal allows preservative jurisdiction in the court that has jurisdiction over the merits, including measures that are effective outside the court's territory, and with respect to other courts, provisional measures are allowed to the extent their execution is restricted within the territory of the relevant country. ${ }^{206}$ Furthermore, in the CLIP Principles, provisional measures may be ordered not only by the courts having jurisdiction on the merits, but also by the courts of a state where the measure is to be enforced and for which protection is sought. ${ }^{207}$ The scope of injunctions is usually limited to activities affecting intellectual property rights protected under the law applied by the court. However, as for conduct carried out through ubiquitous media, an injunction shall be presumed to concern intellectual property rights protected in all states where the signals can be received, except when the impact of activities is strictly limited to a state or states whose law has not been applied in the judgment. ${ }^{208}$

203 Prel. Doc. No 11 of August 2000 - Report on the preliminary draft Convention on Jurisdiction and Foreign Judgments in Civil and Commercial Matters, drawn up by Peter Nygh and Fausto Pocar, available at <http://hcch.e-vision.nl/index en.php?act= publications.details\&pid=3494\&dtid=35> (last visited 16 August 2009), p. 73.

${ }^{204}$ [Article 9. Rule with regard to provisional measure cases]

"Application of Provisional measures may be available to Japanese courts when Japanese courts have jurisdiction on the merits or the object that is to be provisionally seized or the subject of the dispute is located in Japan".

205 This limit relies on ALI/UNIDROIT Principles of Transnational Civil Procedure, Principle 2.3. The American Law Institute (supra note 23) p. 90.

206 Annette Kur, Jurisdiction and Enforcement of Foreign Judgments: The General Structure of the MPI Proposal, in: Drexl/Kur (supra note 120) p. 42.

207 Article 2:501.

208 Article 2:601. 


\section{Comments on the Transparency Proposal}

First, there is a question as to the significance of a Japanese court ordering a provisional measure in a foreign country. ${ }^{209}$ Timely information is highly valuable, and in practice there is generally a high level of demand for the cessation of acts of infringement that are actually taking place at the earliest possible stage in intellectual property disputes. ${ }^{210}$ However, in present times, when infringement in multiple countries, such as infringement on the Internet, is becoming far easier, the need for a court in one country to stop infringement of intellectual property rights in multiple countries as soon as possible is considered even more significant. A provisional measure ordering an injunction against suspected acts of infringement is not different from an injunction order on the merits in terms of features and has significant influence. ${ }^{211}$ Many disputes are no doubt resolved between the parties by the provisional measure itself. Further, considering that there is a possibility that Japanese provisional measures will be recognized in a foreign country, ${ }^{212}$ it can no doubt be said that it would be meaningful, in a practical business sense, for Japanese courts to carry out provisional measures outside the courts' territory as well. Accordingly, it can be said that there would be ample reason in the introduction of provisions on jurisdiction to order provisional measures with respect to international disputes concerning intellectual property, including the possibility of injunctions against acts in foreign countries. The need for provisional measures should no doubt be decided individually and specifically for each case, separately from the issue of jurisdiction. ${ }^{213}$

In this Transparency Proposal, ${ }^{214}$ which takes the position of maintaining the principle of independence of rights and flexibly allowing jurisdiction in the place of performance of the obligation or the place of tortuous acts, it would be questionable as to what extent there is a need to accept jurisdiction to order provisional measures as well, in addition to jurisdiction on the merits. Particularly where the effect of a provisional order and relief given on the merits are similar as described above, there is a need to pay attention to balance with jurisdiction on the merits. ${ }^{215}$ However, there are situations where trials in Japan are not necessarily

${ }^{209}$ Cf. A. Kur (supra note 206) p. 38.

210 ALI (supra note 23) p. 90.

211 Kur (supra note 206) p. 41.

212 Dogauchi (supra note 182) p. 400. Cf. Civ. 1re, 30 juin 2004, Rev. crit. 2004. 815, note H. Muir Watt, Clunet 2005. 112, note G. Cuniberti.

213 The issue arising out of the fact that the application for provisional measures has already been made in a foreign court should also be considered as a factor for determining whether it is necessary that the Japanese court orders a provisional measure.

${ }^{214}$ See Article 111 of the Transparency Proposal, Annex II infra.

215 Kur (supra note 206) p. 36, 41 
accepted, even if claims regarding Japan's intellectual property rights are at issue, such as where there is an agreement on jurisdiction designating a court in a foreign country or an arbitration agreement for the purpose of arbitration proceedings between the parties, or where an action in a foreign country is pending, which incorporates the issue of infringement of intellectual property rights in Japan. In these situations, even if the merits cannot be tried, it may no doubt be found that a provisional measure is needed. Further, where a provisional attachment concerning property located in Japan is at issue, there is no need to introduce a standard for jurisdiction that is different to that of normal international civil disputes, even if the dispute concerns intellectual property. Based on this approach, the Transparency Proposal allows jurisdiction to order provisional measures, even in situations other than where the Japanese courts are found to have jurisdiction on the merits. In order to avoid the uncertainty that would arise where the location of intangible intellectual property is a legal fiction, ${ }^{216}$ however, we incorporated "when the applications for provisional measures are based on intellectual property rights prescribed under the Japanese law," instead of "the location of the subject of the dispute." The jurisdiction based on "the object that is to be provisionally seized" is left unchanged, but we made it clear that this jurisdiction is limited to the provisional seizure (Paragraph 2 of Art. 111). ${ }^{217}$

Lastly, the scope of effectiveness of a provisional measure will not exceed the scope of an injunction order on the merits. Accordingly, in cases of provisional measures based on the infringement of intellectual property rights, its effectiveness would be normally limited to the territory of the country where the intellectual property rights at issue arose. However, under this Proposal, which adopts the "market impact rule," in exceptional cases where products are manufactured in a foreign country clearly targeting the market in the particular country, the effectiveness of the provisional measure will extend to the acts of working in that foreign country. ${ }^{218}$ Additionally, with respect to "ubiquitous infringement," this Proposal advocates not adopting the principle of the independence of rights. In these cases, provisional measures against suspected acts of infringement, such as the deletion of the website that is the source of the "ubiquitous infringement," would be issued in a manner unaffected by national boundaries.

Moreover, this Proposal has not adopted the view that, with respect to acts of infringement of intellectual property rights on the basis of registration, an invalidity defense will negate Japan's international jurisdiction on

\footnotetext{
${ }^{216}$ Norrgård (supra note 120) p. 41.

217 As for the definition of foreign provisional measures to be recognized, see comments regarding Articles 401 and 403.

${ }^{218}$ See comments to Article 301 (Case 1) and (Case 2) in this volume.
} 
the merits. Even if that view had been adopted, however, it should no doubt be considered that in the context of provisional measures where promptness is required and conclusive decisions should not be made regarding the validity of foreign intellectual property rights, jurisdiction will not be hindered by such an invalidity defense. ${ }^{219}$ Accordingly, in such cases, provisions such as "[i]n cases in the preceding paragraph, assertions of the invalidity of intellectual property rights do not affect international jurisdiction over provisional measure cases" should be prescribed.

\section{Parallel Proceedings}

\section{Circumstances Where International Parallel Litigation Becomes an Issue in International Disputes on Intellectual Property}

In cases where courts in each country conduct trials with respect to not only claims concerning intellectual property rights in their own country, but also claims concerning foreign intellectual property rights, there are possibilities that suits will be filed at courts in multiple countries concerning the same dispute, in the same way as with ordinary international civil disputes. The issue here is what kind of decision-making framework should be adopted with respect to international parallel litigation concerning international intellectual property disputes.

\section{International Parallel Litigation under the Current Law \\ a) Japan}

The following opposing theories exist in Japan: the "special circumstances" theory, where the suit that is pending in a foreign country is considered to be an element of a specific decision based on "special circumstances"; 220 the theory based on anticipated recognition, where the suit filed later in Japan is dismissed in cases where it is anticipated that the judgment in a prior foreign suit will be recognized in Japan in the future ${ }^{221}$ and the theory that suggests treating international parallel litigation as an issue of the standing of the suit. ${ }^{222}$ Judicial precedents initially displayed

\footnotetext{
${ }^{219}$ See Szychowska (supra note 196) p. 217 and cases referred to.

${ }^{220}$ Kazunori Ishiguro, Kokusai minji funsô shori no shinsô [Depth of International Civil Dispute Resolution] (Nihon Hyôronsha, 1992), p. 101.

221 E.g., Masato Dogauchi, Kokusai teki soshô kyôgô (5) [International Parallel Litigation (5)], Hôgaku Kyôkai Zasshi [Journal of the Jurisprudence Association], Vol. 100, No. 4 (1983), p. 722.

${ }^{222}$ Satoshi Watanabe, Kokusai teki nijû soshô ron - Uttae no rieki niyoru shori shiron [On International Parallel Litigation: Standing to Suit Approach], in: Hanrei Minji
} 
the approach of giving no consideration whatsoever to suits pending in foreign countries, ${ }^{223}$ but later decisions do consider suits pending in foreign countries to some degree. While there are some cases in which the theory based on anticipated recognition was clearly adopted, ${ }^{224}$ when considering pending foreign suits, many courts have relied on the "special circumstances" theory. ${ }^{225}$

The Tsuburaya Production case described above is an example of disputes concerning intellectual property. In this case, the issue was an existence of a suit in Thailand that $\mathrm{X}$ filed against $\mathrm{Y}$ and three others "demanding an injunction and claiming damages on the basis of a forged contract and on the grounds of acts of infringement of X's copyright with respect to the work in the case." The court at second instance considered the existence of the suit in Thailand to be an element in the "special circumstances" negating Japan's international jurisdiction, on the ground that "the same dispute as this suit is disputed" in the suit in Thailand. ${ }^{226}$ In response, the Supreme Court ruled that

the details of the claim in this suit and the suit in Thailand are not identical, and the subject of the suits are different. Even if one of the disputes in the suit in Thailand were the existence of an exclusive exploitation right over the relevant work, and it was in common with the dispute in this suit, it cannot be said that subjecting $\mathrm{Y}$ to Japan's jurisdiction with respect to this suit is contrary to the principles of fairness as between the parties and the expectation of a proper and speedy trial. Other than the above, no special circum-

Soshô Hô no Riron (Ge) [Theory of Civil Procedure Law Based on Case Law (2)] (1995), p. 475 .

${ }^{223}$ Tokyo District Court, judgment, 23 December 1955, Ka Minshû Vol. 6, No. 12, p. 127, abbreviated English translation available at $<\mathrm{http}: / /$ tomeika.jp/search/content. php?did=1565>; Tokyo High Court, judgment, 18 July 1956, Ka Minsh $\hat{u}$ Vol. 8, No. 7, p. 1282; Osaka District Court, interlocutory judgment, 9 October 1973, Hanrei Jihô No. 728, p. 76, abbreviated English translation available at $<$ http://tomeika.jp/search/ content.php?did=1516>.

224 Tokyo Family Court, judgment, 31 March 2005 (unpublished), but reversed, Tokyo High Court, Judgment, 14 September 2005 (unpublished). Cf. Tokyo District Court, interlocutory judgment, 30 March 1989, Hanrei Jihô No. 1348, p. 91 (anticipated recognition was mentioned).

${ }^{225}$ Tokyo District Court, judgment, 15 February 1984, Hanrei Jihô No. 1135, p. 70; Tokyo District Court, judgment, 23 June 1987, Hanrei Taimuzu No. 639, p. 253, Hanrei Jihô No. 1240, p. 27; Tokyo District Court, interlocutory judgment, 19 June 1989, Hanrei Taimuzu No. 703, p. 246; Tokyo District Court, judgment, 29 January 1991, Hanrei Jihô No. 1390, p. 98; Shizuoka District Court, Hamamatsu Local Branch, judgment, 15 July 1991, Hanrei Jihô No. 1401, p. 98, abbreviated English translation available at <http://tomeika.jp/search/content.php?did=1531>; Tokyo District Court, 27 November 1998, Hanrei Taimuzu No. 1037, p. 235; abbreviated English translation available at $<$ http://tomeika.jp/search/content.php?did=1575>; Tokyo District Court, judgment, 30 January 2004, Hanrei Jihô No. 1854, p. 51; Tokyo District Court, judgment, 20 March 2007, Hanrei Jihô No. 1974, p. 156.

${ }^{226}$ Tokyo High Court, judgment, Minshû Vol. 55, No. 4, p. 778, 792. 
stances such that the international jurisdiction of the Japanese courts' should be negated with respect to this suit are found. ${ }^{227}$

Although some commentaries position this decision as one that adopted the theory of "special circumstances," 228 the existing theory of "special circumstances" emphasizes flexible decisions and does not particularly make an issue of whether or not the subject matter of the suits is the same ${ }^{229}$ while this decision emphasizes the issue of whether or not the subject of this suit and that of the suit in Thailand are the same, as in the theory based on anticipated recognition. Considering this point, this decision is regarded as one which requires, above all else, that the subject of the suits is the same in order for a suit pending in a foreign country to be considered in proceedings in Japan, without deciding in any way how a foreign suit will be considered if the subject of the suits is the same. ${ }^{230}$

\section{b) Other Countries}

Under Brussels I Regulation, it is provided that

[w] here proceedings involving the same cause of action and between the same parties are brought in the courts of different Member States, any court other than the court first seized shall of its own motion stay its proceedings until such time as the jurisdiction of the court first seized is established. (Art. 27(1)).

Where the jurisdiction of the court first seized is established, any court other than the court first seized shall decline jurisdiction in favor of that court (Art. 27(2)). Moreover, where related actions are pending in the courts of different member states, any court other than the court first seized may stay its proceedings (Art. 28(1)). ${ }^{231}$

However, in disputes concerning intellectual property, sometimes these provisions do not work in relation to the scope of the provision on exclusive jurisdiction with regard to the validity of patent. For example, in Ford Dodge Animal Health Ltd and others v Akzo Nobel NV (patent) licensed to Intervet International $B V{ }^{232}$ five companies of the same group, which were defendants in a Dutch litigation concerning the infringement of U.K.

227 Supreme Court, judgment, 8 June 2001, Minsĥ̂ Vol. 55, No. 4, p. 727, English translation available at <www.courts.go.jp/english/judgments/text/2001.6.8-2000-ONo. $929 \% 2$ C.2000-Ju-No.780.html> (last visited at 4 October 2009).

228 Hideyuki Kobayashi, Case Note, Hanrei Hyôron No. 518 (2002), p. 176

229 Ishiguro (supra note 220) pp. 110 et seq.

230 See Dai Yokomizo, Case Note, Hôgaku Kyokai Zasshi [Journal of the Jurisprudence Association], Vol. 119(10), p. 2106 (2002).

231 Related actions are actions "where they are so closely connected that it expedient to hear and determine them together to avoid the risk of irreconcilable judgments resulting from separate proceedings," Article 28(3).

${ }^{232}$ Supra note 153. 
and Dutch patents, sued a Dutch company in a U.K. court for anti-suit injunction against the Dutch litigation. In that case, the U.K. court acknowledged, in spite of the existence of the infringement litigation in the Netherlands, the U.K.'s exclusive jurisdiction, on the grounds that the alleged infringement of the U.K. patent is closely connected with the validity of the said U.K. patent.

In the common law countries which deal with the issue of international parallel litigation mainly by the forum non conveniens doctrine, ${ }^{233}$ sometimes they are hesitant to use this doctrine in intellectual property cases where intellectual property rights in different countries are at issue in respective actions. For example, in TS Production LLC v. Drew Pictures Pty $L t d,{ }^{234}$ the defendant of an action in an Australian court for the confirmation of the ownership of a copyright established by the Australian law claimed the confirmation of the ownership of the copyright established by the U.S. law in a U.S. court, and then claimed the stay in that Australian court on the grounds of forum non conveniens. The Australian court did not allow the stay, holding that the nature of both countries' procedures was different, in spite of the common factual relation and the common expression concerning the right of "copyright." Thus, this is a case where the court did not seek coordination with the foreign litigation concerning the dispute based on the same factual relation, considering the independence of intellectual property rights in different countries.

\section{Proposals for Conventions and Legislation}

The proposals for conventions and legislation that have been published so far commonly recognize the need to provide some coordination with respect to international parallel litigation. However, there are few indications of clear policy with respect to international parallel litigation. For example, the report by Japan's International Jurisdiction Study Group suggests that, under certain conditions, a suit in Japan can be dismissed or suspended in cases where a suit over the same claim is already pending in a foreign country. ${ }^{235}$ After referring to the existing arguments, however,

${ }^{233}$ See generally Arnaud Nuyts, L'exception de forum non conveniens: Étude de droit international privé comparé (Bruylant, 2003).

234 [2008] FCAFC 194 (19 December 2008). Cf. conflictoflaws.net, "Forum non conveniens, anti-suit injunctions, and concurrent US and Australian copyright proceedings," available at <http://conflictoflaws.net/2009/forum-non-conveniens-anti-suitinjunctions-and-concurrent-us-and-australian-copyright-proceedings/ $>$.

${ }^{235}$ Supra note 117, p. 78 et seq.

“Article 7(2) Rules relating to International Parallel Litigation

1. Given that Japanese courts have international jurisdiction, the claim can nevertheless be rejected if proceedings concerning the same claim have been already instituted before a foreign court. 
the report concludes by saying that further examination is required. ${ }^{236} \mathrm{Al}-$ though the Fifth Conference of the International Jurisdiction Legislative Committee of Japan's Legislative Council did not go so far as to propose a specific bill, the Interim Draft proposes rules based on the doctrine of anticipated recognition, on the presupposition that the international parallel litigation should be dealt with as the issue of the standing for the suit. ${ }^{237}$ The Hague Draft Convention on Jurisdiction and Foreign Judgments fundamentally adopts a theory based on anticipated recognition centered on the timing of the filing of the suits. However, certain exceptions are allowed, such as cases where the court in which the second suit is filed is clearly a more appropriate court, or where demand for a declaration of non-existence of the obligation has been filed with the court in which the first suit was filed (Art. 21)..$^{238}$

\section{2. (First drafting proposal)}

Japanese courts can suspend the proceedings concerning the claim based on which proceedings have been instituted before a foreign court, given that Japanese courts have international jurisdiction. Such decisions to suspend the process can be challenged [by the parties].

(Second drafting proposal)

Special rules are not provided.

${ }^{236}$ Id., p. 79

237 "International Parallel Litigation

[Version 1]

[Version A]

1. In cases where a suit was filed in the same case as that which is pending in a foreign court, Japanese courts may, upon a party's request or of their own motion, stay the procedure until the judgment over the case becomes final, provided that it is anticipated that the case which is pending in the foreign court finish by the judgment, and that judgment, which will become final, is likely to be effective under the provisions of Article 118 of the Civil Procedure Code.

2. An objection may be applied against the decision made under Paragraph 1.

[Version B]

1. In cases where a suit was filed in the same case as that which is pending in a foreign court, Japanese courts may stay the procedure until the judgment over the case becomes final, provided that it is anticipated that the case which is pending in the foreign court finish by the judgment, and that judgment, which will become final, is likely to be effective under the provisions of Article 118 of the Civil Procedure Code.

2. An objection may not be applied against the decision made under Paragraph 1 .

[Version 2]

No special provision with respect to international parallel litigation."

However, this provision "does not exclude the possibility of considering as a factor of special circumstances the situation of trial in the litigation pending in the foreign court."

${ }^{238}$ [Article 21 Lis pendens]

" 1 . When the same parties are engaged in proceedings in courts of different Contracting States and when such proceedings are based on the same causes of action, irrespective of the relief sought, the court second seized shall suspend the proceedings if the court first seized has jurisdiction and is expected to render a judgment capable of 
Additionally, among proposals for conventions and legislation regarding international disputes on intellectual property, some coordinate international parallel litigation according to timing, following the Brussels I Regulation as a foundation, and consider the country that granted the rights to have priority in international jurisdiction over deciding the validity of intellectual property rights. ${ }^{239}$ In particular, the CLIP Principles, while basically relying on the Brussels I Regulation, allows exceptions in cases where (a) the court later seized has exclusive jurisdiction and (b) it is manifest that the judgment from the court first seized will not be recognized under these Principles. ${ }^{240}$ In addition, it allows for any court other than the court first seized to terminate the stay in cases where the proceedings in the court first seized do not proceed within reasonable time or in cases where the court first seized has decided not to hear the case. ${ }^{241}$ Furthermore, as factors to be taken into account in cases of related proceedings, some circumstances are mentioned such as "which State has the closest connection to the dispute." 242

While these proposals adopt a relatively traditional approach about international parallel litigation, others begin with drastic plans for the international concentration of jurisdiction (joinder of claims). In other words, the ALI Principles allow the court to coordinate the matter using

being recognised under the Convention in the State of the court second seized, unless the latter has exclusive jurisdiction under Article 4 or 12.

2. ...

3. Upon application of a party, the court second seized may proceed with the case if the plaintiff in the court first seized has failed to take the necessary steps to bring the proceedings to a decision on the merits or if that court has not rendered such a decision within a reasonable time.

4. ...

5. ...

6. If in the action before the court first seized the plaintiff seeks a determination that it has no obligation to the defendant, and if an action seeking substantive relief is brought in the court second seized-

a) the provisions of paragraphs 1 to 5 above shall not apply to the court second seized, and

b) the court first seized shall suspend the proceedings at the request of a party if the court second seized is expected to render a decision capable of being recognised under the Convention.

7. This Article shall not apply if the court first seized, on application by a party, determines that the court second seized is clearly more appropriate to resolve the dispute, under the conditions specified in Article 22".

239 Article 12 of the Waseda Project Proposal proposed at the symposium described in supra note 119 (Coordination of parallel litigation). See <www.globalcoe-waseda-lawcommerce.org/activity/pdf/19/21.pdf $>$ (last visited 28 March 2010).
${ }^{240}$ Article 2:701(1)
241 Article 2:701(2)
${ }^{242}$ Article 2:702(2) 
dismissal, an order for cooperation, an order for the concentration of proceedings, or a combined order for cooperation and the concentration of proceedings, through petitions by the parties involved in the suit regarding the same or a series of transactions or events at courts in different countries. ${ }^{243}$ While a court in one country carries out coordination proceedings, courts in the other countries must wait for the decision of that court, suspending their proceedings. ${ }^{244}$

As described above, proposals for conventions and legislation regarding international parallel litigation vary in many points.

\section{Comments on the Transparency Proposal}

Under the present situation where infringement trials involving foreign intellectual property rights are accepted in many countries, it is likely that suits based on the same contract or facts will arise in the courts of multiple countries, and it is clear that there is a high need for coordination between courts. On the other hand, reasoning from the premise that there is no international convention regarding this kind of coordination at present, and based on the position taken by this paper in proposing legislation with respect to the domestic law in Japan, departing from the ALI Principles, which present a model plan to be accepted by each country, it will no doubt be difficult to adopt an international concentration of proceedings that cannot be expected to be realized through legislating in one country. ${ }^{245}$ Accordingly, it seems rational to adopt a method for dismissing suits and staying procedures in Japan, under certain conditions, with respect to international parallel litigation. However, it would be possible and beneficial at the domestic law level to prescribe cooperation among courts, in forms such as direct communication with, or requests for information from, foreign courts regarding decisions on international parallel litigation and subsequent deliberations. ${ }^{246}$ With respect to disputes concerning intellectual property in particular, the realization of this kind of cooperation seems to be more probable compared to general international civil disputes, considering the development of international exchanges between courts that specialize in this area. ${ }^{247}$ Accordingly, in this Proposal, we have decided to open up the possibility of cooperation with courts in foreign

243 The American Law Institute (supra note 23) § 221-223.

244 ALI, id., § 223 (1).

245 Cf. Annette Kur, Jurisdiction and Enforcement of Foreign Judgments: The General Structure of the MPI Proposal, in: Drexl/Kur (supra note 103) p. 25 (questioning the realizability of the ALI approach with the obstacle of languages and the different legal backgrounds).

${ }^{246}$ Cf. ALI Principles, id., p. 103 (Comment d.).

247 As for the exchange between Japanese IP High Court and foreign courts, see $<$ www.ip.courts.go.jp/documents/thes_03.html > (last visited on 31 March 2009). 
countries in Paragraph 4, using Article 25(2) of the UNCITRAL International Bankruptcy Model Law ${ }^{248}$ as a reference.

In terms of methods of coordinating international parallel litigation, there is one that works from a time-based approach, which involves the issue of which suit was filed first, as well as a method that works from a space-based approach, which involves the issue of which place is more appropriate for the suit. The existing theory of "special circumstances," which is the mainstream among precedents in Japan, takes the latter position. Although to some extent this method ensures propriety in a concrete sense, it is flawed in terms of a complete lack of foreseeability for the parties. On the other hand, it seems problematic to always grant priority to a foreign court which has a more tenuous connection with the claim compared to a court in Japan, for the sole reason that the suit in that court was filed first, even if the indirect jurisdiction of that court is more or less affirmed. The Proposal adopts a method that emphasizes the issue of the place that is more appropriate for the suit, instead of which suit was filed first, emphasizing the perspective of compatibility with the joinder of jurisdiction, and based on the idea that it is desirable for multiple claims to be decided together in the court most closely related to the dispute as a whole. In other words, in cases where the primary obligations should be or should have been performed, or the primary facts occurred or should occur, in a foreign country, and a suit based on the same cause of claim is pending in that foreign country, ${ }^{249}$ the Proposal sets forth that the suit in Japan be dismissed ${ }^{250}$ unless there are special circumstances such that the plaintiff's right to sue in Japan is practically or legally infringed by the suit in the foreign country. ${ }^{251}$ Moreover, from the viewpoint of equality of weaponry between the parties in dispute, there is no reason to always sub-

248 "The Court is entitled to communicate directly with, or to request information or assistance directly from, foreign courts or foreign representatives".

${ }^{249}$ Sometimes the place where the primary obligations should be or should have been performed, or the primary facts occurred or should occur, may not be Japan or that foreign country, but the third country. (We are grateful to Dr. Christian Heinze for his advice on this point.) In such cases, since it would be desirable for the dispute to be entirely resolved in that third country, and the claims are limited that the foreign court where the trial is pending can hear (under our Proposal's view), it would not be so reasonable for the Japanese court to dismiss the case under this provision. Accordingly, in such cases, the court has the authority only to stay the proceeding (Paragraph 2).

250 Moreover, when consideration is also given to cases of international parallel litigation where the plaintiff and the defendant are reversed, decisions regarding priority based on the general venue do not seem desirable in the context of international parallel litigation.

${ }^{251}$ For example, in cases where the scope of claim in Japan, which allows the joinder of jurisdiction, is broader than that of the relevant foreign country, if a claim for which the joinder of jurisdiction is allowed in Japan but is not allowed in such foreign country is dismissed, the international denial of a trial will arise with respect to that claim. 
ordinate suits demanding declarations of the non-existence of obligations to suits such as those that claim infringement as in the Hague Draft Convention on Jurisdiction and Foreign Judgments.

Furthermore, there is an issue of the scope of claims in suits that are coordinated, particularly the issue of how to handle suits concerning intellectual property rights in different countries. On this point, the scope of claims that that can be handled in the same suit through joinder of jurisdiction should no doubt be regarded as the scope for deeming as international parallel litigation. ${ }^{252}$ This means that even if intellectual property rights in a different country are at issue, the cases should be deemed international parallel litigation, so long as the claims are closely related, given the position of the Proposal that an objective joinder is allowed with respect to intellectual property rights in a different country in cases where each claim is closely related. Moreover, the same view would doubtless be applicable to subjective joinder and the "spider in the web" theory. It follows that this Proposal, which allows joinder of jurisdiction in a broad sense, also allows the coordination of international parallel litigation in a broad sense.

Moreover, in the cases described above, it is possible to stay the procedure in Japan until the outcome of the foreign suit is clarified, instead of dismissing the suit. Certainly, it is more or less possible to decide whether to dismiss or pursue the suit in accordance with the general rules, without incorporating provisions for stay, considering the wide variance between the trial periods for suits in each country as well as the parties' costs as a result of delays in the suit or duplicate procedures. ${ }^{253}$ There may be situations, however, where stay of the procedure is more beneficial than the dismissal of the suit - for example, where the foreign court has not begun the trial on the merits and may dismiss the suit, or where it is unclear whether the foreign decision, which is about to be made, will be recognized in Japan. Accordingly, the Proposal also accepts the court's authority to stay the procedure, and at the same time, establishes a reasonable period of time as a brake on delays in litigation.

Furthermore, there is an issue of how to handle the situation where a suit is filed in a court in Japan on the grounds of infringement of a foreign intellectual property right, and proceedings with respect to the validity of such a foreign intellectual property right are already in progress in a foreign state authority. In the case of domestic suits, Article 168(2) of the

\footnotetext{
${ }^{252}$ Cf. The Hague Court of Appeal, 23 April 1998, Expandable Grafts, Ethicon \& Cordis Europe v. Boston Scientific (supra note 151) p. 358.

${ }^{253}$ Cf. Pierre Mayer, Le phénomène de la coordination des ordres juridiques étatiques en droit privé, Recueil des cours, tome 327 (2007), 9, p. 299 (it is claimed that the dismissal is more desirable than the stay in cases of international parallel litigation in general).
} 
Patent Act, ${ }^{254}$ for example, allows the stay of the court proceeding until the trial decision becomes final and conclusive, which is a coordination provision for cases where an infringement suit and an invalidation trial are carried out in parallel. This provision seems to be rarely used, however, due to demands for prompt dispositions. ${ }^{255}$ Promptness of dispute resolution is also important in international trials. On the other hand, it is also important to prevent conflicting legal relationships between countries from occurring to the extent possible, and the Proposal therefore also incorporates provisions for stay. Further, the same matters described for objective joinder apply here as well with respect to claims regarding matters of exclusive jurisdiction.

\section{Concluding Remarks}

The Transparency Proposal takes a pragmatic approach to jurisdictional questions of cross-border intellectual property litigation. It does not preempt Japanese courts from deciding cases over foreign IP rights and opens the gates for decisions upon such issues as validity, existence, and other sovereignty-related issues that arise as a preliminary question. Efficiency is considered as the main underlying objective of the proposed jurisdiction rules pertaining to joinder of related claims and coordination of parallel proceedings. Mindful of the fact that it becomes more and more difficult to agree upon multilateral convention on jurisdiction and foreign judgments, the Transparency Proposal takes a bottom-up approach which aims to streamline international IP dispute settlement proceedings (e.g., by permitting the courts to initiate direct communications). In addition, the partycentered approach is expected to contribute to the development of consonant domestic legal rules and thus facilitate global exploitation of intellectual property assets and access to knowledge.

\footnotetext{
254 "In cases where a suit is filed or a petition for a provisional seizure order or a provisional disposition order is filed, where it is acknowledged as necessary, the court may suspend the court proceedings until the decision becomes final and conclusive".

${ }_{255}$ Makiko Takabe, Tokkyo hô 104 jô no 3 wo kangaeru [Reflecting on Article 104ter of Patent Act], Chiteki Zaisan Hô Seisaku Gaku Kenkyû [Journal of Intellectual Property Law \& Policy], Vol. 11 (2006), p. 123, 134 et seq.
} 


\title{
Summary of Comments and Discussion on Jurisdiction
}

\author{
by Paulius Jurcys, Yuko Nishitani, and Simon Vande Walle
}

\section{Comments made by Prof. Yuko Nishitani}

In her introductory remarks, Prof. Nishitani drew attention to the fact that the Transparency Proposal primarily aims at the reform of current Japanese law, especially in relation to international jurisdiction to adjudicate, ${ }^{1}$ while the ALI Principles and CLIP Principles seek universal principles on issues concerning international intellectual property law. She then commented, among others, on the rules regarding (1) exclusive jurisdiction and (2) jurisdiction over intellectual property infringements.

Prof. Nishitani remarked that it is generally acknowledged that the registration and validity of patents, trademarks, and other similar industrial property rights falls within the exclusive jurisdiction of the country of registration. ${ }^{2}$ This rule concerns in rem disputes as against third parties.

The CLIP Principles provide that there is no exclusive jurisdiction rule when the validity or registration of patents et al. arises in a context other than by principal claim or counterclaim (Art. 2:401(1)). Hence, the court that has jurisdiction over the infringement of a patent can incidentally decide on its validity, ${ }^{3}$ as opposed to the GAT v. LuK ruling of the European Court of Justice. ${ }^{4}$ For the sake of practicality and an expeditious

\footnotetext{
${ }^{1}$ After the original Hague Judgment Project failed, the Ministry of Justice decided to prepare a national legislation and established the Legislative Commission on International Jurisdiction for consultations on 3 September 2008. (The minutes of the Commission on International Jurisdiction can be downloaded from the website of the Ministry of Justice: <www.moj.go.jp> [available only in Japanese].) The enactment by the Diet is envisaged for 2010.

2 See Art. 22 (4) of the Council Regulation (EC) No 44/2001 of 22 December 2000 on jurisdiction and the recognition and enforcement of judgments in civil and commercial matters, O.J. L 12, 16/1/2001, 1 (hereinafter "Brussels I Regulation").

3 See CLIP, Exclusive Jurisdiction and Cross Border IP (Patent) Infringement: Suggestions for Amendment of the Brussels I Regulation, published at: <www.cl-ip.eu> (hereinafter "Opinion").

${ }^{4}$ ECJ, 13 July 2006 - Gesellschaft für Antriebstechnik mbH \& Co. KG (GAT) v. Lamellen und Kupplungsbau Beteiligungs $K G$ (LuK), Case C-4/03, [2006] ECR I-6509; see also ECJ, 13 July 2006 - Roche Nederland BV et al. v. Frederick Primus and Milton Goldenberg, Case C-539/03, [2006] ECR I-6535. If the validity issue were always subject to the exclusive jurisdiction, the right holder would be obliged to enforce his or her IP rights in each country of registration. It is not only cumbersome, but also could result in contradictory decisions for parallel patents. Furthermore, the infringer may strategically raise the invalidity defense to hamper the infringement suit, without bringing an invalidation claim in the country of registration (see the solution adopted by the Handelsgericht Zürich, 13 October 2006 [GRUR Int. 2007, 258; sic! 2006, 854], which set a time frame for the alleged infringer to bring an invalidation suit in the country of registration).
} 
dispute resolution, the same solution was rightly adopted by the ALI Principles and the Transparency Proposal. ${ }^{5}$

Interestingly enough, the Preparatory Report of the Legislative Commission of Japan's Ministry of Justice ${ }^{6}$ advocates a substantive law solution. It puts forth that the admissibility of the invalidity defense in an infringement suit is not a matter of jurisdiction, but of substantive law. This approach certainly has the advantage of guaranteeing the recognition of Japanese judgments in the foreign country of registration. It is said that, concerning Article 22(4) of the Brussels I Regulation, the District Court of Düsseldorf in Germany had adopted a comparable substantive law solution prior to the GAT v. LuK ruling of the European Court of Justice. ${ }^{7}$ Prof. Nishitani stated that she would be interested in hearing more about this and the reason why the CLIP Principles did not follow the substantive law approach. $^{8}$

The ALI Principles and the Transparency Proposal further allow a declaratory judgment on the validity of foreign patents, having effects between the parties. While the ALI Principles restrict this jurisdiction to the defendant's domicile for multiple patents (§ 213(3)), the Transparency Proposal does not set any limits (Art. 101(2)). Japanese courts would then be supposed to declare the invalidity of a German patent as having effects between the parties. The usefulness of such a claim is, however, doubtful. Moreover, under Japanese civil procedure law, which is modeled after German law, the requirement of procedural interests (Feststellungsinteresse) must be fulfilled.

In support of Article 101(2), the Transparency Proposal refers to two court decisions that granted Japan's jurisdiction over disputes on the transfer of a U.S. patent between the employer and the employee, ${ }^{9}$ and the deletion of a transfer registration of Jordanian trademarks. ${ }^{10}$ Although both cases indirectly concerned a registered foreign patent or trademarks, the

\footnotetext{
5 This principle is in line with Japanese law. Under the Japanese Patent Act, courts can incidentally decide on the validity of patent in an infringement dispute (Art. 104ter), without referring to the Patent Office for invalidation (Art.123 seq.).

${ }^{6}$ See supra note 1.

${ }^{7}$ Landgericht Düsseldorf, 1 February 1994; 1 June 1996 (cited from CLIP, Opinion, 3 , note 3 )

${ }^{8}$ The Preparatory Report of the Legislative Commission also rightly contends that, when the invalidation suit is pending in the foreign country of registration, the Japanese judge should have discretion to stay the infringement proceedings in Japan (Art. 168(2) Japanese Patent Act mutatis mutandis).

9 Japanese Supreme Court, 24 January 1995, LEX/DB 28031877 [Tokyo District Court, 22 October 1993, Chiteki Zaisan Hanreishû 26-2, 729; Tokyo High Court, 20 July 1994, Chiteki Zaisan Hanreishû 26-2, 717] [Card Reader case].

${ }_{10}$ Tokyo High Court, 9 August 2004, LEX/DB 28092186 [Tokyo District Court, 4 March 2004, LEX/DB 28090939] [FUJIKA trademark case].
} 
subject matter was not in rem, but the parties' contractual obligations to transfer the intellectual property rights. ${ }^{11}$ In Prof. Nishitani's opinion, these disputes should be characterized as "contracts" and fall a priori outside the scope of Article 101..$^{12}$ In this respect, she said, the meaning, purpose, and scope of this provision need to be clarified.

Prof. Nishitani next addressed the rules on jurisdiction over intellectual property infringements. The ALI Principles, CLIP Principles, and the Transparency Proposal all characterize the infringement of intellectual property rights as a tort. Hence, the plaintiff can bring a suit either at the defendant's domicile (habitual residence), or at the place of the tort. Under the Transparency Proposal (Art. 107), Japan's jurisdiction can exceptionally be declined in "special circumstances," when the exercise of jurisdiction would be contrary to fairness between the parties, or equitable and expeditious proceedings. Such a forum non conveniens exception is not provided for in the ALI Principles and the CLIP Principles.

With regard to "complex torts," the ALI Principles (§ 204(1)(2)) grant jurisdiction to the courts of both the place where the alleged infringer acted (locus delicti commissi) and the place where the damage occurred (locus damni). In intellectual property cases, the locus damni means the country of protection of the intellectual property rights. It includes the country to which the infringing activities are directed by a website or other media. On the other hand, the CLIP Principles do not provide for the jurisdiction of locus delicti commissi (Art. 2:202), on the ground that the infringement can only occur in country of protection A where the right exists; preparatory acts of infringement committed in country B do not open jurisdiction in country B for an infringement that occurred in country A.

Prof. Nishitani gave an example by slightly modifying the BlackBerry case. ${ }^{13}$ Suppose a Japanese company operates BlackBerry devices by sending signals from Canada to the U.S. Then a U.S. company claims that these activities infringe its U.S. patents. If the Japanese company does not have any branch office in Canada, there is no jurisdiction there under the CLIP Principles. However, for the sake of effective remedies, especially injunc-

11 On the other hand, Tokyo District Court, 26 September 2003, LEX/DB 28082748 [cf. Tokyo High Court, 21 January 2004, LEX/DB 28090621] concerned a claim of the employee against the employer for the vindication of Japanese and U.S. patents, which had been obtained by the employer without an agreement, accompanied by a claim for damages. The judge decided that Japan did not have international jurisdiction for the vindication of the U.S. patent.

12 In this sense, also ECJ, 15 November 1983 - Ferdinand M.J.J. Duijnstee v Lodewijk Goderbauer, Case 288/82, [1983] ECR 3663 (a dispute between the employer and the employee over the right to obtain a patent was considered to fall outside Article 16 (4) Brussels Convention (Art. 22 (4) Brussels I)).

${ }_{13}$ U.S. Court of Appeals for the Federal Circuit, NTP v. Research in Motion, Ltd. (418 F.3d 1282) 
tions, it makes sense to grant jurisdiction to the Canadian courts, as the ALI Principles suggest. Otherwise, the U.S. company would have to obtain a judgment in the U.S. or Japan and have it enforced in Canada, even if provisional measures are available in Canada under the CLIP Principles (Art. 2:501). Certainly, because of the territorial characteristics of intellectual property rights, the infringement presupposes that the result is felt in the country of protection. If, however, the U.S. patent is actually being infringed, it may be reasonable to capture the preparatory acts directly in Canada. Prof. Nishitani asked the ALI and CLIP members about their opinion in this respect.

Article 106 of the Transparency Proposal follows the model of the ALI Principles. For "ubiquitous infringements," the locus damni jurisdiction is open when the substantial damage occurs in Japan. However, the locus delicti commissi jurisdiction seems to be excluded. The report explains that the location of a server alone does not constitute a substantial connection with the infringement. Hence, when a company places copies of "Le petit prince" in French on a website operated in Japan and the infringement occurs only in France, Japan's jurisdiction is denied, unless the company has its place of business in Japan. According to Prof. Nishitani, the reasoning is not clear, as it does not constitute a "ubiquitous infringement," the damage being felt only in France, and Japan as the locus delicti commissi should have jurisdiction under Article 106, first sentence. This point should be further clarified in her opinion.

Further, Prof. Nishitani indicated that, in all the proposals, the extent of the locus damni jurisdiction is restricted to infringements that occurred in that country, following the "mosaic approach" (§ 204(2) of the ALI Principles; Art. 2:203 of the CLIP Principles; about the Transparency Proposal see p. 98). The CLIP Principles exceptionally deviate from the mosaic approach in cases of infringements by "ubiquitous media" such as the Internet. It allows the court to exercise jurisdiction over infringements that occurred in other countries if substantial activities have been carried out or substantial harm has been caused in the forum state (Art. 2:203 (2)).

As a specificity of Japanese law, the same result can be reached through "joinder of claims." This means that when Japan has international jurisdiction for one claim, the court can extend its jurisdiction to other claims between the same parties if the claims are related with each other. ${ }^{14}$ To avoid exorbitant jurisdiction, the Transparency Proposal restricts joinder of

\footnotetext{
14 Japanese Supreme Court, 8 June 2001, Minshû 55-4, 727 [Ultraman case]; for further detail, see Nishitani, in: Baum/Bälz (ed.), Handbuch des japanischen Handelsund Wirtschaftsrecht, § 24: Internationales Privat- und Zivilverfahrensrecht (forthcoming 2009).
} 
claims to cases where the substantial parts of the wrongful act took place in Japan (Art. 108).

\section{Discussion}

Prof. Ueno pointed out that the Transparency Proposal uses the term "ubiquitous infringement" (Art. 106), rather than the term "ubiquitous media," which is used in the CLIP Principles (Art. 2:203(2)), because it is hard to foresee how technology and intellectual property infringements will develop in the future. In the future there may be ubiquitous media other than the Internet and ubiquitous infringements may also be caused by non-ubiquitous media. Hence, the drafters of the Transparency Proposal chose the term "ubiquitous infringement" rather than ubiquitous media and the jurisdiction rules were drafted based on that concept.

Prof. Chaen responded to Prof. Nishitani's questions about the rules on jurisdiction over disputes relating to the validity of intellectual property rights. He first clarified that the Transparency Proposal does not contain an exclusive jurisdiction rule: Japanese courts can accept jurisdiction over actions concerning the validity of intellectual property rights prescribed under foreign law. He subsequently addressed Prof. Nishitani's question as to whether this rule was really useful. He pointed out that, according to practitioners, such a rule would indeed be useful. If Japanese courts have to decline jurisdiction every time the defense of invalidity is raised, this could really hamper the smooth conduct of proceedings. For instance, arbitration proceedings could get blocked if the defense of invalidity is raised.

Dr. Heinze responded to Prof. Nishitani's comments about the rules on jurisdiction for intellectual property infringements and, in particular, her question as to why the CLIP Principles only confer jurisdiction for infringements to states where the intellectual property right exists. In her presentation, Prof. Nishitani had pointed out that this rule may raise enforcement issues in certain cases. She had given the example of a case based on a slightly modified version of the BlackBerry case, ${ }^{15}$ i.e., the case of a Japanese company violating a U.S. patent by sending signals from Canada to BlackBerry devices in the U.S. If the Japanese company does not have a branch office in Canada, Canadian courts would not have jurisdiction under the CLIP Principles and preparatory acts could not be enjoined in the state where these acts take place. Instead, the action would have to be filed in the state where the infringement takes place. The judg-

${ }^{15}$ U.S. Court of Appeals for the Federal Circuit, NTP v. Research in Motion, Ltd. (418 F.3d 1282). 
ment rendered in that state would then have to be enforced in the state where the preparatory acts take place.

Dr. Heinze responded that, although he understood the concern about enforcement, there are several objections against a rule that gives jurisdiction to a state in which the right does not even exist. First, from a dogmatic point of view, it is odd to grant jurisdiction over an intellectual property infringement to a state which has no relationship with the infringement. Second, one needs to look at the purpose of the special jurisdiction rules for torts, which is to ensure that there is proximity of evidence, i.e., it is assumed that the relevant evidence relating to the tort can be found in the state where the tort occurred. However, if an action is brought in a state where there is no infringement, because the intellectual property right does not even exist in that state, what evidence relevant to establish the infringement could be found there? Third, Prof. Nishitani's question arises out of a concern for effective enforcement and the need to obtain redress quickly. However, in cases where a quick remedy is required, plaintiffs can seek provisional measures and rely on the special jurisdiction rules for provisional measures.

Prof. Basedow pointed out that Article 2:202 of the CLIP Principles does not provide that infringement actions can only be brought in the court of the state where the infringement occurs. One could see Article 2:202 as an additional ground of jurisdiction. He also questioned whether the view that the only state that matters is the state where the intellectual property right exists, can really be maintained in cases of worldwide dissemination of data. If you upload something in Japan that infringes rights in Germany, Spain, etc., is it reasonable to say that the act of uploading is irrelevant? Prof. Basedow also questioned the view that there is unlikely to be relevant evidence in the state where the preparatory acts take place. In the state where the material is uploaded, there could, for instance, be witnesses who could testify that certain material was uploaded at a certain point in time.

Dr. Heinze subsequently responded to Prof. Nishitani's question as to why the CLIP Principles did not follow the substantive law approach to deciding whether the invalidity defense is admissible. Prof. Nishitani had pointed out that this approach had been adopted by the Landgericht Düsseldorf. ${ }^{16}$ Dr. Heinze replied that this approach is rather complicated because it requires the court to look at the lex loci protectionis to decide whether the invalidity defense is admissible in an infringement action. $\mathrm{He}$ mentioned three reasons why the CLIP Principles did not follow this approach. First, the approach runs squarely counter to the GAT/LuK deci$\operatorname{sion}^{17}$ of the European Court of Justice. A proposal based on that approach

\footnotetext{
16 See supra note 8.

17 Case C-4/03, GAT v. LuK [2006] ECR I-6509.
} 
would therefore have little chance of being adopted by the legislator. Second, it is debatable whether the admissibility of the invalidity defense is really a substantive law question rather than a procedural question. Third, the approach leads to different results depending on the substantive law of different countries. The CLIP Principles tried to find a uniform solution.

A member of the audience asked Dr. Heinze why so many states cling to exclusive jurisdiction rules for disputes relating to the validity of intellectual property rights. Could it be that lobbying by intellectual property practitioners of the countries concerned plays a role? Dr. Heinze stated that lobbying probably plays a role but, above all, the dominant view is that granting an intellectual property right is really an act of state, closely linked to the state's right to conduct its own competition and trade policy. States are therefore wary of a rule that would allow a foreign court to invalidate such an act.

Prof. Dessemontet proposed making a distinction between the validity of a (patent) right and possible remedies. In particular, Prof. Dessemontet thought that it may be useful to draft distinct jurisdiction rules for cases where the defendant has challenged the validity of a given patent and cases where the defense of non-infringement is raised. Hence, there could be two territorial approaches: "a truly territorial approach" for the question of invalidity and a "relaxed territorial approach" allowing consolidation in case of multi-territorial infringements. Even though one might argue that this legislative solution is problematic, a number of problems are also inherent in the traditional approach pursuant to which only the courts of the state of registration have exclusive jurisdiction to decide the validity of a patent right granted by the state of the forum.

Prof. Basedow raised a question concerning the jurisdiction rule for actions concerning license agreements in the Transparency Proposal (Art. 102). He asked what this article meant for choice-of-forum clauses that confer jurisdiction to courts outside of Japan or refer the dispute to arbitration. Prof. Chaen explained that Japanese courts would respect such a choice-of-forum clause. For instance, if a licensing agreement relating to an intellectual property right under Japanese law grants jurisdiction to the courts of Singapore, the courts of Singapore would have jurisdiction, concurrent with the Japanese courts. If the forum selection clause grants exclusive jurisdiction to the courts of Singapore, then only the courts of Singapore would have jurisdiction over disputes relating to the contract.

A member of the audience asked whether Article 102 of the Transparency Proposal implied that the Proposal did not adopt a rule based on the place of performance of the obligation in question, in contrast to the CLIP Principles (Art. 2:201). Prof. Chaen confirmed that this was indeed 
the case. Determining the place of performance of the obligation in question is often a difficult exercise, as license agreements often involve multiple obligations. The rule in the Transparency Proposal is therefore based on whether the intellectual property right is granted under Japanese law or not. This was considered to be the solution that gives the parties the highest degree of clarity and foreseeability.

Prof. Dessemontet asked how Article 102 of the Transparency Proposal would be applied in case of license agreements relating to many different patents, some of which were granted under Japanese law, but some of which were granted under foreign law. Surely, the Japanese court would have jurisdiction over the parts of the dispute relating to the Japanese patents. But would the Japanese court also have jurisdiction over the other patents? Prof. Yokomizo clarified that Article 102 only gives jurisdiction for the intellectual property rights under Japanese law but that joinder of claims may be possible pursuant to Article 108 of the Transparency Proposal. Hence, through a combination of Article 102 on license agreements and Article 108 on consolidation of claims, the Japanese court would likely have jurisdiction over the entire case. 

Part 3: Applicable Law 



\title{
Applicable Law under the CLIP Principles: A Pragmatic Revaluation of Territoriality
}

\author{
AXEL MetzGer

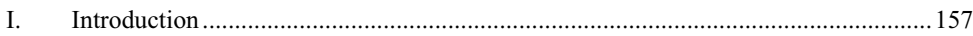

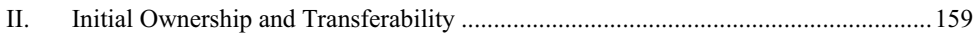

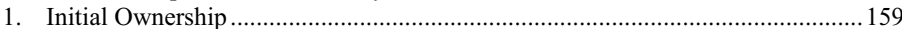

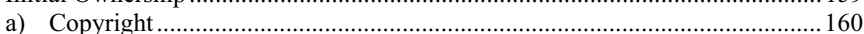

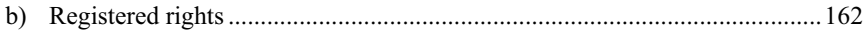

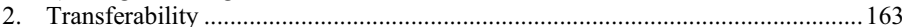

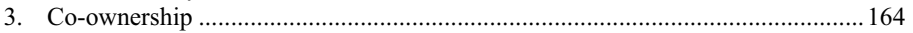

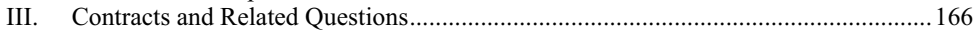

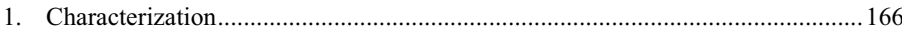 \\ 2. Applicable Law in the Absence of Choice ........................................................ 167

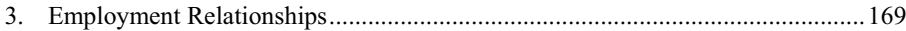 \\ 4. Questions Not Dealt with in the Principles Regarding Contract Law ................... 170

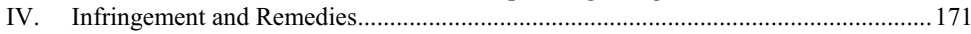

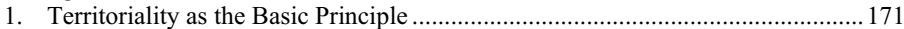

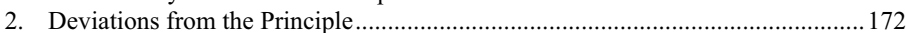

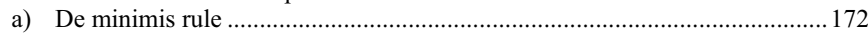

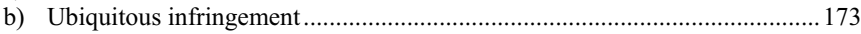

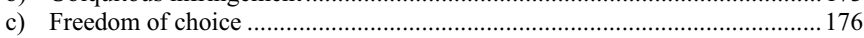

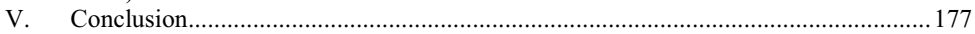

\section{Introduction}

Territoriality has undoubtedly been the leading approach from the early days of protection of intellectual property. ${ }^{1}$ But it is also true that the principle has been controversial for the last forty years. Some early voices pleaded in the 1970s for a universalist concept of intellectual property - at least for copyright law - pointing to the continental theory of copyright as a personal right on the one hand and to the practical problems arising from

\footnotetext{
${ }^{1}$ See the contribution of Jürgen Basedow to this volume, at p. 7 seq.
} 
the territorial approach in multistate situations on the other hand. ${ }^{2}$ But these early universalists always kept their status as an endangered minority. Few lawmakers followed their ideas, ${ }^{3}$ and if courts applied one single law to multistate situations, they often corrected the consequences of the lex originis by reference to the public policy of the forum. Therefore, most authors rejected the universalists' approach and stuck with the traditional territorial concept. According to the predominant theory, it was the state authority that created intellectual property rights, whether by individual decision of the state's authorities, especially the trademark or patent office, or by general legislation granting property rights in the fields of arts and sciences. ${ }^{4}$ As a consequence, according to the territorial approach, intellectual property legislation was not applicable to activities conducted outside the territory of the state granting the intellectual property right. ${ }^{5}$

Nevertheless, the idea of applying one single law to multistate intellectual property cases was born. And it was not surprising that after the World Wide Web was established in the early 1990s, some of the old partisans of the lex originis approach and a fast growing number of new adepts raised the argument that a territorial concept of intellectual property would be outdated and should be avoided when deciding cases from "cyberspace." Against this background, the discussion on territoriality or universalism in intellectual property law heated up again in the early 1990s and has been debated vividly ever since. It is not the subject of this paper to give a comprehensive overview of the arguments and positions taken in this debate.

\footnotetext{
${ }^{2}$ See, e.g., Haimo Schack, Zur Anknüpfung des Urheberrechts im internationalen Privatrecht (1977), pp. 23 et seq.; Paul Heinrich Neuhaus, Freiheit und Gleichheit im internationalen Immaterialgüterrecht, RabelsZ 40 (1976), 191; Ulrich Drobnig, Originärer Erwerb und Übertragung von immaterialgüterrechten im Kollisionsrecht, RabelsZ 40 (1975), 195. From the older literature, see E. Bartin, Localisation territoriale des monopoles intellectuels, Clunet 61 (1934), 781 et seq.

${ }^{3}$ See, e.g., Art. 48 of the Código civil português of 1966 and Art. 67 of the Greek Copyright Act of 1993.

4 A representative description is provided by Hanns Ullrich, Technologieschutz nach TRIPS, Prinzipien und Probleme, GRUR Int. 1995, 623, 624 et seq.

${ }^{5}$ On the extraterritorial application of intellectual property law, see Graeme $B$. Dinwoodie, Extra-Territorial Application of IP Law: A View from America, in: Leible/ Ohly (eds.), Intellectual Property and Private International Law (2009), 123-136; Josef Drexl, Internationales Immaterialgüterrecht, in: Münchener Kommentar zum Bürgerlichen Gesetzbuch, Vol. 11, $4^{\text {th }}$ ed. (2006), IntImmGR, at 174 et seq.

${ }^{6}$ See, e.g., François Dessemontet, Conflict of Laws for Intellectual Property in Cyberspace, 18 J. of Int. Arb. 487, 506-07 (2001); Jane C. Ginsburg, Private International Law Aspects of the Protection of Works and Objects of Related Rights Transmitted Through Digital Networks, 30 November 1998, available at <www.wipo.int/ meetings/en/doc_details.jsp?doc_id=926>, pp. 35-36; Haimo Schack, Internationale Urheber-, Marken- und Wettbewerbsrechtsverletzungen im Internet, MMR 2000, 59-65 and $135-140$.
} 
Rather, this paper will present some core provisions of the current draft of the CLIP Principles ${ }^{7}$ concerning the applicable law. Together with the ALI Principles of $2007,{ }^{8}$ the CLIP Principles represent a condensed outcome of this debate. It should be expected, in all modesty, that the two sets of principles together with the Japanese "Transparency Proposal" will be seen as an important milestone in the ongoing discussion. One of the most interesting aspects of the three projects is that they are not pleading for a universalist concept of intellectual property. Rather, they unanimously establish a modern and pragmatic revaluation of the territoriality principle, notwithstanding some remarkable deviations in certain aspects. Hence, it seems that the principle of territoriality, so far, has resisted the challenge of the Internet revolution and has prevailed in a revised version.

This paper will highlight the core provisions of the CLIP Principles on applicable law and compare them with the ALI Principles, starting with ownership and transferability (infra II.) and continuing with contracts (infra III.) and infringement and remedies (infra IV.). A short conclusion will summarize the main results and identify the current status of the principle of territoriality (infra V.).

\section{Initial Ownership and Transferability}

\section{Initial Ownership}

One of the most controversial questions in international intellectual property disputes is the issue of initial ownership. National copyright systems provide for different solutions on the substantive law level, especially in cases of employed authors, i.e., work-made-for-hire situations. Some jurisdictions define the employer as the initial owner of the copyright in the work. This solution is common to the so-called "copyright systems," especially the United States and the United Kingdom, ${ }^{10}$ but it can also be found elsewhere, e.g., in the Netherlands or in Japan. ${ }^{11}$ By contrast, the traditional approach in the "droit d'auteur" states is to define the natural person who has created the work without any exceptions as the author, and hence

${ }^{7}$ See European Max Planck Group on Conflict of Laws in Intellectual Property $(C L I P)$, Principles for Conflict of Laws in Intellectual Property, Second Preliminary Draft (6 June 2009), infra at Annex II.

${ }^{8}$ See American Law Institute, Intellectual Property: Principles Governing Jurisdiction, Choice of Law, and Judgments in Transnational Disputes, 2007.

9 See the Draft Proposal of the "Transparency Project," infra at Annex III.

${ }^{10}$ See Sec. 201 (b) U.S. Copyright Act of 1976 and Sec. 11 (2) of the U.K. Copyright, Designs and Patents Act of 1988.

${ }^{11}$ See Art. 7 of the Dutch Copyright Act and Sec. 15 of the Japanese Copyright Act. 
as the initial owner of the author's right. ${ }^{12}$ Similar questions may arise in the field of technological inventions made by employees. Here, the entitlement may either be attributed to the employer or to the employee. ${ }^{13}$

\section{a) Copyright}

Initial ownership is not only treated differently on the substantive law level but also in private international law. Some jurisdictions apply the lex loci protectionis, e.g., Germany, Austria, and Belgium, ${ }^{14}$ whereas others plead for the law of the country of origin, e.g., France, Portugal and the United States. ${ }^{15}$ The CLIP working group concluded after intense discussions that a territorial approach is the preferred solution (see Article 3:201 para. 1). At first glance, the application of the lex originis approach may seem better suited for authors and media industries with an international public because it provides for the worldwide application of one national copyright law to the question of ownership. But the practical experience with the approach has shown that courts are not willing to accept the consequences of the lex originis and apply their national copyright law as part of the public policy of the forum. The French case John Houston, decided by the Court of Cassation in $1991,{ }^{16}$ provides a good example of the difficulties of this approach. In this case, the court allowed the director John Houston, an American citizen, to claim for infringement of his moral rights in the black-and-white film Asphalt Jungle when the copyright owner planned to broadcast a colored version of the film in France. Taking the lex originis approach literally would have meant denying the director any rights in the movie since the movie studio was the initial owner of the copyright according to the law of the place of first publication, which was the law of

${ }^{12}$ See, e.g., Sec. 7 of the German Copyright Act and Art. L. 111-1 of the French Intellectual Property Code.

13 For the U.S., see Magnetic Mfg. Co. v. Dings Magnetic Separator Co., 16 F.2d 739 ( $7^{\text {th }}$ Cr. 1927). For Germany, see Sec. 4 Employee's Inventions Act.

${ }^{14}$ For Germany, see Federal Court of Justice, 02 October 1997, GRUR 1999, 152 Spielbankaffaire; for Austria, see Supreme Court, 17 June 1980, JB1. 1986, 655 = GRUR Int. 1986, 728 - Hotel-Video; for Belgium, see Art. 93 para. 1 Private International Law Code. Art. 93 para. 2 is explicitely restricted to industrial property; see Marta Pertegás Sender, Artikel 93 (Recht toepasselijk op intellectuele eigendom), in: Erauw et. al. (eds.), Het Wetboek Internationaal Privaatrecht becommentarieerd (2006), p. 477.

15 For France see Court of Cassation, 28 May 1991, D. 1993, jur. 197 - John Huston; for the United States, see Itar-Tass Russian News Agency v. Russian Kurier, Inc., 153 F.3d 82 ( $2^{\text {nd }}$ Cir. 1998). For Protugal see Art. 48 para. 1 Civil Code and Dário Moura Vicente, La propriété intellectuelle en droit international privé, Recueil des cours 335 (2008), 279-80.

${ }^{16}$ See supra note 15. 
the United States. But the Court of Cassation did not accept this result of the lex originis and applied its national copyright principles.

The disadvantage of this approach is obvious: applying the French copyright law as public policy or as internationally mandatory provisions means that it can only be enforced by French courts, which interferes with international harmony of decisions and favors forum shopping and opportunistic behavior. Applying the lex originis leads to the additional problem of which state should be regarded as the country of origin. The most common approach here is to define the lex originis in accordance with Article 5 para. 4 lit. a) Berne Convention as the law of the place of first publication. By contrast, the ALI Principles suggest in $\S 313$ para. 1 lit. a) the application of the law of the place of habitual residence of the creator at the time of creation or, if the subject matter was created pursuant to an employment relationship, of the law that governs the relationship (lit. c).

Applying the lex loci protectionis prevents those frictions. ${ }^{17}$ If one adheres to the idea, as the French Court of Cassation obviously did, that the regulatory choices of the national copyright legislation should prevail in all cases concerning the use of works within the borders of that state, then one should insist on its application irrespective of whether the claim is brought before a court within the state of protection or whether it is brought before a forum located elsewhere. This may be effected best by the lex loci protections rule. There is also a policy argument for a territorial approach. The attribution of rights has repercussions on the incentives and working conditions of those involved in the creation of copyright-protected contents. It makes a difference in the production of movies, music recordings, etc., if the authors or the producers are the original rightholders. Territoriality is not just a traditional (and some may say obsolete) concept in intellectual property law, but a legal means to execute the cultural policy choices of states. Initial ownership in copyright is an essential part of this policy choice.

Admittedly, the lex loci protectionis may lead to the application of a multitude of applicable laws in multistate situations. As a result, the initial owner of copyright in the work may be a natural person in one state and a legal entity in another state. But the practical problems of this "mosaic approach" are often exaggerated. It is the majority opinion in both German and Austrian copyright law, as examples of typical droit d'auteur systems, that employees explicitly or tacitly grant an exclusive license for all eco-

\footnotetext{
17 On the additional problem of a cumulation of industrial and intellectual property rights under different choice-of-law rules regarding ownership, see Ansgar Ohly, Choice of Law in the Digital Environment - Problems and Possible Solutions, in: Drexl/Kur (eds.), Intellectual Property and Private International Law (2005), p. 241 (249-50).
} 
nomic rights in the work to the employer. ${ }^{18}$ Hence, the attribution of the economic rights would not differ significantly in a typical work-made-forhire situation. This is the background of Article 3:201 para. 2 ("Ownership") of the CLIP Principles. If, e.g., the director of a movie and the movie studio are situated in country $\mathrm{X}$, and if under the law of country $\mathrm{X}$ the movie studio would be the initial owner of the copyright in the film, the parties would probably not make any additional explicit transfer or license grant. A German or Austrian court would nevertheless admit that the movie studio is the transferee or licensee of the economic rights in the work. $^{19}$

\section{b) Registered rights}

Article 3:201 para. 1 CLIP Principles is applicable to all types of intellectual property including industrial property rights, especially patents and trademarks. However, according to Article 3:201 para. 3, different rules apply in case of contractual agreements concerning the initial ownership in registered rights. The right to claim a registered right, in particular the right to file an invention at the patent office, is transferable under the substantive law provisions of many jurisdictions. ${ }^{20}$ Therefore, it was the opinion of the CLIP working group that it should be up to the parties to choose the applicable law to such entitlements. Where the applicable law to the contract has not been determined by the parties, the law with the closest connection according to Article 3:502 shall apply. ${ }^{21}$ In case of an employ-

${ }^{18}$ For Germany, see Sabine Rojahn, in: Schricker (ed.), Urheberrecht, Kommentar, 3. ed. (2006), § 43, at 40. For Austria, see OLG Wien, 27 October 1986, MR 1988, 199 Echo.

19 The wording of Art. 3:201 para. 2 CLIP Principles is partly inspired by Art. 2 para. 3 of the Council Directive 91/250/EEC of 14 May 1991 on the Legal Protection of Computer Programs, OJ L 122, 17 May 1991, pp. 42-46 ("all economic rights"). It would be odd in such a case to attribute the economic rights in the work to the employee since both parties assumed during the production of the work that the exclusive rights should be held by the employer. Here, the provision may give some guidance for the interpretation of the relationship of employer and employee. It can hardly be compared to the "effect may be given" proviso of Art. 9 para. 3 "Rome I" Regulation, which gives discretion to courts regarding foreign overriding mandatory provisions (see Regulation (EC) No 593/2008 of the European Parliament and of the Council of 17 June 2008 on the law applicable to contractual obligations (Rome I), OJ L 177, 4 July 2008, pp. 6-16). For a more skeptical analysis, see the contribution of Jürgen Basedow to this volume, at VII. 2.).

${ }^{20}$ See, e.g., Art. 60 European Patent Convention; Sec. 6 German Patent Act; Sec. 7 (2) lit. c) UK Patents Act; Art. L. 611-6 French Intellectual Property Code; Sec. 261 para. 2 U.S. Patent Act.

${ }^{21}$ This should allow a pragmatic solution of the problems raised by the hypothetical situation discussed in the contribution of Jürgen Basedow, at IV, p. 10. The changes 
ment contract, the specific provisions of Article 3:503 are applicable. As a consequence, the territorial approach to initial ownership as laid down in Article 3:201 para. 1 is only applicable if there is no contractual agreement concerning the right to claim the registered rights.

\section{Transferability}

Closely related to the issue of initial ownership is the question whether intellectual property rights can be transferred. The question, again, is of particular interest for copyright law because the droit d'auteur systems often provide restrictions on the transferability of the copyright or of particular claims. These restrictions are mostly justified by the personal right approach to copyright $\operatorname{law}^{22}$ and the unwritten principle according to which personal rights cannot be transferred. ${ }^{23}$ But non-transferability rules also aim at protecting the author against a total buy-out of his rights in the work. ${ }^{24}$ As such they complement the rules on initial ownership. Whatever contract an author may sign, he is still regarded as the author and as such is entitled with a bundle of essential rights in the work. This is, e.g., the solution of the German (Sec. 29) and the Austrian Copyright Acts (Sec. 23). Under French copyright law, moral rights are unwaivable (Article L. 121-1 al. 3 French Intellectual Property Code); in addition, the transfer and license of economic rights is tied to several restrictions (Articles L. 131-1, 131-3, and 131-6 of the Code). These safeguards would be vain if the initial ownership was not attributed to the author. And, conversely, it would be a useless endeavor to insist on the author as the initial owner if the right in the work could be transferred by handshake. Hence, initial ownership and transferability should not be governed by different laws; a dépeçage should be avoided. Nonetheless, the ALI Principles plead for exactly this approach in $\S 314$, which provides for the lex loci protections approach for the issue of transferability, although $\S 313$ para. 1 lit. a) provides the lex originis approach for the issue of initial ownership.

The CLIP Principles avoid such difficulties. Article 3:301 provides that the transferability of intellectual property rights is also governed by the

\footnotetext{
adopted to Art. 3:201 para. 3 should be mirrored for similar situations regarding coownership. Here the next draft of the CLIP Principles may contain an additional rule in Art. 3:401.

${ }^{22}$ For the classical concept, see, e.g., Henri Desbois, Le droit d'auteur en France, $3^{\text {rd }}$ ed. (1978), p. 470. For a recent comparative analysis, see Cyrill P. Rigamonti, The Conceptual Transformation of Moral Rights, 55 Am. J. Comp. L. 67 (2007).

${ }^{23}$ See, e.g., Dennis Tallon, Personnalité (Droits de la), Encyclopédie Dalloz, Répertoire de droit civile (1996), at 157.

${ }^{24}$ See, e.g., Axel Metzger, Rechtsgeschäfte über das Droit moral im deutschen und französischen Urheberrecht (2002), p. 198.
} 
law of the state for which protection is sought. ${ }^{25}$ Hence, initial ownership and transferability are governed by the same law. In addition, it allows enforcing the author protection rules of the droit d'auteur states, not only when claims are brought before the courts of the respective state but also in disputes arising before the courts of another state. This is a clear advantage when compared with the universalists' approach. Applying the lex originis would mean either setting aside the author-protecting rules of the forum state when the work has been published for the first time in another state, or applying such provisions as public policy of the forum. The second solution has been followed by the French courts in the past. ${ }^{26}$ A similar approach can be found in Sec. 32b of the German Copyright Act. $^{27}$ The price of this approach is, as always with public policy and internationally mandatory rules, a disturbance of the international harmony of decisions and an inherent danger of forum shopping.

\section{Co-ownership}

Although the solitary creator or inventor is still to be found in modern times, innovation and production of technology and media content is increasingly effected by collective entities, whether film production or research teams or online "communities" that share and collect their contributions to Wikipedia, Linux, or similar projects. Network technologies allow these groups and communities to work closely together even if they are spread around the world. ${ }^{28}$ Hence, questions of private international law are of growing importance when it comes to co-ownership. ${ }^{29}$ The crucial question here is one of characterization. It is evident that some aspects of co-ownership are "proprietary" by nature and should be governed by the principles governing the intellectual property right as such, whereas other aspects should be open for contractual arrangements, e.g., the share of the revenues. Hence, the CLIP Principles propose two provisions on co-ownership for these two sets of questions.

${ }^{25}$ This is the solution applied, e.g., by Campbell Connelly \& Co. Ltd. v. Noble, [1963] 1 All ER 237 (High Court) and by the German Federal Court of Justice, 2 October 1997, GRUR 1999, 152 - Spielbankaffaire.

${ }^{26}$ See Paris Court of Appeal, 6 July 1989, D. 1990, Jur. 152 - Sté la Cinq/Angelica Huston et autres (moral rights)

${ }^{27}$ Compare Haimo Schack, Internationally Mandatory Rules in Copyright Licensing Agreements, in: Basedow/Drexl/Kur/Metzger (eds.), Intellectual Property in the Conflict of Laws (2005), 107 et seq.

${ }^{28}$ See Yochai Benkler, The Wealth of Networks (2006), pp. 59-90.

${ }^{29}$ For an in-depth analysis, see Guido Westkamp, Research Agreements and Joint Ownership of Intellectual Property Rights in Private International Law, IIC 2006, 637661. 
Article 3:401 determines that the law of the state for which protection is sought is the law applicable for the issues of initial co-ownership, i.e., who is to be regarded as a co-owner, and the transferability of the shares of each co-owner. ${ }^{30}$ This is in line with the general principles on ownership and transferability. In addition, for these issues third-party interests are most critical. The allocation and transferability of shares of intellectual property rights should be as clear as possible to foster legal certainty and facilitate business transactions. If, e.g., the Patent Act of country X provides that each co-inventor can freely transfer his share of an invention, it would be unacceptable to challenge such a transaction by reference to an agreement between the co-inventors unknown to the transferee. ${ }^{31}$

To the contrary, for the mere exercise of intellectual rights, freedom of choice should be conferred. ${ }^{32}$ This is the bottom line of Article 3:402 of the CLIP Principles. Issues like exploitation of the intellectual property right by licensing agreements and division of revenues are contractual by nature. The right to claim a registered right before the respective patent office or other authority should also be governed by the law chosen by the parties. ${ }^{33}$ For the enforcement of intellectual property rights and the right to bring suits, parties should be free to make contractual arrangements as long as the procedural requirements for such arrangements are met. ${ }^{34}$ If co-owners are situated in different states and the intellectual property right is exploited internationally, freedom of choice will facilitate the exercise of the right because parties can make arrangements under the rules of the jurisdiction most favorable to their needs. Such contractual arrangements may be restricted to the joint exercise of the intellectual property right. But it may also be that the exercise of intellectual property rights is only one aspect of a more complex relationship, especially a corporate agreement or succession by co-heirs or even marriage. In these cases, the law applicable to that relationship should also govern the exercise of the intellectual property right. If no such relationship exists, the law with the closest connection is applicable. ${ }^{35}$

${ }^{30}$ Compare Eugen Ulmer, Die Immaterialgüterrechte im internationalen Privatrecht (1975), pp. 40 et seq.

31 This is the main argument against allowing for party autonomy in international property law; see Jan Kropholler, Internationales Privatrecht, $6^{\text {th }}$ ed. (2006), p. 558.

32 See Westkamp (supra note 29) 643-51.

33 The reasoning underlying Art. 3:201 para. 3 CLIP Principles should also apply in a co-ownership situation.

${ }^{34}$ The procedural aspects are governed by the lex fori; see Art. 3:101 CLIP Principles.

35 Art. 3:402 CLIP Principles characterizes most questions arising in co-ownership relationships as contractual by nature. This should solve most of the collisions analyzed by Westkamp (supra note 29) 651-52. 
The ALI Principles only provide a rule on initial co-ownership in $\S 313$ para. 1 lit. b) pointing to a different country of origin.

\section{Contracts and Related Questions}

In contrast to the issues of ownership and transferability, the CLIP working group did not have to start from scratch when drafting the principles on the law applicable to contractual relationships. Here, the Rome Convention on the Law Applicable to Contractual Obligation of $1980^{36}$ and the EC Regulation 593/2008 on the Law Applicable to Contractual Obligations ("Rome I") ${ }^{37}$ already provide a comprehensive set of European principles. Hence, the CLIP Principles have not tried to re-invent the wheel but to adapt the provisions of the Rome I Regulation to the specific needs of contracts in the field of intellectual property. Some of the CLIP Principles have a strong resemblance to the respective provisions of the Rome I Regulation, e.g., the basic principle on freedom of choice in Article 3:501 and the provisions on formal validity in Article 3:504 and on consent and material validity in Article 3:505. The following remarks will highlight those aspects that have required a more intellectual property-specific approach. ${ }^{38}$

\section{Characterization}

One critical issue when drafting the CLIP Principle on contracts was to draw the line between contractual and proprietary aspects of contracts in the fields of intellectual property. It has already been said that transferability has been characterized as an intellectual property aspect which should be governed by the lex loci protectionis according to Article 3:301. The CLIP Principles took the same stance for transfer by operation of law and compulsory licenses in Article 3:507 as far as questions of intellectual property law are concerned. The same preliminary decision was taken for security interests in intellectual property rights in Article 3:508. ${ }^{39}$ These

\footnotetext{
${ }^{36}$ Rome Convention on the Law Applicable to Contractual Obligations (consolidated version), OJ C 27, 26 January 1998, pp. 34-46.

37 Supra note 19.

${ }^{38}$ On intellectual property transfer and license agreements under the Rome I Regulation, see Paul Torremans, Licenses and Assignments of Intellectual Property Rights under the Rome I Regulation, 4 Journal of Private International Law 397 (2008).

${ }^{39}$ On security interests in intellectual property rights, in particular the question of characterization, see also the Draft Annex to the UNCITRAL Legislative Guide on Secured Transactions dealing with security rights in intellectual property, Note by the Secretariat of 12 February 2009, UN Doc. A/CN.9/WG.VI/WP.37/Add.4. The discussion
} 
questions are too closely related to the intellectual property right as such to allow for any dépeçage.

In contrast, the transfer of an intellectual property right and the requirements for license agreements are contractual by nature and should be governed by the law chosen by the parties in accordance with Article 3:501 or the law with the closest connection according to Article 3:502. The same is true for the interpretation of license agreements, even if special rules on interpretation are to be found in intellectual property legislation. ${ }^{40}$ Article 3:506 para. 1 provides a list of other essential questions of the lex contractus, which was modeled on Article 12 para. 1 of the Rome I Regulation. $^{41}$

The ALI Principles follow a similar approach in $\S \S 314,316,317$ for transferability, transfers by operation of law and security interests. The provisions on choice of law in $\S 315$ deviate more substantially from the CLIP Principles due to the fact that they are understandably not built on the model of the Rome I Regulation.

\section{Applicable Law in the Absence of Choice}

Article 4 Rome I Regulation on the applicable law in the absence of choice does not provide a specific rule on agreements concerning intellectual property rights. ${ }^{42}$ The European Commission's Proposal for the Rome I Regulation of December 2005 proposed such a rule pointing to the law of the transferor or licensor. ${ }^{43}$ But the finally adopted version of the Regulation abandoned this approach because submissions to the European Institutions, among them a comment by the CLIP Project, pointed to the fact that the proposed rule would not be suitable for many contracts having as

on this issue has not been closed in the CLIP project yet. It should be expected that the next draft will contain a more elaborate proposal on security interests.

${ }^{40}$ See, e.g., Sec. 31 para. 5 German Copyright Act; Sec. 33 Austrian Copyright Act; Sec. 119 Italian Copyright Act.

${ }^{41}$ On characterization, see Axel Metzger, Transfer of Rights, License Agreements, and Conflict of Laws, in: Basedow/Drexl/Kur/Metzger (eds.), Intellectual Property in the Conflict of Laws (2005), pp. 61 et seq.

42 On Art. 4 Rome I Regulation, see Nerina Boschiero, Spunti critici sulla nuova disciplina comunitaria della legge applicabile ai contratti relativi alla proprietà intellettuale in mancanza de scelta ad opera delle parti, in Liber Fausto Pocar (2009), pp. 141 et seq.; Pedro A. de Miguel Asensio, Applicable Law in the Absence of Choice to Contracts Relating to Intellectual or Industrial Property Rights, IX Yearbook of PIL 199 (2007); Torremans (supra note 38) 404 et seq.

${ }^{43}$ See Proposal for a Regulation of the European Parliament and the Council on the law applicable to contractual obligation ("Rome I") of 15 December 2005, COM (2005) 650 final. This solution is also provided by Art. 122 para. 1 of the Federal Swiss Private International Law Act. 
their main object the transfer of license of an intellectual property right. ${ }^{44}$ For typical intellectual property contracts, it may also be that the licensee is to effect the performance which is characteristic of the contract (or that the contract is more closely connected with the licensee's country although none of the performances is characteristic for the whole contract). A contract between an author and a publisher may serve as an example. If the book is already written and the publisher has the duty to publish and distribute it and pay royalties expressed as a percentage of the sales price while the author has no other duty but to accept the use of his work, it may well be that the contract is more closely connected to the publisher's habitual residence. ${ }^{45}$ In contrast, it may be that the contract has a closer connection to the transferor's country if the transferee has no other duty but to pay a flat sum as money consideration. ${ }^{46}$ In this case, the contract resembles an outright sale of the intellectual property right and should be governed by the law of the seller's habitual residence. ${ }^{47}$ Due to this heterogeneity of contracts in the field of intellectual property, Article 3:502 para. 2 provides a set of factors that should help to determine the state with which the contract is most closely connected. ${ }^{48}$ It should be noted that the list of factors applies only to contracts that have "as their main object the creation of protectable subject matter or the transfer or license of intellectual property rights." For contracts that are characterized by other duties of the parties but that also provide a license clause, e.g., franchise or distribution contracts, other criteria may be of higher signifi-

${ }^{44}$ Comments on the European Commission's Proposal for a Regulation on the Law Applicable to Contractual Obligations ("Rome I") of 15 December 2005 and the European Parliament Committee on Legal Affairs' Draft Report on the Proposal of 22 August 2006, reprinted in IIC 2006, 472.

${ }^{45}$ See de Miguel Asensio (supra note 42) 214; Muriel Josselin-Gall, Les contrats d'exploitation du droit de propriété littéraire et artistique (1995), p. 379; Moura Vicente (supra note 15) p. 322; Ulmer (supra note 30) p. 54; cf. Torremans (supra note 38) 41920 (for contracts granting rights for several countries). But see the contribution of François Dessemontet to this volume, at p. 31 seq; see already François Dessemontet, Transfer of Technology under UNCTAD and EEC Draft: A European View on Choice of Law in Licensing, 12 J. Int. L. \& Econ. 1, 43-53 (1978).

46 James J. Fawcett/Paul Torremans, Intellectual Property and Private International Law (1998), p. 573; Metzger (supra note 41) p. 69; Ulmer (supra note 30) p. 54.

47 Compare also the examples discussed by Fawcett/Torremans (supra note 46) pp. 572 et seq.

48 Art. 3:502 abstains from using the characteristic performance-criterion for contracts in the field of intellectual property since it is not helpful for complex contracts; see de Miguel Asensio (supra note 42) 212-13; Torremans (supra note 38) 406-07. See the contribution of François Dessemontet to this volume, at p. 31 seq. 
cance. For these contracts, the general presumption of Article 3:502 para. 1 is applicable. ${ }^{49}$

The ALI Principles follow an approach that is close to the European Commission's Proposal of December 2005. According to $\S 315$ para. 2, the law with the closest connection shall govern the contract in the absence of a choice-of-law agreement while it is presumed that this is the law of the state in which the transferor or licensor is habitually resident.

\section{Employment Relationships}

A question of particular interest in intellectual property is the relationship of employers and employees, in particular the right of the employer to claim the intellectual property right and the corresponding right of the employee to claim for additional remuneration. As has been said earlier, the CLIP Principles do not establish a special rule on initial ownership for works created or inventions made in the course of employment (see Article 3:201 para. 3). Rather, the employment relationship and the legal questions concerning a work created or an invention made pursuant to an employment relationship are regarded as contractual matters. ${ }^{50}$ As such, they are governed by the law chosen by the parties, subject to the protection afforded to the employee by the state where he habitually carries out his work (see Article 3:503 para. 1). In the absence of choice, the law of the state where he habitually carries out his work is applicable according to para. 2. The provision follows the structure of Article 8 Rome I Regulation. It is partly in line with Article 60 para. 1 sentence 2 of the European Patent Convention but allows for party autonomy. ${ }^{51}$

The ALI Principles do not provide for special provisions on employment contracts but treat the issue of employment relationship as an issue of initial title. $\S 313$ para. 1) lit. c) refers for the initial title in non-registered rights created pursuant to an employment relationship to the law that governs that relationship. $\S 311$ para. 2 should be understood to provide the same solution for registered intellectual property rights. Since the ALI Principles do no establish an autonomous rule on the applicable law for

49 Art. 3:502 para. 1 is flexible enough to apply the presumptions of Art. 4 para. 1 lit. e) (franchise contracts) and lit. f) (distribution contracts) Rome I Regulation (supra note 19) within its framework.

${ }^{50}$ Fawcett/Torremans (supra note 46) pp. 514-15 and 523-34.

${ }^{51}$ It is controversial whether Art. 60 para. 1 sentence 2 European Patent Convention allows for a renvoi by the choice-of-law rules of the contracting state in which the employee habitually carries out his work, including the contractual choice of different law (see Joseph Straus, Die international-privatrechtliche Beurteilung von Arbeitnehmererfindungen im europäischen Patentrecht, GRUR Int. 1984, 1, 5), or whether such renvo is excluded (see Margarete Singer/Dieter Stauder, European Patent Convention, $3^{\text {rd }}$ ed 2003, Art. 60, at 20). 
employment relationships, the applicable law has to be determined according to the private international law rules of the forum ${ }^{52}$ - a regrettable gap in the principles that should be filled in the next revision.

\section{Questions Not Dealt with in the Principles Regarding Contract Law}

The CLIP Principles are meant to be a comprehensive set of principles for the most crucial aspects of international disputes concerning intellectual property. However, it should be clear that not all questions of general contract law can be solved within the Principles. Therefore, according to Article 3:506 para. 3, the issues of consumer protection, incapacity, authority of an agent, set-off, assignment of other rights than intellectual property rights, legal subrogation, multitude of debtors and compensation between them, as well as obligations arising from pre-contractual relationships shall be governed by the law applicable by virtue of the rules of private international law of the forum state. This list was not controversial during the group's meetings except for the issue of consumer protection. Here the question was brought up whether the specific issues raised by "end user license agreements" and similar contracts concerning protected subject matter could be dealt with adequately by the general principles on consumer protection in private international law such as Article 6 Rome I Regulation. ${ }^{53}$ After intense discussions, the group came to the conclusion that most consumer protection issues, such as consent and validity of massmarket contracts, or warranties and liability, are not specific for intellectual property and should therefore not be the subject of the CLIP Principles. The only visible remainder of the discussion is Article 3:701 para. 2, which determines that the waivability of limitations and exceptions to copyright and other intellectual property shall be determined by the lex loci protectionis. ${ }^{54}$ Hence, "fair use" provisions, the doctrine of first sale, and similar limitations and exceptions of the law of the country for which protection is sought are applicable even if the contractual agreement determines the application of another law. This covers the intellectual property-specific questions of end user license agreements, e.g., restrictions of the end user to use the licensed subject matter and exclusion of the

${ }^{52}$ See American Law Institute (supra note 8) p. 228.

${ }^{53}$ On consumer protection and license agreements, see Josef Drexl, Which Law Protects Consumers and Competition in Conflict with Intellectual Property Rights?, in: Basedow/Drexl/Kur/Metzger (eds.), Intellectual Property in the Conflict of Laws (2005), pp. 81-95.

${ }^{54}$ For a comparative law analysis of the overridability of copyright limitations, see Lucie Guibault, Copyright Limitations and Contracts (2002), passim. 
resale of goods, of safety copies, or of any other fundamental rights of end users under the applicable intellectual property law. ${ }^{55}$

\section{Infringement and Remedies}

\section{Territoriality as the Basic Principle}

The law applicable to infringement and remedies has been controversial in Europe and abroad for a long time. Some jurisdictions applied the lex loci protectionis for the question whether the intellectual property has been infringed and what remedies should be granted to the right holder, e.g., Austria, ${ }^{56}$ Belgium, ${ }^{57}$ England, ${ }^{58}$ Germany, ${ }^{59}$ Italy, ${ }^{60}$ and Switzerland, ${ }^{61}$ whereas other jurisdictions applied in copyright cases the lex loci delicti to the remedies, e.g., France ${ }^{62}$ and Portugal. ${ }^{63}$ Although different from a doctrinal point of view, the practical outcome of the two approaches was mostly the same because an infringement of an intellectual property right arising from activities conducted outside the country of protection is hardly conceivable. The country in which the act of infringement is committed and the country of protection is conceptually the same in intellec-

55 An example for an internally mandatory copyright exception is Art. 5 para. 2 of the EC Directive 91/250 on the Legal Protection of Computer Programs (supra note 19).

56 According to Art. 34 para. 1 of the Austrian Act on Private International Law, the law applicable to the "infringement" of intellectual property rights is the lex loci protectionis. Art. 34 was also applicable to remedies; see Austrian Supreme Court, 14 January 1986, 4 Ob 408/85, GRUR Int. 1986, 735. See also Fritz Schwind, Internationales Privatrecht (1990), p. 191.

57 Art. 93 para. 1 Private International Law Code. See Pertegás Sender (supra note 14) p. 478.

${ }_{58}$ Def Lepp Music v. Stuart-Brown, [1986] RPC 273; Pearce v. Ove Arup Partnership $L t d$, [2000] Ch. 403 (Court of Appeal).

${ }_{59}$ See Federal Court of Justice, 17 June 1992, GRUR 1992, 697 - ALF.

${ }^{60}$ Art. 54 of the Private International Law Act. See Nerina Boschiero, Infringement of Intellectual Property Rights, A Commentary on Article 8 of the Rome II Regulation, IX Yearbook of Private International Law 87, 100 (2007).

${ }^{61}$ Art. 110 para. 1 of the Federal Private International Law Act. See Gion Jegher, Art. 110 (Immaterialgüterrechte), in: Honsell et al. (eds.), Baseler Kommentar, Internationales Privatrecht, $2^{\text {nd }}$ ed. (2007), Art. 110, at 13.

${ }^{62}$ For France, see Court of Cassation, 22 December 1959, D. 1960, jur. 93 - Ridean de fer; the reasoning of Court of Cassation, 5 March 2002, JCP 2002 II, Nr. 10082 Sisro indicates the application of the lex loci protectionis ("les moyens de recours garantis à l'auteur pour sauvegarder ses droits se règlent exclusivement d'après la législation du pays où la protection est réclamée.").

${ }_{63}$ See Dário Moura Vicente, A tutela internacional da propriedade intelectual (2008), $322-23$. 
tual property cases. ${ }^{64}$ Therefore, the material difference between the two approaches related to the question of whether freedom of choice should be allowed for the remedies, especially in case of multistate infringements. Some jurisdictions allowed for freedom of choice concerning non-contractual obligations in general and remedies for intellectual property infringements in particular, ${ }^{65}$ whereas other jurisdictions adhered to a strict interpretation of the territoriality principle and did not allow for any party autonomy. ${ }^{66}$ Today, at least in the European Community, this controversy has to be seen in a different context. Article 8 of the Rome II Regulation determines unmistakably that infringement and remedies in intellectual property cases are governed by the law of the country for which protection is sought. Article 8 para. 3 excludes freedom of choice in the field of intellectual property. ${ }^{67}$

The CLIP Principles affirm in Article 3:601 para. 1, as the basic principle, that the law applicable to infringement and remedies is the law of each state for which protection is sought. A similar approach is taken by the ALI Principle in $\S 301$ para. 1, which refers to the state of registration for registered rights and to the state for which protection is sought for unregistered rights. However, both sets of principles provide for deviations from that basic approach; these deserve a closer look.

\section{Deviations from the Principle}

a) De minimis rule

A first deviation from the territoriality principle can be found in Article 3:602 of the CLIP Principles. Article 3:602 suggests the application of a de

${ }^{64}$ See Ulmer (supra note 30 ) pp. 13-15; this is also the practical consequence of the cases discussed by Fawcett/Torremans (supra note 46) pp.601-06; cf. Axel Metzger, Jurisdiction in Cases Concerning Intellectual Property Infringements on the Internet, in: Leible/Ohly (eds.), Intellectual Property and Private International Law (2009), p. 251 (258) (on jurisdiction under the forum delicti rule).

${ }^{65}$ See, e.g., for Switzerland Art. 110 para. 2 and Art. 132 of the Bundesgesetz über das Internationale Privatrecht of 1987.

${ }^{66}$ See, e.g., for Germany, Federal Court of Justice, 17 June 1992, GRUR 1992, 697 $A L F$.

${ }^{67}$ On Art. 8 Rome II Regulation, see Jürgen Basedow/Axel Metzger, Lex loci protectionis europea - Anmerkungen zu Art. 8 des Vorschlags der EG-Kommission für eine "Verordnung über das auf außervertragliche Schuldverhältnisse anzuwendende Recht" ("Rom II"), in: Festschrift Boguslavskij, Berlin 2004, pp. 153-172; Boschiero (supra note 60); Matthias Leistner, The Law Applicable to Non-Contractual Obligations Arising from an Infringement of National or Community IP Rights, in: Leible/Ohly (eds.), Intellectual Property and Private International Law (2009), 97-121; Haimo Schack, The Law Applicable to (Unregistered) IP Rights: After Rome II, in: Leible/Ohly (eds.), Intellectual Property and Private International Law (2009), 79-96. 
minimis rule in international intellectual property law. ${ }^{68}$ The provision primarily targets multistate infringement cases. If the alleged infringement has taken place in a multitude of states, the court should be free to focus on those countries in which the alleged infringement has either caused a substantial effect or in which the alleged infringer has substantially acted.

It should be noted that this provision is not a rule of private international law stricto sensu but a rule of interpretation which should be applied on the substantive law level ("A court applying the law or laws determined by..."). ${ }^{69}$ The model for the rule has been Article 2 of the Paris Union and WIPO "Joint Recommendation Concerning the Protection of Marks, and Other Industrial Property Rights in Signs, on the Internet," which recommends a cautious application of national (or regional) trademark law in Internet cases. $^{70}$ The Recommendation has already been applied by national courts, e.g., the German Federal Court of Justice in the Hotel Maritime case. ${ }^{71}$ The CLIP Principles generalize this approach for all cases, whether in an Internet or in an "old economy" setting, and for all types of intellectual property. This required a redrafting of the criteria used to define a de minimis situation, e.g., for a violation of moral rights it would not be appropriate to ask for a commercial effect. The ALI Principles do not suggest a comparable rule.

\section{b) Ubiquitous infringement}

It is no surprise that the issue most avidly discussed in the CLIP working group meetings was if and to what extent a deviation from the territoriality principle should be allowed in Internet cases. Obviously the World Wide Web is fundamentally challenging the system of territorially restricted intellectual property rights. Putting a movie sequence on "YouTube" or offering a software application in a "peer-to-peer" file-sharing community may potentially infringe intellectual property rights in all WTO member states and third countries as well. The critical question here is if and under which circumstances it should be allowed for rightholders to claim for damages under one single law (or at least a manageable number of laws) for the entire damage suffered worldwide and, even more critically, to

${ }^{68}$ On the de minimis rule, see Annette Kur, Applicable Law: An Alternative Proposal for International Regulation, 30 Brook. J Int‘1 L 953, 966 et seq. (2005).

${ }^{69}$ It is a current tendency, at least in the intellectual property community, to suggest solutions to the Internet cases on the substantive law level; see, e.g., Ohly (supra note 17) pp. $254-56$.

70 Joint Recommendation Concerning the Protection of Marks, and Other Industrial Property Rights in Signs, on the Internet of October 2001, Adopted by the Paris Union for the Protection of Industrial Property and WIPO, WIPO Publication No. 845.

${ }^{71}$ Federal Court of Justice, 13 October 2004, GRUR 2005, 431 - Hotel Maritime. 
claim for worldwide injunctions without having to plead for 200 or even more jurisdictions. At first glance, the case for the rightholder's position in this debate seems to be clear. The literal application of the "mosaic approach" is burdensome and may produce high litigation costs in Internet cases. $^{72}$

However, there are also strong arguments against a hasty farewell to territoriality. First, the arguments behind the territoriality principle are also valid in Internet or other multistate cases. Applying national intellectual property legislation to infringement cases occurring abroad means applying that legislation extraterritorially. Europeans wouldn't like to have U.S. software patent case law applied to activities conducted in Europe. Vice versa, U.S. or Japanese industries wouldn't like to be sued under EC sui generis database protection legislation. ${ }^{73}$ Intellectual property legislation is part of the national trade policy and should not cause any repercussions outside the state borders. Applying one law to worldwide infringement cases would lead inevitably to such extraterritorial effects. ${ }^{74}$

Second, applying the mosaic approach to infringement cases on the Internet may in theory burden the rightholder with the duty to plead for all jurisdictions concerned. In practice, it should suffice in most cases to ask for damages or injunctions for the most important markets to force the infringer to shut down its service. ${ }^{75}$ The famous decision of the Paris Court of First Instance in the Yahoo/LICRA case illustrates that territorially restricted injunctions can be granted in Internet cases, and that Internet service providers may choose to ban critical services on a global scale even if the injunction was limited to a certain country. ${ }^{76}$

${ }^{72}$ For the different approaches to applying one single law to copyright infringements on the Internet, see Basedow/Metzger (supra note 67) p. 164; Graeme Dinwoodie, Conflicts and International Copyright Litigation: The Role of International Norms, in: Basedow/Drexl/Kur/Metzger (eds.), Intellectual Property in the Conflict of Laws (2005), p. 195 (201-02); Drexl (supra note 5) at 206-11; Mireille van Eechoud, Choice of Law in Copyright and Related Rights: Alternatives to the Lex Loci Protectionis (2003), pp. 169-232; Ginsburg (supra note 6) pp. 36-44; Gerald Spindler, Die kollisionsrechtliche Behandlung von Urheberrechtsverletzungen im Internet, IPRax 2003, 412; Dorothee Thum, Internationalprivatrechtliche Aspekte der Verwertung urheberrechtlich geschützter Werke im Internet, GRUR 2001, 9.

${ }^{73}$ See Art. 7 of Directive 96/9/EC of 11 March 1996 on the legal protection of databases, OJ L 77, 27 March 1996, pp. 20-28.

${ }^{74}$ See Drexl (supra note 5) at 211.

75 Cf. Jack L. Goldsmith, The Internet and the Abiding Significance of Territorial Sovereignty, 5 Ind. J. Global Legal Stud. 475, 487-90 (1998) (spillover effects do not undermine the legitimacy of territorial regulation).

${ }^{76}$ See Paris Court of First Instance, 22 May 2000, <www.juriscom.net/txt/jurisfr/cti/ tgiparis20000522.htm\#texte> - UEFJ et LICRA /Yahoo!. 
Third, one should not forget the interests of the alleged infringer at stake. Applying one law with a higher protection standard to the entire infringement case would deprive the defendant from the exceptions and limitations of the jurisdictions with a lower level of protection.

To summarize, it should be clear that the challenge raised by the Internet has not undermined the policy considerations underlying the territoriality principle entirely. Rather, the question must be how the principle can be reshaped to provide pragmatic solutions to ubiquitous cases. Both the CLIP Project and the ALI provide specific rules on "ubiquitous infringement." Article 3:603 CLIP Principles allows the court to apply one single law to the issues of infringement and remedies in cases in which the infringement is carried out through ubiquitous media such as the Internet, and in which the "infringement takes arguably place in every state in which the signals can be received." Without making it explicit, this provision will only help the rightholder in copyright cases and in cases of well-known trademarks. Here, it can reasonably be argued that an Internet service may infringe copyrights or (at least unregistered) trademarks in every member state of the WTO. By contrast, for patents it would have to be pleaded for every state where the patent has been granted and still exists. For registered rights, the existence of the right cannot be assumed. Even a worldwide service on the Internet may infringe patents in a few states. Hence, in patent cases the infringement does not "arguably take place in every state in which the signal can be received." Again, it should be noted that the provision allows only the concentration under one applicable law for the issues of infringement and remedies and not for existence, validity, or ownership. For these issues, the "mosaic approach" prevails. If a ubiquitous infringement in the sense of Article 3:603 CLIP Principles has taken place, the rightholder may claim for damages or injunctions under the law with the closest connection. Under the factors listed in Article 3:603 para. 2, it will often be the law of the state where the infringer has his habitual residence or principle place of business that is most closely connected. If the court applies one single law to the infringement and remedies, it is still admitted for the parties according to para. 3 to plead that the law of a state covered by the dispute differs from the law applied by the court. ${ }^{77}$ In this case the court shall apply the different laws pleaded unless this would lead to an inconsistent judgment, e.g., if one jurisdiction would grant an injunction whereas the other jurisdiction would not grant the injunction. Here the court may apply one law and take into account the differences when fashioning the remedies.

\footnotetext{
77 This was already suggested by Jane Ginsburg in 1998; see Ginsburg (supra note 6) p. 45 .
} 
Article 3:603 CLIP Principles has used § 321 ALI Principles as a blueprint. Therefore, both provisions have clearly visible similarities. But there are also some main conceptual differences. One crucial difference is that § 321 ALI Principles does not only allow concentration under one applicable law for infringement and remedies but also for the existence, validity, duration, and attributes. But for the existence and validity of registered rights, a deviation from the lex loci protectionis is hardly conceivable. Should a software patent granted under the more patent-friendly approach of the U.S. Patent Office be enforced worldwide if U.S. patent law is the law with the closest connection to the case? Should it also be enforced for states in which the rightholder forgot to pay the fees of the national patent office? Both questions should be answered in the negative.

Another fundamental difference between the ALI and the CLIP Principles is hidden in the list of criteria according to which the closest connection should be determined. $\S 321$ para. 1 lit. a-d) put a stronger onus on the law of the habitual residence of the rightholder. According to the official Comment on $\S 321$, it would suffice for the worldwide application of the intellectual property legislation of the rightholder's home state if two conditions were met: (1) the rightholder and the infringer are habitually resident in different states and (2) the rightholder has centered his creative activities in his home state. ${ }^{78}$ The CLIP Principles, by contrast, are more favorable for the defendant. This second approach seems to be better balanced because it compensates the defendant for the plaintiff's privilege to bring suit under one applicable law.

\section{c) Freedom of choice}

In contrast to Article 8 para. 3 Rome II Regulation, both CLIP and ALI Principles allow for freedom of choice for the remedies in infringement cases (see Article 3:605 CLIP Principles and $\S 302$ para. 1 and 2 ALI Principles). From a doctrinal point of view, there are valuable arguments for the restrictive position taken by the Rome II Regulation. One can argue that the remedies, e.g., the availability of double damages, are a crucial element of the level of protection of intellectual property and therefore part of the national trade policy that cannot be derogated from by contract. ${ }^{79}$ However, the majority of the CLIP working group was not convinced by this line of argument and pleaded for a more liberal approach. The practi-

78 American Law Institute (supra note 8) pp. 246 et seq.

79 See Basedow/Metzger (supra note 67) p. 160; Helmut Heiss/Leander Loacker, Die Vergemeinschaftung des Kollisionsrechts der außervertraglichen Schuldverhältnisse durch Rom II, JB1. 2007, 613, 633 et seq. But see Boschiero (supra note 60) 107 et seq.; Leistner (supra note 67) 105-06; Moura Vicente (supra note 15) p. 352; Schack (supra note 67) 83 . 
cal consequences will, in any case, not be very significant. Parties agreeing deliberately after a dispute has arisen to submit their case to a law different from the law applicable in absence of any choice are a rare species. ${ }^{80}$ One of the parties will typically win by this choice whereas the other party loses. Hence, it is not at all obvious that parties will come to an agreement about the applicable law in infringement cases.

\section{Conclusion}

This fast-forward analysis of the CLIP Principles in comparison to the ALI Principles should, at least, have verified the hypothesis from the beginning of this paper that the basic concept of territorially restricted intellectual property rights seems to prevail in the Internet revolution. The CLIP Principles plead for the lex loci protectionis for the question of ownership as the ALI Principles do for registered rights - but admittedly not for copyright. Concerning transferability, both sets of principles apply the lex loci protectionis. The same holds true for infringement and remedies, where both projects plead for moderate deviations from the territoriality principle, especially in cases of ubiquitous infringement. For partisans of a universal concept of intellectual property, this may be seen as a regrettable setback. But from a public policy point of view, it should be welcomed that the projects have shied away from opening the door wider for an extraterritorial application of intellectual property rights. This remarkable level of congruence should encourage international organizations, especially WIPO, to initiate negotiations on a truly global instrument. ${ }^{81}$

What will be the future role of the CLIP Principles within Europe? Once the Principles are published in a final version, their chance to gain influence on the future development of European private international law will vary from provision to provision depending on the existing legal framework. Two examples may illustrate this. Article 3:502 on contracts in the absence of choice may have a realistic chance of being accepted by legal practice in Europe because Article 4 Rome I Regulation does not provide a special rule on license and transfer agreements. Hence, courts may find it useful to apply the factors listed in Article 3:502 para. 3 to determine the

${ }^{80}$ See Thomas Kadner Graziano, Gemeineuropäisches Internationales Privatrecht (2002), 180-81.

${ }^{81}$ The issue of applicable law was already suggested by the European Community as an issue of future work of WIPO's Standing Committee on Copyright and Related Rights; see WIPO SSCR Doc. SCCR/17/4 of 3 November 2008, p. 3. See also the positive reactions of the U.S. and Japanese Delegations at the Seventeenth Session of SSCR, WIPO SSCR Doc. SCCR/17/5, 25 March 2009, p. 31 
"characteristic performance" or the "closest connection" according to Article 4 paras. 2, 3 and 4 of the Rome I Regulation. By contrast, the provisions on infringement and remedies may have a longer road to arrive in legal practice because Article 8 of the Rome II Regulation provides for a less liberal regime. But even under the regime of the current Article 8 Rome II Regulation, one may consider whether the provisions on ubiquitous infringements could be applied praeter legem since the Regulation obviously was not enacted as an exhaustive answer for infringement cases on the Internet. ${ }^{82}$

${ }^{82}$ See Drexl (supra note 5) at 212 (empfindliche Lücke [regrettable lacuna]). 


\title{
Applicable Law to Exploitation of Intellectual Property Rights in the Transparency Proposal
}

\author{
RYU KOJIMA/RYO SHIMANAMI/MARI NAGATA
}

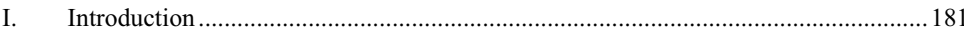

II. Applicable Law to Infringement of Intellectual Property Rights ............................. 181

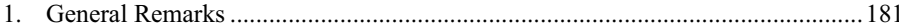

2. Applicable Law in Intellectual Property Infringement ...................................... 182

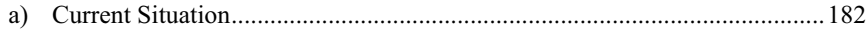

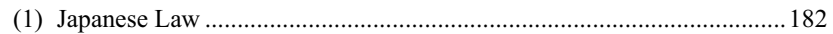

(a) Patent Infringement .......................................................... 182

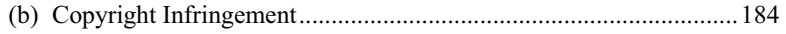

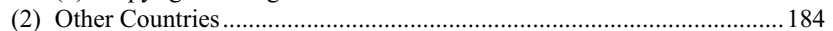

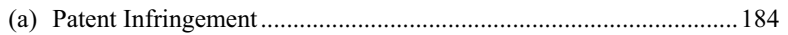

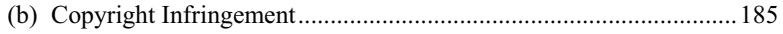

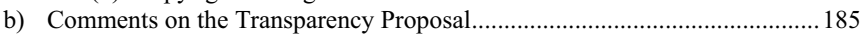

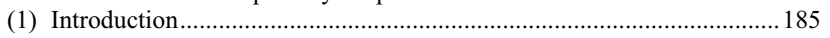

(2) Applicable Law in Patent Infringement ............................................. 188

(a) Understanding of "Territoriality Principle".................................... 188

(b) What Is a "Result of Exploitation"? .............................................. 189

(c) Extraterritorial Application and Applicable Law ............................ 191

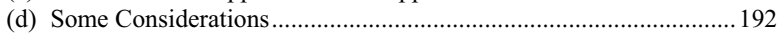

(3) Applicable Law in Copyright Infringement ......................................... 192

(a) The Meaning of Berne Convention Articles. 5(2) and 6bis(3) ........ 192

(b) "Place Where the Results Occur or Are to Occur" in

Copyright Infringement............................................................ 193

(c) Treatment of Moral Rights ............................................................... 194

(4) Provisional Conclusion .................................................................... 195

(5) Other Issues in Intellectual Property Infringement .............................. 195

(a) Infringement between Parties Having a Contractual Relationship.................................................................... 195

(b) Liability of the "Intermediaries" ............................................... 196

III. Applicable Law in Ubiquitous Infringement......................................................... 198

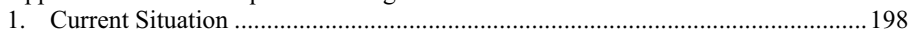

2. Comments on the Transparency Proposal ....................................................... 198

a) Characteristics of "Ubiquitous Infringement" ............................................. 198

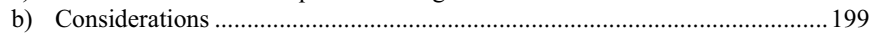

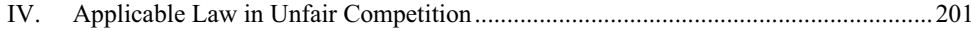

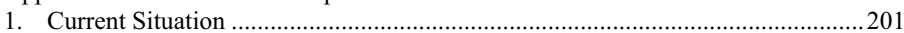

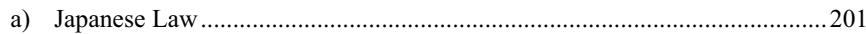




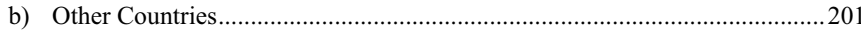

2. Comments on the Transparency Proposal ..........................................................202

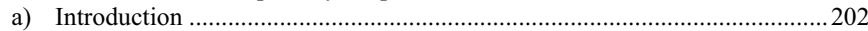

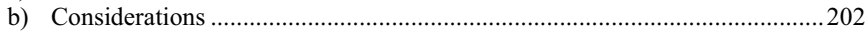

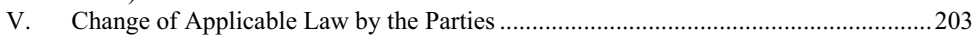

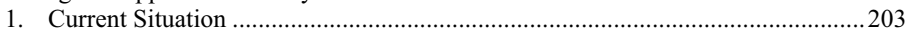

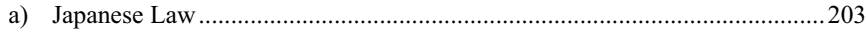

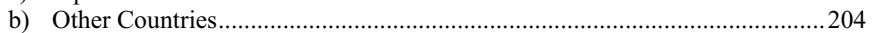

2. Comments on the Transparency Proposal .......................................................2204

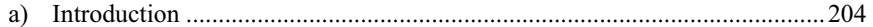

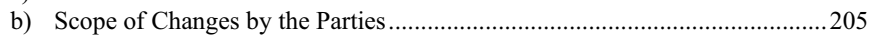

VI. Existence, Primary Ownership, Transferability, and Effects of Intellectual

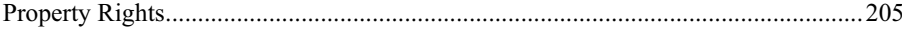

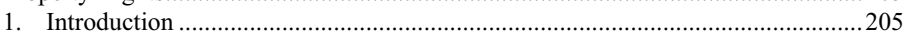

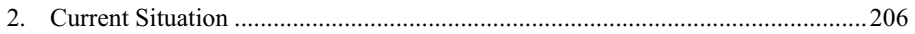

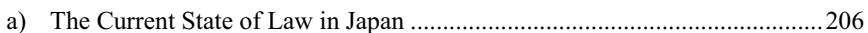

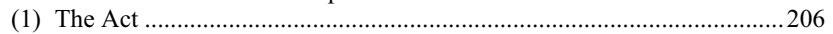

(2) Supreme Court Precedents in Japan ..................................................206

(a) Supreme Court Judgment in the Card Reader Case.........................207

(b) Supreme Court Decision in the Hitachi Case .................................... 208

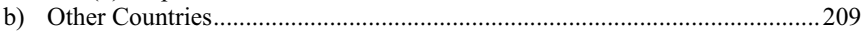

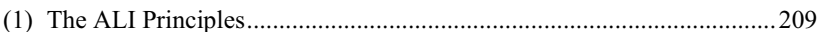

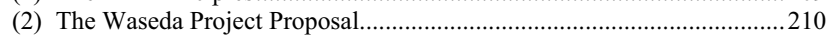

3. Comments on the Transparency Proposal ..................................................... 212

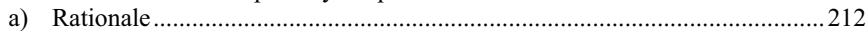

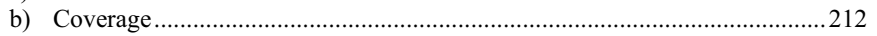

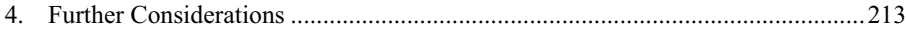

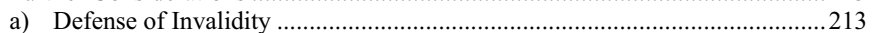

b) Where the Applicable Law Will Be Fragmented.......................................214

VII. Applicable Law to Contracts for the Transfer or Licensing of Intellectual

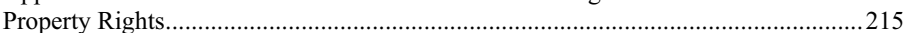

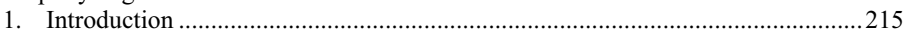

2. The Current State of Japanese Law Concerning the Applicable Law to

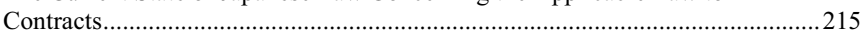

3. Court Cases and Doctrines Concerning the Applicable Law to IP Contracts

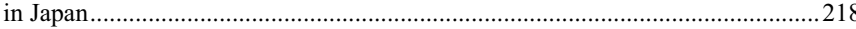

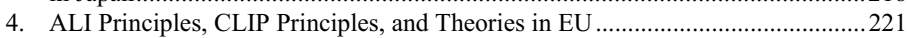

a) Overview of the Current Discussion about the Applicable Law to
Contracts Concerning Intellectual Property Rights in EU ............................22

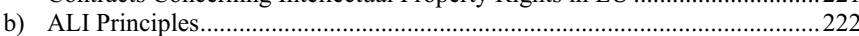

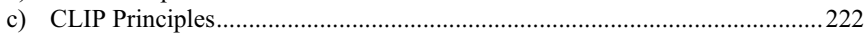

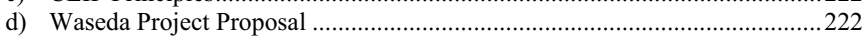

5. Comment on the Transparency Proposal ...........................................................224

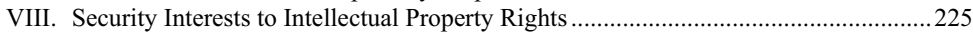

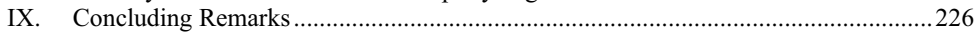

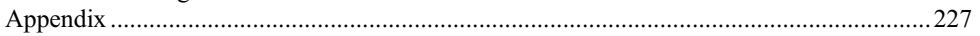




\section{Introduction}

Applicable law to various aspects of cross-border exploitation of intellectual property rights has been at the center of recent discussions among private international law and intellectual property law scholars. This article aims to provide a more detailed account of the Transparency Proposal made by the Transparency Working Group (hereinafter referred to as, "Transparency Proposal"). In particular, applicable law to intellectual property infringements; legal problems related to so-called "ubiquitous infringements"; acts of unfair competition; contracts related to intellectual property rights; and existence, initial title, transferability and effects will be analyzed in the following sections.

\section{Applicable Law to Infringement of Intellectual Property Rights}

\section{General Remarks}

In this paper we would like to argue the issues of applicable law in cases of intellectual property infringement. ${ }^{1}$ The underlying problems can be summarized as follows.

The first question is whether we can consistently conceptualize the applicable law to infringements of intellectual property rights in both industrial property rights with registration and other intellectual property rights without registration. For example, although $\S 301$ of the American Law Institute's Intellectual Property: Principles Governing Jurisdiction, Choice of Law, and Judgments in Transnational Disputes (hereinafter referred to as the "ALI Principles") locates the applicable laws of industrial property and other intellectual property rights differently, ${ }^{2}$ Article 8 of the Regulation (EC) No 864/2007 of the European Parliament and of the Council of 11 July 2007 on the law applicable to non-contractual obligations (Rome II) (hereinafter referred to as "Rome II Regulation") stipulates the applicable law of intellectual property infringement in a comprehensive manner (i.e., without making any distinction between registered and nonregistered intellectual property rights) as the "law of the country for which protection is sought."

1 See Article 301 of the Transparency Proposal, Annex II infra.

2 ALI Principles $§ 301$ stipulates applicable law to infringements of intellectual property rights as follows: (a) for registered rights, the law of each state of registration; (b) for other intellectual property rights, the law of each state for which protection is sought would be. See The American Law Institute, Intellectual Property: Principles Governing Jurisdiction, Choice of Law, and Judgments in Transnational Disputes (2008), p. 122. 
The second question is how the applicable law should be determined in cases of "right-granting statutes" (e.g., for patent and copyright infringements) and "act-regulating statutes" (namely, for acts that are prohibited by unfair competition law). Hence the question arises whether a single choice-of-law rule could be established for both kinds of infringements, or should these two areas of infringing acts be subject to different choice-oflaw provisions? In this regard, it should be mentioned that the ALI Principles and the Rome II Regulation provide for different choice-of law rules pertaining to infringements of intellectual property rights and acts that are prohibited by unfair competition statutes. However, it is still possible to deliberate whether both kinds of infringing acts should not be subjected to the same choice-of-law provision. ${ }^{3}$

We also have to analyze the relationship between the notion of "territoriality," "the country of protection," and their implications to the determination of applicable law. These issues have been discussed in international intellectual property law for a long time. Insofar as "an act of exploitation" and "result arising therefrom" are completed within one jurisdiction, it does not cause a huge problem. However, whether domestic law should govern extraterritorial exploitation of intellectual property brings about the question which of the following rules should be preferred: "lex protectionis," "lex loci protectionis," "market impact rule," or "tort liability at a distance."

\section{Applicable Law in Intellectual Property Infringement}

a) Current Situation

\section{(1) Japanese Law \\ (a) Patent Infringement}

In Japan, there are no specific provisions for intellectual property infringement in "Act on the General Rules for Application of Laws" (hereinafter, the "Act")..$^{5}$ Therefore, discussion will be based primarily upon the case law.

\footnotetext{
3 In the area of "law on mark," the situation is a bit different. In both trademark law and passing off, the concept "use" of mark is widely recognized, and the result can be captured in a parallel manner.

${ }^{4}$ See Annette Kur, Applicable Law: An Alternative Proposal for International Regulation - The Max-Planck Project on International Jurisdiction and Choice of Law, 30 Brooklyn J. Intl. L. p. 951 (2005).

5 The situation was the same under the old Horei.
} 
Regarding patent infringement, we should take a look at the Supreme Court judgment in the Card Reader case. ${ }^{67}$ The Supreme Court separated applicable laws of injunctive relief and damages, and applied "law of the country of registration" for injunctive relief and "law of the country of the place where a fact constituting a cause occurred" for damages. The reason why the Supreme Court relied on different applicable laws stems from the fact that injunctive relief is not granted under the general tort liability in Article 709 of the Civil Code; it is regarded as a special remedy given by Article 100 of the Patent Act.

The Card Reader case has been severely criticized for several reasons. First, it is very difficult to interpret whether the Supreme Court relied on the choice-of-law rules in private international law or "territorial application" in public international law. ${ }^{8}$ Second, the judgment acknowledged that the "principle of territoriality" should be adopted in patent infringement; however, the Court in the end rejected the result of application based upon the strict territoriality principle. In the Card Reader case, applicability of Article 271(b) of the U.S. Patent Act (inducement) was in question. ${ }^{9}$ The Supreme Court mentioned as follows:

The principle of territoriality in relation to patent rights means that a patent right registered with each country is to be governed by the laws of the relevant country with regard to issuance, transfer, validity and the like thereof and such patent right can come into force only within the territory of the relevant country.

The Supreme Court concluded that "extraterritorial application" of the foreign patent is against "public order" of Japan.

The remedy of damages was characterized as tort liability in the Card Reader case. Before the enactment of the Act, there was a provision of "double actionability" (Art. 11(2) of the former "Law Application Prin-

${ }^{6}$ Judgment of the Supreme Court of 26 September, 2002, Minshî Vol. 56, No.7, p. 1551, abbreviated English translation is available at <www.courts.go.jp/english/ judgments/text/2002.9.26-2000.-Ju-.No..580.html> (last visited on 3 May 2009). Also, see Toshiyuki Kono, Recent Judgments in Japan on Intellectual Property Rights, Conflict of Laws and International Jurisdiction, in: Josef Drexl/Annette Kur (eds.), Intellectual Property and Private International Law (Hart Publishing 2005), p. 229 and 232.

7 This is a case before the enactment of the Act.

8 Yoshihisa Hayakawa, Kokusai chiteki zaisanhô no kaishakuronteki kiban [Interpretational Basis in International Intellectual Property Law], Rikkyo Hôgaku [Rikkyo Law Review], No. 58 (2001), p. 188.

935 U.S.C. 271: Infringement of Patent

(a) Except as otherwise provided in this title, whoever without authority makes, uses, offers to sell, or sells any patented invention, within the United States, or imports into the United States any patented invention during the term of the patent therefore, infringes the patent.

(b) Whoever actively induces infringement of a patent shall be liable as an infringer. 
ciples Act"). ${ }^{10}$ Based on this principle, the Supreme Court also precluded the result of the application of the judgment.

\section{(b) Copyright Infringement}

Concerning applicable law in copyright infringement, we have had no Supreme Court judgment so far. However, regarding injunctive relief, several lower courts relied on Article 5(2) of the Berne Convention. ${ }^{11}$ For damages, courts characterized it as tort liability. ${ }^{12}$ Like patent infringement, damages is characterized as tort liability; therefore, we should rely on Article 17 of the Act.

\section{(2) Other Countries}

\section{(a) Patent Infringement}

Because obtaining patents requires application, examination, and registration of the patent office of each country, applicable law related to patent was once understood as closer to the nature of public law, and it was conceived that no problem of private international law arises. However, patent right is a "proprietary" right; therefore, the necessity of the choice-of-law issue in transnational disputes has been gradually acknowledged.

The ALI Principles provide the law of the country of registration as an applicable law in patent infringement. We might be able to see the residue of traditional argument in this formula.

In Europe, the Rome II Regulation adopted the law of the country for which protection is claimed (lex loci protectionis). In the earlier draft, applicable law was conceptualized as tort liability, and it was changed into the current formula because of criticisms of the public comments. For example, the Max Planck Institute was against the previous version because of the ambiguity of the characterization of tort liability, and they did not want to allow the change of applicable law by the parties. ${ }^{13}$

${ }^{10}$ The doctrine of "double actionability" was adopted in U.K. laws long ago. See James J. Fawcett/Paul Torremans, Intellectual Property Law and Private International Law (Oxford University Press, 1998), at p. 607.

${ }_{11}$ The representative case is Judgment of the Intellectual Property High Court on 24 December 2008, available at <www.courts.go.jp/hanrei/pdf/20090109155751.pdf $>$ (in Japanese) and <www.courts.go.jp/hanrei/pdf/20090109151003.pdf $>$ (in Japanese) (North Korean Copyrighted Works case) (last visited on 26 September 2009).

12 The North Korean Copyrighted Works case was decided in the same way.

13 Josef Drexel, The Proposed Rome II Regulation: European Choice of Law in the Field of Intellectual Property, in: Drexel/Kur (supra note 6) p. 154-155. 


\section{(b) Copyright Infringement ${ }^{14}$}

It has been argued whether any international treaties provide for a choiceof-laws rule for copyright infringements. Some commentators assert that Article 5(2) of the Berne Convention is a choice-of-law rule. However, the formula of the law of the country where protection is claimed (lex protectionis) can be misconceptualized as lex fori. To avoid causing the abovementioned problem, this provision has been understood as the law of the country for which protection is claimed, namely lex loci protectionis. ${ }^{15}$

Recently, the formulas of patent infringement and copyright infringement have been closer irrespective of the existence of registration. Lex loci protectionis is widely accepted in various legislations and proposals, such as Article 110 Section 1 of Swiss Private International Law, ${ }^{16} \S 301$ of the ALI principles, Article 8 of the Rome II Regulation, and Article 3:601 of the Second Preliminary Draft of Principles for Conflict of Laws in Intellectual Property, prepared by CLIP (European Max Planck Group on Conflict of Laws in Intellectual Property) (hereinafter, "CLIP Principles"). ${ }^{17}$ In the commentary of the Rome II Regulation, this formula is described as a "universally acknowledged principle."

\section{b) Comments on the Transparency Proposal}

\section{(1) Introduction}

In the Transparency Proposal, we adopt a traditional rule of "objective connection" as often deployed in private international law. In the course of the discussions, the possibility of the law of the country which plaintiff claims was extensively analyzed. ${ }^{18}$ However, we gave up this direction

\footnotetext{
14 See Paul Edward Geller, Conflicts of Laws in Copyright Cases: Infringement and Ownership Issues, 51 J. Copyright Soc'y U.S.A., p. 315 (2004).

15 Eugen Ulmer, Intellectual Property Rights and the Conflict of Laws, (Kluwer Law International and the Commission of the European Communities, 1978), p. 10; Fawcett/ Torremans (supra note 10) p. 467. See Reporter's Notes in The American Law Institute (supra note 2) p. 127.

${ }^{16}$ Article 110(1) of Swiss Private International Law provides as follows: "Intellectual property rights shall be governed by the law of a country for which protection of intellectual property is sought".

17 European Max Planck Group on Conflict of Laws in Intellectual Property, Principles for Conflict of Laws in Intellectual Property (Second Preliminary Draft), available at <www.ip.mpg.de/shared/data/pdf/draft-clip-principles-06-06-2009.pdf>, p. 18 (last visited on 26 September 2009).

18 Similar argument can be seen in Richard Fentiman, Choice of Law and Intellectual Property, in: Drexl/Kur (supra note 6) p. 129, 137. This problem also relates to the interpretation of "law of the country for which protection is sought" (hereinafter lex loci protectionis). Even if the court is not completely subject to the defendant's claim, the
} 
because the "subjective connection" (such as the applicable law in contracts, for example) is very limited in private international law and we would need to elaborate a further theoretical justification. Therefore, we decided to adopt a more traditional approach.

However, we do not employ the law of the country where protection is sought (lex protectionis) or the law of the country for which protection is sought (lex loci protectionis) approach. As to the former, there is already criticism that it cannot be distinguished from lex fori. Concerning the latter, it has been widely adopted, such as in the ALI Principles or the Rome II Regulation. This view, however, seems to be only a fine line with a subjective connection (namely the formula of the law of the country which the plaintiff claims) and many theoretical points should be clarified in order to crystallize the argument. In this regard, this paper is situated as a "gedankenexperiment" to take the understanding of the traditional argument one step further.

In Japan, we have an Act as the choice-of-law rules, and this paper characterizes intellectual property infringement as tort liability. Several issues need to be clarified here. First, we should decide whether remedies of injunctive relief and damages should be distinguished for the purposes of an applicable law rule. Although the Supreme Court judgment in the Card Reader case ${ }^{19}$ concluded that the effect of injunctive relief derives from a patent right itself and damages can be characterized as tortious, it is questionable whether one should differentiate the applicable laws for those two remedies. In the Transparency Proposal, remedies are bracketed together and the connecting factor is the place where the results of the exploitation of intellectual property occur or are to occur.

The Transparency Proposal deals with the issue of applicable law of intellectual property infringement and unfair competition, where "the place where the results" of intellectual property infringement or unfair competition "occur or are to occur" will be the connecting factor. In principle, the place where the results occur or are to occur presupposes the marketplace in each country, and this basic principle applies both to intellectual property infringement and unfair competition. ${ }^{20}$ The term "result" refers to

formula of lex loci protectionis does not exclude the possibility of specifying the country of protection guided by the claims by the defendant. See Kur (supra note 4) at p. 963.

19 See supra note 6.

20 The term "result" does not include indirect damages. It is in line with the majority view toward the Act (see Masato Dogauchi, Kokusai shihô nyûmon [Introduction to Private International Law] ( $6^{\text {th }}$ ed., Yûhikaku, 2006), p. 238; Naoshi Takasugi, Dai 7 shô: fuhôkôi/jimu kanri/futô ritoku [Chapter 7: Torts, Management without Mandate \& Unjust Enrichment], in: Hiroshi Matsuoka (ed.), Kokusai kankei shihô nyûmon [Introduction to Internationally Related Private Law] ( $2^{\text {nd }}$ ed., Yûhikaku, 2009), p. 121; 301 of the ALI Principles and Rome II Regulation follow the same idea. 
the economic loss in the market, whose concept should be determined not to be affected by substantive law, but solely from a conflict-of-laws perspective. ${ }^{21,22}$ In this regard, this proposal adopts a market impact rule. However, there are several underlying problems to be discussed, and this paper will analyze those issues relying on a series of hypothetical case studies.

Second, we are required to decide whether or not to exclude certain provisions of the Act when we consider the proposed legislation in a Japanese context. For example, Article 21 of the Act acknowledges "change of applicable law by the parties" very broadly, so whether the same rule should apply to intellectual property infringement should be decided. While ALI Principle $\S 302$ admits the same rule broadly, the Rome II Regulation takes a negative view toward it. We would like to discuss the latter. Also, we have to consider whether we should follow the basic principle of the place where result of the infringement occurred, or rely on the law of the contract in the situation of intellectual property infringement between the parties already having a contractual relationship.

Third, we have to decide on the necessity of creating a special rule concerning the so-called "ubiquitous infringement." If we conceptualize ubiquitous infringement as just an accumulation of infringement in multiple

\footnotetext{
In intellectual property law, the result of infringement in country A which leads to damages to property or reputation in country B should also be taken into account (a situation such as an act of commercial disparagement in country A bringing damages to commercial reputation in country B). In ALI Principle $\S 301$, it is reduced as an interpretation of "direct and substantial".

${ }^{21}$ Suppose multinational company $\mathrm{X}$ has its headquarters in country $\mathrm{A}$, and the "result" of the unauthorized exploitation of the intellectual property occurs in country B. In this case, it might be possible to interpret the "result" as occurring in country A since the final outcome reflected in the balance sheet of company X materializes in country A. However, the Transparency Proposal does not take this view because intellectual property law of country B guarantees the monopoly profit in the market of country B.

${ }^{22}$ Although the provision is different from ours, the market impact rule was adopted for copyright infringement in the ALI Principles at one point (see, e.g., François Dessemontet, A European Point of View on the ALI Principles - Intellectual Property: Principles Governing Jurisdiction, Choice of Law, and Judgments on Transnational Disputes, 30 Brook. J. Int'l. L. p. 860 (2005)), in the final version the provision was settled as the law of the country for which protection is claimed in copyright infringement.

In this regard, there is an opinion that the market impact rule is not an issue of conflict of laws but one of substantive law (Kur, supra note 4). However, the "result" argued here appears in the choice-of-law rules in tort liability as well. We categorize "tort liability" or "rights in rem" in deciding the question of the applicable law, and this concept comes not from substantive law but conflict of laws. Therefore, it is not right to conclude that we take substantive law in advance. The same argument can be applied to the "result" in intellectual property infringement.
} 
countries (namely a "mosaic approach"), no special provision is necessary. However, ubiquitous infringement is situated in a different phase from traditional intellectual property infringement and we therefore decided to make a new rule.

\section{(2) Applicable Law in Patent Infringement \\ (a) Understanding of "Territoriality Principle"}

The Supreme Court judgment in the BBS case $^{23}$ stated:

The principle of territoriality in relation to patent rights means that a patent right registered with each country is to be governed by the laws of the relevant country with regard to issuance, transfer, validity and the like thereof and such patent right can come into force only within the territory of the relevant country.

This statement is reiterated in the Card Reader case as well.

It is extremely difficult to find a consensus with regard to the abovementioned statement. A commentary written by a then Supreme Court researcher mentioned that the first half refers to the choice-of-law rule, and the latter half the scope of application of the substantive law itself. ${ }^{24}$ If certain exploitation of intellectual property clearly targets the Japanese market, such a patent right may come into force "outside" the territory of the relevant country based upon the market impact rule. In an area of private law, we do not deem the application of foreign law as extraterritorial so long as it is a result of choice of law.

Moreover, the market impact rule that is adopted in this Legislative Proposal also presupposes the principle of "independence of patent rights." Based upon this principle, the Patent Act guarantees monopoly profit to the patent holder in each country's market. Taking into account the economic impact toward each market leads to the adoption of a market impact rule. However, it is true that locating the "market" as a basis for the result that

23 Judgment of the Supreme Court on 1 July 1997, Minshû Vol. 51, No. 6, p. 2299. English translation is available at $<$ www.courts.go.jp/english/judgments/text/1997.07.011995-O-No.1988.html $>$ (last visited on 3 May 2009).

${ }^{24}$ Makiko Takabe, Commentary of Judgment of the Supreme Court on July $1^{\text {st }}, 1997$, in Saiko Saibansho Minji Hanrei Kaisetsu 2005-Nendo [Commentary on the Supreme Court Judgment on Civil Law Cases (FY2005: July-December)] (Hôsôkai, 2005), p. 687, 712. See also Dai Yokomizo, Chiteki zaisanhô ni okeru zokuchi shugi no gensoku teishokuhô jono ichizuke wo chûshin-ni [Priniciple of Territoriality in Intellectual Property: Its Significance in Conflict of Laws], 2 Intellectual Property Law and Policy Journal 17 (Hokkaido University); Yasuto Komada, Kâdo rîdâ jiken saikosai hanketsu no rironteki kôsatsu [A Theoretical Analysis of the "Card Reader" Decision (Supreme Court 1st Petty Bench 26 September 2002)], 2 Intellectual Property Law and Policy Journal 43 (Hokkaido University). 
occurred embraces some kind of public consideration and is distant from the traditional scheme of private law. ${ }^{25}$

Although this paper accepts the basic fact that each market coexists and the "principle of independence of right," it does not follow the strict territoriality principle which states that "the patent act of country A only applies within the territory of country A."

\section{(b) What Is a "Result of Exploitation"?}

How should we conceptualize "the place where the results of intellectual property infringement occur or are to occur"? In the traditional argument of tort liability, "the place of act" and "the place of results" have been discussed especially in the circumstance of "tort at a distance." ${ }^{26}$ Also, the law of destination has been argued in rights in rem (Art. 13 of the Act). ${ }^{27}$

Generally speaking, if exploitation of intellectual property happens within one country, and patented products are distributed only in the same country, nobody will deny that the law of the said country will be applied. However, what approach should be used in the following case?

(Case 1) $\mathrm{X}$ has a patent right in Japan. Y builds an off-shore factory in country A and manufactures products which can be used only in Japan. For off-shore factories, several favorable treatments are given such as a reduction of the import tariff for the importation of the parts from Japan, a reduction or exemption of corporate tax of country A.

In the course of Y's manufacture of products directed to Japan, it turns out that $\mathrm{Y}$ infringes the patent right of $\mathrm{X}$ without authorization. $\mathrm{X}$ brings a patent infringement suit against $\mathrm{Y}$ in Japanese court, claiming injunctive relief of $\mathrm{Y}$ 's unauthorized exploitation of the patent right and damages arising therefrom. Suppose international jurisdiction is accepted in a Japanese court.

(1) If $\mathrm{X}$ does not have a corresponding patent right in country A, how should we decide the applicable law?

(2) If $\mathrm{X}$ has a corresponding patent right in country A, how should we decide the applicable law?

In Case 1, it is obvious that economic loss arising from the patent infringement is realized in the Japanese market. Under the traditional argument,

${ }^{25}$ In competition law, the appropriateness of the "effect doctrine" has been discussed in the area of extraterritorial application in considering the effect of the marketplace and it has something in common with our approach. Concerning the effect doctrine, see Herbert Hovenkamp, Federal Antitrust Policy: The Law of Competition and Its Practice, $\left(3^{\text {rd }}\right.$ ed., West, 2005), p. 746; Tadashi Shiraishi, Dokusen kinshihô, [Anti-Monopoly Law] (2nd ed., Yûhikaku 2009), p. 335.

${ }^{26}$ Takasugi (supra note 20) at p. 120; Yuko Nishitani, Commentary on the Supreme Court Judgment of September 26, 2002, in Kokusai shihô hanrei hyakusen [One Hundred Selected Cases on Private International Law] (Yûhikaku, 2007), p. 74.

27 Miho Tanaka, Dai 9 Sho: Bukken/Chiteki Zaisan [Chap. 9: Rights in rem \& Intellectual Property], in: Hiroshi Matsuoka (ed.), Kokusai kankei shihô nyûmon [Introduction to Internationally Related Private Law] (2 ${ }^{\text {nd }}$ ed., Yûhikaku, 2009), p. 157. 
based upon a strict territoriality principle or the "place where exploitation has taken place," the applicability of the patent law of country A was supported. It is true that exploitation occurs in country A and some sort of the "result" may have been produced from the perspective of the Patent Act of country A. However, the objective of patent rights is information and its location does not matter, unlike rights in rem (Art. 13 of the Act).

If the "results of exploitation" only affect the Japanese market and have nothing to do with economic loss in the market of country of A, it is not consistent to think of the acts that occur in country A as a result of exploitation from a theoretical perspective as well. Especially in Case 1, Y's exploitation is conducted in the off-shore factory of country A, which does not affect the market of country A. Regardless of the corresponding patent in country A, there is no economic loss in country A, which means the place where the results is produced is Japan and the applicable law should be Japanese law.

(Case 2) $\mathrm{X}$ has a patent right in Japan. Y manufactures products in country A (but not in an off-shore factory) which can be used only in Japan.

In the course of Y's manufacture of products directed to Japan, it turns out that Y infringes the patent right of $\mathrm{X}$ without authorization. $\mathrm{X}$ brings a patent infringement suit against $\mathrm{Y}$ in the Japanese court, claiming injunctive relief of $\mathrm{Y}$ 's unauthorized exploitation of the patent right and compensation of damages arising therefrom. Suppose international jurisdiction is accepted in the Japanese court.

(1) If X does not have a corresponding patent right in country A, how should we decide on the applicable law?

(2) If $X$ has a corresponding patent right in country A, how should we decide on the applicable law?

In Case 2, how should we understand the "place where the result of the exploitation of patented invention was produced"? If we adopt a market impact rule as in Case 1 above, the existence of a corresponding patent does not make any difference, because such a way of considering the substantive legal relationship does not fit well with the characterization of the objective connection in private international law.

Unlike Case 1, however, Case 2 does not take the off-shore factory into consideration. As long as $\mathrm{Y}$ is engaged in exploitation targeting the Japanese market with a high probability of results happening in Japan, however, Japanese law should be chosen as the applicable law. In order to ascertain the degree of probability, various elements - such as the language attached to the product (i.e., the rarer the language is, the more obvious that the product is directed to a specific jurisdiction), the existence of the letter of transmittal, the circumstance of packaging and transportation of the patented products, etc. - should be calculated.

If the applicable law becomes Japanese law, X can bring a lawsuit in Japanese court and obtain a ruling in its favor which enables it to get 
recognition of the foreign judgment in country A and prohibit Y's exploitation (the possibility of recognition of the said judgment or the effectiveness of its enforcement in country $\mathrm{A}$ is another question).

On the other hand, there must be an argument that X should interdict the entry of patented products into Japan as a border measure. This is a possible conclusion from a strict territoriality principle. From a practical point of view, however, customs cannot seize all infringing products and it is more effective to prohibit the manufacture of the products in country A as long as the product clearly targets the Japanese market.

Also, border controls are a "defensive measure" for the right holders and the party in this procedure is not $\mathrm{Y}$, but customs. By bringing a lawsuit based on Japanese law, $\mathrm{X}$ can acquire a more aggressive tool, which makes it possible to pull $\mathrm{Y}$ into licensing negotiations.

Here I would like to add one more comment on the situation where a corresponding patent exists in country A (the situation of (1)). Is it possible to file a claim based on the patent act of country A? As long as "the result of exploitation" can be interpreted as an economic loss in the market of country A, it does not cause any problem. However, this product targets the Japanese market. If we question the application of the patent act of country A based upon the exploitation in the same country, we have to understand this position as a territorial application of the patent act apart from the market-oriented consideration. This paper does not concur with this aforementioned idea.

\section{(c) Extraterritorial Application and Applicable Law}

(Case 3) In country A, the following provision is stipulated in the Patent Act in order to protect their domestic industry: Patent infringement should be acknowledged for the extraterritorial exploitation of a patented invention whose scope corresponds with the patent right of country A. The amount of statutory damages is at least 100,000,000 JPY.

$\mathrm{X}$, a company in country $\mathrm{A}$, enters into the Japanese market and manufactures cell phone parts in their Japanese factories. Japanese company Y also manufactures cell phone parts to be sold on the Japanese market and it turns out that $\mathrm{Y}$ infringed $\mathrm{X}$ 's patented invention (the scope of which corresponds with the patent right of country A). X also has a Japanese patent.

$\mathrm{X}$ brought a lawsuit in Japanese court. In addition to the claims of injunctive relief and damages based on the Japanese Patent Act, X claimed that Y's exploitation is also a patent infringement based on the Patent Act of country A, requiring statutory damages of 100,000,000 JPY.

How should Japanese courts resolve this issue?

In Case 3, the Patent Act of country A has a provision of so-called "extraterritorial application." In this situation, should the Patent Act of country A also be chosen as the applicable law on top of Japanese law? Since "damage" is just written in the Act, is it really acceptable to admit that a "result has been produced"? 
In Case 3, since economic loss occurs in the Japanese market, nobody will deny that Japanese law should be applied. The question is whether the law of country A should also be chosen as the applicable law.

Based on a market impact rule - which this paper presupposes - a result based on the law of country A did not, in fact, occur. It is true that the Patent Act of country A has a provision on statutory damages, and economic loss did occur at the substantive law level. However, unlike Case 1 or Case 2, we cannot think of any economic loss at a conflict-of-law level in Case 3, because no element is directed to the market of country A.

\section{(d) Some Considerations}

So far, we have discussed the reasonableness of choosing the place where the results of the exploitation of intellectual property occur or are to occur as a connecting factor. Generally speaking, where the market is completed within one country, we can deem certain economic loss as a "result" of exploitation at the place where the intellectual property is exploited.

If we take into account the argument of tort at a distance, it is doubtful whether we can regard the law of the place where exploitation has taken place as the only applicable law in patent infringement. Especially when exploitation is clearly directed toward a foreign market, we are required to examine whether the complete exclusion of foreign patent law is beneficial, as discussed earlier.

\section{(3) Applicable Law in Copyright Infringement \\ (a) The Meaning of Berne Convention Articles 5(2) and 6bis(3)}

In the area of applicable law in copyright infringement, as was mentioned before, the provisions in international treaties have been discussed for a long time. Above all, whether the "law of the country where protection is sought" (Arts. 5(2) \& 6bis(3) of the Berne Convention) is a choice-of-law rule is a contentious issue that has often been discussed.

Several lower court judgments in Japan ${ }^{28}$ have concluded that Article 5(2) of the Berne Convention is a choice-of-law rule. But it is very difficult to find a consensus on this issue both domestically and internationally, ${ }^{29}$ so this paper does not go into detail on this question.

28 Tokyo District Court, Judgment, 9 December 2004, Hanrei Jihô No.1936, p. 40 (Chinese Poem case); Intellectual Property High Court, Judgment, 24 December 2008, available at <www.courts.go.jp/hanrei/pdf/20090109155751.pdf> (in Japanese) \& $<$ www.courts.go.jp/hanrei/pdf/20090109151003.pdf> (in Japanese) (North Korean Copyrighted Works case) (last visited on 3 May 2009).

${ }_{29}$ Shinomi Matsunaga, Berunu jôyaku ni okeru chosaku butsu no kokusaiteki hogo kokusai shihô no kanten kara [International Protection of Copyrighted Works under the 
As an applicable law in copyright infringement, the so-called lex loci protectionis (law of the country for which protection is sought) is often advocated in order not to cause confusion with lex protectionis (law of the country where protection is sought). Opinions, however, seem to vary from person to person, as has already been argued at the beginning of this paper. ${ }^{30}$ In this paper, therefore, we would like to make some analysis from the perspective of the "place where the results occur or are to occur," which we adopt as a proposal.

\section{(b) "Place Where the Results Occur or Are to Occur" in Copyright Infringement}

(Case 4) X (a Japanese national) wrote a novel in the Japanese language. Professional translator Y (nationality of country A) translated X's novel into English and German in country A without X's authorization (let us assume that the official language of country $\mathrm{A}$ is English). $\mathrm{X}$ sued $\mathrm{Y}$ in Japanese courts, claiming injunctive relief for Y's unauthorized exploitation. If international jurisdiction is accepted in Japan, how should we choose the applicable law?

In Case 4, where is the "place where the results occur or are to occur"? In general, country A should be the answer. It is a matter of copyright infringement in country A and the market of country A is affected because $\mathrm{Y}$ does not obtain a license from $\mathrm{X}$.

In Case 4, is it possible to think that the German market is prejudiced because Y also made a translation into German? German is used not only in Germany, but also in Austria and Switzerland. Also, many people read books written in German throughout the world. From this perspective, it must be difficult to designate the law of a certain country unless the exploitation of copyrighted works is directed to that specific country.

In Case 4, what about a situation where it is obvious that translated books are now being packaged in order to ship to Germany, Austria, and Switzerland? In this scenario, there is a high probability that economic loss will happen in each market of those three countries. Therefore, each country's law should be the applicable law chosen.

How should we approach the so-called "ubiquitous infringement" under "cloud computing," such as uploading materials on the Internet? In cloud computing, the notion of the location of the server or place of uploading is meaningless. Under such circumstances, the concept of the "place where the results occur or are to occur" should be adopted in the sense of which market the alleged infringer targets. It is true that there are so many

Berne Convention: A View from Private International Law], in: Hiroshi Matsuoka (ed.), Kokusai chiteki zaisanhô no chôrŷu [The Current Trends of International Intellectual Property Law] (Tezukayama shuppankai, 2008), p. 51.

${ }^{30}$ A similar comment can be seen on Tanaka (supra note 27) at p. 164-165. 
markets in ubiquitous infringement cases that it is difficult to conclude which market has been specifically targeted. We would like to analyze whether we should narrow down or simplify an applicable law in the later section of ubiquitous infringement.

One thing we should bear in mind is that both the ALI Principles and the Rome II Regulation adopt lex loci protectionis (as was mentioned before, the Rome II Regulation clearly mentions that this principle is universally acknowledged). In other words, is there any difference regarding the conclusion between the principle of lex loci protectionis and our Proposal (without considering indirect damages)? Article 3 of the Rome II Regulation provides for a general principle of tort liability; however, lex loci protectionis was stipulated in Article 8 because there was a strong negative opinion that the general principle now fits well with intellectual property infringement. One of the major arguments was that there was the "change of applicable law by the parties." ALI Principle $\S 302$ allows very broadly for a choice-of-law agreement, which is different from the European view. We would like to analyze this at a later stage.

\section{(c) Treatment of Moral Rights}

Should we conceptualize the applicable law of moral rights infringement as a law of the place where the results of the exploitation of intellectual property occur or are to occur just the same as in the case of copyright infringement? The term "exploitation" is used from an economic point of view, and it is true that the term does not fit well with the situation of moral rights.

From the linkage of moral elements, we also have to question the relationship with Article 19 of the Act (Special Rule for Defamation). One possible solution is to apply Article 19 of the Act based on its similarity with defamation. Defamation mainly relates to natural persons; juristic persons are treated as exceptional. On the other hand, "work for hire" (Art. 15 of the Japanese Copyright Act) is extensively applied, and moral rights also belong to juristic persons under Japanese law. Moral rights function as a tool for the economic control of copyrighted works, a practice that is often made light of by referring to them as "economic moral rights." 31 Therefore, it is dubious to treat moral rights as being the same as defamation.

31 Nobuhiro Nakayama, Chosakuken hô [Copyright Law] (Yûhikaku, 2007), at p. 367. A typical example in Japan can be seen in Judgment of the Supreme Court on 13 February 2001, Minshû Vol. 55, No.1, p. 87 (Tokimeki Memorial case); an English summary of this case is available at <www.tomeika.jur.kyushu-u.ac.jp/ip/pdf/H13.2.13. pdf $>$ (last visited on 26 September 2009). 
In conclusion, we should consider where the exploitation is taking place and where the results arising therefrom are and then conclude the place as a connecting factor.

\section{(4) Provisional Conclusion}

Here let me summarize the argument of the applicable law on intellectual property infringement. We can roughly categorize the following two situations:

(1) place where the exploitation occurs = place where the results occur or are to occur (economic loss is completed in one jurisdiction)

(2) place where the exploitation occurs $\neq$ place where the results occur or are to occur (so-called "tort at a distance")

Many cases fall in the first category, and it therefore makes little difference whether we conceptualize based on the place where the results occur or are to occur or the place where the exploitation occurs. In this case, the conclusion fits with the concept of territoriality or lex protectionis.

The more problematic situation is the second category. In this case, actual economic loss occurs at the place where the results occur or are to occur. When we adopt the law of the place where the results occur or are to occur, it is required that economic loss already happened or there is a high probability that it is about to happen in the place where the results occur or are to occur.

\section{(5) Other Issues in Intellectual Property Infringement}

\section{(a) Infringement between Parties Having a Contractual Relationship}

An exception to the above-mentioned argument is infringement between parties having a contractual relationship. Between parties with a contractual relationship on the exploitation of intellectual property, a breach of duty contained in the license agreement can be argued.

A typical example is the situation where although the licensee is allowed to manufacture 100 patented products based on the license agreement, she manufactures 150 . Does this breach of the license agreement only trigger the issue of breach of contract or does it cause an intellectual property infringement? There is a huge gap between the two in the sense that the legal status of the third parties dramatically differs because the doctrine of exhaustion applies in breach of contract, but not with intellectual property infringement. It also brings up the question of applicable law.

One possibility is to strictly differentiate breach of contract from intellectual property infringement and then apply the law of the contract when it is judged to be a breach of contract (see Comments to Art. 306 of the Transparency Proposal) and the law of the place where the results of the 
infringement occur or are to occur when it is intellectual property infringement. However, whether a breach of the license agreement only triggers a cause of action related to breach of contract or it becomes a question of intellectual property infringement is sometimes very difficult to answer. This is especially so when the question is considered in combination with the issue of categorizing what kind of breach - such as a quantitative restriction, its time and place, and so on - constitutes an intellectual property infringement. ${ }^{32}$ If we are required to differentiate very rigidly, we cannot deny the possibility of an extremely high cost in determining the applicable law.

In an infringement between parties where a contractual relationship already exists as a prerequisite, the phase is different from intellectual property infringement by totally unrelated third parties. As an exception to the basic principle of the law of the place where the result occurred, we therefore decided to rely on the law of the contract even when a breach brings intellectual property infringement (if precisely evaluated).

Although Article 20 of the Act gives discretion to the court in deciding the "most relevant law," the law of the contract should govern the question of the infringement between parties having a contractual relationship without exception.

\section{(b) Liability of the "Intermediaries"}

Another issue we have to consider is the applicable law of the liability for "intermediaries" such as Internet service providers (ISP). ${ }^{33}$

We cannot conceptualize copyright law without considering the existence of intermediaries. The contents will not be widely disseminated without equipment to play back, reproduce, or distribute. Also, we cannot access the contents or send information without connecting to the broadband Internet. Intermediaries play an important role in the information flow in today's society, and we are therefore required to construct a system which does not inhibit the activities of intermediaries while at the same time not depriving the legitimate interests of the authors or right holders. Above all, this problem is heavily argued as "secondary liability" in relation to copyright limitations and exceptions.

Based on the above-mentioned perspective, how should we decide the applicable law for the intermediaries' liability? Take a look at the following hypothetical case.

\footnotetext{
32 Ryo Shimanami, Chosakuken raisensî no hôteki chi-i [The Legal Status of the Copyright Licensee], Kopiraito [Copyright] No. 569, at p. 2 (2008).

33 Graeme B. Dinwoodie, Rochelle Dreyfuss and Annette Kur, The Law Applicable to Secondary Liability in Intellectual Property Cases, available at $<\mathrm{http} / /$ papers.ssrn. com/sol3/papers.cfm?abstract_id=1502244> (Last visited on 26 December 2009).
} 
(Case 5) The Internet service provider Z in country A runs a bulletin board (BBS) on the Internet. Y (residing in country $\mathrm{B}$ ) uploaded the copyrighted works of $\mathrm{X}$ without authorization, which resulted in copyright infringement in country $\mathrm{C}$. In addition to pursuing the liability of $\mathrm{Y}$ based on direct copyright infringement, $\mathrm{X}$ wants legal remedies against company Z. How should we determine the applicable law for the liability of company Z?

Based on the basic principle of this paper, direct copyright infringement occurs in country $\mathrm{C}$. Therefore, applying the law of the place where the result of direct infringement occurred (namely law of the country $\mathrm{C}$ ) to the intermediaries' liability may be one possibility. The problem here is that company $\mathrm{Z}$ is caught short if country $\mathrm{C}$ provides strict liability for intermediaries. Company $\mathrm{Z}$ cannot completely monitor which user from what country subscribes to their service and is engaged in an infringement act targeting which country.

If $\mathrm{Z}$ has a duty of care to prevent the result of direct infringement, the question is whether they should search all the laws throughout the world and take precautionary measures to eliminate infringement. Taking into account the importance of intermediaries in today's world, this would be an excessive restriction that does a poor job of balancing freedom of commerce and would bring an unnecessary chilling effect on their activities. On top of that, in a situation of ubiquitous infringement, it has become widely accepted that the law of one single country should be applied to all of the infringements throughout the world. We are thus hesitant to apply a law that is completely unforeseeable from the standpoint of intermediaries.

Therefore, another possibility is to apply the law of the habitual residence of the intermediaries. It is true that there is a certain level of duty of care to eliminate direct infringement, and it is not a huge problem to determine the applicable law based on this criterion because intermediaries are engaged in business activities following the regulation of their habitual residence. In practice, most intermediaries that are influential in society have a habitual residence in developed countries, where the level of protection is basically in harmony with international treaties and relatively higher. Therefore, it is not harsh for the victims (right holders) as long as the law of those countries is applied.

Nevertheless, there is a concern that intermediaries intentionally put their habitual residence in countries with lower protection and will engage in infringement acts if we always apply the law of the country of habitual residence. If this situation is too overt, application of the law of the place where direct infringement occurs should be seriously taken into consideration as a safety valve.

In addition to the interests of right holders and intermediaries, the free speech interests of users are also crucial. Because users are heavily dependent upon the existence of intermediaries when they express their thoughts, this perspective cannot be overlooked. 
Concerning the issue of the applicable law for intermediaries, the interests between the stakeholders are extremely complicated and lots of problems have yet to be discussed. Therefore, we do not clearly stipulate that the law of a specific country should apply in this situation, and describe the problems in a general manner.

\section{Applicable Law in Ubiquitous Infringement}

\section{Current Situation}

Concerning ubiquitous infringement, there has been no case law in Japan so far. Internationally, the ALI Principles and CLIP Principles provide independent articles. $\S 321$ of the ALI Principles stipulates the following representative four factors: (a) where the parties reside; (b) where the parties' relationship, if any, is centered; (c) the extent of the activities and the investment of the parties; and (d) the principal markets toward which the parties directed their activities.

On the other hand, the Article 3:603 of the CLIP Principles provide as follows:

the court shall take all the relevant factors into account, in particular the following: (a) the infringer's habitual residence, (b) the infringer's principal place of business, (c) the place where substantial activities in furthering of the infringement in its entirety have been carried out and (d) the place where the harm caused by the infringement is substantial in relation to the infringement in its entirety. ${ }^{34}$

\section{Comments on the Transparency Proposal ${ }^{35}$}

a) Characteristics of "Ubiquitous Infringement"

"Ubiquitous infringement" means concurrent multi-territorial infringements evoked by a single act of operation. The question is whether we should permit the application of only one law in ubiquitous infringement. As long as we follow a mosaic approach, although infringements occur concurrently in multiple countries, they are regarded as separate and each law where the results occur or are to occur should be applied. In ubiquitous infringement, the following issues should be treated as distinct.

First, it is meaningless to conceptualize the place where the exploitation has taken place. From a substantive point of view, it makes little difference whether the infringer uploads materials on the Internet either in Tokyo,

\footnotetext{
34 Another interesting point about the CLIP Principles is that they emphasize the usage of "ubiquitous media" in ubiquitous infringement, which is different from the ALI Principles and the Transparency Proposal.

35 See Article 302 of the Transparency Proposal, Annex II infra.
} 
Munich, or New York during her business trip. Therefore, we should concentrate on the place(s) where the results occur or are to occur.

Second, by the infringer's act of clicking the button, it is easily foreseeable that multiple infringements occur concurrently worldwide. Under the traditional argument, the applicable law varies from country to country and the results are a "mosaic." However, the reason why a single applicable law should be recognized is that it is not an easy task to find out which market is specifically targeted.

Based on general principles, the applicable law in this situation is each law of the place where the results occur or are to occur. It is extremely costly, however, to apply all the laws related to infringements. If right holders are expected to undertake this cost, it incentivizes infringing acts.

The next issue is that it is not easy to identify where the results are produced under the environment of cloud computing (results occur or are to occur worldwide and they are always technically transient). If this is the case, we should decide to pick a single law as the applicable law.

\section{b) Considerations}

If we narrow down the applicable law, there seem to be at least six possible choices: (1) $\S 321$ of the ALI Principles, (2) Article 3:603 of the CLIP Principles, (3) choice by the claimant, (4) habitual residence of the right holder, (5) habitual residence of the alleged infringer, and (6) law of the place where the results of the exploitation of intellectual property are or to be maximized. There are pros and cons with each of these alternatives.

First, the ALI Principles and the CLIP Principles balance several elements. Although it looks well balanced, it does not serve party foreseeability.

Second, regarding choice by the claimant, the question of why we should allow a subjective connection only in cases of ubiquitous infringement is a theoretically high hurdle. It may also induce "applicable law shopping" (analogy of "forum shopping") in the sense that a claimant will choose the law with higher intellectual property protection.

Third, habitual residence of the right holder may enhance protection; however, it deprives foreseeability to the alleged or potential infringer.

Fourth, regarding the habitual residence of the alleged infringer, it may bring the situation that an infringer intentionally chooses a habitual residence in a country with a lower level of protection. The problem of applicable law shopping can also be found here.

In ubiquitous infringement, permitting the choice of a single applicable law deprives foreseeability from one of the parties at any rate, since it excludes territorial application of the law. Ultimately, it leads to policy ques- 
tions related to which party - the defendant or the plaintiff - should pay the price of losing foreseeability, and whose freedom should be guaranteed. It is often said that developing countries are not active in the argument of choice-of-law rules, and in the background they must be wondering whether these rules are only favorable for the developed countries. The problem of ubiquitous infringement is probably one of the most distinctive examples of this tension.

In the Transparency Proposal, we included a special rule for ubiquitous infringement. Although we depart from the traditional territorial application of law in this regard, we would like to propose the sixth choice mentioned above, namely the "law of the place where the results of the exploitation of intellectual property are or to be maximized," taking into account the balance with general principles. The maximized result of exploitation is not reduced to the amount of damages from a substantive law perspective, but based on the amount (quantity) of exploitation such as extensive downloading in a specific jurisdiction.

The next question is when we should estimate the results of the exploitation to be "maximized." Is it when the action was filed at the court? Or when oral argument is concluded? While the action is pending there is a possibility that exploitation in one country could dramatically increase all of a sudden, which would lead to the maximization of results. The situation may always vary.

Pursuant to Article 302 of the Transparency Proposal, the results should be decided at the filing of an action. If the situation changes afterward, it should be treated as another ubiquitous infringement and another law of the place where the results are or to be maximized should be applied to solve that distinct problem.

Lastly, we should consider the coherence with Article 302 and the rule governing the initial title (Art. 305). ${ }^{36}$ According to Article 305, initial title is based upon the law of the country which granted the right. If this is the case, unlike the formula of the law of the country of origin, initial title may belong to the different right holders. If a certain right holder brings a lawsuit based upon our proposals, he/she may not have a right in certain jurisdictions. It would be unfair to acknowledge remedies in those countries where he/she does not have a right. In this case, we should rely on Article 302(2). In those countries mentioned above, a "result of the application of Paragraph 1 is extremely unreasonable in relation with a specific country"; therefore, we should exclude those jurisdictions from the possible remedies.

\footnotetext{
36 See Article 305 of the Transparency Proposal, Annex II infra.
} 


\section{Applicable Law in Unfair Competition}

\section{Current Situation}

\section{a) Japanese Law}

In Japanese case law, applicable law of unfair competition has been characterized as tort liability in several cases. In the Coral Sand case (before the enactment of the Act) ${ }^{37}$ the applicable law was determined to be Japanese law based on the fact that the email containing the disparagement was sent from Japan. The Coral Sand case is a typical example of "tort at a distance," in which the place of the "result" of infringing act and the place of the infringing "act" are located in different jurisdictions. Here we are required to decide which law should be applied, and we would like to discuss the details later in considering our Transparency Proposal.

\section{b) Other Countries}

In many countries, applicable law in unfair competition is conceptualized similarly to tort liability. The ALI Principles provide as follows: "The law applicable to a non-contractual obligation arising out of an act of unfair competition is the law of each State in which direct and substantial damage results or is likely to result, irrespective of the State or States in which the act giving rise to the damage occurred., ${ }^{, 38}$

Regarding unfair competition, there is an argument on "unfair competition related to business" and "unfair competition related to market," especially in the European context (for example, Art. 6 of the Rome II Regulation). In Europe, some countries such as Germany allow consumer groups to have standing to sue. In those countries, the above-mentioned dichotomy may be useful to protect the "collective interest of the consumers." For unfair competition related to market, the applicable law is the "law of the country where competitive relations or the collective interests of consumers are, or are likely to be, affected" (Art. 6(1) of the Rome II Regulation), whereas a general principle of Article 4 of the Rome II Regulation will be applied to unfair competition related to business (Art. 6(2) of the Rome II Regulation).

\footnotetext{
37 Tokyo District Court, Judgment, 16 October 2003, Hanrei Jihô No. 1874, p. 23, abbreviated English translation is available at $<\mathrm{http}$ ://tomeika.jp/search/content.php?did $=1591>$ (last visited 4 October 2009).

38 The American Law Institute (supra note 2) at p. 122.
} 


\section{Comments on the Transparency Proposal ${ }^{39}$}

\section{a) Introduction}

Since we cannot think of the "exploitation of intellectual property" in terms of unfair competition, a different provision is stipulated. As mentioned earlier, the analogy of unfair competition with intellectual property infringement can be made possible from the perspective of a market impact rule, and the following analysis is therefore based on a comparison between the two. Especially in Europe, unfair competition is categorized as unfair competition related to business and unfair competition related to the market. To what extent this dichotomy fits well with the Japanese situation should also be examined.

As was mentioned already, there is a consensus in the case law that unfair competition should be characterized as tort liability. ${ }^{40}$ As in intellectual property infringement, we would like to adopt the same applicable law to both remedies of injunctive relief and damages.

"The place where the results of unfair competition occur or are to occur" presupposes the market where a certain corporation is engaged in business practices. In this regard, the criteria should be in which market certain economic loss or damage of reputation occurs.

As we clarified, there is an argument on unfair competition related to business and unfair competition related to market, especially in the European context. In the Transparency Proposal, the applicable law is the law of the place where the results of unfair competition occur or are to occur. Consequently, we think that our proposal can encompass all the possible cases under the European arguments.

\section{b) Considerations}

We can analogize the arguments of intellectual property infringements like patent infringement or copyright infringement with acts of unfair competition such as passing off (Art. 2(1)(i) of the Unfair Competition Prevention Act), imitation of configuration (Art. 2(1)(iii) of the Unfair Competition Prevention Act), and trade secret protection (Art. 2(6) of the Unfair Competition Prevention Act). Basically the question is which law should be applied between the two, namely the law of the place where act of unfair competition occurs or the law of the place where economic loss arises. A similar argument has already been examined in the previous section.

\footnotetext{
39 See Article 303 of the Transparency Proposal, Annex II infra.

40 Dai Yokomizo, Teishokuhô ni okeru fusei kyôsô no toriatsukai [The Treatment of Unfair Competition in Conflict of Laws], 12 Intellectual Property Law and Policy Journal 231 (2006) (Hokkaido University).
} 
The next question is the "commercial disparagement" (Art. 2(1)(xiv) of Unfair Competition Prevention Act). Should we apply Article 19 of the Act in this case? If we adopt this approach, the "law of the place of such defamed person's habitual residence" will be the applicable law.

Some companies are more famous in the foreign market than in the Japanese market. In such cases, the companies would like to make a lawsuit based on the law of the marketplace because their commercial reputation is damaged in the foreign market. ${ }^{41}$ Although Article 20 can be applied if there is a "more closely connected place" between the parties, this justification seems to be a detour. To put it briefly, anticipated circumstances could be covered if the applicable law of commercial disparagement is determined to be the law of the place where the results are produced.

What about the situation where the reputation of company $\mathrm{B}$, a $100 \%$ owned subsidiary of company A, is jeopardized because of commercial disparagement against company A? In general, the damage of subsidiary B should be regarded as indirect damage. If, however, the person engaged in unfair competition maliciously intended to damage subsidiary $\mathrm{B}$, the result should be deemed to be direct rather than indirect damage. In this case, the applicable law should be considered separately as remedies for companies $\mathrm{A}$ and $\mathrm{B}$.

\section{Change of Applicable Law by the Parties}

\section{Current Situation}

\section{a) Japanese Law}

In Japan, we have had no case laws arguing this problem in intellectual property law. However, in ordinary tort liability, a change of applicable law by the parties is allowed (Art. 20 of the Act). The rationale for this is as follows. First, tort claims are widely accepted to be discretionally disposed by the parties in many jurisdictions and they do not have a strong public nature. Second, the rules between the parties become clearer and it contributes to the resolution of the conflict. Third, it conforms to the need for credibility and legal certainty. ${ }^{42}$

\footnotetext{
${ }^{41}$ In the Coral Sand case (before the enactment of the Act), the applicable law was determined to be Japanese law based on the fact that the email containing the disparagement was sent from Japan. However, this view is not incompatible with our Proposal.

42 Takasugi (supra note 20) at p. 133.
} 
Based on those rationales, it is difficult to justify the special treatment in intellectual property so far as the damages are characterized as tort liability under the existing case laws.

\section{b) Other Countries}

In the ALI Principles, a change of applicable law by the parties is widely acknowledged in $\S 302$ so long as it does not affect the third party's interests. ${ }^{43}$ This provision can be evaluated to respect the party autonomy as much as possible, although it tries to strike the balance between the party autonomy and the public interest. A similar provision can be seen in Swiss Private International Law. ${ }^{44}$

As mentioned earlier, Article 8 of the Rome II Regulation adopts lex loci protectionis and does not rely on general principles of tort liability. In the earlier draft, intellectual property infringement was conceptualized under the umbrella of general tort liability. Reflecting criticisms, intellectual property infringement was precluded partly because those commentators against the previous version had been said not to acknowledge change of applicable law by the parties. ${ }^{45}$

\section{Comments on the Transparency Proposal ${ }^{46}$}

a) Introduction

As was mentioned above, the change of applicable law by the parties is acknowledged in general tort liability. On the other hand, the Rome II Regulation has been said to not acknowledge change of applicable law by the parties.

However, it is unclear why a change of applicable law by the parties is not acceptable in intellectual property infringement. A settlement between the parties is allowed in intellectual property infringement. Although there may be criticism that disposition should not be allowed because a change of applicable law by the parties has externality for third parties, a choice-

43 The American Law Institute (supra note 2) at p. 129.

44 Article 110(2) of the Swiss Private International Law provides as follows: "In any case claims arising out of infringement of intellectual property rights, the parties may always agree, after the act causing damage has occurred, that the law of the forum shall be applicable".

${ }_{45}$ Claudia Hahn/Oliver Tell, The European Commission's Agenda: The Future "Rome I and II" Regulation, in: Jürgen Basedow/Josef Drexl/Annette Kur/Axel Metzger, Intellectual Property in the Conflict of Laws (Mohr Siebeck, 2005), p. 12; Drexel, (supra note 6) p. 151.

${ }^{46}$ See Article 304 of the Transparency Proposal, Annex II infra. 
of-law agreement is only effective inter partes and it does not publicly confirm such elements as the validity of intellectual property.

As far as this situation is concerned, when parties prefer a choice-of-law agreement, it seems difficult not to preclude their autonomy as a conclusion.

\section{b) Scope of Changes by the Parties}

The scope of changes by the parties should be examined even if we permit a choice-of-law agreement. When the Patent Act of country A should be applied under normal circumstances, and the parties agree to choose the Patent Act of country B as the applicable law, to what extent should it be subject to change in areas such as the initial title, the scope of protection, the amount of damages, and so on?

If the applicable law becomes the Patent Act of country B, should all elements be relied on in the law of country B? This scenario may allow the conclusion that whereas infringement cannot be permitted based on the Patent Act of country A, infringement can be recognized under the Patent Act of country B regarding the existence or limitations of a patent right. One possibility is to permit party autonomy without any restrictions. Especially when parties want to solve multi-territorial patent infringement comprehensively, from a practical point of view it is no wonder that the cost of solving the problem based on a single law is more efficient than searching for the existence, scope of protection, limitations, and exceptions in every country.

This problem is closely related to the issue of to what extent party autonomy should be allowed. In the above-mentioned example, we are a bit hesitant to rely fully on the Patent Act of country B. At least elements of existence, initial title, and scope of protection should be governed by the Act of country A (see Comments to Art. 305 of the Transparency Proposal) and then the following remedies should be solved by the Act of country B.

\section{Existence, Primary Ownership, Transferability, and Effects of Intellectual Property Rights}

\section{Introduction}

Among choice-of-law rules for intellectual property law, the Transparency Proposal proposes a rule whereby a single unitary legal relationship be established for enforcing the law of the country that grants an intellectual property right as the applicable law for all issues pertaining to that right, 
namely its existence, primary ownership, transferability, and effects. ${ }^{47}$ The proposed rule, however, does not apply to such issues as (1) the infringement of the right and (2) contracts for the transfer or licensing of the right.

Where a dispute arises over the infringement of an intellectual property right, after the applicable law for the dispute has been determined, the country that granted the disputed intellectual property right in question ought to have been identified. ${ }^{48}$ Furthermore, where a dispute arises over the transfer or licensing of an intellectual property right, the country that granted the intellectual property right in the transfer or license ought also to have already been identified. ${ }^{49}$

The purport of the Transparency Proposal is that in these events, the issue of whether the identified intellectual property right in question was validly established, and on what conditions its infringement will be established, ought to be determined pursuant to the law of the country that granted that right, and that cannot be altered by any agreement of the parties.

\section{Current Situation}

a) The Current State of Law in Japan

\section{(1) The Act}

The Act on General Rules of the Application of Laws, which represents the current conflict-of-laws rules in Japan, contains no special provisions relating to the issues dealt with in this paper.

\section{(2) Supreme Court Precedents in Japan}

There are two precedents by Japan's Supreme Court in which this point was directly at issue. The first was the Card Reader case involving litigation for infringement of a patent right, where the applicable law concerning the effects of the relevant patent right was in dispute. The second, the Hitachi Employee Invention case, involved litigation over an employee invention in which the applicable law for compensation where succession to the intellectual property right in question was in dispute. These two cases will now be presented and studied in order.

47 See Article 305 of the Transparency Proposal, Annex II infra.

${ }^{48}$ For example, for a patent infringement dispute between $\mathrm{X}$ and $\mathrm{Y}$, if the law of Country A was chosen as the governing law, the next issue will be whether an infringement of the patent right was established in Country A.

${ }^{49}$ For example, if a dispute arises between $\mathrm{X}$ and $\mathrm{Y}$ over a contract for the transfer or licensing of a Country A patent right, the country that granted the patent right in dispute has been identified as Country A. 


\section{(a) Supreme Court Judgment in the Card Reader Case $e^{50}$}

In this case, the plaintiff and owner of a U.S. patent right sought an injunction and damages against the defendant in connection with goods exported to the United States that were produced by the defendant in Japan under a license of that patent.

The Supreme Court first divided the claims in this case into one claim for an injunction and another for damages. With respect to the former claim, the Supreme Court ruled that the nature of the relevant legal relationship was the effect of the patent right. ${ }^{51}$ Next, pursuant to the principles of logic, the Supreme Court chose U.S. law as the applicable law for the claim for an injunction, since this was the law of the country where the patent right was registered and therefore the country with the closest connection to the right. In conclusion, however, on that basis the Supreme Court refused to apply those clauses of the U.S. patent law on which the claim for the injunction was based, on the grounds that the fact that the effect of a U.S. patent right would be contrary to the principle of territoriality, and hence "contrary to public policy" under Article 33 of the Act on General Rules of the Application of Laws (Hôrei).

Criticism has been directed at this decision from academic authors to the effect that while it might outwardly be concerned with a method of choosing the applicable law for a private law relationship (in the form of choosing the law of the place with the closest connection to the facts), in terms of its actual content the decision adopted a choice-of-law method for a public law relationship that took on the form of the range of applicability of U.S. patent law.

From the standpoint of the Transparency Proposal, the Supreme Court's choice of the applicable law in this case as U.S. patent law, being the law of the place of the consequences of the act, is naturally regarded as appropriate (see comments to Art. 301 of the Transparency Proposal). The Supreme Court was furthermore in step with the standpoint in the Transparency Proposal when it attempted to apply a provision of U.S. patent law to the effect of the U.S. patent right in question (specifically, a provision that sanctioned a right to an injunction against acts of inducing the

50 Supreme Court, Decision, 26 September 2002, Minshû Vol. 56, No. 7 p. 1551, available at $<$ www.courts.go.jp/english/judgments/text/2002.9.26-2000.-Ju-.No.580. html>.

${ }^{51}$ With respect to the latter claim (the claim for damages), after ruling that the nature of its relevant legal relationship was a tortious act, pursuant to Article 11(1) of the Rules on the Application of Laws, the Supreme Court applied the law of the United States since it was the place where the facts giving rise to the claim occurred, before going on to apply Japanese law cumulatively pursuant to Article 11(2) of the Rules on the Application of Laws (Hôrei) 
infringement of a patent right). What happened next, however, is that on the basis of Japan's private international law provisions, the Supreme Court in the end refused to apply U.S. law on the grounds that this would be contrary to the public policy of Japan. Since the Transparency Proposal does not adopt the principle of territoriality in its strict sense (see comments to Art. 301), just given the facts in this case alone, the Transparency Proposal would bring about an opposite conclusion to that of the Supreme Court.

\section{(b) Supreme Court Decision in the Hitachi Case ${ }^{52}$}

In this case, a former employee (a Japanese citizen) of a major Japanese manufacturer claimed payment of compensation for the company's succession to the patent right (or the right to obtain a patent) in the employee invention created by the plaintiff in a range of countries.

The Supreme Court first upheld the principle of party autonomy in the choice of law, making a statement of general theory to the effect that

[q]uestions pertaining to compensation for the transfer of the right to obtain a patent constitute no more than issues of what sort of claims and obligations that the parties to the transfer have against each other, and are to be construed as questions of the validity of the contractual and other juristic acts in the nature of a claim that form the relationship of legal rights and obligations at the base of the transfer between the parties. It follows that it is appropriate to take the view that the applicable law for those questions is primarily to be determined in accordance with the intention of the parties, in accordance with Article 7(1) of the Rules on the Application of Laws [Hôrei].

Applying that general statement to the facts of the case, the Supreme Court chose Japanese law as the applicable law, on the grounds that the lower court had found the existence of "an implied agreement to the effect that Japanese law would be the applicable law." Furthermore, regarding the question of whether or not Article 35 of Japan's Patent Act ${ }^{53}$ could also apply to the "right to obtain a patent in a foreign country," the Supreme Court held that it could, by interpretation by analogy of that Article.

This judgment extends the range of applicability of the employee invention provision of Japan's Patent Act (Art. 35), which offers comparatively strong legal protection to employees, to foreign patent rights as well. ${ }^{54}$ While some lower court decisions reaching an opposite conclusion

52 Supreme Court, Decision, 17 October 2006, Minshû Vol. 60, No. 8, p. 2853, abbreviated English translation available at $<$ http://tomeika.jp/search/ content.php?did= $839>$.

53 Article 35 is the sole provision in Japan's Patent Act (which is comprised of 204 articles in total) that deals with employee inventions.

54 For example, even if an employee invention dispute is between a Japanese enterprise and its Japanese employee, if there is an implied agreement between the parties, Article 35 of Japan's Patent Act will be applied to the compensation for the 
had been seen prior to this judgment, ${ }^{55}$ all such decisions handed down after this decision have adhered to its ruling.

The response to this judgment by academics has included firmly held views opposing such an application of the Patent Act beyond Japan's borders, on grounds including that a country's statutory treatment of employee inventions will deeply reflect that country's particular policies on patent protection and employee-employer relations. Like these predominant views, the Transparency Proposal opposes the decision given by the $\mathrm{Su}$ preme Court of Japan, and proposes that the rules on employee inventions in any country ought to apply to each intellectual property right that that country grants. ${ }^{56}$

\section{b) Other Countries}

\section{(1) The ALI Principles ${ }^{57}$}

With respect to the matters dealt with by this paper, the ALI Principles state that for registration-based rights, in principle, the law of the country of registration is to apply, and for rights that are not registration-based, the law of the country of protection is to apply (Principle 301(1)). With respect to the primary ownership of an intellectual property right, however, the ALI Principles divide rights into three types and stipulate a special rule for each: ALI Principles 311, 312, and 313.

The Transparency Proposal differs from the ALI Principles because it avoids using the expression "the law of each state for which protection is sought" since the phrase used in the ALI Principles might imply multiple meanings. Moreover, it might be questioned whether there are any grounds to make a distinction between the country where the protection is sought and the country of registration. In the light of these considerations, this paper uses the expression "the law of the country that granted the right," which is a combination of the two concepts.

enterprise's succession to all U.S. patent rights and to the compensation for its succession to all U.K. patent rights (which means, specifically, that "reasonable value" is to be paid by the enterprise to the inventor).

${ }^{55}$ One example immediately prior to the Supreme Court decision was the Tokyo District Court decision of 8 September 2006, Hanrei Jihô No. 1988, p. 106.

${ }^{56}$ For example, if an employee invention dispute is between a Japanese enterprise and its Japanese employee, U.S. patent law will apply to the compensation for the enterprise's succession to any U.S. patent rights (which means specifically that the issue will be dealt with by way of a contract in advance), and U.K. patent law will apply to the compensation for its succession to any U.K. patent rights (which means specifically that no value is to be paid).

57 The American Law Institute, supra note 2. 
Furthermore, the Transparency Proposal takes the view that the primary owner of a right created in the course of individual employment relationship should be determined under the law of the country that granted the right. This approach is different from the ALI Principles, which stipulate that the initial title to such rights should be governed by the applicable law of the employment contract. The intention of such a rule provided in the ALI Principles is to avoid conflicting cross-border situations where rights vest in different principals with regard to single invention or copyright work. Since parties are free, however, to transfer rights from different countries separately after the rights in question had been created, there is not thought to be much point in applying a standardized rule for just the principal of primary ownership. Furthermore, since each country's substantive law norms relating to the principle of primary ownership of a right are a reflection of that country's policies on intellectual property, it is inappropriate to ignore that connection and apply a standardized rule using the substantive legal norms of one particular country. Such an approach would moreover have little or no practical benefit with respect to registration-based rights in particular. ${ }^{58}$

Furthermore, although the ALI Principles stipulate a conflict-of-laws rule that would mean that the primary copyright owner is the same around the world, the Transparency Proposal does not pre-empt the application of the law of the country that granted the right; hence situations leading to different right holders for each country are permitted under the Transparency Proposal. Given the feasibility of transferring rights subsequently, this result also reflects the view that there is no point in bundling primary ownership into just one person for every country around the world.

\section{(2) The Waseda Project Proposal ${ }^{59}$}

Under proposals by Professor Kidana (Waseda University), the issues covered in this paper are, in principle, to be governed by the law of the coun-

\footnotetext{
${ }^{58}$ For example, even if as the governing law the law of a country was chosen that holds that employers are the primary owners of rights to employee inventions, the Patent Office in a country like Japan or the U.S. (which adopts a different rule, namely, that employees are the primary owners) would probably not allow the filing of a patent application that was premised on an employer being the primary owner.

59 Shôichi Kidana, Chiteki zaisanken ni kansuru kokusai shihô gensokuan [Draft Private International Law Principles on Intellectual Property Rights], in Dai 8-kai Chiteki zaisanken/Kokusai shihô shinpojiumu [Eight Intellectual Property Rights \& Private International Law Symposium], 20 December 2008, materials distributed with report, p. 57 et seq. See <www.globalcoe-waseda-law-commerce.org/activity/pdf/19/21.pdf> (Last visited on 24 March 2010).
} 
try of protection (Art. 13(1),$^{60}$ and the main clause of Art. 22(1)) ${ }^{61}$ Conceptually, this "country of protection" is exactly the same as the "country that granted the right" in the Transparency Proposal (Art. 13(2)). ${ }^{62}$

There are two points of difference between the the Waseda Project Proposal and this paper. They concern (1) the primary ownership of an intellectual property right where the object of protection of the right arises on the basis of a contract or other previously existing relationship (proviso to Art. 22(1), ${ }^{63}$ and (2) the primary ownership of copyright (Art. 22(2)). ${ }^{64}$ Since the same criticisms of the ALI Proposals apply to these particular the Waseda Project Proposal also, they need not be repeated here.

60 "Unless otherwise provided for in these Principles, issues pertaining to an intellectual property right itself, such as the existence, validity, scope and period of protection or extinction of the intellectual property right, shall be governed by the law of the country of protection".

This text was changed. See <www.globalcoe-waseda-law-commerce.org/activity/pdf/ 19/21.pdf $>$ (Last visited on 28 March 2010).

${ }_{61}$ "The first holder of a right to intellectual property shall be determined pursuant to the law of the country of protection".

This text was changed. See <www.globalcoe-waseda-law-commerce.org/activity/pdf/ 19/21.pdf $>$ (Last visited on 28 March 2010).

62 "In the case referred to in the preceding paragraph, the 'country of protection' shall be, in the case of an intellectual property right that becomes effective upon registration, in principle, the country where registration is effected or sought or the country deemed to be the country of registration pursuant to an international treaty to which the country is a contracting party or the domestic law of the country, and in the case of any other intellectual property right, the country where the force of the intellectual property right is sought in respect of its territory".

This text was changed. See <www.globalcoe-waseda-law-commerce.org/activity/pdf/ 19/21.pdf $>$ (Last visited on 28 March 2010).

63 "Provided, however, that where the object of protection of an intellectual property right arises on the basis of a contract or other previously existing relationship, the first holder of the right is to be determined pursuant to the law applicable to that relationship".

This text was changed. See <www.globalcoe-waseda-law-commerce.org/activity/pdf/ 19/21.pdf $>$ (Last visited on 28 March 2010).

64 "Notwithstanding the provisions of the preceding paragraph, the first holder of the right to the work shall be determined pursuant to the law as provided for as follows: (a) in the case of a work, the law of the country where the work was first 'made public,' (b) where there is no country as provided for in the preceding item or where no such country is clear, the law of the place of habitual residence of the author at the time of creation, (c) in the case of a work with more than one author under the preceding item, the law of the place of habitual residence of the author designated by contract between the authors, and where there is no such author, pursuant to the law of the place of habitual residence of the majority of authors. (d) Notwithstanding the preceding two items, where the work or other object of protection arises on the basis of a contract or other previously existing relationship, the law applicable to that contract or relationship".

This text was changed. See <www.globalcoe-waseda-law-commerce.org/activity/pdf/ 19/21.pdf $>$ (Last visited on 28 March 2010). 


\section{Comments on the Transparency Proposal}

\section{a) Rationale}

The existence, primary ownership, transferability, and effects of an intellectual property right are matters that deeply reflect the intellectual property law policies of the country that granted the right. The reason for the Transparency Proposal is that it is regarded as necessary to respect those policies to the greatest extent. ${ }^{65}$ As intellectual property rights are special privilege on "public goods" granted by the government in order to realize its information policies, each country has its own political intent upon an existence (validity), primary ownership, transferability, and effects of intellectual property rights. ${ }^{66}$

\section{b) Coverage}

The matters covered by Article 305 of the Transparency Proposal will be limited to the existence, primary ownership, transferability, and effects of intellectual property rights. The following are illustrations of the specific content coming within the scope of Article 302.

1. The existence of the right

- The requirements for the creation of the right (including the conditions for registration in the case of registration-based industrial property rights)

- The validity of the right after its creation (including procedures for asserting its invalidity, such as trials for invalidation or filing a defense of invalidity)

- The protection period

${ }^{65}$ A similar approach can be seen in Austrian and Swiss Private International Law, which provide as follows:

Austrian Private International Law Article 34:

(1) Existence, content and extinction of intellectual property rights shall be decided under the law of the country where the act of use or infringement occurs.

(2) Intellectual property rights which are related with employee's activities performed in the course of employment relationship shall be governed by the law which applies to the employment relationship between employer and employee (Art. 44).

Article 110(1) of Swiss Private International Law provides:

Intellectual property rights shall be governed by the law of a country for which protection of intellectual property is sought.

${ }^{66}$ Especially on patent, see Dan L. Burk/Mark A. Lemley, The Patent Crisis and How the Courts Can Solve It (University of Chicago Press, 2009), pp. 109-141; Ryo Shimanami, § 1.1 The Present and Future of the Patent System: From the Legal Standpoint, in: IIP/Ryo Shimanami (eds.), Kiro ni tatsu tokkyo seido [The Future of the Patent System] (Institute of Intellectual Property, 2009), pp. 3-27. 
2. The primary ownership of the right

- The "author principle" and the "inventor principle"

- The first-to-file rule or the first-to-invent rule

- For employee inventions, the rule of ownership and the rule of monetary compensation

3. Transferability of the right

- A transferability of the right by contract

- A transferability of the right by inheritance

- The perfection for the protection of a licensee from a transfer of the right

4. The effect of the right

- The scope of physical protection (specifically, the respective requirements for establishing literal infringement or infringement under the doctrine of equivalents)

- Types of acts of infringement (specifically, the respective requirements for establishing direct infringement and indirect infringement)

- The conditions for exhaustion

- The requirements for restrictions

- The requirements for establishing as well as the effect of licenses based on prior use

- The requirements for establishing as well as the effect of awarded licenses

\section{Further Considerations}

Working from the position taken in this paper, two points are to be raised in conclusion that warrant attention.

\section{a) Defense of Invalidity}

This paper holds that the means for asserting the invalidity of an intellectual property right are also to be governed by the law of the country that granted the right. For example, if Japanese law has been chosen as the applicable law for a particular patent right infringement dispute, since the right in respect of which the establishment of an infringement becomes an issue will be a Japanese patent right, pursuant to Japan's Patent Act (being the law of that country - Japan - granting the right), the defendant in the infringement litigation will be able to avail itself of two means, namely, a "trial for invalidation" and "the defense of invalidity in litigation for infringement" under Article 123 and Article 104-3 of the Patent Act respectively. However, if the law of Country X, which does not allow this defense of invalidity, is chosen as the applicable law, since the right in 
respect of which the establishment of an infringement becomes an issue will therefore be a patent right of Country X, the defense of invalidation, not being recognized under the patent law of Country $X$ (which will be the particular law of the country granting that right), will not be permitted even if its effect is limited to a relative effect as between the parties in question only.

While a firmly held view has been expressed at academic forums to the effect that relative invalidity should be construed broadly so long as no other person suffers damage, this paper would respect the intellectual property law policy of Country X, which does not recognize the lack of effect of a right, even in a relative sense.

If the defense of invalidation cannot be used, a defendant will attempt to use other devices. However, be it the defense of invalidation, abuse of right, or the defense of misappropriation, the facts to be proven to the court will be the same, and in practice almost no difficulty ought to present itself. Since the defense of invalidation will not be the one and only device available to a defendant, the question of what to do about countermeasures to that defense can be governed by the law of the country that granted the right.

\section{b) Where the Applicable Law Will Be Fragmented}

This paper proposes that decisions on the effect and other features of an intellectual property right, over which a dispute has arisen for which the applicable law has been chosen, be made pursuant to the law of the country that granted the disputed right. It follows that where the rights of more than one country are in dispute, some costs will be incurred in researching and applying the substantive law of the various countries involved. In case of ubiquitous infringement, this will all too easily lead to an excessive burden on the right holder.

According to the standpoint of the Transparency Proposal, however, in the case of a ubiquitous infringement a single law is to be chosen as the applicable law concerning remedies in accordance with a fixed rule (see comments to Art. 302). To that extent the inconvenience of such research and application of the substantive law of numerous countries could be eliminated.

Nevertheless, in cases involving the transfer or licensing of an intellectual property right and cases relating to employee creations, from the standpoint of the Transparency Proposal there will remain certain occasions where the disputed rights will be rights from many countries. This, however, is an inevitable outcome once individual rights in the form of rights from more than one country become the object of a dispute, and since it is the enforcement of those numerous rights that will be sought, the 
position of the Transparency Proposal is that that is a cost that ought rightly to be borne by the holder of those rights.

\section{Applicable Law to Contracts for the Transfer or Licensing of Intellectual Property Rights}

\section{Introduction}

Article 306 and 307 provide for the applicable law to contracts concerning intellectual property rights, such as their transfer or licensing. ${ }^{67}$ These Articles cover only contracts whose main object is to transfer or license intellectual property rights. Accordingly, contracts having license or transfer clauses as collateral matters are excluded from the scope of these Articles. Although employee inventions could be considered as coming within the scope of Article 306 and 307 of the Transparency Proposal, in the context of contractual transfer of patent rights, we do not take this position. Hence the transfer of rights to employees' inventions falls outside this provision and is regulated by Article $305 .{ }^{68}$

\section{The Current State of Japanese Law Concerning the Applicable Law to Contracts}

The Japanese statute that sets out general conflict-of-law provisions is the Act on General Rules Relating to the Application of Laws (hereinafter, Tsûsokuhô), which was promulgated on 26 June 2006 and came into force on 1 January 2007. Before then, the Rules on the Application of Laws (hereinafter, Hôrei) was the general conflict-of-law statute. The Hôrei was drafted and entered into force about 120 years ago and was revised only in family matters. As a consequence, many of the rules dealing with transactional matters have become out of date. This is the reason why we needed to revise the old Horrei and thus update the Japanese law. However, as to the applicable law to intellectual property rights, the situation has not changed even after the adoption of the Tsûsokuhô. Still, there is no special rule providing for the choice-of-law rules, not only for the validity issues but also contractual matters. Therefore, we have to take a look at which law would be applied to contracts in general before turning to contracts concerning intellectual property rights.

Article 7 of the Horrei provided for the applicable law to the formation and effects of contracts. ${ }^{69}$ It upheld the general principle of the parties'

\footnotetext{
${ }^{67}$ See Article 306 and 307 of the Transparency Proposal, Annex II infra.

${ }^{68}$ For this point, see supra part VI of this article.

69 Article 7 of Horei
} 
freedom of choice, i.e., party autonomy (Art. 7(1)). In cases where the parties had not chosen the applicable law, the law of the place where the contract was entered into - e.g., where the contract was concluded - was applied on the assumption that it was objectively closely connected (Art. 7(2)). These provisions in the Hôrei attracted considerable criticism surrounding the appropriateness of the place of the act as a connecting factor. Since Article $9(2)^{70}$ of the Hôrei provided for the legal fiction where the contract was concluded between absent persons, then the place from which the notice of offer was sent was the place of the act. For instance, if the contract was concluded between a person in country A and a person in country B, and if the notice of offer was sent from the person in country A, then country A is presumed as the place where the contract was concluded. This provision was severely criticized for being arbitrary, as the place from which the offer was sent might have no connection to the contract at all, and for the inflexibility of the fiction. Consequently, in academic writings and some court cases, an attempt was made to avoid the application of Article 7(2) by expanding the scope of Article 7(1) through interpretations that sought to find the so-called "implied intention" of the parties. This approach required, first, categorizing contracts, and, second, determining the hypothetical intentions of the parties. Although this interpretation is far from the actual text, it attracted relatively strong support among academics. ${ }^{71}$ This approach can be said to have been an attempt at a more flexible objective connection, differing to that in Article 7(2). ${ }^{72}$

The Tsûsokuho, on the other hand, maintains the general principle of the parties' freedom of choice (Art. 7), ${ }^{73}$ but also adopts a more flexible choice-of-law provision, which provides that if the parties have not chosen

(1) The law governing the formation and the effect of a juristic act shall be determined by the parties of such juristic act.

(2) If the parties do not determine the governing law, the law of the place where the contract was entered into shall govern.

70 "The place from which a notice of offer is sent is to be deemed the place of the act with respect to the formation and effect of that contract. However, if the offeree is not aware of the place from which the notice of offer was sent at the time of acceptance, the place of the offeror's address is to be deemed the place of the act".

${ }^{71}$ Ryoichi Yamada, Kokusai shihô [Private International Law] (3 $3^{\text {rd }}$ ed., Yûhikaku, 2004), p. 326; Yoshio Tameike, Kokusai shihô kôgi [Lectures on Private International Law] ( $3^{\text {rd }}$ ed., Yûhikaku, 2004), p. 367 et seq.

${ }^{72}$ However, much criticism was also leveled at searching for an implied intention in this manner. See Yoshiaki Sakurada, Keiyaku no junkyohô [The Law Applicable to Contracts], Kokusai shihô nenpô [Japanese Yearbook of Private International Law], Vol. 2 (2000), p. 17.

${ }^{73}$ Article 7. Choice of Governing Law by the Parties

The formation and effect of a juristic act shall be governed by the law of the place which was chosen by the party/parties at the time when the act was made. 
a governing law, the law of the place with the closest connection to the contract would be applied (Art. 8(1)). ${ }^{74}$ In order to decide with which country the contract is most closely connected, the Tsûsokuhô adopts a "characteristic performance" approach, the same approach as adopted in the EC Convention on the Law Applicable to Contractual Obligations ${ }^{75}$ (hereinafter referred to as, "1980 Rome Convention") and the Regulation (EC) No 593/2008 of the European Parliament and of the Council of 17 June 2008 on the law applicable to contractual obligations (hereinafter referred to as "Rome I Regulation"). ${ }^{76}$ The Tsûsokuhô contains a presumption under which the place of the habitual residence of the party required to effect the characteristic performance is the place with which the contract is most closely connected (Art. 8(2)). As a result of these revisions, the role of the pursuit of an implied or hypothetical intention of parties that had developed under Article 7 of the Hôrei was eliminated, and a choice-of-law provision will now be upheld if only there is an actual express or implied agreement on the applicable law. ${ }^{77}$ It follows that the scope of application of Article 7 of the Tsûsokuhô has become relatively narrower than Article 7(1) of the Hôrei.

The characteristic performance theory, which was recently incorporated into Article 8 of the Tsûsokuhô, has been adopted in various jurisdictions outside of Japan. ${ }^{78}$ Even prior to its incorporation to the new law, some academics even hinted at it in their interpretations of Article 7 of the Horei

74 Article 8. No Governing Law Chosen by the Parties

(1) If there is no applicable law chosen by the party/parties as in the preceding article, the formation and effect of a juristic act shall be governed by the law of the place with which the act was most closely connected at the time the act was made.

(2) In the case of the preceding paragraph, if the characteristic performance of a juristic act is to be made by one party, the law of his/her habitual residence (if the party has an establishment which is related to the juristic act, the law of the place where the establishment is located, and if the party has several establishments in different jurisdictions which are related to the juristic act, the law of the place where the principal establishment is located) is presumed to be the law of the place with which the juristic act is most closely connected.

(3) Notwithstanding the preceding paragraph, in applying paragraph 1 , if the object of the juristic act is an immovable, the law of the place where the immovable is situated is presumed to be the law of the place with which the act is most closely connected.

${ }^{75}$ OJ C 027, 26 January 1998, p. 34-46 (consolidated version).

76 OJ L 177, 4 July 2008, p. 6-16.

77 Kunio Koide, Itchimon ittô atarashii kokusai shihô [Q\&A New Private International Law] (Shôji hômu, 2006), p. 45; Hiroshi Sano, Hôtekiyô tsûsokuhô ni okeru keiyaku junkyohô no kettei [Determination of Law Applicable to Contracts under the New Private International Law of Japan], Minshohô zasshi Vol. 136-1 (2007), p. 27.

${ }^{78}$ See inter alia Article 4 of the 1980 Rome Convention; Article 4 of the Rome I Regulation; Article 117 of Switzerland's Private International Law Statute; Article 26 of Korea's Private International Law. 
through the way of finding the hypothetical intention of parties. ${ }^{79}$ The following should be mentioned as a distinction of determining the applicable law based on characteristic performance under the Tsûsokuhô. Choice of law by characteristic performance is ultimately nothing more than a presumption of the place with the closest connection. The same can be said of the provisions of the 1980 Rome Convention. In the Rome I Regulation, however, characteristic performance is stipulated as one of the objective points of connection. This is a very different stance to that of the Japanese Tsûsokuhô. As it is a presumption, several problems still remain that require elucidation, including the degree of evidence necessary before it is possible to decide the governing law other than by characteristic performance and the strength of the presumption; however, we will have to wait to see the accumulation of interpretative theories and court cases in the future.

\section{Court Cases and Doctrines Concerning the Applicable Law to IP Contracts in Japan}

There have not been many cases to date in Japan where the applicable law to a contract concerned with the transfer or licensing of intellectual property rights was at issue. In fact, there are probably only a handful of cases about contractual transfer of copyrights (Kewpie case; Tokyo High Court decision of 30 May 2001, ${ }^{80}$ 'von Dutch' Logo Registration case; Intellectual Property High Court appeal decision of 27 March $2008^{81}$ and Tokyo District Court decision at first instance of 26 October 2007, "Dari no Sekai" Catalogue case; Tokyo High Court decision of 28 May $2003^{83}$ ). The premise common to these cases is that

\footnotetext{
in determining the governing law that ought to be applied to a transfer of copyright, it is necessary to distinguish between a claim under a contract that is causally connected to the transfer and a change in the control of a real right such as a copyright that is the subject of a contract, and to decide the governing law on a case by case basis with respect to the law on each.

This opinion stands out because, as the quoted sentence itself points out, it conceives of a contract relating to a transfer of intellectual property rights as being the same in substance as a contract relating to the transfer of a real right. The issue that arises from such a contract must then be categorized as a claim or as an intellectual property right itself, after which

79 See, for example, Yasuhiro Okuda, Kokusai torihikihô no riron [The Theory in International Transactions] (Yûhikaku, 1992), p. 62.

${ }^{80}$ Hanrei Jihô No. 1797, p. 111.

${ }^{81}$ Not published in court case reports.

${ }^{82}$ Not published in court case reports.

83 Hanrei Jihô No. 1831, p. 135.
} 
the governing law can then be determined. The courts have pointed out two reasons for carrying out this sort of categorization: ${ }^{84}$

(i) the law and regulations of the place of the subject matter of a real right (lex rei sitae) ought to be the governing law of matters such as the details, effect, and requirements for acquisition and loss of the real right, ${ }^{85}$ because real rights are rights relating to the direct use of a thing and the right vests in its holder to the exclusion of all third parties, so it would be more natural to apply the laws and regulations of the place of the thing to the rights arising with respect to it, and it would also be more appropriate for meeting the demands of achieving the purpose of the right and protecting the interests of third parties, and

(ii) as copyrights, and their details and effect, are provided for by the laws and regulations of the country protecting them (lex loci protectionis), and as they can be exploited to the exclusion of all third parties, they should be thought of in the same manner as when the law of the place is applied to the acquisition and loss of real rights. The stance evident in this opinion also appears in doctrine. ${ }^{86}$

If the problem with respect to contracts concerning intellectual property rights is categorized and broken down in this manner, it should be questioned how to decide the governing law that ought to be applied in each issue. ${ }^{87}$

As to the contractual aspect, as noted above, even the Hôrei, before the Tsûsokuhô came into force, recognized that parties were in general free to choose the governing law to the contract. Hence in relation to contracts for the transfer or licensing of intellectual property rights, the prevailing theory and the court cases under both the Horei admit the parties' freedom to

${ }^{84} \mathrm{See}$, for example, the appeals court decision in the Dari case, and appeals court decision in the von Dutch case.

${ }^{85}$ See Article 13 of Ts $\hat{\text { sisokuhô: }}$

(1) Real rights and any other rights to be registered in relation to movables and/or immovables shall be governed by the law of the country where the concerned object is situated (lex rei sitae).

(2) Acquisition and loss of such rights as stipulated in the preceding paragraph shall be governed by the law of the country where the concerned object was situated at the time of fulfillment of the ground for such acquisition or loss.

${ }^{86}$ Teruo Doi, Kôgyô shoyûken/chosakuken to kokusai torihiki [Industrial Property Rights/Copyrights and International Transactions] (Seibundô, 1967), p. 48; Yamada (supra note 71) p. 386; Jun'ichi Eguchi/Shigeki Chaen, Kokusai torihiki to chiteki zaisanken [International Transactions and Intellectual Property Rights], in: Hiroshi Matsuoka (ed.), Gendai kokusai torihikihô kôgi [Lectures on Modern International Transactions Law] (Hôritsu bunkasha, 1996), p. 191.

${ }^{87}$ As to the applicable law to intellectual property right itself, see supra part VI of this article. 
choose the governing law. ${ }^{88}$ Where the choice of law was not clear from the parties' intentions or in the absence of the parties' choice, then many opinions expressed favored the law of the country protecting the intellectual property right (lex loci protectionis) as being the country of the parties' provisional or hypothetical intention under Article 7(1) of the Hôrei ${ }^{89}$ It has also been argued that if an industrial property right to be transferred or licensed depends for its existence on multiple countries, then the licensor or transferor intended for the law of the licensor's or transferor's country shall be the governing law. ${ }^{90}$ On the other hand, since the entering into force of the Tsûsokuhô, opinions have hinted at determining the place of the characteristic performance under Article 8(2) and using the law of the land where the characteristic performance is to be effected as the governing law. ${ }^{91}$ There are also opinions, however, that combine the characteristic performance doctrine with the implied intention doctrine or, conversely, that suggest keeping the two doctrines separate. ${ }^{92}$ However, in any event, debate in Japan is certainly not exhausted yet when it comes to the governing law of transfers and leases of intellectual property rights. The remaining question is related to the exact content of the notion of characteristic performance and whether it is possible to identify the content of characteristic performance at all.

The Rome I Regulation adopts the characteristic performance theory as one factor for determining the applicable law in the absence of parties' choice, not as a presumption of the most closely connected place, as provided in the Rome Convention or in the Japanese Tsûsokuhô. Accordingly, it could be pointed out that the determination of characteristic performance is much more important in the Rome I Regulation than in the Rome Convention or in the Tsûsokuhô.

We have to admit that it is extremely difficult to determine which performance obligation is the characteristic one in the contract concerning intellectual property rights, except for simple transfer contracts or license contracts. This is the reason why many scholars expressed the view that it

\footnotetext{
${ }^{88}$ Yamada (supra note 71) p. 386; Eguchi/Chaen (supra note 86) p. 191.

${ }^{89}$ Yamada (supra note 71) p. 386, but it should be noted that all of these opinions were expressed based on Hôrei, not on Tsûsokuhô.

90 Yamada (supra note 71) p. 386; Shôichi Kidana, Kokusaitekina chiteki zaisanken funsô no junkyohô [Applicable Law to International Intellectual Property Disputes], L\&T No. 16, p. 57.

91 Yasuto Komada, Chosakuken no jyôto [Transfer of Copyrights], in: Kokusai shihô hyakusen [Collection of Court Cases on Private International Law] (2007), p. 99.

${ }^{92}$ Shôichi Kidana, Kokusai chiteki zaisankenhô [International Intellectual Property Law] (Nihon hyôronsha, 2009), p. 453.
} 
is necessary to determine the characteristic performance case by case,${ }^{93}$ not for a whole group of contracts concerning intellectual property rights. However, there is no consensus in the arguments. For instance, some authors claim that in the simple transfer or license contracts, the characteristic performance is that of the transferor or licensor's, but in the other complex contracts it is that of the transferee or licensee. ${ }^{94}$ But there is also another view that in complex contracts it is useless to determine the characteristic performance and lex protectionis should be applied. ${ }^{95}$ Furthermore, there is one argument which claims that the characteristic performance should be determined in compliance with the provisions of the Rome I Regulation, and contracts concerning intellectual property rights should be placed as far as possible within one of the categories of Article 4 of the Rome I Regulation. ${ }^{96}$ In EU member states, it is an obligation to determine the characteristic performance because of the text of the Rome I Regulation, but in any event, according to these observations by European scholars, it seems that the predictability of the result is at stake.

\section{ALI Principles, CLIP Principles, and Theories in EU}

a) Overview of the Current Discussion about the Applicable Law to Contracts Concerning Intellectual Property Rights in EU

In the EU, the Rome I Regulation came into force in December 2009. When the Rome I Regulation was first drafted, there was a provision concerning the applicable law to the contracts concerning intellectual property. ${ }^{97}$ However, there were many criticisms to this drafted provision, and the final draft did not contain a provision dealing with this matter. ${ }^{98}$ As a consequence, academic debate is still necessary to determine the applicable law for this kind of contracts.

93 See, for instance, Paul Torremans, Licences and Assignments of Intellectual Property Rights under the Rome I Regulation, in: Journal of Private International Law, Vol. 4, No. 3, p. 402 et seq.; Pedro A. De Miguel Asensio, Applicable Law in the Absence of Choice to Contracts Relating to Intellectual or Industrial Property Rights, in Yearbook of Private International Law Vol. 10 (2008), p. 205 et seq.; Axel Metzger, Transfer of Rights, License Agreements, and Conflict of Laws: Remarks on the Rome Convention of 1980 and the Current ALI Draft, in: Basedow et al. (eds.), Intellectual Property in the Conflict of Laws, (Mohr Siebeck, 2005), p. 63 et seq.

${ }_{94}$ See Ulmer (supra note 15) p. 102 et seq.

95 Torremans (supra note 93) p. 420.

96 De Miguel Asensio (supra note 93) p. 205 et seq.

97 COM(2005) 650 final, Article 4.

98 See de Miguel Asensio (supra note 93) p. 200. 


\section{b) The ALI Principles}

ALI adopted its intellectual-property-governing jurisdiction, choice of law, and judgments in transnational disputes in 2008. $\S 315$ of the ALI Principles provides for a special rule on the applicable law to contracts concerning intellectual property rights. According to this Article, parties' choice of law is permitted (paragraph 1), as it is in the Rome I Regulation and the Japanese Tsûsokuhô. In the absence of parties' choice, the contract law of the state with the closest connection to the contract would be applied. Furthermore, in order to determine which state is the closest connected to the contract, the place of residence of the assignor or the licensor is presumed as a connecting factor indicating the closest connection (paragraph 2). In the Reporter's note to this provision, it is explained that this presumed connecting factor provided in paragraph 2 of this Article is derived from the characteristic performance theory. However, as noted above, the characteristic performance in a contract concerning intellectual property rights cannot be determined as easily as ALI did. ${ }^{99}$ This opinion could be supported by the complicated arguments as to Rome I Regulation determining characteristic performance in this matter.

\section{c) CLIP Principles}

Article 3:501 of the CLIP Principles ${ }^{100}$ provides for the freedom of choice for contracts in general, and Article 3:502 provides for the rule of choice of law in the absence of parties' choice. It seems that Article 3:502 gives up characteristic performance theory as a presumable factor in order to determine the most closely connected place to the contract. But there are still so many factors to be taken into account in the CLIP Principles. So, again, it could be pointed out that according to this rule, parties' predictability is at stake, too. For instance, how do they decide the most closely connected place to the contract if the royalties are expressed as a percentage of the sales price and the rights are mainly exercised in the state of the licensor's habitual residence?

\section{d) Waseda Project Proposal}

Under the Waseda Project Proposal, ${ }^{101}$ parties are in principle free to choose the applicable law to their contracts for intellectual property rights

\footnotetext{
99 See Metzger (supra note 93) p. 75.

100 For further information about CLIP and its principles, see $<$ www.cl-ip.eu/ $>$.

$101<$ www.globalcoe-waseda-law-commerce.org/activity/pdf/ 19/21.pdf> (Last visited on 28 March 2010).
} 
(Art. 19). ${ }^{102}$ In addition, there is a provision setting out choice-of-law rules in the absence of parties' choice (Art. 20). ${ }^{103}$ The characteristics of the Waseda Project Proposal are that in the absence of parties' choice, in principle, as with the ALI Principles, the habitual residence of the transferor or licensor is presumed to be the law of the place most closely connected to the contract. Besides, the Waseda Project Proposal leaves some room for determining the characteristic performance for each type of contract, affected by the discussion in the EU (Art. 20(3)). Indeed, by listing factors to be considered in determining whether another law is more closely connected with the contract than the law of the habitual residence of the transferor or licensor, Article 20(3) seems to avoid any inconsist-

102 Article 19 (Parties' Choice of Governing Law Relating to Transfer or License of Intellectual Property Rights)

(1) A contract for the transfer or license of an intellectual property right is governed by the laws of the country chosen expressly or implicitly by the parties with respect to all or a part of the contract at the time of or after entering into the contract.

(2) The governing law provided for in the preceding paragraph does not apply to the existence, validity, scope of protection, term, negotiability, or form of transfer or license of the intellectual property right. These are governed by the laws of the protecting country in Article A.

This text was changed. See <www.globalcoe-waseda-law-commerce.org/activity/pdf/ 19/21.pdf $>$ (Last visited on 28 March 2010).

(3) (If the choice provided for in Paragraph 1 is made in a standard form contract, the non-drafting party is required to be able, at the time of entering into the contract, to reasonably peruse and understand the details of the agreement, and to be able to refer to the details of the agreement subsequently. Such an agreement will be valid only if it is reasonable from the perspective of the transaction and the location, assets, and knowledge of the non-drafting party.)

103 Article 20 (Governing Law in the Absence of Parties' Choice)

(1) If no choice of governing law is made under the preceding article, the contract provided for in the preceding article will be governed by the law of the land most closely connected to the contract at the time it was entered into.

(2) For a contract concerned with intellectual property rights, the habitual residence of the transferor or licensor is presumed to be the law of the place most closely connected to the contract. If the transferor or licensor is a juridical person and has its place of business in multiple countries with different laws, the law of the place of its principal place of business will be presumed to be the law of the most closely connected place.

(3) If on consideration of the factors set out below a court decides that another law is more closely connected with the contract, that law will be the governing law:

(a) the obligations to be borne expressly and implicitly with respect to the use of the intellectual property rights

(b) the connection between principal place intellectual property right is to be exploited on the one hand and the habitual residences and business places of the parties on the other

(c) the quality of the right licensed in terms of whether it is exclusive or not

This text was changed. See <www.globalcoe-waseda-law-commerce.org/activity/pdf/ 19/21.pdf $>$ (Last visited on 28 March 2010). 
ency which might possibly arise out of a rigid process of identifying the place of the characteristic performance. By breaking up contracts into categories, however, the rules have been made complicated, possibly to the extent of diminishing foreseeability for the parties.

\section{Comment on the Transparency Proposal}

Having taken a bird's-eye view of the ALI, CLIP, and Waseda Project Proposal and the discussions that have been taking place among European scholars, we have a sense that characteristic performance theory plays no important role in the field of IP contracts.

If the parties have not chosen the applicable law to their IP contract, then contrary to Article 8 of the Tsûsokuhô, the Rome I Regulation, the ALI Principles, and the CLIP Proposal, we believe that it is not preferable to take the habitual residence of the party required to effect the characteristic obligation as the connecting factor. The characteristic performance doctrine is a tool of localization of the contract and, in the first place, a doctrine whose very crux is that in order to associate a contract with a specific place there is a duty to consider which obligation of the contract is decisive, and to characterize the contract. That characteristic obligation then has to be linked to the habitual residence of the person who has to perform it. ${ }^{104}$ However, if there are other more appropriate points of connection, there is no impediment to them being determinative. Under the Tsûsokuhô, for example, as well as under the Rome I Regulation and the Rome 1980 Convention, the place most closely connected for labor contracts is the place where the characteristic performance is to take effect, in other words, the place where the labor is to be provided. In addition, in these instruments, it is admitted that the contract related with the immovable is mostly connected to the place where the immovable is situated. In light of these points it seems we ought to consider whether there aren't any more appropriate points of connection with respect to contracts for intellectual property rights. When viewed from such a perspective, isn't the distinguishing characteristic of a contract for intellectual property rights simply the objective rights themselves? This is so because we know the unique nature of the intellectual property rights - such as the ownership of the rights, the type of rights, the scope of protection, the independence of the rights, their exclusiveness, and their term - will naturally have to have some effect on the contract. And if that is the case, it should be possible for the country granting the objective intellectual property right to be the

104 See generally Mario Giuliano/Paul Lagarde, Report on the Convention on the Law Applicable to Contractual Obligations, O.J. C 282, 31 October 1980, p. 20. 
place with the closest connection to the contract, as in the contract of immovable.

If the country granting the intellectual property right is the place with the closest connection to the contract, measures will need to be taken to deal with situations where the intellectual property right that is the subject of the contract is granted by multiple countries. One such example would be the transfer of screening rights for a motion picture to be shown at cinemas across the world. To be sure, in most cases the governing law would be chosen, but if it were not chosen and the laws of the country granting the intellectual property right were made the governing law of the contract, there would be too many candidate countries, and foreseeability for the parties would be lost. This would make it necessary to choose one of the places. However, if at that point we then returned to the general doctrine of characteristic performance, it would mean making the connecting factor the habitual residence of the right holder, that is, the transferor or licensor.

Nevertheless, it is still possible that the right holder's habitual place of residence would have no connection with the contract (for example, a business person who has his/her registered principal place of business in a copyright haven and does not actually carry out any substantive activity there at all). Then, of course, we need an exception providing for another place with a closer connection to the contract as a principle. In an actual transaction there are often cross-licenses and multiple right holders. These sorts of cases fall under this principle, as it is impossible or useless to pick up as many factors as possible to categorize contracts and indicate an objective connection to any place instead of determining the law based on the place with the closest connection.

\section{Security Interests to Intellectual Property Rights}

Article 308 of the Transparency Proposal ${ }^{105}$ provides for the rules of choice of law concerning security interests in intellectual property rights. ${ }^{106}$ To date, there is no stipulated rule in Japanese law on the applicable law to security interest in general. Accordingly, the task to determine the applicable law is left for academic discussion. This also holds true for matters of intellectual property rights. However, until now there were not

105 See Annex III.

106 In the process of discussion, there were some opinions which claimed that the mortgage in which ownership of the property is transferred to the lender should be different from other kinds of security interests. We did not take this position because we could not find reasonable grounds for that. 
enough discussions about this issue. For instance, in Japan, there is one Supreme Court case ${ }^{107}$ where the matter concerning applicable law to the pledge on credits was decided. According to this court case, the pledge of obligation is qualified as the real right and the law applicable to the obligation in question determines its governing law. This decision is highly supported by most Japanese academics. ${ }^{108}$

In the Transparency Proposal, as in the Supreme Court case noted above, we take the right that is the object of the pledge as the connecting factor, and the applicable law is determined by the applicable law to the intellectual property right itself, i.e., the law of the country granting the intellectual property right. In the ALI Principles and the CLIP Principles, there are similar provisions to the Transparency Proposal. ${ }^{109}$

\section{Concluding Remarks}

In this part, we have analyzed issues of the applicable law in intellectual property infringement and unfair competition from the perspective of the place where the results occur or are to occur. The law of the country of registration in patent law and the law of the country for which protection is sought can coexist with this market-oriented approach. If the intellectual property law of country A protects the market of country A, the market of the registered country is the most affected (in patent), and the law of the most affected market is the law of the country for which protection is sought (in copyright). This proposal relies on an argument of tort liability as a choice-of-law rule and retains the principle of "independence of IP rights," but does not adopt a strict territoriality principle. We would be extremely grateful if you would accept our argument as an "experiment" of brain storming from the perspective of the "market" in each country. Similarly, other choice-of-law provisions pertaining to initial ownership, transferability of IP rights, or ubiquitous infringements were drafted with an objective to accommodating existing Japanese law to the needs of global business.

107 Supreme Court, Decision, 20 April 1978, Minshû Vol. 32, No.3, p. 616, abbreviated English translation available at <www.courts.go.jp/english/judgments/text/ 1978.04.20-1975.-O-No..347.html>.

${ }^{108}$ See, e.g., Yamada (supra note 71) p. 297; Yuko Nishitani, Bukken junkyohô wo meguru kadai to tenbô [Perspectives and Problems on lex in rem], Minshohô zasshi Vol. 136-2 (2006), p. 242. II.

${ }^{109}$ See ALI-Principles $\S 317$, infra Annex I; see also CLIP Article 3:508, infra Annex 


\section{Appendix}

\section{Copyright Act ${ }^{110}$}

Article 15 (Authorship of a work made by an employee in the course of his duties)

(1) The authorship of a work (except a computer program work) which, on the initiative of a juridical person or other employer (hereinafter in this Article referred to as "juridical person, etc."), is made by an employee in the course of the performance of his duties in connection with the juridical person, etc.'s business and is made public by such juridical person, etc. as a work under its own name, shall be attributed to such juridical person, etc., unless otherwise stipulated by contract, work regulations or the like at the time of the making of the work.

(2) The authorship of a computer program work which, on the initiative of a juridical person, etc. is made by an employee in the course of his duties in connection with the juridical person, etc.'s business, shall be attributed to such juridical person, etc., unless otherwise stipulated by contract, work regulations or the like at the time of the making of the work.

\section{Unfair Competition Prevention Act ${ }^{111}$}

\section{Article 2 (Definitions)}

(1) The term "unfair competition" as used in this Act means any of the following:

(i) acts of creating confusion with another person's goods or business by using an indication of goods or business (which means a name, trade name, trademark, mark, or container or package of goods used in relation to a person's business, or any other indication of a person's goods or business; the same shall apply hereinafter) that is identical or similar to said person's indication of goods or business that is well-known among consumers or other purchasers, or by assigning, delivering, displaying for the purpose of assignment or delivery, exporting, importing or providing through an electric telecommunication line the goods using such an indication;

(iii) for the purpose of assignment or leasing, exporting or importing goods which imitate the configuration (excluding configuration that is indispensable for ensuring the function of said goods) of another person's goods;

\footnotetext{
${ }^{110}$ English translation is available at <www.cas.go.jp/jp/seisaku/hourei/data/CA.pdf $>$ (Last visited on 3 May 2009).

111 English translation is available at $<$ www.cas.go.jp/jp/seisaku/hourei/data/ucpa. pdf $>$ (Last visited on 3 May 2009).
} 
(xiv) acts of making or circulating a false allegation that is injurious to the business reputation of another person in a competitive relationship;

(6) The term "trade secret" as used in this Act means technical or business information useful for commercial activities such as manufacturing or marketing methods that is kept secret and that is not publicly known. 


\title{
Summary of Comments and Discussion on Applicable Law
}

\author{
by Paulius Jurčys and Simon Vande Walle
}

\section{Comments made by Prof. Mari Nagata}

Prof. Nagata first of all drew attention to a number of similarities and differences between the three proposals. While the potential scope of the ALI Principles is worldwide, the CLIP Principles and the Transparency Proposal were drafted with the intention to improve the existing legal regimes in the European Union and Japan respectively. The Transparency Proposal was drafted in light of the Japanese Act on General Rules for Application of Laws. Hence, the Transparency Proposal had to be consistent with general principles of private international law established by the Act. The CLIP Principles were prepared against the background of the existing Rome I and Rome II Regulations on the law applicable to contractual and non-contractual obligations. As to the similarities, she suggested that the three proposals set similar criteria of qualification, such as applying a single governing law to all kinds of remedies in infringement cases. ${ }^{1}$ In addition, all three proposals recognize the parties' basic freedom of choice at least in contractual matters, while it has been argued that parties' freedom of choice of law should be restricted in the case of infringement.

Next, Prof. Nagata commented on the approach taken in the Transparency Proposal, CLIP Principles, and ALI Principles with regard to the rules designating the law applicable to initial ownership, transferability, and effects of intellectual property rights. Whereas the CLIP Principles and ALI Principles refer to the lex loci protectionis, i.e., the law of the state for which protection is sought, as applicable law to initial ownership, transferability, and effects of intellectual property rights, ${ }^{2}$ Article 305 of the Japanese Proposal provides that these matters shall be governed by the law of the country that granted the right. The language in Article 305 is slightly different from the language that is conventionally used to refer to the application of the law of the protecting country as the CLIP Principles and ALI Principles adopted because the Japanese group thought that the expression "law of the state for which protection is sought" is ambiguous. Prof. Nagata mentioned that the Japanese drafters were not absolutely sure about the content of the lex loci protectionis principle. Moreover, the Japanese Proposal was drafted under the assumption that the wording "the law of the country that granted the intellectual property right" was not the

\footnotetext{
${ }^{1}$ Art. 301 Japanese Proposal; Arts. 3:601 and 604 CLIP Principles; Art. 301 ALI Principles.

${ }^{2}$ Art. 3:102 CLIP Principles; Art. 301 ALI Principles.
} 
lex originis that is clearly denied in the CLIP Principles, ${ }^{3}$ nor the law of the protecting country. Prof. Nagata asked her European colleagues to comment on these issues, especially on the ambiguity of the lex loci protectionis.

With regard to choice-of-law rules for licensing agreements, Prof. Nagata expressed her view that the CLIP Principles and the Japanese Proposal are essentially similar when parties choose the applicable law to their contracts. ${ }^{4}$ Nevertheless, some practical problems may arise in situations where parties have failed to choose the applicable law. In such cases, the law with the closest connection will have to be applied, and this approach was taken in all three proposals. In order to determine which law shall be the law with the closest connection, the ALI Principles and CLIP Principles rely on the "characteristic performance theory." Prof. Nagata explained that there may be situations in which it is not possible to determine who is the person performing the characteristic obligation. Such practical problems result in a lack of predictability. Therefore, Prof. Nagata wondered whether some other possible connecting factors might somehow help to solve this problem. Thus, as she mentioned, the Transparency Proposal did not embrace the characteristic performance theory. ${ }^{5}$

According to Prof. Nagata, the determination of the law applicable to infringements and remedies is one of the most challenging issues. Prof. Nagata explained that there are generally two approaches: lex loci protectionis, which was adopted in the CLIP Principles, ${ }^{6}$ and lex loci delicti, which was the approach taken by the Transparency Proposal. ${ }^{7}$ The Japanese Proposal may have chosen the lex loci delicti rule partly because of the existing Japanese case law (namely, the Card Reader case ${ }^{8}$ ). By contrast, the CLIP Principles adopted the lex loci protectionis rule and

${ }^{3}$ It is not clear from the wording of the CLIP Principles, but in the comment to the CLIP Principles Prof. Metzger states that the lex originis should not be used because applying the lex originis would mean either setting aside the author-protecting rules of the forum state when the work has been published for the first time in another state or applying such provisions as public policy of the forum. See Axel Metzger'contribution in this volume supra p. 164.

${ }^{4}$ Art. 306 Japanese Proposal; Art. 3:501 CLIP Principles. See also Art. 315 of ALI Principles.

5 The concept of "characteristic performance" was used in the first version of the CLIP Principles, on which this discussion was based, but it was omitted in the second version.

${ }^{6}$ Arts. 3:601 and 3:602. The ALI Principles also took this approach. See Art. 301 ALI Principles.

7 Art. 301 Japanese Proposal.

8 Supreme Court Decision, 26 September 2002, Minshû vol. 56, No. 7, p. 1551. English translation of this case is available at $<$ http://tomeika.jp/search/content.php?did $=1068>$. 
thereby followed Article 8 of the Rome II Regulation. In any event, it appears that the adoption of the de minimis rule in Article 3:602 of the CLIP Principles illustrates that both rules - lex loci protectionis and lex loci delicti - have their own merits.

Next, Prof. Nagata addressed the choice-of-law rules for ubiquitous infringements, which is also an intensely debated issue. All three proposals contain such rules. ${ }^{9}$ However, one could still question whether such special provisions are necessary at all. None of the three proposals provides for a rule that will ensure legal certainty and foreseeability of the applicable law. Likewise, one could doubt whether the concept of the "place where the results of exploitation of intellectual property rights are or to be maximized" can be of much use in practice. Prof. Nagata mentioned that she would have favored the approach taken in the ALI Principles, which use the criterion of the habitual residence of the infringer as one of the main factors in determining the applicable law to ubiquitous infringements of intellectual property rights.

Finally, Prof. Nagata asked Prof. Shimanami about his opinion concerning the applicable law in the case of inventions by employees because there was no explanation nor provision concerning this matter in the Transparency Proposal or comments. ${ }^{10}$

\section{Discussion}

In his reply to Prof. Nagata's last question, Prof. Shimanami emphasized that choice-of-law rules determining the applicable law to works made for hire and employees' inventions lead to different solutions. While the CLIP Principles lead to universal solutions, the Transparency Proposal follows the mosaic approach, by requiring the application of the law of the country that granted the intellectual property right. One of the underlying reasons for this solution was that harmonization of the substantive intellectual property laws in different states is very difficult. Hence initial ownership issues should be decided on a country-by-country basis. He briefly referred to the Hitachi Optical Disc case ${ }^{11}$ decided by the Supreme Court in 2006, in which the Court viewed initial ownership as a contractual issue, but nevertheless stressed that public policy regarding initial ownership played a much bigger role in the Transparency Proposal than in the CLIP Principles.

\footnotetext{
9 Art. 3:603 CLIP Principles; Art. 302 Japanese Proposal; Art. 321 ALI Principles.

${ }^{10}$ In the CLIP Principles, there is a special provision for this issue. See Art. 3:503 CLIP Principles.

11 Supreme Court, 17 October 2006, abbreviated English translation available at $<$ www.tomeika.jur.kyushu-u.ac.jp/ip/pdf119-148/17\%20October\%202006.pdf>.
} 
In response to Prof. Shimanami's remarks, Prof. Metzger pointed out that the discussion concerning initial ownership in employment relationships had not been finally settled in the CLIP Principles. From a doctrinal point of view, the initial ownership question should be considered as a contractual issue. However, the CLIP Principles do not provide for a "hard-core" freedom of choice, but merely try to take into account the place where the employee is employed. As far as employees' inventions are concerned, this approach is based on Article 60 of the European Patent Convention.

Prof. Kojima discussed the relationship between the lex loci protectionis rule and the "market impact rule" proposed in the Japanese draft (Art. 301 of the Transparency Proposal). This question was debated at length during the drafting process; it appeared that in most cases the lex loci protectionis and the market impact rule would lead to the same result. The members of the Japanese working group were also mindful of the fact that the applicable law under the lex loci protectionis approach is guided by the claims of the plaintiff. The members of the Japanese working group were not so keen on adopting a "subjective" approach. Instead, an "objective" effects rule was introduced.

Prof. Kojima explained that the "effects market impact rule" will be clarified in the comments as referring to the market of the country where the loss is sustained. In fact, the "market impact rule" adopted in the Transparency Proposal was borrowed from recent discussions among European and American scholars. Yet one can still question whether the "market impact rule" is to be understood from the point of view of substantive law rather than conflict of laws. In any case, during the drafting process of the choice-of-law rules, the members of the Transparency Proposal working group aimed for the result that would minimize costs.

Regarding ubiquitous infringements, Prof. Kojima commented that the choice-of-law rule based on the place where the results of the exploitation of the intellectual property are or to be maximized might not function perfectly in the digital environment. Another noteworthy feature of the Transparency Proposal is that Article 302 does not require taking into account the place of habitual residence of the defendant in determining the applicable law.

Prof. Teramoto also addressed the issue of ubiquitous infringements and emphasized that existing differences of the notions could be explained by different purposes of the given draft principles. Moreover, he stressed the need to consider the policy rationale in drafting choice-of-law rules for intellectual property cases. Prof. Kojima replied that the definition of ubiquitous infringement in the Transparency Proposal was omitted intentionally. Instead, several practical examples are provided in the commen- 
tary part. However, from a conceptual point of view, it seems that the notion of ubiquitous infringement is very similar to the one adopted in the CLIP Principles. Prof. Dessemontet wondered whether it is reasonable to limit the definition of ubiquitous infringement to particular technological media because ubiquitous infringements could also occur through other media - for instance, if a picture of a famous Japanese baseball player living in New York were illegally used in an advertisement in a magazine that is published in numerous states across Asia. The ALI Principles would also apply to this kind of infringement, while it appears that this kind of infringement would not fall under the notion of "ubiquitous infringement" as used in the CLIP Principles.

Prof. Metzger indicated that the notion of ubiquitous infringement in the CLIP Principles is much narrower than it is in the ALI Principles. Article 3:603 of the CLIP Principles applies only to infringements of copyrights and well-known trademarks and only in those cases where Internet or similar media that may develop in the future are concerned. The members of the CLIP working group considered whether it would not be worthwhile to make the material scope of the rule wider (e.g., for cases where patents had been granted in most of the states party to the European Patent Convention). However, the majority opinion was to stick to the territoriality principle because the national laws of different countries are still different.

According to Prof. Metzger, the principle of lex loci protectionis has been interpreted differently by the members of the CLIP working group. Prof. Metzger had the impression that the application of the law of the state of protection is subjective: the plaintiff files suit and seeks prohibition of certain actions in particular states. Prohibition would mean that the reference is not made to the remedies but to the activities that are prohibited by the applicable copyright or patent law. However, if the plaintiff has no existing right in the country where the protection is sought, the court could not issue an injunction. As regards the CLIP Principles, the drafters were aware of the different interpretations of Article 5(2) of the Berne Convention but, for the sake of consistency, the same rule was adopted in the CLIP Principles.

Prof. Basedow pointed out that in many European countries, personality rights are not classified as intellectual property rights. Therefore, infringement of personality rights would be decided following the general rules of tort law. Hence, general rules of private international law would be applicable in such case. The Rome II Regulation does not contain any choice-of-law rule for infringements of personality rights, mainly because the publishers and the European Commission could not find a common understanding as to the possible legal regulation of this question. Consequently, national conflict-of-laws rules would still apply. Prof. Basedow 
also stressed that, in his opinion, jurisdictional consolidation of claims is more important than the application of a single law. This is so because if a ubiquitous infringement case can be consolidated before the court of a single country, this would likely facilitate a settlement agreement between the parties.

Prof. Dessemontet raised a question concerning recordation requirements of licensing and assignment agreements of intellectual property rights. In particular, the wording of Article 10(5) of the Japanese Act on General Rules for Application of Laws ${ }^{12}$ appears to create an exception for assignment agreements regarding movables, immovables, or other rights requiring registration. ${ }^{13}$ This is particularly important because in many countries the licensing or transfer of rights does not have legal effects against third parties unless registered. Moreover, if the license is made for an entire continent, which law would be applicable to the form of this licensing agreement under Article 10(5)? Prof. Nishitani commented that the words "rights requiring registration" in Article 10(5) should be read in conjunction with Article 13, which concerns property issues. Yet the formulation about the registration is quite vague and is based on substantive Japanese law. At the time the Act was revised, there was a discussion whether this provision should be amended or not. One of the examples that is often referred to is short-term tenancy agreements. Although these agreements contain short-term obligations, registration of this right in Japan has erga omnes effects, i.e., effects against third parties. It could be said that recordation of title falls into the same category.

Prof. Dessemontet also commented on the concept of characteristic performance. After the adoption of the 1980 Rome Convention, the law governing the contract is no longer the law of the place where the characteristic performance takes place. The relevant factor is the place where the debtor of the characteristic performance has his or her habitual residence or is established. Therefore, the important question is no longer "where does the characteristic performance take place?" but "who performs the characteristic performance?" Many contractual disputes concerning intellectual property relate to technical licenses whereby the licensor is responsible for the quality of the process under the license. In this case it is not important in which country the process will be applied, but in which country the process has been developed. Prof. Dessemontet disagreed with the views expressed previously and stated that in his opinion the creators

\footnotetext{
12 Act No. 78 of 2006 on General Rules for Application of Laws, available at $<$ www. tomeika.jur.kyushu-u.ac.jp/intl/private/tsusokuho.pdf $>$.

${ }_{13}$ Art. 10(5) of the Act on General Rules for Application of Laws provides: "The second, third, and fourth paragraphs of this Article shall not apply to the formalities of a juristic act that establishes or disposes of a right in rem to movables or immovables, or of a right requiring registration".
} 
(authors and directors) are the ones who perform the characteristic obligation because without books or movies there would be no distribution. Prof. Basedow generally agreed with this view, but he also emphasized that there might be certain situations (e.g., in case of "books of consumption") where the contributions of authors may be less significant than those of distributors.

A member of the audience stressed the importance of different notions of intellectual property. Intellectual property is like a chimera. It has two sides: on one hand, intellectual property rights are created by the act of the state; on the other hand, intellectual property rights are used in ordinary commercial transactions. He welcomed the approach toward the territoriality principle taken in the CLIP Principles. He said that the approach taken in the Transparency Proposal (qualifying intellectual property infringements as torts) seems quite surprising. He emphasized that one of the key issues in drafting legal proposals is the policy justification for the adopted solutions.

Prof. Kojima replied that the Transparency Proposal takes a similar approach whereby existence, primary ownership, and effects of intellectual property rights are viewed from a public law perspective while the infringements are considered as having a private nature. The reason why a market-oriented approach to intellectual property infringements was adopted in the Transparency Proposal was that intellectual property law grants the right holder a legal monopoly.

Prof. Metzger expressed concerns about the possibility of distinguishing between the effects (e.g., fair use exception or other limitations of intellectual property rights) and the infringement of intellectual property rights. It appears to be reasonable to provide for a possibility to make a choice of applicable law to remedies for the infringement. Prof. Metzger thus advised clarifying these issues in the commentaries to the black letter rules of the Transparency Proposal.

Prof. Dessemontet invited all members of different working groups to follow a practical approach that would be most acceptable to business practices and oriented to the foreseeable future trends. This is so because right holders wish to administer licensing agreements with regard to different territorial markets in a similar manner. Therefore, the drafters of the principles should take an economic and global view. Legal principles that are not acceptable to the business community will not be followed and disputes will be referred to arbitration proceedings. He also reiterated support for the "effects-oriented" choice-of-law rule which adopts the same methodology to cases of infringement of intellectual property and unfair competition. 

Part 4: Recognition and Enforcement 



\title{
Recognition and Enforcement of Judgments in Intellectual Property Litigation: The CLIP Principles
}

\author{
Pedro A. De Miguel Asensio
}

I. Significance of recognition and enforcement in IP Litigation....................................2. 239

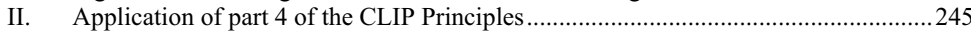

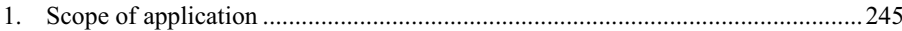

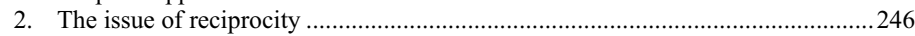

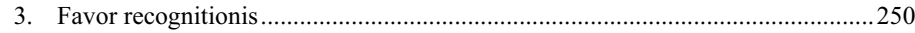

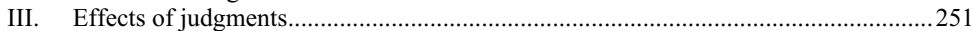

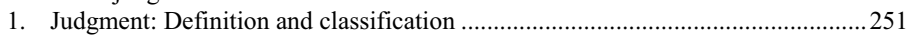

2. Effects of judgments and consequences of recognition ....................................253

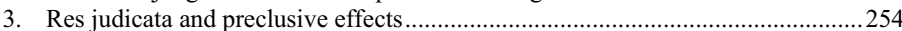

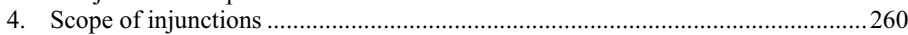

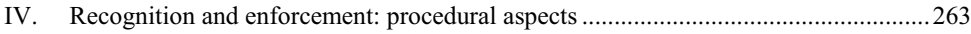

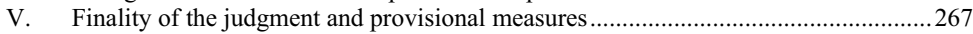

VI. Verification of the jurisdiction of the rendering court............................................271

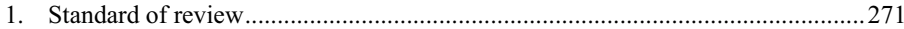

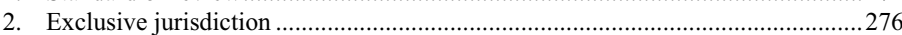

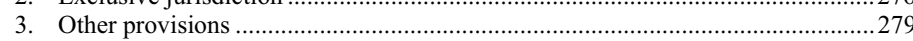

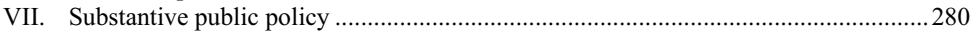

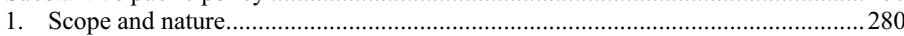

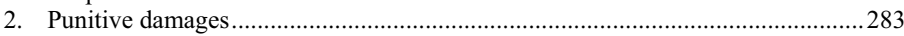

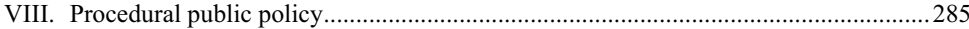

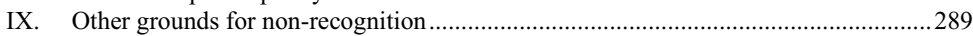

\section{Significance of recognition and enforcement in IP Litigation}

The current global context of economic activities combined with the territorial nature of intellectual property (IP) rights create a situation in which it is very common in practice that IP rightholders hold equivalent rights on the same object in many countries. Also, business models and modern technologies favor that a given activity may infringe rights in several if not many countries. The choices as to whether to litigate disputes concerning 
these equivalent rights only in one jurisdiction, and in which particular jurisdiction, may be greatly influenced by the possibility to have a judgment from a prospective forum recognized and enforced in other countries.

Because of the separation of judicial systems, the effects of a judgment are in principle limited to the territory of the sovereign whose court gave it. A foreign judgment must be recognized or declared enforceable in the local forum in order to produce its typical effects as a judgment in the forum country. A non-recognized judgment can be received in a different forum only as evidence of the matters earlier decided, since it may be regarded as a public document. However, this use of a foreign judgment does not preclude the merits of the underlying cause of action from a complete re-examination in the new forum. ${ }^{1}$ By contrast, recognition of a foreign judgment implies that the interested party does not need to re-litigate the cause in a new forum. It reduces judicial workload and litigation and ensures the protection of rights acquired under a foreign system, which is especially important in a context of increasing globalization.

Litigating multinational infringements in the courts of a single country or even suing an alleged infringer in a country other than where her or his assets are located creates situations in which rights and duties are determined in judgments that may require recognition in foreign jurisdictions. Hence, the development of appropriate principles in the area of recognition and enforcement of foreign judgments is essential for an effective protection of IP rights in the international sphere, where the possibility of relying upon a foreign judgment as res judicata has great strategic importance. ${ }^{2}$ However, it seems that recognition and enforcement have traditionally not played the important role they may deserve in international IP litigation strategies, being very much focused on other relevant aspects of procedural law of the jurisdictions involved. ${ }^{3}$

Enforcement abroad may be decisive to ensure the authority of an injunction ordering a party to desist from an infringement in the territory of several countries since injunctions are typically to be enforced in the country of protection of an IP right. Also, enforcing money judgments against defendants without sufficient assets in the country where the judgment was rendered raises special needs. It makes it necessary to pursue additional litigation in a country where the defendant has assets unless the original judgment can be enforced in such country. In addition, recognition

${ }^{1}$ See, e.g., C.H. Peterson, "Res Judicata and Foreign Judgments," 24 Ohio State LJ 291 (1963), at 291; and R. Geimer, Internationales Zivilprozeßrecht, $3^{\text {rd }}$ ed., 1997, p. 766 .

2 P. Barnett, Res Judicata, Estoppel, and Foreign Judgments, Oxford, 2001, pp. 4-5.

${ }^{3}$ See, e.g., D. Wilson (ed.), International Patent Litigation: Developing an Effective Strategy, 2009, at 14-16. 
of a foreign judgment prevents subsequent litigation in a different forum. Reliance on the res judicata effect of a foreign judgment is necessary to prevent the losing party from bringing new proceedings involving the same cause of action and between the same parties in the courts of another state. One example may illustrate this last point.

Example: The courts of country A have rendered a decision declaring that certain activities of company $\mathrm{Z}$ do not infringe the IP rights that company $\mathrm{Y}$ owns in countries $\mathrm{A}$ and $\mathrm{B}$. Once such a decision has become final according to the law of A, company $\mathrm{Y}$ brings a new claim against company $\mathrm{Z}$ concerning the same activities and claiming again that they infringe the same IP rights but now before the courts of $\mathrm{B}$. Recognition of the res judicata effect of the judgment of country A will be necessary to prevent relitigation in the new forum and would ensure that $\mathrm{Z}$ would not be bothered twice for the same claim.

When the country of origin and the requested state are not parties to a judgments recognition convention, judgments are subject to the local recognition and enforcement rules of the requested state. A significant number of bilateral and multilateral agreements on recognition and enforcement of foreign judgments have been concluded so far. Some of those conventions cover IP disputes, although usually they have no specific provisions in this field. In countries that are parties to international conventions, the conditions applicable to recognition differ depending on which is the country of origin of the judgment, since treaties on recognition and enforcement are usually subject to reciprocity.

Multilateral conventions or instruments covering recognition and enforcement of IP disputes have mainly been drafted at the regional level, especially in Europe. The presence within the EU of a uniform and coherent system of mutual recognition and enforcement of judgments, initially established in the 1968 Brussels Convention and now contained in the socalled Brussels I Regulation, ${ }^{4}$ has decisively contributed to cross-border adjudication of IP disputes within Europe, although the system has significant limitations and is currently under review. Additionally, some EU member states have built a network of bilateral treaties with third countries which, because of their general character, apply to the recognition and enforcement of most IP judgments coming from the respective contracting state. $^{5}$

${ }^{4}$ Regulation (EC) No 44/2001 of 22 December 2000 on jurisdiction and the recognition and enforcement of judgments in civil and commercial matters, OJ L 12, 16 January 2001, p. 1; and Convention on jurisdiction and the enforcement of judgments in civil and commercial matters, consolidated version in OJ C 27, 26 January 1998, p. 1.

5 For instance, Spain has concluded bilateral treaties with countries such as Colombia (1908); Mexico (1989); Israel (1989); Brazil (1989); Russia (1990); China (1992); 
By contrast, other countries are not parties to a single bilateral or multilateral international treaty generally applicable to recognition or enforcement of foreign judgments. This has traditionally been the situation in the United States ${ }^{6}$ and in Japan. ${ }^{7}$ However, from an international perspective, the situation in these countries is not completely different from that of the EU member states. In the EU the common recognition and enforcement rules of the Brussels I Regulation apply only to judgments given by a court of another member state. ${ }^{8}$ There is no uniform approach to the recognition of judgments rendered in third countries, and the dichotomy between the uniform intraCommunity rules and the national rules for third-country judgments still exists. ${ }^{9}$ Given its limited territorial scope of application, one of the features of the current EU system is that it does not ensure equal treatment and effects to third-country judgments throughout the EU. ${ }^{10}$ For instance, the recognition of a Japanese judgment remains outside the scope of application of the Brussels I Regulation and subject in each EU member state to its own domestic rules. ${ }^{11}$ However, the debate is currently open as to the future extension of the common EU rules to cover third-country judgments. ${ }^{12}$

Morocco (1997); El Salvador (2000); Tunisia (2001); Algeria (2005); and Mauritania (2006). However, not all IP disputes fall within the scope of application of these conventions; in particular the Convention with Mexico, Article 3.j), does not apply to disputes on non-contractual liability.

${ }^{6}$ See, e.g., R.A. Brand, "Enforcement of Judgments in the United States and Europe," 13 J.L. \& Com. 193 (1993-1994) at 194.

7 See N. Tada, "Enforcement of Foreign Judgments in Japan Regarding Business Activities," The Japanese Annual of Int'l L, 46, pp. 75-94 (2003), at p. 76, noting that Japan is a party to some international conventions containing provisions for the recognition and enforcement of judgments on specific matters, in particular in relation to compensation for oil pollution damage.

${ }^{8}$ The parallel Lugano Convention of 16 September 1988 extended the application of the rules of the 1968 Brussels Convention to certain member states of the European Free Trade Association. See its successor, the Lugano Convention of 30 October 2007, OJ L 339, 21 December 2007, p. 3.

9 D. Martiny, "Recognition and Enforcement of Foreign Judgments in Germany and Europe," in: J. Basedow/H. Baum/Y. Nishitani (eds.), Japanese and European Private International Law in Comparative Perspective, 2008, p. 377.

${ }^{10}$ See K. Kreuzer, "Zu Stand und Perspektiven des Europäischen Internationalen Privatrechts - Wie europäisch soll das Europäische Internationale Privatrecht sein? -," RabelsZ, 2006, 1, at. 75-76; and P.A. de Miguel Asensio, "Espacio Europeo de Justicia: Evolución y perspectivas en el sector del reconocimiento y ejecución de decisiones," $A E D I P r, 2006,441$, at 463.

${ }^{11}$ Domestic rules in this area still diverge to a significant extent across EU member states. A summary of the situation in several of those countries from the practitioner perspective may be found in P.J. Omar, Procedures to Enforce Foreign Judgments, 2002.

${ }^{12}$ See "Report from the Commission on the application of Regulation (EC) No 44/2001," COM(2009) 174 final of 21 April 2009, p. 5; and "Green Paper on the review of Regulation (EC) No 44/2001," $\operatorname{COM(2009)~} 175$ final of 21 April 2009, p. 4. In this 
The attempts to create international conventions covering the recognition and enforcement of judgments resulting from IP disputes have not been successful beyond regional organizations. The prospects for future developments in global organizations seem gloomy, as illustrated by the failed negotiations at the Hague Conference ${ }^{13}$ on the proposed Convention on Jurisdiction and Foreign Judgments in Civil and Commercial Matters. ${ }^{14}$ Due to the limitations of the existing conventions and the lack of global agreements, the applicable rules on recognition and enforcement usually depend on the law of the country where the enforcement is sought. ${ }^{15}$ The acceptance of uniform rules at the international level would be very significant to promote the efficient enforcement of IP rights. ${ }^{16}$ Fostering international enforceability of judgments is necessary to ensure effective and adequate protection of IP rights.

The progressive development of common standards on jurisdiction, choice of law, and recognition and enforcement of judgments by means of international model provisions may contribute to achieving a more effi-

connection, the CLIP Group in its contribution to the European Commission's consultation launched by the Green Paper referred to the idea that the CLIP Principles could serve as a source of inspiration for the Commission when addressing the issue of the conditions under which third-state judgments should be recognized and enforced in the Community.

13 A. Kur, "International Hague Convention on Jurisdiction and Foreign Judgments: A Way Forward for IP?" EIPR, 2002, 175, at 175-183; R. Dreyfuss, "The ALI Principles on Transnational Intellectual Property Disputes: Why Invite Conflicts?" 30 Brook. J. Int'l L., 819 (2005), at 821-822; and A. Schulz, "The Hague Conference Project for a Global Convention on Jurisdiction, Recognition and Enforcement in Civil and Commercial Matters - An Update," in: J. Drexl/A. Kur (eds.), Intellectual Property and Private International Law, 2005, 5 at 5-18.

${ }^{14}$ After the prolonged and failed negotiations for a global instrument, the Convention on choice of court agreements was concluded on 30 June 2005 (not yet in force, see $<$ www.hcch.net>). This Convention covers only choice-of-court clauses in business-tobusiness cases and does not contain rules on jurisdiction for specific subject matters such as infringement of IP rights. Also, its provisions on recognition and enforcement apply only to judgments given by a court of a contracting state designated in an exclusive choice-of-court agreement (Art. 8.1). Discussing the impact of this Convention on IP litigation, see S. Luginbühl and H. Wollgast, "Das neue Haager Übereinkommen über Gerichtsstandsvereinbarungen: Aussichten für das geistige Eigentum," GRUR Int, 2006, pp. 208-219.

${ }^{15}$ For a general overview, see the more than thirty national reports included in C. Platto/W.G. Horton (eds.), Enforcement of Foreign Judgments Worldwide $2^{\text {nd }}$ ed., 1993.

16 R.C. Dreyfuss/J.C. Ginsburg, "Draft Convention on Jurisdiction and Recognition of Judgments in Intellectual Property Matters," Chi-Kent L. Rev., vol. 77, 2002, 1065, at 1066 . 
cient resolution of international IP disputes. ${ }^{17}$ This rationale inspired both the American Law Institute (ALI) and the European Max Planck Group on Conflict of Laws in Intellectual Property (CLIP) ${ }^{18}$ when drafting their model rules on international IP litigation. Given the significance of recognition and enforcement provisions, this area of international civil procedure must be an essential part of a project aimed at improving international litigation on IP rights. In this context, Part 4 of the Second Preliminary Draft of the CLIP Principles (CLIP Principles) ${ }^{19}$ seeks to facilitate recognition and enforcement of foreign judgments providing adequate safeguards. Also the 2008 ALI Principles devoted Part IV to "Recognition and Enforcement of Foreign Judgments in Transnational Cases."20

The idea that international comity - mentioned in the Preamble as one of the foundations of the CLIP Principles - requires states to give certain effects to foreign judgments under some conditions is well-established in some legal systems. ${ }^{21}$ However, the rules applicable to recognition and enforcement of foreign judgments vary significantly across national legal systems. Additionally, the level of international cooperation achieved in this sector is very limited. Against this background, Part 4 of the CLIP Principles intends to provide national, regional, and international legis-

17 From a broader perspective, see S. Huber, Entwicklung transnationaler Modellregeln für Zivilverfahren, 2008, pp. 32-43.

${ }_{18}$ On the background of the project, see Drexl/Kur (eds.) (supra n. 13), at 21-84 and 308-334; J. Basedow/J. Drexl/A. Kur/A. Metzger (eds.), Intellectual Property in the Conflict of Laws, 2005; and A. Kur, "Applicable Law: An Alternative Proposal for International Regulation - The Max-Planck Project on International Jurisdiction and Choice of Law," Brook. J. Int'l L., vol. 30, 2005, 951, at 955-958. See also <www.clip.eu>.

${ }^{19}$ CLIP, Principles for Conflict of Laws in Intellectual Property, Second Preliminary Draft, of 6 June 2009, see Annex II (infra); as to other parts of the CLIP Principles, see the contributions of Jürgen Basedow (supra p. 3 seq.), Axel Metzger (supra p. 157 seq.) and Christian Heinze (supra p. 53 seq.) to this volume.

${ }^{20}$ See $\S \S 401$ to 413 ALI Principles - Intellectual Property: Principles Governing Jurisdiction, Choice of Law, and Judgments in Transnational Disputes. On the ALI Principles, see the contribution of F. Dessemontet to this volume. Additionally, on the origins and development of the project, see Dreyfuss/Ginsburg (supra n. 16), 1065; Dreyfuss (supra n. 13), at 819-848; and F. Dessemontet, "A European Point of View on the ALI Principles - Intellectual Property: Principles Governing Jurisdiction, Choice of Law, and Judgments in Transnational Disputes," Brook. J. Int'l L., vol. 30, 2005, 849.

${ }^{21}$ Comity is a basic explanation for the recognition and enforcement of foreign nations, as stressed by the U.S. Supreme Court in its Hilton decision Hilton v. Guyot, 159 U.S. 113 (1895). The U.S. Supreme Court gave a well-known definition of comity in this context as "the recognition which one nation allows within its territory to the legislative, executive or judicial acts of another nation, having due regard both to international duty and convenience, and to the rights of its own citizens, or of other persons who are under the protection of its laws" (id. at 163-64). 
lators with a balanced model based upon standards that have achieved significant international acceptance and that can promote cross-border recognition and enforcement of judgments resulting from IP disputes.

\section{Application of part 4 of the CLIP Principles}

\section{Scope of application}

The matters covered by the scope of the CLIP Principles are determined in Article 1:101. This provision refers to the whole of the Principles, including Part 4 on recognition and enforcement of foreign judgments. Under that provision the Principles apply to civil matters involving IP rights and may also be applied mutatis mutandis to the protection of undisclosed information and geographical indications or similar forms of protection or to disputes involving certain allegations of unfair competition. Hence, only judgments given in those matters are covered by Part 4 of the Principles.

International conventions on recognition of judgments are usually subject to reciprocity and hence they apply only to decisions adopted by the courts of other contracting states. Moreover, reciprocity is a precondition for recognition and enforcement in some national legal systems. That situation seems to have influenced the approach chosen by the ALI as regards the applicability of the provisions on recognition of the ALI Principles. Under $\S 401$, Part IV of the ALI Principles applies only to situations in which a judgment has been rendered under the ALI Principles by a court of one jurisdiction and the winning party then seeks enforcement or recognition in the court of another jurisdiction. As $\S 401$ comment $b$ explains, that provision makes recognition and enforcement under the ALI Principles subject to the condition that the dispute was declared by the rendering court as within the scope of the Principles. If the court of origin did not apply the ALI Principles, according to $\S 401(1)$ the court of the country where recognition is sought shall determine whether to recognize or enforce the foreign judgment pursuant to its domestic legislation. ${ }^{22}$

Contrary to international conventions, model rules made by national or private bodies in the area of recognition and enforcement of judgments are

$22 \S 401(1)$ ALI Principle establishes:

"A court in which recognition or enforcement of a foreign judgment is sought shall first ascertain whether the rendering court applied these Principles to the case.

(a) If the rendering court applied the Principles, then the enforcement court shall recognize or enforce the judgment pursuant to these Principles.

(b) If the rendering court did not apply the Principles, then the enforcement court shall determine whether to recognize or enforce the judgment pursuant to its domestic rules on recognition and enforcement of foreign judgments". 
not expected to be applied as such by courts in typical situations. Indeed, Part 4 of the CLIP Principles may in practice mainly be useful as a reference to interpret or supplement international and domestic law and as a model for national and international legislators, in line with the possible uses of the CLIP Principles as stated in the Preamble. Therefore, the provisions of Part 4 of the CLIP Principles are not drafted to be applicable only to situations in which the rendering court has applied the Principles. This approach seems to be more flexible than the one adopted under $\S 401(1)$ ALI Principles. This flexibility may be helpful for designing a model not only for international or treaty legislators but also for national legislators when drafting their own national system to be applied to decisions adopted in any country in the world.

\section{The issue of reciprocity}

Additionally, reciprocity is not a pre-condition for recognition and enforcement under the CLIP Principles. This approach is based on the idea that public or state interests are affected only indirectly by the recognition of judgments that resolve civil controversies between private parties. Therefore, a judgment otherwise entitled to recognition will not be denied recognition because the rendering country might not recognize a judgment of the country where recognition is sought if the circumstances were reversed. The protection of public interests does not justify recourse to reciprocity, since other alternatives more respectful of the rights of the private parties involved and the policy goals behind recognition provide the necessary safeguards, especially the use of public policy as a ground for nonrecognition.

A reciprocity requirement seems to go against the evolving trend in many national systems. For instance, the Swiss Federal Act of Private International Law of 1987 abolished reciprocity. ${ }^{23}$ The criterion adopted by the great majority of courts in the U.S. is that there is no reciprocity requirement to recognize a foreign judgment. ${ }^{24}$ Most U.S. states have abolished reciprocity and only in some jurisdictions do courts have discretion to decide whether or not reciprocity is required. ${ }^{25}$ The criterion that

${ }^{23}$ See Articles 25-27.

24 Although in Hilton v. Guyot, 159 U.S. 113, 16 S.Ct. 139, 40 L.Ed. 95 (1895), the U.S. Supreme Court declared a limited reciprocity requirement applicable when the judgment creditor is a national of the state in which the judgment was rendered and the debtor is a U.S. national, that ruling is no longer followed in the great majority of state and federal courts; see, e.g., Bank of Montreal v. Kough, 612 F.2d 467 (9th Cir.1980) and Tonga Air Services, Ltd. v. Fowler, 118 Wash.2d. 718, 826 P.2d 204 (1992).

${ }^{25}$ R. Beard, "Reciprocity and Comity: Politically Manipulative Tools for Protection of Intellectual Property Rights in the Global Economy," 30 Tex. Tech. L. Rev. 155 
reciprocity is not required prevails in the Uniform Foreign Money-Judgments Recognition Act, ${ }^{26}$ Restatement (Second) of Conflict of Laws, ${ }^{27}$ and Restatement (Third) of Foreign Relations Law. ${ }^{28}$ Additionally, even in some national legal systems that include a reciprocity requirement, the generally held view is that the requirement should be abolished. In practice it does not play a significant role, though it still formally exists, for example, in Spain $^{29}$ or it is found very generously, for instance, in Japan ${ }^{30}$ and South Korea. ${ }^{31}$

Reciprocity is mainly used to achieve diplomatic goals aimed at securing that the foreign state grants to the domestic citizens the same kind of protection available to its own citizens and to encourage recognition of domestic judgments in other countries or the adoption of a common system (in the framework of international conventions). Additionally, reciprocity may be seen as a means to retaliate against countries that apply a more restrictive recognition scheme. ${ }^{32}$ However, the application of the reciprocity doctrine to the recognition and enforcement of foreign judgments in civil and commercial matters has been subject to intense criticism for being inappropriate and unfair. ${ }^{33}$

First, it has been pointed out that reciprocity amounts to a misplaced retaliation against private parties for acts of foreign states unrelated to the dispute. As a result of reciprocity international political policies beyond

(1999), pp. 168-186; and K.R. Miller, "Playground Politics: Assessing the Wisdom of Writing a Reciprocity Requirement into U.S. International Recognition and Enforcement Law," 35 Geo. J. Int'l L. 239 (2003-2004), pp. 253-254.

${ }^{26} 13$ ULA 263 (1986 and 2005 Supp.). Notwithstanding that, several states include lack of reciprocity as a ground for discretionary refusal of recognition.

${ }^{27}$ See $\S 98$ (1971) Comment e; and C.H. Peterson, "Foreign Country Judgments and the Second Restatement of Conflict of Laws," 72 Colum. L. Rev. 220 (1972) 233-236.

${ }^{28}$ See $\S 481$ (1987) Comment d.

29 See, e.g., the decisions (autos) of the Spanish Supreme Court of 5, 12, and 19 of May of 1998 (RAJ 4292, RAJ 4344, and RAJ 4451). See also J.C. Fernández Rozas/ S. Sánchez Lorenzo, Derecho internacional privado, $4^{\text {th }}$ ed., 2007, pp. 183-185; and M. Virgós Soriano/F.J. Garcimartín Alférez, Derecho procesal civil internacional, $2^{\text {nd }}$ ed., 2007, pp. 549-550.

${ }^{30}$ See M. Takeshita, "The Recognition of Foreign Judgments by the Japanese Courts," The Japanese Annual of Int'l L., 39, 1996, 55, at p. 73, discussing how the threshold of reciprocity seems to be easy to pass for most foreign judgments.

${ }^{31}$ See, e.g., in South Korea, S.H. Lee, "Foreign Judgment Recognition and Enforcement System of Korea," 6 J. Korean L. 110 2006-2007, p. 136.

${ }^{32}$ See, e.g., I. Szászy, International Civil Procedure (A Comparative Study), 1967, at 186.

33 For two concise summaries of the main deficiencies of reciprocity in this context, see the Minnesota's Supreme Court decision in Nicol v. Tanner, 256 N.W.2d 796, 800801 (Minn. 1976); and H. Schack, Internationales Zivilverfahrensrecht, $4^{\text {th }}$ ed., 2006, pp. 301-303. 
his or her control deprive an individual from the possibility to enforce a foreign judgment that fulfils all other conditions to be effective in the requested state. Additionally, it has been argued that reciprocity does not achieve its other intended goals, namely protecting nationals of the requested state and encouraging the recognition of its own judgments in foreign countries. Reciprocity may have negative implications for citizens or residents of the country imposing such a requirement. It may happen that the party seeking recognition is not a foreigner but a national of the country where recognition is sought who is interested in having the judgment recognized or enforced in his or her own country. Moreover, it has been argued that reciprocity may seriously undermine judicial efficiencies and the goal of ensuring that there is an end to litigation.

Certainly, recognition and enforcement of judgments in civil and commercial matters cannot be seen primarily as a relationship between two states. The interest of the parties involved must be considered. The possibility to secure the advantage of the foreign judgment by obtaining recognition instead of having to litigate the cause again in a different country may in practice be essential to ensuring the protection of private rights. ${ }^{34}$ In this connection, human rights concerns have been raised, arguing that the right of access to justice would be violated if a country denied effects to a binding decision in private matters adopted by a foreign court solely as a means to retaliate against the rendering country or to press it to change its law. ${ }^{35}$

A different argument in favor of reciprocity is based on the idea that it allows selective non-recognition of judgments of countries that lack a developed judicial system or with judicial authorities suspected of corruption or partiality. ${ }^{36}$ However, to control recognition and enforcement of judgments emanating from such countries, public policy seems to provide an adequate control. At any rate, beyond retaliation and cooperation promotion, the reasons alleged to favor the use of some kind of reciprocity requirement have to do with the need to control certain issues that can be checked by means of the grounds for non-recognition applicable under the

${ }^{34}$ Schack (supra n. 33) at 12 and 302.

35 M. Amores Conradi, "Constitución y proceso civil internacional. Un balance," Pacis Artes. Homenaje a J.D. González Campos, vol. II, 2005, pp. 1184-1215, pp. 12121214 , arguing that the restrictions on private rights resulting from so-called Kooperative Reziprozität are disproportionate.

${ }^{36}$ H.C. Gutteridge, "Reciprocity in Regard to Foreign Judgments," 13 Brit. Yb. Int'l L. 49, (1932), at 66, considering that each country must be allowed to choose the countries on which it proposes to confer the privilege of reciprocal enforcement of judgments. 
CLIP Principles, such as procedural public policy or the verification of notification in the case of default judgments. ${ }^{37}$

Imposing reciprocity as a general precondition would undermine individual rights of private parties and the certainty of private relations and disputes without fulfilling any valuable screening goals. These effects would negatively influence the international compatibility of national legal systems and might endanger international business transactions. When reciprocity applies, a private party may be forced to re-litigate a dispute after having obtained a final judgment in a foreign country that resolved the claim and met all requirements to be recognized or enforced. Reciprocity in this area seems especially inappropriate in the current context of expansion of individual rights and greater interdependence between countries. $^{38}$

Therefore, the CLIP Principles, in line with their nature and aims, do not include reciprocity as a precondition for recognition and enforcement. However, it must be admitted that in most legal systems in which reciprocity still exists it is a general feature of the domestic recognition and enforcement system. Hence, to the extent that model rules for reform cover only the area of IP litigation, it might be difficult to abolish reciprocity as long as it is still a general precondition for recognition. This situation might have influenced the presence of the reciprocity requirement in the 2009 proposal on recognition and enforcement of IP judgments by the "Transparency of Japanese Law" Project, given that it was drafted as a proposal for domestic reform. ${ }^{39}$

Additionally, reciprocity may still play a role in situations in which the CLIP Principles are used as a model for international or regional legislators. As already noted, the scope of application of international conventions is usually limited to reciprocal recognition and enforcement. This is a consequence of the typical model of treaty relationship under which international conventions are drafted as an exchange of commitments to the reciprocal advantage of the parties. Conventions in this field aim at creating a special regime that favors recognition of judgments. It seems acceptable that countries limit the application of that favorable scheme to countries that participate in the same framework. Hence, reciprocal treatment in these situations is a consequence of the limited territorial scope of application of the international convention. Only in the specific context of

37 See, e.g., Beard (supra n. 25) p. 189.

38 See Miller (supra n. 25) pp. 294-317.

39 See T. Kono/N. Tada/M. Shin, "Recognition and Enforcement of Foreign Judgments Relating to Intellectual Property," <www.tomeika.jur.kyushu-u.ac.jp/chizai/ symposium/paper/009_09May09_Kono-Tada-Shin.pdf>, pp. 11-12 and Article 402 (1) (vi) Proposal. 
international conventions may it seem reasonable to use one of the arguments traditionally invoked in support of reciprocity, namely that it creates incentives for foreign countries to enter negotiations or adhere to a convention. ${ }^{40}$

\section{Favor recognitionis}

The CLIP Principles have a specific provision to address the fact that many countries are part of a network of bilateral and multilateral treaties or belong to regional integration organizations that have enacted rules to facilitate mutual recognition of judgments. In this context, Article 4:103 CLIP Principles covers one important aspect of the relationship between the Principles and international, regional, or national instruments governing recognition and the enforcement of judgments. This provision is modeled on the rules establishing the so-called favor recognitionis principle in international conventions, such as Article VII.1 New York Convention on the Recognition and Enforcement of Foreign Arbitral Awards of 1958 and Article 26 Hague Convention on Choice of Court Agreements of 2005. ${ }^{41}$

Article 4:103 ensures that the provisions of Part 4 CLIP Principles shall not restrict the application of multilateral or bilateral agreements concerning the recognition and enforcement of judgments entered into by the state in which enforcement or recognition is sought, nor the rules of a regional integration organization if that country is a member state of the organization to the extent that all these provisions establish a more favorable regime for the recognition and enforcement of the judgment. The rationale of the provision is to enable the recognition and enforcement of foreign judgments to the greatest extent, by ensuring any interested party the possibility to avail itself of the rules applicable in the requested country if they provide a regime more favorable than the Principles. It is based on the idea that international cooperation in this field is aimed at making foreign judgments more easily enforceable. Additionally, this Article guarantees that the Principles are not an obstacle to further cooperation between nations in the field of recognition and enforcement. Future developments that go beyond what the Principles achieve would be covered by Article 4:103 and would prevail over the Principles.

${ }^{40}$ F.O. Ballard, "Turnabout is Fair Play: Why a Reciprocity Requirement Should Be Included in the America Law Institute's Proposed Federal Statute," 28 Hous. J. Int'l L. 199 (2006), pp. 233-234.

${ }^{41}$ See also Article 23 Hague Convention on the Recognition and Enforcement of Decisions Relating to Maintenance Obligations of 1973; and Article 19 European Convention on Recognition and Enforcement of Decisions concerning Custody of Children and on Restoration of Custody of Children, Luxemburg, 20 May 1980. 


\section{Effects of judgments}

\section{Judgment: Definition and classification}

Part 4 of the CLIP Principles begins with the definition of judgment in Article 4:101. It is a very broad definition that encompasses any judgment given by a court of any state, whatever the judgment or the proceedings may be called by that state. It also includes writs of execution and the determination of costs or expenses by an officer of the court, which in some countries are decisions of the registrar. This definition is modeled on Article 32 Brussels I Regulation. ${ }^{42}$ Additionally, under Article 4:801 CLIP Principles, a settlement to which a court has given its authority shall be recognized and enforced under the same conditions as judgments. ${ }^{43}$

The concept of judgment is to be understood broadly and applied in a flexible way to the heterogeneous decisions in the IP field. It covers appealable judgments, provisionally enforceable orders (see V, infra), and also judgments rendered in default of appearance. The term judgment covers orders for the payment of money, orders for the transfer and delivery of property, orders regulating the conduct of the parties, and orders declaring the rights and liabilities of the parties, including negative declarations such as declarations on non-infringement of IP rights. By contrast, interlocutory decisions of a procedural nature are not covered. ${ }^{44}$ As the experience of the Brussels I Regulation illustrates, ${ }^{45}$ the uniform interpretation of this broad concept may raise some difficulties concerning foreign decisions unknown in the requested state and borderline decisions between judicial proceedings and execution, although writs of execution and determination of costs are expressly included even when they are made separately from the decision on the merits in the principal case.

The term judgment in Article 4:101 covers both monetary and nonmonetary judgments. The distinction between monetary and non-monetary judgments has important implications regarding the means of enforcement. In the context of IP litigation, both monetary and non-monetary judgments

${ }^{42}$ For a similar definition, see Article 2 Hague Convention on the Recognition and Enforcement of Foreign Judgments in Civil and Commercial Matters of 1971 and Article 23 Preliminary Draft Convention on Jurisdiction and Foreign Judgments in Civil and Commercial Matters of 30 October 1999.

${ }^{43}$ This approach is well-known from an international perspective, as illustrated by Article 58 EU Brussels I Regulation and Article 12 of The Hague Convention on Choice of Court Agreements of 2005.

${ }^{44}$ See P. Nygh/F. Pocar, "Report. Preliminary Draft Convention on Jurisdiction and Foreign Judgments in Civil and Commercial Matters," Prel. Doc. No 11, August 2000, $<$ www.hcch.net $>$, at 98-99.

${ }^{45}$ B. Hess/T. Pfeiffer/P. Schlosser, The Brussels I Regulation 44/2001 (Application and Enforcement in the EU), 2008, pp. 135-137. 
are very common. Money judgments are usually the result of the authority granted to the courts to order the infringer to pay damages to the rightholder. ${ }^{46}$ Typical non-money judgments include injunctions prohibiting the production or marketing of goods or the use of protected subject matter, orders to surrender and deliver infringing goods, or other orders for specific performance. ${ }^{47}$ Non-money judgments also comprise merely declaratory judgments, including negative declarations.

Traditionally, some legal systems, especially in the common law world, have been reluctant to admit the possibility of enforcing foreign nonmoney judgments ${ }^{48}$ since enforceability of foreign in personam judgments under the common law was considered limited to judgments for a fixed or ascertainable sum of money. ${ }^{49}$ However, in most jurisdictions, including the UK, Australia, and the U.S., a clear trend to disregard the common law rule and allow enforcement of only money judgments can be found in legislation, ${ }^{50}$ and it is also widely accepted that the common law should be extended to make possible the enforcement of foreign non-money judgments. ${ }^{51}$

${ }^{46}$ See, e.g., Article 45 TRIPS Agreement and Articles 13 and 14 Directive 2004/ 48/EC of 29 April 2004 on the enforcement of intellectual property rights (OJ L 195 of 2 June 2004, p. 16).

${ }^{47}$ See, e.g., Articles 44 and 46 TRIPS Agreement and Articles 10 and 11 Directive $2004 / 48$.

${ }^{48}$ See, e.g., Comment b to $\S 481$ Restatement (Third) of Foreign Relations Law of the United States (1987), stating that "judgments granting injunctions, declaring rights or determining status, and judgments arising from attachments of property, are not generally entitled to enforcement, but may be entitled to recognition".

${ }^{49}$ See, e.g., K.W. Patchett, Recognition of Commercial Judgments and Awards in the Commonwealth, 1984, pp. 104-105.

${ }^{50}$ See, e.g., R.F. Oppong, "Enforcing Foreign Non-Money Judgments: An Examination of Some Recent Developments in Canada and Beyond," 39 U.B.C. L. Rev. 258 2006 , at 276 .

${ }^{51}$ See the decision by the Supreme Court of Canada in Pro Swing Inc. v. Elta Golf Inc., [2006] 2 S.C.R. 612, 2006 SCC 52, concluding that the "time is ripe to change the common law rule against the enforcement of foreign non-monetary judgments" (para. 64). Notwithstanding that conclusion, the decision dismissed the appeal against the decision that had reversed the initial decision granting the enforcement in Canada of the consent decree and the contempt order of the U.S. District Court enjoining the defendant from purchasing, marketing, or selling products bearing the mark of the claimant or confusingly similar variations. The dismissal was based on certain problems of the orders that were to be enforced, especially the different significance of a contempt order in the U.S. and Canada, and the unclear extraterritorial scope of the order that referred to a defendant that offered the infringing products over the Internet and to a trademark that was protected only in the U.S. The dissenting opinion argues how these issues could have been addressed without refusing the enforcement of the U.S. judgment (paras. 103-121). 


\section{Effects of judgments and consequences of recognition}

The possible effects of judgments may typically include res judicata or preclusive effects, so-called dispositive effects, and enforceability. Res judicata or preclusive effects refer basically to the binding effect of a judgment on subsequent litigation. A judgment has so-called dispositive effects to the extent that it creates, modifies, or dissolves a legal relationship or status. For instance, this is usually the case of a judgment that decides who is the initial owner of an invention or who is the owner of a patent, and also of a judgment terminating a contract between the parties. Finally, a judgment is enforceable inasmuch as it enables recourse to public coercive force if needed to allow one party the relief granted to it by the judgment. Injunctions ordering a party to desist from an infringement and decisions condemning one party to pay compensation to the other are typically enforceable decisions.

Additionally, judgments as public documents may serve as evidence of a fact in future litigation. However, that possible use is not a specific effect of judgments as such and raises issues common to other foreign public documents. Therefore, the CLIP Principles assume that the evidential use of judgments as public documents in subsequent litigation fall within the law of evidence and is to be determined in accordance with the law of the forum in which the foreign judgment is invoked as evidence. Hence, the CLIP Principles have no provisions on the evidential use of foreign judgments.

The possible consequences of recognition of a foreign judgment may vary between jurisdictions and also depending on the category of the judgment and the kind of effect whose recognition is sought. The two opposing approaches as to possible effectiveness of foreign judgments after recognition are represented by the doctrines of extension of effects (Wirkungserstreckung) and equalization of effects (Gleichstellung). According to the doctrine of extension of effects, the consequences of the judgment in the state of destination are the same effects that such a judgment has in the legal system of origin. By contrast, under the equalization of effects doctrine, the effects after recognition are those of a similar judgment if rendered in the country of destination and hence the law of the requested state is determinative as to the scope of res judicata. In practice, however, both doctrines are to a certain extent mixed and rules of the two systems involved applied. In particular, the extension of effects of the legal system of origin normally applies only to the extent that they are compatible with the legal system of the requested state (Kumulationstheorie). Under this approach, in line with the extension of effects doctrine, a judgment cannot have greater effects in the requested state than it would have in the state of origin, but there is the additional limit that the judgment 
cannot produce in the requested state greater effects than similar local judgments would. ${ }^{52}$

In this connection, the CLIP Principles state the basic criteria that in order to be recognized, a judgment must have in the state of origin the effect whose recognition is sought in the requested state (Article 4:102 (2)), and that the effect of the judgment is determined by the law of the state of origin, although acknowledging that the requested court may interpret the judgment in regard to its subjective, territorial, and substantial scope (Article 4:102 (3)). Furthermore, in order to be enforceable abroad, a judgment must be enforceable in the state of origin ${ }^{53}$ (Article 4:102 (4)). Hence, the effects that the judgment can have in the state of recognition are in principle limited by its effects in the country of origin. This conclusion does not rule out that legal and procedural constraints in the requested state may affect the available remedies, especially to the extent that enforcement of injunctions is at stake, since enforcement takes place in accordance with the law of the requested state.

\section{Res judicata and preclusive effects}

Res judicata as a general term referring to the ways in which one judgment will have a binding effect on another (materielle Rechtskraftwirkung) or to the fact that judicial decisions which have become definitive after all appeals have been exhausted or the time to appeal has expired can no longer be called into question (formelle Rechtskraft) is known in most jurisdictions. Concerning the principle of res judicata and the need to respect the rules of procedure conferring finality on a decision in order to ensure stability of the law and the sound administration of justice, the ECJ has stressed the great importance, both for the Community legal order and

\footnotetext{
${ }^{52}$ See, e.g., Schack (supra n. 33) pp. 277-279. Even in the context of free circulation of judgments, in the EU the Kumulationstheorie seems to prevail; see ECJ Judgment of 28 April 2009, C-420/07, Apostolides, para. 66; and Opinion of Advocate General Darmon of 9 July 1987 in Hoffmann v. Krieg, Case 145/86, para. 20 citing G.A.L. DROZ, Compétence judiciaire et effets des jugements dans le marché commun, 1972, p. 276. In its recent Judgment in Apostolides, para. 66, the ECJ stated: “...although recognition must have the effect, in principle, of conferring on judgments the authority and effectiveness accorded to them in the Member State in which they were given (Judgment of 4 February 1988 Hoffmann, paragraphs 10 and 11), there is however no reason for granting to a judgment, when it is enforced, rights which it does not have in the Member State of origin (see Jenard Report, p. 48, infra n. 55) or effects that a similar judgment given directly in the Member State in which enforcement is sought would not have".

53 See, e.g. Article 38(1) Brussels I Regulation, and ECJ Judgments of 29 April 1999, Case C-267/97 Coursier, para. 23; and 28 April 2009, C-420/07, Apostolides, para. 66.
} 
for the national legal systems of the principle of res judicata ${ }^{54}$ Indeed, the general principle that disputes must come to an end by means of a final decision that excludes further re-litigation of the same subject matter between the same parties is also widely accepted from a broader international perspective. However, significant differences as to the preclusive effects of judgments between the procedural laws of the rendering country and the country of recognition are frequent. Indeed, the objective and subjective scope of res judicata varies across different legal systems, and doctrines such as collateral estoppel or issue preclusion in the U.S. are not known as such in other countries. Therefore, from a comparative perspective the meaning and scope of res judicata is subject to significant variation.

In fact, the term res judicata has been avoided in the text of both the European instruments on recognition and of the ALI Principles. The reason given in the Jenard Report for that omission is that under the 1968 Brussels Convention, judgments given in interlocutory proceedings and ex parte may be recognized, and those judgments do not always have the force of res judicata. ${ }^{55}$ The ALI Principles acknowledge that the term res judicata has different meanings in different places and hence use the words enforcement, recognition, and preclusive effect to cover the whole range of possible consequences of a judgment. ${ }^{56}$ The CLIP Principles do not mention res judicata, since so-called formelle Rechtskraft is not a requirement for recognition and enforcement, ${ }^{57}$ but preclusive or res judicata effects are a basic component of the effects of a judgment whose recognition may be sought in accordance with Article 4:102 (2).

In most countries sharing the common law traditions, judgments are granted broad preclusive effects in comparison with the situation in other jurisdictions. In the U.S., issue preclusion, also known as collateral estoppel, prevents a party and its privies from re-litigating questions of fact or law which were actually litigated and determined in a prior suit, even if the later suit involves a different claim or cause of action. ${ }^{58}$ Even within the

\footnotetext{
${ }^{54}$ See, with further references, ECJ Judgment of 6 October 2009, Case C-40/08, Asturcom, paras. 36-38, confirming that due to the lack of Community provisions on this issue, the rules implementing the principle of res judicata are a matter for the national legal orders of the member states.

${ }^{55} \mathrm{P}$. Jenard, "Report on the Convention on jurisdiction and the enforcement of judgments in civil and commercial matters," OJ C 59 of 5 March 1979, p. 1, at p. 44

56 See Reporters' Notes to $\S 401$ ALI Principles.

57 See $\mathrm{V}$, infra.

${ }^{58}$ In the U.S., the law of res judicata covers two main branches, known as claim preclusion and issue preclusion. Claim preclusion prohibits a later suit based on the same cause of action which was asserted in the first suit that resulted in a final judgment on the merits. The preclusive effect of the judgment covers all issues that might have been
} 
common law countries, the name of the doctrines on res judicata and their effects vary, especially the scope of issue preclusion and the extension of res judicata to unlitigated or undisputed issues. ${ }^{59}$

At any rate, the Anglo-American concept of res judicata is broader than the preclusive effect granted to a judgment in other countries, such as most countries in continental Europe and Latin America. In these countries the preclusive effect of a judgment is limited to a later suit that is identical with the previous judgment in object, cause, and parties. In addition, the effects are restricted to the dispositive part of the judgment and do not extend to the grounds. The identities of object and cause are similar to the identity of cause of action in the Anglo-American model. By contrast, the effects resulting from collateral estoppel, which preclude re-litigation of issues in a suit on a different cause of action, are not covered by the concept of res judicata in those other countries. ${ }^{60}$ Most countries outside of the Anglo-American legal tradition do not consider judgments as precluding the re-litigation of just any issue litigated and decided in a prior suit, and res judicata effects extend only to matters expressly declared in the dispositive part of the judgment, rather than to the reasons or the fact determinations on which the decision is based. ${ }^{61}$

Furthermore, the precise scope of res judicata may be decisively influenced by the meaning of concepts such as "cause of action," "final decision on the merits," or "actually litigated" in the relevant domestic system. Moreover, although res judicata effects are usually limited to the parties in the proceedings and certain related persons, the determination of the persons who are so closely related to a party as to be bound by the judgment and of who may benefit from it varies across the different legal systems.

It is not a goal of the CLIP Principles to provide a general solution to the difficulties raised by these differences in the national legal systems, and therefore national considerations on the possible effects of foreign

litigated. See, e.g., P.A. Trautman, "Claim and Issue Preclusion in Civil Litigation in Washington,” 60 Wash.L.Rev. 805 (1985), pp. 805-842.

${ }^{59}$ Issue estoppel in England seems to be both broader and narrower in scope than in the U.S. In England it may preclude issues that were never actually litigated and decided but it is limited only to later suits between the same parties or privies and a non-party cannot invoke issue preclusion against one who was a party. See R.C. Casad, "Issue Preclusion and Foreign Country Judgments: Whose Law?" 70 Iowa L. Rev. 53 19841985, 62-63.

${ }^{60}$ Comparing the situation between some Latin American countries and the U.S., see R.C. Casad, Civil Judgment Recognition and the Integration of Multiple-State Associations, 1981, p. 46.

${ }^{61}$ See W.J. Habscheid, "Rechtsvergleichende Bemerkungen zum Problem der materiellen Rechtskraft des Zivilurteils," Mélanges C. Fragistas, vol. I, 1966, pp. 529-566, at 545; and Casad (supra n. 59) at 55 and 64-65. 
judgments that go beyond the minimum standards provided for by Article 4:102 may be compatible with the Principles. It seems noteworthy that when a foreign judgment is recognized in England under the traditional common law rules, the preclusive effects recognized to the foreign judgment are typically the same conferred to a judgment rendered by an English court and recognition is subject to the fulfillment of requirements similar to those applied for an English judgment to become res judicata. This approach favors the application of the so-called doctrine of equalization of effects, which is in line with the English common law traditional preference that recognition implies treating judgments that have been recognized as conclusive as English judgments. At any rate, such treatment is connected to the fact that recognition is subject to the verification that the foreign judgment has the same characteristic as an English judgment producing the relevant effects. ${ }^{62}$

However, the so-called Kumulationstheorie seems to provide a balanced approach to solving these issues, especially in light of the grounds for nonrecognition established in the CLIP Principles. When the foreign court gives more preclusive effect to a judgment than the effect that would be given to it in the country where recognition is sought, it may be acceptable for the latter country to preclude re-litigation to the extent resulting from the foreign law, provided that such an approach undermines neither the position of those affected by the recognition nor basic principles or public policies of the country of recognition, since the prevailing criterion is that the judgment can not produce in the requested State greater effects than similar local judgments would. When the foreign court gives less preclusive effect to a judgment than the country of recognition, in principle the judgment is to be given only the effects that may be accorded to it under the law of the rendering court. As noted earlier, the basic criterion should be that a foreign judgment may not have greater effect in the country of recognition than in the rendering country. A different approach may undermine the expectations of the parties involved and the safeguards resulting from the procedural rules applied to litigation in the rendering court. ${ }^{63}$ Indeed, to the extent that the country of recognition has broader rules on preclusion than the country of origin (for instance, because only under the law of the country where recognition is sought does such a

${ }^{62}$ By contrast, foreign judgments recognized in England under Brussels I Regulation and international conventions are not subject to that approach and the recognizing court has the opportunity to consider the appropriate legal system by which to verify the res judicata effects of the foreign judgment; see Barnett (supra n. 2) at pp. 38-39.

${ }^{63}$ Schack (supra n. 33) pp. 278-279 and pp. 315-316. 
judgment preclude re-litigation as to matters actually not litigated) restraint should be exercised by the recognizing court. ${ }^{64}$

Under the U.S. doctrine of issue preclusion, a judgment may affect subsequent litigation to a greater extent than the consequences of res judicata in many other countries, as illustrated by the use of that doctrine to resolve issues raised in suits relating to U.S. patents based on the determination of similar issues in foreign judgments on foreign counterpart patents. In VasCath Inc. v. Mahurkar, ${ }^{65}$ the U.S. District Court for the Northern District of Illinois recognized a Canadian judgment on a Canadian patent and precluded litigation in the U.S. concerning a U.S. patent of the same issues decided in the Canadian litigation with respect to the Canadian patent. The court based its decision on the similarity of U.S. and Canadian laws on the relevant issue. However, in general terms the Federal Circuit has a very negative position and rejects attempts to rely on foreign decisions concerning foreign patents to preclude litigation in U.S. courts on the same issues of the corresponding U.S. patents, considering that foreign patent judgments do not present the same issues as U.S. patent disputes. ${ }^{66}$

Territoriality of IP rights may play a significant role as an obstacle to the extension to other states of the preclusive effect of a foreign judgment on a local IP right. Because of the application of the lex protectionis, infringing claims that refer to protection in different countries would be decided under diverse laws. In this connection, U.S. courts have stated that differences in patent laws and in language of patents prevent issue preclusion to the extent that the claims refer to the protection of patents of different countries, ${ }^{67}$ and that also differences in the copyright laws of the countries involved may exclude collateral estoppel. ${ }^{68}$

${ }^{64}$ See Casad (supra n. 59) at 74-75, considering that before applying the doctrine of collateral estoppel to judgments rendered in countries where such concepts are unknown, a U.S. court must satisfy itself that the party to be bound had fair opportunity and incentive to litigate in the foreign court the issue sought to be precluded from relitigation in the U.S.

65745 F. Supp. 517, 520 (N.D. Ill. 1990), rev'd on other grounds, 935 F.2d 1555 (Fed. Cir. 1991).

${ }^{66}$ See, for example, Medtronic, Inc. v. Daig Corp. (789 F. 2d 903 (Fed. Cir. 1986)) and Cuno Inc. v Pall Corp. (729 F. Supp. 234, 235 (E.D.N.Y. 1989)) and, with further references, J.P. Muraff, "Issue Preclusion - Recognizing Foreign Judgments in United States Patent Infringement: A New Approach," 26 J. Marshall L. Rev. 627, 654-659 (1993); and D.R. Marsh, "The Preclusive Effect of Foreign Country Patent Judgments in the United States," 27 N.Y.U. J. Int'l L. \& Pol. 484 1994-1995, at 484-485. They do not address the possibility, which might be compatible with more restrictive doctrines of res judicata and modern conceptions of jurisdiction, of accepting the preclusive effect of a foreign judgment concerning exactly the same patent, national or foreign, at subsequent U.S. litigation.

${ }^{67}$ See Cuno, Inc. v. Pall Corp., 729 F. Supp. 234 (1989) (Weinstein, J). 
A broad application of claim preclusion and issue preclusion in the context of massive schemes of infringement also poses significant risks of excessively restricting parties' access to justice in the digital age, ${ }^{69}$ as illustrated by Bouchat v. Champion Products, Inc. ${ }^{70}$ Modern technologies and litigation strategies for the protection of IP rights render increasingly common disputes in which a large number of persons are accused of infringing several rights based on what may be different causes of action. The application of res judicata doctrines may in practice be determinative as to the impact of a judgment to foreclose litigation founded on interrelated but different bases for liability and damages against several participants in an allegedly massive infringement. From an international perspective, the broad preclusive effects granted to some of these judgments under U.S. law might not be recognized in their integrity in countries having more restrictive notions of res judicata.

A different issue is raised by the fact that legal systems give different answers with respect to the impact of patent invalidation on res judicata of prior judgments on infringement of the subsequently annulled patent. ${ }^{71}$ In some countries, such as Italy and Spain, the issue is regulated by statute, providing that infringement decisions based on the validity of a registered IP right that have become res judicata are typically not affected by a subsequent declaration of invalidation of the patent (or other IP subject to registration) to the extent that they have been enforced prior to the declaration of invalidity. ${ }^{72}$ The same position prevails in other national systems, such as the United Kingdom and France, according to case law. ${ }^{73}$ By con-

${ }^{68}$ See Computer Assocs. Int'l, Inc. v. Altai, Inc., 126 F.3d 365, (2d Cir. 1997), cert. denied, 523 U.S. 1106 (1998), stressing the implications of the subtle differences between French and U.S. copyright law. However, see Leo Feist, Inc. v. Debmar Publ'g Co., 232 F. Supp. 623 (E.D. Pa. 1964), giving issue preclusion in an infringement copyright action brought in the U.S. under copyright law to a finding by an English court under English copyright law that defendant had not copied.

${ }^{69}$ See M.B. BYARS, “Bouchat v. Bon-ton Department Stores, Inc.: Claim Preclusion, Copyright Law, and Massive Infringements," 21 Harv. J. L. \& Tech. 631 (2007-2008).

${ }_{70} 327$ F. Supp. 2d 537, 544 (D. Md. 2003). Applying traditional rules of claim preclusion, the court held that the downstream defendants were precluded from denying their infringement of the plaintiff's copyright, but it also granted defendant's motions to preclude the plaintiff from seeking any damages from them. The Court of Appeals affirmed in Bouchat v. Bon-ton Department Stores, Inc., 506 F 3d 315, 332 (4 $\left.{ }^{\text {th }} 2007\right)$, cert denied, 76 U.S.L.W. 3568 (U.S. Apr. 21, 2008) (No. 07-153).

${ }^{71}$ See C. Heath, "Wrongful Patent Enforcement - Threats and Post-Infringement Invalidity in Comparative Perspective," 39, IIC, 2008, 307, at 316-320.

72 See Article 77 Italian Industrial Property Code; Article 114(2) of the 1986 Spanish Patent Act; Article 54(2) of the 2001 Spanish Trademark Act; and Article 55(3)(a) Regulation 207/2009 on the Community trade mark.

${ }^{73}$ See Heath (supra n. 71) at 316-317. 
trast, countries with a split jurisdiction for infringement and invalidity, in particular Germany and Japan, seem to be more favorable to the possibility of a retrial of a previous infringement dispute based on the later invalidation of the relevant patent, and consider that the retroactive effect of a revocation or a decision on invalidity allows for a reopening of past infringement proceedings. ${ }^{74}$

From an international perspective, it can be noted that under the CLIP Principles the courts of the country of protection have exclusive jurisdiction in disputes having as their object the validity of any IP right protected on the basis of registration, and that only decisions rendered by those courts may affect the validity of those rights as against third parties (Article 2:401 CLIP Principles). In principle, previous decisions on the infringement of any of those rights will only be affected by invalidity decisions given in the country of protection. The prevailing view that a request for recognition may not go further than the original judgment and that the effects that the judgment can have in the state of recognition are limited by its effects in the country of origin may be determinative in these situations. The limitations of the legal system of origin (and country of protection) as regards the effects of the invalidity decision on previous infringement judgments should in principle be respected in third countries when recognizing the non-validity judgment.

\section{Scope of injunctions}

Under Article 4:102(3) CLIP Principles, the court in the state of recognition shall interpret the judgment in regard to its subjective, territorial, and substantial scope and take into account any change of circumstances. This interpretation should in principle not result in enforcement beyond the limits of res judicata in the legal system of origin and the procedural rules

\footnotetext{
${ }^{74}$ Ibid. at 317-320. In Japan patentees that execute certain interim injunctions have been regarded as acting negligently and held liable for damages where a patent is later invalidated; see Decision of the Tokyo High Court of 31 January 2005 Nisó K.K. v. Mishin Kizai K.K, 39 IIC, 2008, p. 359. However, the practical consequences of these different approaches may not be as intense as they appear. For instance, to the extent that restrictions to the retroactive effect of the invalidity decisions cover only infringements decisions that have become res judicata (Art. 114(2)(a)Spanish Patent Act), provisionally enforceable injunctions that were enforced would not benefit unless a final and conclusive decision had already been rendered. Additionally, restrictions to the retroactive effect of invalidation apply only with limitations; for instance, under Art. 114(2)(a) Spanish Patent Act they apply without prejudice to compensation for damages when the owner of the patent acted in bad faith. In this connection, it can be noted that under Article 55.3 Community trade mark Regulation this restriction to the retroactivity of the non-validity judgment applies without prejudice to provisions on compensation for damage caused by negligence or lack of good faith and to unjust enrichment.
} 
of the enforcing country. Additionally, Article 4:102(3) is subject to the prohibition on substantive review of Article 4:601. This provision sets forth the basic principle that recognition and enforcement shall be decided without reviewing the substance or merits of the foreign judgment. This criterion is common to almost all international, regional, and national systems of recognition and enforcement, since it results from the separation of judicial systems and the essence of recognition and enforcement. ${ }^{75}$ Under this criterion, consideration of the merits of foreign judgments is limited to the verification of the grounds for non-recognition, especially to ensure it does not infringe public policy.

In connection with Article 4:102(3), it is remarkable that compared to judgments for a fixed sum of money, the recognition and enforcement of foreign non-money judgments may raise specific difficulties and demand additional involvement by the authorities of the destination country. That is especially the case when injunctive relief is ordered. With respect to IP litigation it can be noted that the TRIPS Agreement establishes a comprehensive set of remedies (Articles 45-48) that influences that the remedies admitted in a given country are usually rather similar or at least not completely unfamiliar in other jurisdictions. Difficulties may arise in cases in which the kind of relief granted in the foreign judgment is unknown or is not available in the country where recognition or enforcement is sought. To overcome possible difficulties, it seems appropriate to grant a remedy available in the enforcing country that is functionally or substantially equivalent to the one awarded in the foreign judgment because it fulfils the object sought by the foreign order. ${ }^{76}$

The requirements under which injunctions, preliminary or permanent, are issued and the sort of relief granted depend on the law applicable to the infringement by the rendering court, and significant divergences may exist as to those requirements that evolve in the national legal systems. ${ }^{77}$ In this context, the content of the foreign injunction, construed under a foreign law, as to when, where, and how the defendant must do or abstain from

75 See, e.g., Article 12 Hague Convention on the Recognition and Enforcement of Decisions Relating to Maintenance Obligations of 1973; Article 27 Hague Convention on Jurisdiction, Applicable Law, Recognition, Enforcement and Co-operation in Respect of Parental Responsibility and Measures for the Protection of Children of 1996; Article 36 Brussels I Regulation; Article 24.2 Japanese Civil Execution Act; Article 27.3 Swiss Federal Act of Private International Law of 1987; Article 23.2 Belgian Code of Private International Law of 2004; and Article 121(1) Bulgarian Code of Private International Law of 2005 .

${ }^{76}$ Oppong (supra n. 50) at 268.

77 As to the grant of injunctions against alleged patent infringements in the U.S., see eBay Inc. v. MercExchange, LLC, 546 U.S. 1029 (2005), and B. Petersen, "Injunctive Relief in the Post-eBay World," 23 Berkeley Tech. L.J. 1942008. 
doing something may require interpretation or adaptation to new circumstances (for instance, as a result of succession of parties or modifications of corporation scheme after the judgment was rendered). The courts of the country where enforcement is sought may have to assess the scope of the order and limit its territorial reach or its impact on third parties. In particular, the territorial scope of injunctive relief may need interpretation in situations concerning the use in ubiquitous media of subject matter protected by territorial rights. ${ }^{78}$

In case of relief concerning Internet activities, it may be especially important to safeguard the interests of third parties in foreign countries who can be affected by the enforcement of the order in certain situations, as illustrated by the notorious German decision in the Hotel Maritime case concerning trademark use in Internet activities. ${ }^{79}$ Hence, some room for discretion when securing compliance in the enforcing country seems justified provided that it does not amount to re-litigation of the issues that the foreign judgment decided and it does not create an inappropriate assumption of jurisdiction over the dispute. ${ }^{80}$ Article 4:102(3) concerns only the interpretation of the foreign judgment. As regards control of the territorial scope of injunctions, account must be taken of the fact that verification of the jurisdiction of the rendering court (Article 4:201) ${ }^{81}$ shall be relevant to control enforcement in third countries.

In Article 2:601, the CLIP Principles intend to reconcile the basic criterion that an injunction may only prohibit the infringer's behavior insofar as it produces its infringing effects in a country or several countries whose law has been applied in the judgment ${ }^{82}$ with the practical need to adapt that rule with respect to infringements committed through ubiquitous media. This issue is related to the territoriality of IP rights, but it is also very much a question of power to adjudicate. Hence compliance with the standards established in Part 2 of the Principles becomes a precondition for recognition and enforcement.

\footnotetext{
78 See Pro Swing Inc. v. Elta Golf Inc., [2006] 2 S.C.R. 612, 2006 SCC 52, paragraphs 52-58.

${ }^{79}$ Bundesgerichtshof Judgment of 13 October 2004, JZ, 2005 at 736-738 and comment by A. Ohly, at 738-740.

${ }^{80}$ Oppong (supra n. 50) at 285, arguing that doubts about the scope of an injunction resulting from lack of clarity of the foreign judgment should be resolved in favor of the party against whom enforcement is sought.

${ }_{81}$ See VI, infra.

82 On the implications of this idea to limit enforcement abroad of decisions on unfair competition, see W.E. Lindacher, "Die internationale Dimension lauterkeitsrechtlicher Unterlassungsansprüche: Marktterritorialität versus Universalität,” GRURInt, 2008, 453, at 456 .
} 
In the Internet context, the displaying, offering for sale, or download of a product protected by IP might be legal in some countries of reception but not in others. Under such circumstances, a court's injunction must only encompass the illicit part of the behavior, and the infringer must be allowed to continue his legal Internet activities or be able to adapt his Internet presence without the right holder having the possibility to prevent him from doing so on the basis of the original judgment. Verification of jurisdiction or even public policy (Article 4:401) if necessary may be invoked to refuse the recognition of the foreign injunction to the extent that its territorial scope effects grossly exceed the territorial scope of the laws applied to the infringement, unfairly undermining the activities of the defendant in territories in which they are completely legal.

\section{Recognition and enforcement: procedural aspects}

The CLIP Principles acknowledge the well-known conceptual distinction between recognition and declaration of enforceability. That distinction does not affect the conditions applicable since the grounds to deny recognition are the same that apply when the declaration of enforceability is at issue. The only additional requirement is that in order to be enforceable, a judgment must be enforceable in the state of origin. Although a foreign judgment cannot be enforced unless it is previously recognized, recognition has significance outside the enforcement context because a foreign judgment also must be recognized in order to be given preclusive effect or to produce in the requested state its so-called dispositive effects regarding the creation, modification, or termination of a legal relationship or situation.

In contrast with recognition, enforcement means that the courts of the destination country will take the necessary steps to give one party the relief granted to it by the foreign judgment, having recourse to public coercive force when needed. The possibility to enforce a foreign judgment normally requires a previous declaration of enforceability by the courts of the enforcing country. In particular, the grant of enforceability is typically subject in the different systems to a specific procedure, usually referred to as exequatur in some European and Latin American countries and registration in some common law countries. ${ }^{83}$

Under the CLIP Principles, recognition and declaration of enforceability may differ as to the procedure, in line with the prevailing comparative and international approach. Article 4:702(1) establishes that foreign judgments shall be recognized by operation of law and without any special procedure

${ }^{83}$ See, e.g., P. Kaye. Civil Jurisdiction and Enforcement of Foreign Judgments, 1987, pp, 1338-1343. 
being required. By contrast, the enforcement of the foreign judgment may be subject to a special procedure (Article 4:703) ${ }^{84}$ Hence, the CLIP Principles follow the criterion of so-called automatic recognition and mere recognition as such does not require any specific proceeding in the requested state. Automatic recognition means that foreign judgments may take effect ipso iure whenever recognition is invoked as an incidental question or as a main question before a competent authority of the recognizing country. "Automatic recognition" only refers to the possibility of recognition without a specific procedure, but recognition is subject to the same requirements as a declaration of recognition adopted in a specific procedure.

Recognition not subject to a specific procedure means that any interested party may invoke recognition as an incidental question in the course of other proceedings or as a defense. For instance, when recognition is sought only to invoke the res judicata effects of the foreign judgment in order to block subsequent proceedings in a new forum, the request for recognition can be submitted to the court in which the new action is pending. The court competent in the subsequent proceedings can recognize the foreign judgment if it meets the conditions for recognition.

Additionally, automatic recognition means that no special recognition procedure is required for updating the records of the registries of a state on the basis of a foreign judgment that meets the requirements to be recognized. The authority in charge of the registry shall control whether the recognition conditions are met in the process of deciding on the registration. An example may illustrate this.

Example: In a dispute concerning the ownership of certain trademark rights, the courts of country $\mathrm{Z}$ have ruled that $\mathrm{A}$ is the owner of a trademark registered in country $Y$. Under an automatic recognition scheme, A is entitled to apply directly to the authority in charge of the registry in $\mathrm{Y}$ to amend the records on the basis of the foreign judgment. That authority

${ }^{84}$ Provisions similar to the rules of Article 4:702 and Article 4:703 CLIP Principles may be found, e.g., in Articles 23(1), 24, 26 and 28 Hague Convention on Jurisdiction, Applicable Law, Recognition, Enforcement and Co-operation in Respect of Parental Responsibility and Measures for the Protection of Children of 1996. See also Article 33 Brussels I Regulation; Section 6 Uniform Foreign-Country Money Judgments Recognition Act (2005); and $\S 99$ Restatement (Second) of Conflict of Laws, concerning enforcement. This clear distinction is well known in the Japanese system, where a foreign judgment may be recognized without any formality or special procedure and it is automatically entitled to recognition if the judgment meets the conditions set out in Article 118 of the Code of Civil Procedure. Article 24 of the Japanese Civil Execution Act requires a special action that the party seeking to enforce a foreign judgment must bring in order to obtain a decision granting its enforcement that will be awarded if the foreign judgment fulfils the requirements for recognition; see Tada (supra n. 7) pp. 7879. 
shall determine whether the decision meets the requirements for recognition, ${ }^{85}$ and if it does the records shall be amended without any special procedure for recognition being required.

Additionally, any interested party may bring an action for a decision that the judgment be recognized or not. Under these circumstances, the new proceedings have as their object the recognition or non-recognition of the foreign judgment. Under the Principles, procedural rules on that specific issue are left to the law of the requested state (Article 4:702), although Article 4:701 establishes that recognition and enforcement procedures shall not be unnecessarily complicated or costly, or entail unreasonable time limits or unwarranted delays, based on the general obligations imposed by Article 41(2) TRIPS Agreement.

Therefore, the procedural law of the state in which recognition is sought applies to the methods by which any interested party may request a declaration of recognition in a special procedure in cases where recognition of a judgment is itself the principal issue, there being no other proceedings involved. The CLIP Principles establish that such a declaration is not necessary to obtain recognition but acknowledges that in limited circumstances a party may have a legitimate interest in obtaining a formal declaration of recognition or non-recognition.

Litigation in one country of activities carried out through ubiquitous media makes this possibility more significant than ever before. Although not concerned with the exploitation of IP rights, the litigation before the U.S. courts and their controversial decisions in the notorious case involving Yahoo! Inc. and La Ligue contre le racisme et l'antisémitisme ${ }^{86}$ offer a good example of how a party defeated in a foreign country may be interested in obtaining a decision declaring that the foreign judgment cannot be recognized or enforced in the forum country.

In line with the usual approach of international instruments on recognition and enforcement, the CLIP Principles only cover issues regarding recognition and declaration of enforceability. Under Article 4:703 CLIP Principles, the law of the requested state determines the methods by which a foreign judgment is declared enforceable. Such a declaration may be refused only for one of the reasons set out in Part 4 of the Principles: the grounds for non-recognition and the lack of enforceability of the judgment in the rendering country. An action to obtain a declaration of enforceability of a foreign judgment is to be distinguished from an application for the

${ }^{85}$ Discussing non-finality of the foreign judgment as a ground for non-recognition in these situations, see $\mathrm{V}$, infra; and on the verification of the jurisdiction of the rendering court with respect to foreign judgments regarding the ownership of IP rights, see VI, infra.

${ }^{86} 433$ F.3d 1199, $1200\left(9^{\text {th }}\right.$ Cir. 2006). 
enforcement process itself. The possibility to enforce a foreign judgment follows from the declaration of enforceability (recognition) of the relevant judgment. The basic criterion is that once the foreign judgment becomes enforceable in the requested state it has to be treated as a judgment of the requested state and hence the law of the enforcing country applies to the execution process.

Most legal systems distinguish between monetary and non-monetary enforcement based on the claim to be satisfied. ${ }^{87}$ Monetary enforcement consists mainly in the neutral liquidation of the debtor's assets and depends on the debtor's solvency. Money judgments are usually enforced by imposing a levy on the debtor's assets. Non-monetary enforcement depends upon indirect mechanisms to restrain the resistance of the debtor or to impose negative consequences on him for his failure to comply. ${ }^{88}$ Non-money judgments and specific performance have a great significance in IP litigation, in particular to enforce injunctions ordering a party to desist from an infringement. Legal systems have created different mechanisms to overcome the problems raised by the enforcement of their own non-money decisions. Such mechanisms include money penalties, such as coercive fines, astreintes, substituted performance of not strictly personal acts, coercive detention, and, in the common law world, the institution of contempt of court.

Comparative studies have shown structural differences between national systems even within Europe concerning issues such as the qualification and the organization of the enforcement organs or the distribution of proceeds ${ }^{89}$ Under Article 4:703(3) CLIP Principles, all these issues are left to the legislation of the enforcing country and no specific provisions have been adopted. Therefore, the procedural law of the enforcing country determines issues such as the following: organs of enforcement, including the judicial or administrative nature of enforcement; modes of enforcement of money and non-money judgments; methods of coercion (such as a levy on assets or garnishment); the possibility of the cumulative employment of several types of monetary enforcement; the relevant time for the conversion of the foreign currency in which the judgment was expressed into the

\footnotetext{
${ }^{87}$ On the application of the CLIP Principles to non-money judgments, see III.1, supra.

${ }^{88}$ K.D. Kerameus, "Enforcement Proceedings," Int. Enc. Com. Law, vol. XVI, ch. 10,

${ }^{89}$ See the national reports contained in P. Kaye, Methods of Execution of Orders and Judgments in Europe, 1996; and B. Hess, "Study on making more efficient the enforcement of judicial decisions within the European Union: Transparency of a debtor's assets, attachment of bank accounts, provisional enforcement and protective measures," Study No. JAI/A3/2002/02, pp. 8-9, available at <http://ec.europa.eu/civiljustice/publications/ docs/enforcement_judicial_decisions_180204_en.pdf $>$.
} p. 5. 
domestic currency; sanctions against non-compliance with enforceability; the consequences of irregular enforcement; and the level of intervention by the courts as an ultimate guarantee of legality. ${ }^{90}$

\section{Finality of the judgment and provisional measures}

The prevailing situation in many national systems is that only final and conclusive foreign judgments can be recognized and that a judgment meets that requirement when there is no possibility of an appeal because no further appeal is possible or the time for filing an appeal has elapsed. Provisional orders and interim decisions do not meet that requirement and cannot be recognized in those systems. ${ }^{91}$ Indeed, many instruments establish that the foreign judgment must be final and conclusive or have the effect of res judicata under the law of the rendering country. ${ }^{92}$

However, the understanding of finality and conclusiveness in international instruments and from a comparative perspective remains controversial given the differences between legal systems as to the point in time when a decision acquires the effect of res judicata. As already noted, according to Article 4:102(2) CLIP Principles, in order to be recognized, a judgment must have in the state of origin the effect whose recognition is sought in the requested state. In common law countries res judicata typically arises when the judgment on the merits cannot be reconsidered by the same court in ordinary proceedings, even though the decision may be subject to appeal. Hence, the term final, even as a condition for recognition and enforcement, is understood in a very flexible way. ${ }^{93}$ By contrast, in some civil law countries a judgment may only be considered final and produce the preclusive or binding effect of res judicata (materielle Rechtskraftwirkung) when it is no longer subject to ordinary forms of review (formelle Rechtskraft). ${ }^{94}$

${ }^{90}$ On these issues, from a comparative perspective, see Kerameus (supra n. 88) pp. $8-12$.

${ }_{91}$ See, for instance, in South Korea, Lee (supra n. 31) p. 116.

92 See, e.g., Section 3.2 Uniform Foreign-Country Money Judgments Recognition Act (2005); and Article 25(2) Preliminary Draft Convention on Jurisdiction and Foreign Judgments in Civil and Commercial Matters of 30 October 1999.

93 See, e.g., the Comment to $\S 481$ Restatement (Third) of Foreign Relations Law: "A final judgment is one that is not subject to additional proceedings in the rendering court other than execution. That a judgment is subject to appeal or to modification in light of changed circumstances does not deprive it of its character as a final judgment".

${ }^{94}$ However, finality in this restrictive sense is not necessarily a requirement for recognition and enforcement; see Articles 38(1), 46(1) Brussels I Regulation. See also H. Gaudemet-Tallon, Compétence et execution des jugements en Europe, $3^{\text {rd }}$ ed., 2002, 
Under the CLIP Principles, it is not necessary that the foreign judgment should have become final and conclusive to be recognized or enforced. The law of the country where the judgment was rendered establishes whether it is final and conclusive because it determines if it is possible to appeal and the effects of an appeal. However, the Principles do not impose finality in the restrictive sense in which it is usually used in civil law countries (formelle Rechtskraft) as a requirement for recognition or enforcement, which is coherent with the position adopted concerning the possibility to enforce provisional measures in Section 3 of Part 4 of the Principles.

As has been noted earlier, enforcement (declaration of enforceability) is only possible to the extent that the foreign judgment is enforceable in the state of origin (Article 4:102(2)). Legal systems determine a point in time at which judgments are enforceable and to what extent judgments that are still subject to appeal may be enforced. Different approaches can be found in civil law and common law concerning the time at which judgments become effective. The prevailing approach in civil law countries has traditionally been that regular enforceability depends on res judicata or exhaustion of the methods of appeal. By contrast, the basic approach in common law systems is that all final judgments are effective from the day of pronouncement or entry in the civil docket regardless of the availability of methods of appeal against them. ${ }^{95}$ This trend to favor the availability of enforcement for decisions of first-instance courts is becoming more common in a comparative perspective. In this connection, some systems in which regular enforceability is only possible once some or all methods of appeal available have been exhausted, accept that judgments may become provisionally enforceable before, by operation of law, or by judicial declaration. Those cases raise similar issues to those posed by all situations in which the enforceable judgment may be revised on appeal, such as the possibility of staying provisional enforceability or making enforcement subject to a security; and the liability of the claimant in case a judgment was vacated on appeal after having been enforced. At any rate, the basic principle in the enforcement context remains that only judgments that are enforceable under the law of the country of origin may be enforced in foreign countries.

p. 298; and, K. Kerameus, in: U. Magnus/P. Mankowski (eds), Brussels I Regulation, 2007 , at pp. 636-637, noting that no particular degree of procedural maturity is required since the decisive element is that the law of the country of origin confers the foreign judgment the effects that are to be expanded to the requested state and hence a judgment provisionally enforceable in the member state of origin may be provisionally enforced in another member state.

${ }^{95}$ Kerameus (supra n. 88) pp. 19-26. 
Specific safeguards have been introduced in paragraph 5 of Article 4:102 CLIP Principles for those situations in which the judgment entitled to enforcement or recognition is subject to appeal in the country of origin. These safeguards apply to all provisional, interim, or interlocutory judgments. According to this provision, in case an ordinary appeal against the judgment has been lodged in the state of origin, or if the time limit for seeking ordinary review has not expired, recognition or enforcement may be postponed or refused, although a refusal based on that reason does not prevent a subsequent application for recognition or enforcement (Article 4:102(5)). The flexible approach of Article 4:102(5) may be of particular practical significance due to the different approaches in national legal systems as to the possibility to recognize or enforce judgments that are still subject to ordinary forms of review.

Given that refusal of recognition and enforcement is admitted, less intense restrictions, such as imposing certain securities on the enforcing party, are also compatible with the Principles. In particular, refusing recognition of a foreign judgment that is still subject to appeal seems appropriate in situations in which recognition is pursued before a registry with a view to updating its records on the basis of the foreign judgment (a possibility discussed at IV, supra). ${ }^{96}$

Provisional and protective measures adopted by a foreign court can be recognized and enforced under the CLIP Principles (Article 4:301). Part 4 does not contain its own concept of provisional and protective measures because it rests on the definition established in Article 2:501(4), which makes clear that such a concept covers the kind of measures that are particularly important in IP matters, such as orders to prevent an infringement, to preserve relevant evidence, and to seize goods or assets. It is a broad concept that encompasses the measures referred to in Article 50 TRIPS Agreement. $^{97}$

Article 4:301 CLIP Principles establishes two specific limitations. This provision allows only cross-border enforcement of provisional measures adopted by a court having jurisdiction over the merits in accordance with the relevant provisions of Part 2 of the Principles. Therefore, provisional measures ordered by the courts of another country, even under the specific rule on jurisdiction over provisional and protective measures of the Prin-

96 Although in a very different context, Regulation (EC) No 2201/2003 of 27 November 2003 concerning jurisdiction and the recognition and enforcement of judgments in matrimonial matters and the matters of parental responsibility (OJ L 338/1 23 December 2003) imposes such a restriction in Article 21(2); see T. Rauscher in T. Rauscher (ed.), Europäisches Zivilprozeßrecht Kommentar, $2^{\text {nd }}$ ed., 2006, p. 987.

${ }^{97}$ C. Heinze, Einstweiliger Rechtsschutz im europäischen Immaterialgüterrecht, 2007, pp. 72-129. 
ciples, shall not be enforceable. This criterion is in line with the one adopted in the European instruments on unitary industrial property rights ${ }^{98}$ and it is also similar to the position that was adopted in the Preliminary Draft Convention on Jurisdiction and Foreign Judgments in Civil and Commercial Matters of 30 October 1999 (Article 23(b) in connection with Article 13).

The second limitation is that provisional and protective measures adopted without prior hearing of the adverse party and enforceable without prior service of process to that party shall not be recognized or enforced. This provision is based on the interpretation of the Brussels Convention made by the ECJ in Denilauler ${ }^{99}$ and seems to be in conformity with the ground for non-recognition established in Article 4:501(1) CLIP Principles, since the document which instituted the proceedings was not notified to the defendant in sufficient time and in such a way as to enable her or him to arrange for her or his defense. ${ }^{100}$

Such an approach seems especially justified when designing a scheme that may be applicable to decisions rendered by countries all over the world, and it does not prevent the establishment of a more liberal approach between countries that belong to a regional integration organization or agree on a convention. In these cases the so-called favor recognitionis principle would allow the application of the most favorable regime in accordance with Article 4:103 CLIP Principles. It can be noted that although Article 50(2) TRIPS Agreement establishes that courts shall have the authority to adopt provisional measures inaudita altera parte where appropriate, it does not impose on member states an obligation to recognize foreign decisions adopted under these circumstances. Given the paramount importance of ensuring adequate protection to the rights of the defendant, it seems justified to exclude enforcement of those foreign provisional measures in an instrument such as the CLIP Principles. However,

98 See Article 103.2 Council Regulation (EC) No 207/2009 of 26 February 2009 on Community trademarks (OJ L 78, 24 March 2009, pp. 1-42, p. 25); and Article 90 Regulation (EC) 6/2002 of 12 December 2001 on Community designs (OJ L 3, 5 January 2002, pp. 1-24).

99 ECJ Judgment of 21 May 1980, 125/79, Denilauler. In this connection see also EMI Records Ltd. v. Modern Music Karl-Ulrich Walterbach GmbH, [1992], Q.B. 115, [1992] 1 All E.R. 616, refusing enforcement in the UK of a German injunction restraining the defendant from reproducing or distributing a musical recording because the order had been adopted ex parte without prior notice to the defendant.

${ }^{100}$ Although in the context of the Brussels I Regulation, the Dutch Supreme Court has considered that the ground for non-recognition of Article 34(2) does not apply in situations in which the defendant did not have to be summoned; see Hoge Raad, 20 June 2008, No. R07/124HR; LJN: BD0138, German Graphics Graphische Maschinen GmbH v. Van der Schee, available at $<$ http://zoeken.rechtspraak.nl $>$. 
if the measure is confirmed after the defendant has been served with the judgment and been given the opportunity to appear and seek its discharge in due time, it may be enforceable abroad. ${ }^{101}$

\section{Verification of the jurisdiction of the rendering court}

\section{Standard of review}

Among the grounds for non-recognition of foreign judgments, the review of the international jurisdiction of the judge of origin plays an essential role in the scheme of the CLIP Principles. By virtue of that requirement, the enforcing court reviews whether the original court exercised jurisdiction in a manner considered appropriate in the recognizing country. In this respect, the CLIP Principles resemble to a certain extent the prevailing approach in so-called pure double conventions. Contrary to single conventions, double conventions cover both jurisdiction and recognition rules. ${ }^{102}$ In that kind of instrument, unification of jurisdiction provisions among member states may be decisive to limit the scope of jurisdiction review in the recognition stage. As illustrated by the Brussels Convention, unification of jurisdiction rules makes recognition and enforcement easier between the countries involved, ${ }^{103}$ although the double nature of the Brussels system has traditionally been imperfect ${ }^{104}$ since some bases of jurisdiction of the different domestic legal systems of the member states remain

${ }^{101}$ Recently the Dutch Supreme Court held enforceable under the Brussels I Regulation a German decision on the determination of costs based on a provisional measure that had been granted ex parte, given that both decisions had been served on the defendant who had the opportunity to challenge them after service; see the judgment of the Hoge Raad of 7 November 2008, No. 07/12641; LJN: BD7568 available at <http:// zoeken.rechtspraak.nl>, that emphasizes the conformity of this approach with the case law of the ECJ in Denilauler and in Maersk (ECJ, 14 October 2004, case C-39/02). At any rate, with respect to measures ordered without the defendant being summoned to appear, the 2009 Report from the Commission on the application of the Brussels I Regulation concludes that it is not entirely clear whether such measures can be enforced on the basis of the Regulation if the defendant has the opportunity to contest the measure subsequently, $\operatorname{COM}(2009) 174$ final, p. 8.

${ }^{102}$ Hague Conference on Private International Law, "Note on the Recognition and Enforcement of Decisions in the Perspective of a Double Convention with Special Regard to Foreign Judgments Awarding Punitive Damages or Excessive Damages," Prel.Doc. No 4, 1996, at 4-6 (available at <www.hcch.net $>$ ).

103 J. Kropholler, Europäisches Zivilprozeßrecht, $5^{\text {th }}$ ed.,1996, pp. 348-349.

104 See, e.g., T. Kruger, Civil Jurisdiction Rules of the EU and their Impact on Third States, Oxford, 2008, pp. 395-396. 
applicable under the unified system. ${ }^{105}$ The Brussels I Regulation cannot be a direct model for the Principles regarding the scope of verification of jurisdiction given the distinct nature and functions of the Principles from those of the Regulation. ${ }^{106}$

A distinction is also made between mixed conventions and pure double conventions. ${ }^{107}$ Mixed conventions establish grounds of jurisdiction that are predicaments to recognition in all member states and grounds of jurisdiction that are prohibited. A judgment rendered under a prohibited ground of jurisdiction shall not be recognized in other member states. Member states have freedom to decide about recognition of judgments based on grounds of jurisdiction other than those expressly admitted or prohibited. In pure double conventions, member states are required to adopt certain grounds of jurisdiction, and to the extent that the rendering court based its jurisdiction on any of those grounds it shall be considered that the original court's jurisdiction meets the standards required for its recognition and enforcement in other member states. However, the resemblance between the Principles and the approach of double conventions is not without limitations, since the Principles are aimed also at being a model for national legislators as stated in their Preamble. ${ }^{108}$

Section 2 of Part 4 CLIP Principles is devoted to "Verification of Jurisdiction." Its basic criterion is that judgments based on jurisdictional rules which conflict with the Principles are excluded from recognition and

${ }^{105}$ ECJ Opinion 1/03 of 7 February 2006, paragraph 148, establishing that Article 4.1 of Brussels I Regulation forms part of the system implemented by that Regulation and contains a reference to the legislation of the member state before whose court the matter is brought.

${ }^{106}$ Under the Brussels I Regulation the international jurisdiction of the court of the member state of origin is reviewed only exceptionally (Art. 35). This instrument has been developed in the specific framework of the EU and its objective of establishing an area of freedom, security, and justice. In this context, mutual trust in the administration of justice in the Community and in the application of Community instruments by the courts of the member states influences the recognition and enforcement scheme.

107 See in the context of the Hague Conference project on jurisdiction, recognition, and enforcement of foreign judgments in civil and commercial matters, A.T. von Mehren, "Enforcing Judgments Abroad: Reflections on the Design of Recognition Conventions," 24 Brook. J. Int'l L. 17 (1998-1999), at 19.

108 At any rate, a provision has been included in the Principles to open the possibility for a flexible approach in cases in which the foreign judgment has been rendered in a country that applies the Principles. Even if it is true that it cannot be expected that in typical situations courts will apply the Principles as such, it is clear that to the extent that the Principles are used as a model for legislators it may happen that in practice the rules applied are those of the Principles. To facilitate recognition and enforcement of foreign judgments, a sort of presumption of conformity has been introduced in Article 4:201 (2): "If the court of origin applied the Principles, it shall be presumed that the foreign judgment does not conflict with the rules established in Part 2". 
enforcement. Under Article 4:201(1), “A judgment shall not be recognized or enforced if there is no ground of jurisdiction under Part 2 of the Principles which would have allowed the foreign court to assert its jurisdiction." Recognition is not subject to the direct application by the rendering court of the jurisdiction grounds established in the Principles. Furthermore, the Principles do not require the enforcing country to verify that the rendering court had jurisdiction to adjudicate under the laws of its own state. ${ }^{109}$ It is sufficient that the foreign court would have had in principle jurisdiction under the Principles. Inconsistency of proceedings in the foreign court with a forum selection clause may be a ground for nonrecognition, provided that the defendant did not participate in the proceedings before the foreign court and did not submit to its jurisdiction.

The indirect application of the jurisdictional rules of Part 2 to recognition and enforcement ${ }^{110}$ determines that some restrictive criteria applied in national domestic systems as to the verification of the jurisdiction of the rendering court would not be an obstacle to enforcement under the Principles. The 2008 decision of the High Court (England) in Lucasfilm v. Ainsworth $^{111}$ offers an example of an approach more restrictive than the one resulting from the Principles. The High Court decided that a U.S. judgment on an IP infringement claim was not enforceable in England because the U.S. court could not be regarded as having jurisdiction for the purposes of recognition and enforcement. The High Court held that for the rendering court to have proper jurisdiction it is necessary that the defendant submitted to the jurisdiction of the foreign court or was physically present within the jurisdiction of the rendering court when the proceedings were instituted. Under the interpretation made of physical presence, that requirement was not met by a U.S. judgment on U.S. copyright infringement claims in a situation in which the defendant had advertised goods for sale on his web-

109 Although such a requirement applies in some systems (see $\S 482(1)$ (b) Restatement (Third) of Foreign Relations Law), it is related to the fact that between states of the U.S., full faith and credit requires the enforcing court to look to the law of the rendering state to determine if the judgment is void for lack of jurisdiction, but such a requirement does not seem appropriate in the case of judgments rendered in foreign countries (see $\S 104$ and $\S 105$ Restatement (Second) of Conflict of Laws and Section 4(b)(2) and 5 Uniform Foreign-Country Money Judgments Recognition Act (2005)).

110 A similar approach has been made explicit in some recent national codifications of private international law, such as the Italian Act of Private International Law of 31 May 1995 (Article 64(1)(a)) and the Venezuelan Act of Private International Law of 1998 (Article 53 (4)).

${ }^{111}$ Lucasfilm Ltd, Star Wars Productions Ltd, and Lucasfilm Entertainment Co. Ltd v Andrew Ainsworth and Shepperton Design Studios Ltd [2008] EWHC 1878. See G. Pratt, "Lucasfilm v Ainsworth: The English strike back (A review of the enforceability of US IP judgments, and the justiciability of US IP claims, in England)," Journal of Intellectual Property Law \& Practice, 2009, pp. 434-438. 
site in U.S. dollars and included shipping prices for the U.S., had advertised in a magazine distributed primarily in the U.S., and sold a material number of goods in the U.S. By contrast, Article 2:202 CLIP Principles and the relevant provisions of Part 2 in connection with Article 4:201 would lead to the conclusion that the rendering court might be regarded as having jurisdiction for the purposes of recognition under those circumstances.

From the wording of Article 4:201 CLIP Principles it is clear that some grounds of jurisdiction used in certain systems are not sufficient, such as jurisdiction founded solely on the document instituting the proceedings having been served on the defendant during his temporary presence in the rendering country, or jurisdiction based only in the presence within the country of origin of property belonging to the defendant not directly related to the dispute. However, it was not deemed necessary to expressly mention in the Principles the grounds of jurisdiction that are not acceptable, ${ }^{112}$ because given the connection of this provision with Part 2 of the Principles the standard of review seems detailed enough. Additionally, considering the potential application of the Principles to judgments coming from any country in the world, it could not be a closed list.

The CLIP Principles do not impose a self-contained regime in which the standard of review of the foreign court jurisdiction is to be identical to the jurisdictional provisions of the Principles. Hence judgments that are based on jurisdictional rules other than those contained in the Principles are not $a$ priori excluded from recognition under the Principles. The approach underlying Article 4:201 is flexible and commands the authorities of the country where recognition is sought to assess the circumstances under which the rendering court assumed jurisdiction. The scheme adopted in the Principles differs from those national systems that apply the so-called mirror-image principle to verify the jurisdiction of the rendering court ("indirect jurisdiction"). Therefore, the CLIP Principles support the view that the standards to assess the jurisdiction of the rendering court need not be identical with the "direct jurisdiction" rules of the requested state. This approach is increasingly accepted from a comparative perspective, as illustrated by the current situation in Japan. ${ }^{113}$

112 An example of that kind of provision in national legislations can be found in 25 $\S 1$ (8) Belgian Code of Private International Law of 2004.

${ }^{113}$ See Tada (supra n. 7) p. 85, referring to the Judgment of the Japanese Supreme Court of 28 April 1998 granting the enforcement of a Hong Kong judgment. The Supreme Court stated that "whether the rendering court has international jurisdiction is to be determined in accordance with principles of justice and good reasons, basically applying the jurisdiction provisions of the Japanese Code of Civil Procedure, and taking into account the circumstances of each case, from the viewpoint of whether or not it is 
Under Article 4:201 CLIP a standard of equivalence applies and the proximity between the dispute and the rendering court must be equivalent to the connections that may provide direct jurisdiction under Part 2 . Therefore, it cannot be ruled out that judgments formally based even on grounds of jurisdiction incompatible with Part 2 of the Principles may be enforceable to the extent that the rendering court would have had jurisdiction under the Principles due to the existence of other connections between the dispute and the country of origin. This may be the situation where the law of the country of origin includes some excessive grounds of jurisdiction and the rendering court founded on one of them its jurisdiction but other more relevant connections with that country are also present.

GlobalSantaFe Corp. v. Globalsantafe.com ${ }^{114}$ may be an example of such a situation. ${ }^{115}$ This decision came after a South Korean court refused to enforce a previous U.S. judgment ordering the transfer of a domain name. The original action was brought before the U.S. court because hours after the claimants had announced their decision to merge into an entity to be named GlobalSantaFe Corporation, the defendant - a South Korean citizen resident in South Korea - registered the domain name globalsantafe.com with a South Korean registrar. Based on the Anticybersquatting Consumer Protection Act (ACPA), ${ }^{116}$ the U.S. court determined that it could exercise jurisdiction because the entity that administers the entire ".com" registry is located in Virginia and ordered the transfer of the domain name. Granting jurisdiction to U.S. courts over any domain name dispute only because the central registry is located in the U.S. seems excessive and in typical situations does not meet the standards of Part 2 CLIP Principles. Once the U.S. court had issued its order, the defendant filed an application in the District Court of Seoul seeking an order preventing the South Korean domain name registrar from transferring the domain name. The South Korean court considered that the jurisdiction of the U.S. court was improper and granted the injunction. The claimant returned to the U.S. court that granted an additional order directing the entity that controls the central registry to cancel the infringing domain. Notwithstanding the excessive nature of the ACPA provision on which the

proper for Japan to recognize the foreign judgment." An English summary of the judgment may be found in The Japanese Annual of Int'l L., 42, 1999, pp. 155-158.

114250 F. Supp. 2d 610 (E.D. Va. 2003).

115 Discussing the case, see P.S. Berman, "Choice of Law and Jurisdiction on the Internet - Towards a Cosmopolitan Vision of Conflict of Laws: Redefining Governmental Interests in a Global Era," 153 U. Pa. L. Rev. 1819 (2004-2005), at 1823-1829.

116 Anticybersquatting Consumer Protection Act, Pub. L. No. 106-113, § 3002, 113 Stat. 1501A-545, 1501A-545 (1999), codified at 15 U.S.C. $\$ 1125$ (d) (2000). The ACPA provides in rem jurisdiction over a domain name wherever that name is registered and where the overall domain name registry is located. 
U.S. court based its jurisdiction, the connections of this particular case with the U.S. were very close. In particular, the defendant deliberately chose the name of the U.S. corporation in order to take advantage of the confusion immediately after its creation had been announced; hence his actions were aimed at the U.S., and the registration of the name of the new U.S. corporation based in the U.S. had substantial effect and was directed to the U.S. ${ }^{117}$ Under these circumstances, Article 2:202 of the Principles would have allowed the U.S. court to assert its jurisdiction and hence verification of jurisdiction should have not been an obstacle to the recognition of the initial U.S. judgment under the Principles.

\section{Exclusive jurisdiction}

Articles 4:201 and 4:202 in combination with Article 2:401 ensure that a judgment that conflicts with the exclusive jurisdiction provisions of the CLIP Principles shall not be recognized or enforced. Hence, the interpretation and scope of the exclusive jurisdiction rules are decisive not only directly to allocate competence to the courts but also indirectly because due to their mandatory character they may decisively influence non-recognition of foreign judgments. A judgment which falls foul of the provisions on exclusive jurisdiction does not benefit from the system of recognition and enforcement under the Principles. The scope of exclusive jurisdiction in Article 2:401 is more restrictive than the one prevailing in most legal systems, including the interpretation made by the ECJ of Article 22(4) Brussels I Regulation in the GAT judgment. ${ }^{118}$ Article 2:401(2) excludes from the scope of exclusive jurisdiction the disputes in which validity or registration arises in a context other than by principal claim or counterclaim to the extent that the resulting decisions do not affect the validity or registration of those rights as against third parties.

Article 4:202 establishes that recognition and enforcement of a foreign judgment may not be refused on the ground that in the proceedings before the court of origin the validity or registration of an IP right registered in a state other than the state of origin was challenged, provided that the recognition and enforcement produces effects only between the parties. This approach facilitates the adjudication before the courts of a single country of infringement claims in cases in which validity is incidentally challenged because it makes possible the cross-border enforcement of decisions rendered in these situations.

Nevertheless, in practice, this criterion seems only applicable when the rendering country has enacted the CLIP Principles or similar rules as to the

117 See Berman (supra n. 115) at 1873-1874.

118 ECJ Judgment of 13 July 2006, C-4/03, GAT. 
scope of exclusive jurisdiction on validity and registration disputes. Otherwise, the rendering court will usually decline its jurisdiction as regards validity even in cases in which validity is incidentally challenged. However, it is noteworthy that even under the GAT doctrine of a broad scope of exclusive jurisdiction (extending to "all proceedings relating to the registration or validity of a patent, irrespective of whether the issue is raised by way of an action or a plea in objection"), a trend has developed to make such exclusive jurisdiction compatible with the possibility to recognize foreign judgments covering the adjudication of infringement claims concerning IP rights registered in the requested state even if the validity of the IP right has been incidentally challenged by the alleged infringer before the foreign court. ${ }^{119}$

Given that the provisions of the Principles on exclusive jurisdiction are future oriented and do not reflect the currently prevailing situation in national systems and international conventions, it seems appropriate to stress that incidental validity challenges of foreign IP rights may not be an obstacle for recognition and enforcement of judgments even in countries that apply a broader scope of exclusive jurisdiction than the model advocated by the Principles. In this connection it seems possible to consider that, regardless of an incidental validity challenge, certain infringement proceedings do not relate to the registration or validity of a patent in the meaning of the GAT ruling, since the judgment does not take any decision on those issues. ${ }^{120}$ Even in countries adhering to a broader scope of exclusive jurisdiction than the one proposed in the Principles, such as the current situation within the EU after $G A T$, infringement decisions concerning IP rights of the requested state that are existing and have not been cancelled should be recognized and enforced in that country regardless of the incidental validity challenge before the rendering court (at least inasmuch as a non-validity challenge is not pending before the court of the requested country).

The interpretation of the scope of exclusive jurisdiction under Part 2 of the Principles is determinative of the meaning of Articles 4:201 and 4:202

119 See P.A. de Miguel Asensio, "Cross-Border Adjudication of Intellectual Property Rights and Competition between Jurisdictions," AIDA, vol. XVI, 2007, pp. 105-154, at 143-145, 150; also available at <http://eprints.ucm.es/7828/>.

120 Particularly significant in this respect, especially in reacting against abusive incidental validity challenges, may be the fact that existing registered IP rights are to be taken for valid and effective as long as they have not been declared invalid by the competent court; see, e.g., Article 99(1) and (2) Regulation (EC) No 207/2009 on Community trademarks. In U.S. patent litigation, there is also a presumption of validity that requires that a patent be proven invalid by "clear and convincing evidence," Tate Access Floors, Inc. v. Interface Architectural Res., Inc., 279 F.3d 1357, 1367 (Fed. Cir. 2002). 
as a ground for non-recognition. The rationale behind the exclusive jurisdiction established in Article 2:401 CLIP Principles rests on the close connection of certain disputes with the public proceedings that determine the existence of the exclusive right and with the functioning of the public registries involved. The scope of the exclusive jurisdiction must be limited to what is essential to achieve its purposes. Therefore, not all disputes that may result in decisions that can be the basis for changes in the records of the registries of a state fall within the exclusive jurisdiction of the courts of the respective state. Judgments on some of those issues may not be concerned with the registration, grant, or the validity of the IP right as such. Only judgments that interfere in the functioning or operation of the public registry may be deemed to have as their object the registration of the right. As the ECJ put it, when a dispute does not itself concern the validity or the existence of the deposit or registration, there is no special reason to confer exclusive jurisdiction. ${ }^{121}$

For instance, a foreign judgment on the entitlement or the ownership of an IP right subject to registration does not conflict with the exclusive jurisdiction of the courts of the country of registration. Indeed, the jurisdiction granted by Article 2:205 CLIP Principles ("Entitlement and ownership") to the courts of the state where the right exists is not exclusive and may not be invoked in connection with Articles 4:201 and 4:202 as a ground for non-recognition, to the extent that neither the validity of the IP right nor the legality of its registration were disputed by the parties. ${ }^{122}$

Given that the existence of copyright and related rights is not subject to registration, the exclusive jurisdiction of Article 2:401 does not refer to them. However, many countries have established optional copyright registration mechanisms that set up a public record of copyright claims and provide some advantages to copyright owners, such as establishing prima facie evidence in court of the validity of the copyright and of the facts stated in the register. In this respect, under the rationale of Article 2:401 it may be appropriate to conclude that foreign judgments resulting from proceedings which have as their object the validity or legality of entries in these public registers cannot be recognized in the country where the registry is kept. ${ }^{123}$

121 ECJ Judgment of 15 November 1983, 288/82, Duijnstee, paras. 23-25.

122 Ibid., paras. 26-27, stressing the distinction between disputes concerning the right to a patent (not falling within the exclusive jurisdiction of Article 22(4) Brussels I Regulation) and disputes concerning the registration or validity of a patent which are covered by the exclusive jurisdiction.

${ }^{123}$ In the framework of the Brussels I Regulation, Article 22(3) that grants exclusive jurisdiction to the courts of the member state in which the register is kept seems to cover proceedings having as their object the validity of entries in copyright registers; see P.A. de Miguel Asensio (supra n. 119) at 136. 


\section{Other provisions}

Article 4:204 CLIP Principles refers to the verification of jurisdiction concerning rules protecting consumers or employees and is connected with Article 2:101. The CLIP Principles do not contain specific jurisdictional provisions aimed at protecting weaker parties, but acknowledge that a significant number of legislations include protective and mandatory rules on jurisdiction concerning consumers and employees. ${ }^{124}$ According to Article 2:101, the provisions of Part 2 of the CLIP Principles on jurisdiction are to be applied without prejudice to specific jurisdictional rules of the forum protecting consumers and employees. Hence, national protective jurisdictional provisions prevail over the rules of the Principles and these allow for the application of national provisions in these fields.

Due to the lack of common jurisdictional standards on these issues in Part 2, the CLIP Principles adopt a flexible approach regarding recognition. Under Article 4:204, recognition and enforcement may be refused if the judgment is manifestly incompatible with specific jurisdictional rules protecting consumers or employees in the state of recognition. The Principles assume that national policies and rules in this area differ widely, as illustrated by the difficulties of reaching a consensus in these areas at the international level. ${ }^{125}$ On account of the different national consumer and employee protection statutes, Article 4:204 is drafted widely in order to give courts flexibility in deciding whether to recognize and enforce. However, Article 4:204 makes it clear that this ground for non-recognition is to be interpreted restrictively, because it requires that the foreign judgment is "manifestly incompatible" with the specific jurisdictional rules protecting consumers or employees in the state of recognition.

Under Article 4:203, when reviewing the jurisdiction of the rendering court, the authority of the requested state shall be bound by the findings of fact on which the original authority based its jurisdiction. Therefore, the requested court is not allowed to re-examine the relevant facts. This provision aims at avoiding duplication and waste of resources and is common to

124 See, e.g., Articles 15-21 Brussels I Regulation.

125 On the insurmountable problems posed by the drafting of rules on consumer contracts in the negotiations at the Hague Conference on the proposed Convention on Jurisdiction and Foreign Judgments in Civil and Commercial Matters, see, e.g., L. Silberman, "Comparative Jurisdiction in the International Context: Will the Proposed Hague Judgments Convention be Stalled?" 52 DePaul L. Rev. 319 (2002), at 325; and M. Keller, "Lessons for The Hague: Internet Jurisdiction in Contract and Tort Cases in the European Community and the United States," 23 J. Marshall J. Computer \& Info. L. 1 (2004) at 69. The 2005 Convention on choice of court agreements does not apply to consumer and employment contracts (Article 2.1) 
most international instruments dealing with the recognition and enforcement of foreign judgments. ${ }^{126}$

Article 4:203 makes it clear that the requested court shall be bound only by the findings of fact of the original court for the purpose of examining jurisdiction according to Articles 4:201 and 4:202. This is a limitation of the preclusive effect of the foreign judgment under this provision. The limitation is intended to ensure that the foreign court's determination of facts on which its jurisdiction is based shall not be binding in other circumstances, in line with the current situation in those legal systems which do not have a concept of issue preclusion in their res judicata doctrine.

\section{Substantive public policy}

\section{Scope and nature}

Public policy as a ground for non-recognition is present in the different international conventions and national legislations in this field. ${ }^{127}$ Article 4:401 CLIP Principles refers to substantive and procedural public policy in separate provisions. Although in some conventions substantive and procedural public policy are mixed in the same provision ${ }^{128}$ and some international, regional, and national instruments do not include a specific reference to procedural public policy, it has been considered appropriate to deal with substantive and procedural public policy in different provisions. This approach is also a feature of many national systems. ${ }^{129}$ Common to both provisions [Article 4:401 (1) and (2)] is that the incompatibility with

${ }^{126}$ See, e.g., Article 35(2) Brussels I Regulation; Article 9 Hague Convention on the Recognition and Enforcement of Decisions Relating to Maintenance Obligations of 1973; Article 25 Hague Convention on Jurisdiction, Applicable Law, Recognition, Enforcement and Co-operation in Respect of Parental Responsibility and Measures for the Protection of Children of 1996; and Article 27(2) Preliminary Draft Convention on Jurisdiction and Foreign Judgments in Civil and Commercial Matters of 30 October 1999.

${ }_{127}$ See, e.g., Article 34(1) Brussels I Regulation, and Article 118(3) Japanese Code of Civil Procedure.

128 See Article 9(e) 2005 Convention on Choice of Court Agreements, and Article 5(1) Convention on the Recognition and Enforcement of Foreign Judgments in Civil and Commercial Matters of 1971.

129 See Article $25 \S 1$ (1) and (2) Belgian Code of Private International Law of 2004; Articles 5 and 53(5) Venezuelan Act of Private International Law of 1998; section 4(b)(1), 4(c)(2) and 4(c)(3) Uniform Foreign-Country Money Judgments Recognition Act (2005); § 482(1)(a) §482(2)(d) Restatement (Third) of Foreign Relations Law and $\S 403$ (1)(a), (b), (c), (d) and (e) ALI Principles. A similar approach can be found in Article 28(1)(c) and (f) Preliminary Draft Convention on Jurisdiction and Foreign Judgments in Civil and Commercial Matters of 1999. 
the public policy of the requested state has to be manifest. This wording stresses the exceptional nature of public policy in tune with the prevailing approach in international instruments and national legislations. ${ }^{130}$

According to the first paragraph of Article 4:401, recognition or enforcement is not possible to the extent that it would be manifestly incompatible with the public policy of the requested state. The application of public policy as a ground for non-recognition is limited to situations in which the violation can be easily ascertained by the requested court. This restriction makes it easier to avoid a review of the substance or merits of the foreign judgment, in line with the prohibition established in Article 4:601 CLIP Principles, when applying the public policy exception. ${ }^{131}$

Mere differences in substantive law do not give rise to a manifest incompatibility with the essential fundamental principles and values of the requested state. Further, under the Principles, recognition is not to be refused on the sole ground that the court of origin applied a law other than that which would have been applicable under the private international law of the state in which recognition is sought. The text of the provision reflects that the duty of the requested authority is to verify whether extension of the relevant judgment effects to the country of recognition would be contrary to public policy, but not to decide in general on the compatibility of the foreign judgment as such with the public policy of the country of recognition. ${ }^{132}$

Although public policy is typically a national defense, based on the basic values and fundamental principles of a national legal system, the exceptional nature of the substantive public defense in IP litigation must be reaffirmed based on the significant level of international harmonization in this field, resulting mainly from the TRIPS Agreement and the conventions administered by WIPO. Additionally, religious differences do not have such a strong impact on the structure and basic principles of IP litigation as in family law and other areas of the law. For instance, with respect to Islamic law, the prevailing view is that there is no serious conflict between

${ }^{130}$ See, e.g., Article 34(1) Brussels I Regulation; Article 23 (a) Regulation (EC) 2201/2003; Article 5.1 Hague Convention on the Recognition and Enforcement of Decisions Relating to Maintenance Obligations of 1973; Article 27(1) Swiss Federal Act of Private International Law of 1987; Article 64(1)(g) Italian Act of Private International Law of 31 May 1995; and Article 117.5 Bulgarian Code of Private International Law of 2005.

131 ECJ 28 March 2000, Case C-7/98, Krombach, para. 37. Concerning the limited scope of the verification of procedural public policy in connection with the exclusion of substantive review of the judgment, see ECJ 2 April 2009, Case C-394/07, Gambazzi, para. 46.

132 Jenard (supra n. 55) p. 54. 
the principles and objectives of Shari'a and modern mechanisms for protecting IP as presented in international treaties. ${ }^{133}$

Notwithstanding the degree of international harmonization achieved in this field, IP disputes may affect significant public interests in sensitive areas in which basic values differ across different jurisdictions. For instance, scope of patent protection may have strong consequences on the availability of products necessary to meet health and safety needs. Restrictions on the patentability of bio-technological inventions are usually intended to safeguard human dignity and additional ethical values. This may lead to refuse the enforcement of a foreign judgment concerning the protection of bio-technological inventions that are regarded as contrary to such basic values of the country in which enforcement is sought. The mandatory nature of moral rights of authors may also be an obstacle to the enforcement in some countries of foreign judgments disregarding such rights. ${ }^{134}$ Also, cultural policies may be deeply influenced by copyright protection. Interaction between some fundamental rights and IP protection may also raise difficulties as to the application of public policy to the extent that such fundamental rights vary across nations. Sarl Louise Ferand Int'l v. Viewfinder ${ }^{135}$ illustrates how competing interests between the copyright laws and the rights protected by the First Amendment in the U.S. may also raise public policy concerns. The decision of the Court of Appeals offers an example of some of the consequences of the restrictive and exceptional nature of public policy. In particular, the Court of Appeals noted that the fact that the foreign judgment found copyright infringement under foreign law on a subject matter that is not copyrightable in the U.S. does not make the foreign judgment contrary to public policy. ${ }^{136}$ The ECJ has also considered that discrepancies between the country of origin and the enforcing country as to the subject matter that may be protected by intellectual property rights do not allow recourse to the clause on public policy of the Brussels I Regulation unless the differences amount to a

${ }^{133}$ See, e.g., H.A. Raslan, "Shari'a and the Protection of Intellectual Property: The Example of Egypt," 47 IDEA 497 2006-2007, 554, discussing how only some minor IP issues, especially some forms of licensing agreements, may create difficulties as to their compatibility with Shari'a.

${ }_{134}$ See D. Moura Vicente, "La propriété intellectuelle en droit international privé", $R$. des C., 335 (2008) p. 422.

${ }_{135}$ Sarl Louis Feraud Int'l v. Viewfinder, Inc., 406 F. Supp. 2d 274, 285 (S.D.N.Y. 2005), vacated, 489 F.3d 474 (2d Cir. 2007).

${ }_{136}$ Viewfinder, 489 F.3d at 480 n. 3. The Court of Appeals supported in this connection the view of the district court that copyright laws are not "matters of strong moral principle" but rather represent "economic legislation based on policy decisions that assign rights based on assessments of what legal rules will produce the greatest economic good for society as a whole." Viewfinder, 406 F.Supp. 2d at 281. 
manifest breach of a fundamental principle of the legal order of the country in which enforcement is sought. ${ }^{137}$

\section{Punitive damages}

Article 4:402 CLIP Principles includes a specific provision as to the enforceability of decisions awarding non-compensatory damages in jurisdictions where civil liability is considered essentially compensatory. In the U.S., punitive damages do not have a compensatory nature since their main goal is to punish and prevent future wrongdoing. This situation reflects significant differences between the social systems of the countries concerned, including the reliance on administrative control vis-à-vis private litigation to regulate hazardous conduct. ${ }^{138}$ The rationale behind Article 4:402 is that also in situations affecting diverging principles on the purposes and function of the liability system, public policy as a ground to refuse recognition should be restrictively constructed.

The trend to rationalize and restrict the award of punitive damages in the legal systems that admit this category, as illustrated by U.S. practice, ${ }^{139}$ may contribute to reducing the gap with other legal systems. In this regard, it is important to note that punitive damages are remedies under private law. Additionally, in civil law countries, examples can be found of institutions in which certain civil liability rules have additional functions, such as discouraging certain activities in the future, as illustrated by provisions on the extent of civil liability resulting from environmental damage. ${ }^{140}$

${ }^{137}$ See ECJ 11 May 2000, Case C-38/98, Renault, paras. 30-34, establishing that a foreign judgment recognising the existence of an industrial property right in body parts for cars, and enabling the holder of that right to prevent third parties from manufacturing, selling or exporting to a country that does not recognise the existence of such rights in spare parts for cars should not be considered to be contrary to public policy in this country.

138 Hague Conference on Private International Law (supra n. 102) p. 16.

139 See the notorious U.S. Supreme Court decisions in BMW of North America $v$. Gore BMW of North America, Inc. v. Gore, 517 U.S. 559 (1996); State Farm Mutual Automobile Insurance Co v. Campbell et al., 538 U.S. 408 (2003); and Philip Morris v. Williams 549 U.S. 346 (2007).

${ }^{140}$ See, e.g., M. López de Gonzalo, "Punitive damages e ordine pubblico," Riv.dir. int.pr.proc., 2007 , p. 77 , at $82-83$. It is remarkable that although U.S. courts award punitive damages in tort actions, they do not allow punitive damages for breach of contract even if the contract includes a liquidated damages clause. By contrast, in many jurisdictions that generally limit liability to compensatory damages, contractual clauses aimed at compelling the breaching party to pay extra-compensatory damages are enforceable; see C. Calleros, "Punitive Damages, Liquidated Damages, and Clauses Pénales in Contract Actions: A Comparative Analysis of the American Common Law and the French Civil Code," 32 Brook. J. Int'l L. 68 (2006-2007). However, the contrac- 
Moreover, given that in many jurisdictions compensatory damages may cover non-monetary damage and that the costs related to litigation are commonly awarded to the successful claimant, it may happen that the amount of punitive damages awarded by a U.S. court may not always go grossly beyond the amount a court in a country whose liability system is compensatory would grant the plaintiff in the same dispute. ${ }^{141}$

Courts in several jurisdictions not having punitive damages, such as Germany, ${ }^{142}$ Italy, ${ }^{143}$ Japan, ${ }^{144}$ and South Korea, ${ }^{145}$ have considered that recognition and enforcement of foreign judgments imposing punitive or similar damages may be contrary to public policy, at least to the extent that they exceed the amount of the actual damage to be compensated. In other legal systems not having punitive damages, the situation seems to be similar even in those cases in which courts have reflected a more favorable attitude to the recognition of foreign judgments awarding punitive damages. In Spain, the Supreme Court declared enforceable a U.S. judgment imposing punitive damages against a Spanish company in a dispute concerning the infringement of IP rights. ${ }^{146}$ Although the Court held that

tual nature of these clauses implies significant divergences with the interests involved in punitive liability.

${ }^{141}$ F. Blumer, "Jurisdiction and Recognition in Transatlantic Patent Litigation," Tex. Intell. Prop. L. J., vol. 9, 2001, 329, at 385-386.

${ }^{142}$ Bundesgerichtshof decision of 4 June 1992 (Case IX ZR 149/91, ZIP 1992, 1256, 1261-1262).

${ }^{143}$ Corte di Cassazione, judgment No. 1183 of 19 January 2007, Riv.dir.int.pr.proc., 2007, p. 781; and Corte d'Appello di Venezia, judgment of 15 October 2001, Riv.dir. int.pr.proc., 2002, p. 1021.

${ }^{144}$ In its judgment of 11 July 1997, the Supreme Court of Japan denied the enforcement of a Californian judgment as contrary to public policy. Stating that the Californian punitive damage system has a clear purpose of punishment, the Court regarded it as incompatible with the basic principles of the Japanese system of compensatory damages. The Court denied the enforcement of the part of the judgment ordering punitive damages but granted the enforcement as to the award of compensatory damages. For an English summary, see The Japanese Annual of Int'l L., 41, 1998, pp. 107-109.

${ }^{145}$ In a decision of 10 February 1995, 93 Ga Hap 19069, the East Branch of Seoul District Court held that because a punitive damage award has a feature of criminal sanction it might violate the public policy of Korea where only compensatory damages for torts are allowed. Considering the principle of proportionality, only part of the amount awarded in the U.S. judgment was recognized. However, in appeal the Seoul High Court - Decision of 18 September 1996, $95 \mathrm{Na} 14840$ - and the Supreme Court of Korea - Decision of 9 September 1997, Da 47517 - considered that the U.S. judgment was not an award of punitive damage but a merely compensatory unliquidated damage award and hence it did not violate Korea's public policy; see Lee (supra n. 31) at 122123.

146 Decision (Auto) of the Spanish Supreme Court of 13 November 2001 (Exequatur No. 2039/1999), JUR 2002/608, AEDIPr, 2003, 914-919. For an English translation, see S.R. Jablonski, "Translation and Comment: Enforcing U.S. Punitive Damages Awards in 
the category of punitive damages is not per se repugnant to Spanish public policy, the result was influenced by the circumstances of the case. The Court highlighted that the underlying interests protected by U.S. law were not unknown to Spanish law, and reviewed the proportionality of the amount awarded that was deemed to reflect the defendant's intentional and egregious conduct in violating the plaintiffs' IP rights. ${ }^{147}$

Under the CLIP Principles, recognition and enforcement of a judgment may only be refused if, and only to the extent that, the judgment awards damages that do not compensate a party for actual loss and exceed the amount of damages that could have been awarded by the courts of the state where enforcement is sought if the same events had been adjudicated in this country (Article 4:402). The approach adopted - modeled on Article 11 Hague Convention on Choice of Court Agreements of $2005^{148}$ requires a comparison both as to the function and as to the amount of the sums awarded. The second paragraph of Article 4:402 makes amounts aimed at covering costs and expenses relating to the proceedings significant to that comparison. ${ }^{149}$ This approach reflects the trend to assume that refusal to recognize judgments imposing punitive damages is mainly a reaction against the excessive amount of money awarded. ${ }^{150}$

\section{Procedural public policy}

Only if the specific foreign proceedings leading to the judgment were manifestly incompatible with fundamental principles of procedural fairness of the requested state is the foreign judgment regarded by the CLIP Prin-

Foreign Courts - A Recent Case in the Supreme Court of Spain," 24 J.L. \& Com. 225 (2005), at p. 231.

${ }^{147}$ It seems reasonable to foresee that in other cases public policy may impose only a partial recognition of U.S. judgments awarding punitive damages, so that enforcement would be limited to the amount of damages that are acceptable under Spanish law; see F. Ramos Romeu, "Litigation Under the Shadow of an Exequatur: The Spanish Recognition of U.S. Judgments," 38 Int'l Law. 945(2004), at 968; and Jablonski (supra n. 146) at 230 .

${ }^{148}$ Luginbühl/Wollgast (supra n. 14) at 216-217.

149 For a similar approach, see $\S 411$ ALI Principles.

150 Within the uniform EU rules on applicable law, paragraph 32 of the Preamble of Regulation (EC) No 864/2007 of 11 July 2007 on the law applicable to non-contractual obligations (Rome II) (OJ L 199, 31 July 2007, p. 40) refers to the possibility that provisions of the applicable law awarding non-compensatory exemplary or punitive damages of an excessive nature be regarded as contrary to the public policy of the forum depending on the circumstances of the case and the legal order of the forum. Also the ECJ in its judgment of 13 July 2006, C-295/04 to C-298/04, Manfredi seems to have adopted an ambivalent position on punitive damages. 
ciples as contrary to public policy (Article 4:401(2)). The basic standards of the right to a fair trial or due process are determinative of the content of the public policy defense as a ground for non-recognition. In Europe the development of common standards as to the right of fair trial under Article 6 European Convention on Human Rights (ECHR) has important consequences in the area of recognition and enforcement of judgments. ${ }^{151}$

A contracting state of the ECHR may infringe Article 6 by enforcing a foreign judgment that has been obtained in conditions which constitute a breach of that Article. In light of the case law of the European Court of Human Rights (ECtHR) and especially its judgment in Pellegrini, the right to a fair trial under Article 6.1 ECHR demands a review of whether the proceedings before the foreign court that rendered the judgment which is to be recognized fulfilled the guarantees of Article $6 .{ }^{152}$ In its recent judgment in Saccoccia v. Austria, the ECtHR expressly held that the applicability of Article 6 ECHR extends to "proceedings relating to the execution of a foreign court's decision, provided that the decision in question concerned a civil right or obligation." ${ }^{, 153}$ In its decision on inadmissibility of 29 April 2008 in McDonald v. France, the ECtHR reaffirmed the view that in cases concerning recognition and enforcement of foreign judgments the ECtHR verifies the lawfulness of the procedure followed before the foreign courts from the standpoint of Article 6 ECHR. ${ }^{154}$ The ECJ when

151 See H. Muir Watt, "Evidence of an Emergent European Legal Culture: Public Policy Requirements of Procedural Fairness under the Brussels and Lugano Conventions," 36 Tex. Int'l L.J. 539 (2001) pp. 539-554, pp. 549-552; J.D. González Campos, "Reconocimiento y ejecución de decisiones judiciales extranjeras y respeto de los derechos humanos relativos al proceso," Homenaje a J.A. Carrillo Salcedo, 2005, pp. 695716; E. Guinchard, "Procès équitable (Article $6 \mathrm{CESDH})$ et droit internacional privé," A. Nuys/N. Watté (eds.), International Civil Litigation in Europe and Relations with Third Status, pp. 199-245, pp. 214-232; and J.J. Fawcett, "The Impact of Article 6(1) of the ECHR on Private International Law," ICLQ, 2007, pp 1-48, at 44.

152 Pellegrini v. Italy, Judgment of 20 July 2001, para. 40; and Maumousseau et Washington v. France, Judgment of 6 December 2007, para. 96, available at <www. echr.coe.int/echr/Homepage_EN>. Although Pellegrini referred only to the control of the enforcement of judgment originating from the courts of a country that is not a contracting state of the ECHR, it seems reasonable to consider that the ECHR imposes a similar obligation to deny recognition of a judgment that emanates from the courts of another contracting state if the foreign proceedings did not fulfill the guarantees of Article 6 ECHR.

${ }^{153}$ Saccoccia v. Austria, Judgment of 18 December 2008, para. 62. At any rate, in Saccoccia the Court considered that in exequatur proceedings courts may dispense from holding a hearing, since all they have to do is examine whether the conditions for granting execution have been met.

154 With respect to the rules on indirect jurisdiction as a ground for non-recognition, the ECtHR added that it examines the rules in force in the contracting states to make sure they did not infringe any of the rights protected by the ECHR. In this connection, the 
applying Article 34(1) Brussels I Regulation has acknowledged that in determining procedural public policy, guidance is to be found in the jurisprudence of the ECtHR. ${ }^{155}$

From an international perspective, fundamental principles of procedural fairness may comprise basic standards of independence and impartiality of the court and its judges; procedural equality of the parties, including equal treatment and reasonable opportunity for litigants to assert or defend their rights and avoidance of any kind of illegitimate discrimination; due notice and the right to be heard; the right of the parties to engage a lawyer; a reasoned explanation of the essential basis of the judgment; and prompt rendition of justice. ${ }^{156}$ However, the consequences and restrictions resulting from these principles and their interpretation may vary significantly between different legal systems. For instance, rendering judgments by default without trial and without giving additional reasons is a well-established practice in some countries but may be regarded as a violation of the right to a fair trial in other systems. ${ }^{157}$

With respect to IP litigation it is noteworthy that Part III TRIPS Agreement has been the basis for an important approximation of national procedural laws regarding the means of enforcing IP rights. TRIPS is a source of international standards implemented in the legislation of the contracting states that may contribute to reducing the number of situations in which

ECtHR held that the refusal to authorize the execution of a United States court's judgments in France based on the exemption of French nationals from the jurisdiction of foreign courts provided for by the French Civil Code, amounted to an interference with the applicant's right to a fair hearing However, the ECtHR decided the inadmissibility of the application because a person should not complain about a situation they had helped to bring about by their own inaction, and the applicant did not appeal against the French court's decision dismissing his petition but instead turned to the U.S. courts that rendered the judgment that he later intended to enforce in France, McDonald v. France (No 18648/04), Decision of 29 April 2008. A summary of this decision of non-admissibility may be found in ECtHR, "Information Note on the Court's case law," No. 110, July 2008, at pp. 30-31<www.echr.coe.int/echr/NoteInformation/en>.

155 ECJ 28 March 2000, Case C-7/98, Krombach, para. 44; ECJ 2 May 2006, Case C341/04, Eurofood IFSC Ltd, para. 65; and ECJ 2 April 2009, Case C-394/07, Gambazzi, para. 28. The ECJ has expressly recognized that the right to be notified of procedural documents and the right to be heard occupy an eminent position in the organization and conduct of a fair legal process; see ECJ 2 May 2006, Case C-341/04, Eurofood IFSC Ltd, para. 66; and ECJ 2 April 2009, Case C-394/07, Gambazzi, para. 47.

${ }^{156}$ On the progressive development of international standards on those issues, see ALI/UNIDROIT Principles of Transnational Civil Procedure, adopted by the American Law Institute (ALI) in May 2004 and by the International Institute for the Unification of Private Law (UNIDROIT) in April 2004, Unif. L. Rev. 2004-4, 758.

${ }^{157}$ G. Cuniberti, "The Recognition of Foreign Judgments Lacking Reasons in Europe: Access to Justice, Foreign Court Avoidance, and Efficiency," 57 ICLQ (2008), pp. 2552 . 
procedural public policy is an obstacle to recognition and enforcement in IP litigation. For instance, Article 42 TRIPS Agreement lists some basic features that civil procedures concerning the enforcement of IP rights must have in order to qualify as fair and equitable. These include the right of defendants to timely and written notice containing sufficient detail; the possibility of the parties of being represented by independent legal counsel; the avoidance of overly burdensome requirements concerning mandatory personal appearances; and the right of the parties to substantiate their claims and to present all relevant evidence.

Because of the exceptional nature of public policy, the existence of differences between the procedural law of the country of origin and that of the requested country is not determinative to refuse enforcement inasmuch as such differences do not decisively affect in the case concerned fundamental procedural fairness and do not undermine essential principles of the system in which enforcement is sought. In this respect, significant differences may be found between common law systems and civil law systems, but they may not affect fundamental principles of procedural fairness, to the extent that the legal systems involved provide sufficient guarantees for a fair and impartial trial. ${ }^{158}$

For example, it seems appropriate to consider that a civil judgment based on a jury verdict should not in principle be regarded as contrary to public policy in countries that do not use civil juries. Also, differences with respect to the availability of discovery devices between the country of origin and the requested country should not be an obstacle to the enforcement of the judgment. ${ }^{159}$ Finally, procedural public policy objections based on the fact that the evidential and other legal standards used by the rendering court in a default judgment do not meet the standards for a decision on the merits in the requested country should only be a ground for non-recognition if they were manifestly incompatible with the criteria applied to default judgments in the requested state and basic principles of procedural fairness prevailing in that state.

158 See Blumer (supra n. 141) p. 399.

159 See U. Haas, "Zur Anerkennung US-amerikanischer Urteile in der Bundesrepublik Deutschland," IPRax, vol. 21, 2001, 195, at 199; and Reporter's Note 1 to Section 403 ALI Principles. In Germany, see the Bundesgerichtshof decision of 4 June 1992 (ZIP $1992,1256,1261-1262$ ), considering that the fulfillment of far-reaching pre-trial discovery procedures and the lack of recovery of attorney's fees to the successful party in U.S. litigation do not amount to a violation of the German procedural public policy exception in the field of recognition. 


\section{Other grounds for non-recognition}

Article 4:501 CLIP Principles includes other grounds for non-recognition. Its first paragraph refers to the situations in which the document which instituted the proceedings was not notified to the defendant in sufficient time and in such a way as to enable him to arrange for his defense. The provision controls the respect in the court of origin of the rights of defense of the defaulting defendant by proper summons in adequate time. Hence, it typically applies to default judgments not covering those situations in which the defendant entered an appearance and presented his case without contesting notification in the court of origin, provided that the law of the state of origin permitted notification to be contested. A similar ground for non-recognition may be found in many international and bilateral conventions and in the domestic legal systems of many countries, although the exact wording of these provisions and the interpretation of some terms have traditionally been controversial, as illustrated by the origins and interpretation of Article 27.2 Brussels Convention and 34.2 Brussels I Regulation. ${ }^{160}$ Given the presence of Article 4:501(1), the public policy clause of Article 4:401 normally applies with regard to procedure in situations in which the breach does not refer to the initial service of the document that instituted the proceedings. ${ }^{161}$

The standard of review under Article 4:501(1) CLIP Principles is neither the internal law of the state in which the judgment was given nor that of the requested country. The focus rests on the verification that the defendant was notified of the proceedings in a way that did not hinder his right of defense, that he received actual knowledge of the proceedings, and that he was given the opportunity to defend himself. ${ }^{162}$ Process serving not undertaken in accordance with a treaty on judicial cooperation to which the country of origin and the enforcing country are parties does not necessarily make recognition contrary to Article 4:501(1). This solution rests on the idea that control of the acts of communication in the framework of recognition is aimed at ensuring the effective judicial protection of the defen-

${ }^{160}$ J. Newton, The Uniform Interpretation of the Brussels and Lugano Conventions, Oxford, 2002, pp. 437-518; and the ECJ Judgment in Apostolides, paras. 72-80.

${ }^{161}$ However, the procedural public policy exception is broader and covers situations in which there has been a violation of the right to a fair trial in connection with the service of the document which instituted the proceedings, even though the judgment was not rendered in default of appearance, Fawcett (supra n. 151) at 29.

${ }^{162}$ As to the creation of international standards guaranteeing due notice to the defendant and the right to be heard, see Principle 5 of the ALI/UNIDROIT Principles of Transnational Civil Procedure (supra n. 156) p. 768. 
dant. ${ }^{163}$ Hence, where the defendant has received actual knowledge of the existence and the content of the suit brought against him in sufficient time and in such a way as to enable him to arrange for his defense, there is no justification for refusing recognition on the basis of this ground. Under this regime, it is in the defendant's best interests to appear in court and to defend himself in any foreign jurisdiction to the extent that he is notified in a way that enabled him to get proper knowledge of the commencement of the action with sufficient time to prepare his defense, especially when the jurisdiction of the forum is based on a ground that meets the standards of Article 4:201 as to the verification of jurisdiction. At any rate, from the practical perspective, it seems reasonable to advise any party who may be interested in the future enforcement of the judgment abroad to ensure that service is through a method admitted in the future requested state, to avoid possible risks of non-recognition given the current state of the law in many countries.

Article 4:501(1) is in line with Article 9(c)(i) Hague Convention on Choice of Court Agreements of $2005,{ }^{164}$ that is also modeled on Article 34(2) Brussels I Regulation. A similar approach can be found in other instruments, such as Section 4(c)(1) Uniform Foreign-Country Money Judgments Recognition Act (2005).

An additional ground for non-recognition established in Article 4:501 (2) CLIP Principles refers to the situations in which proceedings between the same parties and having the same cause of action are pending before a court of the requested state, provided that those proceedings were the first to be instituted. Since this ground for non-recognition is limited to the situations in which the proceedings in the country where recognition is sought were the first to be instituted, ${ }^{165}$ this provision must be read in con-

163 This progressive approach is in agreement with the interpretation made of this requirement in some national systems. In this connection, when accepting the enforcement of a U.S. judgment concerning the infringement of IP rights, the Spanish Supreme Court concluded that the fact that the act of notice and summons was not done through the mechanisms contemplated in the Hague Convention on the Service Abroad of Judicial Documents of 15 November 1965 - as Spain and the U.S. are parties to that Convention - was not a reason to deny recognition given that the defendant had clear knowledge of the suit advanced in the U.S. See Decision (Auto) of the Spanish Supreme Court of 13 November 2001, AEDIPr, 2003, p. 917.

${ }^{164}$ However, the Principles do not include a provision like Article 9(c)(ii) Hague Convention on Choice of Court Agreements of 2005, which adds as a ground for nonrecognition that notification to the defendant in the requested state was made "in a manner that is incompatible with fundamental principles of the requested State concerning service of documents." Under the Principles these situations will usually be covered by the procedural public policy provision.

165 Many international conventions on recognition and enforcement as well as national legislations follow this approach: Article 5(3) Hague Convention on the Recognition 
nection with Article 2:706 CLIP Principles that sets forth the relevant criteria to determine the time when a court is deemed to be seized. Additionally, Section 7 of Part 2 on coordination of proceedings and especially Article 2:701 on congruent proceedings establish means to coordinate congruent proceedings commenced in the courts of different states with a view to avoid the risk of inconsistent judgments. Article 4:501 (2) applies only to situations in which proceedings brought in the court first seized should have prevailed under Article 2:701. If the proceedings in the court first seized have come to a judgment, Article 4:501 (3) shall apply regardless of which court had priority under Article 2:701.

Indeed, incompatibility of the foreign judgment with a judgment given in the requested state between the same parties is the third ground for nonrecognition established in Article 4:501. In order to guarantee the rule of law in the enforcing country a judgment rendered in that state must prevail over the foreign conflicting judgment regardless of which suit was filed earlier and which judgment was given earlier. Concerning this ground of non-recognition, different approaches can be found in international conventions and national systems as to whether the judgment given in the state addressed has to have become res judicata or if it is sufficient for the judgment to be final and conclusive at that stage of procedure. In line with the approach taken in the Brussels I Regulation, ${ }^{166}$ the wording used in the Principles is flexible on that issue that is to be decided by the court in which recognition is sought.

A similar ground for non-recognition is envisaged in case a conflict arises between two incompatible foreign judgments concerning the same parties and having the same cause of action to the extent that the recognition of one of those judgments has already been declared in the requested state. Under Article 4:501(4) the judgment that has been recognized always prevails. In situations in which none of the conflicting foreign judgments has already been recognized, the judgment that was given earlier prevails. These two provisions under (3) and (4) reflect criteria that have achieved significant acceptance from a comparative perspective. ${ }^{167}$

and Enforcement of Foreign Judgments in Civil and Commercial Matters of 1971; Article 28(1)(a) Preliminary Draft Convention on Jurisdiction and Foreign Judgments in Civil and Commercial Matters of 1999; and Article 27(2)(c) Swiss Federal Act of Private International Law of 1987

166 Jenard (supra n. 55) p. 45.

167 They are based on similar rules such as Article 5(3) Hague Convention on the Recognition and Enforcement of Foreign Judgments in Civil and Commercial Matters of 1971; Article 9(f) and (g) Hague Convention on Choice of Court Agreements of 2005; Article 34(3) and (4) Brussels I Regulation; Article 22(c) and (d) Regulation (EC) 2201/2003; § 482(2)(e) Restatement (Third) of Foreign Relations Law; Section 4(c)(4) Uniform Foreign-Country Money Judgments Recognition Act (2005); Article 27(2)(c) 
The grounds for non-recognition are enumerated exhaustively in Part 4 of the CLIP Principles, and no other checks may be used to control recognition of foreign judgments. Recognition and declaration of enforceability may be refused only for one of the reasons set out in Part 4 of the Principles. Therefore, other checks that may apply in some systems cannot be used in the scheme of the Principles. For instance, application by the rendering court of a law other than that which would have been applicable under the choice-of-law rules of the country of recognition cannot be by itself a reason to refuse recognition. Additionally, as already noted, no control is established in order to refuse recognition based on reciprocity.

Although the CLIP Group discussed the introduction of a ground for non-recognition, referring to fraud in connection with procedure, it was decided finally not to introduce it. Fraud has traditionally occupied a special place as a defense in common law ${ }^{168}$ and a provision refusing recognition in cases in which the foreign judgment has been obtained by fraud is found in many international conventions. ${ }^{169}$ However, fraud provisions in the field of recognition are typically aimed at providing a defense against situations in which a fraudulent action by the prevailing party deprived the other party of a reasonable opportunity to defend its case. ${ }^{170}$ To the extent that one of the parties, typically the defendant, was deprived of such an opportunity in the original proceedings, recourse to the provision on procedural public policy seems sufficient to refuse recognition. ${ }^{171}$

Swiss Federal Act of Private International Law of 1987; Article 28(1)(b) Preliminary Draft Convention on Jurisdiction and Foreign Judgments in Civil and Commercial Matters of 1999.

168 See, e.g., J. Newton (supra n. 160) p. 417.

169 See, e.g., Article 9(d) Convention on Choice of Court Agreements of 2005 or Article 5(2) Hague Convention on the Recognition and Enforcement of Decisions Relating to Maintenance Obligations of 1973.

${ }^{170}$ See, e.g., Comment to Section 4 Uniform Foreign-Country Money Judgments Recognition Act (2005), that in 4(c)(2) includes fraud as a ground for non-recognition.

${ }^{171}$ See, e.g., M. Stürner, "Inländischer Rechtsschutz gegen ausländische Urteile," RabelsZ, 2007, pp. 597-643, pp. 624-625. Indeed, a significant number of cases where the public policy exception of Article 34.1 Brussels I Regulation has been raised refer to the allegation of fraudulent behavior, Hess/Pfeiffer/Schlosser (supra n. 45) pp. 141-144. 


\title{
Recognition and Enforcement of Foreign Judgments Relating to IP Rights and Unfair Competition: The Transparency Proposal
}

\author{
TOSHIYUKI KonO/NOZOMI TADA/MiHO SHIN
}

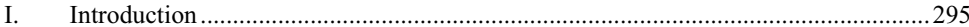

II. Judgments and Provisional Measures of Foreign Courts .............................................296

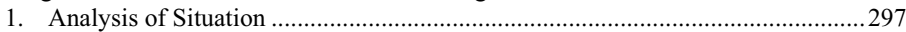

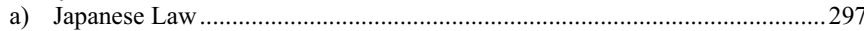

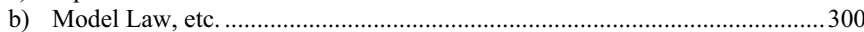

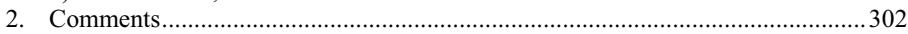

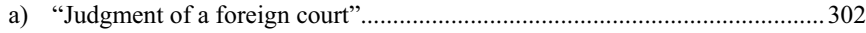

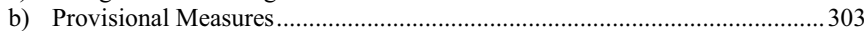

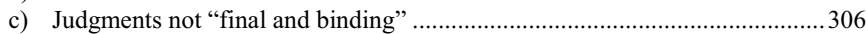

III. Recognition and Enforcement of Final and Binding Judgments of Foreign Courts ....307

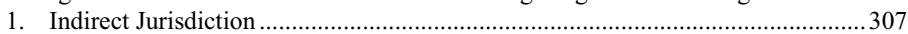

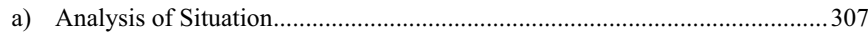

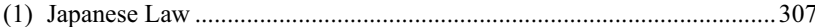

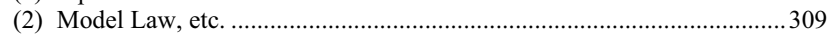

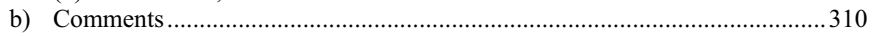

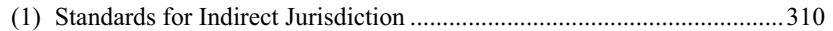

(2) Purposes of the System of Recognition and Enforcement of

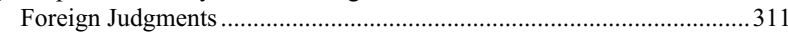

2. Service ...

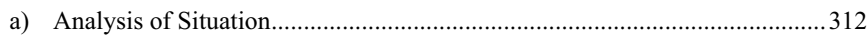

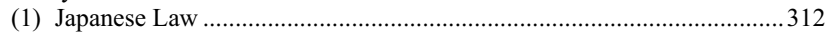

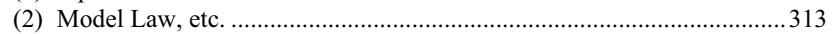

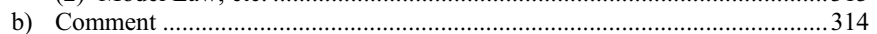

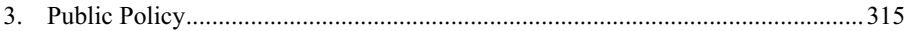

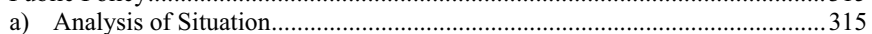

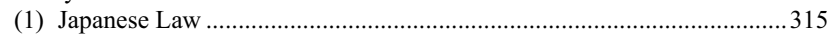

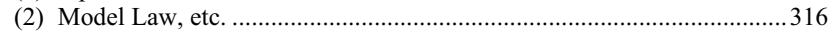

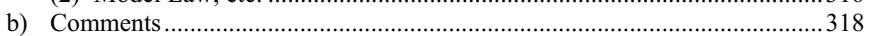

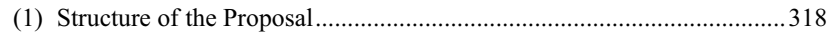

(2) Non-application of International Mandatory Rules of the Country

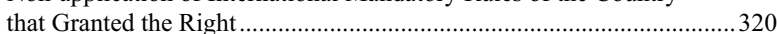

(3) Discrepancy with the Status of a Right in the Granting Country ............ 322

(4) A Proper Opportunity to Produce Allegations Concerning the Validity and Scope of a Right. 
(5) Matters Decided not in Court Proceedings under the Law of the

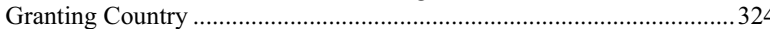

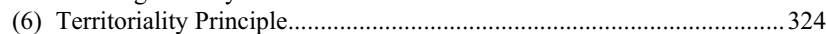

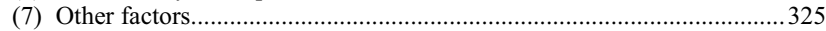

4. International Parallel Litigation and Incompatible Japanese Judgments ...............325

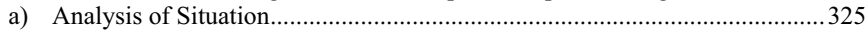

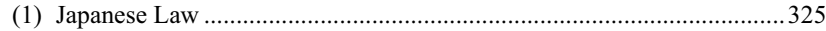

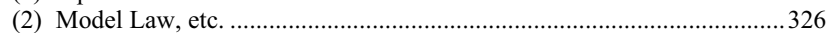

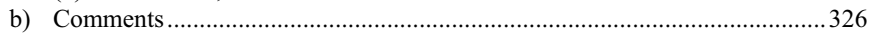

(1) Foreign Judgment Resulting from International Parallel Litigation.........326

(2) Foreign Judgment Incompatible with Japanese Judgment ........................327

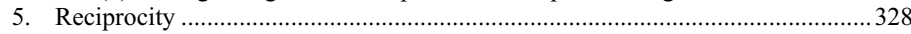

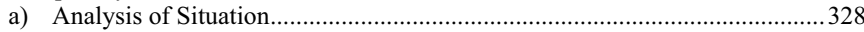

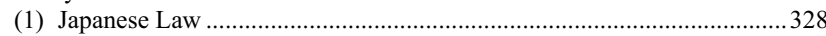

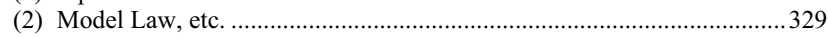

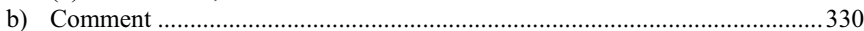

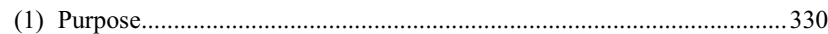

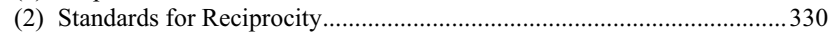

IV. Enforcement of Foreign Provisional Measures and Foreign Not "Final and

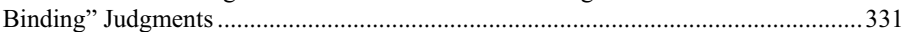

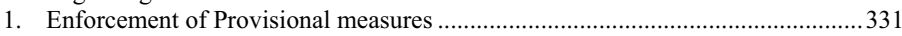

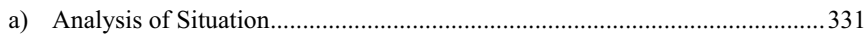

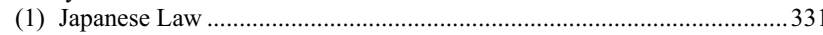

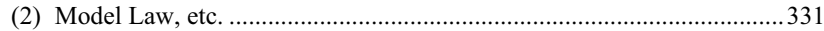

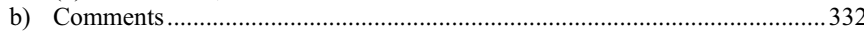

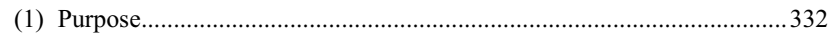

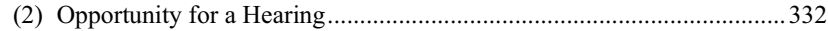

(3) Opportunity to State Opinion on the Validity of Rights..........................333

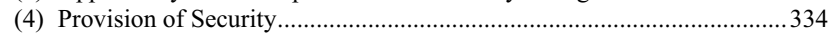

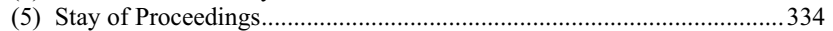

2. Enforcement of Foreign Not "Final and Binding" Judgment ................................. 335

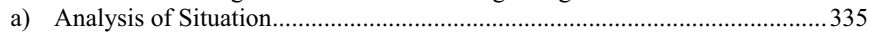

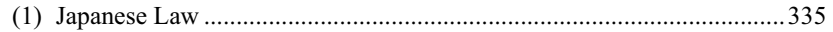

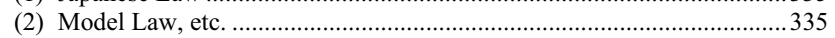

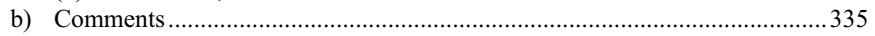

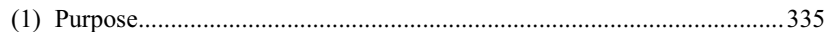

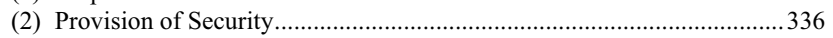

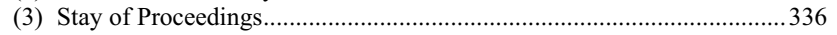

V. Effects of Foreign Judgments and Provisional Measures..............................................337

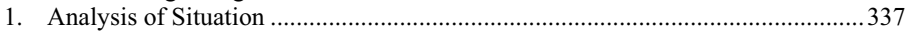

a) Japanese Law

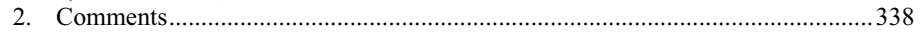

a) Effect of Judgments or Provisional Measures in Partial Recognition

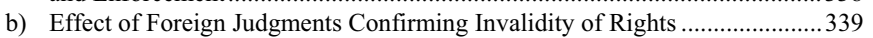

c) Provision of Suitable Compensation where a Compulsory License is Granted

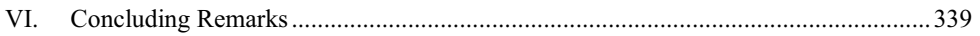




\section{Introduction}

Chapter 4 of the Legislative Proposal of the Transparency Project (hereinafter referred to as "the Transparency Proposal") deals with the recognition and enforcement of foreign judgments relating to transnational civil disputes on IP rights and unfair competition (see Art. 001 ${ }^{*}$ ). In Japan, foreign judgments in general are recognized under Article 118 of the Code of Civil Procedure and the enforcement of them is dealt with by Article 24 of the Civil Execution Act. ${ }^{1}$ There are more than thirty court reported cases in Japan dealing with recognition or enforcement of foreign judgments regarding business activity. ${ }^{2}$ Based on developments in doctrine and case

${ }^{*}$ For this and other references to the provisions of the Transparency Proposal see Annex III infra.

${ }^{1}$ As recent commentary treatises on the Japanese system of recognition and enforcement of foreign judgments in general, see e.g., Mikio Akiyama et al., Kommentaru minji soshô hô II [Commentaries on the Code of Civil Procedure, Vol. II] (2nd ed., Nihon Hyôronsha, 2006), p. 509; Teiichiro Nakano, Minji shikkô hô [Civil Execution Act], (enlarged and revised edition of the 5th ed., Seirin Shoin, 2006), p. 185; Nozomi Tada, Note, Enforcement of Foreign Judgments in Japan Regarding Business Activities, The Japanese Annual of Int'l L. No. 46 (2003), p. 75. In IP matters, the Waseda University Global-COE Project proposes the Principles on Private International Law on Intellectual Property which contain several provisions on recognition and enforcement of foreign judgments. This Paper refers to its version of 15 December 2008 (see Kigyô to hô sozo, Vol. 6, No. 2 (2009), pp. 250-257, available at <www.globalcoe-waseda-law-commerce. org/activity/pdf/19/21.pdf $>$ (hereinafter cited as "the Waseda Project Proposal").

2 For these court decisions, see Court Cases: Recognition and Enforcement of Foreign Judgments, in: Transparency of Japanese Law Project, available at $<$ www. tomeika.jur.kyushu-u.ac.jp/procedure/courtcases.html>, which provides an English summary of these cases. Unfortunately, there are no reported court cases that directly deal with a foreign judgment regarding IP rights and unfair competition, such as a judgment awarding damages or an injunction for infringement of IP rights. But three cases may be worth referring to. First is the Maruman case (Tokyo District Court, judgment, 13 November 1967, Ka Minshû Vol. 18, No. 11, p. 1093, abbreviated English translation available at $<$ http://tomeika.jp/search/content.php?did=1551>), in which it was decided to enforce in Japan decisions given by the Commercial Court in the canton of Zurich (Switzerland). It is sure that in the Zurich court the declaration of invalidity of a Swiss patent were sought and so granted, but the decisions of which enforcement was sought in Japan were part of an order to pay court costs and award damages as compensation for having the plaintiff defend the counter claim which the defendant brought in the original case and not for patent infringements. Second is Leonard Tsuguharu Foujita case (Tokyo District Court, judgment, 27 November 1987, Hanrei Jihô No. 1269, p. 232, abbreviated English translation available at $<$ http://tomeika.jp/search/content.php?did=1561 $>$ ), in which a provisional measure enjoining the import and sale of books to/in Japan under Japanese copyrights was granted, although the obligor argued that the favorable judgment given by a French court should be recognized and the application of the provisional measure should be denied. The reason for the decision is so simple however that we 
law on recognition and enforcement of foreign judgments in general, this Chapter presents the Transparency Proposal for revision of these provisions, for the purpose of the effective protection of right holders in civil disputes on IP rights and unfair competition.

It should be noted that the Transparency Proposal still maintains and is based on some fundamental principles prerequisite for Article 118 of the Code of Civil Procedure and Article 24 of the Civil Execution Act. They are as follows: (i) no review of the merits of the foreign judgments or the prohibition of review of their merits for recognition (the prevailing interpretation) and enforcement (Art. 24(2) of the Civil Execution Act); (ii) the recognition of foreign judgments without any special procedure, i.e. automatic recognition (see Art. 118 of the Code of Civil Procedure); and (iii) an action seeking an execution judgment for foreign judgments (Art. 24 (1) of the Civil Execution Act). Although this Chapter includes no provisions setting forth these principles, it presupposes them as a matter of course.

\section{Judgments and Provisional Measures of Foreign Courts}

Judgments to be recognized or enforced by this Chapter are (i) judgments of foreign courts, and (ii) provisional measures of foreign courts, as defined in Article 401. The Transparency Proposal seeks not only to recognize and enforce final and binding judgments given by foreign courts relating to transnational civil disputes on IP rights and unfair competition, but also to enforce foreign provisional measures and foreign not "final and binding" judgments. Since the last two have not been recognized and enforced in Japan, the Transparency Proposal is an innovation for the effective protection of IP rights. While recognition and enforcement of foreign final and binding judgments are dealt with by Article 402, the enforcement of foreign provisional measures and foreign not "final and binding" judgments is dealt with by Article 403.

\footnotetext{
cannot know how the recognition question was dealt with by the Court. And the third case is Salvador Dali case (Tokyo High Court, judgment, 28 May 2003, Hanrei Jihô No. 1831, p. 135), in which, in interpreting the Spanish Civil Code in order to determine the type of a contract for transfer of the Spanish copyright in question, reference was made to the Spanish court judgment which was not "final and binding". For Salvador Dali case, see Yuriko Haga, Hanpi (Comments on Court Cases), Kyûdai Hôgaku No. 96 (2007), p. 85, which tries to examine the case from the viewpoint of the recognition of the Spanish judgment, if possible.
} 


\section{Analysis of Situation}

\section{a) Japanese Law}

In Japan, a "final and binding judgment of a foreign court" is to be recognized and enforced (see Art. 118 of the Code of Civil Procedure and Arts. 24 (1), (3) of the Civil Execution Act). The Supreme Court defined a "judgment of a foreign court" as a "final judgment rendered by a foreign court on private law relations by providing procedural guarantee to both parties, regardless of the name, procedure, or form of judgment." ${ }^{3}$ Any decision of such nature as the Supreme Court defines, whatever it may be called in the foreign state, such as a decree, order, determination or ruling, is a "judgment". According to scholars" views and court cases, "judgment" generally includes a money judgment or a non-money judgment (for example, a judgment ordering the delivery of property or injunctions); a judgment given after contested proceedings or given in default of the appearance of the defendant; ${ }^{4}$ a judgment by default against a party failing to obey a court order; ${ }^{5}$ a judgment given in a summary procedure $;^{6}$ a court costs order. ${ }^{7}$ In addition, it contains the interest which accrues from a sum

\footnotetext{
${ }^{3}$ Supreme Court, judgment, 28 April 1998, Minshû Vol. 52, No. 3, p. 853 (granting enforcement of a court costs order issued by the Hong Kong High Court) (English translation by the Supreme Court of Japan available at <www.courts.go.jp/english/ judgments/text/1998.04.28-1994-O-No.1838.html>; an English summary appears in The Japanese Annual of Int'l L. No. 42 (1999), p. 155).

${ }^{4}$ Foreign judgments given in default of the appearance of the Japanese defendant have been granted enforcement. See e.g., Tokyo District Court, judgment, 14 January 1994, Hanrei Jihô No. 1509, p. 96, Hanrei Taimuzu No. 864, p. 267, abbreviated English translation available at $<$ http://tomeika.jp/search/content.php?did=1587> (a New York State court judgment); Nagoya District Court, judgment, 6 February 1987, Hanrei Jihô No. 1236, p. 113 (a summary in English appears in The Japanese Annual of Int'l L. No. 33 (1990), p. 189) (a German court judgment); Tokyo District Court, judgment, 31 January 1994, Hanrei Jihô No. 1509, p. 101, Hanrei Taimuzu No. 837, p. 300 (a judgment of the High Court of Justice of England, Queen's Bench Division).

5 Mito District Court, Ryugasaki Branch, judgment, 29 October 1999, Hanrei Taimuzu No. 1034, p. 270, abbreviated English translation available at $<$ http://tomeika. $\mathrm{jp} /$ search/content.php?did=1597 $>$ (granting enforcement of a default judgment rendered by the United States District Court for the District of Hawaii, as a sanction against the judgment debtor who failed to attend his own deposition after being served with a proper notice, under Federal Rules of Civil Procedure, Rule 37(d)).

6 Tokyo District Court, judgment, 25 February 1998, Hanrei Taimuzu, No. 972 , p. 258, abbreviated English translation available at $<$ http://tomeika.jp/search/content. php?did=1595> (granting enforcement of a summary judgment by the Supreme Court of Queensland, Australia)

${ }^{7}$ Nagoya District Court, judgment, 6 February 1987, supra note 4 (granting enforcement of a court costs order of a German court); Tokyo District Court, judgment 13 November 1967, supra note 2, (granting enforcement of a court costs decision of a
} 
payable under a foreign judgment but not specified in the judgment itself. ${ }^{8}$ Authentic instruments drawn up by a foreign notary seem not to be a "judgment" to be enforced or recognized. ${ }^{9}$

The term "court" means an authority which regularly exercises judicial functions and is entitled to give a judgment as regards legal relationships under private law. It need not be a court, but may be an administrative tribunal. If a judgment rendered by a foreign criminal court imposes a fine on the accused and also orders him or her to pay compensation to the injured party ${ }^{10}$ the latter part of the judgment can be severed from the former and enforced in Japan. ${ }^{11}$ Views of authors are divided as to the question of whether a foreign "country" must be a state recognized by the Japanese government in accordance with international law. ${ }^{12}$ The view that it is

Swiss commercial court); Supreme Court, judgment, 28 April 1998, supra note 3 (the judgment creditors who were alleged by the judgment debtors to have been paid money but won in the Hong Kong High Court sought to enforce the orders thereby that the judgment debtors should compensate the total amount of the court costs of about 1.2 million Hong Kong dollars borne by the judgment creditors).

${ }^{8}$ Supreme Court, judgment, 11 July 1997, Minshû Vol. 51, No. 6, p. 2530 (granting enforcement of a compensatory damages part of a California judgment and the interest under California law) (English translation by the Supreme Court of Japan available at <www.courts.go.jp/english/judgments/text/1997.07.11-1993-O-No.1761-154401.html>; a summary in English appears in The Japanese Annual of Int'l L. No. 41 (1998), p. 107). The Supreme Court reasons that, when it is clear that the calculable interest accrues from a sum payable under a foreign judgment, it is a technical matter whether the order for the payment is to be written in the judgment itself, or its enforceability is otherwise given by the statutory provisions of the state of origin. It confirms again its conclusion, in Supreme Court, judgment, 28 April 1998, supra note 3.

9 See, e.g., Akira Takakuwa, Gaikoku saiban no shônin [Recognition of Foreign Judgments], in: Akira Takakuwa/Masato Dogauchi, Shin saiban jitsumu taikei [New Compendium of Court Practice], Vol. 3: Kokusai minji soshô hô (Zaisan hô kankei) [International Civil Procedure Law (Regarding Business Activities)], (Seirin Shoin, 2002), p. 308.

${ }^{10}$ In Japan, on 1 December 2008, the Act on Measures Ancillary to Criminal Proceedings for Protection of Crime Victims' Rights and Profits comes into force. Article 17 of the Act provides that, in criminal proceedings of such a case as a murder, the crime victims may file to the court seized with the criminal proceedings a tort claim for compensation for the damage caused in the case.

${ }_{11}$ See e.g., Takakuwa (supra note 9) p. 308.

12 Some argue that a foreign state must be one recognized officially by Japan. See Akira Takakuwa, Gaikoku hanketsu no shônin oyobi shikkô [Recognition and Enforcement of Foreign Judgments], Shin jitsumu minji soshô kôza [New Lectures on the Practice of Civil Procedure], Vol. 7, (Nihon Hyôronsha, 1982), p. 132; Youmatsu Hinagata, Article 118 (Gaikoku saibansho no kakutei hanketsu no kôryoku [The Effect of Final and Binding Judgments of a Foreign Court]), in Shozo Miyake et al., Chûkai minji soshô hô [Commentary on Civil Execution Act], Vol. 2, (Seirin Shoin, 2000), p. 545. Others oppose this view. See Morio Takeshita, The Recognition of Foreign Judgments by 
not required to be recognized officially by Japan seems to be gaining strong support.

For recognition or enforcement, a foreign judgment must be "final and binding" (Art. 118 of the Code of Civil Procedure, Art. 24(3) of the Civil Execution Act). It is generally understood that a judgment becomes final and binding at the point in time when it is no longer subject to ordinary forms of review under the law of the rendering country. ${ }^{13}$ Thus a foreign judgment is not recognized nor enforced if an appeal or other similar form of review is pending or still available in the state of origin. ${ }^{14}$

According to the prevailing view, provisional measures are not enforced in Japan. ${ }^{15}$ No reported court case has enforced foreign provisional measures. ${ }^{16}$

It is argued that a foreign judgment must be valid under the law of the State of origin. ${ }^{17}$ There is a court decision which refused to enforce a

the Japanese Courts, The Japanese Annual of Int'l L. No. 39 (1996), p. 56, 58; T. Nakano, (supra note 1) p. 185; Toshiyuki Kono, Gaikoku saiban sho [Foreign Court], in: Takakuwa/Dogauchi (supra note 9) p. 318; Hiroshige Takada, Gaikoku hanketsu no kôryoku [The Effect of Foreign Judgments], in: Masahiro Suzuki/Yoshimitsu Aoyama, Chûshaku miniji sosho hô [Annotation of the Code of Civil Procedure] (4), (Yûhikaku, 1997), p. 361.

${ }^{13}$ See e.g., T. Nakano (supra note 1) p. 186; Hideyuki Kobayashi/Yoshimasa Furuta, Products Liability Act and Transnational Litigation in Japan, Tex. Int'l L. J. Vol. 34 (1999), p. 114.

${ }^{14}$ For a lower court judgment in which reference to a not "final and binding" Spanish judgment was made for interpreting the Spanish Civil Code, see Tokyo High Court, judgment, 28 May 2003, supra note 2.

${ }^{15} \mathrm{See}$, e.g., Hajime Kaneko, et al., Jôkai minji soshô hô [Annotation of Code of Civil Procedure] (1986), Takao Sawaki, Recognition and Enforcement of Foreign Judgments in Japan, Int'l Law. Vol. 23 (Kôbundô, 1989), p. 29, Part II.A. But T. Nakano (supra note 1) p. 186 suggests a possibility to recognize and enforce foreign provisional measures in exceptional cases, citing Shunichiro Nakano, Hozen meirei no kokusai teki kôryoku [The Transnational Effect of Foreign Provisional and Protective Orders], in: Teiichiro Nakano, et al., Minji hozen hô kôza [Lectures on the Civil Preservation], Vol. 1 (1996), p. 317, which takes a positive attitude toward recognition and enforcement of foreign provisional measures.

${ }^{16}$ See Grand Court of Cassation, judgment, 28 May 1917, Minroku Vol. 23, p. 793 (denying the effect in Japan of a Massachusetts judgment on custody of a child, because it "possesses only provisional nature, so does not possess the characteristics of a final and binding judgment"); Supreme Court, judgment, 26 February 1985, Kagetsu Vol. 37, No. 6, p. 25 (holding that an urgent and provisional order to determine a person having child custody issued in divorce proceedings by an Italian court "does not fall into a final and binding judgment"). However, some authors criticize the first judgment on the ground that the Court misunderstood the nature of the Massachusetts judgment.

17 See, e.g., Takeshita (supra note 12) p. 59; Yasuhiro Fujita, Recognition and Enforcement of Foreign Judgments and Arbitration Awards, in 5-XIV-5 Doing Business in Japan (2002), § 5.04. 
United States judgment by the District Court for the Southern District of California because the judgment was not valid under U.S. law. ${ }^{18}$

b) Model Law, etc.

American Law Institute's Intellectual Property: Principles Governing Jurisdiction, Choice of Law, and Judgments in Transnational Disputes (hereinafter referred to as "the ALI Principles") in 2008 contains in $\S 401$ some basic rules on foreign judgments to be recognized or enforced, ${ }^{19}$ and $\S 101(2)$ defines "judgment". ${ }^{20}$ According to these rules, judgments or orders are entitled to recognition and enforcement if they are "final", or subject to enforcement in the State of origin and not stayed by a court in that State ( $\S 401(2)$ and the last sentence of $\S 101(2))$. Judgments or orders are not necessarily "final and binding" as required under Japanese law. ${ }^{21}$ In addition, not only a judgment but also a provisional or protective order is to be recognized and enforced (§ 401(4)).

In the Second Preliminary Draft of Principles for Conflict of Laws in Intellectual Property, prepared by CLIP (European Max Planck Group on Conflict of Laws in Intellectual Property) (hereinafter referred to as "the CLIP Principles") in 2009, Article 4:101 defines "judgment" widely. ${ }^{22}$ It

${ }^{18}$ Tokyo District Court, judgment, 21 July 1960, Ka minsh û Vol. 11, No. 7, p. 1535, abbreviated English translation available at $<$ http://tomeika.jp/search/content.php?did= $1549>$ (refusing enforcement of a U.S. judgment in favor of a Belgian company which had been dissolved and extinguished during the proceedings in a U.S. court, to which the successor sought enforcement, on the ground that the judgment was invalid under U.S. law because of the abatement of the entire proceedings due to the extinction of its legal entity).

${ }_{19}$ Strictly speaking, only subsections (2) and (4) of $\S 401$ of the ALI Principles deal with the concept of judgments to be recognized or enforced. Subsections (1) and (3) of $\S 401$ concern respectively the application scope of the ALI Principles (see III..5.a)(2) below) and the effect of foreign judgments granted recognition or enforcement (see V. 1.b) below).

${ }^{20}$ The definition of "judgment" seems to derive from $\S 4$ (b) of the ALI Project on Recognition and Enforcement of Foreign Judgments: Analysis and Proposed Statute $<$ www.ali.org/index.cfm? fuseaction=publications.ppage\&node_id=82>.

${ }^{21}$ The ALI Principles presuppose a general view in common law countries that the effect of a judgment is not necessarily stayed just by an appeal. The reasons are that (i) even judgments in the first instance are final ones after trial, so they have sufficient trust; (ii) especially in U.S., trial is held only in the first instance, and actually the original decision is not so often reversed through appellate review; (iii) even though the decision may be potentially subject to an appeal to a superior court, it is not fair to the successful plaintiff who presented such a good case that he or she won in the first instance. See Kichimoto Asaka, Amerika minji tetsuzuki hô [American Civil Procedure Law] (2nd ed., Kôbundô, 2008), pp. 147-148.

${ }^{22}$ For the CLIP Principles, see $<$ http://www.cl-ip.eu>. Article 4:101 follows Article 32 of the so-called Brussels I Regulation (Regulation (EC) No 44/2001 of 22 December 
includes on the one hand judgments which are actually subject to ordinary appeal in the State of origin or to which ordinary review is still available (Art. 4:102(5)). On the other hand it also includes provisional and protective measures (Art. 4:301). According to Article 4:801, judicial settlements are also to be recognized and enforced. ${ }^{23}$ Although the Waseda Project Proposal has no provision for the definition of a "judgment" (Art. 28), it seems to adopt the view that a judgment includes ones which are not "final and binding" and provisional orders (see Art. 30).

With regard to foreign provisional measures, although the national law of countries was traditionally reluctant to recognize and enforce them, there is recently a tendency towards their recognition and enforcement. ${ }^{24}$ The Brussels I Regulation and Convention, from the original version, have developed a practice for the recognition and enforcement of provisional, including protective, measures (for the Regulation, see Arts. 31 and 32). There are remarkable preliminary rulings of the European Court of Justice dealing with provisional measures, and the problems and excellent research on them have attracted considerable attention. ${ }^{25}$

2000 on jurisdiction and the recognition and enforcement of judgments in civil and commercial matters, OJ L 12, 16.1.2001, p. 1) or Article 25 of the so-called Brussels Convention (1968 Brussels Convention on jurisdiction and the enforcement of judgments in civil and commercial matters, OJ L 299, 31.12.1972, p. 32, as amended). See Pedro A. De Miguel Asensio's contribution in this volume, infra p. 239.

${ }_{23}$ See also, Article 58 of the Brussels I Regulation and Article 12 of the Hague Convention on Choice of Court Agreements of 2005.

${ }^{24}$ For a survey of selected national law on the recognition and enforcement of foreign provisional measures, see Catherine Kessedjian, Note on Provisional and Protective Measures in Private International Law and Comparative Law, Preliminary Document No 10 of October 1998 for the attention of the Special Commission of November 1998 on the Question of Jurisdiction, Recognition and Enforcement of Foreign Judgments in Civil and Commercial Matters, p. 13 (English law), p. 22 (U.S. law), p. 35 (French law), p. 46 (Swiss law).

${ }^{25}$ See e.g., Burkhard Hess/Thomas Pfeiffer/Peter Schlosser, The Brussels I-Regulation (EC) No 44/2001 (C.H. Beck, 2008), pp. 167-188, 196-201, 135-136, 78-79; Thalia Kruger, Civil Jurisdiction Rules of the EU and Their Impact on Third States (Oxford University Press, 2008), p. 331. The former book is the comparative study report on the application of Brussels I Regulation after five years from its entry into force. For a study of the ECJ rulings in Japan, see Asako Matoba, Ôshû shihô saiban sho niyoru hozen meirei kanren handan: Burasseru jôyaku 24 jô (Kisoku 31 jô) no kaishaku [Rulings of European Court of Justice with regard to Provisional Measures: Interpretation of Article 24 of Brussels Convention (Article 31 of Brussels I Regulation)], Kobe Hôgaku Zasshi, Vol. 58, No. 2 (2008), p. 99. 


\section{Comments}

\section{a) "Judgment of a foreign court"}

Since the purpose of a system of recognition and enforcement of foreign judgments is the efficient resolution of civil disputes, they must be ones given in civil cases. It is a country asked to recognize or enforce them that shall determine what a civil case is, and thus the country will recognize or enforce judgments which a foreign authority rendered over disputes that would have been resolved by the exercise of civil jurisdiction in accordance with that country's law. From this viewpoint, the definition of a "judgment of a foreign court" expressed in the 1998 judgment of the Supreme Court is generally acceptable, and thus Article 401(1) of the Transparency Proposal adopts as its basis the standards given by the Supreme Court. ${ }^{26}$

Article 401 (1) defining "judgment" basically accepts the existing interpretation of Japanese law (see II.1.a) above); it includes (a) a money or a non-money judgment, (b) a judgment ordering affirmative relief, or a declaratory judgment, (c) a judgment given after contested proceedings or a judgment given in default of the appearance of the defendant, and (d) a judgment given in a summary procedure, etc., whatever the judgment might be called. The interpretation that a non-money judgment such as an injunctive order is entitled to enforcement has great practical significance as far as IP or unfair competition cases are concerned, because the enforcement of a foreign injunction in order to shut any infringing goods out of the market is often more effective for the protection of the right holder than that of a foreign money judgment awarding damages for the infringement. With regard to a judgment given in default of appearance, it is proposed that a special treatment is needed. ${ }^{27}$ However, it is important on the one hand to protect the rights of a plaintiff whose legal interests have been infringed by a defendant, and it is possible on the other hand to protect the interest of an absent defendant by deliberately checking, from the viewpoint of due process, the fulfillment of requirements for the recognition or enforcement of indirect jurisdiction, service and public policy. Accordingly, the Transparency Proposal does not treat default judgments differently, and considers it enough to refuse the recognition or enforce-

\footnotetext{
${ }^{26}$ See Supreme Court, judgment, 28 April 1998, supra note 3. Setting aside the exclusion of provisional measures in the definition of "judgment", the basic meaning of "judgment" of Article 401(1) of the Transparency Proposal is to the same effect as in the ALI Principles $\S 101(2)$, and is not substantially different from the CLIP Proposal Article 4:101.

27 See the ALI Principles $\S 402$.
} 
ment of these judgments if the general requirements for recognition and enforcement relating to due process are not met.

A "foreign court" means the authority of a foreign country that exercises civil jurisdiction, whatever name is given to that authority. Accordingly, even if in a foreign country the authority to settle a civil dispute concerning IP by adjudication is given to an administrative authority, such as a patent office, a decision rendered by that authority, such as a trial decision, still constitutes a "judgment of a foreign court" under the Transparency Proposal. Matters such as whether the foreign court for the purpose of this Article was fair or not in a particular case will be determined in the light of public policy (Art. 402(iii)).

The Transparency Proposal provides for the recognition and enforcement, in principle, of a "final and binding" judgment of a foreign court in Article 402. With regard to a not "final and binding" judgment (see Comment c) below), enforcement is entitled only to that which is enforceable in the country of origin, such as a judgment with declaration of provisional execution (Art. 403(4), see IV.2. below). The Proposal also adopts as an interpretation a rule that a judgment becomes final and binding at the point in time when it is no longer subject to ordinary forms of review under the law of the rendering country.

\section{b) Provisional Measures}

As far as IP rights and unfair competition cases are concerned, provisional measures ${ }^{28}$ are very useful to protect promptly and effectively the right holder from infringements. For example, in IP infringement cases, a provisional disposition or interim injunction enjoining the alleged infringer from producing and selling infringing goods is quite effective for the purpose of immediately shutting them out of the market. ${ }^{29}$ Such a provisional disposition would have, in fact, the same effect as a final judgment on the

\footnotetext{
${ }^{28}$ For international jurisdiction of provisional measures in the Transparency Proposal, see Article 111 and the Comments.

${ }^{29}$ See ALI Principles $\S 214$, Reporters' Note 2; Katarzyna Szychowska, Jurisdiction to Grant Provisional and Protective Measures in Intellectual Property Matters, in: Arnaud Nuyts (ed.), International Litigation in Intellectual Property and Information Technology (Kluwer, 2008), p. 207. In Japan, almost of all provisional dispositions in IP matters are orders enjoining the alleged infringer from producing and selling infringing goods. See Toshiaki Iimura/Shin Sano, Chiteki zaisan funsô ni okeru karishobun no katsuyô ni tsuite [The Practical Use of Provisional Disposition in IP Disputes], in: Akiyoshi Toshihiro Sensei Kiju Kinen [77th Birthday Commemoration of Toshihiro Akiyoshi], Chiteki zaisanken: sono keisei to hogo [IP Rights: Their Formation and Protection] (Shin Nihon Hôki Shuppan, 2002), p. 34.
} 
merits and may practically speaking bring the dispute to an end ${ }^{30}$ From the viewpoint of the prompt and effective protection of IP rights, it is necessary to enforce in Japan provisional measures, especially provisional dispositions of foreign courts which prevent the production and sale of alleged infringing goods in Japan. In addition, it is of course useful to enforce in Japan a foreign provisional seizure of a defendant's property in order to safeguard the payment of damages. Therefore, in view of the great importance of providing remedies against IP infringements, the Transparency Proposal intends to change the existing approach in Japan and allows provisional measures to be enforced. ${ }^{31}$

According to Article 401(2) of the Transparency Proposal, a provisional measure of a foreign court includes three types of measure, that is, (i) a measure that corresponds to a provisional seizure or attachment of property for the purpose of securing the enforcement of the right on the merits in a civil action, (ii) a measure that corresponds to the provisional disposition of the object in dispute for the purpose of securing the enforcement of the right on the merits in a civil action, and (iii) a measure that corresponds to provisional disposition to establish a provisional state in legal relationships on the merits in a civil action. These measures are enforced in Japan in accordance with the Civil Provisional Remedies Act, if their enforcement is granted under Article 403(1)-(3). For smoothness of enforcement in Japan, it is convenient for a foreign provisional measure to be limited to the equivalent of the Japanese concept of measures of "civil preservation" (see Article 1 of the Civil Provisional Remedies Act). In view of such convenience, Article 401(2) defines a provisional measure of a foreign court as such. ${ }^{32}$

Among these three types of measure above, type (iii) is very important in practice relating to IP rights and unfair competition. This may include, for example, a provisional disposition of a foreign court enjoining the production and sale of the alleged infringing goods. In the European Union there are court cases in which such a provisional disposition or measure of

\footnotetext{
${ }^{30}$ See e.g., Iimura/Sano (supra note 29) p. 36; Toshiaki Makino, Tokkyo shingai to karishobun: hozen no hitsuyôsei no kentô [Infringement of Patent Rights and Provisional Disposition: Study on the Necessity of Preservation], in: T. Nakano et al., Minji hozen kôza (supra note 15) Vol. 3, p. 518; Hiroshi Seki, Minji hozen hô [Civil Preservation Act] (3rd ed., Hanrei Taimzu Sha, 2009), p. 44; Marcus Norrgård, Provisional Measures and Multiple Defendants in the MPI Proposal, in: Josef Drexl/Annette Kur, IP and Private International Law: Heading for the Future (Hart, 2005), pp. 35, 36.

31 See also, the ALI Principles $\S 401(4)$, the CLIP Principles Article 4:301 and Article 29 of the Waseda Project Proposal. See II.1.b) above.

32 Article 401(2) of the Transparency Proposal is modeled on the definition of "foreign insolvency proceedings" under item 1 of Article 2(1) of the Act on Recognition and Assistance for Foreign Insolvency Procedures (Act No. 129 of 2000).
} 
a court of one Member State was enforced in another Member State in accordance with the Brussels Convention or Brussels I Regulation. ${ }^{33}$

The definition of provisional and protective measures by the CLIP Principles is based on that contained in Article 2:501(4) dealing with international jurisdiction of provisional measures. ${ }^{34}$ It considers the following orders as provisional, including protective, measures: (a) ones to prevent an infringement of an IP right; (b) ones to preserve relevant evidence in regard to the alleged infringement ${ }^{35}$ (c) ones to seize goods suspected of infringing an IP right; (d) ones to seize, attach or prevent the dissipation or removal from the jurisdiction of assets to safeguard enforcement of the judgment on the merits; and (e) ones to provide information about the location of obligor's assets. Among them, (a) and (c) would correspond to the type (iii), as mentioned above, of Article 401(2), and (d) would correspond to the type (i) of (ii), as mentioned above. However, (b) and (e) would not fall into the scope of Article 401(2); first, the preservation of evidence under (b) should be executed by way of letters rogatory, that is, international judicial assistance in the taking of evidence $;^{36}$ secondly, since

${ }^{33}$ For a case where the enforcement of a Dutch kort geding ordering to enjoin the infringement of an European patent right in France was granted in France, see Albert Grynwald (translated by Misao Toba), Yôroppa ni okeru kurosu bôdâ injankushon: kokkyô wo koeru sashitome [Cross-border Injunction in Europe], AIPPI Vol. 42, No. 5 (1997), p. 386; The Project on Judicial Cooperation in Matters of IP and Information Technology, Recognition and enforcement of judgments in IP matters (2006), pp. 2-3, available at $<$ www.ulb.ac.be/droit/ipit/docs/Recog_enforcem.pdf $>$.

34 See De Miguel Asensio's contribution in this volume, infra p. 239. The definition of provisional measures by the CLIP Principles broadly covers provisional measures under Article 50 of the TRIPS Agreement.

${ }^{35}$ In the European Union, despite of the ECJ judgment of St. Paul Dairy Industries NV v. Unibel Exser BVBA (judgment of 28 April 2005, C-104/03, [2005] ECR I-3481), the view is vigorously expressed that the preservation of evidence with respect to the alleged infringement is possible not only under the so-called EU Evidence Regulation (Council Regulation (EC) No. 1206/2001 on cooperation between the courts of the Member States in the taking of evidence in civil or commercial matters (OJ 2001 L 174, p.1)), but also under the Brussels I Regulation. See e.g., Burkhard Hess, Preservation and Taking of Evidence in Cross-Border Proceedings - Comparative Remarks in the Context of IP Litigation, in: Nuyts (supra note 29) p. 290. Hess, Pfeiffer \& Schlosser (supra note 25) p. 201, after stating that "[i]n respect to intellectual property rights judicial practice is in some respects unsatisfactory", proposes that "[p]re-action measures for obtaining information should, by express terms, be included into the text of Article 31 " of the Brussels I Regulation. Such tendency would be influenced by the existence of the so-called Enforcement Directive (Directive 2004/48/CE of the European Parliament and of the Council of 29 April 2004 on the enforcement of intellectual property rights (OJ L 157, 30.4.2004, p.45)).

${ }^{36}$ See Nozomi Tada, Kokusai minji shôko kyôjo hô no kenkŷ̂ [International Judicial Assistance in the Taking of Evidence Abroad in the Civil or Commercial Matters] (Osaka Daigaku Shuppan Kai, 2000), pp. 52, 59, 108. Although Article 50(1)(b) of the TRIPS 
an order of property disclosure under (e) is intrusive into the personal information or privacy of the obligor, it should be allowed only if the existence of the obligee's right or claim on the merits is affirmed by a final and binding judgment or its equivalent. ${ }^{37}$

\section{c) Judgments not "final and binding"}

In the Transparency Proposal, there is a difference between a foreign final and binding judgment and a foreign not "final and binding" judgment. The latter is entitled only to enforcement by mutatis mutandis application of the rules on enforcement of a foreign provisional measure (Art. 403(4)). Some authors suggest there may be difficulties in restitution in cases where a not "final and binding" judgment is reversed by appeal courts in the country of origin. However, there is a great need, particularly in connection with IP, for the timely and effective protection of a rights holder from an infringement. For example, in a case where an injunction against acts such as the manufacture or sale of infringing goods has been ordered by a foreign court in a judgment on the merits, even if that judgment has not become final and binding, provided it is enforceable in the country of origin, for example, if it is with a declaration of provisional execution, the actual necessity of enforcing that judgment is generally recognized from the viewpoint of the timely and effective protection of the IP right. In

\footnotetext{
Agreement provides that "[t]he judicial authorities shall have the authority to order prompt and effective provisional measures: (b) to preserve relevant evidence in regard to the alleged infringement", this would not necessarily mean that an order of perpetuation of evidence has to be effectuated by the system of recognition and enforcement of foreign judgments, as well as by international judicial assistance. Since the discussion in the European Union (see supra note 35) contains very important problems to be examined, however, research on this topic should be continued in Japan.

37 Although, in Japan, provisional disposition ordering the payment of money is considered as a "title of obligation" (Article 52(2) of the Civil Preservation Act), it is explained that such provisional disposition is not entitled to commence the property disclosure procedure in Chapter 4 (Articles 196-203) of the Civil Execution Act, because of its provisional or interim nature. See Sonoe Taniguchi/Takeo Tsutsui, Kaisei tanpô shikkô hô no kaisetsu [Explanation of the Revised Security and Execution Acts] (Shôji Hômu, 2004), p. 142. Furthermore, the main part of Article 197(1) of the Civil Execution Act does not exclude an execution judgment for foreign judgments, would presuppose the existing interpretation of exclusion of foreign provisional measures from foreign judgments. Among practitioner, there is an opinion that means of disclosure of obligor's assets are generally insufficient. See Junichi Matsushita, Dai go sesshion: minji tetsuzuki hô no kokusaika to sono mondaiten [5th Session: Internationalization of Civil Procedure

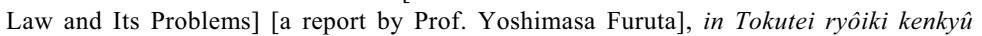
"Nihon hô no Tomeika" purojekuto shusai shinposiumu "Koko ga hen dayo Nihon hô" [Symposium on Transparency of Japanese Law (the Specified Field Research) "Koko ga hen dayo Nihon hô'], NBL No. 900 (2009), p. 98.
} 
addition, not "final and binding" judgments are given on the merits, although they are subject to ordinary forms of review. Thus it is theoretically difficult to treat them as inferior to provisional measures. The Transparency Proposal therefore stipulates that a foreign not "final and binding" judgment is entitled to enforcement, provided that it is enforceable in the country of origin (Art. 403(4)). This would include, for example, such things as a judgment with a declaration of provisional execution. ${ }^{38}$

\section{Recognition and Enforcement of Final and Binding Judgments of Foreign Courts}

Article 402 provides for the requirements of recognition and enforcement of foreign final and binding judgments. They are on (i) indirect jurisdiction, (ii) service, (iii) public policy, (iv) international parallel litigation, (v) an incompatible judgment and (vi) reciprocity. Among them, (i) to (iii) and (vi) fundamentally exist in Article 118 of the Code of Civil Procedure or Article 24 of the Civil Execution Act. New requirements of (iv) and (v), which have been discussed in the context of the contrariety to public policy, are inserted for clarification. Whereas there is a considerable discussion on public policy peculiar to foreign judgments relating to IP rights or unfair competition, no wide differences exist as to the other requirements between foreign judgments in general and those relating to IP rights.

\section{Indirect Jurisdiction \\ a) Analysis of Situation \\ (1) Japanese Law}

With regard to the jurisdiction of a foreign court whose judgment is required to be recognized or enforced in Japan, referred to as "indirect jurisdiction", Article 118(i) of the Code of Civil Procedure provides that "[t]he jurisdiction of the foreign court is recognized under laws or regulations or conventions or treaties." Since "laws or regulation or conventions or treaties" are now uniformly understood to be those of Japan, the foreign court must have jurisdiction in the view of Japanese law. ${ }^{39}$ The prevailing view of authors and many decisions by lower courts ${ }^{40}$ have held that the

38 The ALI Principles $\S 401(2)$, the CLIP Principles Article 4:102(4) and the Waseda Project Proposal Article 30 do not require that foreign judgments are final and binding.

39 Supreme Court, judgment, 28 April 1998, supra note 3.

40 See, e.g., Sawaki (supra note 15) Part II.B; Tokyo District Court, judgment, 14 January 1994, supra note 4. 
standards for determining indirect jurisdiction should be identical to those for determining the jurisdiction of Japanese courts required to entertain a claim there, referred to as "direct jurisdiction" 41 . However, the Supreme Court, in a 1998 decision, ${ }^{42}$ seems to support the view ${ }^{43}$ that the standards for determining indirect jurisdiction need not be identical with those for determining direct jurisdiction, ${ }^{44}$ stating that:

"whether or not the country of judgment has international jurisdiction should be determined in the light of reason, basically in accordance with the provisions of the [Code of Civil Procedure] on the territorial jurisdiction of the courts from the viewpoint of whether it is appropriate to recognize the given foreign judgment, taking into consideration specific circumstances of each case."

In court cases, for example, the following grounds under the Code of Civil Procedure have often been relied on: the defendant's domicile (Art. 4), ${ }^{45}$

${ }^{41}$ As to the standards for "direct jurisdiction", the so called "exceptional circumstances theory" is well-established in case law. See comment on Article 109. See also Tatsuo Ikeda et al., Transnational Litigation and the Evolution on the Law of Evidence in Japan, Osaka University L. Rev. No. 42 (1995), pp. 48-51 (Japanese courts have jurisdiction, in principle, if Japan has a (or some) ground(s) for territorial competences under the Code of Civil Procedure. However, if there are "exceptional circumstances" causing violation of an idea of fairness between the parties, fair and expeditious administration of justice, jurisdiction of Japanese courts should be denied); Masato Dogauchi, The Hague Draft Convention on Jurisdiction and Foreign Judgments in Civil and Commercial Matters From a Perspective of Japan, Kokusai Shihô Nenpô [Japanese Yearbook of Private International Law], No. 3 (2001), pp. 86-90.

42 Supreme Court, judgment, 28 April 1998, supra note 3.

${ }^{43}$ Recently this view has been gaining support. See, e.g., Masaaki Haga, Gaikoku hanketsu shônin shikkô yôken to shiteno kokusai saiban kankatsu: kansetsu kankatsu no kihon shisei to kyôzô riron no tekiyô wo megutte [International Judicial Jurisdiction as a Requirement for Recognition and Enforcement of Foreign Judgments: Basic Attitude Toward Indirect Jurisdiction and Application of Mirror Image Theory], Hôritsu Ronsô Vol. 72, No. 5 (2000), p. 1. Some authors suggest that a Japanese court may impose more rigorous jurisdiction standards on foreign courts than apply to the Japanese court itself. See Takeo Kosugi, Shônin yôken toshiteno kankatsuken [Jurisdiction as a Requirement for Recognition], in: Takao Sawaki/Junichi Akiba, (eds.), Kokusai shihô no sôten (shinpan) [Issues on Private International Law] (2nd ed., 1996), p. 235. See also Hiroshi Matsuoka, Kokusai torihiki to kokusai shihô [International Business Transaction and Private International Law] (1993), p. 105.

${ }^{44}$ For the explanation that the Supreme Court judgment of 1998 supports the view that the standards for indirect jurisdiction need not be identical with those for direct jurisdiction, see e.g., Yoshinori Kawabe, Hankai [Comments on Supreme Court Judgments), in Hosokai, Saikô saibansho hanrei kaisetsu minji hen: Heisei 10 (jo) [Commentary Explanation of Supreme Court Judgments: Civil Cases of Heisei 10 (1)] (2001), p. 473 .

${ }^{45}$ Supreme Court, judgment, 28 April 1998, supra note 3 (upholding jurisdiction of the Hong Kong High Court based on the domicile of defendants (judgment creditors) in 
the place of performance (Art. 5(i)), ${ }^{46}$ the place of tort (Art. 5(ix)),${ }^{47}$ forum of related actions (Art. 7), ${ }^{48}$ appearance by the defendant (Art. 12), and choice of court agreement (Art. 11). ${ }^{49}$ Concerning foreign judgments regarding business activities, the enforcement of three judgments have so far been refused because of a lack of jurisdiction based on the place of performance. $^{50}$

\section{(2) Model Law, etc.}

With regard to indirect jurisdiction, ALI Principles $\S 403$ provides, on the one hand, as grounds for the mandatory refusal of recognition and en-

Hong Kong, with regard to the First Case in which the judgment creditors were required to pay a certain sum under an alleged guaranty agreement).

${ }_{46}$ Tokyo District Court, judgment, 14 January 1994, supra note 4 (upholding jurisdiction of a New York state court, partly based on the place of performance because, according to the contents of the contract, the judgment debtor's obligation of performance was completed in New York).

${ }^{47}$ Tokyo District Court, judgment, 14 January 1994, supra note 4 (upholding jurisdiction of a New York state court, partly based on the place of tort because the judgment debtor and a person domiciled in New York jointly violated the contract and caused damage in New York); Tokyo District Court, Hachioji Branch, judgment, 13 February 1998, Hanrei Taimuzu No.987, p. 282 (upholding jurisdiction of a California state court).

${ }^{48}$ Tokyo District Court, judgment, 14 January 1994, supra note 4 (upholding jurisdiction of a New York state court, partly based on the co-defendant's domicile in New York); Supreme Court, judgment, 28 April 1998, supra note 3 (upholding jurisdiction of the Hong Kong High Court over the Second Case because that was a counterclaim of the First Case or closely related to its cause of action; with regard to the Third Case, which was in nature a third party proceeding known in common law, upholding jurisdiction thereof because there is a strong necessity for uniform decisions to the Second and the Third Cases, which are based on the same cause of substantive law and have a close connection with each other; lastly, upholding jurisdiction thereof over the Fourth Case because it was to be a counterclaim in relation to the Third Case).

49 Nagoya District Court, judgment, 6 February 1987, supra note 4.

50 Osaka District Court, judgment, 25 March 1991, Hanrei Jihô No. 1408, p. 100, Hanrei Taimuzu No. 783, p. 252 (refusing enforcement of a judgment of the U.S. District Court for the District of Minnesota because of lack of jurisdiction on the grounds that the judgment debtor's performance of obligation should have been completed in Japan under the contract), affirmed by Osaka High Court, judgment, 25 February 1992, Hanrei Taimuzu No. 783 p. 248 (a summary in English appears in The Japanese Annual of Int'l L. No. 36 (1993), p. 217); Tokyo District Court, judgment, 31 January 1994, supra note 4 (as to the second case, denying jurisdiction of an English court on the grounds that only the place of performance determined by the law applicable to the contract between the parties did not constitute sufficient base for jurisdiction of the rendering court); Tokyo District Court, judgment, May 2, 1972, Ka minshû Vol. 23, Nos. 5-8, p. 224 (denying jurisdiction of a French court, because place of performance should not be considered as an appropriate ground for international judicial jurisdiction). 
forcement, that the jurisdiction of a foreign court was based on a choice of court clause inconsistent with the safeguards (subsection (1)(f) of $\S 403$ ), or on exorbitant jurisdiction (subsection $(1)(\mathrm{g})$ ). On the other hand, it provides as grounds for discretionary refusal that a basis of indirect jurisdiction was inconsistent with the norms of $\S \S 201,202(1)-(3), 203-206$ (subsection (2)(a)). As far as the latter is concerned, the standards of indirect jurisdiction are not identical with those of direct jurisdiction. CLIP Principles Article 4:201 provides, as grounds for mandatory refusal, that there was "no ground of jurisdiction under Part 2 of the Principles which would have allowed the foreign court to assert its jurisdiction." However, Article 4:204 adopts a special rule of discretionary refusal on the ground of manifest incompatibility with specific jurisdictional rules protecting consumers or employees. Thus, there is a case where the standards of indirect jurisdiction are not identical with those of direct jurisdiction, and this means that the former is broader than the latter. ${ }^{51}$ Compared with these Principles, the Waseda Project Proposal adopts the view that the standards for indirect jurisdiction are identical to that for direct jurisdiction (Art. 28(1)(i)).

\section{b) Comments}

\section{(1) Standards for Indirect Jurisdiction}

Article 402(i) provides that indirect jurisdiction should be determined "in light of the provisions of the Transparency Proposal and the purposes of the system of recognition and enforcement of foreign judgments". Indirect jurisdiction is an important factor in determining whether or not the foreign court was a proper forum. If the forum is a place to which both parties had proper access to assert their rights, and which has a sufficient interest in the appropriate resolution of the dispute in question, the judgment rendered in that forum seems to be justifiable, and this constitutes a credible basis for its recognition and enforcement in other countries. For a country in which recognition or enforcement is sought, the appropriate standard to assess the adequacy of the forum state is, firstly, the standard to determine the direct jurisdiction of that country itself, i.e. the standard for determining whether that country's own courts are the "proper forum". However, the standard to determine direct jurisdiction is not necessarily the only one for assessing whether or not the foreign court was the "proper forum". Because the standard of direct jurisdiction has the nature of "norms of conduct" (of the own courts), while the standard for indirect

51 See De Miguel Asensio's contribution in this volume, infra p. 239, states that Article 4:201 itself is flexible and the CLIP Principles does not adopt the so-called mirror-image principle. 
jurisdiction is characterized as the "norms of evaluation" (of the courts in other states), there is self-evidently a difference in the purpose between a case of "doing something in the future from now on" and a case of "evaluating something done in the past". Hence, the Transparency Proposal, Article 402(i), basically adopts the standpoint that the standard for indirect jurisdiction is not necessarily identical to the standard for direct jurisdiction. ${ }^{52}$ This also incorporates the view of the Supreme Court in the 1998 decision. $^{53}$

\section{(2) Purposes of the System of Recognition and Enforcement of Foreign Judgments}

The "purposes of the system of recognition and enforcement of foreign judgments" are to establish the well-balanced international order for movement of judgments by giving weight to, inter alia, (a) the convenience of the parties, (b) the prevention of incompatible judgments, (c) judicial economy, and (d) the maintenance of public policy. In any particular case of recognition and enforcement, indirect jurisdiction will be examined taking the standard for direct jurisdiction and these purposes into consideration. The "provisions of the Transparency Proposal" mean the provisions for direct jurisdiction, that is, (i) Articles 101-108, 110 and with regard to provisional measures, Article 111 and (ii) the provision for exceptional circumstances based on public-interest policy (Art. 109).

The provisions (Arts. 101-108, 110) are not necessarily the only statutory basis for the "purposes of the system of recognition and enforcement of foreign judgments". For example, even if a foreign judgment was based on a ground other than those specified in Articles 101-108 and 110, the indirect jurisdiction of the foreign court which rendered that judgment may be recognized. ${ }^{54}$

In addition it would have an influence on the interpretation of publicinterest policy in Article 109. Even if a Japanese court would not exercise its direct jurisdiction because there would be exceptional circumstances in Article 109, an assessment of exceptional circumstances may possibly be

52 This part of the Transparency Proposal shares a similar idea with the ALI Principles and the CLIP Principles which incorporate discretionary decisions, as long as they do not adopt the standards identical to those for direct jurisdiction.

${ }_{53}$ Supreme Court, judgment, 28 April 1998, supra note 3.

54 For example, the CLIP Principles Article 2:204 allows jurisdiction of a court seized with criminal proceedings to which civil claims for remedies gave rise. If recognition or enforcement of a judgment given by the court exercising such jurisdiction, which is not set out in Articles 101-108 and 110 of the Transparency Proposal, is sought in Japan, a chance may not be denied that indirect jurisdiction of that court which is evaluated after the facts of the individual case, will be recognized in the light of "purposes of the system of recognition and enforcement of foreign judgments". 
different in determining indirect jurisdiction by giving appropriate consideration to "the purposes of the system of recognition and enforcement of foreign judgments", because determining indirect jurisdiction involves a post facto evaluation.

For example, suppose that exceptional circumstances prescribed in Article 109 were present, but a court in the forum state affirmed its direct jurisdiction over a case. In the proceedings in the forum state, the parties had fully exhausted the assertion of their rights and claims. In this case, despite the presence of exceptional circumstances in Article 109, the indirect jurisdiction may be affirmed in light of the "purposes of the system of recognition and enforcement of foreign judgments". This is so because after giving proper consideration to the nature of the a posteriori evaluation of indirect jurisdiction, the recognizing court could determine that any exceptional circumstances were not present ${ }^{55}$

It is worth mentioning that in contrast to recognizing indirect jurisdiction more broadly than direct jurisdiction, cases where indirect jurisdiction must be interpreted more narrowly than direct jurisdiction should be rare.

\section{Service}

a) Analysis of Situation

\section{(1) Japanese Law}

A defendant should be given the opportunity to defend himself/herself in the proceedings. Article 118(ii) of the Code of Civil Procedure provides: " $[\mathrm{t}]$ he defeated defendant has received a service (excluding a service by publication or any other service similar thereto) of a summons or order necessary for the commencement of the suit, or has appeared without receiving such service." As to the meaning of the "service", the Supreme Court, in the above mentioned case of $1998,{ }^{56}$ held that: (i) it does not have to be a service on the basis of Japanese Law or Regulation on civil procedure; (ii) it "must be sufficient for the defendant actually to become aware of the commencement of the litigation abroad and to defend himself/ herself"; (iii) "if there is a treaty of judicial cooperation between the country of judgment and Japan and if this treaty provides that the service of the document required for the commencement of litigation must be effected in a manner set out in this treaty, service of documents not in

${ }^{55}$ In addition, if jurisdiction concerning types of suit not found in Japan becomes an issue, it will also probably be necessary to adopt a flexible interpretation of provisions concerning direct jurisdiction. The 1998 Supreme Court, judgment, supra note 3, which ruled on indirect jurisdiction in the third party proceedings, may be described as such a case.

56 Supreme Court, judgment, 28 April 1998, supra note 3. 
accordance with the manner set out in the treaty should not be regarded as service which fulfils the requirement of the above provision [Art. 118(ii)] of the Code of Civil Procedure."

Japan is a party to multilateral conventions applicable to service abroad, such as the 1965 Hague Convention on the Service Abroad of Judicial and Extrajudicial Documents in Civil or Commercial Matters and the 1954 Hague Convention on Civil Procedure. If these Conventions should be applied, the service of process must comply with the manner of service provided by them. However, even if the defeated defendant has not received the "service", the requirement of Article 118(ii) is satisfied if he/ she "appeared" in the foreign proceedings. ${ }^{57}$

It should be noted that there are lower court decisions that a service of process by mail without a Japanese translation from the United States, a Contracting State of the Hague Service Convention, does not fulfill the requirement set forth in Article 118(ii). ${ }^{58}$

\section{(2) Model Law, etc.}

ALI Principles $\S 403(1)(c)$ provides, as grounds for the mandatory refusal of recognition and enforcement, that "the judgment was rendered without notice reasonably calculated to inform the defendant of the pendency of the proceeding in a timely manner". There is no provision as to the manner of service in the applicable international conventions or appearance without receiving such notice. CLIP Principles Article 4:501(1) requires notice in sufficient time to enable the arrangement of the defense. Even without such notice, if the defendant responded to the suit, fulfillment of

57 In the Supreme Court, judgment, 28 April 1998, supra note 3, service of notice of motion by direct delivery was considered invalid because it was not permitted by any applicable treaty or convention, including the Hague Service Convention. However, the fulfillment of the requirement of Article 118(ii) was ensured by the Supreme Court on the grounds that the judgment debtors appeared in the action in the Hong Kong High Court. As to the words "appear[ance] without receiving such service", the Supreme Court held that "unlike the response to the claim in determining the jurisdiction based upon response, [it] includes cases where the defendant was given the opportunity of defense and effected defensive measures in court, such as a case where a defense to contest jurisdiction is submitted".

58 Tokyo District Court, judgment, 26 March 1990, Kinyû shôji hanrei No. 857 p. 39 (a summary in English appears in The Japanese Annual of Int'l L. No. 34 (1991), p. 174) (denying the enforcement of a Hawaiian judgment ordering the payment of a sum as damages against a Japanese domiciliary). See also Tokyo District Court, judgment, 21 December 1976, Hanrei Taimuzu No. 352, p. 246 (refusing the recognition of a French judgment given in default of the appearance of the Japanese defendant who was served by mail the summons without Japanese translation). 
the notice requirement is ensured in principle. ${ }^{59}$ It does not, however, contain an explicit clause for the requirement as to the manner of notice in the applicable conventions. ${ }^{60}$ Article 28(1)(ii) of the Waseda Project Proposal provides for a requirement of notice and an appearance exception.

\section{b) Comment}

Article 402(ii) is based on an understanding of the importance of procedural fairness that finds expression in the requirement for notice of the commencement of the suit to the defendant as a core of the system of the recognition and enforcement of foreign judgments. ${ }^{61}$ It incorporates the standards elaborated in the Supreme Court judgment of 1998 as an interpretation of this requirement. ${ }^{62}$ The functions of giving notice and creating defense possibilities, which the service must fulfill under this provision, could be required through interpretation of the term "service". However interpretation does not always lead to the requirement of complying with the applicable conventions. Thus, the Transparency Proposal, from the viewpoint of stressing the significance of international judicial assistance conventions and ensuring the stability of the procedure, provides for the requirement for the compliance with such conventions in Article 402(ii). ${ }^{63}$

${ }^{59}$ CLIP Principles Article 4:501(1) is almost the same as Article 9(1)(1) of the Hague Convention on Choice of Court Agreements and similar to Article 34(2) of the Brussels I Regulation. See De Miguel Asensio's contribution in this volume, infra p. 239.

60 According to De Miguel Asensio (supra note 22 footnote 161) the procedural public policy will cover such a situation as is dealt with in Article 9(c)(ii) of the Hague Convention on Choice of Court Agreements. This Article of the Convention mainly aims to allow the country addressed to refuse recognition or enforcement when the writ was served in a manner that was not recognized by international judicial assistance conventions to be applied. See infra note 63 .

61 On this point, Article 402(2) has the same purpose as the ALI Principles $\S 403(1)(c)$, the CLIP Principles Article 4:501(1) and the Waseda Project Proposal Article 28(1)(ii) do. See III.2.a)(1) above.

${ }^{62}$ Supreme Court, judgment, 28 April 1998, supra note 3. See also, III.2.a)(1) above.

63 A provision to the same effect, although in a more general form, is also introduced in the 2005 Hague Convention on Choice of Court Agreements. See Masato Dogauchi, Hâgu kankatsu gôi ni kansuru jôyaku (2005 nen) no sakusei katei ni okeru Nihon no kanshin jikô ni tsuite [On Some Concerns of Japan in the Drafting of the Hague Convention on Choice of Court Agreements], Dôshisha Hôgaku Vol. 58, No. 3 (2006), p. 1284. Another reason for insertion of the last sentence to Article 402(ii) is that it would be necessary to suppress the opposition to such a requirement which still exists after the Supreme Court decision of 1998, supra note 3. 


\section{Public Policy}

a) Analysis of Situation

\section{(1) Japanese Law}

According to Article 118(iii) of the Code of Civil Procedure, a foreign judgment would not be recognized or enforced in Japan if its contents or the proceedings are contrary to public policy in Japan. The public policy is to be understood differently from the domestic public policy in Article 90 of the Civil Code. In other words, it is not required that the contents and proceedings themselves be completely compatible with those in the Japanese legal system. ${ }^{64}$

It is widely accepted that not only the conclusion of a foreign judgment but also its grounds may become the objects of a public policy examination in terms of substantive public policy. ${ }^{65}$ Challenging the appropriateness of the foreign judgment or the choice/application of the law in the judgment, however, is not permitted (the prohibition of review of the merits, see Art. 24(2) of the Civil Execution Act). With regard to the procedural public policy, other than the service provided in Article 118(ii), whether or not minimum protection of the due process had been ensured in the foreign court is to be determined under Article 118(iii).

In court cases, parties opposing recognition or enforcement have actually raised various issues as being contrary to public policy ${ }^{66}$ However, their arguments on contrariety to public policy have all been denied by Japanese courts, except for only a few issues. These exceptional cases

${ }^{64}$ Shôichi Kidana/Hiroshi Matsuoka/Satoshi Watanabe, Kokusai shihô gairon [Survey of the Private International Law], (5th ed., Yûhikaku, 2007), p. 352.

${ }_{65}$ Takakuwa (supra note 12) p. 142; Akira Ishikawa/Takeshi Kojima (eds.), Kokusai minji soshô hô [International Civil Procedure Law] (Seirin Shoin, 1994), p. 146; Takao Sawaki/Masato Dogauchi, Kokusai shihô nyûmon [Introduction to Private International Law] (6th ed., Yûhikaku, 2006), p. 292; Yoshiaki Sakurada, Kokusai shihô [Private International Law] (5th ed., Yûhikaku, 2006), p. 341, etc. It is explained that matters that have not been written in a ruling may also be considered: see Yoshihisa Hayakawa, Jittai teki kôjo [Substantive Public Policy], in: Takakuwa/Dogauchi (supra note 9) p. 361.

${ }^{66}$ E.g., Tokyo District Court, Hachioji Branch, judgment, February 13, 1998, supra note 47 (the judgment debtor argued that a California court did not rely on Japanese law, which should have been applied in accordance with the rules of conflict of laws of Japan); Tokyo District Court, judgment, 6 September 1969, Hanrei Jihô No. 586, p. 73, Hanrei Taimuzu No. 242, p. 263 (the judgment debtor argued that a California court judgment was based on a contract to which had been not obtained the necessary approval of the Japanese government under the Japanese Foreign Exchange Control Law); Mito District Court, Ryugasaki Branch, judgment, 29 October 1999, supra note 5 (the judgment debtor argued that a U.S. court judgment was a default judgment as a sanction against him who failed to attend at own deposition). 
involve a California State judgment order in punitive damages, ${ }^{67}$ a Washington State judgment incompatible with an existing Japanese judgment, ${ }^{68}$ and a Korean decision confirming a marital relationship obtained by fraud. ${ }^{6}$

\section{(2) Model Law, etc.}

As with the Article 118(iii) of the Code of Civil Procedure, most of national legislations and conventions commonly refer to the contrariety to public policy as one of the grounds for non recognition of foreign judgments. This is also the case for the legislative proposals regarding cross border IP disputes. The ALI Principles, the CLIP Principles and the Waseda Project Proposal equally provide such a requirement for recognition and enforcement. Still, the provisions on the public policy are differently designed in each proposal.

ALI Principles $\S 403(1)(e)$ provides that the enforcing court shall not recognize or enforce a foreign judgment if it determines that recognition or enforcement would be contrary to public policy in the enforcement jurisdiction. In $\S 403$, Comment $\mathrm{c}$, some illustrations for cross border IP disputes are shown.

In cases where the rendering court issued an injunction against an act in the enforcing jurisdiction, although the IP right is not established under the law of the enforcement country, the enforcing court shall refuse to recognize or enforce the foreign judgment. ${ }^{70}$ On the other hand, where a foreign court rendered a judgment concerning an act in the rendering country applying its own law, recognition and enforcement should not be refused, even if the protection for the equivalent act is lacking under the law of the enforcing country. ${ }^{71}$ Under the ALI Principles $\S 403$, the following circumstances shall be the grounds to refuse recognition or enforcement inter alia: when fairness has not been secured in the litigation (subsection

${ }^{67}$ Supreme Court, judgment, 11 July 1997, Minshû Vol. 51, No. 6, p. 2573 (English translation by the Supreme Court of Japan available at <www.courts.go.jp/english/ judgments/text/1997.07.11-1993-O-No.1762.html>; a summary in English appears in The Japanese Annual of Int'1 L. No. 41 (1998), p. 104).

${ }^{68}$ Osaka District Court, judgment, 22 December 1977, Hanrei Taimuzu No. 361, p. 127. Some authors criticize the conclusion of the Court. See Takeshita (supra note 12) pp. 70-71; Sawaki (supra note 15) Part III. See also Fujita (supra note 17) Part [3].

69 Yokohama District Court, judgment, 24 March 1989, Hanrei Jihô No. 1332, p. 109, Hanrei Таiтuzu No. 703, p. 268.

${ }^{70}$ The ALI Principles $\S 403$, Comment c, Illustration 3. It states that the basis for refusal of enforcement is not that the rendering country misapplied the governing law (that would be the review of the merits), but that the remedy would violate public policy in enforcement country.

71 Ibid. 
(1)(a)); when doubt about the integrity of the rendering court has been raised (subsection $(1)(b)$ ); and when the judgment was obtained by fraud (subsection (1)(d)). In addition, under $\S 403(2)(b)$, the enforcing court may refuse to recognize or enforce a foreign judgment when the rendering court chose a law other than that which would have been chosen under the choice-of-law rules in Part III of the Principles (the so-called applicablelaw requirement).

The Waseda Project Proposal sets forth contrariety to public policy as one of the grounds for non recognition in Article 28(1)(iii). However, concrete illustrations are lacking except for typical cases specified in Article 29, involving a foreign judgment which awards punitive damages (subparagraph (1)) and inconsistency with the precedent domestic judgment (subparagraph (2)). ${ }^{72}$ And under Article 28(1)(iv), the applicable-law requirement must be satisfied as in the ALI Principles.

The CLIP Principles provide for substantive and procedural public policy separately (Arts. 4:401(1), (2)), whilst Article 4:402 prescribes non recognition of a foreign punitive damages award which does not compensate for actual loss. ${ }^{73}$ Since the public policy exception should be restrictively applied, recognition and enforcement should not be refused simply because: there are differences in substantive laws between the rendering country and the enforcing country, a law other than that which would have been chosen under the choice-of-law rules of the enforcing country was applied by the rendering court $;^{74}$ or the judgment was rendered through jury verdict. ${ }^{75}$

72 See the legislative proposal published in the Symposium held at the Waseda University in December, 2008. Professor Nakano expressed doubt on the need for and propriety of including a special provision for recognition and enforcement (including the public policy provision) by taking into account circumstances peculiar to IP, see Shunichiro Nakano, Kokusai chiteki zaisan hô ni kansuru ALI gensoku to gaikoku hanketsu no shônin shikkô [The ALI Principles on International IP Law and the Recognition and Enforcement of Foreign Judgments], Kigyô to hô sozo, Vol. 3, No. 1 (2007), p. 190.

73 After the International Symposium "IP and International Civil Litigation" held at Tokyo on May 8-9 2009, Second Preliminary Draft has been published. No revision for provisions in this part can be found.

${ }^{74}$ See De Miguel Asensio's contribution in this volume, infra p. 239 seq.

75 A civil judgment based on a jury verdict has been mentioned as an example. See $i d$. p. 239 . 


\section{b) Comments}

\section{(1) Structure of the Proposal}

In Article 402(iii), the Transparency Proposal provides for the contrariety to substantive/procedural public policy ("public order or good morals") as one of the grounds for refusing the recognition and enforcement of a foreign judgment. Whether or not a foreign judgment is contrary to public policy in Japan will be determined by the court in light of the particular circumstances of the individual case and after considering a sufficient connection with Japan and the degree of contrariety to public policy. The purpose and idea of Article 402(iii) is inherently the same as Article 118(iii) of the Code of Civil Procedure.

The Transparency Proposal provides for public policy in Article 402(iii) as a general clause like other legislative proposals. However it is not intended to disregard the specificities of IP disputes when determining whether or not the content and proceeding of a foreign judgment violates public policy in Japan. Rather, in the process of the discussion in the Transparency Project, it has been debated how to clarify the content of public policy peculiar to IP and put them into a written form as a provision. ${ }^{76}$ At the end of the day it was decided to lay down only a general

${ }^{76}$ The former Transparency Proposal at the time of the International Symposium supra note 73, provided, in addition to the former Article 402(1)(iii) which was the same as the present Article 402(iii), the former Article 403 in order to make specifically clear the content of public policy, as follows.

"[The former] Article 403. Public policy

(1) A judgment of a foreign court shall be deemed to be contrary to the public policy in Japan as provided for in [the former] Article 402(1)(iii) if:

(i) the judgment aims to realize content in contravention of a provision of Japanese law by applying foreign law to a matter pertaining to an application for or the registration or cancellation of registration of an intellectual property right stipulated by laws and regulations of Japan;

(ii) the judgment aims to realize a right, the assertion of which is not permitted under Japanese law in court proceedings, concerning an intellectual property right stipulated by laws and regulations of Japan;

(iii) the judgment upholds a claim concerning an intellectual property right stipulated by laws and regulations of Japan on the basis of a right already invalidated by a decision of Japan Patent Office.

(2) A judgment of a foreign court shall be presumed to be contrary to the public policy in Japan as provided for in [the former] Article 402(1)(iii) if:

(i) Japanese law was not applied with respect to the validity, ownership, scope, content, duration, transferability or perfection requirement of or for an intellectual property right stipulated by laws and regulations of Japan; provided, however, that this shall not apply in the case of "ubiquitous infringement"; 
provision for public policy in the Transparency Proposal due to two reasons. First, there were difficulties in creating an exhaustive list of stipulations due to the wide variety of circumstances peculiar to IP disputes. Second, there were concerns raised that a public policy clause with a long list of considerations would lead to the misconception that the Transparency Proposal was very reluctant to recognize foreign judgments regarding IP disputes. ${ }^{77}$

Although it was decided not to single out typical cases of public policy in terms of IP in a provision, there are some typical circumstances which may be quite contrary to public policy and these should be clarified as much as possible. Thus the cases that are most likely to be contrary to public policy in Japan are illustrated in Comments as follows. It had originally been proposed that these cases be inserted into a provision.

In the following illustrations, cases related to substantive public policy and those related to procedural public policy are not separated because it seems difficult to distinguish them in some cases. In the context of IP law, particularly the industrial property law which governs registered rights, the substance and the proceedings are closely connected to each other.

(ii) a proper opportunity to dispute assertions concerning the validity and scope of an intellectual property right stipulated by laws and regulations of Japan was not guaranteed in the court proceedings".

Instead of enumerating the cases where contrariety to public policy is suspected in the same category, the former Articles 403 and 402(1)(iii) adopted an approach of stipulating stages in proportion to the degree of strength of the contrariety to public policy, namely, a three-stage approach of (a) a provision deeming contrariety to public policy (Paragraph 1 and the former Art. 402(1)(iii)), (b) a provision of presumption of contrariety to public policy (Paragraph 2 and the former Art. 402(1)(iii)), and finally (c) an examination of general contrariety to public policy in other cases (the former Art. 402(1)(iii)). This approach was adopted because, in view of the diverse political objectives reflected by the various systems and provisions among IP laws, it seemed that the content and strength of public policy that those systems and provisions implicate were not identical. This deeming provision and presumption provision would apply only to foreign judgments rendered concerning Japanese IP rights, and the reason for this is that Japan's fundamental domestic legal order, and that order alone, is thought to be that which ought first and foremost to be protected under a system of recognition and enforcement of foreign judgments. Accordingly, the public policy contrariety of a foreign judgment rendered concerning a foreign IP right would be handled exclusively as a general contrariety to public policy under the former Article 402(1)(iii).

77 Other reasons for the deletion are that: the theoretical inconsistency with the principle of no review on the merits (Article 24(2) of the Civil Execution Act) has not been satisfactorily overcome; foreign IP disputes should not be discriminated from domestic IP disputes, while the former Article 403 was a unilateral rule whose coverage was limited only to litigations concerning Japanese IP disputes. 


\section{(2) Non-application of International Mandatory Rules of the Country that Granted the Right}

When an action regarding an IP dispute was brought in a country other than the country that granted the right, non-application or non-consideration of international mandatory rules of the granting country in the litigation would be highly suspected of violating public policy. The international mandatory rules in cross border IP litigation involve some provisions in IP law.

First, when a foreign judgment was rendered applying the law other than that of the granting country to matters such as filing of application, registration or cancellation of registration of IP rights, its recognition or enforcement is likely to be refused due to the contrariety to public policy. ${ }^{78}$ It seems to be unarguable that, for instance, grounds for invalidation of patents should be governed only by the law of the registered country. Such provisions for application/registration of patents are substantive laws that are closely associated with the patent procedural law as part of public law (i.e. administrative procedure law) reflecting the industrial policies of each country. Therefore, it is not expected that those matters will be governed by the law other than that of the registered country. In other words, these provisions are a kind of international mandatory rules, the application of which is always to be ensured (hence this is not the proposal for applicable-law requirement). Application of such rules mentioned above would come into question under the Transparency Proposal because it does not provide for exclusive jurisdiction for the actions concerning the validity of registered IP rights (see Art. 103 and the Comments) and, as a result, even a foreign judgment determining the validity of patents of Japan or of a third country may be recognized and enforced in Japan. It cannot be accepted that those matters may not be governed by the law other than that of the registered country, even if the effect of a foreign judgment pertaining to the invalidity of a registered right are limited to having an inter partes effect as set forth in Articles 103(3) and 404(2).

Provisions regarding initial ownership for a right to obtain a patent is another typical example of this matter. This is because the initial ownership of such a right is an issue relating to eligibility to file an application. ${ }^{79}$

Second, provisions pertaining to matters such as the existence, validity and initial ownership of a non-registered right, and matters such as the

\footnotetext{
${ }^{78}$ Corresponds to the content of the former Article 403(1)(i).

79 In the Japanese Patent Act, the right to obtain a patent is always regarded as belonging primarily to the inventor (a natural person). Accordingly, for example, recognition of a foreign judgment ordering the change of an applicant applying a foreign law which provides a right to obtain a patent primarily belongs to an employer (a corporation) should be deemed contrary to public policy in Japan.
} 
protection period, effect (scope of protection, etc.) and transferability of both registered rights and non-registered rights are also deemed to be international mandatory provisions. It follows that for these matters the question of whether or not the law of the granting country was applied should be examined. ${ }^{80}$ Provisions regarding these matters are not of the nature of procedural law, however, they ought not to be substituted with foreign law because they deeply reflect the policies of the granting country. Consequently, it is thought that the law of the granting country should be applied at any time.$^{81}$ On the other hand, it seems that provisions for matters such as remedies for infringement of IP rights (e.g. calculation of damage) should not be deemed international mandatory provisions which are not to be substituted with foreign law, as noted above, considering that some legislation allows the ex-post choice of law for them (the Transparency Proposal also accepts it under Art. $304^{82}$ ). The same holds also for the governing law of a contract. In addition, although the effect of a right such as the scope of the right involves issues relating to infringement (e.g. infringement under the doctrine of equivalents), in case of ubiquitous infringement, non-application of the law of the granting country should not lead to the contrariety to the public policy, and eventually, non-recognition in Japan, since it cannot be supposed that the law of the granting country should always be applied in such a case. ${ }^{83}$

Under Article 305 of the Transparency Proposal that provides for the governing law of the existence, primary ownership, the transferability, and effects of IP rights, ${ }^{84}$ foreign law may also be applied to these issues by Japanese courts. In our view, the illustrations described above should be applied not only for Japanese IP rights but also for foreign IP rights as well. Therefore, when a foreign court have applied the law other than that of the IP right-granting country for the above mentioned matters, ${ }^{85}$ irrespective of the applicable law was of Japan or of foreign country, the

\footnotetext{
${ }^{80}$ Corresponds to the content of the former Article 403(2)(i).

81 See Comments on Articles 304 and 305 of the Transparency Proposal.

82 As an example of such legislation, see Article 110(2) of the Swiss Private International Law.

${ }^{83}$ This is also the case for the Transparency Proposal (see Article 302).

${ }^{84}$ See Comments on Article 305.

${ }^{85}$ Where issues for those matters have been raised as preliminary questions, it seems arguable whether they should receive equal treatment or not. However, the application of the law of the country that granted the right in question should be checked at least in cases where the decision for those matters held a special place in the reasons of a judgment.
} 
recognition or enforcement of the foreign judgment in Japan should be refused for being contrary to public policy. ${ }^{86}$

Meanwhile, under the principle of no review of the merits of foreign judgments, the appropriateness of the interpretation and the application of the law of the granting country at the foreign court are not questioned in principle, i.e., misinterpretation or misapplication of Japanese law itself does not offer grounds for non-recognition. ${ }^{87} \mathrm{In}$ addition, when it is clear that the application of the law of the country other than the granting country does not affect the conclusion of the judgment, it is thought that, from the viewpoint of judicial economy, the foreign judgment may be still recognized or enforced in Japan. ${ }^{88}$

\section{(3) Discrepancy with the Status of a Right in the Granting Country ${ }^{89}$}

Contrariety to public policy may come into question when the validity or scope of a IP right on which a foreign judgment is based is discrepant with that in the granting country. Such a case occurs, for example, when a Japanese patent right had already been invalidated by a final and binding trial decision of the Japan Patent Office at the time of conclusion of oral proceedings in a foreign court, or when, although the scope of claims had been restricted by trial decision of correction of the Japan Patent Office, a foreign judgment awarded compensation of damages or ordered injunction based on the original claims. In these cases, the contrariety to public policy may be assumed, because in these cases it is safe to say that the factual premise of the foreign judgment had been mistaken by the foreign court.

On the other hand, when, after a final decision has been handed down by a foreign court, the validity or scope of the IP right had been modified

\footnotetext{
${ }^{86}$ As long as those provisions are regarded as international mandatory rules, it should not be expected theoretically that they are going to be "applied" by a foreign court, given the so-called non application of foreign public law principle. Consequently, when examining "application", it does not always have to be application itself. It should be deemed sufficient where their substantive contents have been taken into account in such a way of "consideration".

${ }^{87}$ Obviously, Japanese IP law should properly be applied and construed in foreign courts as well and it is undesirable that cases where Japanese laws was misapplied will be accumulated in foreign countries. However, such foreign judgments have to be accepted too, as long as the Transparency Proposal rejects the exclusive jurisdiction of the granting country (see Art. 103) and lets foreign court adjudicate on Japanese IP disputes as well as property disputes in general. No special argument to allow review on the merits exceptionally in IP litigation can be found. It is hoped that problems of misapplication/misconstruction of Japanese law will be solved by making the Japanese law "transparent" through academic activities to point out such problems or to introduce Japanese law.

${ }_{88}$ The Waseda Project Proposal adopts such position in Article 28(1)(iv).

${ }^{89}$ Corresponds to the content of the former Article 403(1)(iii).
} 
before an action seeking the enforcement of the foreign judgment was brought in front of a Japanese court, the recognition of this foreign judgment needs careful consideration. There are discussions on whether or not circumstances after the delivery of a foreign judgment can be taken into account under public policy where the system of automatic recognition is adopted. ${ }^{90}$ Even if such circumstances can be taken into consideration, nonrecognition of the foreign judgment should not always be expected despite the fact that the status of IP rights in the granting country is now different due to the changes which arose after the termination of the foreign proceedings. For example, when allegations on the invalidation or correction of a Japanese patent right had not been timely produced in foreign proceedings, or when the actual content of a request for correction to be made by the Japan Patent Office was discrepant from that asserted in foreign proceedings, there might be room to recognize the foreign judgment in Japan. This conclusion might be justified, since, according to Article 104-3 of the Japanese Patent Act which allows parties to produce allegations for the invalidation of a patent in infringement proceedings, overdue allegations must be dismissed. ${ }^{91}$ This is an issue to be further discussed and hence the Transparency Proposal is not yet in the position to decide its standpoint.

\section{(4) A Proper Opportunity to Produce Allegations Concerning the Validity and Scope of a Right ${ }^{92}$}

The Japanese Patent Act allows parties to assert the invalidation of a right in infringement proceedings as a defense. ${ }^{93}$ If such opportunities to produce

\footnotetext{
${ }^{90}$ See Hayakawa (supra note 65) p. 360 et seq. There is a court case in which such circumstances are considered (Tokyo High Court, judgment, 15 November 1993, Kasai Geppo Vol. 46, No. 6, p. 47).

${ }^{91}$ In a domestic case, Japanese Supreme Court held that, while there would be the ground for retrial set forth in Article 338 (1)(viii) of the Code of Civil Procedure where a trial decision to allow correction become final and binding after the judgment of dismissal of the claims for damages etc. for patent infringement became final and binding, an counter allegation of the correction against the defense of invalidation in the infringement litigation is, if it was an overdue allegation, impermissible in light of the purport of Article 104-3 of the Japanese Patent Act. Supreme Court, judgment, 24 April 2008, Minsh $\hat{u}$ Vol. 62, No. 5, p. 1262 (English translation by the Supreme Court of Japan available at <www.courts.go.jp/english/judgments/text/2008.04.24-2006.-Ju-.No..1772. html >).

92 Corresponds to the content of the former Article 403(2)(ii).

93 With regard to a defense of invalidity of a patent in infringement litigation in Japan, see Supreme Court, judgment, 11 April 2002, Minsh û Vol. 54, No. 4, p. 1368 (English translation by the Supreme Court of Japan available at <www.courts.go.jp/ english/judgments/text/2000.04.11-1998-O-No.364-134718.html $>$ ); Article 104-3 of Japanese Patent Act.
} 
a defense of invalidation or a counter defense of correction were not ensured in infringement proceedings at a foreign court, it would very probably be contrary to public policy in Japan. This is because it concerns the validity and scope of the right itself, and will have a great influence on the conclusion of disputes. This issue also has an aspect of procedural public policy. For the enforcement of a foreign provisional measure, the opportunity to state opinion on the validity of the rights in question had to be properly ensured in foreign proceedings (the last sentence of Art. 403(1)).

\section{(5) Matters not to be Decided in Court Proceedings under the Law of the Granting Country ${ }^{94}$}

In Japan, the compulsory licensing of patent rights and copyrights (award systems) ${ }^{95}$ are decided by administrative authorities. In some foreign countries, the compulsory creation of licenses can be made through judicial proceedings. ${ }^{96}$ As this example shows, if a foreign court held a judgment about matters which could not be decided by the courts under Japanese law, this foreign judgment should not be recognized in Japan. The reason is that the recognition of such a foreign judgment would undermine the purpose of the institutional scheme where administrative authorities should make decisions, applying different procedures and standards from those of the judicial proceedings.

\section{(6) Territoriality Principle}

In the Card Reader case,${ }^{97}$ the Supreme Court held that the U.S. patent law violates the principle of territoriality, since it allows the extraterritorial application of the U.S. patent law to active inducement and contributory infringement outside the United States. However, the Transparency Proposal, in contrast to the Supreme Court, does not take such a strict meaning of principle of territoriality (see Art. 301 and the Comments). Accordingly, the contrariety to public policy will not arise in principle as an issue to be

\footnotetext{
94 Corresponds to the content of the former Article 403(1)(ii).

95 See Japanese Patent Act, Article 83 et seq., and Japanese Copyright Act, Article 67 et seq.

${ }^{96}$ For example, France has two routes: one is administrative, and the other is judicial. For more information on compulsory licensing system in each country, see the following report published by the Japan Patent Office, <www.jpo.go.jp/shiryou/toushin/shingikai/ pdf/strategy_wg10/file4.pdf>.

97 Supreme Court, judgment, 26 September 2002, Minshû Vol. 56, No. 7, p. 1551 (English translation by the Supreme Court of Japan available at <www.courts.go.jp/ english/judgments/text/2002.9.26-2000.-Ju-.No..580.html>).
} 
examined, even if the recognition and enforcement of a foreign judgment which applied similar law to the U.S. patent law would be sought in Japan.

\section{(7) Other factors}

Some other circumstances may raise questions under the public policy, for example, in a case where a foreign court ruled on an invention that employed extremely advanced technology, although the court lacked advanced specialists with sufficient knowledge to understand the content of the invention. Or, under certain circumstances that also may arise in nonIP dispute cases, the recognition of a foreign judgment may possibly be considered contrary to the public policy. For example, judgments awarding punitive damages or judgments obtained by fraud can be mentioned as typical examples.

In the Mansei Kogyo Case, the Supreme Court refused to enforce a Californian judgment awarding punitive damages under Section 3294 of the California Civil Code, on the grounds that punitive damages were contrary to public policy in Japan. ${ }^{98}$ The Transparency Proposal takes a position that punitive damages, however, will not always be contrary to public policy. A part of punitive damages award might be acceptable in Japan. This is an issue to be resolved in a flexible manner on the case-by-case basis. See also Article 404(1) concerning the partial recognition and enforcement of a foreign judgment.

\section{International Parallel Litigation and Incompatible Japanese Judgments}

a) Analysis of Situation

\section{(1) Japanese Law}

Article 118 of the Code of Civil Procedure and Article 24 of the Civil Execution Act contain no provision to deal with international parallel litigation and the existence of an incompatible Japanese judgment. There is a lower court decision which denied the enforcement of a U.S. judgment incompatible with an existing Japanese judgment, because the recognition or enforcement of a foreign judgment incompatible with a Japanese final and binding judgment concerning the same case between the same parties is contrary to public policy in Japan, irrespective of which action was commenced first, was rendered first or became final and binding first. ${ }^{99}$ However, this decision has been strongly opposed. Academic views on this

\footnotetext{
98 Supreme Court, judgment, 11 July 11, 1997, supra note 67.

99 Osaka District Court, judgment, 22 December 1977, supra note 68.
} 
issue are divided, depending on how international parallel litigation should be regulated and how retrial should relate to this issue. ${ }^{100}$

\section{(2) Model Law, etc.}

Subsections (2)(c) and (2)(d) of $\S 403$ of the ALI Principles, which are premised on the coordination principles ( $\S 221-223)$, provide as grounds for discretionary refusal of recognition and enforcement that: parallel proceedings are pending before the designated court or a court cooperating in the adjudication or chosen for consolidation; or a foreign judgment is inconsistent with the judgment of one of those courts. According to the CLIP Principles, which are premised on the "first seized" rule (Art. 2:701 and the followings), a foreign judgment shall not be recognized or enforced if: parallel proceedings are pending before a court of the requested State, which was first seized (Art. 4:501(2)); it is incompatible with a judgment given in this State (Art. 4:501(3)); it is incompatible with a judgment given in another State which fulfils certain conditions (Art. 4:501(4)). ${ }^{101}$ The Waseda Project Proposal Article 29(2) provides that a foreign judgment is not recognized or enforced if it is incompatible with a Japanese judgment given before it was given.

\section{b) Comments}

\section{(1) Foreign Judgment Resulting from International Parallel Litigation}

While Article 402(iv) of the Transparency Proposal is intended to regulate a foreign judgment resulting from international parallel litigation, Article 402(v) regulates a foreign incompatible judgment not resulting from international parallel litigation. As Article 402(iv) provides that "[i]f a situation of international parallel litigation under paragraphs 1 and 2 of Article 201 had arisen in relation to the foreign judgment", item (iv) of Article 402 clearly deals with cases falling under Article 201(1), where "a suit based on the same cause as a claim in a court in Japan, or a closely related claim, [was] pending in a court in a foreign country" which rendered the judgment. While how to regulate international parallel litigation or proceedings or lis alibi pendens is a difficult issue to tackle, ${ }^{102}$ Japanese courts may recognize and enforce a foreign judgment resulting from an international parallel litigation if a Japanese court has already dismissed a parallel claim

\footnotetext{
${ }^{100}$ See Masato Dogauchi, Naigai hanketsu tono teishoku [Conflict with a Japanese or Foreign Judgment], in: Takakuwa/Dogauchi (supra note 9) p. 365.

101 For the explanation in detail, see De Miguel Asensio's contribution in this volume, infra p. 239 seq.

${ }^{102}$ For international parallel litigation in the Transparency Proposal, see Article 201 and the Comments.
} 
or stayed a parallel suit, respectively under paragraph 1 or paragraph 2 of Article 201.

On the other hand, if Japanese courts maintain the proceedings in Japan, giving priority to the Japanese proceedings and the Japanese judgment in the future is logically consistent, because, in this case, Japanese courts would justify the exercise of jurisdiction as the place of performance of the primary obligation or the place of occurrence of the primary facts adopted by Article 201(1)(2), i.e. the "the proper forum approach". Thus the foreign judgment is not to be recognized or enforced, even if it has been rendered or has become final and binding earlier than the existing or future Japanese judgment has. Article 402(iv) clarifies that purpose. ${ }^{103}$

\section{(2) Foreign Judgment Incompatible with Japanese Judgment}

Article $402(\mathrm{v})$ is intended to regulate a situation where, if the recognition and enforcement of a foreign judgment is sought, there already exists a Japanese judgment incompatible with that foreign judgment which did not result from international parallel litigation. In this situation, the Japanese judgment should have priority over the foreign judgment if the former had become final and binding earlier than the latter had, for the purpose of protecting the domestic legal order. Therefore, according to Article 402(v), if such circumstances occur, the foreign judgment will not be recognized or enforced in Japan. ${ }^{104}$

103 As long as in cases of international parallel litigation proceedings to which priority should be given and judgments resulting from such proceedings should be respected, Article 402(iv) of the Transparency Proposal has a common base with subsections (2)(c) and (2)(d) of $\S 403$ of the ALI Principles.

104 The former Article 402(1)(v) at the time of the International Symposium (supra note 73) was unclear in its purpose, it was modified and became the present Art. 402(v). It should be also noted that as to other cases of conflict of judgments, such as conflict between a judgment given in one foreign country and that given in another foreign country (see the CLIP Principles Art. 4:501(4)), the Transparency Proposal contains no special provision. Thus, they are covered by a general interpretation of public policy (Art. 402(iii)). For a foreign judgment on an IP right infringement case which conflicts with the declaration of invalidity of the right by a court of a country in which it was registered, see III.3.b)(3) above; see also, De Miguel Asensio's contribution in this volume, infra p. 239 seq. 


\section{Reciprocity}

a) Analysis of Situation

\section{(1) Japanese Law}

The requirement of reciprocity can be satisfied if, in a foreign country whose judgment is sought to be enforced in Japan, a Japanese judgment of the same type as that foreign judgment will have effects under such conditions that are not substantially different in any respect from those listed in Article 118 of the Code of Civil Procedure. ${ }^{105}$ Foreign judgments regarding business activities from the following jurisdictions have been held to satisfy the reciprocity requirement: Queensland (Australia), ${ }^{106}$ Hong Kong ${ }^{107}$ (China), Singapore ${ }^{108}$, Germany, ${ }^{109}$ Switzerland, ${ }^{110}$ England ${ }^{111}$ (the United Kingdom), and several states of the USA (e.g. New York ${ }^{112}$ and California $\left.{ }^{113}\right) .{ }^{114}$ However, Belgium ${ }^{115}$ and the People's Republic of China ${ }^{116}$ have been declared as States which do not satisfy the reciprocity requirement.

${ }^{105}$ Supreme Court, judgment, 7 June 1983, Minshî Vol. 37, No. 5, p. 611 (granting enforcement of a Washington D.C. judgment) (English translation by the Supreme Court of Japan available at <www.courts.go.jp/english/judgments/text/1983.06.07-1982-O-No. 826.html>; a summary in English appears in The Japanese Annual of Int'l L. No. 27 (1984), p. 119). See also Takeshita (supra note 12) p. 73; Sawaki (supra note 15) Part II.E.

106 Tokyo District Court, judgment, 25 February 1998, supra note 6.

107 Supreme Court, judgment, 28 April 1998, supra note 3, concludes that reciprocity is assured between Japan and Hong Kong before it reverted to the People's Republic of China on 1 July 1997. According to the view of one author, reciprocity is also assured between Japan and the Hong Kong Special Administrative Region of the People's Republic of China after the reversion. See Satoshi Watanabe, Hanpi [Comments on a Case], Hanrei Hyôron No. 484 (1999), p. 39.

108 Tokyo District Court, judgment, 19 January 2006, Hanrei Taimuzu No. 1229, p. 334, abbreviated English translation available at $<$ http://tomeika.jp/search/content. php?did=1110>.

109 Nagoya District Court, judgment, 6 February 1987, supra note 4.

110 Tokyo District Court, judgment, 13 November 1967, supra note 2.

111 Tokyo District Court, judgment, 31 January 1994, supra note 4.

112 Tokyo District Court, judgment, 14 January 1994, supra note 4.

113 Tokyo District Court, Hachioji Branch, judgment, 13 February 1998, supra note 47, etc.

114 The other states which have been held to satisfy the reciprocity requirement are Hawaii (Tokyo District Court, judgment, October 24, 1970, Hanrei Jihô No. 625, p. 66, Hanrei Taimuzu No. 259, p. 254, abbreviated English translation available at $<$ http:// tomeika.jp/search/content.php?did=1553>; Mito District Court, Ryugasaki Branch, judgment, 29 October 1999, supra note 5); Nevada (Tokyo District Court, judgment, December 16, 1991, Hanrei Taimuzu No. 794, p. 246 abbreviated English translation available at $<$ http://tomeika.jp/search/content.php?did=1557>); and Washington, D.C. (Supreme Court, judgment, June 7,1983 , supra note 105). 
The view that the requirement of reciprocity should be deleted from Article 118 has been gaining strong support recently. ${ }^{117}$ It is grounded on several reasons: first, it is theoretically problematic that the lack of efforts of the concerned governments to establish reciprocity would bring about burdens on private persons as users of the system of the recognition and enforcement of foreign judgments; second, it takes too much time and costs to gather and translate foreign legal materials for examining the requirement of reciprocity.

\section{(2) Model Law, etc.}

Since the ALI Principles are attempting to enhance the circulation of judgments among countries which adopted the Principles, they do not need a traditional provision of reciprocity. ${ }^{118}$ ALI Principles $\S 401$ provides that, if the rendering court applied the ALI Principles, the enforcement court shall recognize or enforce the judgment pursuant to the Principles (subsection (1)(a)); if the rendering court did not apply the Principles, the enforcement court shall determine whether to recognize or enforce the judgment pursuant to its domestic rules on recognition and enforcement (subsection (1)(b)). The CLIP Principles adopt a more flexible approach than the ALI Principles in that the provisions in Part 4 are applicable even if the

115 Tokyo District Court, judgment, 20 July 1960, Ka minsh û Vol. 11, No. 7, p. 1522 (a Belgian judgment was refused enforcement because of lack of reciprocity on the ground that, unless there was a treaty on mutual recognition and enforcement between Belgium and the country of origin, the substance of its judgment was usually to be reviewed in a Belgian court).

116 Osaka High Court, judgment, 9 April 2003, Hanrei Jihô No. 1841, p. 111, Hanrei Taimuzu No. 1141, p. 270, abbreviated English translation available at $<$ http:// tomeika.jp/search/content.php?did=1599> (denying the existence of reciprocity between Japan and China because in China the people's courts shall not recognize or enforce any Japanese judgment in accordance with Article 268 of the Chinese Civil Procedure Law).

117 See e.g., Yoshiaki Sakurada, Hanpi [Comments on a Case], Hanrei Hyôron No. 288 (1983), p. 32; Matsuoka (supra note 43) p. 123; Yoshihisa Hayakawa, Gaikoku hanketsu shônin shikkô seido ni okeru "Sôgo no hosho" no yohi ["Reciprocity" in the System of Recognition and Enforcement of Foreign Judgments], Jurisuto [Jurist], No. 1232 (2002), p. 136. For vigorous and critical analysis in detail, see also De Miguel Asensio's contribution in this volume, infra p. 239 seq.

118 The ALI Principles do not provide for the requirement of reciprocity, while $\S 7$ of the ALI Foreign Judgments Project (see supra note 20) does. The reason is that the former are not designed to be the law of any one jurisdiction and therefore "diplomatic objectives related to encouraging enforcement of judgments generally are out of place". Moreover, "in multinational intellectual property instruments, reciprocity is rarely the norm”. See the ALI Principles, Part IV, Introductory Note. 
rendering court did not applied the CLIP Principles. ${ }^{119}$ The Waseda Project Proposal provides for the requirement of reciprocity (Art. 28(1)(v)).

\section{b) Comment \\ (1) Purpose}

The Transparency Proposal is a proposal for Japanese domestic legislation and not internationally applicable rules. Therefore the Transparency Proposal retains the reciprocity requirement for the recognition and enforcement of foreign judgments.

Various criticisms have been made against the reciprocity requirement so far, and thus, in general, keeping this requirement would certainly need careful consideration. Under the current state of international society, quite a few countries still maintain the requirement of reciprocity or require the bringing of a fresh action for enforcement. ${ }^{120}$ Moreover, due to considerable differences of legal policies on IP rights and unfair competition, there are many varieties concerning the scope, degree and method of the protection of rights. Under these circumstances, it is still unclear if for only Japan to abandon the reciprocity requirement would create more protection of IP rights or fair competition. Thus, the Transparency Proposal still maintains the reciprocity requirement to recognize and enforce foreign judgments relating to IP rights or unfair competition. However, the standards for determining the reciprocity should be relaxed as explained below.

\section{(2) Standards for Reciprocity}

The requirement of reciprocity would be satisfied, if, in the rendering court, a Japanese judgment of the same kind relating to IP or unfair competition would be recognized or enforced under substantially the same conditions as those prescribed in the Transparency Proposal. This is based on academic opinions and judgments so far, which have generously recognized the existence of reciprocity (see III.5.a)(1) above).

119 See De Miguel Asensio's contribution in this volume, infra p. 239 seq.

120 According to Alexander Layton/Hugh Mercer (eds.), European Civil Practice (2nd ed., Sweet \& Maxwell, 2004) countries maintaining the reciprocity requirement are Austria (p. 40), Germany (p. 210), Luxembourg (p. 368), Poland (p. 458), Spain (p. 530. However, De Miguel Asensio (in this volume p. 239) comments that the reciprocity requirement in practice does not play a significant role in Spain although it formally exists), etc. And Belgium re-examines the merits of the case (p. 75); in Denmark (p. 103), Finland (p. 136), Iceland (p. 270), the Netherlands (p. 399), Norway (p. 423), Sweden (p. 556), etc., foreign judgments in general have only an evidential effect and a fresh action is to be brought for enforcement. 


\section{Enforcement of Foreign Provisional Measures and Foreign Not "Final and Binding" Judgments}

The Transparency Proposal provides that foreign provisional measures are to be enforced, in the view of their essential role as an effective remedy against infringements of IP rights and unfair competition (see Art. 401(2)). Requirements for their enforcement are stipulated in Article 403(1)-(3): like foreign final and binding judgments, (i) they must fulfill the requirements prescribed for in Article 402 (the first sentence of Art. 403(1)); furthermore, there are special rules for foreign provisional measures, i.e. (ii) an opportunity in foreign proceedings to be heard and to state an opinion on the validity of rights in question (the second sentence of Art. 403(1)), (iii) provision of security (Art. 403(2)), and (iv) stay of proceedings for their execution (Art. 403(3)). On the other hand, a foreign not "final and binding" judgment which, for example, is with a declaration of provisional execution has a character of a provisional or interim relief, like a provisional measure. Therefore, such a judgment is to be enforced principally by mutatis mutandis application of Article 403(1)-(3) in the view of its provisional or interim nature (Art. 403(4)).

\section{Enforcement of Provisional measures}

a) Analysis of Situation

\section{(1) Japanese Law}

According to the prevailing view and case law, provisional measures do not fall under the term "judgment" of Article 118 of the Code of Civil Procedure and Article 24 of the Civil Execution Act (see II.1.a) above). Thus there is no provision in the existing law of Japan for requirements for enforcement of foreign provisional measures.

\section{(2) Model Law, etc.}

The ALI Principles contain a provision which states only that foreign provisional and protective measures are included in foreign judgments $(\S 401(4))$, and thus, one could assume that foreign provisional and protective measures are recognized or enforced by application of the same requirements and procedure as for foreign judgments in general. The CLIP Principles, on the premise that "judgment" includes widely provisional and protective measures, are supposed to require the fulfillment of requirements of (i) indirect jurisdiction, (ii) notification, (iii) public policy (iv) non-existence of incompatible judgments, etc., like judgments in general. However, Article 4:301 recognizes as grounds of indirect jurisdiction only 
those of jurisdiction over the merits of a case (Art. 4:301(1)) and, on the other hand, refuses the recognition and enforcement of foreign provisional and protective measures which were adopted without prior hearing of the obligor and are enforceable without prior service of process (Art. 4:301(2)). The Waseda Project Proposal Article 30 provides that a court of a country addressed may stay proceedings if foreign judgments will be possibly modified in an ordinary appeal or proceedings on the merits relating to the provisional order in that foreign country.

\section{b) Comments}

\section{(1) Purpose}

Article 403(1)-(3) is a special provision for the requirements for the enforcement of foreign provisional measures, which are to be enforced since they are positioned as a powerful tool in the actual practice of IP or unfair competition litigation (see Art. 401(2), and II.2.b) above). Fulfillment of the requirements listed in Article 402 is also required in order to enforce foreign provisional measures. This is not different from the case of a foreign final and binding judgment in general (the first sentence of Art. 403(1)). However, certain provisional measures such as a type of provisional disposition enjoining the alleged infringer from producing, manufacturing or selling the alleged infringing goods may result in fatal damage to the alleged infringer's business activities, ${ }^{121}$ which may possibly even affect the Japanese economy. Therefore, to decide whether such a measure should be enforced or not requires very careful consideration. Thus, the Transparency Proposal contains special provisions as follows. First, it adds to the general requirements, as noted above, a more rigorous procedural due process requirement that opportunities to be heard and to state an opinion on the validity of rights in question must be ensured in foreign proceedings (the second sentence of Art. 403(1)). Furthermore, the provision of security (Art. 403(2)) and a stay of proceedings for their execution (Art. 403(3)) may be ordered by a court.

\section{(2) Opportunity for a Hearing}

For the enforcement of foreign provisional measures relating to IP rights and unfair competition, "an opportunity to be heard" had to be given to the obligor in foreign proceedings (the last sentence of Art. 403(1)). ${ }^{122}$ In cases of the recognition and enforcement of "regular" foreign judgments, pro-

\footnotetext{
121 See e.g., Iimura/Sano (supra note 29) pp. 36, 40. See also, Hess (supra note 35) p. 290.

22 See also, the CLIP Principles Article 4:301(2).
} 
cedural details of the court proceedings as the basis of a foreign judgment are, in principle, subject to lex fori, and accordingly, in the context of recognition and enforcement, to the examination of public policy. However, some legal systems may exist, under which in order to accelerate the proceedings of provisional measures only a petition and statement from an obligee would suffice to complete the procedure. This requirement makes clear that the Transparency Proposal would not recognize provisional measures obtained in such proceedings especially to protect the obligor's interest in due process. ${ }^{123}$ Thus it will enable the exclusion of such foreign provisional measures as derived from unduly easy or simple procedures, and materialize careful screening of foreign provisional measures that would suit execution in Japan both in name and reality. ${ }^{124}$

\section{(3) Opportunity to State Opinion on the Validity of Rights}

The second specific procedural requirement for the foreign proceedings is that "an opportunity to state an opinion on the validity of the rights" should be properly ensured. The purpose of this requirement is to exclude foreign provisional measures that were issued simply based on a petition filed for the purpose of abuse or harassment on the basis of an IP right of dubious creation or existence. The enforcement of foreign provisional measures in Japan will accordingly be allowed only if the petitioned obligor was properly given an opportunity in the foreign court to contest effectively the validity of the IP right asserted by the obligee as the ground for the provisional measures.

123 According to Article 23(4) of the Civil Preservation Act of Japan, a hearing from an obligor, the adverse party, is, in principle, required for the issue of provisional disposition orders. Iimura/Sano (supra note 29) p. 40 notes that there are few cases where provisional disposition orders are issued without a hearing from an obligor.

${ }^{124}$ An idea to secure for an obligor an opportunity to be heard derives from a series of preliminary rulings of the European Court of Justice, beginning at the Denilauler case (Case 125/79, Bernhard Denilauler v. SNC Couchet Frères [1980] ECR 1553). Such an opportunity in IP infringement proceedings, however, is involved with Article 50(2) of TRIPS Agreement, which provides that: "The judicial authorities shall have the authority to adopt provisional measures inaudita altera parte where appropriate, in particular where any delay is likely to cause irreparable harm to the right holder, or where there is a demonstrable risk of evidence being destroyed." But, one author notes that "it does not impose on Member States an obligation to recognize foreign decisions adopted under these circumstances." See De Miguel Asensio's contribution in this volume, infra p. 239 seq. This is a problem to be further examined by taking notice of future ECJ rulings. See Hess/ Pfeiffer/Schlosser (supra note 25) 197. 


\section{(4) Provision of Security}

In allowing the enforcement of foreign provisional measures, the court may require the obligee to provide security (Art. 403(2)). Since provisional measures will sometimes be petitioned for in an IP or unfair competition dispute in order to pressure the obligor and just to observe his/her reaction and response, the purpose of Article 403(2) is to make good use of provision of security for testing the obligee's seriousness about protecting his/ her own rights. The provision of security is to be determined at the discretion of the court.

\section{(5) Stay of Proceedings}

Although the protection of the rights of obligee is very important in ordering provisional measures relating to IP infringement or unfair competition disputes, there is a risk that a fatal loss on the obligor's business activities may possibly be caused, so that a deliberate and delicate balance of interests of both parties is needed, taking the specificities of the case into consideration. Accordingly, it is necessary to enable the court to react in a flexible manner by granting it discretion in allowing the enforcement of a foreign provisional measure. Important factors to be considered in the court's discretion will be, for example, the type of provisional measures ${ }^{125}$ and whether the suit is filed on the merits. As to the latter, discretion will incline towards allowing the enforcement of a foreign provisional measure, if a suit on the merits has been brought in a court in the foreign country or Japan. If it has not yet been done, it will also be open to the court to urge the parties to promptly bring a suit on the merits and to stay the proceedings for an enforcement judgment until that step is taken. ${ }^{126}$

125 A type of provisional disposition enjoining the manufacture and sale of the alleged infringing goods would be a more urgent remedy than a type of provisional seizure of attachment of property of the obligor for securing a claim for damages. However, since the former, as already noted, may possibly cause a fatal loss to the obligor's business activities, careful consideration is needed in individual cases.

126 Article 50(6) of TRIPS Agreement provides that: “... provisional measures... shall, upon request by the defendant, be revoked or otherwise cease to have effect, if proceedings leading to a decision on the merits of the case are not initiated within a reasonable period, to be determined by the judicial authority ordering the measures where a Member's law so permits or, in the absence of such a determination, not to exceed 20 working days or 31 calendar days, whichever is the longer." Attention should be paid to an institution of proceedings leading to a decision on the merits. 


\section{Enforcement of Foreign Not "Final and Binding" Judgment}

a) Analysis of Situation

(1) Japanese Law

For recognition or enforcement, a foreign judgment must be "final and binding" (Art. 118 of the Code of Civil Procedure, and the main sentence of Art. 24 (3) of the Civil Execution Act). Thus a foreign judgment which is not "final and binding" shall not be recognized nor enforced in Japan (see II.1.a) above).

\section{(2) Model Law, etc.}

The ALI principles recognize or enforce foreign judgments whether they are "final and binding" or not (see § 401(2)). The CLIP Principles recognize or enforce a not "final and binding" judgment, in principle, on the same requirements and under the same procedure as for a "final and binding" judgment, but Article 4:102(5) enables courts to postpone or refuse to recognize or enforce not "final and binding" judgments. The Waseda Project Proposal allows a court to stay proceedings for recognition and enforcement of not "final and binding" judgments (Art. 30).

\section{b) Comments}

\section{(1) Purpose}

Article 403(4) of the Transparency Proposal stipulates special provisions concerning the enforcement of not "final and binding" judgments which are enforceable in the country of origin, based on the fact that not only a final and binding judgment but also a not "final and binding" judgment is included in a "judgment" in Article 401(1) (see II.2.c) above).

Not "final and binding" foreign judgments must fulfill the requirements stipulated in Article 402, as is the case for a final and binding judgment.

As far as Article 402(v) dealing with the existence of incompatible Japanese judgments is concerned, a criterion for priority should be modified because the temporal criterion, i.e. when it becomes final and binding, is inappropriate for the situation of a not "final and binding" judgment. Thus the criterion is replaced with when it was given (see the last sentence of Art. 403(4)).

However, particular caution ought to be required for enforcing a not "final and binding" judgment, because, if the judgment were reversed on an appeal in the country of origin after its enforcement, rehabilitation in the original state would be very cumbersome. Accordingly, even if the general requirements for enforcement are met, additional careful consid- 
eration of the following is required. First, not "final and binding" judgments are entitled to enforcement in Japan, only if they are enforceable in the country of origin in view of giving prompt relief; for example, in cases where they are declared to be entitled to provisional execution. In this respect, such judgments have an aspect of a provisional or interim relief like provisional measures.

From the viewpoint of such an aspect, special provisions for provisional measures as follows are applied mutatis mutandis to not "final and binding" judgments (Art. 403(4)): Article 403(2) setting out the provision of security and Article 403(3) setting out stay of proceedings for their enforcement. Unlike provisional measures, more rigorous procedural requirements such as an opportunity in foreign proceedings to be heard and to state an opinion on the validity of rights in question (the second sentence of Art. 403(1)) are not added, because as to non "final and binding" judgments a procedural guarantee is thought to be sufficiently covered in the definition of "a judgment of a foreign court" (Art. 401(1)) and public policy (Art. 402(iii)).

\section{(2) Provision of Security}

Like provisional measures, when enforcing a foreign not "final and binding" judgment, the court may require an obligee to provide security (mutatis mutandis application of Article 403(2) by Article 403(4)). The provision of security is to be decided at the discretion of the court. It may be ordered for the principal purpose of easing any rehabilitation in the original state if the judgment is modified on an appeal in the country of the rendering court.

\section{(3) Stay of Proceedings}

Since a not "final and binding" judgment involves difficulties in the possible rehabilitation, a flexible consideration of the circumstances of each case is extremely necessary. Therefore, like provisional measures, it is necessary to grant the court discretion to flexibly deal with a case, and thus a court may stay proceedings in order to determine whether or not enforcement should be granted (mutatis mutandis application of Art. 403(3) by Art. 403(4)). In the court's exercise of its discretion, while the specific circumstances of the case will be usually considered, important factors for consideration also include whether there is an urgent need to provide a remedy for the judgment creditor, ${ }^{127}$ whether or not an appeal has been brought in the country of origin, how far those appeal proceedings have progressed, and what the prospect is for that appeal.

\footnotetext{
127 See also, supra note 125.
} 


\section{Effects of Foreign Judgments and Provisional Measures}

Article 404 provides for effects that foreign judgments or protective measures will have if they fulfill the requirements set out by Articles 402 or 403 and are recognized or enforced in Japan. The fundamental principle adopted by the Transparency Proposal concerning their effects is that in Japan they do not have greater effect than they have under the law of the country of origin. ${ }^{128}$ Under this principle, Article 404 provides for three special rules on the effect of foreign judgments and provisional measures in Japan. First is their effect in case of partial recognition and enforcement (Art. 404(1)). The second relates to foreign judgments declaring the invalidity of IP rights (Art. 404(2)), and the third concerns provision of suitable compensation in cases where a compulsory license is granted (Art. 404(3)).

\section{Analysis of Situation}

a) Japanese Law

A foreign judgment, when it is recognized, has in Japan the same effect that it has in the country of the rendering court. ${ }^{129}$ It is said that its effect is determined by the law of that foreign country. On the other hand, when it is enforced in Japan, views are divided. One is that like recognition it has the same effect as it has in the country of origin, ${ }^{130}$ the other is that the same effect that an enforceable Japanese judgment has is given to it. ${ }^{131}$ As to effect of judgments in partial recognition and enforcement, the Supreme Court judgment of 1997, ${ }^{132}$ which held that the enforcement in Japan of punitive damages judgments is contrary to public policy, granted only enforcement of part of the judgment ordering compensatory damages. Thus, the Supreme Court allows the recognition or enforcement of foreign judgments in part.

b) Model Law, etc.

ALI Principles $\S 401(3)$ provides the preclusive effect (res judicata) of a foreign judgment is no greater than that of the judgment in the rendering country. Enforcement of a part of foreign judgments is allowed, since a judgment awarding punitive damages is to be enforced at least to the extent

128 ALI $\S 401(3)$ is to the same effect.

129 See, e.g. Akiyama et al. (supra note 1), p. 510; T. Nakano (supra note 1) p. 184. But see Takakuwa (supra note 9) p. 310.

${ }^{130}$ See, e.g. Akiyama et al. (supra note 1) p. 510.

131 See, e.g. T. Nakano (supra note 1) p. 184.

132 Supreme Court, judgment, 11 July 1997, supra note 67. 
that similar or comparable damages could have been awarded in the country addressed $(\S 411(2))$. As to the effect of judgments ordering injunctive relief, $\S 412$ provides, on the one hand, that they are enforced in accordance with the law of the country addressed (subsection (1)(a)) and, on the other hand, that, under certain conditions, the country addressed may award monetary relief instead of the injunction (subsection (1)(b)). Furthermore, according to $\S 413(2)$, when a court of a country declared that a right registered in another country is invalid, the declaration is effective only to resolve the dispute between or among the parties to the litigation. CLIP Principles Article 4:102(6) provides that a severable part of a foreign judgment is separately recognized or enforced; see also, Article 4:402(1) dealing with non compensatory damages judgments. And Article 4:703(3) provides that the law of the requested country determines to the extent to which enforcement takes place. The Waseda Project Proposal Article 401(3) provides for the recognition and enforcement of severable parts of a foreign judgment.

\section{Comments}

\section{a) Effect of Judgments or Provisional Measures in Partial Recognition and Enforcement}

If grounds for refusal would apply to only a part of a foreign judgment or provisional measures, refusing the recognition and enforcement of the entire judgment or order would be excessive, especially for the convenience of the parties. Accordingly the remaining part of the judgment or order not subject to the grounds for refusal will be recognized or enforced, and only that part of the foreign judgment or provisional measure will have effect (Art. 404(1)). ${ }^{133}$ The scope of effect of a judgment or order will be closely related to the content of the procedural due process granted to the parties in the court proceedings in the foreign country where the judgment or order was given. Therefore it will be appropriate, in principle, to decide that scope in accordance with the law of that foreign country. However, if Japanese procedural public policy (Art. 402(iii)) would be prejudiced, because the foreign judgment or provisional measure in question has been given excessive effect in light of the fundamental principles of Japanese procedural law, there will be no alternative to an exceptional reduction of the effect of the judgment or order. Article 404(1) is a provision that implies this sort of process.

133 This is to the same effect as the CLIP Principles Article 4:102(6) and Article 401(3) of the Waseda Project. 


\section{b) Effect of Foreign Judgments Confirming Invalidity of Rights}

A judgment declaring the invalidity of IP rights granted pursuant to the law and regulation of a foreign country will have effect only between the parties to the suit (see Art. 101(3) which provides for suits on the existence, registration, ownership and validity of IP rights). If this general principle is applied to the effect of a foreign judgment, "[i]f a judgment of a foreign court declares the invalidity of a right registered in a country other than that country, where the foreign court is situated, the declaration shall be effective only to resolve the dispute between the parties to the litigation" (Art. 404(2)). ${ }^{134}$ Accordingly, if a judgment in which a foreign court declares the invalidity of a right registered in a country other than that foreign country meets requirements for recognition in Japan, the effect of that judgment will be limited to only between the parties to the suit, even if that judgment takes effect erga omnes (or effect against third parties) in the country of origin.

\section{c) Provision of Adequate Compensation where a Compulsory License is Granted}

Article 403(3) provides that if a foreign judgment ordering a defendant to enjoin acts in Japan will not be enforced in whole or in part due to a compulsory license in Japan, compensation is to be given in the form of an adequate money payment. This is for the purpose of incorporation of provisions such as Articles 27(2) and 31(h) of the TRIPS Agreement into the recognition and enforcement of foreign judgments or provisional measures. ${ }^{135}$

\section{Concluding Remarks}

Besides international jurisdiction and applicable law, recognition and enforcement is one of the three pillars in transnational dispute settlement. The rules of the Transparency Proposal concerning recognition and enforcement of foreign judgments were drafted in light of principles adopted designing jurisdiction and choice-of-law provisions. This Transparency Proposal was drafted so as to fit the existing legal practices of Japanese

134 The ALI Principles $\S 413(2)$ is to the same effect.

135 This is to the same effect as ALI $\S 412(1)$ (b) (for compensation, see ALI Principles $\S 412$, Reporters' Note 4). In Japan, the party of the license who considers as inadequate the amount of the compensation determined in the award and is not satisfied with it may file a suit demanding an increase or decrease of the said amount against the other party. See Article 183 et seq. of the Japanese Patent Act. 
courts. However, in order to assure more legal certainty and efficiency to cross-border IP disputes, this Transparency Proposal provides not only for certain clarifications (e.g. questions related with the treatment of parallel litigation issues), but also for more flexibility (e.g. recognition of punitive damages judgments). Proposed modifications such as recognition of interim orders issued by foreign courts go hand in hand with current needs of global businesses and reflect the overall intention to facilitate efficient resolution of international IP disputes. 


\title{
Summary of Comments and Discussion on Recognition and Enforcement
}

\author{
by Paulius Jurčys and Simon Vande Walle
}

\section{Comments made by Prof. Toshiyuki Kono}

Prof. Kono commented on the following four topics: (1) the purpose of the rules on recognition and enforcement of foreign judgments, (2) the extent to which the enforcement court, i.e. the court in the State where enforcement is sought, reviews the jurisdiction of the original court, i.e. the court that rendered the foreign judgment (3) the extent to which the enforcement court examines the choice of law by the original court and (4) the extent to which provisional orders can be recognized and enforced.

With respect to the purpose of the rules, Prof. Kono pointed out that, under the ALI Principles, the rules on recognition and enforcement act as an incentive for States and other entities to adopt the ALI Principles on jurisdiction and applicable law. This is evidenced by $\S 401(1)(a)$ of the ALI Principles, which provides that a foreign judgment shall be recognized pursuant to the ALI Principles if the foreign court applied the ALI Principles.

Prof. Kono then examined the purpose of the Transparency Proposal. He pointed out that the drafters of the Transparency Proposal had intended to facilitate the free movement of judgments in the field of IP. However, based on some provisions, one could get the impression that the purpose of the Transparency Proposal is merely to create a kind of international assistance system. Such an impression could be created by the rule on reciprocity (Art. 402(vi)), the discretion of the court to require security (Art. 403(2)) and, in case of provisional orders, the discretion to refuse enforcement altogether (Art. 403(3)).

Next, Prof. Kono wondered what the underlying purpose of the CLIP Principles is. Prof. De Miguel had mentioned that the rules could be used "as a reference to interpret or supplement international and domestic law and as a model for national and international legislators." The reference to both domestic and international law is somewhat ambiguous. A move towards domestic law and national legislators could possibly lead to an environment that is more hostile towards recognition and enforcement. On the other hand, increased reliance on international law and international legislators could lead to a more recognition-friendly framework. This ambiguous approach contrasts with the approach taken by the ALI Principles, which is clearly aimed at creating a community of States adhering to the ALI Principles.

\footnotetext{
${ }^{1}$ See Pedro A. de Miguel Asensio's contribution in this volume, infra p. 239.
} 
Prof. Kono also stressed that the Brussels-Lugano regime has been extremely successful for several decades now. One should not ignore that success and hence, one has to wonder: what can be done on top of the Brussels-Lugano?

With respect to the extent to which the enforcement court can review the jurisdiction of the original court, Prof. Kono explained that the standard of review in the Transparency Proposal is more relaxed than the standard under existing law. This results from the use of the words "in light of" (Art. 402(i)). ${ }^{2}$ Prof. Kono requested clarification about the extent to which, under the CLIP Principles, the enforcement court could apply its domestic law to assess whether the original court had jurisdiction.

Prof. Kono mentioned that, under the ALI Principles, there is some connection between the rules on applicable law and the rules on enforcement. If the original court did not apply the ALI Principles on applicable law, it need not recognize or enforce the foreign judgment ( $\$ 403(2)(b)$ ALI Principles). By contrast, both the CLIP Principles and the Transparency Proposal seem to separate these aspects completely. However, in patent law, procedural and substantive aspects are often inextricably interwoven. In such cases, should a foreign judgment that applied a law different from the one designated by the applicable law rules of the enforcement court be recognized and enforced? Wouldn't that result in the rules of the enforcement court being bypassed and couldn't this be problematic in situations where procedural and substantive issues are interwoven? In this respect, one could wonder whether the ALI Principles aren't more appropriate, because they do establish a connection between the applicable law rules and the rules on recognition and enforcement.

Prof. Kono highlighted that the ALI Principles, the CLIP Principles and the Transparency Proposal all allow for the recognition and enforcement of provisional orders. For Japan, this is rather revolutionary, because, under current law, only final and conclusive judgments can be recognized and enforced. The Transparency proposal does not, however, allow for the recognition and enforcement of settlements. Is this an additional step that could be taken? The rules on provisional orders in the CLIP Principles are quite liberal and may potentially be abused. Hence, we need to think about how such abuse can be avoided.

\footnotetext{
${ }^{2}$ Compare: Art. 118 of the Japanese Code of Civil Procedure: "A final and binding judgment shall be effective only where it meets all of the following requirements: (i) The jurisdiction of the foreign court is recognized under laws or regulations or conventions or treaties. (...)".
} 


\section{Discussion}

Prof. Dessemontet commented on the issue of enforcement of foreign judgments that are not yet final and conclusive. He pointed out that the rule proposed by the Transparency Proposal allows for the enforcement of a foreign judgment that is not yet final and conclusive, although the Japanese court has discretion to refuse enforcement and can require the person seeking enforcement to provide security. By contrast, the ALI Principles require the court of the State where enforcement is sought to stay enforcement proceedings until the foreign judgment is final and conclusive.

The ALI rule was inspired by the experience with enforcement of arbitral awards. In the famous Hilmarton case, ${ }^{3}$ the French Cour de Cassation held that an arbitral award can be enforced even if it is not yet final and binding in the State of the arbitration's seat. The case involved the enforcement of a Swiss arbitral award, against which an appeal was pending in Switzerland. In spite of the appeal, the French courts declared the arbitral award enforceable. The arbitral award was subsequently set aside by the Swiss courts and a second arbitral award was rendered. This second arbitral award was also declared enforceable in France. The result was a situation in which two contradictory arbitral awards were simultaneously being enforced in France. The Hilmarton case illustrates the grave risk of allowing enforcement of arbitral awards that are not yet final and binding. This risk also exists with respect to enforcement of foreign judgments in intellectual property cases. That is why, under the ALI Principles, the court will stay the proceedings until the judgment is final and binding.

Prof. De Miguel explained that, under the CLIP Principles, judgments that are not yet final do not have to be enforced. The court has the possibility to postpone or refuse recognition and enforcement (Art. 4:102 CLIP Principles). He suggested that it could perhaps be clarified in the comments that enforcement can also be made conditional, e.g. on the provision of security by the party seeking enforcement.

Prof. Dessemontet commented on the public policy exception in the Transparency Proposal, i.e. the non-enforcement of a foreign judgment because it is contrary to public policy. He wondered whether fraud should not be listed separately as a ground for non-enforcement. This is the solution adopted by the ALI Principles (§ 403(1)(d) ALI Principles).

In addition, Prof. Dessemontet mentioned that it may be worth clarifying whether the concept of "public policy" used in the Transparency Proposal refers to a domestic concept of public policy - public policy as understood in regular cases with no international connection - or whether

\footnotetext{
${ }^{3}$ Cass. 1e civ., 23 March 1994 (Société Hilmarton v. Société OTV), Rev. Arb. 1994, 327, note Ch. Jarrosson.
} 
it refers to a more limited concept of "international" public policy, specifically applied in international cases.

Dr. Shin clarified that the concept of public policy as used in the Transparency Proposal refers to public policy in Japan, which however applies only to cross-border cases.

In response to the question raised by Prof. Kono during his presentation ("What can be done on top of Brussels-Lugano?"), Prof. Basedow pointed out that the Brussels-Lugano jurisdictional system is currently under review and that it will probably be subject to a major overhaul. The CLIP Principles can provide a meaningful contribution in this context. Prof. De Miguel pointed out that the Brussels-Lugano regime only covers the recognition and enforcement of judgments rendered by EU Member States, Switzerland, Norway and Iceland. For judgments from third States, each State applies its own national law. As part of the review of the Brussels Regulation, the European Commission may want to adopt rules on the recognition and enforcement of judgments from third States. Hence, the CLIP Principles can be relevant for the European legislator.

Prof. Basedow expressed concern about the fact that, in the Transparency Proposal, the public policy exception seems to be defined in such a way that it requires Japanese courts to assess whether the foreign court applied the right law. Making enforcement of a foreign judgment conditional on the application of the right law inevitably leads to a very in-depth review of the case. In the end, this comes down to a review of the merits and this is exactly what recognition and enforcement proceedings are supposed to avoid.

Prof. Dessemontet agreed that avoiding a review of the merits is crucial. However, he also pointed out that any assessment by the court in the State where enforcement is sought would always be based on the facts as stated in the foreign judgment. Hence, at least with respect to the facts, the case would not have to be re-litigated.

Prof. Basedow pointed out that there seems to be a lack of equivalence between the conflict-of-laws rules in the Transparency Proposal and the rules on recognition and enforcement. If one reads the conflict-of-laws rules together with the rules on recognition and enforcement, it seems that Japanese courts would not recognize some foreign judgments that applied conflict-of-laws rules similar to the Japanese ones. Suppose, for instance, that a Taiwanese court applied a conflict-of-laws rule that resulted in the application of Taiwanese law to a "ubiquitous" infringement that took place in Taiwan, China, Japan, etc. It seems such a judgment would not be enforceable in Japan under the proposed rules because the foreign court did not apply Japanese law to intellectual property rights existing under Japanese law. In sum, Japanese courts would not be willing to enforce 
foreign judgments that applied conflict-of-laws rules that are similar or identical to Japan's own conflict-of-laws rules. In private international law, there should be equivalence between what we claim for our own courts and what we are willing to accept from other courts. If we allow Japanese courts to apply Japanese law to a multi-state infringement in some circumstances, we should not, at the same time, refuse enforcement of a foreign judgment that applies foreign law to a multi-state infringement in similar circumstances.

A member of the audience raised concerns about situations in which a party seeks enforcement in Japan of a foreign judgment rendered by a court that was influenced by a bribe or corruption. Often the defendant against whom enforcement is sought knows, based upon credible rumor, that there was bribery or corruption, but it is impossible to prove this. How do the rules protect against such a nightmare situation? Prof. Dessemontet responded that, in the ALI Principles, this situation is addressed by $\S 403(1)(\mathrm{b})$, which provides that the judgment will not be enforced if it was rendered in circumstances that raise "substantial and justifiable doubt about the integrity of the rendering court".

Prof. Tada commented on the enforcement of foreign judgments that are not yet final and binding and provisional orders. He mentioned that the Transparency Proposal tried to look at the specific needs in the area of intellectual property rights. In intellectual property litigation, injunctions are often the first measure used to protect intellectual property rights. Damages often come only in a second stage. That is why the members of the working group felt there was a need to have some possibility to recognize foreign judgments that grant injunctive relief. The actual aim was to facilitate the free movement of judgments, but without going too far in this direction.

Prof. Kono asked how other European jurisdictions deal with the recognition of provisional measures. Prof. Dessemontet first stressed that there are two distinct issues at stake. One question is how to deal with judgments that are not yet final. Another question is how to deal with judgments that grant provisional measures. He subsequently stated that, in his view, recognition and enforcement should not be limited to judgments on the substance (as opposed to judgments granting provisional measures). This would be tantamount to a denial of justice.

Dr. Heinze mentioned that, under German law, the traditional rule was that foreign judgments granting provisional measures could not be enforced. Germany abandoned this rule for judgments from other European States as a result of the Brussels/Lugano regime. He subsequently mentioned that, in the CLIP Principles, two limits to the recognition and enforcement of provisional measures had been built in. First, the provi- 
sional measures must have been granted by a court that also has jurisdiction on the merits (Art. 4:301(1) CLIP Principles). Second, provisional measures granted after ex parte proceedings, i.e. without the adverse party being heard, cannot be recognized or enforced (Art. 4:301(2) CLIP Principles).

Prof. Basedow mentioned that, in Germany, intellectual property litigation often involved only provisional proceedings, without any proceedings on the merits. Given this situation, it seems imperative to allow for the enforcement of provisional measures at least to some degree. 


\section{Annex I}

\section{American Law Institute (ALI)}

Copyright 2008 by The American Law Institute (ALI). The complete version of this publication - which includes extensive commentary and reference notes - is available in print form through the ALI website $<$ www.ali.org $>$ or electronically through Westlaw. All rights reserved. Reprinted with permission.

\section{Intellectual Property:}

\section{Principles Governing Jurisdiction, Choice of Law, and Judgments in Transnational Disputes}

\section{Part I}

\section{Definitions and Scope of the Principles}

\section{$\S 101$. Definitions}

The following definitions apply to these Principles:

(1) "Agreement" means a bargain of two or more parties that results in legal obligations. The term includes agreements, contracts, licenses, assignments, pledges, grants, and other voluntary transfers, regardless of how the particular transaction or transfer is denominated.

(2) "Judgment" means any final judgment or final order of a court determining a legal controversy; a judgment or order is "final" for the purposes of these Principles when it is subject to enforcement in the State of origin and not stayed by a court in that State.

(3) "Registered right" means any intellectual property right covered by $\S$ 102(1) that is not valid unless and until granted by a competent State authority.

(4) "Standard form agreement" means an agreement that:

(a) is prepared by one party for repeated use; 
(b) is presented to another party or parties (the "nondrafting party") by the party on behalf of whom the draft has been prepared (the "drafting party"); and

(c) does not afford the nondrafting party a meaningful opportunity to negotiate its terms.

(5) "State" means an entity with a defined territory and a permanent population, under the control of its own government, which engages in, or has the capacity to engage in, foreign relations with other such entities. A regional economic integration organization is considered a "State" for purposes of the Principles when the organization created the intellectual property right at issue in the dispute. The allocation of authority between a State and its territorial subdivisions is determined under the law of that State.

(6) "Transnational civil dispute" means a civil action in a court of a State (the "forum State") in which:

(a) there is a claim or defense under the intellectual property rights of another State (the "non-forum State"); or

(b) there is a claim arising out of activities that implicate intellectual property rights where the activities occur, at least in part, outside the forum State.

\section{$\S 102$. Scope and Applicability of the Principles}

(1) These Principles apply to transnational civil disputes that involve copyrights, neighboring rights, patents, trade secrets, trademarks, geographic indications, other intellectual property rights, and agreements related to any of these rights.

(2) A court shall, upon a party's timely request or upon its own motion, make a specific finding as to whether a dispute before it comes within the Principles.

$\S 103$. Distinction Between Jurisdiction and Applicable Law

(1) Competence to adjudicate does not imply application of the forum State's substantive law.

(2) A court shall not dismiss or suspend proceedings merely because the dispute raises questions of foreign law. 


\section{Part II}

\section{Jurisdiction}

\section{Chapter 1}

Personal Jurisdiction over the Defendant

\section{$\S 201$. Defendant's Residence}

(1) A person may be sued in any State in which the person is resident, regardless of whether or not the claim arose in that State.

(2) A natural person is resident in the State in which he or she is habitually found or maintains significant professional or personal connections.

(3) A juridical person is resident in any State or States in which:

(a) it has a statutory seat;

(b) it is incorporated or formed;

(c) its central administration or chief executive office is located; or

(d) it maintains its principal place of business.

\section{$\S$ 202. Choice-of-Court Agreements}

(1) Subject to subsections (3) and (4), a person may be sued in any court that the parties have agreed will have jurisdiction with respect to the dispute in question, and, unless the parties' agreement clearly provides otherwise,

(a) the designated court will have exclusive jurisdiction with respect to that dispute, and

(b) the parties will be deemed to have waived objections to the designated court's personal jurisdiction over them.

(2) Except as provided in $\S \S 221-223$, a court that has jurisdiction under subsection (1) shall not decline to exercise jurisdiction on the ground that the dispute should be decided in a court in another State.

(3) (a) Except as provided in subsection (4), a choice-of-court agreement is valid as to form and substance if it is valid under the entire law of the designated forum State, including its conflicts rules.

(b) Capacity of a party to enter into the agreement is determined by the internal law of the State in which that party was resident at the time the agreement was concluded; if that party had more than one residence, capacity will be recognized if it existed under the law of any one of its residences. 
(4) (a) A choice-of-court clause in a standard form agreement is valid only if the choice-of-court clause was reasonable and readily accessible to the nondrafting party at the time the agreement was concluded, and is available for subsequent reference by the court and the parties.

(b) Reasonableness under subparagraph (a) is determined in light of:

(i) the parties' locations, interests, and resources, taking particular account of the resources and sophistication of the nondrafting party;

(ii) the interests of any States connected to the dispute or to the parties;

(iii) the availability of remote adjudication in the designated court, such as online dispute resolution; and

(iv) whether the designated court was established in the forum State to foster expertise in adjudicating disputes of this type.

(5) If the choice-of-court clause is not valid under this Section, then jurisdiction is determined according to the other provisions of Part II of the Principles.

\section{$\S 203$. Appearance by a Defendant Not Resident in the Forum}

(1) A defendant submits to the authority of a court in which it proceeds on the merits without timely contesting jurisdiction.

(2) The defendant has the right to contest jurisdiction no later than the time of the first defense on the merits.

(3) If the defendant does not appear, the court shall satisfy itself that the plaintiff's assertions of the basis of jurisdiction are reasonably supported. If they are, the court may enter judgment; the enforceability of the judgment in other States will be subject to scrutiny under $\S \S 402-403$.

\section{$\S 204$. Infringement Activity by a Defendant Not Resident in the Forum}

(1) A person may be sued in any State in which that person has substantially acted, or taken substantial preparatory acts, to initiate or to further an alleged infringement. The court's jurisdiction extends to claims respecting all injuries arising out of the conduct within the State that initiates or furthers the alleged infringement, wherever the injuries occur.

(2) A person may be sued in any State in which that person's activities give rise to an infringement claim, if that person directed those activities to that State. The court's jurisdiction extends to claims respecting injuries occurring in that State.

(3) A person who cannot be sued in a World Trade Organization-member State with respect to the full territorial scope of the claim through the application of $\S \S 201-204(1)$ may be sued in any State in which that person's activities give rise to an infringement claim if: 
(a) that person directed those activities to that State, and

(b) that person solicits or maintains contacts, business, or an audience in that State on a regular basis, whether or not such activity initiates or furthers the infringing activity.

The court's jurisdiction extends to claims respecting injuries arising out of conduct outside the State that relates to the alleged infringement in the State, wherever the injuries occur.

\section{$\S 205$. Agreements Pertaining to Intellectual Property Rights}

A person may be sued in a State with respect to any claim alleging the breach of an agreement transferring or licensing intellectual property rights for exploitation in that State. When this Section affords the sole basis of jurisdiction, the defendant may be sued only with respect to those intellectual property rights provided by that State and related to the agreement.

\section{$\S$ 206. Personal Jurisdiction over Multiple Defendants}

(1) A plaintiff bringing an action against a person in a State in which that person is resident may also proceed in that State against one or more nonresident defendants if the claims against the resident defendant and such other defendants are so closely connected that they should be adjudicated together to avoid a risk of inconsistent judgments, and if:

(a) there is a substantial, direct, and foreseeable connection between the forum's intellectual property rights at issue and each nonresident defendant; or

(b) as between the forum and the States in which the added defendants are resident, there is no forum that is more closely related to the entire dispute.

(2) There is a risk of inconsistent judgments if it appears that the ensuing judgments:

(a) would impose redundant liability;

(b) would conflict in that the judgment in one case would undermine the judgment in another case; or

(c) would conflict in that a party would not be able to conform its behavior to both judgments.

(3) Subsection (1) does not apply to any defendant invoking an exclusive choice-of-court agreement with the plaintiff that conforms with $\S 202$.

(4) If an action is brought in a State on the basis of this Section, then that court has jurisdiction with respect to injuries, wherever occurring, that arise out of the activities that allegedly create the risk of inconsistent judgments. 


\section{$\S 207$. Insufficient Grounds for Jurisdiction over Transnational Disputes}

Jurisdiction to adjudicate a transnational dispute under these Principles is insufficient when exercised solely on the basis of any one of the following grounds:

(1) the presence in that State of tangible property belonging to the defendant, except when the dispute is directly related to that property;

(2) the existence of defendant's intellectual property rights under the law of that State, except when the dispute is directly related to that intellectual property;

(3) the nationality of the plaintiff;

(4) the nationality of the defendant;

(5) the presence of the plaintiff in that State;

(6) the conduct of commercial or other activities by the defendant in that State, except when the dispute arises out of those activities;

(7) service of a writ upon the defendant in that State; or

(8) completion in that State of the formalities necessary to execute the agreement to which the dispute pertains.

\section{Chapter 2}

Jurisdiction over the Subject Matter

\section{$\S 211$. Subject-Matter Jurisdiction over Claims}

(1) Except as provided in subsection (2), a court is competent to adjudicate claims arising under foreign laws pertaining to the subject matter of these Principles. However, with respect to each asserted claim, the court must have subject-matter jurisdiction under its local law and personal jurisdiction under $\S \S 201-207$.

(2) A judgment holding registered rights granted under the laws of another State invalid is effective only to resolve the dispute between or among the parties to the action.

\section{$\S 212$. Subject-Matter Jurisdiction over Counterclaims, Supplemental Claims, and Defenses}

(1) A court may determine all claims and defenses among the parties arising out of the transaction, occurrence, or series of transactions or occurrences on which the original claim is based, regardless of the territorial source of the rights at issue or of the party that asserts them. However, with 
respect to each asserted claim, the court must have subject-matter jurisdiction under its local law and personal jurisdiction under $\S \S 201-207$.

(2) A court may decline to exercise jurisdiction over a claim unrelated to intellectual property rights when the claim substantially predominates over the claims properly within the scope of these Principles.

(3) A court shall not decline to exercise jurisdiction over any claims for the sole reason that the claims are based on foreign law.

(4) A court has authority to consider defenses related to the invalidity of registered rights. In a dispute in which a court in one State has determined that a right registered in another State is invalid, the judgment is effective only to resolve the dispute between or among the parties to that action.

(5) A court may permit intervention by a person having an interest substantially connected to the subject matter of the proceeding if the court finds that the intervention will not cause undue confusion or delay, or otherwise unfairly prejudice a party.

\section{$\S 213$. Declaratory Judgments}

(1) An action for a declaratory judgment other than one to declare a registered right invalid may be brought on the same terms as an action seeking substantive relief.

(2) Except as provided in subsection (3), an action to obtain a declaration of the invalidity of a registered right may be brought only in the State of registration.

(3) An action to declare the invalidity of the rights registered in two or more States may be brought in the State or States in which the defendant is resident, but the judgment will be effective only to resolve the dispute between or among the parties to the action.

(4) A court exercising jurisdiction under this Section may not exercise coordination authority under $\S 221$.

\section{$\S 214$. Provisional and Protective Measures}

(1) A court has jurisdiction to order any provisional or protective measures consistent with its authority under $\S \S 201-207$ and $\S \S 221-223$ of these Principles.

(2) The courts in any States in which intellectual property rights are registered or in which tangible property is located have jurisdiction to order any provisional or protective measures with respect to that property. The measure shall be limited to the territory of that State. 
(3) A person having custody or control of goods in transit, even if not an infringer by the law of the State in which the goods are temporarily located, may be the subject of an action for an order of temporary detention of the goods while the true owner or owners are identified and joined to the proceedings.

\section{Chapter 3}

Jurisdiction over Simplification: Coordinating Multiterritorial Actions

\section{$\S 221$. Coordination Authority of the Court First Seized with an Action Involving the Party Seeking Coordination}

(1) Any party engaged in actions involving the same transaction, occurrence, or series of transactions or occurrences in the courts in different States may move to have the actions coordinated through cooperation or consolidation under these Principles. The motion shall be timely submitted and specify the actions to be coordinated.

(a) If the parties in all the actions are the same, the motion should be made in the court first seized.

(b) If the parties in all the actions are not the same, the motion should be made in the court first seized with an action involving the moving party.

(c) Where permitted by local law, the court first seized may consider coordination on its own motion, while affording the parties an opportunity to be heard in the matter.

(2) If the court designated by subsection (1) finds that some or all of the claims in the specified actions in other courts arise out of the same transaction, occurrence, or series of transactions or occurrences as the claims before the court, the court shall assert coordination authority over those actions and decide, in accordance with $\S 222$, whether the actions will proceed through cooperation or consolidation or a combination of the two.

(3) Any other court before which an action is pending that contains claims that the designated court has deemed to fall within its coordination authority shall follow the procedures set out in $\S 223$.

(4) A court is "seized":

(a) when the document instituting the action, or an equivalent document, is filed with the court, provided that the plaintiff subsequently takes the required steps to provide notice to the defendant; or

(b) if the document has to be served before being filed with the court, when it is served or received by the authority responsible for service, whichever is earlier, provided that the plaintiff subsequently files the document with the court. 
(5) A court seized with a coercive action seeking substantive relief is "first seized" when:

(a) the subject matter of the action is not within another tribunal's exclusive jurisdiction under $\S 202$; and

(b) no other court had previously been seized with a coercive action seeking substantive relief; and

(c) in the case of actions between different parties, no other court has a pending motion to coordinate actions under subsection (1).

(6) If the court in which a motion to coordinate is pending fails within a reasonable time to take the necessary steps to act on the motion, or if the court before which actions have been consolidated cannot be expected to render a decision within a reasonable time, then the nondesignated court or courts may proceed to adjudicate.

\section{$\S 222$. Coordination Among Courts and Consolidation of Territorial Claims} by the Court First Seized

(1) If the court designated by $\S 221$ decides that related actions will be coordinated, it then determines whether coordination should proceed through cooperation, consolidation, or a combination of the two. Considerations bearing on this matter include:

(a) the convenience and efficiency of centralized adjudication versus the convenience and efficiency of cooperation;

(b) the cost of pursuing related actions in multiple courts;

(c) the need for specific expertise in light of the complexity and novelty of the legal issues;

(d) the time required to resolve all the claims;

(e) the relative resources of the parties;

(f) whether there is a court with adjudicatory authority over all the parties under $\S \S 201-207$;

(g) whether adjudication by multiple courts could result in inconsistent judgments; and

(h) whether the judgment resulting from consolidated proceedings will be enforceable in other States.

(2) If the court determines that coordination of all or part of the dispute is appropriate, it should invite the parties to identify other related pending actions between any of the parties to the dispute and other litigants that the court should, in order to promote efficiency, consider for inclusion in the coordination plan. 
(3) If the court determines that cooperative resolution of all or part of the dispute is appropriate, the court shall so inform all courts involved in the coordination and order the parties to draw up a plan for resolving the dispute in a just and expeditious manner.

(4) If the court determines that consolidation of all or part of the dispute is appropriate, the court shall next decide, in a timely manner, whether to retain jurisdiction over the consolidated action or instead to suspend proceedings in favor of another court. Considerations bearing on this matter include:

(a) which State has the closest connection to the dispute; in deciding this the court should take into account:

(i) any enforceable choice-of-court clauses in contracts relevant to the dispute between or among any of the parties;

(ii) the States in which the parties reside;

(iii) the relative resources of the parties;

(iv) which States' intellectual property rights are in issue; and

(v) the State whose law governs initial title to the intellectual property rights or other rights in issue under $\S \S 311-313$;

(b) which court has authority to adjudicate the fullest scope of the consolidated action, taking into account the court's authority over the subject matter and the parties;

(c) the difficulty of managing the litigation, including the complexity, familiarity, and novelty of the legal issues, and, particularly in patent cases, the expertise of each potential consolidation court;

(d) the availability of process to summon and examine witnesses and obtain nontestimonial evidence, and the location of the evidence and of witnesses;

(e) each potential consolidation court's power to award an adequate remedy; and

(f) the availability of judicial process consistent with international norms.

(5) The issues of cooperation and consolidation shall be decided in a timely manner.

(6) A party seeking to appeal a decision on coordination or consolidation shall do so at the first opportunity provided by the jurisdiction of the court that made the decision. Failure to do so constitutes a waiver of the right to appeal the decision.

$\S 223$. Disposition of the Dispute by Other Court or Courts Seized with the Action 
(1) When the court designated by $\S 221$ asserts coordination authority, courts in which related actions are pending shall suspend proceedings awaiting:

(a) a determination by the designated court that the suit falls within the Principles; and

(b) that court's decision, in accord with $\S 222$, whether there should be coordination, and, if so, whether the method of adjudication should be by cooperation among the courts seized, or by consolidation of the entire dispute before one court.

(2) If the court designated determines that the dispute should be adjudicated cooperatively, courts in which related actions are pending shall consult with the parties, the court first seized, and other courts in which related actions are pending, to determine the scope of each court's authority and the timing of each court's proceedings.

(3) If the court designated by $\S 221$ consolidates the dispute and chooses the court in which the consolidated action will be adjudicated, courts other than the consolidation court shall suspend proceedings in any action within the scope of consolidation. If any court suspends its proceedings under this subsection, it may order the litigants to provide security sufficient to satisfy any final decision on the merits.

(4) When a court has suspended its proceedings under subsection (3), it may resume proceedings if:

(a) the consolidation court declines to exercise jurisdiction or determines that the actions are not subject to coordination;

(b) the plaintiff in the suspended action fails to proceed in the consolidation court within a reasonable time; or

(c) the consolidation court fails to proceed within a reasonable time.

(5) Another court seized with the action shall dismiss the suspended case when presented with a final judgment rendered by the consolidation court that decides the claims on the merits in compliance with the requirements for recognition or enforcement under Part IV of these Principles.

(6) The judgment rendered through coordinated adjudication does not foreclose proceeding with claims that were not made subject to coordination. 


\section{Part III}

\section{Applicable Law}

\section{Chapter 1}

In General

\section{$\S 301$. Territoriality}

Except as provided in $\S \S 302$ and $321-323$,

(1) The law applicable to determine the existence, validity, duration, attributes, and infringement of intellectual property rights and the remedies for their infringement is:

(a) for registered rights, the law of each State of registration.

(b) for other intellectual property rights, the law of each State for which protection is sought.

(2) The law applicable to a noncontractual obligation arising out of an act of unfair competition is the law of each State in which direct and substantial damage results or is likely to result, irrespective of the State or States in which the act giving rise to the damage occurred.

\section{$\S 302$. Agreements Pertaining to Choice of Law}

(1) Subject to the other provisions of this Section, the parties may agree at any time, including after a dispute arises, to designate a law that will govern all or part of their dispute. issues:

(2) The parties may not choose the law that will govern the following

(a) the validity and maintenance of registered rights;

(b) the existence, attributes, transferability, and duration of rights, whether or not registered; and

(c) formal requirements for recording assignments and licenses.

(3) Any choice-of-law agreement under subsection (1) may not adversely affect the rights of third parties.

(4) (a) Except as provided in subsection (5), a choice-of-law agreement is valid if it is valid under the designated law.

(b) Capacity of a party to enter into the agreement is determined by the internal law of the State in which that party was resident at the time the agreement was concluded; if that party had more than one residence, capacity will be recognized if it existed under the law of any one of its residences. 
(5) (a) In addition, choice-of-law clauses in standard form agreements are valid only if the choice-of-law clause was reasonable and readily accessible to the nondrafting party at the time the agreement was concluded, and is available for subsequent reference by the court and the parties.

(b) Reasonableness under subsection (a) is determined in light of:

(i) the closeness of the connection between the parties, the substance of the agreement, and the State whose law is chosen, and

(ii) the parties' residences, interests, and resources, taking particular account of the resources and sophistication of the nondrafting party.

(6) If the choice-of-law clause is not valid under this Section, the applicable law is determined according to the other provisions of Part III.

\section{Chapter 2}

Title to and Transfer of Rights

\section{$\S 311$. Initial Title to Registered Rights}

(1) Initial title to rights that arise out of registration is governed by the law of each State of registration, except as provided in subsection (2).

(2) When the subject matter of the registered right arises out of a contractual or other preexisting relationship between or among the parties, initial title is governed by the law that governs the contract or relationship.

\section{$\S 312$. Initial Title to Unregistered Trademark and Trade-Dress Rights}

(1) Initial title to an unregistered trademark or trade dress is governed by the law of each State in which the trademark or trade dress identifies and distinguishes the source of the goods or the services, except as provided in subsection (2).

(2) When there is a contractual or other preexisting relationship among the parties, the law applicable to that contract or relationship will govern initial title.

\section{$\S$ 313. Initial Title to Other Rights That Do Not Arise Out of Registration}

(1) Initial title to other rights that do not arise out of registration is governed by:

(a) If there is one creator, the law of the creator's residence at the time the subject matter was created;

(b) If there is more than one creator:

(i) the law of one of the creators' residences, as designated by contract between or among the creators; 
(ii) if no contract resolves the issue, the law of the State in which the majority of the creators resided at the time of the creation of the subject matter;

(iii) if no contract resolves the issue and a majority of the creators did not reside in the same State, the law of the State with the closest connection to the first exploitation of the subject matter; or

(c) If the subject matter was created pursuant to an employment relationship, the law of the State that governs the relationship; or

(2) If the State whose law would govern under subsection (1) does not extend protection to the subject matter, then initial title is governed by the law of the first State in which the subject matter is exploited and the right is recognized.

\section{$\S 314$. Transferability}

(1) The intellectual property law of each State for which rights are transferred governs the extent of their transferability for each State.

(2) The law of each state for which rights are transferred determines any recordation rules relating to the transfer, and the effect, if any, of failure to comply with them.

\section{$\S 315$. Transfers of Title and Grants of Licenses}

(1) Except as provided in subsection (3), $\S 314$, and $\S \S 316-317$, the contract law of the State designated by agreement of the parties governs a transfer of interest in, or grant or license of, intellectual property rights.

(2) In the absence of a choice-of-law agreement, the contract law of the State with the closest connection to the contract governs. The contract is presumed to be most closely connected to the State in which the assignor or the licensor resided at the time of the execution of the contract.

(3) (a) In standard form agreements of transfer or licenses, the contract law of the State designated in the contract governs if the choice-of-law provision is valid in light of the factors set out in $\S 302(5)$.

(b) If the choice-of-law clause is not valid under this Section, the applicable law is determined according to subsection (2).

\section{$\S 316$. Transfers by Operation of Law (Involuntary Transfers)}

(1) For rights that arise out of registration, the law of the State of registration governs transfers by operation of intellectual property law. 
(2) For rights that do not arise out of registration, transfer by operation of law is determined by the intellectual property law of the State for which protection is sought.

\section{$\S 317$. Security Interests}

(1) The laws pertaining to the existence, attributes, and the extent of transferability of intellectual property rights are applicable with respect to secured transactions to the same extent that they apply to other transactions involving intellectual property rights.

(2) These Principles do not address the law applicable to the perfection, priority, or enforcement of security interests in intellectual property rights.

\section{Chapter 3}

\section{Residual Principles Regarding Choice of Law}

\section{$\S 321$. Law or Laws to Be Applied in Cases of Ubiquitous Infringement}

(1) When the alleged infringing activity is ubiquitous and the laws of multiple States are pleaded, the court may choose to apply to the issues of existence, validity, duration, attributes, and infringement of intellectual property rights and remedies for their infringement, the law or laws of the State or States with close connections to the dispute, as evidenced, for example, by:

(a) where the parties reside;

(b) where the parties' relationship, if any, is centered;

(c) the extent of the activities and the investment of the parties; and

(d) the principal markets toward which the parties directed their activities.

(2) Notwithstanding the State or States designated pursuant to subsection (1), a party may prove that, with respect to particular States covered by the action, the solution provided by any of those States' laws differs from that obtained under the law(s) chosen to apply to the case as a whole. The court shall take into account such differences in determining the scope of liability and remedies.

\section{$\S 322$. Public Policy (ordre public)}

The application of particular rules of foreign law is excluded if such application leads to a result that is repugnant to public policy. 


\section{$\S 323$. Mandatory Rules}

The court may give effect to the mandatory rules of any State with which the dispute has a close connection.

\section{$\S 324$. Exclusion of the Renvoi}

Except as provided in $\S 202(3)(a)$, the law of any State declared applicable under these Principles does not include its choice-of-law rules.

\section{Part IV \\ Recognition and Enforcement of Foreign Judgments in Transnational Cases}

Chapter 1

In General

\section{$\S$ 401. Foreign Judgments to Be Recognized or Enforced}

(1) A court in which recognition or enforcement of a foreign judgment is sought shall first ascertain whether the rendering court applied these Principles to the case.

(a) If the rendering court applied the Principles, then the enforcement court shall recognize or enforce the judgment pursuant to these Principles.

(b) If the rendering court did not apply the Principles, then the enforcement court shall determine whether to recognize or enforce the judgment pursuant to its domestic rules on recognition and enforcement of foreign judgments.

(2) In order to be recognized or enforced, a foreign judgment must be final in the rendering State and not stayed by a court in that State.

(3) The preclusive effect given a foreign judgment shall be no greater than the preclusive effect of the judgment in the rendering State.

(4) For purposes of this Part IV of the Principles, a provisional or protective order rendered in accord with $\S 214(1)$ shall be considered a judgment entitled to recognition and enforcement.

\section{$\S$ 402. Default Judgments}

In addition to the provisions of $\S 403$, the enforcement court shall not enforce a foreign judgment that has been rendered in default of appearance unless the enforcement court determines that the rendering court's assertion of personal jurisdiction was consistent with the law of the rendering State. 


\section{$\S$ 403. Judgments Not to Be Recognized or Enforced}

(1) The enforcement court shall not recognize or enforce a judgment if it determines that:

(a) the judgment was rendered under a system that does not provide impartial tribunals or procedures compatible with fundamental principles of fairness;

(b) the judgment was rendered in circumstances that raise substantial and justifiable doubt about the integrity of the rendering court with respect to the judgment in question;

(c) the judgment was rendered without notice reasonably calculated to inform the defendant of the pendency of the proceeding in a timely manner;

(d) the judgment was obtained by fraud that had the effect of depriving the defendant of adequate opportunity to present its case to the rendering court;

(e) recognition or enforcement would be repugnant to the public policy in the State in which enforcement is sought;

(f) the rendering court exercised jurisdiction on the basis of a courtselection clause inconsistent with the safeguards set out in $\S 202(4)$;

(g) the rendering court exercised jurisdiction solely on a basis insufficient under $\S 207$; or

(h) the rendering court exercised jurisdiction in violation of the forum's own rules of judicial competence.

(2) The enforcement court need not recognize or enforce a judgment if it determines that:

(a) the rendering court exercised jurisdiction on a basis inconsistent with the norms of $\S \S 201,202(1)-(3), 203-206$;

(b) the rendering court chose a law inconsistent with the norms of $\S \S 301-324$;

(c) proceedings between the same parties and having the same subject matter are pending before the court designated by $\S 221$ or before a court cooperating in the adjudication or chosen for consolidation under $\S 222$; or

(d) the judgment is inconsistent with the judgment of the court designated by $\S 221$, or the actions were coordinated in accordance with $\S 222$ and the judgment is inconsistent with the judgment of the court of consolidation or of the courts that cooperated in resolving the dispute.

(3) Except with respect to judgments rendered in default of appearance, the enforcement court, in making any determination listed in subsections (1)(e)-(g) or (2), shall defer to the facts found by the rendering court. In other cases, the court shall make its own determinations of fact and law. 
Chapter 2

Remedies

\section{$\S$ 411. Monetary Relief}

If a foreign judgment is recognized by the enforcement court under these Principles:

(1) The rendering court's order awarding compensatory damages, including attorney's fees, costs, accounting for profits, and damages intended to compensate the plaintiff without requiring proof of actual damages, shall be enforced; and

(2) The rendering court's order awarding noncompensatory damages, including exemplary or punitive damages, shall be enforced at least to the extent that similar or comparable damages could have been awarded in the State of the enforcement court. The enforcement court shall take into account whether and to what extent the damages awarded by the rendering court are not punitive but serve to cover costs and expenses relating to the proceedings not otherwise covered by provisions relating to the award of attorney's fees.

\section{$\S$ 412. Injunctions}

(1) (a) Except as provided in subsection (1)(b), if a foreign judgment is recognized by the enforcement court under these Principles, the rendering court's order awarding an injunction as a remedy for intellectual property infringement shall be enforced in accord with the procedures available to the enforcement court.

(b) If injunctive relief would not have been available for the enforcement court's territory had the enforcement court been the rendering court and reached the same decision on the merits, the enforcement court may decline to enjoin or to order the commission of acts within the territory that impact exclusively within the territory. If the court so limits the scope of the injunction, it shall award monetary relief in lieu of the injunction.

(2) The enforcement court may order such other relief as provided in the judgment, including seizure and destruction of infringing articles and the means of their manufacture or reproduction and to order the publication of the judgment.

$\S$ 413. Declarations of Validity, Invalidity, Infringement, and Ownership of Rights

(1) Except as provided in subsection (2), declarations by a foreign court of validity, invalidity, infringement, or ownership of intellectual property rights shall be recognized and enforced by the enforcement court.

(2) If a court in one State declares that a right registered in another State is invalid, the declaration is effective only to resolve the dispute between or among the parties to the litigation. 
Annex II

Principles for Conflict of Laws

in Intellectual Property

\author{
Prepared by the \\ European Max-Planck Group \\ on Conflict of Laws in Intellectual Property
}

Second Preliminary Draft

June 6, 2009 


\section{About the draft and the project}

This draft of principles has been prepared by the European Max-Planck Group on Conflict of Laws in Intellectual Property (CLIP).

CLIP is a group of scholars in the fields of intellectual property and private international law. It was established in 2004 and meets regularly to discuss issues of intellectual property, private international law, jurisdiction and enforcement. The group is funded by the Max Planck Society. The group's primary goal is to draft a set of principles for conflict of laws in intellectual property. CLIP also provides independent advice to European and national law makers.

Once the principles are published in a final version, they may serve for different purposes. They may be used to interpret or supplement international and domestic law. They may also serve as a model for national and international legislators. Finally, they may assist parties in shaping their contractual and extra-contractual dealings including the resolution of disputes.

This is the second preliminary draft of the principles that is available to the public. Everybody is invited to make suggestions or advance critical remarks to the members of the group. We expect the final version of the principles to be published together with comments in 2010 .

For any comments please contact Annette Kur (annette.kur@ip.mpg.de), Axel Metzger (metzger@iri.uni-hannover.de), or Christian Heinze (heinze@ mpipriv.de).

\section{Members of the Group}

Professor Dr. Dr. h.c. Jürgen Basedow

Hamburg

Professor Dr. Graeme Dinwoodie

Chicago/Oxford

Professor Dr. Josef Drexl

Munich

Dr. Mireille van Eechoud

Amsterdam

Professor Dr. Jean-Christophe Galloux

Paris

Dr. Christian Heinze

Hamburg

Dr. Nadine Klass

Munich

Professor Dr. Annette Kur

Munich

Professor Dr. Axel Metzger

Hanover

Professor Dr. Pedro Alberto de Miguel Asensio

Madrid

Thomas Petz

Munich

Professor Dr. Alexander Peukert

Frankfurt

Professor Dr. Heiki Pisuke

Tartu

Professor Dr. Paul Torremans

Nottingham/Gent 


\section{Past events}

The group organized two conferences and twelve working group meetings:

"Symposium on Jurisdiction and Choice of Law in Intellectual Property Matters - Perspectives for the Future (EU and World-Wide)", International Conference organized by the Max Planck Institute for Intellectual Property, Competition and Tax Law, Frauenchiemsee, July 20-22, 2003.

"Intellectual Property in the Conflict of Laws", International Conference coorganized by the Max Planck Institute for Foreign Private and Private International Law and the Max Planck Institute for Intellectual Property and Tax Law, Hamburg, March 2-3, 2004.

CLIP Working Group Meeting

CLIP Working Group Meeting

CLIP Working Group Meeting

CLIP Working Group Meeting

CLIP Working Group Meeting

CLIP Working Group Meeting

CLIP Working Group Meeting

CLIP Working Group Meeting

CLIP Working Group Meeting

CLIP Working Group Meeting

CLIP Working Group Meeting

CLIP Working Group Meeting
Munich, December 10, 2004.

Hamburg, July 19, 2005.

Amsterdam, February 18, 2006.

Paris, September 9, 2006.

New York, December 1-2, 2006.

Florence, April 3-4, 2007.

Munich, July 9-10, 2007

Hamburg, January 25-26, 2008.

Madrid, March 27-29, 2008.

Stockholm, August 29-30, 2008.

Munich, December 5-6, 2008.

Hamburg, June 5-6, 2009.

\section{Upcoming events}

The next events of the group will be:

Presentation of the Second Preliminary Draft of CLIP Principles, Munich, October 23-24, 2009. 


\section{Draft CLIP Principles}

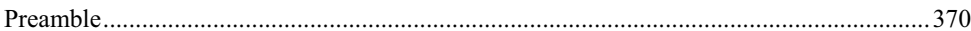

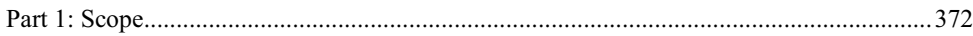

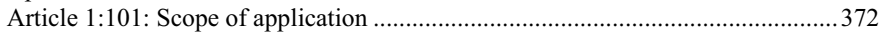

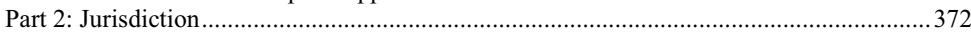

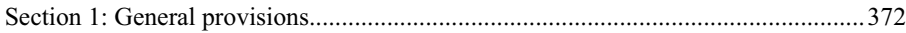

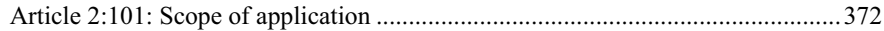

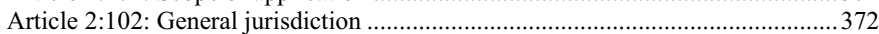

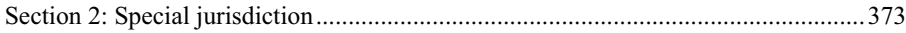

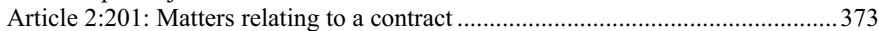

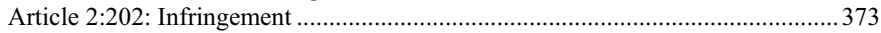

Article 2:203: Extent of jurisdiction over infringement claims .............................374

Article 2:204: Civil claims arising out of criminal proceedings ............................. 374

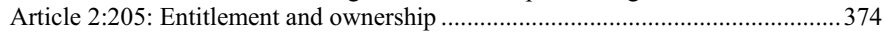

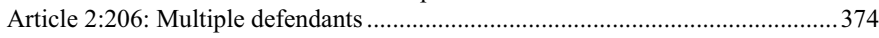

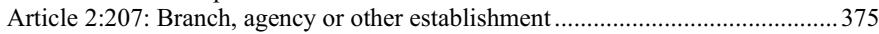

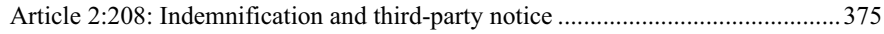

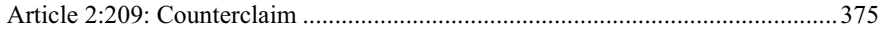

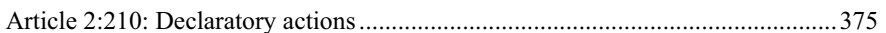

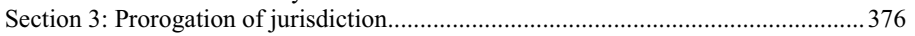

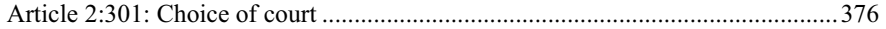

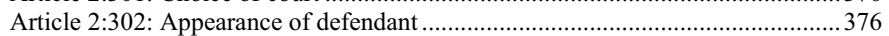

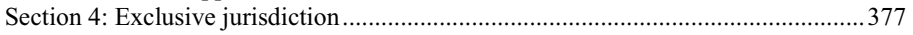

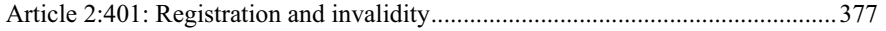

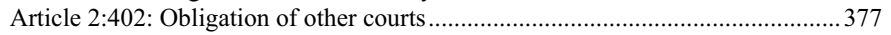

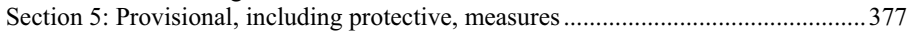

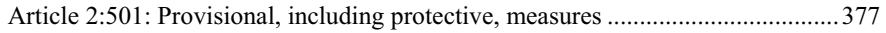

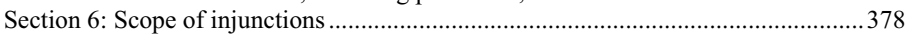

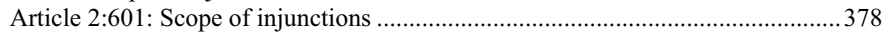

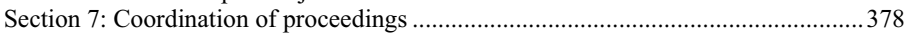

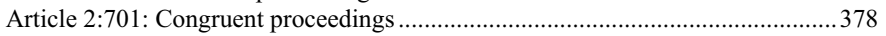

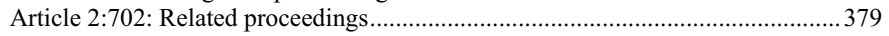

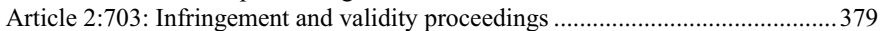

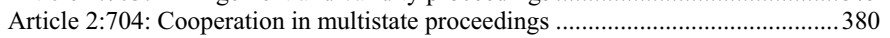

Article 2:705: Congruent and related preliminary proceedings ...............................38

Article 2:706: Time when a court is deemed to be seized .......................................380

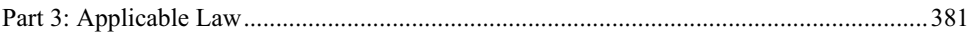

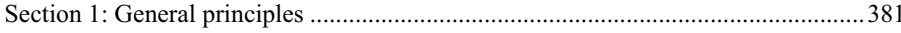

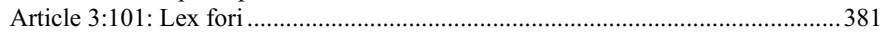

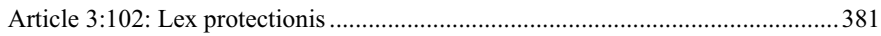

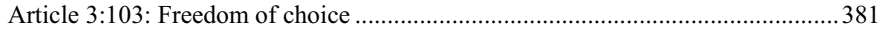

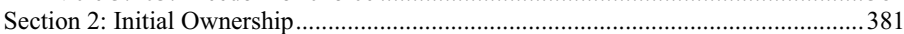

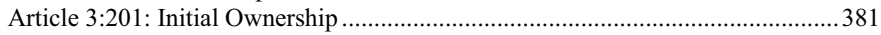

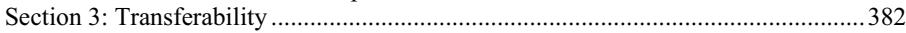

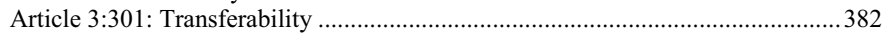

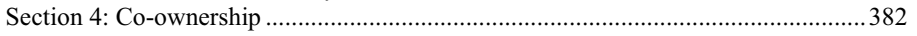

Article 3:401: Initial co-ownership and transferability of shares...........................382

Article 3:402: Relations between the co-owners ................................................. 382 


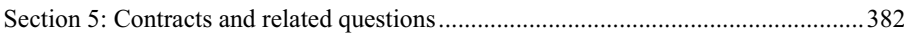

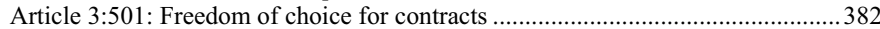

Article 3:502: Applicable law in the absence of choice........................................... 383

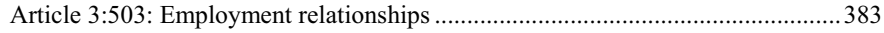

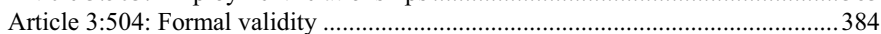

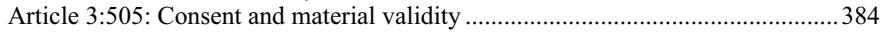

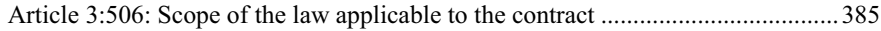

Article 3:507: Transfers by operation of law and compulsory licenses ....................385

Article 3:508: Law applicable to security interests in intellectual property rights.. 385

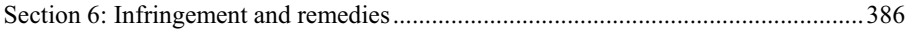

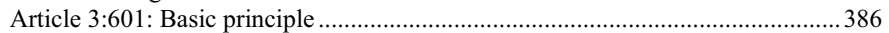

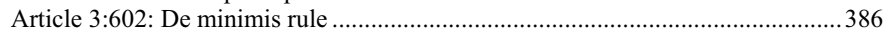

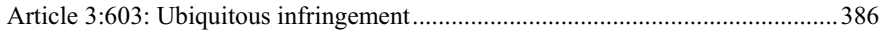

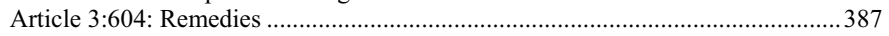

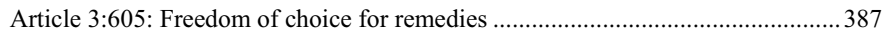

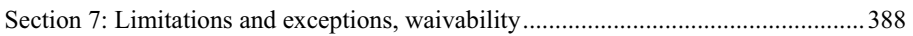

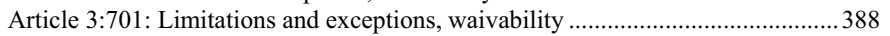

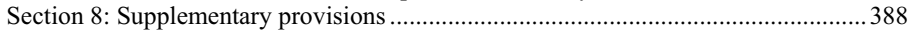

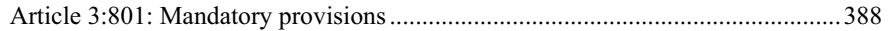

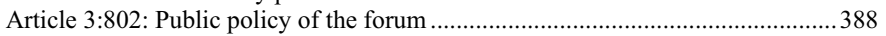

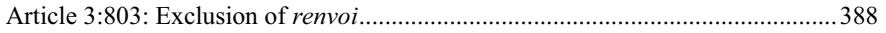

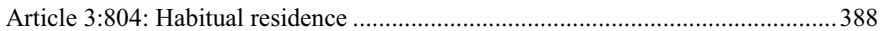

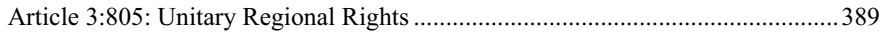

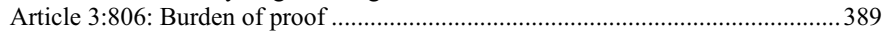

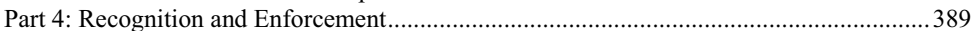

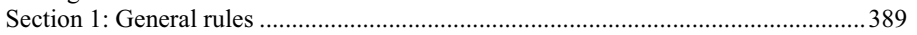

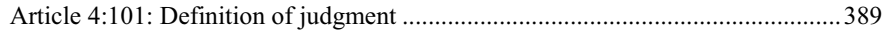

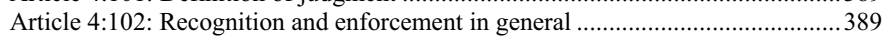

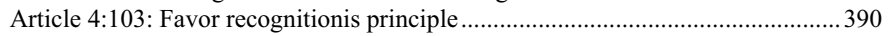

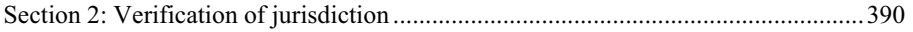

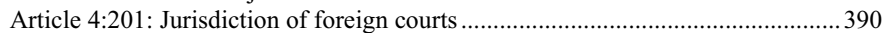

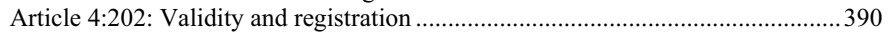

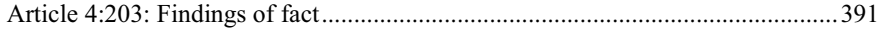

Article 4:204: Jurisdictional rules protecting consumers or employees...................391

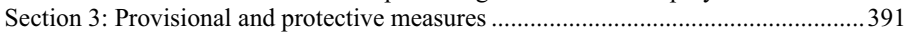

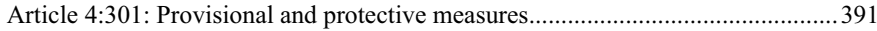

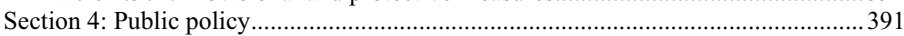

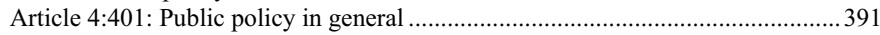

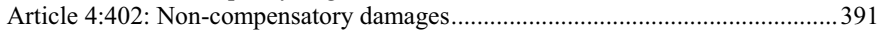

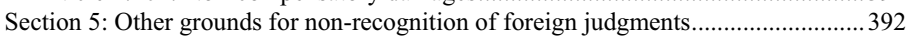

Article 4:501: Other grounds for non-recognition of foreign judgments ................ 392

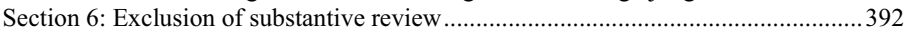

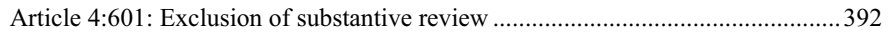

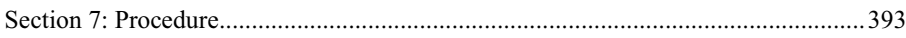

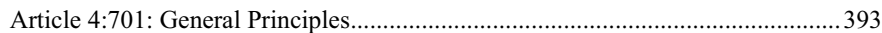

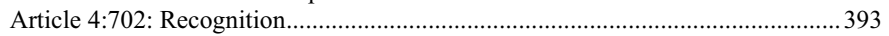

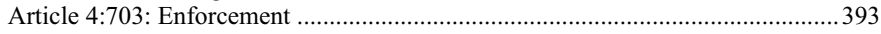

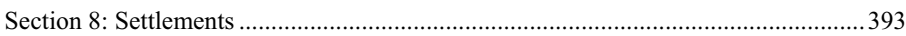

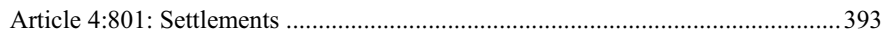




\section{Preamble}

Building on existing rules and initiatives regarding private international law and intellectual property, these Principles

aim

at reducing distortions and impediments to international trade involving intellectual property rights and facilitating the flow of information and cultural exchange across borders;

aim

at fostering judicial co-operation with regard to international disputes concerned with intellectual property rights, based on international comity and mutual trust;

aim

at improving the legal situation of plaintiffs and defendants to enforce, and to defend themselves against, claims concerned with intellectual property rights on an international scale;

\section{acknowledge}

that it is therefore necessary to provide legal certainty and predictability as to the jurisdiction of courts and the applicable law as well as to facilitate the recognition and enforcement of judgments concerned with intellectual property rights;

recognize

the need to consider and balance all interests involved, including the interests of owners of intellectual property rights, their contracting partners, and other users of intellectual property, and the broader public interest, in particular in access to, and use of, information as well as other public interests;

recognize

that intellectual property rights are private rights, limited in their exercise and enforcement to specific territories, and that each sovereign State is free, subject to international obligations, to regulate whether and under which conditions intangible goods shall enjoy legal protection;

recognize

the freedom of private parties to choose the competent court and the applicable law whenever that is appropriate. 
These Principles may be used to interpret or supplement international and domestic law including the law of regional organizations for economic integration where applicable.

They may serve as a model for national, regional and international legislators.

They may assist parties in shaping their contractual and extra-contractual dealings including the resolution of disputes. 


\section{Part 1: Scope}

\section{Article 1:101: Scope of application}

(1) These are Principles on international jurisdiction, the applicable law and the enforcement of foreign judgments. They do not apply to purely domestic situations.

(2) These Principles apply to civil matters involving intellectual property rights. For the purpose of these Principles, intellectual property rights are copyrights, moral rights, neighbouring rights, patents, marks, industrial design rights and similar exclusive rights.

(3) These Principles may also be applied mutatis mutandis to

(a) the protection of undisclosed information and geographical indications or similar forms of protection or

(b) disputes involving allegations of unfair competition arising from the same set of facts as relating allegations involving intellectual property rights.

(4) Subject to domestic procedural law, a court shall, upon a party's timely request or of its own motion, make a specific finding as to whether a dispute before it falls within the scope of the Principles.

\section{Part 2: Jurisdiction}

\section{Section 1: General provisions}

\section{Article 2:101: Scope of application}

Without prejudice to specific jurisdictional rules of the forum protecting consumers and employees, the following rules shall govern the jurisdiction for claims under these Principles.

\section{Article 2:102: General jurisdiction}

(1) Subject to these Principles, a person may be sued in the courts of any State in which the person is habitually resident.

(2) For the purposes of this Part, the habitual residence of a natural person acting in the course of a business activity shall be the principal place of business. 
(3) For the purposes of this Part, a company or other legal person or association of natural or legal persons shall have its habitual residence in any State

(a) where it has its statutory seat or registered office, or

(b) where it has its central administration, or

(c) where it has its principal place of business.

If the entity lacks a statutory seat or registered office, it may also be sued in the State where it was incorporated or, if no such place exists, under whose law it was formed.

(4) The principal place of business shall be the place from which the main business activities are conducted.

\section{Section 2: Special jurisdiction}

\section{Article 2:201: Matters relating to a contract}

(1) In disputes concerned with contractual obligations, a person may be sued in the courts of the State where the obligation in question is to be performed.

(2) In disputes concerned with contracts having as their main object the transfer or license of an intellectual property right, the State where the obligation in question is to be performed shall be, for the purpose of this provision and unless otherwise agreed, the State for which the license is granted or the right is transferred. When this provision offers the sole basis of jurisdiction, the court shall have jurisdiction only with respect to activities relating to the license or transfer of the intellectual property right for that particular State.

(3) In disputes concerned with infringement claims arising out of a contractual relationship between the parties, a court having jurisdiction with regard to the contract shall also have jurisdiction in respect of the infringement, without prejudice to Article 2:202.

\section{Article 2:202: Infringement}

(1) In disputes concerned with infringement of an intellectual property right, a person may be sued in the courts of the State where the alleged infringement occurs or may occur.

(2) For the purposes of paragraph 1, an infringement occurs in a State where the intellectual property right exists, provided that 
(a) the defendant has substantially acted or has taken substantial preparatory action in that State to initiate or further the infringement, or

(b) the activity by which the right is claimed to be infringed has substantial effect within, or is directed to, the territory of that State.

\section{Article 2:203: Extent of jurisdiction over infringement claims}

(1) Subject to paragraph 2, a court whose jurisdiction is based on Article 2:202 shall have jurisdiction in respect of infringements that occur or may occur within the territory of the State in which that court is situated.

(2) In disputes concerned with infringement carried out through ubiquitous media such as the Internet, the court whose jurisdiction is based on Article 2:202 shall also have jurisdiction in respect of infringements that occur or may occur within the territory of any other State, provided that the infringement has no substantial effect in the State, or any of the States, where the infringer is habitually resident (Article 2:102) and

(a) substantial activities in furtherance of the infringement in its entirety have been carried out within the territory of the country in which the court is situated, or

(b) the harm caused by the infringement in the State where the court is situated is substantial in relation to the infringement in its entirety.

\section{Article 2:204: Civil claims arising out of criminal proceedings}

As regards civil claims for remedies for infringements giving rise to criminal proceedings, a court seized with those proceedings shall have jurisdiction with regard to the infringement to the extent prescribed in Article 2:203, and provided that that court has jurisdiction under its own law to entertain civil proceedings.

\section{Article 2:205: Entitlement and ownership}

As regards entitlement and ownership of an intellectual property right, the State where the right exists or for which an application is pending shall have jurisdiction.

\section{Article 2:206: Multiple defendants}

(1) A person who is one of a number of defendants may also be sued in the 
courts of the place where any of the defendants is habitually resident, provided the claims are so closely connected that it is expedient to hear and determine them together to avoid the risk of irreconcilable judgments resulting from separate proceedings. For the purposes of this provision, a risk of irreconcilable judgments exists in disputes involving essentially the same legal and factual situation.

(2) In disputes concerned with infringements committed by several persons, paragraph 1 confers jurisdiction only on the courts in the State of the habitual residence of the defendant who coordinated the activities leading to the infringements or is otherwise most closely connected with the dispute in its entirety.

\section{Article 2:207: Branch, agency or other establishment}

In disputes arising out of the operations of a branch, agency or other establishment, a person may be sued in the courts of the place in which in the branch, agency or other establishment is situated.

\section{Article 2:208: Indemnification and third-party notice}

Subject to the applicable procedural law, a person may be sued as a third party in an action for warranty or guarantee or in any other third party proceedings, in the court seized of the original proceedings, unless these were instituted solely with the object of removing her/him from the jurisdiction of the court which would be competent in this case. If the national procedural law establishes a system of third-party notice, a person may be subject to a thirdparty notice in the court seized with the main proceedings.

\section{Article 2:209: Counterclaim}

Subject to Article 2:401, a court which has jurisdiction to determine a claim under these Principles shall also have jurisdiction to determine a counterclaim arising out of the same set of facts on which the original claim is based.

\section{Article 2:210: Declaratory actions}

Subject to Article 2:401, an action for a declaratory judgment may be based on the same ground of jurisdiction as a corresponding action seeking substantive relief. 


\section{Section 3: Prorogation of jurisdiction}

\section{Article 2:301: Choice of court}

(1) If the parties have agreed that a court or the courts of a State are to have jurisdiction to settle any disputes which have arisen or which may arise in connection with a particular legal relationship, that court or those courts shall have jurisdiction to decide on all contractual and non-contractual obligations and all other claims arising from that legal relationship unless the parties express an intent to restrict the court's jurisdiction. Such jurisdiction shall be exclusive unless the parties have agreed otherwise.

(2) Subject to paragraphs 3 to 5, the validity of a choice of court agreement shall be determined according to the national law of the State of the designated court or courts.

(3) An agreement conferring jurisdiction shall be either

(a) in writing or evidenced in writing; any communication by electronic means which provides a durable record of the agreement shall be equivalent to "writing"; or

(b) in a form which accords with the practices which the parties have established between themselves; or

(c) in international trade or commerce, in a form which accords with a usage of which the parties are or ought to have been aware and which in such trade or commerce is widely known to, and regularly observed by, parties to contracts of the type involved in the particular trade or commerce concerned.

(4) Agreements shall have no legal force if the courts whose jurisdiction they purport to exclude have exclusive jurisdiction by virtue of Article 2:401.

(5) A choice of court agreement that forms part of a contract shall be treated as an agreement independent of the other terms of the contract.

\section{Article 2:302: Appearance of defendant}

Apart from jurisdiction derived from other provisions of the Principles, a court or the courts of a State before which a defendant enters an appearance shall have jurisdiction. This rule shall not apply where appearance was entered to contest the jurisdiction, or where another court has exclusive jurisdiction by virtue of Article 2:401. 


\section{Section 4: Exclusive jurisdiction}

\section{Article 2:401: Registration and invalidity}

(1) In disputes having as their object a judgment on the grant, registration, validity, abandonment or revocation of a patent, a mark, an industrial design or any other intellectual property right protected on the basis of registration, the courts in the State where the right has been registered or is deemed to have been registered under the terms of an international Convention shall have exclusive jurisdiction.

(2) Paragraph 1 does not apply where validity or registration arises in a context other than by principal claim or counterclaim. The decisions resulting from such disputes do not affect the validity or registration of those rights as against third parties.

\section{Article 2:402: Obligation of other courts}

Where a court of a State is seized of a claim which has as its object a matter over which the courts of another State have exclusive jurisdiction by virtue of Article 2:401, it shall declare of its own motion that it has no jurisdiction.

\section{Section 5: Provisional, including protective, measures}

Article 2:501: Provisional, including protective, measures

(1) A court having jurisdiction in accordance with Articles 2:102 to 2:401 also has jurisdiction to order any provisional, including protective, measures.

(2) Provisional, including protective, measures may also be ordered by the courts of a State

(a) where the measure is to be enforced, or

(b) for which protection is sought.

(3) The measures referred to in paragraphs 1 and 2 shall cease to apply when the court of the State having jurisdiction under these Principles as to the substance of the matter has taken the measures it considers appropriate. Such measures may include a refusal of provisional relief.

(4) Provisional, including protective, measures are measures which are intended to preserve a factual or legal situation so as to safeguard rights the recognition of which is otherwise sought from the court having jurisdiction as to the substance of the case. Such measures may include 
(a) orders to prevent an (imminent or continuing) infringement of an intellectual property right from occurring;

(b) orders to preserve relevant evidence in regard to the alleged infringement;

(c) orders to seize goods suspected of infringing an intellectual property right;

(d) orders to seize, attach or prevent the dissipation or removal from the jurisdiction of assets to safeguard enforcement of the judgment on the merits; and

(e) orders directing a party to provide information about the location of assets which are subject of an order under lit. (d).

\section{Section 6: Scope of injunctions}

\section{Article 2:601: Scope of injunctions}

(1) An injunction issued in a court of competent jurisdiction shall concern only activities affecting intellectual property rights protected under the national law or laws applied by the court.

(2) However, an injunction concerning conduct carried out through ubiquitous media such as the Internet shall be presumed to concern intellectual property rights protected in all States where the signals can be received. This rule does not apply to activities whose impact is strictly limited to a State or States whose law has not been applied in the judgment.

\section{Section 7: Coordination of proceedings}

\section{Article 2:701: Congruent proceedings}

(1) Where proceedings involving the same cause of action and between the same parties are brought in the courts of different States, any court other than the court first seized shall stay its proceedings unless

(a) the court later seized has exclusive jurisdiction under these Principles, or

(b) it is manifest that the judgment from the court first seized will not be recognized under these Principles.

(2) Any court other than the court first seized may terminate the stay of its proceedings if 
(a) the proceedings in the court first seized do not proceed within reasonable time, or

(b) the court first seized has decided not to hear the case.

(3) Provisional and protective measures do not involve the same cause of action as main proceedings.

\section{Article 2:702: Related proceedings}

(1) Where related proceedings are pending in the courts of different States, any court other than the court first seized may stay its proceedings.

(2) In determining whether to stay proceedings according to paragraph 1 , the court or the courts later seized shall take all relevant factors into account, in particular

(a) which court seized is best placed to adjudicate the fullest scope of the related proceedings under these Principles;

(b) which State has the closest connection to the dispute;

(c) the procedural efficiency of centralized adjudication versus procedural efficiency of cooperation in multistate proceedings.

(3) For the purposes of this Section, proceedings are deemed to be related where they are so closely connected that it is expedient to hear and determine them together in order to avoid the risk of inconsistent holdings or judgments.

\section{Article 2:703: Infringement and validity proceedings}

(1) If proceedings having as their object a judgment on the grant, registration, validity, abandonment or revocation of a patent, a mark, an industrial design or any other intellectual property right protected on the basis of registration are brought in the State of registration after related proceedings in a court of another State concerned with that intellectual property right, the court first seized may stay its proceedings.

(2) Where the court first seized stays the proceedings, it may order provisional and protective measures for the duration of the stay according to Article 2:501. 


\section{Article 2:704: Cooperation in multistate proceedings}

(1) If congruent or related proceedings are or have been pending in different States, the courts seized may, subject to applicable procedural law, take into account

(a) evidence produced in another proceeding,

(b) a finding of another court on the validity or invalidity of an intellectual property right,

(c) any other finding of another court relevant for the pending proceeding.

(2) In order to facilitate cooperation, prevent inconsistent holdings and judgments and promote efficiency in multistate proceedings, the courts seized should cooperate with each other. In particular, they should take all appropriate measures to provide information to the courts seized as to the status of their proceeding and their findings. The courts concerned may proceed to an exchange of views.

\section{Article 2:705: Congruent and related preliminary proceedings}

(1) Where proceedings having as their object provisional or protective measures according to Article 2:501 and involving the same cause of action between the same parties are brought in the courts of different States under these Principles, any court other than the court first seized may stay its proceedings.

(2) Where related proceedings having as their object provisional or protective measures according to Article 2:501, the courts seized may cooperate according to Article 2:704.

\section{Article 2:706: Time when a court is deemed to be seized}

For the purposes of the Principles, a court shall be deemed to be seized:

(1) at the time when the document instituting the proceedings or an equivalent document is lodged with the court, provided that the plaintiff has not subsequently failed to take the steps she/he was required to take to have service effected on the defendant, or

(2) if the document has to be served before being lodged with the court, at the time when it is received by the authority responsible for service, provided that the plaintiff has not subsequently failed to take the steps she/he was required to take to have the document lodged with the court. 


\section{Part 3: Applicable Law}

\section{Section 1: General principles}

\section{Article 3:101: Lex fori}

The law applicable to procedural matters, including procurement of evidence, is the law of the State where the court seized with the proceedings is situated.

\section{Article 3:102: Lex protectionis}

The law applicable to existence, validity, scope and duration of an intellectual property right and all other matters concerning the right as such is the law of the State for which protection is sought.

\section{Article 3:103: Freedom of choice}

Parties may choose the applicable law in the cases specified in Articles 3:501, Art. 3:503 and 3:605.

\section{Section 2: Initial Ownership}

\section{Article 3:201: Initial Ownership}

(1) Initial ownership including in particular authorship of a copyrighted work and entitlement to intellectual property rights arising out of registration is governed by the law of the State for which protection is sought.

(2) If the situation has a close connection with another State that has a work made for hire provision or deems a transfer or exclusive license of all economic rights in the work to have taken place by virtue of the parties' contractual relationship, effect may be given to such rules by constructing the parties' relationship under the law applicable according to paragraph 1 as involving a transfer or exclusive license of all economic rights in the work.

(3) In the framework of a contractual relationship, in particular an employment contract or a research and development contract, the law applicable to the right to claim a registered right is determined in accordance with Section 5. 


\section{Section 3: Transferability}

\section{Article 3:301: Transferability}

The transferability of intellectual property rights and the question whether the transfer or license can be invoked against third parties shall be determined by the law of each State for which protection is sought.

\section{Section 4: Co-ownership}

\section{Article 3:401: Initial co-ownership and transferability of shares}

Initial co-ownership and transferability of the shares of each co-owner shall be governed by the law of the State for which protection is sought.

\section{Article 3:402: Relations between the co-owners}

Relations between the co-owners, in particular the licensing, waiver, consent and any other form of exploitation, the division of revenues, the authority to enforce the intellectual property rights and to bring suits, shall be governed by the law applicable to the parties' relationship such as contract, corporate agreements, succession or marriage. Otherwise the law with the closest connection shall apply.

\section{Section 5: Contracts and related questions}

\section{Article 3:501: Freedom of choice for contracts}

(1) Transfer, license agreements and other contracts relating to an intellectual property right shall be governed by the law chosen by the parties. The choice must be expressed or demonstrated with reasonable certainty by the terms of the contract or the parties' conduct in the circumstances of the case. If the parties have agreed to confer jurisdiction on a court of a State to hear and determine disputes that have arisen or may arise out of the contract, they shall be presumed to have chosen the law of that State. By their choice the parties can select the law applicable to the whole or a part only of the contract.

(2) The parties may at any time agree to subject the contract to a law other than the law that previously governed it, whether as a result of an earlier choice under this Article or of other provisions of these Principles. Any change in the law to be applied that is made after the conclusion of the contract shall not prejudice its formal validity or adversely affect the rights of third parties. 
(3) The existence and validity of the consent of the parties as to the choice of law shall be determined in accordance with Articles 3:504 and 3:505.

\section{Article 3:502: Applicable law in the absence of choice}

(1) In the absence of a contractual choice of law in accordance with Article 3:501, the contract shall be governed by the law of the State with which the contract is most closely connected.

(2) In contracts having as their main object the creation of protectable subject matter or the transfer or license of intellectual property rights, the court shall take into consideration in determining the State with the closest connection:

(a) as factors tending to the law of the State in which the transferee or licensee has its habitual residence at the time of conclusion of the contract:

- the transferee or licensee has the explicit or implicit duty to exploit the right;

- the rights are mainly exercised in the State of the transferee's or licensee's habitual residence or place of business;

- the royalties or other form of money consideration is expressed as a percentage of the sales price;

- the licensee or transferee has a duty to report about her/his efforts to exploit the rights;

(b) as factors tending to the law of the State in which the creator, transferor or licensor has its habitual residence at the time of conclusion of the contract:

- the transferee or licensee has no other explicit or implicit duty but to pay a flat sum as money consideration;

- the rights are mainly exercised in the State of the transferor's or licensor's habitual residence or place of business;

- the license is for a single use;

- the creator of the protectable subject matter has the duty to create that matter.

\section{Article 3:503: Employment relationships}

(1) The mutual obligations of employer and employee in relation to the transfer or license of an intellectual property right arising from the employee's efforts, in particular the right of the employer to claim the intellectual property right and the right of the employee to remuneration, 
shall be governed by the law chosen by the parties in accordance with Article 3:501. Such a choice of law may not, however, have the result of depriving the employee of the protection afforded to him by the provisions that cannot be derogated from by agreement under the law that, in the absence of choice, would have been applicable pursuant to paragraphs 2 and 3 of this Article.

(2) To the extent that the law has not been chosen by the parties, the mutual obligations of employer and employee in relation to the transfer or license of an intellectual property right arising from the employee's efforts, in particular the right of the employer to claim the intellectual property right and the right of the employee to remuneration, shall be governed by the law of the State in which or, failing that, from which the employee habitually carries out his work in performance of the contract. The country where the work is habitually carried out shall not be deemed to have changed if the employee is temporarily employed in another country.

(3) Where it appears from the circumstances as a whole that the contract is more closely connected with a State other than that indicated in paragraph 2, the law of that other State shall apply.

\section{Article 3:504: Formal validity}

A transfer or license grant of an intellectual property right, a contract relating to such transfer or license and any act intended to have legal effect relating to an existing or contemplated contract shall be formally valid to the extent that it satisfies the formal requirements

(a) of the law which governs it in substance under these Principles, or

(b) of the law of the State in which either of the parties or its agent is present at the time of the conclusion of the contract, or

(c) of the law of the State in which either of the parties is habitually resident at that time.

\section{Article 3:505: Consent and material validity}

(1) The existence and validity of a contract, or of any terms of a contract, shall be determined by the law which would govern the contract or term under these Principles if the contract or term were valid.

(2) Nevertheless, a party, in order to establish that she/he did not consent, may rely upon the law of the State in which she/he has her/his habitual residence if it appears from the circumstances that it would not be 
reasonable to determine the effect of her/his conduct in accordance with the law specified in the paragraph 1.

\section{Article 3:506: Scope of the law applicable to the contract}

(1) The law applicable to a contract by virtue of this Section shall govern in particular:

(a) interpretation;

(b) performance;

(c) the consequences of a total or partial breach of obligations, including avoidance of the contract and the assessment of damages;

(d) the various ways of extinguishing obligations, the prescription and limitation of actions;

(e) the consequences of nullity of the contract.

(2) In relation to the manner of performance and the steps to be taken in the event of defective performance, regard shall be had to the law of the State in which performance takes place.

(3) Questions of contract law not dealt with in these Principles such as consumer protection, incapacity, authority of an agent, set-off, assignment of other rights than intellectual property rights, legal subrogation, multitude of debtors and compensation between them as well as obligations arising from pre-contractual relationships shall be governed by the law applicable by virtue of the rules of private international law of the forum State.

\section{Article 3:507: Transfers by operation of law and compulsory licenses}

(1) The law applicable to transfers by operation of law and the duty to grant a license is the law of the State for which protection is sought.

(2) Articles 3:501 to 3:507 paragraph 1 do not apply to transfers by operation of law other than intellectual property law such as company, insolvency, succession or family law.

\section{Article 3:508: Law applicable to security interests in intellectual property rights}

The law applicable to security interests in intellectual property rights is the law applicable to the intellectual property right as determined by Article 
3:102. This does not affect the law applicable to the obligation to provide security and the law applicable to the obligation to be secured.

\section{Section 6: Infringement and remedies}

\section{Article 3:601: Basic principle}

(1) Unless otherwise provided in this Section, the law applicable to the infringement is the law of each State for which protection is sought.

(2) For the purpose of these provisions, "infringement" includes

(a) the violation of the intellectual property right, including contributory infringement;

(b) the remedies, as defined in Article 3:604.

\section{Article 3:602: De minimis rule}

(1) A court applying the law or the laws determined by Article 3:601 shall only find for infringement if

(a) the defendant has substantially acted or has taken substantial preparatory action to initiate or further the infringement in the State or the States for which protection is sought, or

(b) the activity by which the right is claimed to be infringed has substantial effect within, or is directed to the State or the States for which protection is sought.

(2) The court may exceptionally derogate from that general rule when reasonable under the circumstances of the case.

\section{Article 3:603: Ubiquitous infringement}

(1) In disputes concerned with infringement carried out through ubiquitous media such as the Internet, the court may apply the law or the laws of the State or the States having the closest connection with the infringement, if the infringement arguably takes place in every State in which the signals can be received.

(2) In determining which State has the closest connection with the infringement, the court shall take all the relevant factors into account, in particular the following:

(a) the infringer's habitual residence;

(b) the infringer's principal place of business; 
(c) the place where substantial activities in furthering of the infringement in its entiretyhave been carried out;

(d) the place where the harm caused by the infringement is substantial in relation to the infringement in its entirety.

(3) Notwithstanding the law applicable pursuant to paragraph 2, any party may prove that the rules applying in a State or States covered by the dispute differ from the law applicable to the dispute in aspects which are essential for the decision. The court shall apply the different national laws unless this leads to inconsistent judgments, in which case the differences shall be taken into account in fashioning the remedy.

\section{Article 3:604: Remedies}

For the purpose of these provisions, remedies shall include

(1) injunctions, damages, and other means of redress for injury caused or threatening;

(2) claims based on unjust enrichment and negotiorum gestio, to the extent they concern the non-contractual obligations arising out of the violation of an intellectual property right, without encompassing the violation as such;

(3) the question whether a right to claim damages or other remedies may be transferred, including by inheritance;

(4) various ways of extinguishing obligations, the prescription and limitation of actions.

\section{Article 3:605: Freedom of choice for remedies}

(1) In accordance with Article 3:501, the parties to a dispute concerning the infringement of an intellectual property right may agree to submit the remedies claimed for the infringement to the law of their choice by an agreement entered into before or after the dispute has arisen.

(2) If the infringement is closely connected with a pre-existent relationship between the parties, such as a contract, the law governing the pre-existing relationship shall also govern the remedies for the infringement, unless

(a) the parties have expressly excluded the application of the law governing the pre-existing relationship with regard to the remedies for infringement, or

(b) it is clear from the all the circumstances of the case that the claim is more closely connected with another State. 


\section{Section 7: Limitations and exceptions, waivability}

\section{Article 3:701: Limitations and exceptions, waivability}

(1) Limitations and exceptions are governed by the law of the State for which protection is sought.

(2) The waivability of limitations of, and exceptions to, an intellectual property right shall be determined by the law of the State for which protection is sought.

\section{Section 8: Supplementary provisions}

\section{Article 3:801: Mandatory provisions}

(1) When applying under these Principles the law of a country, effect may be given to the overriding mandatory provisions of another country with which the situation has a close connection. In considering whether to give effect to these overriding mandatory provisions, regard shall be had to their nature and purpose and to the consequences of their application or non-application.

(2) Overriding mandatory provisions are provisions the respect for which is regarded as crucial by a State for safeguarding its public interests, such as its political, social or economic organisation, to such an extent that they are applicable to any situation falling within their scope, irrespective of the law otherwise applicable under these Principles.

(3) Nothing in these Principles shall restrict the application of the overriding mandatory provisions of the law of the forum.

\section{Article 3:802: Public policy of the forum}

The application of a provision of the law of any State specified by these Principles may be refused only if such application is manifestly incompatible with the public policy (ordre public) of the forum.

\section{Article 3:803: Exclusion of renvoi}

The application of the law of any State specified by these Principles means the application of the rules of law in force in that State other than its rules of private international law.

\section{Article 3:804: Habitual residence}

(1) For the purpose of this Part, the habitual residence of companies and other 
bodies, corporate or unincorporated, shall be the place of central administration. The habitual residence of a natural person acting in the course of her/his business activity shall be her/his principal place of business.

(2) Where the relevant activities occur in the course of operation of a branch, agency or any other establishment, the place where the branch, agency or any other establishment is located shall be treated as the place of habitual residence.

\section{Article 3:805: Unitary Regional Rights}

Where the provisions of this Part are applied to unitary rights of intellectual property existing under the law of a Regional Organisation of Economic Integration, they are to be construed in such a way as to designate the pertinent law of the Organisation including its provisions on private international law.

\section{Article 3:806: Burden of proof}

The law applicable under this Part to the substance of the dispute shall apply to the extent that it contains rules which raise presumptions of law or determine the burden of proof.

\section{Part 4: Recognition and Enforcement}

\section{Section 1: General rules}

\section{Article 4:101: Definition of judgment}

For the purposes of these Principles, judgment means any judgment given by a court or tribunal of any State, irrespective of the name given by that State to the proceedings which gave rise to the judgment or of the name given to the judgment itself, such as decree, order, decision or writ of execution. It also includes the determination of costs or expenses by an officer of the court.

\section{Article 4:102: Recognition and enforcement in general}

(1) A judgment given by a foreign court shall be recognized and enforced in accordance with this Part of the Principles.

(2) In order to be recognized, a judgment must have in the State of origin the effect whose recognition is sought in the requested State. 
(3) The effect of the judgment is determined by the law of the State of origin. Subject to Article 4:601, the court in the State of recognition shall interpret the judgment in respect of its subjective, territorial and substantial scope and take into account any change of circumstances.

(4) In order to be enforceable, a judgment must be enforceable in the State of origin.

(5) Recognition or enforcement may be postponed or refused if an ordinary appeal against the judgment has been lodged in the State of origin or if the time limit for seeking ordinary review has not expired. A refusal does not prevent a subsequent application for recognition or enforcement of the judgment.

(6) If the foreign judgment contains elements which are severable, one or more of them may be separately recognized or enforced.

\section{Article 4:103: Favor recognitionis principle}

The provisions of Part 4 of the Principles shall not restrict the application of multilateral or bilateral agreements concerning the recognition and enforcement of judgments entered into by the State in which enforcement or recognition is sought nor deprive any interested party of any right he may have to avail himself of a judgment in the manner and to the extent allowed by the law or the treaties of that country including the rules of a regional integration organisation if that country is a Member State of the organisation.

\section{Section 2: Verification of jurisdiction}

\section{Article 4:201: Jurisdiction of foreign courts}

(1) A judgment shall not be recognized or enforced if there is no ground of jurisdiction under Part 2 of the Principles which would have allowed the foreign court to assert its jurisdiction.

(2) If the court of origin applied the Principles, it shall be presumed that the foreign judgment does not conflict with the rules established in Part 2.

\section{Article 4:202: Validity and registration}

Recognition and enforcement of a foreign judgment may not be refused on the ground that in the proceedings before the court of origin the validity or registration of an intellectual property right registered in a State other than the State of origin was challenged, provided that the recognition and enforcement produces effects only between the parties. 


\section{Article 4:203: Findings of fact}

In its examination of the grounds of jurisdiction according to Article 4:201 to $4: 202$, the authority of the requested State shall be bound by the findings of fact on which the authority of the State where the judgment was rendered based its jurisdiction.

\section{Article 4:204: Jurisdictional rules protecting consumers or employees}

Recognition and enforcement may be refused if the judgment is manifestly incompatible with specific jurisdictional rules protecting consumers or employees in the State of recognition.

\section{Section 3: Provisional and protective measures}

\section{Article 4:301: Provisional and protective measures}

(1) Provisional and protective measures adopted by a foreign court shall not be recognized and enforced if there is no ground of jurisdiction under Part 2 of these Principles, which would have allowed the foreign court to decide on the merits.

(2) Provisional and protective measures adopted without prior hearing of the adverse party and enforceable without prior service of process to that party shall not be recognized or enforced.

\section{Section 4: Public policy}

\section{Article 4:401: Public policy in general}

A judgment shall not be recognized or enforced if:

(1) such recognition or enforcement would be manifestly incompatible with the public policy of the requested State;

(2) the specific proceedings leading to the judgment were manifestly incompatible with fundamental principles of procedural fairness of the requested State.

\section{Article 4:402: Non-compensatory damages}

(1) Recognition and enforcement of a judgment may be refused if, and only to the extent that, the judgment awards damages, including exemplary or punitive damages, that do not compensate a party for actual loss or harm 
suffered and exceed the amount of damages that could have been awarded by the courts of the State where enforcement is sought.

(2) The court addressed shall take into account whether and to what extent the damages awarded by the court of origin serve to cover costs and expenses relating to the proceedings.

\section{Section 5: Other grounds for non-recognition of foreign judgments}

\section{Article 4:501: Other grounds for non-recognition of foreign judgments}

A judgment shall not be recognized or enforced if:

(1) the document which instituted the proceedings or an equivalent document was not notified to the defendant in sufficient time and in such a way as to enable her/him to arrange for her/his defence, unless the defendant entered an appearance and presented her/his case without contesting notification in the court of origin, provided that the law of the State of origin permitted notification to be contested;

(2) proceedings between the same parties and having the same cause of action are pending before a court of the requested State, provided that those proceedings were the first to be instituted;

(3) it is incompatible with a judgment given in the requested State between the same parties;

(4) it is incompatible with a judgment given in another State between the same parties and having the same cause of action, provided that this judgment fulfils the conditions necessary for its recognition in the requested State and it was given earlier or its recognition has already been declared in the requested State.

\section{Section 6: Exclusion of substantive review}

\section{Article 4:601: Exclusion of substantive review}

A foreign judgment may not be reviewed as to its substance or merits, without prejudice to the application of the provisions of this Part. 


\section{Section 7: Procedure}

\section{Article 4:701: General Principles}

(1) Recognition and enforcement procedures shall not be unnecessarily complicated or costly, or entail unreasonable time-limits or unwarranted delays.

(2) The requested court shall act expeditiously.

\section{Article 4:702: Recognition}

(1) A foreign judgment shall be recognised by operation of law and without any special procedure being required. Recognition may be raised as an incidental question and by way of counterclaim, cross-claim or defence.

(2) Without prejudice to paragraph 1, any interested party may request from the competent authorities of a State that they decide on the recognition or non-recognition of a foreign judgment. The procedure shall be governed by the law of the requested State.

(3) Recognition may be refused only for one of the reasons set out in this Part of the Principles.

\section{Article 4:703: Enforcement}

(1) The law of the requested State determines the methods by which a foreign judgment is declared enforceable.

(2) The declaration of enforceability may be refused only for one of the reasons set out in this Part of the Principles.

(3) Foreign judgments declared enforceable in the requested State shall be enforced as if they had been taken by the authorities of that State. Enforcement takes place in accordance with the law of the requested State to the extent provided by such law.

\section{Section 8: Settlements}

\section{Article 4:801: Settlements}

A settlement to which a court has given its authority shall be recognized and declared enforceable in the requested State under the same conditions as judgments, so far as those conditions apply to settlements. 


\title{
Annex III
}

\section{Transparency Proposal on Jurisdiction, Choice of Law, Recognition and Enforcement of Foreign Judgments in Intellectual Property \\ (October, 2009)}

\begin{abstract}
Scope
Article 001. Scope

(1) These legislative proposals apply to international civil disputes involving intellectual property rights and unfair competition. For the purpose of these legislative proposals, intellectual property rights are patent rights, utility model rights, plant breeder's rights, design rights, copyrights, trademark rights and similar exclusive rights.

(2) A court shall, upon a party's timely request or of its own motion, make a specific finding as to whether a dispute before it falls within the scope of the legislative proposals.
\end{abstract}

\section{Jurisdiction}

\section{Article 101. General Jurisdiction}

(1) Where the defendant is domiciled in Japan, Japanese courts shall have international jurisdiction over an action concerning intellectual property rights.

(2) Where the defendant had no domicile, or his/her domicile is unknown, Japanese courts shall have international jurisdiction, if he/she has residence in Japan.

(3) Where the defendant has no residence, or his/her residence is unknown, Japanese courts shall have international jurisdiction, if he/she had domicile in Japan prior to institution of an action ; provided, however, that this shall not apply where he/she had domicile in a foreign country after he/she had domicile in Japan. 


\section{Article 102. General Jurisdiction (Juridical Person)}

(1) Where the defendant is a juridical person or any other association or foundation, Japanese courts shall have international jurisdiction, if the defendant's principal office or establishment is in Japan.

(2) Where the defendant is a juridical person or any other association or foundation, Japanese courts shall have international jurisdiction, if the defendant has no principal office or establishment, or its principal office or establishment is unknown, and its representative or any other principal person in charge of its business had domicile in Japan.

\section{Article 103. Actions concerning Existence, Registration, Validity or Ownership of Intellectual Property Rights}

(1) Japanese courts shall have international jurisdiction over actions concerning the existence, registration, validity, or ownership of intellectual property rights prescribed under Japanese law (including intellectual property rights that are deemed to be granted under Japanese law pursuant to the provisions of an international treaty).

(2) Japanese courts shall have international jurisdiction over actions concerning the existence, registration, validity, or ownership of intellectual property rights prescribed under foreign law (including intellectual property rights that are deemed to be granted under foreign law pursuant to the provisions of an international treaty), provided that there is a ground to affirm the jurisdiction of Japanese courts.

(3) Judgments invalidating intellectual property rights prescribed under foreign law shall only be effective as between the parties to the action.

\section{Article 104. Actions Concerning Contracts relating to Intellectual Property}

Japanese courts shall have international jurisdiction over actions concerning contracts having as the object intellectual property rights prescribed under Japanese law (including intellectual property rights that are deemed to be granted under Japanese law pursuant to the provisions of an international treaty).

\section{Article 105. Jurisdiction over Intellectual Property Infringement}

Japanese courts shall have jurisdiction over intellectual property infringement claims of, when the results of an intellectual property infringement occurred or are to occur in Japan, or when an infringing act took place or is to take place in Japan, excluding "ubiquitous infringement" claims except the case where the results of an "ubiquitous infringement" are maximized or to be maximized in Japan. 


\section{Article 106. Jurisdiction (Place of Business)}

Where the defendant is a juridical person or any other association or foundation that has its office or establishment in Japan, Japanese courts shall have international jurisdiction, if the action relates to the business conducted at such office or establishment.

\section{Article 107. Choice of Court Agreements}

(1) Japanese courts shall have international jurisdiction over an action concerning intellectual property rights, where there is an agreement that Japanese courts shall have jurisdiction.

(2) An agreement in paragraph 1 (hereinafter referred to as "choice of court agreement") shall not be effective unless made in writing.

(3) If a choice of court agreement is made by means of an electromagnetic record (meaning a record made in an electronic form, a magnetic form or any other form not recognizable to human perception, which is used in information processing by computers), it shall be deemed to have been made in writing.

\section{Article 108. Jurisdiction by Appearance}

Japanese courts shall have international jurisdiction where, in a Japanese court of first instance, the defendant does not submit a defense of lack of international jurisdiction, and makes an oral argument, or a statement in preliminary proceedings, on the merits.

\section{Article 109. Exception based on Public-interest Policy}

Even if Japanese court can exercise its jurisdiction according to the previous provisions, the Japanese court may dismiss claims, when the claims are so closely related to other countries' public-interest policy and the proceeding in these countries is manifestly more appropriate than in Japan.

\section{Article 110. Joinder of Claims}

(1) In cases where multiple claims or counterclaims between the same parties are closely related, and Japanese courts have international jurisdiction over one of the claims, Japanese courts shall have international jurisdiction over the other claims or counterclaims as well; provided, however, that when Japanese courts shall have international jurisdiction in accordance with provisions regarding special jurisdiction, international jurisdiction of Japanese courts shall be limited to cases where the primary obligations should be or should have been performed in Japan, or where the primary facts occurred or should occur in Japan. 
(2) In cases of multiple claims against different defendants, or claims by multiple plaintiffs, where the claims are closely related to each other, and where Japanese courts have international jurisdiction over one of the claims, Japanese courts shall have international jurisdiction over the other claims as well; provided, however, that in regard to different defendants, international jurisdiction of Japanese courts shall be limited to persons who would ordinarily foresee that Japanese courts would have international jurisdiction over them.

(3) In cases of multiple claims against different defendants, where the intellectual property rights that are the basis for each claim have been granted in different countries, where Japanese courts have international jurisdiction over one of the claims, and where each of the intellectual property rights is substantively related to the others, Japanese courts shall have international jurisdiction over the other claims as well; provided, however, that when Japanese courts shall have international jurisdiction in accordance with provisions regarding special jurisdiction, international jurisdiction of Japanese courts shall be limited to cases where the primary obligations should be or should have been performed in Japan, or the primary facts occurred or should occur in Japan, and that in regard to different defendants, international jurisdiction of Japanese courts shall be limited to persons who would ordinarily foresee that Japanese courts would have international jurisdiction over them.

\section{Article 111. Jurisdiction to Order Provisional Measures}

(1) Japanese courts shall have international jurisdiction to order provisional measures, when Japanese courts have international jurisdiction over the case on the merits, or when the applications for provisional measures are based on intellectual property rights prescribed under the Japanese law.

(2) When the object to be provisionally seized is located in Japan, Japanese courts shall have international jurisdiction to order provisional seizure.

\section{Coordination of proceedings}

\section{Article 201. International Parallel Litigation}

(1) In cases where a suit is pending in a court in a foreign country and is based on the same cause of action as or the cause of action related to that in a lawsuit before the Japanese court, when the primary obligation should be or should have been performed in that foreign country, or the primary facts occurred or should occur in that foreign country, in the absence of special circumstances, the claim shall be dismissed. 
(2) In cases such as in the preceding paragraph, the court may stay the procedure for a reasonable period of time that the court determines, or until the suit in the foreign country is dismissed or the decision in the foreign country becomes final and conclusive. The previous sentence also applies, when the primary obligations should be or should have been performed in a foreign country other than that foreign country, or the primary facts occurred or should occur in a foreign country other than that foreign country.

(3) In cases where a proceeding concerning the validity of the intellectual property right that is the basis of the claim, is in progress in a foreign state authority, the court may stay the procedure for a reasonable period of time that the court determines, or until the foreign court renders a final decision.

(4) In cases in the previous three paragraphs, the court may communicate directly with, or may request information directly from, the court in the foreign country, in order to make the decision to dismiss the claim, stay the procedure or conduct the subsequent deliberations.

\section{Applicable law}

\section{Article 301. Intellectual Property Infringement}

(1) The law applicable to an intellectual property infringement shall be the law of the place where the results of the exploitation of intellectual property occur or are to occur.

(2) Regardless of Paragraph 1, the formation and effect of claims arising from the intellectual property infringement shall be governed by the law of the contract when intellectual property infringement occurred in breach of the obligations of the contract between the parties.

\section{Article 302. "Ubiquitous Infringement"}

(1) Intellectual property infringements where the alleged infringement act is "ubiquitous" shall be governed by the law of the place where the results of the exploitation of intellectual property are or to be maximized.

(2) If the result of the application of Paragraph 1 is extremely unreasonable in relation with specific country, the liability or remedy based on the law determined by paragraph 1 shall not be applied in relation to the specific country.

\section{Article 303. Unfair Competition}

The applicable law to unfair competition shall the law of the place where the results of unfair competition occur or are to occur. 


\section{Article 304. Change of Applicable Law by the Parties}

(1) The parties to an intellectual property infringement may, after the intellectual property infringement occurred, change the law governing the formation and effect of claims arising therefrom. However, if the change of the applicable law would prejudice the rights of a third party, the change may not be asserted against such third party.

(2) The parties to an unfair competition may, after the unfair competition occurred, change the law governing the formation and effect of claims arising therefrom. However, if the change of the applicable law would prejudice the rights of a third party, the change may not be asserted against such third party.

\section{Article 305. Existence, primary ownership, transferability and effects of intellectual property rights}

The existence, primary ownership, transferability and effects of intellectual property rights shall be governed by the law of the country that granted the intellectual property right. Any choice of law agreement by the parties concerning these matters shall be null and void.

\section{Article 306. Governing Law of Contracts for the Transfer or Licensing of Intellectual Property Right}

(1) The law governing the formation and effects of contracts concerning intellectual property rights is the governing law provided for in Article 7 of the Act on General Rules Relating to the Application of Laws.

(2) The law governing the formation and effects of a contract provided for in the preceding paragraph is determined by the law of the country granting the intellectual property right that is the subject matter of the contract, unless the parties have chosen the governing law. If there are multiple countries granting the intellectual property right that is the subject matter of the contract, the governing law will be the law governing the place of the habitual residence of the rights holder (or, if the rights holder is a juridical person, the place of its principal place of business).

(3) If another country has a closer connection to the contract than the country of the governing law provided for in the preceding paragraph, the laws of that other country will govern.

(4) The law governing the form of the contract provided for in Paragraph 1 is the governing law provided for in Article 10 of the Act on General Rules Relating to the Application of Laws. 


\section{Article 307. Formalities of a contract concerning intellectual property rights}

(1) The formalities of a contract concerning intellectual property rights shall be governed by the law which applies to the formation of the contract (if the applicable law is changed after the contract was made pursuant to $\$ 306$ paragraph 4 , it shall be governed by the law that was previously applicable).

(2) Notwithstanding the preceding paragraph, a contract concerning intellectual property rights shall be formally valid if it conforms with the law of the place where the contract was made.

(3) In applying the preceding paragraph, with regard to a declaration of intention to make a contract concerning intellectual property rights to a person who is in a different jurisdiction, the law of the place where the declaration was made is deemed to be the place where the contract was made.

(4) The provisions of the preceding two paragraphs shall not be applicable to a contract concerning intellectual property rights concluded between persons who are in different jurisdictions. In this case, notwithstanding Paragraph 1, the contract shall be formally valid if it conforms with the law of the place from which the notice of offer or that of acceptance has been sent.

\section{Article 308. Security Interests}

The law governing the security interests in intellectual property rights is the law of the country granting the intellectual property right.

\section{Recognition and Enforcement of Foreign Judgments}

\section{Article 401. Judgments and Provisional Measures of Foreign Courts}

The following definitions apply to the Legislative Proposal:

(1) "Judgment of a foreign court" means a final judgment given by a court of a foreign country on civil and commercial matters as a result of the fair trial to both parties.

(2) "Provisional measure of a foreign court" means a measure ordered by a foreign country that corresponds to a provisional seizure of property or a provisional disposition of the object in dispute, for securing the enforcement of the right on the merits in a civil action, or provisional disposition to establish a provisional state in legal relationships on the merits in a civil action. 


\section{Article 402. Recognition and Enforcement of a Final and Binding Judgment of a Foreign Court}

A final and binding judgment of a foreign court shall be recognized or enforced if it meets all of the following requirements:

(i) The foreign court would have international judicial jurisdiction in light of the provisions of the Legislative Proposal and the purposes of the recognition and enforcement of foreign judgments;

(ii) The defeated defendant has received a service (excluding a service by publication or any other service similar thereto) of a summons or order necessary for the commencement of the suit, or has appeared in the action without receiving such service. If any convention on judicial assistance concluded between Japan and the country of the foreign court is to be applicable, service shall be effected in a manner set out in that convention;

(iii) The content of the judgment and the court proceedings are not contrary to public policy in Japan;

(iv) If a situation of international parallel litigation under paragraphs 1 and 2 of Article 201 had arisen in relation to the foreign judgment, the claim in a Japanese court has been dismissed or the suit in Japanese court has been suspended;

(v) The judgment of a foreign court is not incompatible with a judgment of a court in Japan which has become final and binding before the foreign judgment becomes final and binding, unless the situation referred to in the preceding item had arisen;

(vi) A reciprocity exists.

\section{Article 403. Enforcement of a Provisional Measure and a Not "Final and Binding" Judgment of a Foreign Court}

(1) A provisional measure of a foreign court shall be enforced if it meets the requirements listed in the items of Article 402. However, it shall not be enforced unless the opposing party of the applicant for the provisional measure was given an opportunity to be heard or to state an opinion on the validity of rights in question in the foreign proceedings in which the provisional measures was granted.

(2) If a court implements the execution of a provisional measure of a foreign court, the court may require the party seeking enforcement to provide security.

(3) A court may stay proceedings, for a reasonable period of time as determined by the court, for the purposes of implementing the execution of a provisional measure when the court deems it necessary to do so.

(4) Paragraphs 1 to 3, except for the second sentence of the paragraph 1, shall apply mutatis mutandis to the enforcement of a not "final and binding" judgment of a foreign court that is enforceable in the country in which the 
court giving the judgment is situated. In this case, the term "which has become final and binding before the foreign judgment becomes final and binding" in item (v) of Article 402 shall be deemed to be replaced with "given before the foreign judgment is given".

\section{Article 404. Effect of Judgments and Provisional Measures of Foreign Courts to Be Recognized or Enforced}

(1) If only a part of a judgment or a provisional measure of a foreign court meets the requirements for recognition or enforcement, the part of the judgment or the provisional measure shall be recognized or enforced.

(2) If a judgment of a foreign court declares the invalidity of a right registered in a country other than the country where the foreign court is situated, the declaration shall be effective only to resolve the dispute between the parties to the litigation.

(3) If a judgment of a foreign court that orders a party to enjoin acts within Japan is not enforced in whole or in part, since the party is authorized by the Government of Japan to use the IP in question without the authorization of the right holder, the right holder shall be paid adequate remuneration. 


\title{
Table of Principles
}

\author{
ALI Principles \\ $\S 101300,302$ \\ $\S 20159,310$ \\ $\S 20246,73,106,310$ \\ § $30213,15,24,176,187,194,204$ \\ $\S 31119,43,169,209$ \\ $\S 31219,209$ \\ $\S 20373,310$ \\ $\S 20436,37,65,67,69,97,148,149$, \\ $\S 31319,43,161,163,166,169,209$ \\ $\S 314163,167$ \\ 310 \\ $\S 20571,92,93,310$ \\ $\S 20673,125,126,310$ \\ $\S 31516,45,167,169,222,230$ \\ $\S 316167$ \\ $\S 317167,226$ \\ $\S 20737$ \\ $\S 21160,61,73$ \\ $\S 212114,115$ \\ $\S 21261,85,88,147$ \\ $\S 21475,303$ \\ $\S 221142,326$ \\ $\S 222108,142,326$ \\ $\S 223142,326$ \\ $\S 32127,49,176,198,199,231$ \\ $\S 401$ 244-246, 255, 300, 304, 307, \\ $329,331,335,337,341$ \\ $\S 402244,302$ \\ $\S 403244,288,309,310,313-317$, \\ $326,327,342,343,345$ \\ $\S 411244,285,338$ \\ $\S 412244,338,339$ \\ $\S 30111,13,41,172,181,185-187$, \\ $\S 413244,338,339$
} 209, 229, 230

CLIP Principles

Art. 1:101 245

Art. 2:101 73

Art. 2:102 59, 74

Art. 2:201 70, 71, 92, 93, 152, 279

Art. 2:202 65-68, 71, 75, 97, 148, 151, 274,276

Art. 2:203 69, 97, 149, 150

Art. 2:204 62, 311

Art. 2:205 62, 278

Art. 2:206 73, 123-125

Art. 2:207 62

Art. 2:208 62

Art. 2:209 62

Art. 2:210 62, 66

Art. 2:301 73, 106

Art. 2:401 61, 62, 85, 106, 146, 260, 276,278
Art. 2:501 66, 74-76, 133, 149, 269, 305

Art. 2:601 133, 262

Art. 2:701 208, 141, 291, 326

Art. 2:702 141

Art. 2:705 76

Art. 2:706 291

Art. 3:101 15, 16, 165

Art. 3:102 229

Art. 3:201 20,162, 163, 165, 169

Art. 3:301 16, 163, 166

Art. 3:401 163, 165

Art. 3:501 16, 166, 167, 222, 230

Art. 3:502 17, 162, 167-169, 177, 222

Art. 3:503 163, 169

Art. 3:504 166

Art. 3:505 166 
Art. 3:506 18, 167, 170

Art. 3:507 166

Art. 3:508 166, 226

Art. 3:601 172, 185, 229, 230

Art. 3:602 68, 172, 230, 231

Art. 3:603 27, 49, 175, 176, 198, 199, 231,233

Art. 3:601 172, 185, 229, 230

Art. 3:602 68, 172, 230, 231

Art. 3:603 27, 49, 175, 176, 199, 231, 233

Art. 3:604 18, 229

Art. 3:605 176

Art. 3:701 170

Art. 4:101 251, 300

Art. 4:102 254, 255, 257, 260-262,

267-269, 301, 307, 335, 338, 343
Art. 4:103 76, 250, 270

Art. 4:201 262, 272-280, 290, 310

Art. 4:202 276-280

Art. 4:203 279, 280

Art. 4:204 279, 310

Art. 4:301 75, 76, 269, 301, 304, 331, 332,346

Art. 4:401 263, 280, 281, 286, 289, 302,317

Art. 4:402 283, 285, 317, 338

Art. 4:501 270, 289-291, 313, 314

Art. 4:601 261, 281

Art. 4:701 265

Art. 4:702 263-265

Art. 4:703 264-266, 338

Art. 4:801 251

Principles of the Japanese Transparency Group

Art. 001295

Art. 101 100, 147, 148, 311, 339

Art. 102 100, 152, 153, 311

Art. 103 79, 88, 89, 91, 107, 311, 320,

322

Art. 104 31, 311

Art. 105 98, 100, 311

Art. 106 149, 150, 311

Art. 107 106, 148, 311

Art. 108 150, 153, 311

Art. 109 108, 311, 312

Art. 110 93, 99, 109, 118, 311

Art. 111 134, 135, 311

Art. $20187,107,118,326,327$

Art. 301 135, 207, 208, 229, 230, 232,

324
Art. 302 49, 298, 200, 212, 231, 232, 321

Art. 303202

Art. 304 204, 321

Art. 305 200, 205, 206, 212, 215, 229, 321

Art. 306 195, 215, 230

Art. 307215

Art. 401 135, 225, 296, 302, 304, 305, $331,332,335,336$

Art. 402 87, 249, 296, 303, 307, 310, $311,314,318,327,331,332,335$ $338,341,342$

Art. 403 135, 296, 303-307, 324, 326, 331-339, 341

Art. 404 320, 325, 337-339 